


\section{Rebound 1947}

\section{WHITNEY LIBRARY,}

\section{HARVARD UNIVERSITY.}

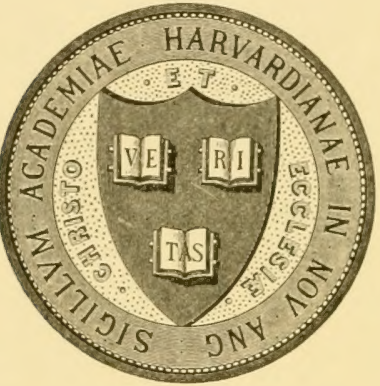

THE GIFT OF

J. D. W H I T N E Y, Sturgis Hooper Professor IN THE

MUSEUM OF COMPARATIVE ZOÖLOGY

\section{9}



PA L AON TOLOGY. 




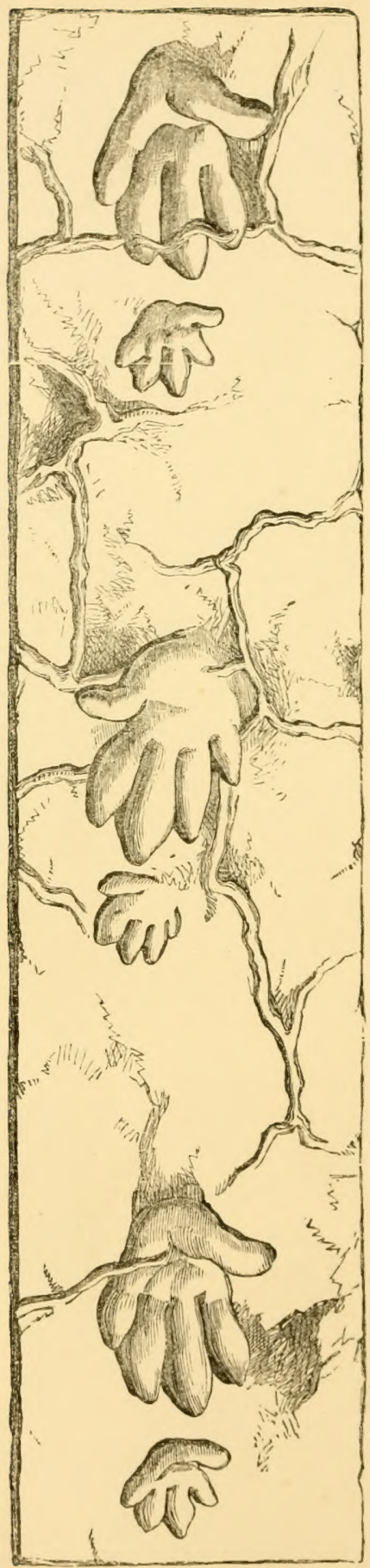

Fig. 68.

Foot-prints of Labyrinthodon (Cheirotherium). 


\section{PALAONTOLOGY}

or

\section{A SYSTEMATIC SUMMARY OF EXTINCT ANIMALS}

AND

\section{THEIR GEOLOGICAL RELATIONS.}

BY

\section{RICHARD OWEN, F.R.S.}

Superintendent of the Natural History Departments in the British Museum, Fullerian Professor of Physiology in the Royal Institution of Great Britain, Foreign Associate of the Institute of France, etc.

EDINBURGH :

ADAM AND CHARLES BLACK.

MDCCCLX.

1860 



\section{CONTENTS, OR SYSTEMATIC INDEX.}

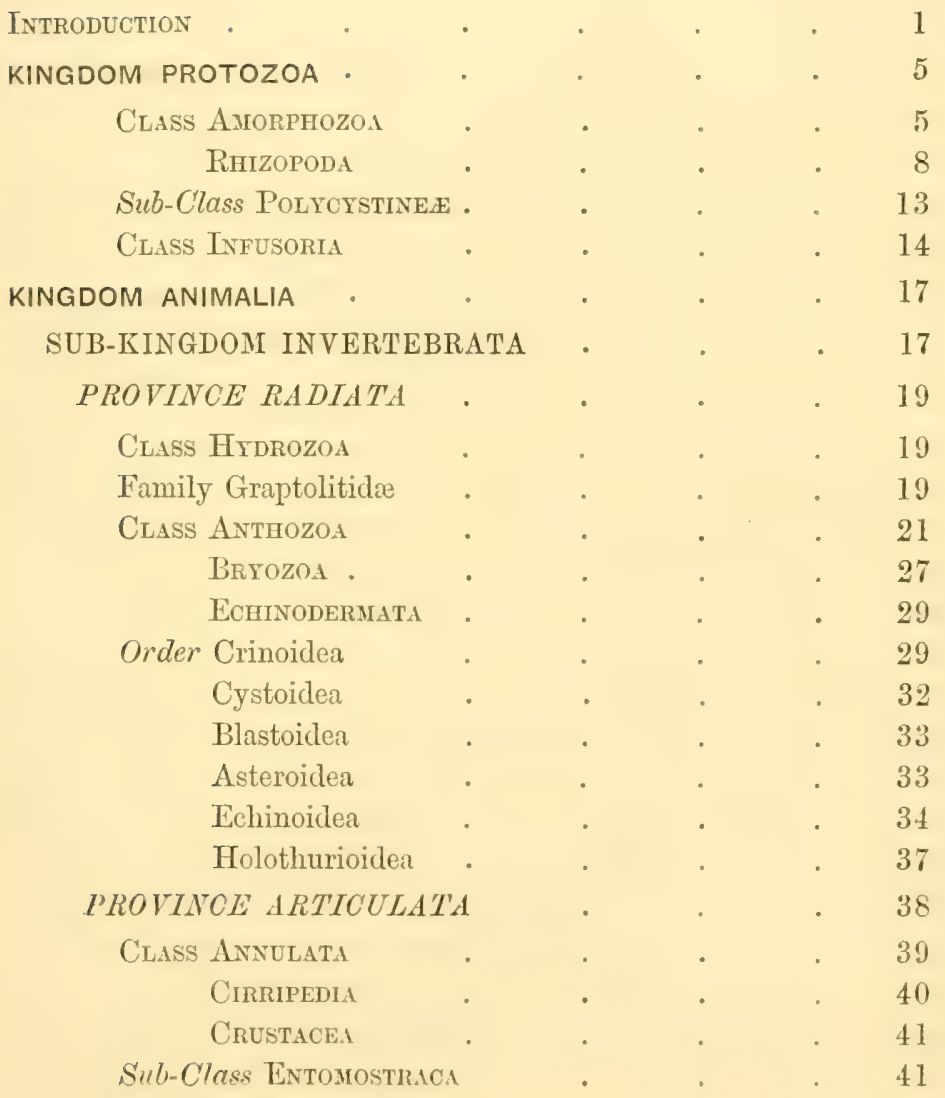


Order Trilobites

Sub-Class Mradacostraca.

Cuass Insecta .

PROVINCE MOLLUSCA .

Crass Brachiopoda

LaMELLIBRANCHJATA

Gasteropoda

Oider Pteropoda

Nucleobranchiata .

Pectinibranchiata

Fitmily Strombidæ

Muricida

Conidx .

Volutidx

Cypræidæe

Order Holostomata

Family Naticidre

Cerithiadie

Calyptræidze

Neritida

Patellidæe

Order Pulmonifera

Tectibranchiata

Cuass Cephalopoda

Order Tetrabranchiata

Family Nautilida

Orthoceratide

Ammonitidx

Orler Dibranchiata

Sepiadre .

'leuthide

Belemnitidie 
CONTENTS, OR SYSTEMATIC INDEX.

Teeth

Page

Family

Cestraciontidre

Hybodontidæ

Squalide

Raiidæ .

Order Holocephali

Genus Chimæra

Ischiodus

Ganodus

Edaphodus

105

Elasmodus

Order Ganoidei

Sub-Order Placoganoidei

Family Placodermata

Siluride

Sturionidæe

Sub-Order Lepidoganoidei

Family Dipteridæx

Genus Dipterus

Diplopterus

Osteolepis

Acanthodii

Genus Diplacanthus

Cheirolepis

Colacanthi

Genus Glyptolepis

Phyllolepis

Asterolepis

Bothriolepis

Glyptopomus

Holoptychidæ

Genus Holoptychius

Rhizodus

Dendrodus

Palroniscidx .

Genus Palreoniscus

Amblypterus

Saurichthyidie.

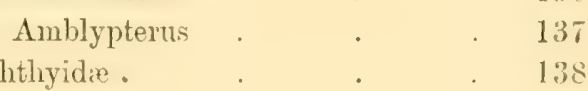


Genus Megalichthys

Saurichthys . . . 138

Family Caturidæ

Genus Caturus

Pachycormus

Pycuodontes

Genus Platysomus

Echmodus

Pycnodus

Dapedidæ

Genus Dapedius

Amblyurus

Pholidophorus

Lepidotidæe .

Genus Lepidotus

Nothosomus .

Propterus

Leptolepidæ

Genus Leptolepis .

Marropomidæ

Genus Macropoma

Sturionide

Genus Chondrosteus

Oreler Acanthopteri

Sub-Order Ctenoidei .

Genus Semiophorus

Smerdis

Sub-Order Cycloidei

Genus Histiophorus .

Crlorhynchus

Order Anacanthini 
Genus Batrachopus . Sauropus

Class Reptilia .

Order I. Ganocephala

Genus Archegosaurus

Dendrerpeton Raniceps

Order II. Labyrinthodontia Genus Baphetes

Family Labyrinthodontidæ

Genus Labyrinthodon

Mastodonsaurus

Nematosaurus .

Metopias

Capitosaurus .

Zygosaurus

Odontosaurus

Xestorrhytias .

Order IIr. Ichthyopterygia

Genus Ichthyosaurus

Order Iv. Sauropterygia

Genus Nothosaurus .

Pistosaurus

Conchiosaurus

Simosaurus

Placodus

T'anystrophrus

Sphenosaurus

Plesiosaurus

Pliosaurus

Polyptychodon

Order v. Anomodontia .

Family Dicynodontia

Genus Dicynodon

Ptychognathus

Fimily Cryptodontia

Genus Oudenorlon .

Rhynchosaurus 
Order vi. Pterosauria • • • • 214

Genus Dimorphodon ～. . 246

Ramphorhynchus . • . 246

Pterodactylus . $\quad . \quad \cdots \quad .247$

Order vir. Thecodontia . . . . 248

Genus Thecodontosauris . . . 248

Palæosaurus . $\quad$. $\quad$. $\quad$. 249

Belodon • $\quad$ • $\quad . \quad 251$

Cladyodon • $\quad$. $\quad$.

Bathygnathus . . . 252

Protorosaurus $\quad$. $\quad . \quad 253$

Staganolepis $\quad . \quad 2 \quad . \quad 255$

Leptopleuron _ . . $\quad 2 \quad 256$

Oider vilr Dinosauria . . . . . 257

Genus Scelidosaurus $\quad$. $\quad$. $\quad 258$

Megalosaurus $\quad$. $\quad . \quad 258$

Hylæosaurus $\quad$. $\quad$. $\quad 261$

Iguanodon . $\quad . \quad$. 265

Order Ix. Crocodilia . . . . 271

Sub-Order 1. Amphicoelia . . . 271

Genus Teleosaurus ․ $\quad$ • 271

Suchosaurus . . . 271

Goniopholis . . . 271

Sub-Order 2. Opisthocœlia . . . 272

Genus Streptospondylus . . . 272

Cetiosaurus $\cdot \quad$. 272

Sub-Order 3. Procœlia . . . 273

Genus Alligator $\quad$. $\quad$. 273

Crocodilus $\quad . \quad$. $\quad .273$

Gavialis . . . $\quad 273$

Teeth of Crocodiles $\quad$. $\quad 27 t$

Order x. Lacertilia . . . .

Genus Raphiosaurus . . . . 278

Coniasaurus . $\quad . \quad$. 278

Dolichosaurus $\quad$. $\quad$. $\quad$. 278

Mosasaurus . $\quad$. $\quad$. $\quad 27 !$

Teiolon . . . . 279

Sautillus . . . . $27 ?$ 
Gerus Macellodon .

Page

Order xI. Ophidia

279

279

Genus Palreophis

Paleryx

Laophis

Orcler xiI. Chelonia

Genus Tretosternon

Pleurosternon

Chelone

$\therefore 80$

Trionyx

Emys

Platemys

Chelydra

'Testudo

Colossochelys .

Order Batrachia

Palæophrynos

Rana

Andrias .

Summary on Fossil Reptiles

Class ili. Aves

Ornithichnites

Brontozoum

Gastornis

Lithornis

Halcyornis

Protornis

Phoenicopterus

Fossil Eggs

Fossil Feathers

Apteryx

Dinornis

Palapteryx .

Aptornis

Notornis

Epionis

Didus

Pezophaps 
Cluass iv. Mammalia - 295

Composition of Bones . • . . $\quad 295$

Law of Correlation _ . . . . $\quad$. 298

Genus Microlestes . . . . $\quad 301$

Dromatherium _ . $\quad 302$

Amphitherium . . 302

Amphilestes . $\quad$. $\quad$. 303

Phascolotherium . $\quad$ • 304

Stereognathus . . 308

Spalacotherium _ . $\quad$. 315

Triconodon . $\quad$. $\quad$. 318

Plagiaulax . $\quad$. $\quad$. 319

Coryphodon . $\quad$. $\quad$. 322

Pliolophus . . . . 325

Lophiodon . $\quad$ • . 329

Palæotherium . . 330

Anoplotherium . $\quad$. $\quad 232$

Dichodon . $\quad$. $\quad$. 333

Dichobune . $\quad$. $\quad$. 336

Xiphodon . . . 337

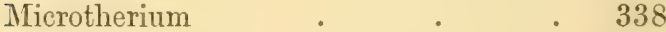

Hyænodon • $\quad$ • $\quad$ • 339

Amphicyon . . . 340

Gulo . . . . 340

Didelphis . $\quad$. $\quad$. 340

Balænodon . • . . 342

Ziphius . $\quad$. $\quad$. 342

Zeuglodon . . . . . 344

Halitherium . $\quad$. 346

Macrotherium . . . 346

Pliopithecus . $\quad$. 350

Dryopithecus • • 350

Mesopithecus _ . 351

Dinotherium . $\quad$. 352

Mastodon . . . . 353

Elephas . . . 360

Hippopotamus . $\quad 361$

Rhinoceros . . . $366^{\circ}$ 
Genus Chæropotamus

Anthracotherium

Hyopotamus .

Sus .

Order Ruminantia

Genus Bison

Bos .

Bubalus

367

Antilope

Family Cervidæ

Genus Dorcatherium

Cervus Dicranocerus

Megaceros

Cervus Somonensis

Tarandus

Martialis

Americanus

Strongylocerus Spelæus

Elaphus

Capreolus

Orcler Carnivora

Genus Galecynus

Felis

Law of Correlation illustrated by Feline Structures

Do. do.

Bovine Structures

Genus Machairodus

'leeth of Carnivora

Genus Ursus

Hyæna

Order Rodentia

Family Leporidæ

Genus Myoxus

Sciurus

Lagomys

Trogontherium

Hystrix

Lagostomus

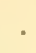

\begin{tabular}{|c|c|}
\hline - & • \\
\hline • & • \\
\hline - & $\cdot$ \\
\hline - & • \\
\hline - & • \\
\hline - & • \\
\hline - & • \\
\hline • & . \\
\hline - & . \\
\hline . & \\
\hline . & . \\
\hline & \\
\hline
\end{tabular}




\section{Genus Echimys}

Ctenomys

Cælogenys

Geographical Distribution of Pleistocene Mammalia

Genus Merycotherium

Elasmotherium

Sivatherium .

Macacus

Camelopardalis

Mylodon

Negatherium .

Megalonyx

390

Scelidotherium

Giyptodon .

Toxodon

Macrauchenia .

Protopithecus .

Australien .

Thylacinus
Dasyurus
Macropus
Diprotodon
Nototherium
Phascolomys
Thylacoleo

Geographical Distribution modified in past time 


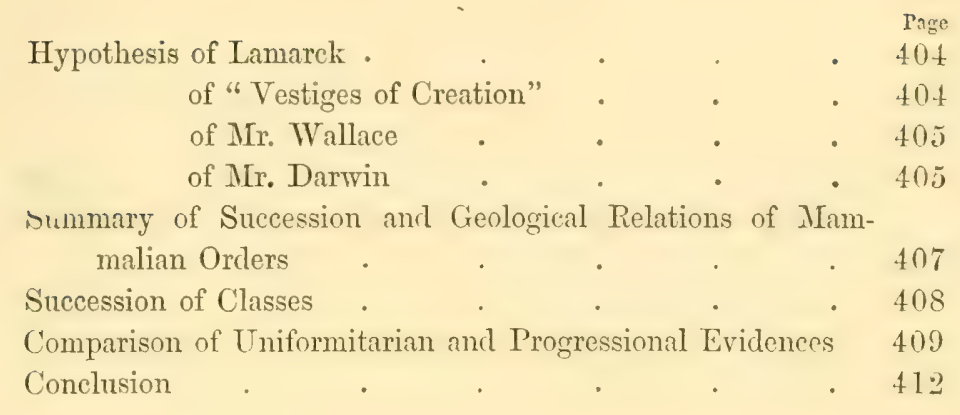

Cuts 2 to 22 inclusive are from Original Drawings by S. P. WOODWARD, F.G.S. 


Table of Strata and Order of Appearance of Antylal Life UPON THE EARTH.

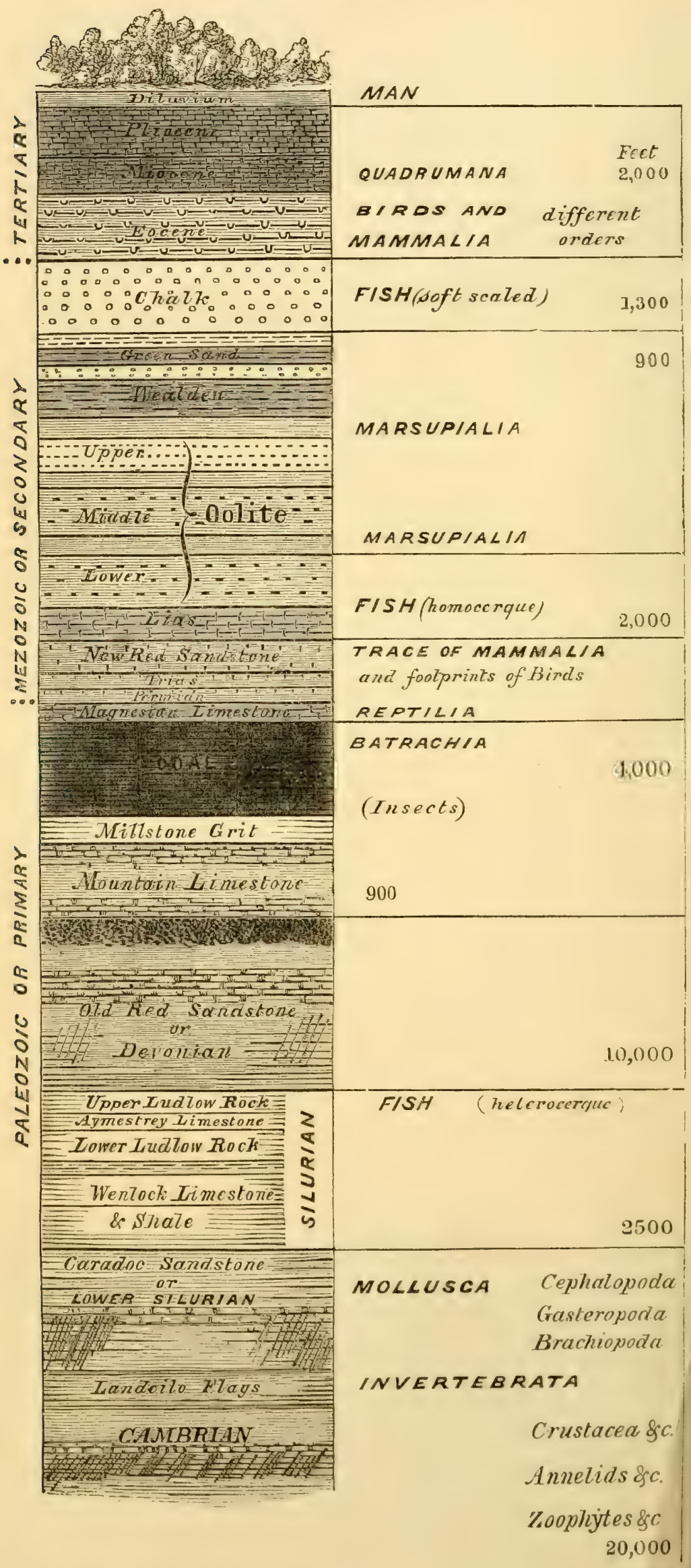




\section{P'I LAONTOLOOY.}

P'ALAONGLOG: is the science which treats of the evidences in the earth's strata of organic beings, which mainly consist of pretrified or fossil remains of plants and animals, leelonging, for the most part, to species that are extinct.

The eudeavour to interpret such evidences has led to comparisons of the forms and structures of existing plants and animals, which have greatly and rapidly advanced the science of comparative anatomy, especially as apulied to the animal kingdom, and more particularly to the lard and enduring parts of the animal frame, such as corals, shells, spines, crusts, scales, scutes, bones, and teeth.

In applying the results of these comparisons to the restoration of extinct species, physiology has benefited by the study of the relations of structure to function requisite to obtain an idea of the food and habits of such species. It has thus been emriched by the well-defined law of "correlation of structures."

Zoology has gained an immense accession of subjects through the determination of the nature and aftinities of extinct animals, and its best aims have been proportionally adrancel. Nuch further and truer insight has been carried into the natural arrangement and sublivision of the classes of animals since palitontology expanded our survey of them.

The knowledge of the type or fundamental pattern of certain systems of organs, e.y., the framework of the Verte-

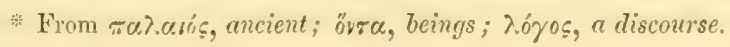


Wratar and the teeth of the Mammalia, hats heen artranecel by the more frepuent and closer adherence to such type discovered in extinct animals, and thus the highest aim of the zoologist has been greatly promoted by jalatentology.

But no collateral science has profited so munch hy palitontology as that which teaches the structure and mosle of formation of the earth's crust, with the relative position, time, order, and mode of formation of its constituent stratified and unstratified parts. Geology, indeed, seems to have left her old handmaiden mineralogy, to rest almost wholly upon her young and vigorous oftspring, the seience of arganic remains.

By this seience the law of the gengraplical clistrilutiom of animals, as deduced from existing species, is shown to have been in force during periods of time long antecedent to human history, or to any evidence of human existence; and yet, in relation to the whole known period of liferphenomena upon this plinet, to have been a comparatively recent result of geological forees determining the present configuration and position of continents. Hereby paleontology throws light upou a most interesting branch of geographical science, that, viz., which relates to former configurations of the earth's surfice, and to other dispositions of land and sea than prevail at the present day.

Finally, palieontology has yielded the most important facts to the highest range of knowlerlge to which the human intellecet aspires. It teaches that the glohe allotted to man has revolved in its onthit though a period of time so vast, that the mind, in the cucleavour to realize it, is stamed by an effort like that by whirh it strives to conceive the space dividing the solar system from the most distant nebulæ.

l'alicontology has shown that, from the inconecivaluly

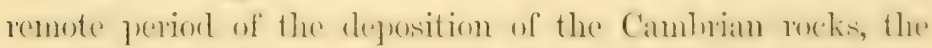

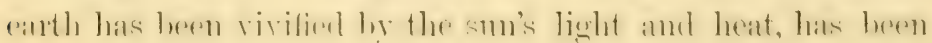


fertilized by refreshing showers, and washed hy tidal wares; that the ocean not only moved in orderly uscillations regnlated, as now, by sm and moon, but was ribleded and agitaterl by winds and storms; that the atmosphere, besides these movenents, was healthily influenced by clouds and rapoun's, rising, condensing, and falling in ceaseless circulation. With these conditions of life, palieontology demonstrates that life hats been enjoyed during the same comntless thousands of years; and that with life, from the begimning, there has been death. The earliest testimony of the living thing, whether coral, crust, or shell, in the ollest fossiliferous rock, is at the same time proof that it died. At no period does it appear that the gift of life has been monopolized by contemporary individuals throngh a stagnant sameness of untold time, lut it has been handed down from generation to generation, and suceessively enjoyed by the countless thousands that constitute the species. Palieontulogy further teaches, that not only the individual, but the species perishes; that as death is Inlanced by generation, so extinction has been concomitant with the creative power which has continued to provicle al snceession of species; and furthemore, that, as reginds the various forms of life which this planet has supported, there has heen "an advance and progress in the main." Thus w" learn, that the creative force has not deserted the earth cluring any of the epochs of geological time that have snceceded to the first manifestation of such force; and that, in respect to no one class of animals, has the operation of creative force been limited to one geological epoch; and prerhipls the most important and significant result of palierontological rescarreh has been the establishment of the axion of the mutimums operation of the ordained becoming of living things.

The present survey of the evidences of organic beings in the earth's crust commences with the lowest or most 
simple forms, and embraces chictly the remains of the animil kingdom.

A reference to the sulpioined "Talle of Strata" (fig. 1) will indicate the relative prosition of the geological formations. cited. The numerals opposite the right hand give the apluroximative depth or vertical thickness of the strata.

Organisms, or living things, are those which possess such an internal cellular or cellulo-vaseular structure as can receive fhid matter fiom withont, alter its nature, and add it to the alterative structure. Such fluid matter is called "nutritive," and the actions which make it so are called "assimilation" and "intus-susception." These actions are classed as "vital," because, as long as they are contimued, the "organism" is sainl "to live."

When the organism can also nove, when it receives the nutritive matter by a mouth, inhales oxygen and exhales carbonic acil, and developes tissues the proximate principles of which are quaternary compoumds of carbon, hydrogen, "xygen, and nitrogen, it is called an "animil." When the organism is rooted, has neither mouth nor stomich, exhales oxygen, and has tissues composed of "celluluse" or of bimary (1) termary compounds, it is called a "plant." But the two livisions of organisms called "plants" and "animals" are specialized members of the great natural group of living things; and there are numerous beings, mostly of minute size and retaining the form of mucleated cells, which manifest the common organic characters, lout withont the distinctive superalclitions of true plants or animals. Such organisms are called "I'rotozua," and include the spronges ar A morplonson, the Forreminifie or Rhizopods, the P'olyeystince, the Dirtemenere.

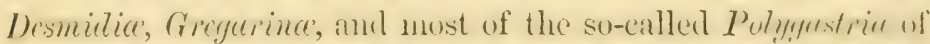

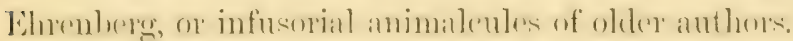




\section{PROTOZOA.}

\section{Class I.-AMORPHOZOA.}

Fussil sponges take an innertant place among the organic remains of the former worlel, not only on account of their great variety of form and structure, but still more because of the extraordinary abundance of individuals in certain strata. In England they specially characterize the chall formation,-'xtensive heds of silicified sponges ocem in the upper greensimul, and in some beds of the oulite and carboniferous limestone. In Germany a member of the Oxford oolite is callerl the "spongitenkalk," from its numerous fossils of the present class.

Existing sponges are divided into homy, flinty, and lim!y, "1r "ceratose" "silicions," and "calcareous," acemeling to the substance of their hard sustaining parts, which parts are commonly in the shape of fine needles, or spiculu, of very varied forms, but in many species of sufficient constancy to "haracterize such species. The soft organic substance called "sarcode" appears to be structureless, and is diffluent; it is meontractile and impassive, hut consists of an aggregate of more or less radiated corpuscles, in some of which the trace of a nucleus may he discemed. The latrger orifies's on the surfice of a sponge are termed "oscula," and are those out of which the currents of water flow: these enter by more numerous and minute "pores."

The calcareous spongets abound in the oolitic: and crota(exuss strata, attaining their maximum of derelopment in the chalk; they are now almost extinct, or are representerl ly. other families with calcareous spicula. The horny sponges appear to be more abundant now than in the ancient seas, but their remains are only recognisable in those instances where they were charged with silicious spicula. 


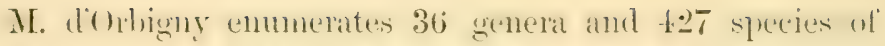
fussil sponges; and this is probably only a small proportion of the actual number in museums, as the difficulty of determining the limits of the species is rery great, and many remain undescribed.

Palcospongie and itenthospongie occur in the lower silurian; and Stromatognere, with its concentrically laminated masses, attains a large size in the Wrenlock limestone. Str-

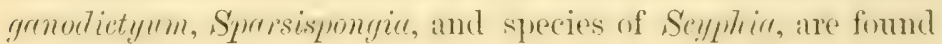

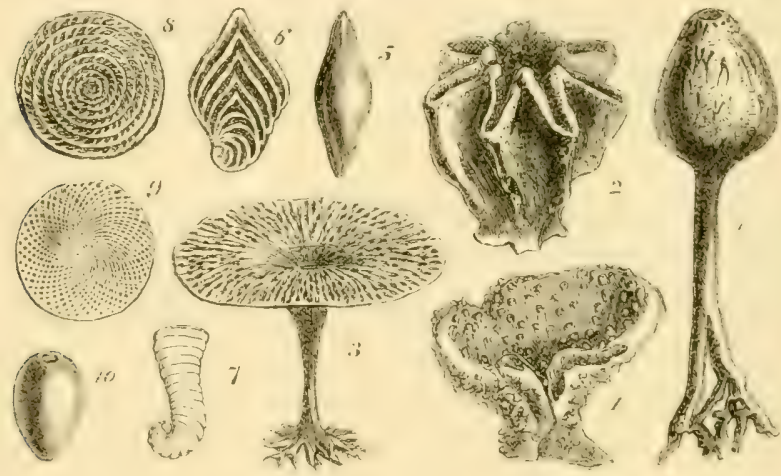

Fig. $: 2$.

Amorphozoa; lihizopode.

1. Siphonia psriformis, Goldf.; Greensand, Blacklown.

2. Guettardia 'Thiolati, D'Arch.; U. Chalk, Biarritz.

3. Ventriculites radiatus, Mant.; $U$. Chall, Sussex.

4. Manon osculiferum, Phil.; U. Chall; Yorkshire.

5. Fusulina cylindrica, Fisch. ; Carboniferous, Russia.

6. Flabellina rugosa, D'Orb.; Chalk, Europe.

7. Lituola nautiloidea, Lam, ; Chalk, Lurope.

8. Nummulites nummularia, Brug.; Eocene, Old Worled.

9. Orbitoides media, D'Areh.; U. Chall, France.

10. Ovulites margaritula, Lam.; Chalk, Europe.

in the Devonian; and Buthroesmis, Memillogene, and Trenges, in the Permina or mannesian linestone. Sereral gernerat are

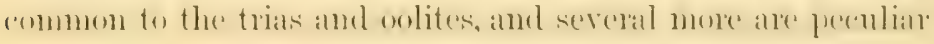


to the latter stratil. The Oxfortian sprenges helong chictly to the generar Eudea, Hippetimus, Cribrispongia, Stcllispongia, and Cupulispongiu. Their fibrons skeleton appears to have been entirely calcareous, and often very solid; their form is ('ul-shaped, or mammillated, or incrusting, and many have a sieve-like appearanee, from the regulat distribution of the excurrent orifices (oscula) over their surface.

The greensand of Faringtom in Berkishire is a stratum prolifie in sponges, chicty cup-shaped and calcareous, of the genera Serymire and Chemendogorer ; or mammillated, like Cnemitium and Terticilloporr. The Kentish rag is full of sponges, which are most apparent on the water-worn sides of fissures. Some bets are so full of silicious spienla as to irritate the hands of the quarrymen working those heds. The greensand of Blakkdown is famons for the number and presfect preservation of its pear-shaped Siphonia (fig. 2, 1): whilst those of Warminster are ornamented with three or more lobes. The latter locality is the riehest in England for large cupshaped and branching sponges (Polypothecia), which are all silicified : the long stems of these sponges have heen mistaken for hones. The sponges, chicfly Siphomia, of the upler sreensamel of Farnham are infiltrated with phosphate of lime, and have been used in agriculture.

The sponges of the ehalk belong to several distinct families. Choanites resembles the Siphonia, hut is sessile, and exhibit. in section, or in weathered specinens, a spiral tube winding round the central cavity. It is the commonest sponge in the Brighton brooch-pelbles. Others are irregularly cup-shaped and calcareous; and many of the Wiltshire flints have a nueleus of branching sponge (S. clevellate). The chalk flints, arranged in regular layers, or built "p in columms of "Paramoudra," all contain traces of sponge structure, and their origin is in some measure comnected with the periodic growth of laree crops of spomeses. Frequently the crust or outer 
surfice anly of the sponge has heen silicitied, while the centre hats decayerl, leaving a botryolid or stalactitic cavity. The cup-shaped sponges are almost always more or less enreloped with flint, which invests the stem and lines the interion, leaving the rim exposed. The sponges of the Turkshire chalk are of a different character: some are elongated and radiciform, others horizontally expanded, but they contain comparatively little silica; while those helonging to the genus Manon (fig. 2, 4), having prominent "oscula," are superficially silicified, and will bear immersion and cleaning with hydrochloric acid. The largest group of chalk sponges, typified by Teuticulites (fig. $\boldsymbol{2}, 3$ ), have the form of a eup) or fumnel, slender or expanded, or folded into star-like shipe (Guctfardin, fig. 2, z), with processes from the angles to give them firmer attachment. Some have a tortuous or lahyrinthic outline, and others are branched or compound, like Biachiotites. Curious sections of these may be obtained from specinens enveloped with flint or pyrites. The hurrowing-sponge, Cliona, is commonly found in shells of the tertiaries and chalk. The great cretaceous Exogyre of the United States are frecuently mined by them; and flint casts of Beleminites and Inoceremi are often covered by their ramifying cells and filmes. Thin sections of ehalk flints, when polished and examined with the microscolve, sometimes exhlibit minute spherical bodies (Spriniforites) covered with radiating and multicuspid spines. From their clnse resemblance to the little fresh-water orwanism Xunthidium, they long hore that name ; hut they are certainly. marine bodies, and probably the spores of sponges.

\section{Class II.-RHIZOPODA.}

The organisms of this class are small and for the most

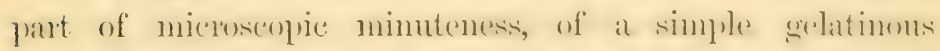
structure, commonly protected by a shell. The most simple 
rhizopods, called Amaba, present a globular form when contracted, hut can extend portions of their substance ("sarcode") like roots, and use them to draw along the rest of the mass, like the feet or tentacles of polyzs, whenee the name of the class. These root-like processes can also attach themselves to foreign particles, and draw them into the "sireode," or sulsstance of the body, where the soluble organic part, so "intus-suscepted," may be assinilated, the insoluble part heing extruded. I solid hyaline corpuscle or nucleus is commonly discernilile in the interior of the $A$ matu, sometimes accompanied ly one or more clear contractile vesicles. When the productions of the sarcode are numerous, filiform, and seemingly constant, radiating from all parts of the body, the rhizopod presents the characters of Actinombry.s. When the tentacles are produced from only one extremity of the body we have the genus Pamphagus. When such a rhizopod is enclosed in a membranous sac it is a Difflugia ; if the sac he discoid with a slit on the flat surface for the protrusion of the tentacles, it is an Arcella. In other rhizopods the sac is calcifierl, or becomes a "shell," which is sonetimes simple", but usually consists of an aggregate of chambers, inter-communicating hy minute apertures, whence the name Foreminifir giren to the testaceous rhizopods. These chamhers grow by successive gemmation from a primordial segment, sonetimes in a straight line, more commonly in a spiral curve; and each segment so developed has its own shelly envelope. As, however, they are organically commected, the whole seems to form " "chambered" or "polythalamous" shell. The last-formerl segment is usually distinguished by the very long, slender, pellucid, colourless, contractile filaments which have suguested the name "Phizopods" for the class. But, in the Form minifu" both the outer wall and the septa of the compound shell are perforated hy minute apertures, through which either comnerting or projecting filaments of the soft organire tissue "an pass. 


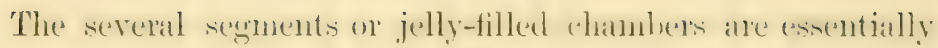
repetitions of each other ; and there is no proof that the inner and earlier segments derive their nourishnent from the outer and last-formed one. A Foraminifer may therefore he rexarted vither as a series of inclivicluals, organically miterl, or as a single aggresate being, compounded aceording to the law of vegetative repetition.

The minute chambered shells of Forctminiferce enter' largely into the composition of all the sedimentary strata, and are so abundant in many common and fimiliar materials, like the chalk, as to justify the expression of Buffon, that the very dust had been alive. The deep-sea somndings of the Atlantic Telegraph Company have shown that the hexl of that creat ocean, at a depth apluoaching, or even excesting, two miles, is eomposed of little else than the calcareous shells of a Globigerine and a few other Rhizopods, with the silicious shields of the allied Polycystinee. The composition of the chalk is extremely similar: when the finer portion, anounting to half or eren less, has been washed away, the remaining sediment consists almost entirely of foraminated shells, some perfect, others in various stages of disintegration. They have also been found in other marine formations, which are soft enough to be washed, down to the Lower Silurian; and in the hard limestones and marbles they can be detected in prolished sections, and in thin slices laid on glass. The greater part of these shells are micorosenpie, hut some of the larege extinct Forminifera, callerl, from resembling a pieser of moner, "Nummulites," are two inches in diameter.

The enenere divisions in use for these shells were mostly invented ly M. dorbigny, lut om artificial grounds, viz.,

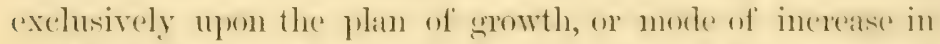
the number of chambers. The strueture and amamompleseses of these complex atoms have been reerently investigated ly

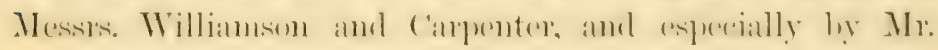


W. K. Parker. The following are the primary groups of Foraminifora in the system of d'Orbigny:-

1. Monostega-Borly (onsisting of a single segment: shell of one chamber.

2. Stichostegr.-Borly composed of segments disposed in a single line: shell consisting of a linear series of chambers.

3. Mrlicustegu-Body consisting of a sprial series of segments: shell made up of a number of convolutions.

4. Entonostege.-Body consisting of alternate segments spirally arranged : shell chambers disposed on two alternatines axes forming a spiral.

万. Encellostega.-Body composed of altemate sexments mot forming a spiral: chambers arranged on two or three axes which do not form a spiral.

4. Agathistrya-Body consisting of segments wound romul an axis : chambers arranged in a similar manner, each investing half the entire circumference.

I somewhat different arlangenent has been adopted hy schultze, who divides the Polyfherlemine into three sections, viz.

1. Mrticuden, including those forms in which the sereral chambers of the shell are arranged in a convolute series, and answering to the last four orders of d'Orbigny.

2. Rhabdoidea, in which they are placed in a direct line (Stichostega, d'Orb.) ; and

3. Sorviden, where they are disposed in an irregular mammer (Acervutina).

Lagena is a genus of Monostega, or single-chambered Foraminifera, with a flask-shaped shell, sometimes presenting a beantiful fluted exterion: Enfosolenier is like as 
Leefene, with the tubular neck inverted inte the cavity of the shell.

Among the many-chambered Foraninifers the modificittions of form seem endless. Toduscriu resembles a crolindrical beaded rod: C'ristellurir hergins hy heing spinal and afterwards becomes straight : most species are wholly spiral : in some, as Nummutites, the convolutions are on the same plane: in many the spiral tums obliquely romul an axis, and gives the shell a trochoid form.

Upwards of six humbed and fifty-seven fossil species. helonging to seventy-three genera, have been descrilued : they commence in the palaenoic age, increase in munluer and variety with each successive stratum, and attain their maximum in the present seas. Must of the fossil gencra, and eren some of the species, pass through many formations: indeed, if correctly observed, the existing forms are the oldest known living organisms. Dentulina communis, Odbitolites complanatus, Rosalina italica, and Rotelina ylutulese, all living species, are said to be found in the chalk; Rotalinu umlilicate ranges to the gault; and Wiblina rugosa is common to the upper lias, the chalk, and present sea. It has, howerer, been observed, that fossil Rhizopods, set free ly the disintesration of rocks, are mingled with the recent shells on erery beach; and Mr. M'Andrew has obtained them in this combition from great depths of the mid-chamel.

The earliest important form is the Fusulinu (fig. 2, 5), which forms layers many inches, or even lect, in thickness in the camboniferous limestone of liussia. The recent gentera

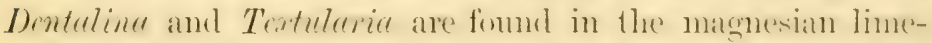

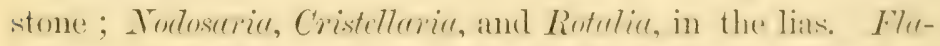
belline (fig. 2, 6) is preculiar to the challe; O, Thituides (figs. 2, 9)

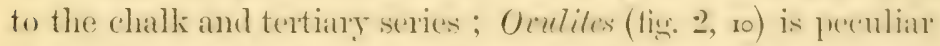

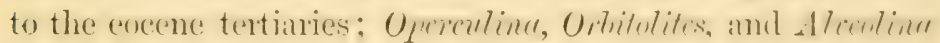
appear first in the tertiary, and are still living. The Lildele 
(fig. 2, 7) vecurs in the chalk and chatk flints, and hats been rescribed as at species of "Spirolinite." Many of the cretaceons Fordminifere contain a hrown colouring matter, which remains after the shell has been dissolved with weak acid, and has been regarded as the remins of the organic substance which once filled all the cells.

The "calcaire grossier," which is employed at Paris as a building-stone, contains Foraminifere in such abundance that one may say the capital of France is almost constructed of those minute and complex shells.

But it is in the middle eocene, or "nummulitic jeriod," that the Rhizopods attained their greatest size, and played their most important part. Wherever limestones or calcareous sands of this period are met with, these Foraminifers abound, and literally form strata which in the aggregate hecome mountain masses. These "nummulitic limestones" are found in Southern Europe, in Northern Africa, and in India; they also oceur in Jamaica. The commonest form is the Nummulite (fig. 2, 8), which occurs in the building-stone of the Great Pyranid. The Nummulites were evidently sedentury organisus; and, in the large thin species, one side is moulded to the inequalities of the sea-bed on which it grew.

Polyeystinece.-The tertiary marls of Barbadoes afforded to Ehrenberg an exteusive series of novel and extraorlinary microscopic organisms, composed of silica, but foraminated like the shells of the Rhizopods. The same forms, and others similar to them, have heen met with in the deep-sea mud of the Gulf of the Erebus and Terror, and more recently in the mul of the North Atlantic somdings. They are quite distinct in form and character from most of the silicious-shichled Diatomacere, hut some of them resemble the Coscinoctiscus and Actinocyctus. No less than 282 forms, gromper in th purisional genera, have been describerl. 


\section{Class III. - INFUSORIA.}

(Polygastria, Elırenberg.)

Numerons genera and multitudes of so-called species of free and locomotive microscopic orgunisms, which, becaune they do not present the distinctive characters of plants or animals, have been by turns refered to one or other kinglon, jossess shells of flint, and consequently enter lingely into the domain of fossil evidences of former life. The silicious shells of these infusory organisms present under the microscope the most definite as well as beautiful characters of form and sculpture, which are as recognisable and distinctive as those of the calcareous shells of Mollusea. The plates of the incomparable works and memoirs of Ehrenberg abound with exact figures of the delicate sheaths, shells, and shiekls of the loricated Infusoria of past and present aras of life, the deposits of which, by reason of their pure, flinty, atomic constitution, were known in the arts long before science had detected their nature and vital origin. In 1836 portions of the stone called "tripoli" or "polierschiefer" (polishing-slate of lapidaries) were mieroscopically examined by Ehrenberg, who discovered it to be wholly composed of the silicious shells of Infusoria, and chiefly of an extinet species called Guillonelle distuns. It Bilin, in Bohemia, there is a single stratum of polierschicfer, not less than fourteen feet thick, forming the ulper layer of a hill, in every cubic inch of which there are forty-one thousinel millions of the above-named organic mit. This mineral likewise contains shells of Nericule, Bucilleriu, Actineryders, and other silicious organisms. The lower part of the stratum eonsists of the shells eompacted together without any visilub cement; in the mlyer masses the shells are eementerl togrether, and filled by anophous silieious matter formed ont of di-solved sholls. At Eena, in Pinhemia, there is at statum uf 1 wo miles 
in length, and averaging twenty-eight feet in thickness, of which the mpermost ten feet are composed wholly of the silicious shells of Infusoria, including the beautiful Comp?ludiscus ; the remaining eighteen feet consist of the shells mixed with a pulverulent substance. Corresponding deposits of the silicious cases of Infusoria have since been discovered in many other parts of the world, some including fresh-water species, others marine species of Infusoria.

The conditions of such depositions will be readily understood by examining the sedinentary deposits of bogs and of stagnant or slow-flowing sheets of water. In warm latitudes and seasons, such water swarms with infusorial life, and the indestructible cases of the loricated linds are found in great quantities in the sedinentary deposits. Beneath peat bogs they have been found to form strata of many feet in thickness, and co-extensive with the turhary, forming a silicious marl of pure whiteness. A quantity of pulverulent matter is deposited upon the shores of the lake near Uranea, in Sweden, which, from its extreme fineness, resembles flour : this has long been known to the poorer inhabitants under the name of "bergmehl," or mountain-meal, and is used by them, mixed up with Hour, as an article of food. It consists in great part of silicious shells of Infusoria, with a little organic matter. With regard to the sumree of fossil infusorial remains in sea-water, the following evidence is given in the United States Coast Survey, $1856:$

Soundings of the gulf-stream near Key Sisenyne, Floricli, varying in depths from 1.77 fathoms to 205 fathoms, give a light greenish-grey mud composed chicfly of Fonanmilers, Diatoms, Polycystins, and Geolites, in a profusion only surpassed by the fossil polycystinous strata of Barlarloes. The Foraminifers compose the largest part of these muds, inchuling Tratulerice dmericene, Murginule Bechi, and other forms,

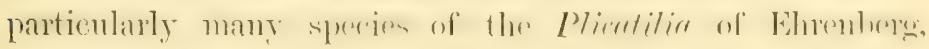


which hat lexen supposed to live omly in shallower hatmots. The silicious shells of Liatoms abound in the residue, after the calcareous Foraninifers have been dissolved by acid. The inorganic portion of the soundings is chiefly quartz samd, and its proportion is quite small.

Such manifestations of life, with its mineral results, hare leen detected from the carliest sedimentary deposits to the present time; but as regards the Infusoria, they are given un the grandest scale in formations of the tertiary age. The town of Richmond, in Virginia, United States, is built on farren silicious strata of mane origin and tertiary age. The strata are twenty feet in thickness, composed chicfly of infusorial thint-shells, including the well-known and heautiful microscopic objects, Actinocycles.s and Coscinodiscus.

Most of the infusorial formations, as the polishing-slates at Cassel, Planitz, and Bilin, are astounding monments of the operation of microseopic organisms at former periods of the history of this planet. The minute size, clementary structure, tenacity of life, and marrellous reproductive powrer of the Infusoria have enabled them to survive as species those destroying causes which have exterminated contemporaneous higher forms of organism. Species of Bacillaria still exist which were in being at the period of the deposition of the chalk. Existing species of Diatomacce have been detected as low down as the oolite. The discovery by Ehrenberg of more than twenty species of silicions-shelled Infusoria, fossil, in the ehalk and chalk-narls, which are idcontical in species with some now living in the hed of the Baltic, is an instructive addition to the olsceure history of the introduction of species of living things in this plunet, and must add greatly to the interest of the infusorial class in the "yes of the geen-

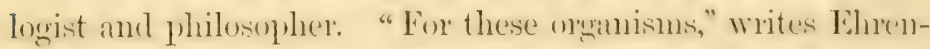
herg, "constitute a chain which, thomgh in the inchividual link

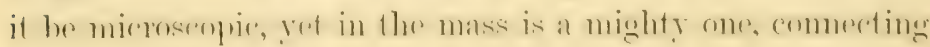


the life-phenomena of distant inges of the earth, and froving that the dawn of the organic nature co-existent with us reaches further back in the history of the earth than harl hitherto been suspected." "The microscopic organisms are rery infurior in individual energy to lions and elephants, but in their united influences they are far more important than all these animals." If it he erer permitted to man to penetrate the mystery which enshrouds the origin of organic force in the wide-spread mud-beds of fresh and salt waters, it will be, most probably, by experiment and observation on the atoms which manifest the simplest conditions of life.

\section{ANIMALIA.}

\section{INVERTEBRATA.}

Remains of invertebrate animals occur in strata of every age, from the partially metamorphic and crystalline rocks of the Cambrian system to the deposits formed by the floods of last winter and the tidles of yesterday. They are found in every country, from the lighest latitude attained by Aretic voyagers to the extremities of the southern continents, and at the greatest elevation hitherto climbed in the Andes or Himalaya. If some classes- - .y., Tunicuta, Acalcpha-seem not to be represented in stratified deposits, they are such as, either from the soluble or perishable tissues composing the entire frame, could not be expected to be fossilized under any conceivalle circumstances; or from the same cause, are only not so recognisable at one of their metagenetic phases. Evidence of compound Hydrozoa-i.e., of the polypes which Ellis called "Corallines"-and especially of the gemus Campanularia, would show that the acalephal type and grade of organization had been manifesterl at the period of the formation of the strata containing such fosisil P'olypir. With the alove seeming 
exceptions, every class of invertebrate animal is representenl by fossil remains.

They consist of corals and shells, of the petrified sledetons of star-fishes and sea-urchins, of the hard corerings of crabs and insects, of the tracks and shelly habitations of worms, and of impressions of surfaces, and casts of cavities, of organisms, retained by the matrix after the animals lad perisherl.

The condition in which invertelnate fossils oceur depends on the nature of the matrix and other accilental circumstances; for while some are scarcely altered in composition, or even in colour, others are silicified or infiltrated with carbonate of lime. Some may he cleared by the action of acid or exposure to the weather, and some require the chisel of the mason or the mill of the lapidary for the proper exhibition of their structure.

Multitudes of recent species are fossilized in the newer tertiaries whose history can be made out perfectly from living specimens; but the number of these climinishes gradually in each older stratum, while the proportion of extinct forms is ever on the increase. No living speries more highly organized than a Phizopod is found in the secondary rocks. Recent gencra extend further hack in time; indeed a few may he recognised in strata of palreozoic age, shedeling a light on the proballe affinities and conditions of their associates. Many of the smaller groups of genera, called fomitics, disalplear in the secondary, and still more in the prataromic period, and are to a limited extent replaced by groms which no longer exist. But as to the larger gromps of Protosod and of true invertebrate animals, it may le aflimerl that erey known fossil helongs to some one or other of the existing dakses, and that the ormanie remains of the most ancient fossiliferous strata do not indieate or suggest that any earlice and diflerent clilss of

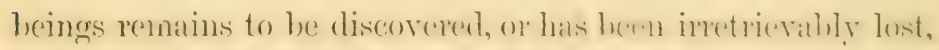
in the universal metamorphism ol the oblest rewelis. 


\section{Province I.-RADIATA*}

\section{Sub-Province POLYPI.}

A polype is a small soft-bodied apuatic animal which generally presents a cylindrical oval or oblong body, with an aperture at one of its extremities surrounded by a crown of radiating filaments or "tentacles." This aperture leads to the digestive cavity, which, in most Polypes, is without intestine or vent. A very large proportion of these animals has organs of support, called "polyparies" or corals, of various form and substance, but for the most part consisting of carhonate of lime; and, as a general rule, locomotion is lost with the development of the polypary, which usually attaches the polype to some foreign body. The organization of the soft tissues is in general simple; the faculties of the Polypes are rery limited; and the vital phenomena, save those of initability and contractility, are inconspicuous. Nevertheless, the influence of the combined powers of some of the species, in adding to and modifying the crust of the earth, is neither slight nor of limited extent.

\section{Ciass I.-HYDROZOA.}

Char-Colypary, when present, flexilsle, external; for the most part developing cells for the prolyes accomling to regular patterns.

\section{Family I.-Graptoliาiox.}

To this class may probably belong the organic remains called "Graptolites," which are exchisively and characteristically Silurian fossils. A certain knowledge of their affinities

* For the characteristic organization of the provinces, classes, orders, and families of Invertebrata, reference may be made to the writer"s "Lectures on Invertebrata," 8vo, Longmans, 1855. 
would require examination of the soft parts; and the fimily has long been extinct. Indications of the flexible consistency of the polypary, and M. Barrande's statement of the existence of a cylindrical canal in its axis, which he conjectures to have contained the common connecting tissue of the polypes, have weighed with the writer in placing the Graptolites provisionally in the present class of Polypi. The axis of the polypary is sometimes straight (fig. 3, 3), sometimes spiral (fig. 3, 6). The ordinary form, as given by the Gireptolites priodon (fig. 3, 3),
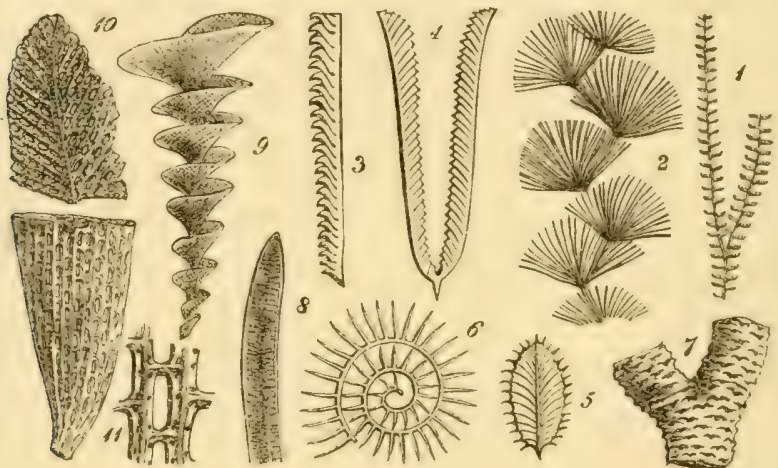

Fig. : :.

Hydrozoa; Anthozoa; Bryozoa.

x. Protovirgularia dichotoma, $\mathrm{MI}^{\circ} \mathrm{C}$; Silurian, Dumfries.

2. Oldhamia antiqua, Forbes; Cambrian, Wicklow.

3. Graptolites priodon, Brun, ; Silurian, Britain.

4. Didymograpsus Murchisoni, Beck; L. Silurian, Wales.

5. Diplograpsus folium, His.; L. Silurian, Britain.

6. Rastrites peregrinus, Barr; Silurian, Bohemia.

7. Cœnites juniperinus, Eichw: $U$. Silurian, Dudley.

8. Ptilodictya lanceolata, Lonsd.; U. Silurian, Tortworth.

9. Archimedipora Archimedea, Lesuer.; Carboniferous, Kentucky.

ı. Ptilopora pluma, $\mathrm{M}^{\mathrm{C}} \mathrm{C}$; ; Carboniferous, Ireland.

Ir. Fenestrella membranacen, Ph.; Carboniferous, Britain.

is serrated on one side only, and is found abundantly in the Cambrian or older Silurian beds of Sicotland and Wales; it occurs also in the Ludlow rocks. The double ciraptolites 
(Diplograipsus, fig. 3, 5 , and Didlymograpsus, fig. 3, 4) are Cambrian forms. Restrites (fig. 3, 6) had the polypes only in one side, and they are less crowded: it characterises Barrande's division $\mathrm{E}$ of the Lower Silurian beds of Bohemia, and has not yet been found in Britain. The Graptolites occur in argillaceous strata, especially in the mud-stones of Wales and Cumberland, and in the alum-slates of Sweden. These beds remind one of the mud bottoms in which the Virgularia and other long and slender graptolite forms of "Pematulidec" Hourish in forestlike crowds. The primeval ciraptulite may have presented it more generalized polype strueture than is now met with in the specially differentiated Sertularians and sea-pens.

\section{Class II.-ANTHOZOA.}

In this class of Polypes the tentacles are hollow, and, in most, with pectinated margins. The polypary is usually internal, and forms the bodies more properly called "corals and "madrepores."

Asteroidd.-Great doulht attaches to some of the fossils referred to this class of Polypi. The terms "Gorgonia" and "Alcyonimu" have been applied to objects not well understood, and usually proving to be Bryosod and sponges. The Lower Siluxian fossil called Pyritoncma consists of a fasciculus of silicious fibres, and has been supposed to be related to the glass zoophyte (Hyaloncma). The miocene deposits of l'iedmont contain a species of the Mediterrmean genus Corellim, an Antipethes, and an Isis (or Isisine, d'Orb.), which is also found in Malta. The London elay contains one coral (Gicly,hulavia), referred to the Pennatulide, and two Gorgonida (Mopsece and Websteria).

Actinoida.-The lamelliferous or stony corals are (next to the Testacea) the largest and most important class of invertebrate fossils. They attained a great development in 
the carliest seas, and were perhaps more widely diffused and individually abundant in the silurian age than at any subse(quent period. "Reef-building" corals are now confined to warm seas, and are wanting eren on great tracts of tropical const. The Oculina is the only large coral now found in the north. But in palieozoic times the representatives of the modern Astrieas and Caryophyllias extended as fir northward as Arctic royagers have penetrated; and at a much later perior they formed reefs of considerable thickness and extent in the area of the coralline oolite. The silurian limestone of Wenlock Elge is itself a coral reef thirty miles in length : and the Plymouth limestone and carboniferous limestone have frequently the aspect of coral-banks skirting the older regions of Cambrian slate and Deronian "killas." The structure of coral-banks may be studied in the lofty limestone cliff's of Cheddar, and in the ware-rom shores of Lough Eme, as well as in the upheaved coral islands of the southem seas. In the fields about Steeple-Ashton, every stone turned up by the plough is a coral; and our inland quarries and challi-pits afford to the palreontologist materials for the study of a class almost wholly wanting on the present sea-shores of Europe. The history of the British fossil corals, as given by Milne Edwards and Haime in the "NIonographs of the Paleontographical Society," exhibits, equally with that of the fossil shells by other authors, a transition from a state very different from that which now sulsists in our part of the world, and a graclual aplroximation to the present order of things.

In the palieozoie stratal the corals belong chicfly to two extinct orders; those of the secondary period more resemble living corals of warmer climates than ours; ant the few tertiary genera and speciess resemble these: of Southern Europe and our ówn coast.

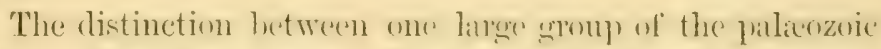

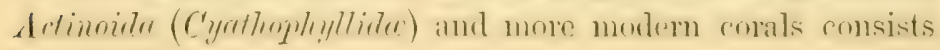


in the quachipartite character of their plaited cups or stars, whereas the lamellix (or septe) of the uther families are developed in multiples of 6 . A remarkable exception exists in the Holocystis (fig. 5, 8), an Astrea-like coral with quadripartite stars, which is found in the lower greensand. The old-rock corals are also remarkable for the manner in which they are partitioned off by horizuntal "tabulec" (fig. 4,3 ), like the septa

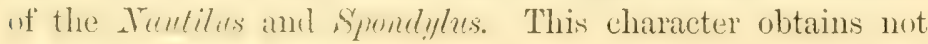
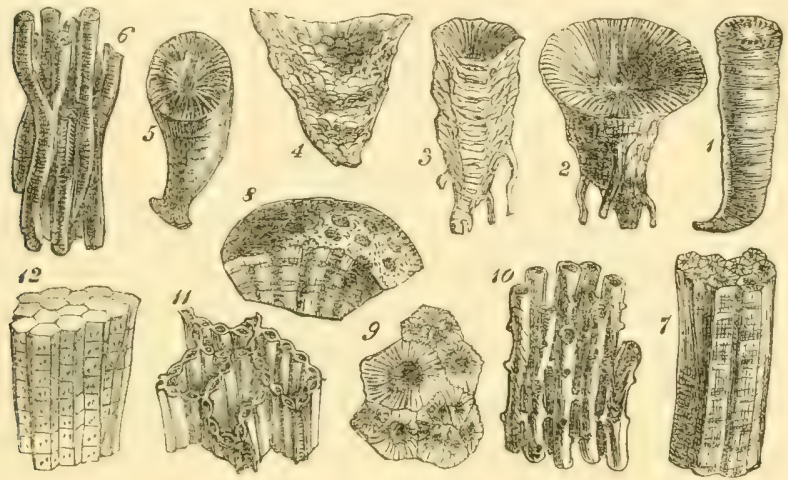

Fin. 4

Palceozoic Corals (Anthozoa).

I. Amplexus Sowerbyi, Ph.; Carboniferous, Ireland.

2. Cyathophyllum turbinatum, Lin.; U. Silurian, Wenlock.

3. Cyathophyllum subturbinatum (section); U. Silurian, Wenluck.

4. Cystiplyyllum Siluriense, Lonsd.; U. Silurian, Wenlock.

5. Zaphrentis Phillipsi, M. Edw.; Carboniferous, Somerset.

6. Lithodendron irregulare, Ph. ; Carboniferous, Europe.

7. Lithostrotion striatum, Flem.; Carboniferous, Europe.

8. Acervularia luxurians, Eich.; U. Silurian, Europe.

9. Heliolites interstincta, Wahl.; U. Silurian, Europe.

I o. Syringopora ramulosa, Goldf.; Carboniferous, Europe.

1 I. Malysites catenulatus, L. ; Silurian, Northern Regions.

12. Favosites Gothlandica, Lam.; Silurian, North.

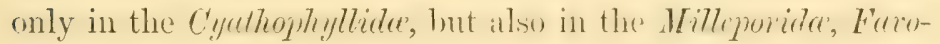

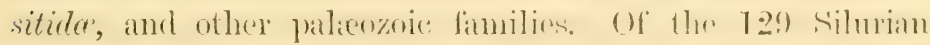
corals, 121 belong to the tabulated divisions. 
The Devonian system contains about 150 described corals, the carboniferous limestone 76 , and the manesian limestone only 5 or 6 . The commonest forms of simple, turbinated corals, are Cyathophyllum (tig. t, 2 and 3), which exhibits four slight fossule in its cup, and is often supported by root-like processes. In Zaplurntis (fig. t, 5) there is but one deep fossula. Amplexus (fig. $4, \mathrm{~s}$ ) is a characteristic carboniferous fossil, nearly cylindrical, and often so straight and regular in its growth as to have been originally described as a chambered shell. The radiating septa are very slight, and the horizontal partitions simple, flat, and almost as regular as the septa of the Orthocerces. In the Silurian C'ystiphlyllum (fig. 4,4 ) the lamellie are also evanescent; but the tabule are represented by numerous vesicular plates. The corals of these genera are not always solitary, or merely in groups; some species of Cyathophyllum constantly form compound masses, with cups rendered polygonal by contact, like C'. regium of the Bristol limestone. The allied genus Accruluria (fig. 4,8) resembles an Astrea, and exhibits, in a remarkable manner, the unultiplication of its corallites by calicular gemmation. The genus Lithostrotion (fig. 4, 7) of the carboniferous limestone is also compact and astraform, lut the new corallites are produced hy lateral gemmation. Corals, with the same structure, but not compact, are known by the name Lithodendion (fig. 4, 6). The "chain-coral" Halysites (fig. t, II) and Syrinyopora. (fig. 4, г) resemble, at first sight, the recent asteroid Tubiporide: in IIcelysites the radiating septa are quite rudimentary; and in Sypingopore the tahnlie are fumnel-shaperl, forming a central axis to each tube. The Fucositide (fig. 4, 12) are mostly very regular both as to their polygonal shape and transverse tabulae; the eells of aljacent corallites are comnected hy pores, either in the sides or angles of the walls ; the serptat are rudimentary. In the genus Chatetes the tulnes are always slender, and much elongated, and their walls imperforate. Mickelinie resembles 
the fruit of the Nelumbium; it has vesicular tabula and root-like processes to its basal plate. Heliolites (fig. 4, 9), of which many species are found in the silurian and Devonian limestones, is related to the recent Millepore. The radiating septa are distinct, and the tabula regular; the interspaces between the stars are filled up with fine and regular tubes. One genus of Fungide (Palcooyclus) occurs in the Upper Silurian.

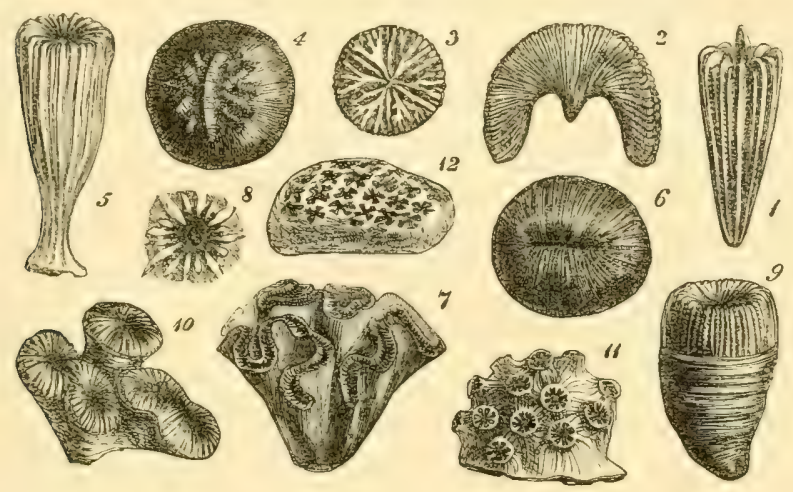

Fig. 5.

Secondary and Tertiary Corals (Anthozoa).

I. Turbinolia sulcata, Lam.; $\boldsymbol{I I}$. Eocene, Europe.

2. Diploctenium lunatum, Brug.; Chalk, France.

3. Micrabacia coronula, Goldf.; U. Greensand, Europe.

4. Aspidiscus cristatus, Lam.; Cretaceous (?), Algeria.

5. Cyclolites elliptica, Lam.; L. Chalk, France.

6. Parasmilia centralis, Mant.; U. Chalk, England.

7. Pachyggra labyrinthica, Mich.; L. Chalk, France.

8. Holocystis elegans, Lonsd. ; L. Greensand, Isle of Wight.

9. Montlivaltia caryophyllata, Lam.; Great Oolite, France.

10. Stylina De la Bechei, M. Edw.; Corallian, Wilts.

I . Thecosmilia annularis, Flem.; Corallian, Wilts.

The British secondary corals are not very numerous ; for although specimens abound in the coral-rag districts, only fourteen species are found in that formation. Altogether, sixty-five species are found in the English oolites, and twenty- 
two in the challe and glecensands. These are mostly dstrcirle, or related to Fungia. Three common forms in the oolites are Montlixaltice (fig. 5, 9), Styline! (fig. 5, ro) and Thecosmilia (fig. 5 , x). The English cretaceous strata afford the Holueystis (fig. 5, 8), which is the most recent conal with quadripartite septar; Trochocyuthes and Perusmiliu (tig. 5, 6), resembling the recent Cyuthina; and the little "Fungia" coronulu (fig. 5,3 ), described in two grenera of distinct orders (Micrubuciu and Stiphenophyllia) in the "Monographlis of the Palieontographical Society." The lower chalk of France and Germany contains many other corals, especially Cyclulites (fig. 5, 5), Pachygyra (fig. 5), 7), and Dipluctenium (fig. 5, z). The Aspidiscus (fig. 5, 4) was sent by Dr. Shaw from Algeria.

The English eocene strata contain twenty-five coruls, all extinct, and belonging to fifteen genera. These include an Astree (Litheree Websteri), which grows on the water-worn flint pebbles; a Balenopleylliu, similar to the existing coral ; a Dondrophyllin, which is the oldest member of the genus ; an Oculine; and eight species of the genus Turbinuliu (fig. 5, r). The corals of the English pliocene are mostly Bryfurou; only four true corals have been found in the coralline crag lelonging to the genera sphenotrochus, Flutullum, Cryptengia, and Bulanoplyglliu, all reputed extinct, although the first is very closely related to the living Sphenotrochus Muccundremi.

The total number of fossil corals enumerated by M. d'Orbigny in the "P'rodrome de Paliontologie," anmounts to 113.5, grouped under 21 (5 genera. Jint notwithstanding all the labour which has hexen lestowed on this hranch of palieontology by coldfuss, Dichelin, Lonstale, and Milne Elwands, species are continually discovered or lirought home from abroal which are altogether new, and cammot lu plated in an! of the constituted genera. 
Class III.-BRYozoA.

Chur:-Tentacles of the polype hollow, with ciliated maryins; alimentary canal with stomach, intestime, and anus; polypary, when mesent, external, horny, and calcareous.

The metamorphose's which the Bryozoc undergo are like those of the lower Polyyi; the embryo developed from the orum is an oval, discoid, or subdepressed body, with a general or partial ciliated surface, by which it enjoys a brief locomotive life after its liberation from the parent. The Bryosoa are allied to the compound $A$ scidiu ; but not one of the ascidian Molluscoids quits the orum as a gemmule swimming by means of cilia; and no Bryozoon quits the orum in the guise of a Cercarian or taclpole, to swim abroad by the alternate inflexions of a caudal appendage. In a progressive and contimuous series of teachings, by pen or word of mouth, the place of an oseulent or transitional group is governed by convenience, by considerations of how best to teach by comparison and easy gradation. The real merits of the man who would make scientific capital hy changing the position of such groul, and by imputing crror or ignorance to the author from whom he may differ in this respect, are easily weighed and soon understood.

The Bryozod, whether regarded as the highest organized Polypes, or as the lowest organized Mollusea, or as an intermediate type, are treated of in systematic palaontology in the position here assigned to them. The practical palieontologist finds himself compelled to arrange and study the fossil Bryozoc along with the corals, if only on account of the dificulty he, in many cases, experiences of determining to which dass of Polypi his specimens belong. M. dOObigny, who has devoted much attention to this ralss, ('mumerates 5tt fossil

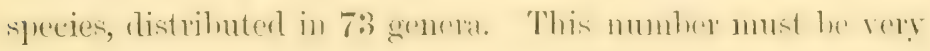


far below the real one, since the Bryozoc of the chalk, which alone have been carefully examined, anount to 213 species; while only two species are known from the trias, none at all from the lias, and only five from the upper oolites, so rich in corals and sponges. In the "Cours Elémentaire" of d'Orbigny the fossil Bryozoa are stated to amount to 1676 .

Of the 19 or 20 palieozoic genera, none extend into the secondary strata; but of the 18 oolitic genera, Eintalophore and Defrencic range onwards to the tertiaries; and Alecto, Idmenea, and Eschara still survive. The oldest known fussil, Oldhemia (fig. 3, 2), is supposed to be a Bryozoon. The most common palæozoic form is Fenestrella (fig. 3, r1), resembling the recent "lace-coral"; there are 35 species, ranging from the Lower Silurian to the Permian. One of its modifications resembles a feather (Ptilopora, fig. 3, 10), and is found in the carboniferous limestone. Another, more remarkable, las a spiral axis (Aretimedipore, fig. 3, 9), and occurs in the same formation in Kentucky. One of the oldest genera is Ptilodictyce (fig. 3, 8), of which seven species are found in the Lower Silurian formations. The slabs of Silurian limestone obtained at Dudley are covered with myriads of small and delicate fossils, including many Bryozod. Some of these are spread like a film over other fossils, and have been doubtfully referred to the modem genera Discopora and Bereniced; others, with slender branches, and erect or creeping, are called Nilleporas, Heteroporas, and Escharinas. The genus Cenites (fig. 3, 7), perhaps belongs here. The magnesian limestone contains several large "lace-corals" of the generia Fenesticlle, S'ynoctedia, and Phyllophora; and two lramehing species of Thamniscus and deanthoclatie. The oolites aflord many small incrusting species related to Diastopora, and branching forms like Terduellarie and Chrysecore. In the challi, the Esscheres are most numerous, and Lumulites and C'upulerie first appear. Some thin beds of the lower chalk are almost composed of 
Bryozoc, mingled with Forcminifere. The coralline crag of Suffolk takes its name from the great abundance of Brygzoce it contains, among which Eschera, Cellepora, Fascicularia, Theonoa, Hornera, Idmonea, Flustra, and Tubutipora are the most important.

\section{Class IV.-ECHINODERMIATA.}

(Star-Fishes, Sea-Urchins.)

Char:-1Iarine; commonly free, repent animals, with the integument in most perforated by erectile tubular tentacles, hardened by a reticulate deposit of calcareons salts, and in many armed with spines.

The fossil Radiata present a mine of comparatively unexhausted riches to the paliontologist. More difficult of study than shells, and less uniformly present in all strata, the enduring remains of echinoderms and corals are unsurpassed in beauty of form and structure, and in the value of the evidence they afford.

The present summary of the extinct forms of Echinodermate will commence with

\section{Order 1.-Crinoidea.}

Cheir-Body with ranified rays, supported temporarily or permanently on it jointed calcareous stem ; alimentary canal, with mouth and vent, both, as in Bryozoa, approximated.

The "stone-lilies," or crinoid star-fishes, formed a numerous and important group in the palieozoic seas, where they obtained their maximum number and variety. MI. d'Orligny describes thirty-one palreozoic genera, two triassic, ten oolitic, and four cretaceous-of which latter three (Pentacrinus, Bourgucticrinus and Comatula) are found in the tertiaries and mo- 


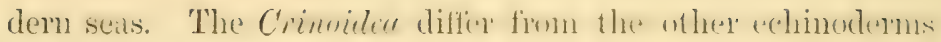
in having the generative oreans eomlineel with the arms, and opening into special orifices near their hase. Nearly all the

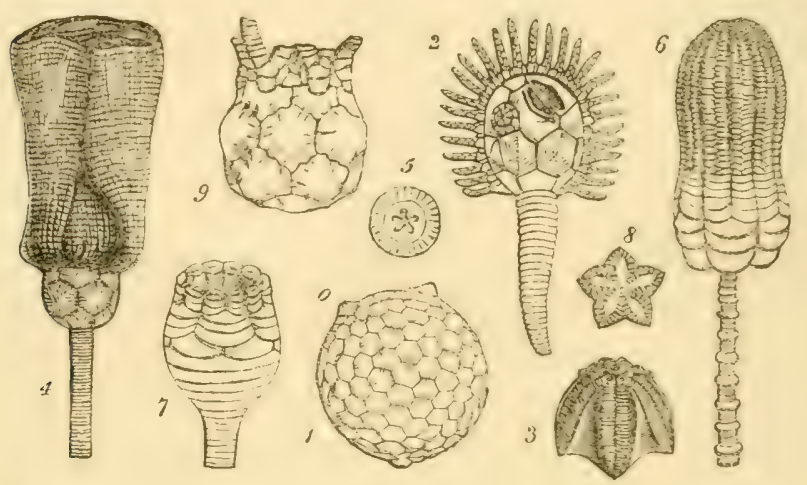

Fig. 6.

Crinoidea; Blastoidea; Cystoidea.

I. Sphreronites aurantium, Wahl.; L. Silurian, Sweden.

2. Pseudocrinus bifasciatus, Pearce; U. Silurian, Dudley.

3. Pentremites florealis, Say; Carboniferous, Ohio.

4. Crotalocrinus rugosus, Mill.; $U$. Silurian, Dudley.

5. Poteriocrinus (joint of column); Carboniferous, Iorkshire.

6. Encrinus entrocha; L. Muschellalk, Germany.

7. Apiocrinus Parkinsoni, Mill.; Bradford Clay.

8. Pentacrinus basaltiformis, Mill. ; Lias, Lyme.

9. Marsupites ornatus, Mill.; Chalk, Sussex.

genera, except Comatula and Mersupites (fig. 6, 9), alppear to have been attached either hy the expanded hase of the erolumn, as in Aprocrinus, or by jointed processes, as in Bouryneticrines. In many instances the lower part of the eolumm thews out immunerable root-like side-arms, which stremethen anel suplort it. The columm is comparatively short in Apiocrines Porlinsoni, and extremely elongated in Pentacrimus Hicmeri. It is romel in nearly all the palarozoic Crinoirls; and when fivesided, the articular surlaces of the joints ane simply latiaterl, as in the rest. These joints are perforated in the centre, and 
when detached, are the "St. C'uthbert's beads" of story (fig. 6, 5).* In Platycinus the stem is compressed, and the articular surfaces are elliptical. In the gemus Pcntacinus, which commences in the lias, the sculpturing of the articulations is more complex (fig. 6,8 ), but it is quite simple in the other modern genera. The body of the Crinoid is composed of polygonal plates forming a cup, which is corererl by a canopy of smaller plates. The mouth is often proboscidiform ; the anal orifice is near it. The five arms which crown the cup are sometimes nearly simple, but feathered with slender, jointerl fingers; in other genera they divide again and again, dichotomously; and in two remarkable Silurian forms, Anthocrinus and Crotalocinus (fig. 6, 4), these subdivisions are extremely numerous, and the successive ossicles are articulated to each other laterally, forming weh-like expansions, similar in appearance to the coral Fenesticlla (fig. 3, ir). Other remarkalile Silurian ('rinoids belong to the genera Glyptocinus, Eucalyptocrinus, Georinus (the "Dudley Encrinite") and Caryocrimus. Several are common to the Silurian and Devonian, as $I / C$ locrinus, Cyuthocrinus, and Rhodocrinus; the two last, and Poterioerinus, extend into the carhoniferous formations. C'umessocimus and some others are feculiarly Deronian; Platycrinus, common to Deronian and coal formations; and many genera (including the "nave Encrinite"-Actinocrinus, Gitbertsocinus, and Wooducrimes), are lroper to the carboniferous limestone. The famous "lily Encrinite" (Encrinus cntrocher, fig. 6,6$)$ is characteristic of the middle trias, or "muschelkilk ; the "clove Encrinite" (Eurgeniacrinu, fig. 7, 9) ahounds in the Oxfordian oolites of Germany; A procinus, Millericrinus, and several forms related to Comatule-c.y., Pterocomu and Seccosoma-are also peeuliarly oolitic. The "tortoise

* Casts, in chert, of the canal which passes down the crinoidal column are called "screw stones;" and those limestones which abound in columns and detached joints are called "entrochal marbles." 
Encrinite" (Marsuprites, fig. 6,9), is found only in the chalk, along with Bourgucticrinus (fig. 7, го); and the boties of $\mathrm{CO}^{\mathrm{O}}$ matule, which, when they have lost their ams ant claspers, are called "Crlenotremites." (Fig. 7, 7,-upper surface with sockets of the five arms ; 8,-under surface, showing articulations of claspers, and the scar of the larval stem.)

\section{Order 2.-CystoIDEA.}

'This order was established by Von Buch for a small group of palæozoic echinoderms formerly included with the $\mathrm{C}$ inoidec. They have a globular body covered with close-fitting polygonal plates attached by a simple jointed sten. The mouth is minute, and opposite to the stalk; close to it is the small anal opening; and a little more distant the generative orifice, covered by a pyramid of five or six little valves. Some of the genera, like Pseudocrinus (fig. 6, 2), have two or four tentaculiferous arms, bent down over the body and lodged in grooves, to which they are anchylosed. Others, like the Spharonitcs (fig. 6, r), have only obscure indications of tentacles situated close to the mouth. In Psendocinuses and some. other genera two or three pairs of lamellated organs, called pectinated rhombs, are placed on the contiguous margins of certain body-plates. They are supposed not to penetrate the interior, and no office has been conjecturally assigned to them; but Professor Forbes sugrgested that they might represent the " epaulettes" of the larval Echimile, to which group he supposed the Cystidean bore the same relation as the Crinoids hold to the star-fishes. There are nine genera, of which eight are found in the British strata - four in the upper and four in the lower Silurian. 


\section{Order 3.-BLAstoidea.}

A separate order has been proposed for another small group of palieozoic fossils typified by Pcnticmites (fig. 6, 3 ). The body is globular or elliptical, and supported on a small, jointed stalk, with radiated articular surfaces and irregular side-arms. It is composed of solid polygonal plates, with a minute oral orifice at the summit surrounded by five other openings, four of which are double and ovarian, the fifth rather larger and anal. There are five petaloid ambulacra of variable length, converging to the mouth, furrowed down the centre, and striated across. According to the observations of Dr. Ferdinand Romer, these supported numerous slender, jointed tentacula, indicated by the rows of marginal pores. One species is found in the upper Silurian, six in the Devonian, and twenty-four in the Carboniferous, which has received the name of "pentremite limestone" in the United States, on account of the abundance of these fossils it contains.

Order 4.-Asteroidea.

(Sea-Stars, Brittle Stars.)

Chur.-Body radiate; integument hardened by calcureous pieces, and more or less armed with spines ; no dental apparatus.

Asteriada and Ophiurida.-Fossil star-fishes, though less common, have a wider range than their allies the fossil urehins, being found amongst the earliest organic forms. Paloaster, Protaster (fig. 7, 6), and Lepiduster (fig. 7, 5), are Silurian starfishes, presenting many anomalies, and scarcely referable to any existing families. Tropidaster, Pleuraster, Aspidura, Opthiniella, and Amphiure are oolitic genera; Ophiodermu, Luidia. istropeten range from the lias to the present seas: Stellastri 
and Arthrester are peculiar to the cretaceous ; and Ophiure,

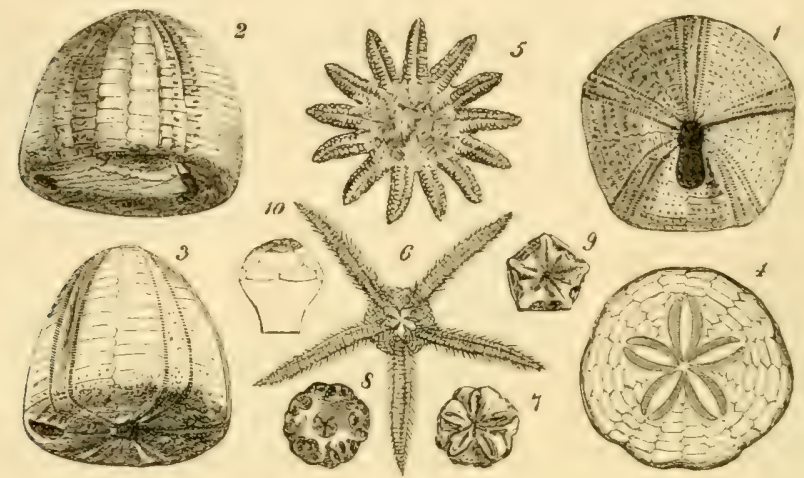

Fig. 7 .

Galeritidce; Asteriadce; Crinoidea.

1. Pygaster semisulcatus, Ph.; Inf. Oolite, Cheltenham.

2. Ananchytes ovatus, Lam. ; $U$. Chalk, Europe.

3. Galerites albogalerus, Lam.; $U$. Chalk, Kent.

4. Scutella subrotunda; Miocene, Malta.

5. Lepidaster Grayi, Forbes; U. Silurian, Dudley.

6. Protaster Miltoni, Salter; L. Ludlow rock, Salop.

7. Comatula (Glenotremites), upper surface of body.

8. Comatula (lower surface); Chalk, Sussex.

9. Eugeniacrinus quinquedactylus, Schl.; Oxfordian, Wurtemberg.

ı. Bourgueticrinus ellipticus, Mill.; Chalk, Kent.

Astrogonium, Oreaster, and Goniodiscus are both cretaceous and living.

\section{Order 5.-EchinoIdeA.}

\section{(Sea-Urchins.)}

Char:-Body spheroid or discoid, incased in a crust of inflexilhly-joined calcareous plates, and amed with spines: dental system complex, arranged so as to resemble a "lantern."

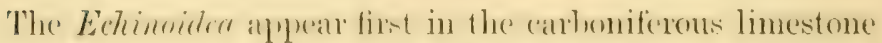
and attain their maximum in the eretaceous strata. In all 
secondary and more modern Echinide, the shell is composed of five double rows of ambulacral plates, and five inter-ambulacral; but in the Pulcetinus (fig. 8, г) of the carboniferous limestone there are six rows of inter-ambulacral plates, and in Perischodomus five. Only detached plates of Archoocidui:
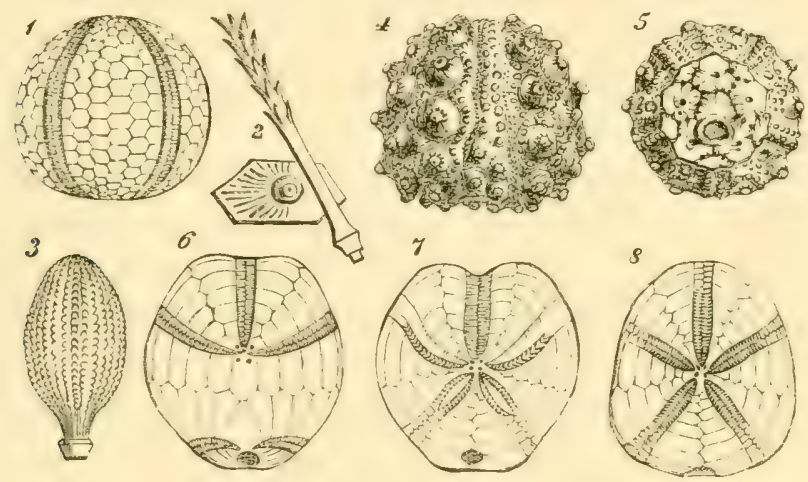

lig. 8.

Echinida; Spatangidce.

1. Palæchinus sphæricus, Scouler; Carboniferous, Ireland.

2. Archæocidaris Urii, Flem. ; Carboniferous, Ireland.

3. Cidaris glandifera, Goldf. (spine); Jura, Mount Carmel.

4. Hemicidaris intermedia, Flem.; Corallian, Calne.

5. Salenia petalifera, Desm.; $U$. Greensand, Wilts.

6. Disaster ringens, Ag.; Inferior Oolite, Dorset.

7. Hemipneustes Greenovii, Forbes; U. Greensand, Blackdown.

8. Catopygus carinatus, Goldf.; U. Greensand, Wilts.

(fig. $8, z$ ), have been seen, and these, by their six-sided form, seem also to have been arranged in more than double series. Normal Echinide, of the existing genus Cidaris, abound in the upper trias. Some of the secondary species of Cidaris have the ambulacral pores widely separated (-Rhabdocirluris); in others the rows of pores are doubled (=Diplocidaris). The genus Itemicidaris (fig. 8, 4), distinguished ly. the large spine-bearing tubercles on the lower part of the ambulacrat, ranges from the trias to the chatk-nnarl. Dirrtime, 
with smooth, solid spines (=IItmidiudema), appear in the lias, and continue to the chalk, where the modem type, with ammulated, hollow spines, appears. Echinopsis also occurs in the lias; and Acroseleniu, a genus characteristic of the oolites, and distinguished from Sulcnic by its perforated tubercles. Acrocideris and Hcliociduris, with Glypticus, and several other sub-genera of Echinus, are also peculiar to the oolites. Sulcnia (fig. 8,5 ) with its ornamental disk, is characteristically cretaceous. Arbacia and Temnopleumes appear first in the eocene. The Cassidulidee commence in the oolites, with Pygaster (fig. $7, \mathbf{x})$ and Holcctypus, and abound in the cretaceous system. Gallerites (fig. 7, 3), Discoideu, Pyrinu, and Cassidulus are peculiar to the chalk. The Clypectstrida are represented in the oolites by numerous species of Echinolampers and Nucleolites (or Clypous); the latter genus attains a large size. The subgenus Catopygus (fig. 8, 8) is peculiar to the cretaceous series. Conoclypeus occurs in the chalk and tertiaries. Clypeuster flourished most in the miocene age; many large species are found in the south of Europe, Madeira, and the West Indies. Numerous genera, remarkable for their flattened form, and popularly known as "calie-urehins," are peculiar to the tertiaries and existing seas. Lenite and Scutellince are eocene: Scutclle (fig. 7, 4) is miocene. Mcellita and Echinarcchnius are both fossil and recent. The heart-shaped urehins (Spatanyidce), are only remotely represented in the oolites by Disaster (fig. 8, 6) ; they are numerous in the chalk, to which Micruster. Épicester, IIcmiqmenstes (fig. 8, 7), Archiucie, IIoluster, and Anenchytes (fig. 7,2 ), are peculiar. Tor'ester is characteristic of the lower neocomian. Hemierster is eretaceous and tertiary.

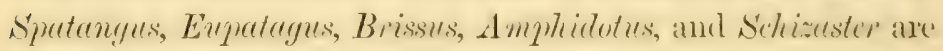
tertiary and recent forms.

The shell of the Echinodermate has the same intimate struedure in all the onders and families, and in every part of the skeleton, whether "test," or "spine," or "tooth." The 
smallest plates resemble bits of perforated card-hoard, and the largest and most solid are formed of a repetition of similar lamine. In a few membranous structures, minute spicula, curved, bi-hamate, or anchor-shaped, are met with. They are always composed of carbonate of lime; but owing to their porosity, fossil examples are commonly impregnated with carth, or pyrites, or silica, and form bad subjects for microscopic investigation. Without, however, losing their organic structure, the fossil Echinoderms exhibit a cleavage like that of calcareous spar, by which the smallest ossicle of star-fish or Crinoid may be recognised : this peculiarity is most strikingly obvious in the great spines of the Cidaris (fig. 8, 3), or the enlarged column of the "pear Encrinite" (fig. 6, 7). Examples of the latter may be seen which had been crushed when recent, and before the sparry structure was superinduced.

\section{Order 6.-Holothurioidea.}

(Sea-Cucumbers, Trepang.)

Char.-Body vermiform; integument flexible, with scattered reticulate calcareous corpuseles, or beset with small anchor-shaped spicula.

The Holothurioid order presents scarcely any examples likely to be met with in a fossil state, except the genus Psolus, of whose imbricated shield a fragment has been found by Mr. Richmond in the northern drift of Bute. Count Münster has figured the microscopic plates, apparently of a Holothuria, from the chalk of Warminster; and the anchor of a Synapta from a still older formation,-the upper oolite of Bavaria.* Microscopic observers will doubtless meet with many such detached plates and spines when searching for Polycystince and other Rhizopods in the oolitic and cretaceous strata ; but it is scarcely probable that the order has dated far back in time.

* Beitrage, heft $6,1843$. 


\section{P'ROVINGE II.-ARTICLLATA.}

In the great division of invertelyrate animals called Articulate the brain is in the form of a ring encircling the gullet. A double ganglion alore the tube supplies the chief organs of sense. The ganglions below the tulue are comnected with two chords which extend along the ventral surface of the abdomen, and are in most species united at certain distances by double ganglions, which are connected with the nerves supplying the body segments and their appendages. The body presents a corresponding symmetrical form. The skeleton is external, and consists of articulated segments of a more or less annular form. The articulated limbs, in the species possessing them, have a like condition of the hard parts, in the form of a sheath which incloses the muscles. The jaws, when present, are lateral, and move from side to side.

The worm, the lobster, the scorpion, and the bectle, exemplify this province.

The articulate division of the animal kingdom, most unirersally distributed and numerically abundant at the present. day, is least perfectly represented amongst the relics of the former world. Their chitinous integuments, often hardened with earthy salts, are quite as capable of preservation as the shells of the Hollusea, and remains of them are met with in all arqueous deposits; hut that manifold, complex organization, which in the recent state fits them so admirably for generie and specific comparisons, is fatal to their entire preservation, and the fossil examples are often so fragmentary as to adnit of little more than the determination of their class and family.

The most ancient fossiliferous rocks bear imprints which have been reganded as the tracks and hurrows of marine worms. With these are foumd Crustacea of the lowest division, and of a group which is wholly extinct. A little later appear the 
Phyllopods, Copepods, and other existing order's of Entonostraca. Only a few obscure forms, doubtfully referred to the higher division, Malacostraca, have been found in the carboniferous and Permian systems. The secondary strata contain abumdant remains of Isopods, and of lobster's and hermit-crabs. True crabs (Brachyura) abound in the oldest tertiaries. Airlreathing insects and Arachnida existed even in the palieozoic age; the "sombre shadles" of the carboniferous forests were not " uncheered by the hum of insects ;" nor were the insects blind, like those which now inhabit the vast eaverns of Kentucky and Camiola. The Articulute which eome latest are the Cimipedes, whose lowest family appears in the lias; while the Balanida are only found in the tertiaries.

The number of fossil Articulata catalogued and described forms but a very small proportion of those which have probably existed. Brom enumerates 1551 fossil insects, 131 arachnids, $89 \mathrm{t}$ crustaceans, and 292 anellides. Darwin describes 69 fossil cirriperles, 12 of which are living species.

\section{CLASS I.-ANNTLATA.}

(ITorms, Tube-Worms, Nereids.)

Char.-Body soft, symmetrical, vermiform, annulated, with suckers, or setre, or setigerous tube-feet; blond of a red colour in most.

The peculiar markings on the surface of the old Cambrian slate rocks, conjectured to afford the earliest indications of the existence of marine worms, are not without suspicion as to their origin. The so-called "Nereites" bear considerable resemblance to other equally ancient impressions which have been described as Zoophytes, under the name of Protorirgulevia (fig. 3, r). No such doubt attaches to the worm-tracks which abound in the thin-bedded sandy strata of the forestmarble; and the "Colnlites" of the lithngraphic limestone are 
most probably the eastings of worms. Long ealeareous tubes oceur in the upper Silurian and carboniferous strata, which have received the name of Scrmilites. The Microconchus of the carboniferous period is now regarded as an Anellide; and in all the later formations, tubicolar Anellides, especially of the genera Scrpula, Spirortis, and Vermitia abound. Some of these, although attached and gregarious, are so regular in their growth as to have been usually ealled Vermeti, but are now placed in the genus Vermicularia. Spiroglyphus, and some other shell-exeavators, are indicater in the tertiaries. Amongst the problematic fossils of the palrozoic strata, two are supposed to be anellidous, viz., the Tentaculites (fig. 10, 7), which was apparently free, and almost always regular in its growth, so as more to resemlle one of the gregarious Pteropods; and the Coinulite (fig. 10,8), which is attached when young, singly or in groups, to Silurian shells and corals: the structure of its shell is vesicular, and the cavity resembles a series of inverted cones. The unattached and gregarious Ditrupa appears in the upper chalk, and abounds in the London clay and crag.

\section{Class II. - CIRRIPEDIA.}

\section{(Barnacles, Acorn-Shells.)}

Chur.-Body chitinous or chitino-testaceous, subarticulated, mostly symmetrical, with aborted antennæ and eyes; thorax attached to the stemal surface of the carapace, with six pairs of multiarticulate, biramous, setigerous limbs; metamorphosis resulting in a permanent parasitic attachment of the fully-developed female to some foreign body.

The fossil Cirripedes belong chiefly to the sessile division, and consist of the ordinary forms of the still-existing Bulanide. They are rare in the eocene tertiary, lout more abundant afterwards. The Balanus porcutus attrins a great size in the shelly 
leeds of northern drift; its large basal plate, when detacherl, is a puzzling fossil, and has caused some mistakes. A Coromulu has been found in the middle division of the crag which has afforded so many cetaceous bones. Remains of pedunculated Cimipedes occur in older deposits, but are mostly scarce and fragmentary. A species of Pollicipes is found adhering to drift-rrood, perforated by bivalves, in the lias; another occurs in the Oxford clay, attached in groups to drift-wood, and the shells of Ammonites, which probably floated in the sea after death. The chalk affords many species of Pollicipes and Scrtpellum, a species of the anomalous genus Treruce, and the only extinct genus of Cimiperles-Loricula (fig. 10,6). This remarkable fossil is found attached to Ammonites, and exhilits only one side in any of the examples litherto found. In this unsymmetrical development and the imbrication of its valves it more resembles Termece than any other Cirriped. "During the deposition of the great cretaceous system, the Lepadide arrived at their culminant point: there were then three genera, and at least thirty-two species ;" whereas at the present day the Philippine Archipelago, which is the richest marine province, affords but five species.

\section{Class ITI. - CRUST A CEA.}

Char.-Body articulated, with articulated limbs; hearl with antennx ; branchial respiratory organs ; sexes distinct ; metamorphosis in most, in none resulting in fixed individuals.

\section{Sub-Class 1.-ENTOMIOSTRACA.}

Char-Body with more or fewer segments than fourteen: integument chitinous, forming in some a bivalve shell, eyes sessile.

Small hivalve entomostracous Crustacea are formd in all 
strata, and attain their maximum size in the vhler rocks. Minute Ostracoclu, related to the recent Cypu is (fig. 10,5), swarm in the laminated fresh-water clays of the Wealden; whilst the marine Cytherilce assist with their multitudinous atoms in building up the chalk. Amongst the Plyyllopods, the gregarious Estheria covers the slabs of Wealden and of Keuper with crowds of bivalve shells which have been commonly mistaken for Cyclades and Posidonomya. Estheria abounds in the

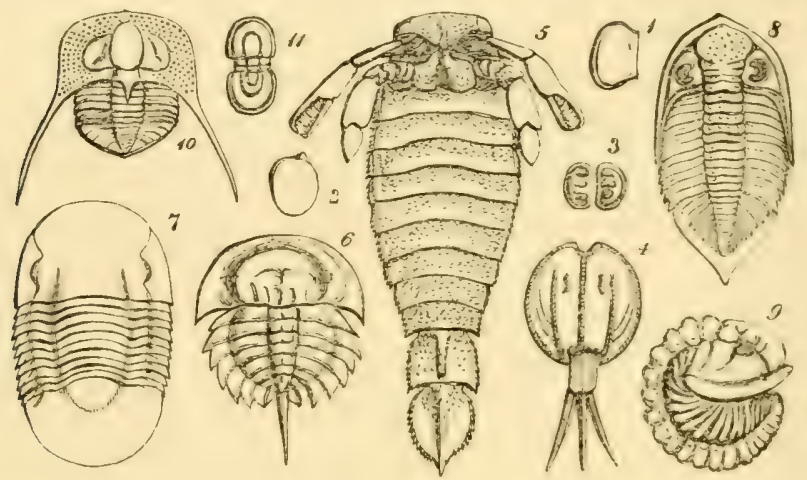

Fig. 9.

Palcozoic Entomostraca.

1. Leperditia Baltica, Wahl.; U. Silurian, Gothland.

2. Entomoconchus Scouleri, M'C.; Carboniferous, Ireland.

3. Beyrichia complicata, Salter; L. Silurian, Wales.

4. Dithyrocaris Scouleri, M'C.; Carboniferous, Ireland.

5. Pterygotus Anglicus, Ag.; Old Red Sandstone, Ludlow.

6. Bellinurus bellulus, König॰; Carboniferous, Coalbrookdale.

7. Illenus Davisii, Salter; L. Silurian, Bala.

8. Phacops caudatus, Brnn.; U. Silurian, Dudley.

9. Calymene Blumenbachii, Br.; U. Silurian, Dudley.

10. Trinucleus ornatus, Sternb. ; L. Silurian, Britain.

II. Agmostus trinodus, Salter; L. Silurian, Britain.

Caithness flags of the middle Ieronian series. The globose Entomoconchus (fig. 9, 2) is found in the carboniferous limestone; Leperditia (fig. 9, r) in the Silurian rocks of the north : and Beyrichie (fig. 9, 3), which is characteristically Silurian. 
may be distinguished from the young forms of Trilobites hy the unsymmetrical shape of its separated valves. Other paleozoic Phyllopods (Ceratiocaris and Hymenoceris) related to the recent Nebalia, and having a conspicuous tail, occur in the upper and lower Silurian strata ; the genus Leptocheles ( $\mathrm{I}^{\circ} \mathrm{C}$.) was founded on the tail-spines of these C'mustacea. Dithyiocaris (fig. 9, 4), which resembles the recent Apus in the horizontal compression of its carapace, is found in the carboniferous limestone. The lower coal measures also contain, in their nodules of clay-ironstone, frequent exauples of Bellinurus (fig. 9, 6), a small Poecilopod, differing from the recent king-crab (Limulus) in the moveable condition of the loodysegments. But the most extraordinary of the palixozoic Crustacea are the Eurypterus, Himantopiterus, and Ptorygotus (fig. $9,5^{*}$ ), from the Lpper Silurian and Old Red Sandstone, of which some far surpassed the largest living lobster or kingcrab in size. They have been considered an extinct family, related to the Limuli; or as the representatives of the larral condition of the stalk-ered Malacostrace. But the following structures show an affinity to the Ostrocodo. Their carapace is comparatively small, with compound eyes on the antero-lateral margins; the body segments are eleven or twelve in number, without appendages, and terminated by a pointed or hilobed tail. Eurypterus has eight feet; the others have three pairs of limbs-viz., the chelate antenne, the foot-jaws, and the natatory feet, with their fin-like palettes, which spring from the under side of their cephalo-thorax. The surface of the borly and limhs often presents a peeuliar imbricated seulpture, which caused them at one time to be regarded as fishes hy Agassiz. The Pterygotus problematicus is supposed to have attained a length of seven feet, and some of the others were a yard long. C'rustacea of this magnitude may have formed tracks on the

* This figure (by Mr. Salter) as well as several others, are taken from the Siluria of Sir R. Murchison, P.G.S. 
sea-bed, like those on the Potsdam sandstone of America, called "Protichnites," sulosequently to he described.

\section{Order Trilobites.}

Char:-Trunk segments trilobed; sessile compound eyes in most ; limbs aborted.

The great family of Trilobites is entirely confined to the palienzoic age ; none are found even in the upper coal measures or Permian system. Above 400 species have been described, and grouped in 50 genera. Of these 46 are Silurian, 22 Devonian, and 4 carboniferous. According to Bronn, 13 genera are peculiarly Lower Silurian, 3 Upper Silurian, 1 Deronian, and 3 carboniferous.

The skeleton of the Trilobite consists of the cephalic shield, a variable number of trunk-rings or segments, and the pygidium or tail composed of a number of joints more or less anchylosed. In some species a labmu (or "hypostome") has been discovered, but no indications of antennse or limbs have ever been detected ; still there can he no donbt they enjoyed such locomotive power as even the limpet and chiton exhibit when requisite. Variations in the length of the cephalic and caudal spines (c.g. in Ascuphus caudatus and longi-caudatus), and in the prominence of the head-lobes, have been considered indications of difference of sex. One of the oldest and simplest forms is the minute Agnostus (fig 9, г1) ; it is usually found in little shoals, with only the cephalic shield preserved, as if it were the larval form of some large Trilobite. According to the olservations of M. Barrande, the Sao passes through twenty stages of growth, being first a simple dise, and ultimately having seventeen free thoracic segments and two caudal joints ; the additional segments are developed between the thorax and abdomen. The Trinueleus (fig. 9, 10) with its ornamental horder, and Illenus (fig. ?, 7), in which the tribhation is less enn- 
spicuous than in most genera, are characteristic of the Lower Silurian strata. Two others from the Wenlock limestone have long been celebrated, viz., Calymene (fig. 9, 9), or the "Dudley Trilobite," so compactly rolled up; and Asciphus (or Phacops) cuuclutus (fig. 9, 8), in which the lenses of the large eyes are frequently well preserved, and visible without a glass. Each eye has at least 400 facets, and in the great $A$ sophus tyrannus each is computed to hare 6000. In one species (Asciphus Korculcustiii) the eyes are supported on peduncles. The largest Trilobite is Asaphus gigas; some of the fragments inclicate a creature eighteen inches long:

\section{Sub-Class 2.-MIALACOSTRACA.}

Char:-Body divided into thorax and abdomen, with seven segments in each.

The Isopods are represented in the upper oolite by $\mathrm{Arch}$ wuniscus Broctici, which is gregarious, in large numbers in the slabs of Purbeck linestone; and in the Pernian system by the Prosoponiscus (or Palcocrangon). The problematic Pygocepllaclus, and the "Apus dubius," both from the carboniferous strata, are doubtfully referred to the Stomapoda, and, with the exception of the Gitociangon of Richter, are the oldest of the known stalk-eyed Decapods.

Macrourous Crustacea are of constant occurrence throughout the oolites and cretaceous strata. One of the most remarkable forms, Eryon (fig. 10,3), is found in the lias (with the closely-allied Tropifer and Colcia) and in the Oxford clay. The small lobsters of the genus Glyphou, in the oulites, and Mcyeria, in the Speeton clay and greensand, are commonly the nucleus of hard nodules of phosphate of lime. The larger species of the chalk form the gemus Enoploclytiu. The Oxfordian oolite of solenhofen, with its finely-laminated lithographic slates, opens like a bonk filled with compressed and wonder- 
fully preserved shrimps and lobsters. One of them, remarlable for its long and slender arms (Megachirus, fig. 10, 4), is also found in the Oxford clay of Wiltshire. One of the most remarkable repositories of fossil C'ustacea is the Isle of Sheppy, where the "London clay" has afforded countless examples of

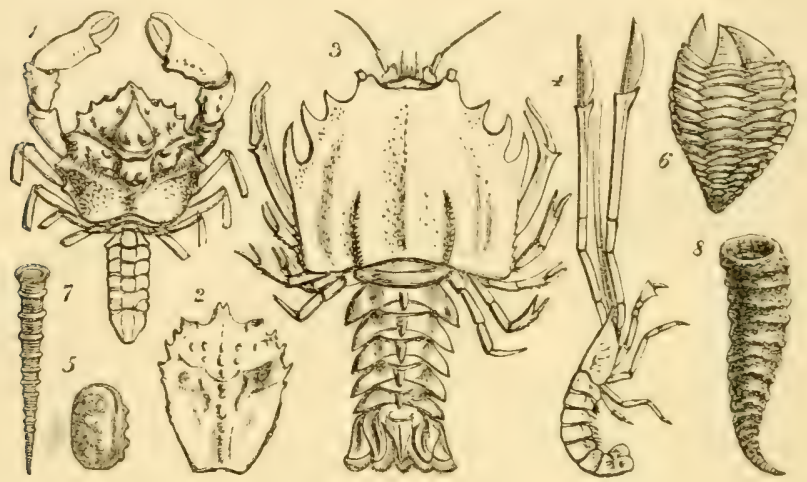

Fig. 10.

Crustacea; Anellida.

1. Dromilites Lamarckii, Desm.; London Clay, Sheppy.

2. Notopocorystes Stokesii, Mant.; Gault, Folkestone.

3. Eryon arctiformis, Schl.; Oxfordian, Solenhofen.

4. Megachirus locusta, Germar.; Oxfordian, Solenhofen.

5. Cypridea tuberculata, Sby.; Weald, Sussex.

6. Loricula pulchella, G. B. Sby.; $L$. Chall, Sussex.

7. Tentaculites ornatus, J. Sby.; U. Silurian, Dudley.

8. Cornulites serpularius, Schl.; $U$. Silurian, Dudley.

the higher organized division, including nine Brachyura, three Anomura, and five macromrous species. The island of Hainan, on the coast of China, abounds with fossil cratos of the grenus Macropthalma, which are sold in the drug-market of Shanghate. Others are found in the miocene of Malta, and of P'rim Island in the Red Sea. The reputed instanees of secondary Bruchyure. are open to doulit; in England we have only the little Etyus Martini (or Reussia) from the gault, for the Podepitumnus (MC.) is probably from some foreign tertiary eleposit. Tairs 
of chelate claws oceur in the upper chalk, which are referred to a hermit-crab (Mesostylus Fanjasii). Small Crustaceans, resembling in form the living Corystes, abound in the gault (fig. 10,2), but they are known to be anomourous by the small size and dorsal position of the posterior legs, and by the little plates intercalated between the last joints of the tail, as seen also in the Dromilites (tig. 10, r) from the London clay.

\section{Class IV.-INSECTA.}

Cher:-Body ehitinous, articulated, with articulated and uncinated limbs; head provided with jointed antemne; respiratory system tracheal.

The fossil insects hitherto examined have afforded no new types or forms of unusual interest. The oldest known, those from the lower coal measures, resemble the Curculionide and Blattide or Locustide of the present day. The lias limestones have afforded a greater variety to the persevering slill of $\mathrm{Mr}$. Brodie: species of the genera Berosus, Elater, Gyrinus, Laccophilus, and Mclolontha, and undetermined genera of the families Carabida, Buprestida, Chrysomelida, and Teleghorida; Panorpa-like insects of the genus Orthophlebia; dragon-flies, Nepude and Cimicide, Cicada, and the dipterous genus Asilus. Next in age is the insect depository of the Stonesfield slate, which aftords the large wing-covers of Buprestis Buctilendi, species of Prionus and Coccinella, and the great neuropteran Hemerobioides. The Purbeck limestone has supplied, in addition, species of Cerylon and Colymbetes, Cyphon, Helophorus, and Limnius; and examples of Staphylinida, Cantharida, Harpalide, Hydroplitide, and Tenebrionider, Libellulde and Phryyance, Achete and Blatta, Aphis, Cercopis, and other Homoptera, and ten dipterous genera. In the newer pliocene fresh-water formations the recent Copmis huaris has been detected, and the elvtra of Donacier and Hamalus. 'The principal 
foreign sources of fossil insects have been the lithographic slates of Solenhofen, and the tertiary deposits of Aix in Provence, and Eningen, near Constance, on the Rhine. Remains of species of Tince and Sphinx are said to have been found in the lower Jura, and of a diurnal Lepidopterin in the Molasse. Numerous examples of insects in true amber have been obtained, and much more abundantly in "gum animi," a more modern fossil resin. These are all unknown to entomologists, and are probably extinct, since no department of recent natural history has been so closely worked, although the fossil insects have been comparatively neglected. It has been suggested by Mr. Westwood that the lias insects have a subalpine charaeter, and may have been brought down by torrents from some higher region. But no attempt has been made to show whether these or any other group of fossil insects most nearly resemble those of any particular zoological province of the present day.

Much has been said of the "indusial limestone" of Auvergne, supposed to be built up of the fossilized cases of caddiswoms (Phrygancidec); but Mr. Waterhouse, the only entomologist who has visited the country and examined the formation, entertains doubts of the correctness of this interpretation.

Of the Myriapoda, 17 fossil species have been found, commencing in the oolitic system. And of the Arachinile, 131 species are catalogued; the earliest and most interesting of these is the fossil scorpion (Cyclopthutmus scuior) of the Bohemian conl measures (figured in Buckland's Brielyenceter Treatise). Fossil spiders are found in the Solenhofen slates and in the tertiary marls of Aix.

\section{Province III.-MLOLLUSCA.}

liemains of the Testecen, or shell-heaning mollusens animals, ane the most enmmon of all fersils, and afford the most 
complete series of "medals," or characteristic signs for the identification of strata. The duration of types and species, as a general rule, is inversely proportional to rank and intelligence. The most highly organized fossils have the smallest range, and mark with greatest exactitude the age of the deposit from whence they have been derived. But the evidence afforded hy shells, if less preeise, is more easily and constantly ohtained, and holds good over larger tracts of country.

\section{Class I.-BRACHIOPODA.}

The lamp-shells (Brachiopoda), more than any other group, have suffered with the layse of time. Of 1300 known species, only 75 are living; and of the 34 genera, the larger part (21) are extinct. The number of generic forms is greatest in the Deronian period and least in the upper oolites, after which a second set of new types gradually appears. The preponderance of fossil Brachiopoda is contrasted with the scarcity of the recent shells even more strongly by the abundance of indiviluals than by the number of species; for the living shells mostly inhabit deep water and rocky situations inaccessible to the dredger, and are seldom ohtained in large numbers.

The genus Tereluratula, as now restricted to shells with a short internal loop, musters ahove 100 fossil species, of which only one survives ( $T$. vitrea), an :uhabitant of the Lusitanian province. The Waldheimias, or Tercluatule with long loops, are widely distributed in our present seas, although only nine living species are linor. $n$; individuals of one or more of these are found on the coast of Spitzbergen and Labrador, at Cape IIorn, and most abundantly in New South Wales and New Zealand: there are sixty fossil species dating from the trias. The Tercbratelle, having the loop fixed to a mid ridge, commenced in the lias, and oceur in small numbers throughout the cretaceous and tertiary periods, and are the only lanu-shells 
which attain their climax in recent seas. Five species of Aryiopr oceur in the greensand, chalk, and tertiaries. The allied genus Thecidirm is represented by one species in the carboniferous and one in the triassic system, becomes comparatively common in the secondary period, and dwindles again to a single species in the newer tertiary; this species survives within still narrower limits in the Mediterranean Sea. The sub-genus Terbratulina is represented by twenty species in the secondary and

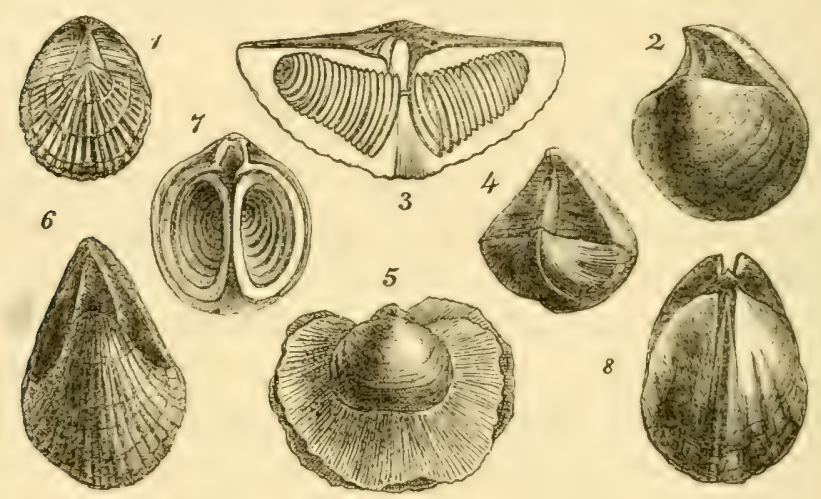

Fig. 11.

Brachiopode.

I. Trigonosemus Palissyi, Woodw.; U. Cretaceous, Ciply.

2. Stringocephalus Burtini, Defr.; Devonian, Eifel.

3. Spirifera striata; Carboniferous, Britain.

4. Cyrtia trapezoidalis; U. Silurian, Dudley.

5. Athyris Roissyi, Ler.; Carboniferous, Ireland.

6. Uncites grypluts, Schl.; Devonian, Belgium.

7. Atrypa reticularis, L.; U. Silurian, Malvern.

8. Pentamerus levis; Caradoe $S$., Salop.

tertiary formations. T. stricte of the chalk is so like the recent T. caput serpentis as to he with diffienlty distinguished from it. Several extinct sub-genera occur in the cretaceous strata, of which the most remarkalle are Trigmosimus (fig. 11, I) and Lyjo, shatped like a riolin. The genus stringecplualus (fig. $11,2)$ is peculiar to the Devonian strata, and has a large 
internal loop, and a very prominent cardinal process, forked at the end, and fitting over the central plate of the opposite valve.

The shell of Terbrutule and some of its allies (Argiope, Thecidium, Cyptiu, and Spiriforina) is dotted with minute quincuncial perforations, sometimes visible to the naked eye, as in T. lima, but usually requiring a lens of low power. They are smallest in T. carnca.

The lamp-shells with sharp beaks and plaited valves have been separated from the Terebrutula under the name Rhynchonclla (Fisch.) Their shells do not exhihit the punctate structure under a magnifying-glass, and they have no internal skeletun to support their ams, which in the recent species are coiled up spirally, and directed towards the concavity of the smaller valve, like the spires of the extinct Atrypa (fig. 11, 7). Of the three living species of Rhynchonella, one is found throughout the Arctic Seas, a second in New Zealand, and the third at the Feejees (?). The fossil species exceed 250, and are found in all parts of the world; those from the palæozoic strata may prove distinct from the rest, since the permian species are known to be provided with large internal processes (Camarophoria, King). Casts of these shells are frequently impressed with the narrow and angular pallio-vascular impressions. The extinct genus Atrypa differs from Rhynchonclla solely in having calcareous spires, which are preserved in many instances, and may be cleared to some extent by the application of acicl. The foramen is separated from the hingeline by a deltidium ; and the interior of the valve is marked by ovarian and vascular spaces exactly as in Rhynchonclle. The lower Silurian rock contains another genus, Porambonites (Pander), as yet imperfectly understood, but having the valves marked externally by impressed dots, which are not perforations. The genus Pentamerus oceurs in all the strata below the carboniferous limestone, and is remarkalle for its great 
internal partitions, causing the shell to sulit readily across the middle; and giving rise to deep incisions in those casts of the interior which are so common in the Caradoe sandstone (fig. $11,8)$.

The extinct Spiriferide are a fanily characterized by the possession of internal calcareous spires extending from the centre of the shell outwards (fig. 11,3). These spires, like the shell itself, are frequently silicified, and may be disengaged from the matrix by the action of acid. At other times the shell is imberded in soft marl, removeable by careful washing, so as to show the calcareous lamina of the spire fringed with hair-like processes, formerly the support of cirri. In the genus Spirifere the shell has a long straight hinge-line, and the flattened area of the larger valve has a deltoid byssal notch." The typical species are characteristie of the palsezoic strata, and have a shell-structure like Rhynchonellr. The liassic species (Spiriferina, dOrb.), have punctate shells, and the byssal opening is clnserl (at least in the adult) by a thin archerl plate or " prseudo-rleltirlium." In the sul)-genus C'yptia (fig. 11, 4), the linge-area is ultimately as long as it is wille, and the deltidium is perforated in the centre liy a hyssal tube; some of the species have a punctate shell. The genus Athyris (Dalman), not always easily distinguished from Tercbratula, has usually a smooth and rounded shell, ornamented with concentric lamelle or wing-like expansions (fig. 11, s); the beak is truncated by a round foramen; the hinge-area is olsolete; and the spires are as in Sprifere, with the addition of some further eomplications near the hinge. There are twenty-five species, mostly from the Devonian and cartoniferous rocks. The species of Retzin (King) are still more like plaited Terboretule, but have lateral spires; they range from the Silurian

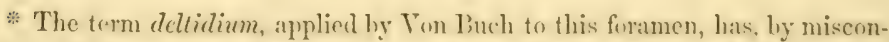
ception of his meaning, heceme constantly used for the plates which partially close it. 
strata to the trias. Uncites gryphus (fig. 11,6), a peculiar Devonian fossil, has at prominent beak, perforated in the young shell by a minute apical foramen; the hingre-area is filled up by a deeply concave deltidium, on each side of which (but only in some specimens) there is a lateral pouch formed by an inflection of the margin of both valves.

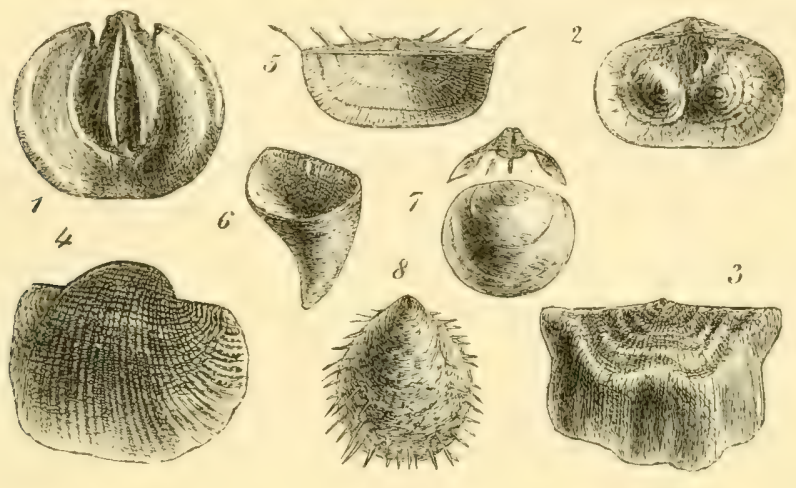

Fig. 12.

Brachiopoda.

I. Orthis hysterita, L. (cast); Devonian, Rhine.

2. Davidsonia Verneuili, Bouch ; Devonian, Eifel.

3. Strophomena rhomboidalis, Wahl.; U. Silurian, Dudley.

4. Producta semireticulata, Martin; Carboniferous, Derbyshire.

5. Chonetes striatella, Dalm.; $U$. Ludlow rock, Herefordshire.

6. Calceola sandalina, Lam.; Devonian, Eifel.

7. Obolus Apollinis, Eichw.; L. Silurian, Northern Europe.

8. Siphonotreta unguiculata, Echw.; U. Silurian, Britain.

The family Orthide consists of shells with a straight hingeline, bordered by a flat, narrow area, with a central noteh in each valve; the ventral valve is furmished with articulating hinge-teeth, and the dorsal valve has short processes for the support of the oral arms, which appear to have been horizontally spiral (as in Atrypa). Between the oral processes there is a central projection for the attachnent of the cardinal muscles. Interual moulds of the Orthis (fig. 12, 1) exhibit om 
the ventral side the single attachment of the adductor muscles in the centre, and on each side of it the cardinal muscles; these are surromded by the punctate orarian spaces and impressions of the large pallial sinuses. The genus Orthis includes 100 species, ranging upwards to the Permian, but it is most abundant in the Silurian rocks. Sume of the lower Silurian species have a round foramen in the " pseudo-deltidium," and are called Orthisince (d'Orb.) Other species in the upper palrozoic rocks have the beak twisted or deformed, probably owing to the attachment of the shell when young (= Streptorhynchus, King). In Strophomena, Rafiu (= Leptecna, Dalm.), there is a minute byssal foramen when young, of which no trace exists in the adult; and the deltoid noteh is also closed, except the space required to receire the divided cardinal process of the dorsal valve. The oral processes appear to be shifted to the centre of the valve. The shell, when young, is plano-convex, but when it has attained a certain size the valves are bent over to one side or the other, and more or less suddenly. The pallial impressions are the same as in Orthis.

The genus Davirlsonia, peculiar to the Devonian limestones, resembles an Orthis attached, like Thecidium, by the ventral valve to corals, and sometimes taking the markings of the body on which it grows, like the oyster and Anomia. The pallial impressions are like those of Oithis, and the form of the spiral arms is indieated by prominenees which almost fill up the interion of the shell in aged examples. Some indications have heen obtained of slender calcareous spires for the support of the arms in this genus; and also in froninetian, a small shell from the trials of St. Cassian, in which there are always spinal grooves in the interior of the values crosed by the impressions of the pallial sinuses.

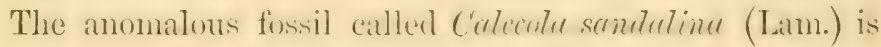
also prentiar to the Toxomian limestones. In shape it resembles 
C'yrtiu, but has no hinge, and neither foramen nor internal processes, except a row of small projections along the hingeline, and two small lateral groups of ridges in the smaller valve. The interior is punctato-striate, but has no recognisable muscular markings.

The Prochuctide are altogether palieozoic fossils, and most abundant in the carboniferous limestones. Their valves are concaro-convex, the hinge-line straight, and the interior marked with distinct impressions of the muscles for opening and closing the valves, and simple viscular spaces. There are ¿0 species of Prochute found in the uper palacozoic rocks, and having a very wide range in North and South America, and from Spitzbergen to Thibet and Tasmania. Some of them are extremely variable in form ; many are armed with long tubular spines, and others completely clothed with short, hair-like processes ; they have no hinge-teeth, and the hingearea is extremely narrow, except in the sub-genus Aulosteges of the Russian zechstein. Producta proboscidec has its convexvalve prolonged into a tube, as if for the constant supply of respiratory currents. The Permian genus Strophalosia has its valves articulated by hinge-teeth, and covered with long and slender hollow spines; the shell is attached when young by the umbo of the large valve. Chonetes is distinguished from Producte by a row of spines along the hinge-margin of the convex-ralve; it also has a narrow hinge-area with a covered notch, and small hinge-teeth. There are 25 species in the Silurian and carboniferous, usually of small size, and finely striated.

Crania is one of the oldest living types, ranging upwards from the lower Silurian. One of the earliest species appears to have been unattached, and another to have had hinge-teeth. Crania Ignaborgensis, of the chalk of Sweden, has the valves externally alike, being attached only when very young. The internal makings of $C$. antiqua, and other fossil species, are 
remarkibly grotesque. Lower valves of this genus and Thecielium are not uncommon, attacherl to the tests of sea-urchins, in the chalk; but upper valves are scarce, either retached or in situ.

The Discinida are also ancient fossils, few in number, but appearing in every period. Some of the yalieozuic Discina (=Ordiculoided, dOrh.) cannot be generically distinguished from the recent species by any characters with which we are as yet acquainted ; but others (= Tremutis, Sharpe) are ornamented with quincuncial punctures, and the casts exhibit indications of diverging internal plates, which imply very considerable difference in the orwanization of the aninal. The genus Siphonoticta (Terneuil), peculiar to the Silurian formations, is covered with moniliform tubular spines.

Lingula, which has given its mame to one of the oldest fossiliferous rocks, is another form oecurring unchanged in strata of every period. Only $3 t$ species are lnown, and none of them are very common. The latest British Lingulu is foumd in the coralline crag (older pliocenc) of Suffolk: the nearest living species is as far off as the Philippines. L. Durisil, of the "lingula flags" in North Wales, has a pedicle groove in the ventral valve, by which the posterior adductor (or cardinal muscle) must have been dirided into two elements, as in the genus Obolus; externally it has all the aplyearance of an ordinary existing shell. From the fragments of Lingule in the lower. Silurian stiper stones of Shropshire, they appear to belome to a species distinct from L. Darisii. Otolus, Eichw. (= L'ugule, T'ander) is so abundant in the lower silurian sandstones of sweden and liussia as to have given its name to the "obolite grit." In England it wecurs only in the uplere Silurian of Dudley. The shell is horny in texture, and often stained blue, like the Lingulu, ly the presence of phospluate of iron. In shape it is regularly oval, and differs from Limgule in the character of the internal muscular impressions. 


\section{Class II.-LAMELLIBRANCHIATA.}

\section{(Bivalve Shells.)}

More than a third part of the known fossil shells are ordinary bivalves (Conchifera, Dh.) They anount to nearly 6000 , while the recent species scarcely exceed half that number. Nevertheless, it is a group which attains its maxinum in the present seas. The genera are seven times nore numerous in the newer tertiary than in the oldest geological system; and the number of species found in the entire silurian series is less than 100, while the chalk contains 500, and the miocene 800 . Out of 150 genera, 3.5 have become extinct,

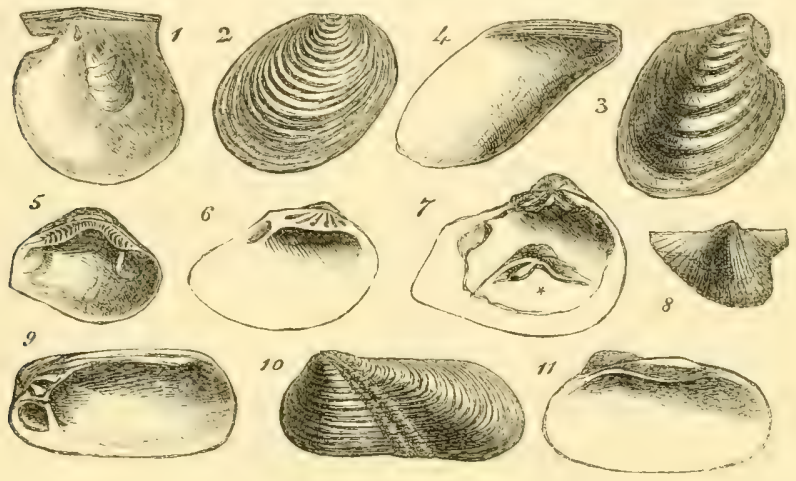

Fig. 13.

Palcozoic Bivalves.

r. Aviculopecten, sp.; Carboniferous, Belgium.

2. Posidonomya Becheri; Carboniferous, Hesse.

3. Ambonychia vetusta, Sby.; Carboniferous, Belginm.

4. Myalina Goldfussi, Dkr,; Carboniferous, Vise.

5. Ctenodonta cuneata, Hall; L. Silurian, Canada.

6. Lyrodesma plana, Conrad; L. Silurian, Hudson River.

7. Axinus obscurus, Sby.; Magnesian limestone, Durham.

8. Conocardium armatum, $\mathrm{Ph}$.; Carboniferous, 'Tournay.

9. Pleurophorus costatus, 'T. Br.; Magnesian limestone, Durham.

I0. Grammysia cingulata, His.; Ludlow rocks, Kiendal.

Ir. Edmondia, sp.; Carboniferous, Belgium.

besides numerous sulh-genera. The families Cyprimider, al sturtida, and Anatinide, have passed their maximum; the 
Trigoniede are nearly extinct; and the Hippuritide have no living representatives.

The monomyary bivalves, and others with an open mantle, attain a degree of importance at an early period ; and with them some of the burrowing families (Hyacide and Anatinitce) ; while the highest organized siphonated shells (e.g., Vencride and Tellinide), unknown in the older rocks, are most abundant now.

The fanily Ostreida, distinguished from the Pectens and Anomice by resting on the left valve, contains two fossil forms. Of these, Erogyra resembles an oyster with spiral umbones, directed backward, or to the left hand; it is an attached shell, characteristic of the cretaceous strata. The gemus Gryplece (fig. 1t, r) abounds in the oolites, and is gregarious, but unattached, the umbo of the larger valve being curved inward like a claw. A single Ostrec occurs in the carboniferous limestone, after which the species become abundant, and are with difficulty distinguishable from the smooth and plaited, or "cocks-comb," oyster of the present day.

Several curious modifications of Anomice and Plecunce have been obtained in a fossil state. Limunomic (Bouchard) has ears like Lima, and is attached to shells and corals of the Devonian age. Plecunopsis (MI. and L.), found in the oolites, has a transverse ligamental groove, which, like the umbo of the upper valve, is some way within the margin of the shell. And Cerolia (Cantr.), a tertiary form of Placuna, has a lirsal plug passing through a foramen like that of Anomiu when young, but closed in the adult.

Fossil Pectinida are very numerous. Some of them in the (arboniferous limestone (e.g., P. Somerbyi) camot be distinguished generically from the living l'eetens, and retain diverging hands of coldour. But the greater part of these old speeies are somewhat avienlois in form (tig. 13, 1), and their lingearea is grooved with cartilage-furrows, like these of Aren. 
The most beautiful forms occur in the chalk and greensand, and resemble the recent scallop (Janiru, Schum.) in the

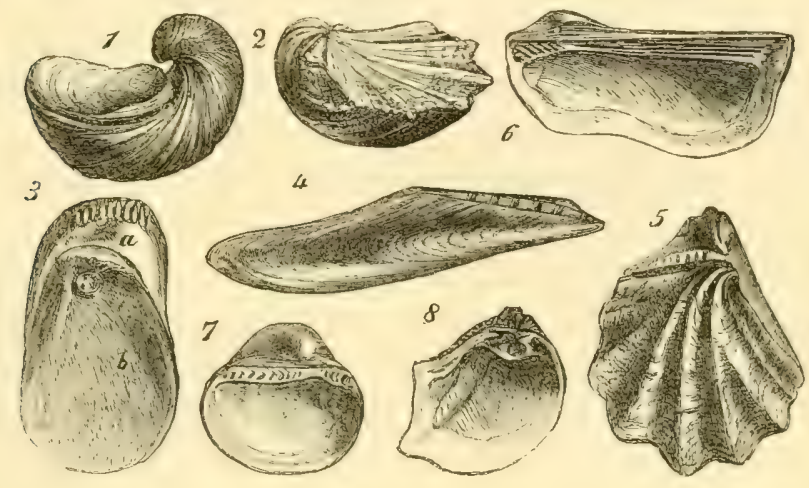

Fig. 14.

Secondary Bivalves.

1. Gryphrea arcuata, Lam.; Lias, Charmouth.

2. Pecten (Neithea) quinquecostata, Sby.; Chalk, Sussex.

3. Pulvinites Adansoni, Defr. (internal mould); Corallian, Rochelle.

4. Gervillia anceps, Dh.; L. Greensand, Isle of Wight.

5. Inoceramus sulcatus, Park.; Gault, Folkestone.

6. Cucullæa (Macrodon) Hirsonensis, D'Arch.; Great Oolite, Minchinhampton.

7. Isoarca cordiformis, Schloth.; Corallian, Nattheim.

8. Myophoria decussata, Münt.; Trias, S. Cassian.

inequality of their valves, but are further characterized by the possession of articulating hinge-teeth like Spondylus. These constitute the genus Trithea (fig. 14, 2). Plicatule exist in the trias and oolites, along with shells referred dubiously to Himites and Spondylus. True Hinnites (a sub-genus of Pecten) are cluitlacteristic of the miocene. Spondyli appear in the greensand and chalk. Some of them (like the so-called "Plargiostomu spinosum") are unattached ; others resemble the ree(nt deep-water s. Gussonii, and have been called "Dianchoree." The imner layer, including the hinge of these shells, is seldom preserved. Lima proboscidea first appears in the lower oolite, and reappears in the great nolite, and in the Kelloway rock. Limo duptionte. 
and some other oolitic species, have two ranges of little hingeteeth, but not like those of the reeent species of Limad. The large and smooth or striated Limas of the oolites have been called Plagiostoma, a name originally given by Llhwyd.

The pearl-oysters (Aviculide) are also very abundant fossils : but owing to the frequent repetition of similar forms, it is difficult to determine the genera with any degree of certainty by the aid of extemal characters alone. The Silurian species mostly belong to the genus Pterined (Goldfinss), and are broally winged, and have the hinge-area striated lengthwise, and a few diverging hinge-teeth. Amboncychia (Hall) resembles Inoceramus, and ranges from the silurian to the carboniferous strata (fig. 13, 3). The Silurian genus Curdivlu is ridged like a cockle ; and Posidonomya, which is found in all the palieozoic rocks, is very thin and concentrically furrowed (fig. 13, z). Many other genera have been proposed whose characters are even more imperfectly understood. Monotis (Salinarius), one of the common shells of the trias, has no anterior ear. Ptoropena (Lycett), an oolitic form, has a winged shell, with numerous small anterior teeth and long posterior laminie. The genus Gervillia (fig. 1t, 4), ranging from the carboniferous limestone to the chalk, consists of elongated shells, with several cartilage-pits in the liganental area. Bakcucllia, found in the Permian, has an anterior muscular impression like Arca. The recent genus Porne commenced in the lias or preceding formation, and exhibits great variety of shape. Pulvinites Adensonii (fig. 14,3) appears to have been a Perna with a byssal foramen like Anomiu; and Invecremus (fig. 14,5), characteristic of the cretaceons strata and oolites, differs from Perna chiefly in form, the larger valve being sometimes completely involute, and resembling a Nautilus. The grenus Pinne, which alpears to belong to this fimily, althomgh povided with two adductor muscles, oceurs fossil in the Iexonian and all sulusequent strata. Somme of the 
oolitic species, distinguished hy the name Trichites, are ineruivalre and irregular, and attain a thickness of more than an inch, resembling mineral masses of fibrous carhonate of lime.

Amongst the Myfitide are many Silurian species distinguished by their large, round, anterior muscular sear (Moctiolopsis, Hall), and others which have a straight hinge-line and plaited ralves (Orthonotus, Comrad). Myalina has the cartilage-groove repeated (fig. 13,4), and is found in the upper paleozoic rocks. Sometimes the anterior adductor is supported on a shelf, as in the reeent Scptifera and Dreissmia. True Mytili and Moctiole abound in the oolitic strata. Dreissenia, now confined to the rivers of the Aralo-Caspian region, or only naturalized in Trestern Europe, was represented by many species, and some of large size, in the ecene of Hanpshire and miocene of Vienna.

Fossil Arcade are far more numerous than the recent shells, and mostly helong to the division Cucullare, of which a single species survires in the Coral Sea. The palrozoic Arks have anterior teeth like Area, and posterior teeth like C'ucullace, and differ from both in the reduction of the hingearea to a narrow tract corresponding with the posterior half only in the recent shells. The easts of Ark-like shells in the Silurian rocks are further distingnished by a deep furrow hehind the front muscular impression. These constitute the gemus C'tenodontu (Salter), which has hinge-teeth like Nuculu, and a prominent extemal ligament (fig. 13, 5). Some of the oolitic Arks, with a byssal sinus, and the posterior teeth very long and parallel, form a sub-genus called Mucroctom (fig. 1t, 6). Others, with prominent umbones, teeth like STuculu, and a striated ligamental area, form the geums Isocrea of Münster (fig. 14,7). Above 200 species of Tucula and Lode are known only as fossils, and range through all the rock systems. The palrozoic species are anomalous in form, and when better understond, will certainly he considered distinct as genera. 
Yoldia is a newer tertiary form characteristic of high northern latiturles; and Solenella oceurs fossil in Patagonia and New Zealand. The problematic nemus Solemye is supposed to have exister in the carhoniferous period. Pcctunculi appear first in the cretaceous strata, being less ancient than Limopsis, which oceurs in the Bath oolite. A member of the latter genus found in the Belgian eocene has the ligamental area entirely behind the cartilage-pit, and is called Sucunclla hy d'Orhigny. The "Stalagmium" of Comrad (= Myopara, Lea) is identical with Crenclla (T. Br.), a sub-genus of Moctiola, found in the cretaceous and tertiary strata.

The Trigoniude are representer in the lower Silurian strata by Lyroclesma (fig. 13, 6), a shell with several radiating linge-teeth, striated transversely ; and in the upper palieozoics by Aximus (fig. 13,7) and several other imperfectly-known genera. Schizodus occurs in the permian at Garford (with Turbo and Rissoce), near Manchester. The trias contains true Trigonice associated with the genus Mypphoria (fig. 1t, 8), which has the umhones turned forwards, and a posterior hinge-tuoth. The only member of this family which has yet been found in tertiary strata is the little genus Trenticordia (Wood) of the crag. To Trigonia have been met with, although 100 species are known in the secondary rocks, and two are still living on the coasts of South Australia.

Fresh-water mussels (Unionide), of large size and rarious form, oceur in the Wealden formation, and are not generically distinguishable from recent shells; but those of the coal measures and older rocks are extremely problematic, and may even belong to marine genera.

Of the genus Chama there is one species in the uplere greensand and chalk of England, and another in the London clay. Elsewhere they are more abundant, amomnting to thirty species. Closerly allied to Cleneme is the J) irereses (Lam.), of which the remarkalle casts attracted attention at an carly 
period (fig. 14, I). They are found in the coral rag of France and Germany, and resemble the horns of some animal. The shell is attached by the umbo of either valve, indifferently, like some of the recent Chamas. The posterior adductor muscle is supported on a prominent ridge (as in Pachydesma, Megralodon, and the recent Corditia), which causes a spiral furrow in each hom of the cast. The shells which succeed Diceras, in the lower cretaceous strata, have the right valve usually much smaller than the left, and in one instance (fig. 1t, z) it is like the opereulum of a spiral mivalve. The only British species of this group is Requimin. Lonsctalii, found in the ironsand of Bowool. In France, ant also in Texas, another form occurs, with the attached valve simple and conical, like a Hipunite. The ligamental groove is straight, and the umbo of the free valve marginal.

These shells are so intimately allind to the Hipmuritider, that Requiuice has been frequently included with them in the apocryphal order "Rudista." The mentbers of the Hippurite group are attached and gregarious, like oysters, often occurring in great numbers, and filling large tracts of rock. Their valves are different in structure and sculpturing, and are articulated by two prominent teeth above and one below; the cartilage is internal, but there is a conspicuous ligamental furrow ontside. There are nearly 100 species characteristic of the cretaceous strata, and especially of the lower chalk, or "hippurite limestone." Only one species (Rartioltes Mortoni) is found in England; the rest are from the West Inrlies, Southem Europe, Algeria, and the East. The form which approaches nearest to Chama is the little genus Caprotina (fig. 1.5, 7), whose upper valve has a marginal umbo, but is in other respects like a miniature Racholite. C'aprine (d'Orb.) has the free valve perforated by canals which open in the immer margin, and in Caprinella the outer lamina of both valves possesses this structure. One valve is sometimes spiral (tig. 
15, 6), and partitioned off internally hy numerous septe, like the water-Spondylus, lut so regularly as to resemble the chambered shell of a Trutitus. In the Ractiolite (fig. 15, 5),
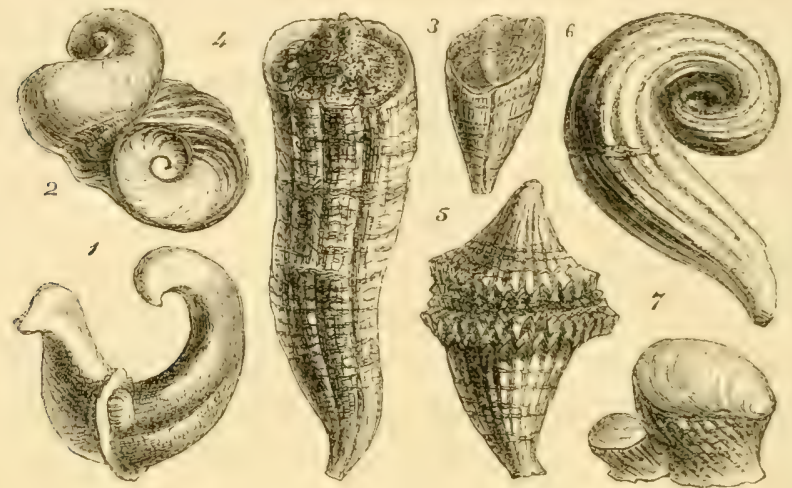

Fig. 15.

Secondary Bivalves.

I. Diceras arietinum, Lam.; Corallian, France.

2. Requienia ammonia; Neocomian, S. France.

3. Monopleura trilobata, d'Orb. ; Neocomian, Orgon.

4. Hippurites 'T'oucasiana, d'Orb. ; L. Chall, France.

5. Radiolites angeiodes, Lam.; L. Chall, Gosau.

6. Caprinella Buissyi, d'Orb; L. Chalk, Valley of Alcantara.

7. Caprotina semistriata, d'Orb.; U. Greensand, Le Mans.

both ralves are conical, and the umbo of the free valve (marginal in the very young shell) becomes central in the adult. The structure of the hinge is modified by the alsence of any spirality in the valyes, hut is essentially the same as in C'apmotina and Diceras; the prominent tecth of the upper valve support eurved plates for the attachment of the adductor muscles, which become continually more undereut in the course of their growth. In II igmurites the anterior muscular plate projects horizontally, the posterior vertically, like a third forth, for which it has hecen mistaken. In this gemus there ane two longitulinal inflexions of the onter shell-wall beside the ligmental furmer, one correspondines to the posterior 
muscular plate, the other (or third) apparently a siphonal inflexion like that in Trigunia and Lala (fig. 15, 4).

The cockle-shells (Cartiada), as they have a world-wide distribution now, had a corresponding range in time, and are found in all strata from the Silurian upwards. The conmonest fossil type of Carlium is ribbed concentrically on the sides, and radiately on the posterior slope, a style of ornanent almost unique amongst the 200 recent species. The Casprian cockles, distinguished hy a sinus in the pallial line, appear to have inhabited the Aralo-Caspian region almost from the middle tertiary periou; the hinge-tecth are reduced to one (Monodacna) or two (Didacne) in each valve, and are sometimes quite wanting even in the young shell (Adacke, Eichw.) Lithocertium aviculare (fig. 16,7) is a chatracteristic shell of the Paris basin, and applears to have spum a byssus, like the fry of some recent cockles; it also resembles the oriental Tridecna, of which a species is found in the miocene of Poland. The genus Conncridium (fig. 13, 8) of the upper Silurian and carboniferous systems is remarkable for the prismatie cellular structure of its shell, and the truncation of the posterior (?) side of the ralves, which are furnisherl in some species with a slender siphonal process.

The Lucinide, allied to the cockles in their hinge-structure, are also plentiful in the fossil state, and have as wicle a range. They are usually recognisalle, eren when in the condition of internal casts, by their cireular form and the oblique ridge on their disk. Casts of Lucinu also exhibit the peculiar narrow outline of the anterior adductor detached from the pallial line. Cryptodon, Diplodonta, Fellia, and Pythina are found in the eocene tertiary. Corbis, under the sub-generie form of Sphara, commences in the trias; another modification, found in the volites and chalk (Unicurlium, d'Orb.), is edentulous ; ant Trencedia (Iyeett), a compressed triangular shrell, with a dentition like Corbis, is frequent in the lias and onlite. 
The fresh-water C'ycluctide are represented in the Wealden and eocene by many species of Cypene, mostly of small size. The recent c'orbicula fluminulis of eastem rivers is a common fussil of the pliveene tertiary in England and Sicily.

The Cyprinide and Astertide are more abundant as fussil shells, and had a wider range of old than at the present day. Nearly 100 species of Cyprina have been catalogued, commencing in the trias; the dentition of the older species is, however, somewhat peculiar. The Isocurdice are almost as numerous, and have the same range, but many of the fossil Isucardia-looking shells are really related to the Anctinide. A yet higher antiquity has been assigned to Cypricardia, a genus now very searce and difficult to obtain, on account of its hahit. The palieozoic Pleurophome (fig. 13,9) is distinguished by the prominent ridge behind the anterior muscular impression; and Meyulodon (J. Shy.), by the plate supporting the posterior adductor. This genus is represented in the oolites hy Pechyrismo (fig. 16, r), and in the tertiaries and modern seas by Carditic.

The genus Asterte, now limited to a dozen species in the North Atlantic and Arctie seas, has an almost world-wide geological distribution, and counts 200 species in d'Orbigny's atalngue, enmmeneing with the lias period. Crassatella, now ahmost a southern form, is common in the cretaceous and tertiary strata of Europe. Closely allied to Asterte is the extinct genus Opis (fig. 16,3), of which there are t2 species in the secomtary series ; and Cardinie (fig. 16, z), chanacteristic. of the lias and oolites. The so-caller Unios of the coal measures (Anthrernsin, King) are probalily members of this group.** One hundred speeies of Cerdita (including Venericerrfire) are found in the secendary and tertiary strata of the

* "They occur in the valuable layers of clay-ironstone called 'mussel-

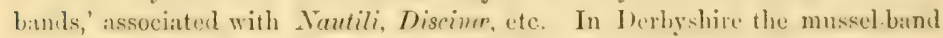
is wrought, like marble, into vases." - Wooducard. 
50 recent forms, one only is Aretic, and this oceurs in the glacial deposits of England. The allied genus Hyoconchu is characteristic of the older secondary rocks, and Himmpoctium of the lias.

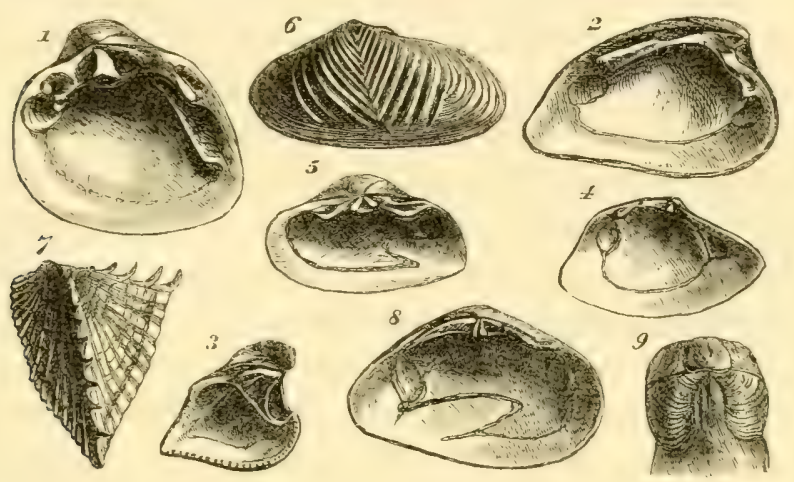

Fig. 16.

Secondury and Tertiary Bivalves.

1. Pachyrisma septiferum, Bur.; Corallian, Meuse.

2. Cardinia hybrida, Sby.; Lias, Gloucester.

3. Opis tumulatus, Mill.; Inf. Oolite, Bayeux.

4. Tancredia secariformis, Dkr.; Lias, Saxony.

5. Sowerbya crassa, d'Orb.; Oxfordian, Ardennes.

6. Goniomya scripta, Sby. ; Kelloway rock, Wilts.

7. Lithocardium aviculare, Lam. ; Eocene, Paris.

8. Grateloupia irregularis, Bart.; Miocene, Bordeaux.

9. Teredina personata, Lam, ; Eocene, Bognor.

The Veneride are pre-eminently characteristic of the tertiary and present period. Some obscure sprecies of Venus are found in the oolites: Cytherea oceur in the greensands; Artemis, Trigona, Lucinopsis, Venerupis, and Tapes appear in the midule tertiary; Petricola in the eocene. The only extinct form is Grateloupia (fig. 16,8), which difters hut little from Trigona.

The Nactras and Tellens are also commaratively modern groups ; mosit of the smplosed oolitic species belongr to Lucinide, except Somerbyga. (fig. 16,5), which has a pallial simus. and is found in the onlites of Malton and Portland. Parm- 
motice and Mesudesme occur in the greensand; Donax and Syndosmya in the encene ; Gastrana, (=Venerupis, Lam.) and Lutraria in the miocene. Lutraria megosa, still living on the const of Portugal, is fossil in the raised beaches of Sussex.

The oldest forms of razor-fish (Solenidce) are those with the transverse internal rib (Solccurtus), which occur in the neocomian, whilst true solens and Glycimeris appear first in the eocene strata. The genus Mya, as now restricted to the species resembling $\boldsymbol{M}$. arenaria, are only met with in the newer tertiary. Corbula ranges upwards from the lower oolites; Necre appears in the upper greensand; and Thetis (=Poromya, Forbes) in the neocomian.

Above 100 species of Panopaca (a genus essentially like $M y(a)$ have been obtained from oolitic and tertiary strata in all parts of the workd. They are with diffienlty distinguished from those equally numerous forms of Anatinide which have been associated with Pholatumya on account of the tenuity of their finely-granulated valves; they constitute the genus Myacites (Bromn), and oceur in all the palrozoic and secondary rocks; some of the oolitic and cretaceous species are distinguished by V-shaped furrows (fig. 16, 6). Still more numerous are the fossil forms of Pholadomya, which range upwards from the lias, but are reduced to a single species now living in the Caribbean seas. Shells with the umbones fissured like Anctina also occur in the oolites. Pandora first aprears in the older tertiary. Anongst the extinct genera referred to this family are the Silurian Grammysia (fig. 13, 10), with valves folked transversely ; the carboniferous Edmondia (fig. 13, гx), with large oblique cartilage plates ; and Curdiomorphe, shaperl like Isocarlia; and the onlitic Ceromye (Ag.), which also resembles the heart-cockle in form. Cecermyse is an oolitic Anatine, with the posterior ent of the ralres much attenuated.

The genus Gedstrochend appears in the lower onlites; and casts of its hmows are frepuently preserved after the derom- 
position of the coral in which they were made. Clarryclla dates from the upper greensand, and Aspergillum from the miocene. Saxicara is found in the newer tertiary and raised beaches of Northern Europe; and the great species commonly called "Panopeca" Norwegica is a characteristic fossil of the newer pliocene of Britain and Greenland.

The Pholades and ship-worms appear first in the oolitic strata. Forms resembling the recent Martesia striatc have been discovered in fossil wood of the lias and specton clay. Jouannetia (Desm.) was first known as a miocene fossil ; and Pholas occurs in the older tertiary. Extinct species of Teredo are found in the silicified wool of the greensand of Blackdown and in the fussil palm-fruits of Brabant and Sheppy. The drift-rood of the London clay is usually perforated by the ship-worm, and also by an extinct form (Teredinee, fig. 16, 9), which resembles Martesia in possessing an umbonal shield: when adult it not only closes the anterior pedal opening, but also cements its valves to the shelly lining of its burrow, like an Aspergillum. Specimens have been obtained in which the whole interior of the valves and tube hat been excessively thickened towards the close of life by successive layers of shell.

\section{Class III.-GASTEROPODA.}

Fossil univalves-the remains of spiral and limpet-like shells-are not wanting in any but the rery oldest fossiliferous rocks ("lingula flags"). From the lower Silurian, where less than 100 species, referable to scarcely more than ten genera, are found, they increase in number and variety slowly and regularly up to the newer tertiaries, which have afforded ten times as many genera and twenty times as many species. The total number of fossil marine univalves is less than 6000 ; the recent exceed 8000 ; and although we may expect to discover more new fossil species than recent, yet it 
is evident that, in comparison with past conditions, the groul' of univalyes has only now attained its maximum development,

Between the extinct and living air-loreathers the numerical discrepancy is still greater. Alout 300 land-snails, and half as many fresh-water Pulmonifer are enumerated in the fossil catalogues; but the greater part of these are recent species, and the whole bears no proportion to the number of living land-snails, which exceeds 4000. That many more have formerly existed is indicated by the fact, that the fossil landsnails of the older tertiaries of Europe are entirely different from their living successors, and most nearly represented at the present time in the West Indies and Brazil. The generic forms peculiar to oceanic islands (remains of old continents) are more numerous than those of the mainlands, as if this order had once been more important. But the circumstances favourable to their petrifaction must have been of such rare occurrence as to preclude the probability of attaining more than the scantiest information concerning them.

From the large and proportional number of living Gasteropods, and the great amount of information which has been obtained of late years respecting their structure and habits, it might be expected that the affinities of the fossil univalves would be easily worked out, and their indications fully interpreted. Such, however, is not the case. Univalve shells present no internal markings, easily accessible like those of bivalves, and exhiliting the essential character's of the soft parts; and their external forms are often so overlaid with ornament, and disguised by mimetic characters, as to mislead upon a furst examination. Shells of any family may he limpet-shaped, or turreted, or discoidal, plain or ornamented. It is more desiralile to ascertain whether they lave been nacreous or porcellanous; whether the apex (or nuclous) presents any peculiarities; and if opereulatert, whether the operculum was pauci- or multi-spiral. 
The earlier describers of fossil univalres mhesitatingly recognised many familiar recent genera, even in the oldex. rocks. But their Mclonia were marine shells; the sup-

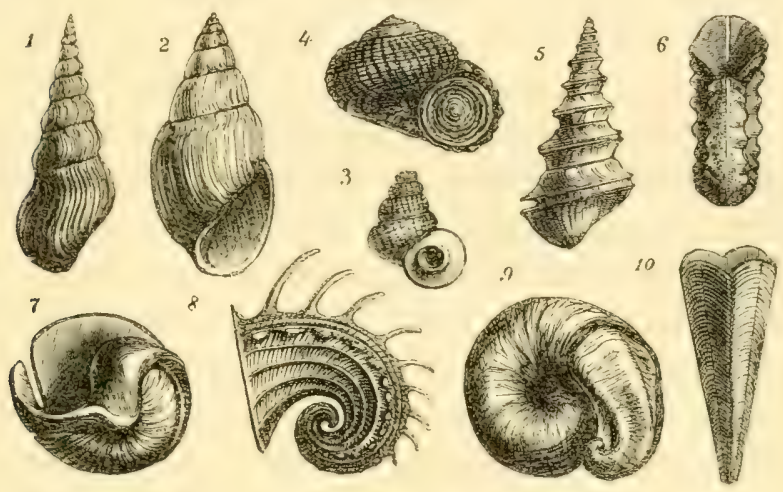

Fig. 17.

Palaozoic Univalves.

1. Loxonema Lefeburei, Lév.; Carboniferous, 'T'ournay.

2. Macrochilus Schlotheimi, d'Arch.; Devonian, Eifel.

3. Scoliostoma expansilabrum, Sdg1.; Devonian, Nassau.

4. Euomphalus sculptus, Sby.; Wenlock Limestone, May Hill.

5. Murchisonia angulati, Ph.; Devonian, Eifel.

6. Porcellia Puzosi, Lév.; Carboniferous, Tournay.

7. Bellerophon bi-carinatus, Lév.; Carboniferous, Tournay.

8. Tubina armata, Barr.; U. Silurian, Bohemia.

9. Maclurea Peachii, Salter; L. Silurian, Sutherland.

10. Conularia quadrisulcata, Sby.; Carboniferous, Lanark.

posed Buccinm had no notch; the Solaria were pearly ; the Nerite assumed, when ardult, the irregular aperture of Pilcopsis; the Natice had non-spiral opereula ; and the Marlurea was figured upside down.

The more closely palrozoic univalves are examinel, so much the more do they ajpear to differ from ordinary recent types; and the search for allied forms has to he conducted amongst the rare and minute and least understood of recent shells.

Pteropoda.-The fragile shells of Hyalece and Clcotora are 
found in the newer tertiary of Italy, with Varginella (fig. 19, rz), a form allied to Curicria. But the occurrence of Ptcropoda in the older rocks is attended with considerable obscurity. Ecculiomphalus is like an incompletely convoluted Euomplualus, Machurca is like Eumphalus with a depressed spire; the shells called Thece are slender and conical ; Ptcrothece has a winglike expansion; and Conularia (fig. 17, 10) is a four-sided sheath, with the apex partitioned off, as in the recent C'uricria. If really pteropodous, these shells are the giants of the order.

Nuclobranchiata.-Those fossil univalves, which in their symmetry resemble the Nautilus, but are unfurnished with air-chambers, have been compared to the recent Heteropoda (or Nuclcobranchiata, Bl.), and especially to that division typified by the tiny Atlanta, in which the animal can withdraw itself completely into its shell, and close the aperture with an opereulum. The genus Porcellia, characteristic of the carboniferous age, has a discoidal shell, with a spiral nucleus projecting, as in Atlanta, from the right sicle; the whirls are exposed, and marked with a narrow band along the back, ending in a deep slit (fig. 17,6). Another genus (Bcllerophon) resembles the recent Oxyyyrus in its more globose form, with a similar narrow umbilicus on either side (fig. 17, 7) ; sometimes the shell is thin and the apcrture expanded, like a trumpet, whilst other speeies are globular and solid ; the former may have been tenanted by large animals living at the surface of the open sea, the latter seem to have been more adapted to protect their owners crawling over the bottom, for it can searcely be insisted that all were necessarily floaters on account of their organization. The species of Belleroplem are numeroms in all the palieozoic rocks, and some of the smaller kinds apjear to have been gregarious : those with discomected whirls have been called C'yrtolites (Comad.) The Bellerophina of d'Orbigny (fig. 18, $x$ ), is a minute shell found in the gault. The other division (Firolida) consists of Mollusks in which 
the shell is wanting or rudimentary, and small compared with the bulk of the animal. A single species of the genus Carinaria has been found in the middle tertiary of Turin.

Strombidce.-The Strombs with their massive shells, nevertheless, resemble the fragile Heteropods in some respects. They have the same lingual dentition, and the same carnivorous habits; and though living on the sea-bed, they rather leap' than glide, having a namow sole and a deeply-divided operculigerous lobe. Characteristic of the warmer zones of existing seas, they are only found fossilized in the newer tertiary strata of countries south of Britain; but there is a group of little shells related to the recent Strombus fissurellus in the older tertiaries of London, Paris, and America, to which Agassiz has given the name Rimella. The allied genus of scorpion-shells (Pterocera), now peculiar to eastern seas, has been described as occurring fussil in the secondary strata of Europe; but the extinct species appear to be more nearly related to Apormais. This genus, now confined to the western shores of Europe, oceurs in all the tertiaries, and is represented in the secondary rocks by many remarkable forms. Some have been separated under the name Alaria; and to this group the so-called Ptciocera Bentleyi may perhaps be referred (fig. 18, 2). Rostcllaria and Serranis (or Terebellum), now peculiar to the Red or eastern seas, are conspicuous fossils of the European eocene, at which time their range extended to America. Some of the ancient Rostellarias have the outer lip enormously expanded, as in the R. ampla (Hippocicna) of the London clay. In the oolites and chalk there are slender fusiform shells (Spinigcra, d'Orb., fig. 18,1$)$ with spines on the sides of the whirls, as in some recent Ranelloe.

Muricide.-The great family of whelks, by far the most important group of living sea-shells, is scarcely of higher antiquity than the eocene tertiary. The Purpurina of the oolites (fig. 18, 3), and Columbellina of the chalk, are extinct generi, 
somewhat resembling Prinura and Columbellu. But since the so-called "cones" of the oolites have proverd to he Tormatcller,

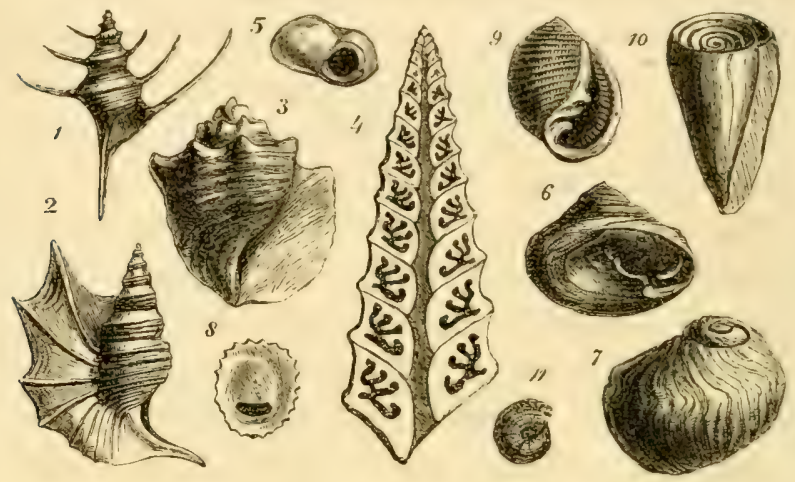

Fig. 18.

S'econdary Univalves.

1. Spinigera, sp.; Oxford Clay, Chippenham.

2. Alaria Bentleyi, M. and L.; Great Oolite, Collyweston.

3. Purpurina Morrisii, Buv., Great Oolite, Minchinhampton.

4. Nerinæa Bruntrutana, Thurm. ; Corallian, Poland.

5. Crossostoma Pratti, M. and L.; Great Oolite, Minchinhampton.

6. Trochotoma conuloides, Desl.; Great Oolite, Minchinhampton.

7. Neritoma bisinnata, Buv.; Oxfordian, Ardennes.

8. Pileolus plicatus, Sby.; Great Oolite, Ancliff.

9. Cinulia incrassata, J. Sby.; U. Greensand, Blackdown.

ı. Acteonina concava, Desl.; Lias, Normandy.

I r. Bellerophina minuta, Sby.; Gault, Folkestone.

it may not be unreasonable to distrust these other presumed affinities. The huge mivalve of the chalk, which sowerty called a Dolium, has been deseribed as a Pterucera by d'Orbigny. In the tertiaries siphonated mivalves abound, and are mustly referable with certainty to recent genera. The only marked change consists in the comparative abundance of some searce existing forms, and the absence or rarity of mun now most conspicuous. Noreover, the geographical distribution of the? genera has undergone a great change since the close of the cocene period. This change is most noticealle in the coldtemperate zone, and is evidently the result of altered climate. 
The northern seas must ever have been inclement, and the tropical seas always tropical; but the latitude of England being most liable to ricissitudes of climate, might be expected to show the greatest variety, and the most complete and rapir alterations of organic life. In the London clay are found many

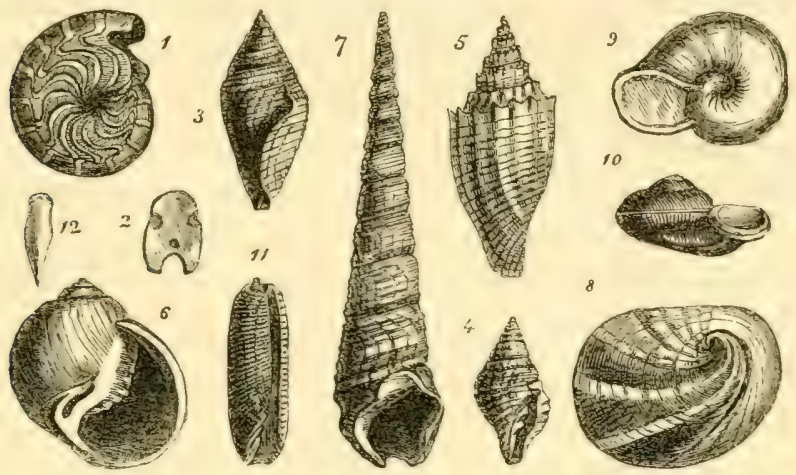

Fig. 19.

Tertiary Univalves.

1. Nautilus (Aturia) zic-zac, Sby.; Eocene, Britain.

2. Nautilus zic-zac, front view of a septum.

3. Conorbis dormitor, Sol.; Eocene, Britain.

4. Borsonia lineata, T. Edw.; $\boldsymbol{M}$. Eocene, Hants.

5. Volutilithes luctator, Sol.; Eocene, Britain.

6. Natica (Deshayesia) cochlearia, Brongn.; Eocene, N. Italy.

7. Turritella (Proto) cathedralis, Brongn.; Miocene, Bordeaux.

8. Nerita (Velates) perversa, Gm.; Eocene, France.

9. Helix (Lychnus) Matheroni, Req.; Eocene, S. France.

I0. Ferussina tricarinata, M. Br, ; Miocene, Hockheim.

I1. Volvaria bulloides, Lam.; Eocene, Grignon.

12. Vaginella depressa, Bast.; Hiocene, Bordeaux.

species of Clavella, Typhis, Mitre, Pscudolive, Otive, and Ancillarice; and some extinct forms (Lciostome and Strcpsidura) related to Fusus. The middle tertiary, wanting in England, but largely developed in Central and Southern Europe, also contaius many genera helonging now to warmer latitudes, and many species still living in the south. In the newer tertiaries of Europe these southern forms disappear, and are gradually 
replaced by others of an opyosite character (Trophon, Neptuniu, and Trichotropis), now inhabiting the Aretic and boreal coasts. The entire number of fossil Muricide amounts to 1000, or about half as many as the recent. The older tertiaries of England also contain species of Triton, Cassidaria, Cancellaria, and Pyrula, shells (now foreign to our seas), which hare formerly been included in this family. As regards bulk, there are no fossil species of Fusus, Triton, and Cassis (or Strombus and Voluta) to compare with those of the present day.

Conide.-The Cones and Pleurotomas appear first in the chalk, and are abundant in the eocene, accompanied by an intermediate form (Conortis, fig. 19, 3), and another extinct sul)genus (Borsonia, fig. 19, 4), in which the column is plaited, as in Mitra. The genus Terebre is more common in the mincene.

Volutidc.-The Volutes also appear as cretaceous fossils in Emope and Southern India; they are very abundant in the London clay, and one occurs in the English crag. The ancient species are mostly distinguished by their spires being acute, as in Mitra (fig. 19,5), a peculiarity only found in one very rare living (?) species, dredged from a bed of dead shells in 132 fathoms water ( 792 feet) off the Cape. The crag Volute resembles the Magellanic form. Cymba olla, the only living European Volute, is a fossil in the pliocene of Majorea.

Cyprecila.-The Cowries form another group of subtropical shells once common in the temperate zone. Several large species are found in the London clay, most nearly related to the southern Cymorula; whilst the crag contains only members of the sub-genus Trivia, one of which still lives on our coast.

The round-mouthed shells (Holostomate), whether animalfeeters or vegutirians, make a conspicuous figure amongst the fossils of an earlier period than that in which the last group began to flourish. The carnivorous Naticide and Pyramidellide are represented in the palienzoic strata ly Naticopsis, 
Loxonema (fig. 17, 1), and Macrochitus (fig. 17, 2). The violetsnail (Ianthina), so unlike any other existing shell-fish, seems related to the Silurian Scalites, Raphistoma, and Holopece. Shells like Scalaria and Solarium occur in the trias and oolites associated with Chcmnitsice (?) of extraordinary size, and species of Eulima and Niso. These families of shells and the Cerithiade are more abundant fossil than recent, the known numbers being 1500 extinct and 900 living forms. Solaria, with discomnected whirls and pyramidal opercula (Bifiontic, I)h.), are common in the eocene tertiary, and a single living species (B. zancloca) has been discovered by $\mathrm{M}^{*}$ Andrew.

Amongst the tertiary Naticas are many with an oblique aperture and peculiar perforation (Glubulus, J. Sloy., = Ampullina, Bl.), and others with prominences on the pillar (Deshaycsia, fig. 19, 6.) The Ncrinces of the oolites are remarkable for the spiral ridges (like the "worm" of a screw) winding round their interior, and giving rise to the variety of singular patterns seen in sections (fig. 18, 4). A similar structure exists in the recent "telescope-shell" (Tcrctrotia). The fresh-water uniralyes of the Wealden and older tertiaries differ but little from their recent congeners of the genera Paludina, Potumides, Melunie, and Melenopsis. Fossil Turritelle are of doubtful oceurrence before the tertiary; the Silurian species have the peristome complete (Holopelle, M.C.); another form (Proto, fig. 19, 7) is characteristic of the miocene.

The bonnet-limpets (Calyptraida) are common in the old rocks, which also contain a few species of Chiton and shells like Dentalium. Fossil Trochicle are very numerous, but hitherto many Litorinida have doubtless been included with them. Perhaps no true Turo is known from strata before the cretaceous. The Euom, hali (fig. 17, 4), which characterize the older rocks, have multispiral calcareous operenla, like the recent C'yclostremu ( = Adcortis). The genus Maclured (fig. 17, 9), which has heen rexgalded as a "left-handerl" Einnmplic- 
lus, is probably very different; it has a thick shelly operculum, sinistrally spiral, and furnished with an internal process, as the Nerites are; the spire is sunk and concealed, whilst the whirls are exposed on the flattened under-side; it occurs in the older Silurian rocks of Scotland and North America. One common feature of the palicozoic spiral shells is their tendency to become irregular towards the conclusion of their growth : in Serpularia (= Phanerotinus, Shy.), the whirls are all dismnited ; in Scoliostomu (fig. 17, 3 ) and Catantostoma the aperture is expanded. Some small oolitic shells have a thickened peristome (Crossostoma, fig. 18, 5), like the recent Lictiu, which commences in the older tertiary. A large proportion of the trochiform fossil shells have their whirls, whether round or angular, marker by a peculiar hand, terminating in a deep) slit at the aperture; most of these were solid nacreous shells belonging to the genus Pleurotomariu, of which but a single species survives; others in their slendemess resemble Turritelle, and have been named Murchisonia (fig. 17, 5). The carboniferous shell callex Polytremerice has a row of holes in place of a slit; and the Silurian Tubina (fig. 17, 8) has three rows of tubular spines. The C'irrus of the inferior oolite is a reversed shell with one row of similar ornaments; and $T r(1-$ chotoma (fig. 18,6) has a perforation near the margin of the aperture, which is carried onward as the shell grows. Seissurclle, which is always diminutive and not pearly, makes its first appearance only in the newer tertiary. Haliotis occurs in the miocene of Malta. The Tritide alprear in the oolites: besides true Nerites, there are Teritome (fig. 18, 7), with a channeled outer lip ; Pilenlus, which is prerfectly limpet-like above (fig. 18,8) : and Toritrusis, with its angulan columellar noteh most distinetly marked. Key-hole limpets (Fissurdlide) oceur as early as the eartoniformus period, but are very searee at first, and never beeome numerous. The oolitic Rimula is a minute shell supposed to be related to a rery rare living 
species. Ordinary limpets (Patcllide) of mequivocal form are found in the Bath oolite, but are afterwards less plentiful, and almost disappear from the tertiaries; M. d'Orbigny regarded them as generically distinct, but employed for them a name (Helcion, Mont.) synonymous with Patella.

Pulmonifera.-The existence of air-breathing snails in the palieozoic rocks is shown by a small "chrysalis-shell, with a round, not toothed, aperture, (Dendropupa), discovered by Dr. Dawson and Sir C. Lyell in a hollow coal tree of Nova Scotia." Upwards of 40 species of Prpa have been found fossil in eocene stratil. The Purbeck limestone contains a modern-looking Physc ; and other species of extraordinary size are found in the older tertiary of France, and also in Central India, where the genus does not exist at the present clay. The fresh-water eocene of the Isle of Wight and Paris has afforded many species of Limnece and Planorbis; a Glandine rivalling in size the G. truncate of South Carolina ; a Cyclostome, with a sculptured operculum like the Cyclotus Jamaicensis; and an elonwated species of the section Megalomastoma, which is now living in hoth East and Vest Indies. At Hordle has been found the little Hclix labyrinthicus, still living in Texas; and in the south of France occur representatives of the Brazilian genera Megaspire and Anastome (fig. 19, 9). In the miocene is found another genus (Fomssina, fig. 19, 10) resembling the lamp-snail, but supposed to be operculated. The Pulmonifere of the English plioene are in a few instances extinct, at least in England; nearly all are still living here, but more or less abundant now than they were in the times of the mastodon and elephant. The extinct land-snails of the Atlantie islands Marleira and Porto Sitnto are associated with remains of many recent species oceuring in numbers which have relatively altered, telling the same tale of grarlual changes, affecting some species prejudicially, but favourable to the increase of others. The fossil landsnails of St. Helena were suplosed ly Mr. I birwin to have beenure 
finally extinct only in the list century, owing to the destruction of the native woods by the instrumentality of goats and swine.

Tectibranchiata.-The families typified by Tornatclla, Rinyiculc, and Bulle played a more important part in the secondary and tertiary periods, but their affinities have been seldom understood. The conc-like Acteonina appeared in the carboniferous rocks, and attained a remarkable development in the lias (fig. 18, 10). They were succeeded by the Actconclla', with a plaited columella, in the cretaceous strata; and by Volderia (fig. 19, ri) in the eocene. The diminutive Rinyicule of omr seas were precerled by large species of the same gemus in the tertiaries, and by Cinulice (fig. 18, 9), Giluticonche, and Tylostoma, in the cretaceous strata. The genus Irarigcra has varices recurring twice in each whirl, like Eulime; and Pterodontre is winged like Strombus.

Class IV.-CEPHALOPODA.

Order 1.-Tetrabranchiata.

(Nautiloid Cephalapoda.)

Of the lower group of Cephalopods, possessing chambered shells similar to the pearly 1 Tautiti, there are 1 too extinct species, belonging to above 30 genera, while 3 or 4 species alone exist in modern seas. These fossils resemble the $T^{\text {Taut }}$ lus, and differ from the dibranchiate Spiruld in the structure of their shell, which is composed of two layers, the onter porcellanous, the immer pearly; whereas the Spirula-an internal shell-is entirely nacreous. They also agree with the Noutilus in the relative eapacity of their list chamber, which seems obviously large enough to contain the whole aninal. Noreover, it appears, from the position of the siphuncle and the form of the aperture, that these shells were revolutely spiral, or coiled over the back of the animal, and not involute like. the Sprimele. No trates of forsil ink (sepire) or lonny colaws have beren fomm assoriater with them, nor any indieatioms of 
dense muscular tissue, even in the same matrix which has preserved so completely the mummy cuttle-fish. By their form and size they were ill adapted for rapid locomotion, and must have depended for safety on the shelter afforded by their solid shell. The discoidal Ammonites attained a diameter approaching 3 feet, and the straight-shelled Orthocerata were sometimes not less than 6 feet in length. These latter must have lived habitually in a position nearly vertical; whilst the discoidal genera would creep over the sea-bed with their air-chambers above then, like a snail-shell reversed. The Ammonites appear to have been provided with an operculum, more secure than the "hood" of the Nautilus, composecl, like it, of two elements, not, however, fibrous and confluent, but calcified and united by a straight suture. These opercula, which have been mistaken for bivalve shells, have a porous structure altogether peculiar, and are frequently sculptured on their outer convex surface; whilst their concavity exhibits only lines of growth (fig. 21, 7). Special forms are associated, in all localities, with particular species of ammonite; and their size is adapted exactly to the specimens in which they are found. Calcareous mandibles occur in all the secondary strata, but not, hitherto, in such numbers or circumstances as to imply that they belonged to any other genus beside the true Nautilus. They are of two forms: those corresponting to the upper mandible (fig. 21, 8) have been called "Phyncholites" (Palcotcuthis and Rynchoteuthis of d'Orbigny) ; whilst the lower mandibles constitute the genus Conchorhynchus of De Blainville (fig. 21, 9). The arms of the extinct Tetrabranchs may have been organized like those of the Nautilus, but were probably less numerous in the genera with slender shells, and in those early forms with a small many-lobed aperture. The length of the body-chamber is greatest when its diameter is least; and the prominent spines which ormament the exterior are partitioned off internally by a nacreous lanina, indicating con- 
siderable motion of the animal in its shell. When the outer shell of the fossil is removed hy decomposition or the hammer, the margins of the internal septa (or partitions of the air-chambers) are exposed: these marginal lines are called "sutures."

The chambered shells may be divided into two principal groups, viz., those with simple sutures, like the recent Nautilus; and those in which the margins of the septa are lobed and foliaceous, the Ammonites. In the former the siphuncle is central or internal (i.e., at the margin next the spire) ; in the latter it is extermal (i.c., at the back of the shell, but ventral as regards the animal). There are, however, $N$ autili with lobed sutures (Aturia, Bronn, fig. 19, r) ; and some with an external siphuncle (Cryptoceras, d'Orb.) And on the other hand, the sutures of the Ammonite are at first very slightly lobed, and become progressively more complex; so that specimens of the same species have been referred to three genera-Goniatites, Ceratites, and Ammonites-accorling to their age.

With the exception of Goniatites, the Ammonitille are peculiar to, and co-extensive with, the secondary strata; while the Nautilida, with the exception of Nautilus and Aturia, are confined to the palreozoic rocks. But the palrozoic so-called Nautilidoe exhibit peculiarities suggesting very wide differences from the modern pearly Nautilus. It has been proposed to associate the greater part of them with the Orthoccrate as a distinct family, but at present the data are defectire. Lilie the Ammonitide, their shells assume almost erery conceivible form and curvature, and the genera founded on these characters are very ill defined.

The simplest form of Orthoccras is like a Nautilus umrolled; and Lituites (fig. 20, z) is the same with the apex spiral. Some of the carboniferous $\mathbf{Y}$ autili have a square back, and the whirls either compact or open in the centre (fig. 20, r) ; whilst the last chamber is more or less disunited. The species with the 
whirls quite disunited constitute the genus Trigonoceras, $\mathrm{M} \cdot \mathrm{C}$. (= Nautiloccras, d'Orb.) The Silurian genus Trochoccras, Barr, is a spiral Nautilus. Clymenia, a characteristic Deronian fossil, has angular sutures and an internal siphuncle; it may perhaps be coiled up ventrally like the Spirula. The tertiary shell called Tautilus zic- $\approx \alpha c$ (Aturia, Br., fig. 19, 1, z), which is so widely distributed in Europe, America, and India, has a siphuncle nearly marginal when young, but gradually becoming more central in the adult: it has no special relation to Clymenia.

Those species of Orthocerata in which the aperture is contracted form the genus Apioceras, Fischer (= Potcrioceras, $\mathrm{II}^{\circ} \mathrm{C}$.), or when also curved, the Oncoccres of Hall. In Barrande's genus Ascoceras (fig. 20, 9), the shell is flask-shaped, the chambered and siphunculated apex being apparently deciduous; the aperture is contracted, and the air-chambers occupy only the dorsal half of the shell. In Phragmoceras (fig. 20, 7), the shell is slightly curved to the rentral side, and the aperture is remarkably contracted, the opening for the respiratory funnel being nearly distinct from the cephalic aperture. In Cyrtoceras the curvature is dorsal.

In some other members of this family the siphuncle attains a remarkable size or extraordinary complexity.

In Camaroceras (fig. 20, 4), the siphuncle is lateral, quite simple, and equal to half the diameter of the shell. Casts of these great siphuncles were called "Hyolites" by Eichwald; they frequently contain small shells of Orthoceres, Bellerophon, and other genera. In some species the siphuncle is strengthened internally by repeated layers of shell, or partitioned off by a succession of funnel-shaped diaphragms ; these constitute the genus Endoccras of Hall. The same author has given the name Discosomes to a fossil which is eridently the siphuncle of some very delicate and perishable chambered shell (fig. 20, 6). In those Orthocerata with siphuncles most nearly resembling 
the Discosorus they diminish rapidly towards the last chamber. Perhaps the most remarkable fossil of this group is the Huronia (fig. 20, 5), found in the upper Silurian limestone of Drummond Island. Siphuncles 6 feet in length and $1 \frac{1}{2}$ inch in diameter, were seen by Dr. Bigsby in the cliffs ; they are silicified, and stand out in bold relief from the matrix, but are unaccompanied by any vestige of the shell, except in one or two instances, where the septa are faintly indicated by coloured lines. They are sometimes overgrown with coral, and were

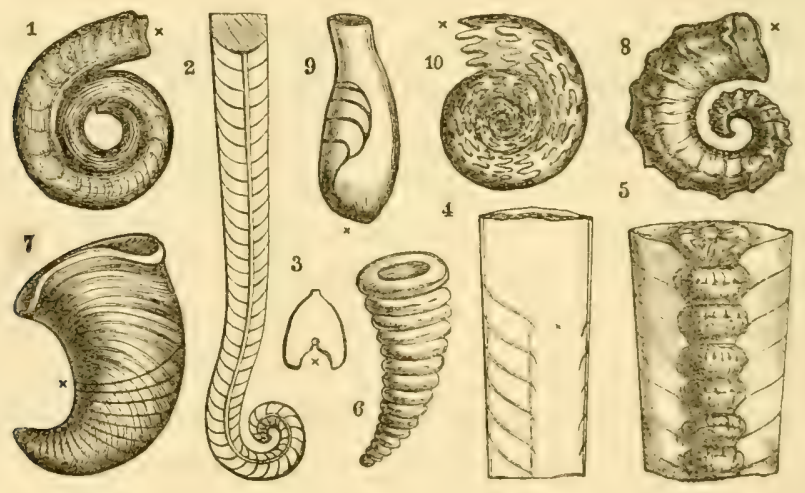

Fig. 20.

1. Nautiloceras Omalii, de Kon.; Carboniferous, Belgium.

2. Lituites (Breynius), U. Silurian, Sweden.

3. Section of Clymenia, showing internal siphuncle; Devonian, Petherwin.

4. Section of Camaroceras duplex, Wahl.; L. Silurian, Russia.

5. Siphuncle of Huronia Bigsbyi, Stokes; with outline of shell, and septa.

6. Siphuncle of Discosorus, Hall ; U. Silurian, Lake Huron.

7. Phragmoceras ventricosum, Sby.; L. Ludlow rock, Herefordshire.

8. Gyroceras Eifeliense, d'Arch.; Devonian, Prussia.

9. Ascoceras Bohemicum, Barr.; U. Silurian, Prague.

10. Goniatites, Henslowi, Sby.; Carboniferous, Asturias.

evidently so durable as to remain on the sea-bed long after the shell itself had decayed. The joints of the siphumcle are swollen at the upper part, and the interior is filled with an irregularly-radiated structure, apparently produced by the plaiting and calcification of the lining membrane. This struc- 
ture also exists and is very regular in the siphuncle of the Devonian Orthoceras trigonale, and in the shells referred to Gyroceres by d'Orbigny (fig. 20,8) ; also in Actinoceras, a subgenus of Orthoceras, discovered by Dr. Bigsby, and described by Stokes (Geol. Trans., vol. i., 1825). The plication of this interior structure takes place in segments corresponding to the septa, and meeting in the centres of the siphuncular beads, leaving spaces or foramina for the passage of blood-vessels to the lining membrane of the air-chambers." The vascularity of the latter is well shown in the impression of septa on the fine mudstones of the Ludlow rock, often mistaken for Spongaria, which they somewhat resemble.

Towards the conclusion of its growth the air-chambers of the Orthoccras frequently become shallower, and the siphuncle diminishes in size. These indications of changed or diminished energies are accompanied by a diminution or disappearance of the internal radiated structure in the last part of the siphuncle.

In Orthoceras bisiphonatum (Tretoceras, Salter) the bodychamber is prolonged in the form of a marginal lobe, simulating a second siphuncle.

The genus Bactrites of Sandberger also resembles an Orthoceras with single-lobed sutures.

Ammonitida.-In the second division or family of chambered shells-those with lobed sutures and a marginal siphuncle-we find a similar series of forms, straight, spiral, and discoidal, but more varied and more highly ornamented.

One large geuus (Goniatites, fig. 20, 10) is found in the Devonian, carboniferous, and triassic strata, and permanently resembles the youngest form of the Ammonitcs, having the sutures lobed but not foliated. They seldom exceed 6 inches in diameter and are usually very much smaller. The whirls are

* In the carboniferous species of Actinoceras (e.g., A. gigantcum), these foramina form a cross on the ventral side of tho siphuncle. 
most frequently concealed to some extent, and often marked by cross furrows or "periodic mouths."

The Ceratites are distinguished by having the lobes of the sutures serrated, while the interrening "saddles" (or curres (lirected towards the aperture) are simple. They are found in the trias of Europe, Thibet, and South America; and again, though rarely, in the cretaceous strata of France and Syria-a circumstance quite anomalous in the history of the geological

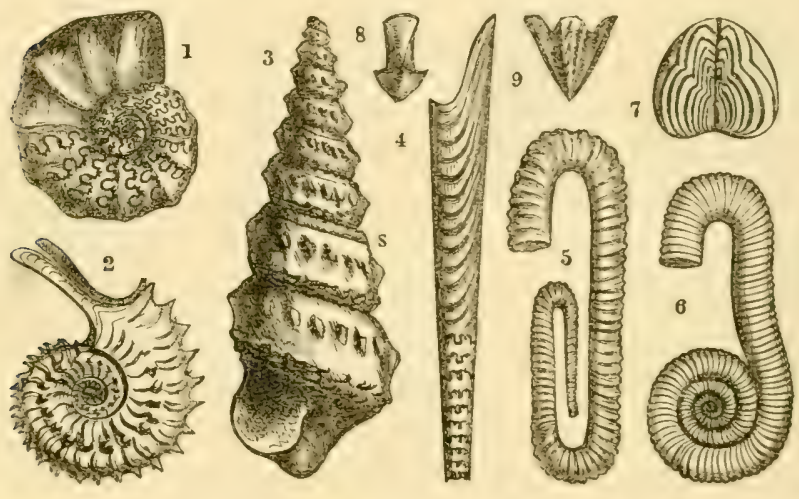

Fig. 21.

I. Ceratites nodosus; Muschelkalk, Bavaria.

2. Ammonites Duncani (spinosus, Sby.); Oxford Clay, Wilts.
3. Turrilites.
5. Hamites.
4. Baculites.
6. Ancyloceras.

7. (Trigonellites or Aptychus), operculum of Ammonites.

8. (Rhyncholites hirundo), upper mandible of Nautilus arietis, Rein. Muschelkall.

9. Lower mandible (Conchorynchus avirostris).

distribution of life. Many Ammonites, perhaps all, are like Ceratites when young.

A bisected specimen of the Ammonites obtusus, in the Hunterian collection (No. 188), shows well the extent of the last, or inhabiterl, chamber of the shell, and the effects of the influenes of the animal matter of the decaying epphalopor 
upon the petrifactive processes after death. The liassic clay has penetrated as far as the retracted soft parts of the ammonite permitted: the decomposing mollusk had been partially replaced by crystals of silex, discoloured by the pigmental or carbonized parts of the animal. The silex, which has more slowly infiltrated through the pores of the shell into the air-chambers, is of a much lighter colour. In the same collection may be seen exemplifications of injury and repair of the shell. In No. 195, Ammonites Goliathus, from "Oxford clay," a portion of the shell, at the period when it formed the dwelling-chamber, "had been broken away during the lifetime of the animal, and repaired by fresh nacreous material, wanting the ribbed structure of the originally formed shell."**

The species of Ammonite exceed 500 ; and their range is co-extensive with that of the secondary rocks. They are found throughout Europe, and at the Cape, in Kamtschatka, Thibet, and S. India. They are absent from a large area of the United States, but are found in the cretaceous strata of New Jersey, Missouri, and the West Indian Islands; also in Chili and Bogota.

The sections into which, for the sake of convenience, this extremely natural group has been broken up, are very ill-defined, and have no pretension to be considered subgeneric. The group (called Cassicni) characterising the triassic period, is remarkable for many-lobed and elaboratelyfoliated sutures-a circumstance more important because it is the oldest group, and associated with Coratites and the last-surviving Goniatites and Orthocerata. They abound in the "alpine limestone" of St. Cassian, and Hallstatt in Austria. A second group (Arictes), having the back keeled,

* Catalogue of Fossil Invertebrata, M[us. College of Surgeons, London, 4to, p. 43, in which work the writer has described upwards of 350 specimens, illustrative of the different sections of Ammonitide, collected by John II unter in the last century. 
with a furrow on each side of the keel, as in the great Ammonites called Bucklandi and Coneybearei, mark the lias period; they are less plentiful in the oolites, and are represented in the greensands by the Cristati, which are keeled, but not furrowed, and develope a "beak," or process, from the keel when adult. The Arietes pass by many intermediate forms into the Fulcifori (e.g., A. scrpentinus), also characteristic of the upper lias, and these are represented by a few quoit-shaped species (Disci), with sharp backs, in the oolites.

Ammonites with serrated keels (Amalthei), exemplified by A. spinatus and margaritatus, abound in the middle and upper lias, and again in the oolites (c.g., A. cordatus and crecuratus). They are succeeded by the Rothomagenses in the challithick Ammonites with a line of tubercles in the place of the keel.

Ammonites with channelled backs (Colliciati) are represented in the lias (A. angulifcrus), inferior oolites (A. Parkinsoni), and middle oolite (A. anceps), and in the cretaceous strata by numerous species (c. g., A. scrratus, lautus, and falcatus), remarkable for their elegance.

Of the species with backs more or less squared, armatus and capricormus occur in the lias, athleta and porarmatus in the Oxfordian. But the oolitic forms which have the back square, and ornamented with two rows of spines when young, like Goucri, Duncani (fig. 21, 2), and Jason, become rounded and unarmed in their old age.

Round-backed Ammonites abound in the lias and oolites. The snake-like annulatus, the spine-bearing coroncutus, and fimbriatus with its ornamented fringes, have been regarded as types of small groups. A more important division (Ligati) is distinguished by nearly smooth whirls, constrictions recurring at regular intervals. These are seen in A. tatricus, and others related to Hetrophyllus; in many neocomian Ammonites, and in $A$. planulatus of the lower chalk. 
These constrictions, often accompanied by a prominent rib, undoubtedly indicate periods of rest, when the Ammonite ceased for a while to grow. They may be traced in species belonging to other groups, as well, e.g., in biplex and triplicatus, as in the Ligati; but most frequently all indications are obliterated by subsequent growth. It has been a question whether the lateral processes of Ammonites Duncani (fig. 21, 2), are formed and removed periodically, or whether they are peculiar to the adults, and mark the close of their outward growth. The first conclusion is more probable from amalogy ; and they are commonly found with small and apparently young shells, but not (any more than the lateral spines of the living Argonaut) in those of adult size and condition.

It was remarked by the eleler Sowerby that Ammonites were most beautiful when of midulle growth, the ormamental characters being less developed in the young, and lost in the adult. The ribs and spines, and eren the keel or furrow of the back disappear, in many instances, from the boly-whirl of the full-grown shell.

Varieties of form, such as marked the palæozoic Nautilide, are met with in the Ammoniticle, chiefly towards the close of their reign. The Baculite (fig. 21, 4), with its straight shell, is characteristic of the upper chalk; and the Turritite, which is spiral, and usually a left-handed spiral, abounds in the lowest beds of the same formation. In Hamitcs the shell is straight, returuing upon itself after a certain space, and forming a simple or complex hook. In Ptychoccres these limbs of the hook-like shell are in close contact. The Toxoceras is curved like a bow ; in Crioceras the discoidal whirls are separate; and in Scaptites (including Ancylocerces) the shell, at first compact like an Ammonite, or open-whirled like Crioceres, lengthens out finally, and returns upon itself like the crozier of the Hamite. Hclicoceras, again, connects the last with the Turitite hy its elevated spire terminating in a prolonged crozier. 
Of these forms, Ancyloccras alone is found in the oolites; all the rest are cretaceous; and most abound in the alpine districts of the south of France.

\section{Order 2.-Dibranchiata.}

(Cuttle-fishes.)

Of the two great divisions of cephalopodous Mollusea, that which is represented at the present day by the pearly $N^{\top}$ autilus was developed in the greatest profusion and variety in the palrozoic and secondary periods; whilst the more active and intelligent cuttle-fishes and squids have not been (certainly) found in rocks older than the lias, and scarcely above 100 are found in the whole secondary and tertiary series, while twice as many have been obtained in existing seas.

The Scpiado are represented in the widdle and upper oolites by the genus Coccotcuthis (fig. 22, 6), whose strong and granulated bone is furnished with broader lateral expansions than the recent cuttle-fishes. In the older tertiaries of London and Paris, many species of Scpic appear to have existed, but only the solid mucro (fig. 22, 5) of the shell is usually preserved. In the miocene tertiary of Malta, a diminutive cuttle-bone is not rare; and at Turin a remarkable form (Spirutirostre, fig. 22, 7) has been discovered, in which the apex is provided with a chambered and siphonated cavity like the shell of the Spirula. Two other genera, Bcloptera (fig. 22,8) and Bclcmnoris, very imperfectly known by rare and fragmentary examples, occur in the eocene tertiary.

Remains of the Calamaries (Teuthide) are often found in the fine-grained and laminated argillaceous limestones of the lias and Oxford clays, as at Lyme Riegis, and Büll of Solenhofen. Some of these are slender, like the pens of the recent Ommastrephes, and fumished with a small conical appendix, as in that genus; whilkt others are broal, and pointed at each end (Belotrullics). The most common form has the shaft wide 
and longer than the wings, and is truncated posteriorly. It has a nacreous lining, and is usually accompanied by a large and well-preserved ink-bag (fig. 22,4). These were called Belemnosepia by Agassiz and Buckland, who supposed them to belong to the same animal with the Belemnite. They have also been called Lotigo-scpice and Loliginites; but the name Geoteuthis, given by Count Münster, appears less objectionable. One species (Mastigophora brevipinnis*) is of frequent occurrence in the Oxford clay near Chippenham, which retains not only the horny (chitinous) pen and ink-bag, but also the muscular mantle, the rhombic terminal fins, and at least the bases of the arms, with the minute hooks, and traces of the mandibles. Horny claws, like those of the uncinated Calamary (Onychoteuthis), have been observed arranged in double series in the lias of Watchett, and they sometimes occur in great numbers in the coprolitic remains of the Enaliosauri. The most remarkable examples of this kind are preserved in the lithographic limestones of Solenhofen, and show that the extinct Calamary had ten nearly equal arms, the tentacles, in their retracted condition, being undistinguishable from the rest-each furnished with 20 to 30 pairs of formidable hooks. What further evidence was needed respecting the nature of this creature has been supplied by the Chippenham fossils, which in all probability are identical in genus, if not in species, with the Acanthoteuthis described by Münster. One of these extraordinary fossilsthe mummy of a cuttle-fish more ancient than the chalk formation and the upper oolites-is represented in (fig. 22, 2, ) reduced to one-sixth from the original in the British Museum. Nine of the arms are preserved, the sclerotic plates of the eyes, the bases of the large lateral fins, the small ink-bag, and the conical shell. This shell, which is chambered internally,

* Catalogue of Fossil Invertebrata, in the Museum of the College of Surgeons, London. 1to, 1856, p. 1. 
like the phrarmocone of the Belemnite (fig. 22, I), has an outer sheath of fibrous structure, one-fourth of an inch thick at the

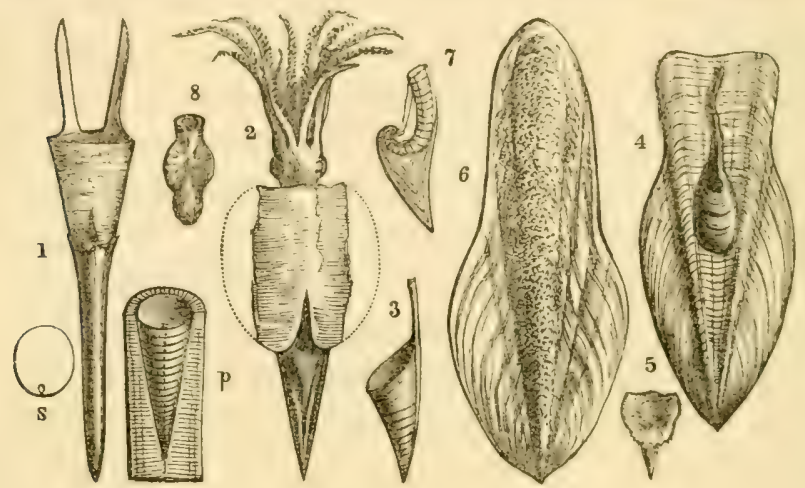

Fig. 22.

I. Belemnites Oweni; Oxford Clay, Chippenham. p. Phragmocone exposed by the removal of the fibrous guard from one side; s, septum, showing the marginal siphuncle.

2. Acanthoteuthis antiquus (Cunnington) Orvford Clay, Chippenham; dorsal aspect.

3. Conoteuthis Dupinii; Gault, Folkestone.

4. Geoteuthis.

5. Sepia.

6. Coccotenthis.

7. Spirulirostra.

8. Beloptera anomala.

apex, and furnished with two converging ridges on its dorsil side ; the external surface, however, is horny (or chitinous), like the pen of the Calamary. These chambered shells occur in great numbers, and are so like the phragmocones of the associated Belemnites, both in structure and proportions, that they were originally described by me as such, ${ }^{*}$ and I still view them as evidences of the close aftinity of the cephlialopod possessing them to the true Belemmite: hitherto they have only been noticed in the laminated Oxford clay of Wilts, and the equivalent lithographic shales of Solenhofen.

* Philnsnphical Transactions, 1814; and Cat. Fossil Invert., Miss. Coll. of Surgeons. 4to, p. 5. 
Species of Belemnite are found in all the oolitic and cretaceous strata, from the lowest lias to the upper chalk. In its ordinary imperfect state, it is a cylinder pointed at one end (fig. 22, r), and truncated or excarated by a funnelshaped cavity (alvcolus, ib. $p$ ) at the other, and has a radiating fibrous structure, with less distinet concentric laminæ of growth. But even this "guard," which corresponds simply to the "mucro" of the cuttle-bone (ib. 5), exhibits such remarkable modifications of form, that nearly 100 species have been founded upon no higher eridence. In some Belemnites of half an inch diameter, the guard is scarcely an inch longer than the phragmocone, whilst in others it attains a length of ten inches, and is tubular, as in B. acuctivs. Some are fusiform, others laterally compressed; some have a longitudinal groove extending from the apex along the upper or under side, and in others the apex is furrowed laterally as well. The Belemnites of the chalk have been callerl Bclemnitclle (d'Orb.), because they have a slit in the ventral side of the alveolar border of the guard; their external surface also exhibits more distinct traces of vascular impressions.

Specimens of Belemnite have heen discovered in which the guard had been broken during the lifetime of the animal ; but the broken portions, being held together by the investing organised integuments, had been re-united by the deposition of new layers of the filbrous structure peculiar to the guard. Several examples of Belemnites, with the apex injured and healed during life, are preserved in the British Muscum. In all perfect Belemnites, the alrcolus is occupied by a phragmocone (fig. 22, p), with tender nacreous walls and septa, terminating in a minute globular apex, and perforated by a ventral siphuncle (fig. 22, ז). The last chamber is rarely preserved, and appears to have thimmed off into a mere homy sheatl, with sometimes two pearly bands like knife-blades on the dorsal side. It must have been sufficiently capacions to 
contain all the viscera. The ink-bag has been very rarely found, and is eren smaller than in the last genus, as if in relation to the more greatly developed shell.

The Conotcuthis (fig. 22,3) of the Gault has an oblique phragmocone, with a very thin shell, and seems to have been attached to a slender style, like the fumel-shaped appendix of the gladius in the recent sagittated Calamary.

Mr. Dana has described, under the name Helicerus Fugiensis, a belemnitoid fossil from the "slate" rock of Cape Horn. It is half an inch in diameter, has a thick fibrous guard, and the slender phragmacone terminates in a fusiform spiral nucleus.*

Subjoined is a table of the extinct genera of the mollnscous province:-

Brachiopoda.-Trigonosemus, Lyra, Magas, Rhynchora, Zellania, Stringocephalus, Meganteris ; Spirifera, Cyrtia, Suessia, Athyris, Merista, Retzia, Uncites ; Camarophoria, Porambonites, Pentamerus, Atrypa, Anoplotheca ; Orthis, Orthisina, Strophomena, Koninckia, Darirlsonia, Calceola ; Producta, Chonetes, Aulosteges, Strophalosia ; Trematis, Siphonotreta; Obolus.

Conchifera.-Gry]hæa, Exogyra, Limanomia, Carolia, Placunopsis, Neithea, Eligmus; Pteroperna, Ancella, Ambonychia, Cardiola, Eurydesma, Pterinea, Monotis, Posidonomya, Aviculopecten, Gervillia, Streblopterial, Pulvinites, Inoceramus, Trichites; Megalina, Orthouotus, Modiolopsis, Hoplomytilus; Macrodon, Isoarea, Bakewellia, Nueulina, Nucinella, Cucullella, Ctenodonta ; Myophoria, Axinus, Lyrodesma ; Diceris, Monopleura, Requienia ; Hippurites, Radiolites, Caprinella, Caprina,

* For the drawings and nost of the facts, or their verification, relating to invertebrate fossils, the writer is indebted to his experienced colleague in charge of that department of the British Museum, Mr. S. P. Woodward, F.G.S. 
Caprotina ; Lithocardium, Conocardium, Corbicella, Sphrera, Unicardium, Tancredia, Volupia ; Plemrophorus, Myoconcha, Anthracosia, Megalodon, Pachydomus, Pachyrisma, Cleobis, Mreonia, Opis, Cardinia, Hippopodium, Megaloma; Grateloupia, Sowerbya, Quenstedtia, Gomiophora, Redonia; Cercomya, Myacites, Goniomya, Grammyria, Ceromya, Cardiomorpha, Edomondia, Ribeiria.

Gasteropoda.-Bellerophon, Porcellia, Cyrtolites, Ecculiomphalus ; Rimella, Hippocrena, Alaria, Spinigera, Amberlya ; Leiostomus, Strepsidura, Purpurina, Columbellina, Borsonia, Conorbis ; Euspira, Naticopsis, Globulus, Deshayesia, Loxonema, Macrochilus; Diastoma, Nerinaea, Brachytrema, Ceritella, Vicarya, Scoliostoma, Proto, Holopella, Catantostoma, Naticella ; Platyceras, Mctoptoma, Hypodema, Deslonchampsia ; Euomphalus, Ophileta, Phanerotinus, Serpularia, Discohelix, Platystoma, Crossostoma, Pleurotomaria, Murchisonia, Polytremaria, Cirrus, Trochotoma, Platyschisma, Scalites, Phaphistoma, Holopea, Maclurea; Neritoma, Velates, Pileolus ; Helminthochiton; Lychmus, Dendropupa, Ferussina ; Cylindrites, Acteonina, Acteonella, Cinulia, Globiconcha, Varigera, Tylostoma, Pterodonta, Volraria, Chilostoma; Vaginella, Theca, Pterotheca, Conularia.

Cephalopoda.-Aturia, Discites, Nautiloceras, Trigonoceras, Temnochilus, Iituites, Trocholites, Trochoceras, Clymenia; Orthoceras, Camaroceras, Huronia, Actinoceras, Discosorus, Gonioceras, Tretoceras, Apioceras, Gomplioceras, Phragmoceras, Cyrtoceras, Gyroceras, Ascoceras; Goniatites, Bactrites, Ceratites, Ammonites, Crioceras, Toxiceras, Ancyloceras, Scaphites, Helicoceras, Turrilites, Hamites, Ptychoceras, Baculites; Mastigophora, Teudopsis, Beloteuthis, Geoteuthis, Leptoteuthis, Bel- 
ennites, Acanthoteuthis, Helicerus, Conoteuthis, Coccoteuthis, Belosepia, Spirliurostra, Beloptera, Belemnosis.

\section{Province IV.-VVERTEBRATA.}

There is an enormous series of subaqueous sediment, originally composed of mud, sand, or pebbles, the successive bottoms of a former sea, derived from pre-existing rocks, which has not undergone any change from heat, and in which no trace of organic life has yet been detected. These nonfossiliferous, non-crystalline, sedimentary beds form, in all countries where they have yet been examined, the base-rocks on which the Cambrian or oldest Silurian strata rest.

Whether they be significative of ocean abysses never reached by the remains of coeval living beings, or whether they truly indicate the period antecedent to the begiming of life on this planet, are questions of the deepest significance, and demanding much farther observation before they can he authoritatively answered.

It has been shown that every type of invertebrate animal is represented in the superimposed stratified deposits called Cambrian and lower Silurian.

An important work, "* embodying the labours of the accomplished naturalist and acute observer, Dr. Christian $\mathrm{H}$. Pander, has recently heen published by the Russian government, descriptive of the fossil fishes of the Silurian formations of that empire. Of some hundred fossils described and beautifully figured in this work, and referred to different genera and species of fishes, from lower Silurian rocks, the writer, after the closest comparison and consideration of the evidence, is disposed to regard only those referred by I'mder to the genera Ctenognathus, Cortylodins, and Guathodus, as

* Monographie der Fossilen Fische (Lintersilurische Fische Conodunten, etc.), 4to, P'etcrsburgh, 1856. 
having any probable claims to vertebrate rank; and to this admission must be appended the remark, that the parts referred to jaws and teeth may be but remains of the dentated claws of Crustricea. With regard to the fossils called "Conodonts," on which the main part of MI. Pander's evidence of lower Silurian fishes rests, the following remarks, penned after microscopic examination of original specimens, are applicable to them.

Minute, glistening, slender, conical bodies, hollow at the base, pointed at the end, more or less bent, with sharp opposite margins, might well be lingual teeth of Gastropods, acetabular hooklets of Cephalopods, or teeth of cartilaginous fishes. Against the latter determination is the minute size of the "Conodont" bodies. Their basal cavity doubtless contained a formative pulp, but the proof that the product of such pulp was "dentine" is wanting: the observed structure of the hooklet presents concentric conical lamellæ of a dense structureless substance, containing minute nuclei or cells.

In some specimens the base is abruptly produced and divided from the body of the hooklet by a constriction-a form unknown in the teeth of any fishes, but presented by certain lingual teeth of Gastropods-. g., the lateral teeth of Sparella. In other Conodonts the elongated base is denticulate or serrate, as in the lateral teeth of Buccinum and Chrysorlomus. It is improbable, howerer, that they belong to any conchiferous toothed Mollusk, the shells of such being wanting in the deposit where the Conodonts are most abundant.

The more minute hooklets have a yellowish, transparent, horny appearance; the larger, perhaps olcler ones, present a harder whitish appearance. Their analysis by Pander yielded " carbonate of lime," carbonic acid being crolved by application of dilute nitrie acid, and oxalic acid producing an obvions pnecipitate. Some English analysts have believed that the Conodonts yielded a trace of phosphate of lime. 
The detached condition of the hooklets, and the integrity of the thin border of the basal pulp-cavity, indicate that they have not been broken away from any of those kinds of attachment to a bone which the minute villiform teeth of osseons fishes would show signs of. The Conodonts have been supported upon a soft suhstance, such as the skin of a mollusk or worm, the mucous membrane of a mouth or throat, or the covering of a proboscis; but to select the teeth of cyclostomous or plagiostomous fishes as the exclusive illustration of the above condition, would be to take a partial and limited view of the subject.

In comparing the Conodonts with the teeth of fishes, they present most resemblance to the minute conical recurved teeth of the genus Rhinodon of Smith : they more remotely resemble the conical, pointed, horny teeth of Myximoids and Lampreys in that class: and the absence of any other hard part in the strata containing the Conodonts tallies with the condition of the cartilaginous skeleton; lout not more than it does with the like perishable soft condition of annelidous worms and naked mollusks. Rhinodon has very small teeth, "en brosse," of a simple conical recurved form : there are 12 or 13 teeth in each rertical row, and about 250 such rows in each jaw : so that each fish may have from 6000 to 7000 tecth. But the teeth of Rhinodon have not the basal extensions and processes of many of the Conodonts; and the teeth of all known Cyclostomes are much less slender and are less raried in form than in the Conoclonts. Certain lingual plates of Myxinoids are serrate, but not with a main rlenticle of much greater length-such as shown in the form of the Conodont called Machairodus by Pander. MIost cyclostomous tecth are simple, thick cones, with a subcircular hase; and every known tooth of a cyclostomous fish is much larger than any of the forms of Conodon, which rarely equal half a line in length. This minuteness of size, with the preculiarities of 
form, supports a reference of the Conodonts rather to some soft invertebrate genus. Certain parts of small Crustaceac.g., the pygidium or tail of some minute Entomostraca-m resemble in shape the more simple Conodonts; but when we perceive that these bodies occur in thousand, detached, with entire bases, and that any part of the carapace, or shell of an Entomostracan or other Crustacean, has been rarely detected in the lower Silurian Conodont beds, it is highly improbable that they can have bulonged to an organism protected by a substance as susceptible of preservation as their own sulustance. Much more likely is it that the body to which the minute hooklets were attached was as soluble and perishable as the soft pulp upon which the Conodont was sheathed. The writer finds no form of spine, denticle, or hooklet in any Echinoderm, and especially in any soft-bodied one, to match the Conodonts; and concludes that they have most analogy with the spines, or hooklets, or denticles of naked Mollusks or Aunelides. The formal publication of these minute ambiguous bodies of the oldest fossiliferous rocks, as proved evidences of fishes, is much to be deprecated.

Class I.-PISCES.

Order 1.-Plagiostom.

(Sharks, Rays.)

Char.-Endo-slieleton cartilaginous or partially ossified ; exoskeleton placoid; gills fixed with five or more gillapertures; no srim-bladder; scapular arch detached from the head; ventrals abdominal; intestine with spiral valve.*

The earliest good evidence which has been obtained of a vertebrate animal in the earth's crust is a spine, of the nature

* For an explanation of the technical terms in these characters, see the article Icнтнтодояx, especially of the scales, Enc. Brit. rol. xii., p. 216. 
of the dorsal spine of the dog-fish (Accnthias), and a buckler like that of Cephalaspis. Both have been found in the most recent deposits of the Silurian period, in the formation called "upper Ludiow rock." The discovery of the first is due to Murchison ; ${ }^{*}$ its determination to Agassiz, who assigns it to a genus of plagiostomous cartilaginous fishes called Onchus. The buckler was discovered by Mrr. Banks, in the "passagebeds" of Kington, Herefordshire, and is referred to the genus Pteraspis, Knerr, with microscopic evidence of its piscine nature, by Huxley.

The Onchus spines from the upper Ludlow bone-beds are compressed, slightly curved, less than two inches in length, with no trace at their base of the joint characteristic of the dorsal spines of the "sheat-fishes" (Ganoids of the family Siluridce), or "file-fishes" (Balistidce). The sides of the spine are finely grooved lengthwise, with rounded ribs between the grooves. They are referred to two species-Onchus Murchisoni, and $O$. semistriatus. Sir P. Egerton has lately figured another species from the argillaceous beds near Ludlow, which is more curved, and is armed along the posterior edge ; the longitudinal ribs are fine and numerous, but are constricted at intervals, as in the genus Ctencacanthus, and become subtuberculate at the base. He deems them significant of a distinct genus of sharklike fishes. $\dagger$

With the dorsal spines of Onchus are found petrified portions of skin, tubercular and prickly, like the shagreen of shark's skin, and referreel to a genums called Spllungulus; also coprolitic boulies of phosphate and carlonate of line, inchuling recognisalule parts of the small Miollusks and Crinvils which

* Silurian System, ch. xlv., p. 606.

$f$ In a firmation in Indiana, Lnited States of Amerien, referred ly Messrs. Norword and J bile (Jwen to the Silurian formation, a hally-preserved fossil, considered as an Ichthrodite, and referret to a genus allient to Pterichthys, has been discovered, and called Ilucropetalichlhys ret)lüidolulis. (siliman's Journal, 1816, p. 367.) 
inhabited the sea-bottom in company with the Onchus-fish. No vertebre, or other parts of the endo-skeleton of a fish, have been discovered, unless the fragments of a calcified bar, with tooth-like processes, called Plectroclus, be truly jaws with teeth. They resemble, however, parts of the pincer claws of Crustaceans, as well as of the jaws and teeth of fishes, and do not indicate that class so satisfactorily as the Onchus spines and Splacadus shagreen. I't the denticles are confluent with an outer ridge of the bone, according to the "pleurodont" type, and consist of separated large teeth, with minute serial teeth in the interspaces; and the large teeth are grooved longitudinally.*

If the Plectrodonts be jaws with anchylosed teeth, they belong to an order distinct from the Plagiostomi. If they should belong to any of the fishes indicated by the dorsal spines and shagreen skin, a combination of characters would be exemplified not known in other formations or in any existing fishes.

No detached teeth unequirocally referable to a plagiostomous genus, nor any true ganoid scale of a fish, have yet been found in the formations that have rercaled these earliest known evidences of vertebrate animals. What, then, it may he asked, were the conditions under which so immense an extent, as well as amount, of sediment was deposited_-including chambered Cephalopods, Gastropods, Lamellibranchs, Brachiopods, various and large trilobitic and entomostracous Crustaceans, with Crinoids, Polypes, and Protozoa-that precluded the preservation of the fossilizable parts of fishes, if that class of vertebrate animals had existed in numbers, and under the variety of forms, comparable to those that people the ocean at the present day? Bonitos now pursue flying-fishes through the upper regions of an ocean as deep as any known part of the Silurian seas of which the deposits afford an idea of greatest

* Egerton, Proc. Geol. Soc., March 1857, p. 288, pl. x., figs. 2-4. 
depth. If fishes of cognate halits with the present deep-sea fishes, under whatever difference of form such Silurian fishes may have heen manifested, had really existed, we might reasonably expect to find the remains of some of the countless generations that succeeded each other during that vast and inclefinite period, sufficing for the gradual deposition of sedimentary beds of thousands of feet in depth or rertical thickmess.

The evidences of plagiostomous fishes afforded by fossil spines will be here pursued. In most of the existing cartilaginous fishes of this order the defensive spine which stands erect in front of the dorsal fin is smooth; such is the case in the dog-fishes (Spinacide) in which each dorsal fin is fronted with a spine. In the Port-Jackson sharks (C'estracionticle) the spine in front of each dorsal is bony, and is armed along its hinder or concave border with bent spines. The fin is connected with this border, and its movements are regulated by the elevation or depression of the spine during the peculiar rotatory action of the body of the shark. This action of the spine in raising and depressing the fin, resembles, Dr. Buckland has remarlied, that of the moveable or jointed mast, raising and lowering backwirds the sail of a barge. But their more obvious use, in the mall Plagiostomes possessing such spines, is as defensive weapons against the larger and stronger voracious tishes. The spine of the Onchus indicates its danger from some larger, and as yet unknown, predatory fish.

Certain bony fishes are similarly armed-c.y., sticklebacks (Gesterostei), sheat-fishes (Siluricle), trigger-fishes (Bulistes), and some species of snipe-tishes (Fistuleride). In the latter fumily the Centrisens humerosus (fig. 23) shows a dorsal spine, denticulated behind, as in the C'estracionts ; but the base of the spine in bony fishes is peeuliarly modified for articulation with another hone. In the Plaginstomes the hase of the spine is hellow, leeomes thin and susooth when the hody of the spine is sconlptured, and is in the rerent lish implanterd in the flesh. 
The following genera of plagiostomous fishes have been founded on the fussil spines, or "ichthyodorulites," which have been discovered in the "Deronian," or "Old Red Sandstone

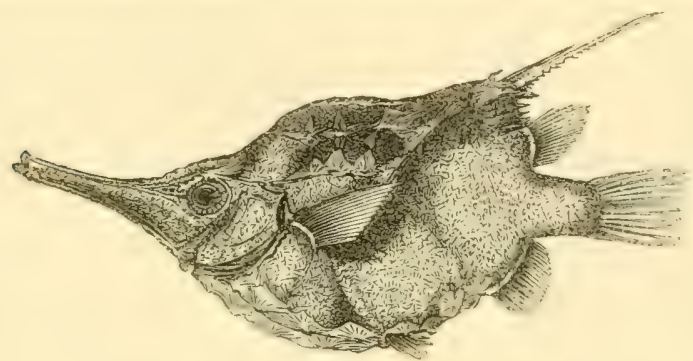

Fig 23.

Centriscus humerosus.

series." Onchus (represented by O. semistriatus, O. hetcroyyrus), Dimeracenthus, Haplecenthe!s, Tarades, Naules, Byssacanthus, Cosmeenthus, Homecenthus (fig. 24), Ctenacanthus, Ptyacanthus, Climetius, Parexus, Odontacanthus, and Plouracanthus.

The genus Homacanthus is founded on small compressed spines, with fine recurved teeth on the back edge, and longitudinal strix on the sides. Specimens of Hoinucunthus arcuutus (fig. 24) have been foumd in Devonian formations near St. Petersburg.

The carboniferous series of formations includes the mountain limestone, millstone grit, and the coal measures (see fig. 1). In this series the genus Onchus is still represented by the $O$. sulcatus, 0 . rectus, and $O$. subulatus; and the genus Homacanthus, by $H$. macrodus and $H$. microdus, from the carboniferous limestone of Armagh. Ptyacanthus, Ctenacanthus, and Pleuracanthus are also forms common to the Devonian and

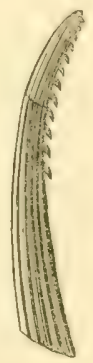

Fig. 24.

IIomacanthus arcuatus.

(Devonian, Russia.) carbonifervus periods. The spine of the latter genus is denticulated along both nurgins, a structure which is presented, in existing Plagiostomes, only ly sprecies of the ray family; 
Pleuracanthus, therefore, as Agassiz concludes, may offer the earliest example of the flat form of cartilaginous fish which is represented by the sting-rays (Trigon, IIyliobates) in the

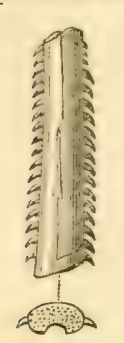

Fig. 25. present seas. The ichthyodorulite (ichthys, a fish ; dora, a spear ; lithos, a stone) here selected to illustrate this fossil, is a portion of the spine of the Pleurecenthus levissimus (fig. 25), from the carboniferous beds near Dudley. The other plagiostomous genera based upon fossil spines from the coal formations are,-Oracanthus, GyraPleuracanthus thus, Homacanthus, Trystichines, Asteroptcrychius,
levissimus. (Coal, Dudley.) Physonemus, Sphenacenthus, Platyacenthus, Dipriacenthus, Erismacanthus, Orthacanthus, Cledecanthus, Lepracanthus.

Immediately above the coal measures lie a rariable series of sands and clays of different colours, including the coal plants; above this, a marl slate in thin layers, containing scanty evidences of fishes; lout these are more abundant and instructive in the superincumbent magnesian limestone, in which formation, near Belfast, ichthyodorulites of the genus Gyropristis (Ag.) have been found. Above this are the penean red sandstones, in which, at Westoe, have been found fossil spines closely allied to, if not identical with, the Gyracanthus formosus (Ag.) The foregoing formations constitute the uppermost of the palieozoic series called "Permian," from the Russian province in which these strata are most extensively developed. Their relative position is known ly the term " magnesian limestone" in the "Talile of strata," fig. 1.

The superimposed strata, marked "new red sandstone," includes also a varied series of red and white sands, marls, and conglomerates, forming collectively the system called "triassic." The ichthyodorulites of this system are referable to the genera Nemacanthus, Lciacanthus, and Hyborlus. In 
the "lias," which is the oldest or lowest of the great " volitic" system, the dorsal spines of the genus Hybodus (fig. 26), are the largest and most abundant; this genus, however, is represented by detached teeth in the keuper and muschelkalk members of the "trias." The lias formations give evidence that the dorsal spines and fins of Hybodus were two in number; and the genus is shown, both by the structure of the spine and the form of the teeth, to have had its nearest affinities with the Cestracion amongst existing Plagiostomes. Hybodus continued to be represented by successive and varying specific forms up to, and including, the cretaceous period. Hybodus is therefore a genus of cartilaginous fishes eminently characteristic of the secondary or mezozoic period in palæontology, and ranges through every formation of that period. The specimen selected for the illustration of the dorsal spine of Hybodus is that of the H. subcarinatus, from the Wealden of Tilgate Forest.

Large fossil spines, longitudinally grooved, have been found associated with the teeth of the extinct cestraciont genus (Ptychochus) of the chalk formations.

In the tertiary formations, the fossil spines present for the most part the generic characters of those of existing Plagiostomes- $\ell$. I. Sininax,

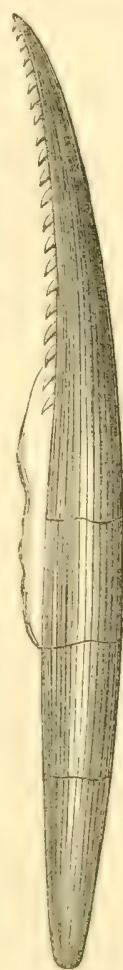

Fig. 26.

Hybodus subcarinatus.

(IVealden.) Trigon, and MIytiolates; but one form, found in the eocene beds near Paris, is the type of the extinct genus Aulacanthus of Agassiz.

The teeth of the plagiostomous fishes-viz., sharks (Squalidce), rays (Raiida), and Cestracionts, are very numerous, and, being attached only by ligament to the membrane of the mouth, they must soon fall off in the decomposition of 
the dead fish, become scattered abroad by the movements of the body through the action of the waters, and sink into the sediment.

\section{Family I.-Cestraciontida.}

\section{(Port-Jackson Shark.)}

The existing grenus which has thrown most light upon the fussil teeth which have thus become imbedded in the oceanic deposits of the palæozoic and mezozoic periods, is the Cestracion, now restricted to the Australian and Chinese seas, where it is represented by two or three species, and suggests the idea of a form verging towards extinction. It formerly flourished under a great number of raried generic or family modifications, represented by species, some of which attained dimensions far exceeding the largest known living Cestracions. The dentition of these fishes is adapted to the prehension and mastication of crustaceous and testaceous animals; they are of a harmless, timid character ; and have the before-described denticulate dorsal spines given to them as defensire weapons. Fig. 27 gives a side view of the upper and lower jaws of

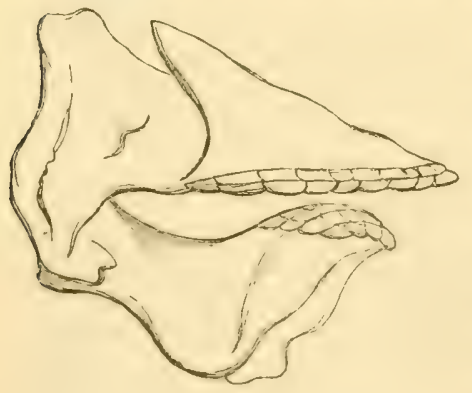

Fig. 27.

Cestrarion Philippi (recent). the "Port Jackson shark," showing the oblique disposition of the large crushing teeth, which cover like a pavement the working borders of the mouth. The anterior teeth were small and pointed. Behind the cuspidate teeth the five consecutive rows of teeth progressively increase in all their dimensions, but principally in their antero-posterior extent. The shary, point is converted into a longitulinal ridge traversing a convex crushing surface, and the ridge itsolf rlisilplears in the 
largest teeth. As the teeth increase in size, they diminish in number in each row. The series of the largest teeth includes from six to seven in the upper, and from seven to eight in the lower jaw. Behind this row the tecth, although preserving

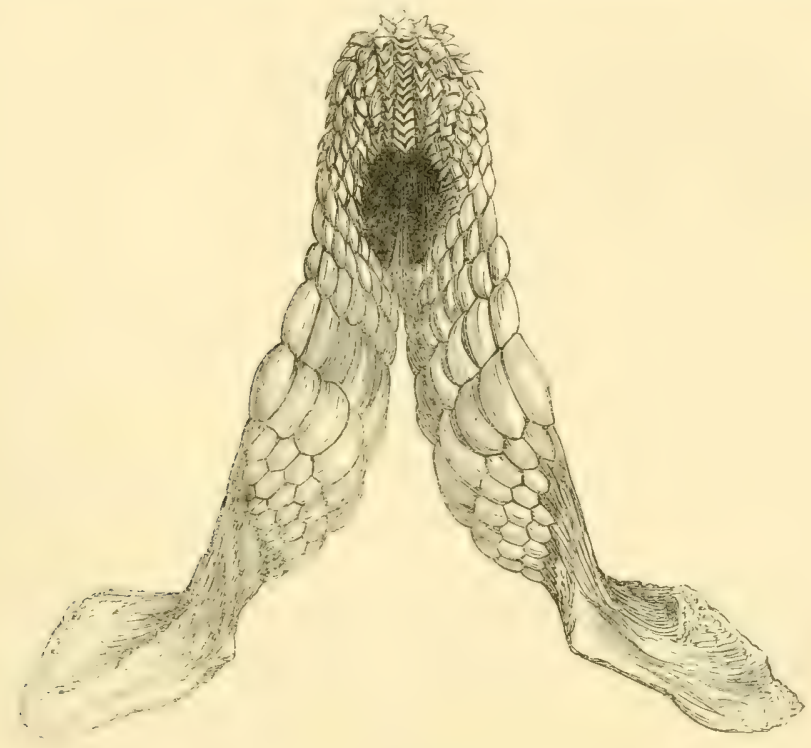

Fig. $27 a$.

Upper jaw and teeth of Port-Jackson Shark (C'estracion), half nat. size.

their form as crushing instruments, progressively diminish in size, while at the same time the number composing each row decreases. From the oblique and apparently spiral disposition of the rows of teeth, their symmetrical arrangement on the opposite sides of the jaw, and their graduated diversity of form, they constitute the most elegant tesselated covering to the jaws which is to be met with in the whole class of fishes.

The modifications of the form of the teeth above described, by which the anterior ones are adapted for seizing and retaining, and the posterior for cracking and erushing alimentary sulsctances, are frequently repeated, with varinus modifications 
and under different conditions, in the osseous fishes. They indicate, in the present cartilaginous species, a diet of a lower organized character than in the true sharks ; and a corresponding difference of habit and disposition is associated therewith. The testaceous and crustaceous invertebrate animals constitute most probably the principal food of the Cestracion, as they appear, by their abundant remains in secondary rocks, to have done in regard to the extinct Cestracionts, with whose fossil teeth they are associated.

From their mode of attachment, these teeth would become detached from the jaws of the dead fish, and dispersed in the way above described; and it is by such detached fossil teeth that we first get dental evidence of the Cestraciont family in former periods of the earth's history.

The teeth of the Hylodonts are conical, but broader and less sharp than those of true sharks. The enamel is strongly marked by longitudinal grooves and folds. One cone is larger than the rest, and called the "principal ;" the others are "secondary." In one genus (Cladodus, Ag.), the secondary cones go on enlarging as they recede from the principal cone; and teeth of this genus, refered by Eichwald to the IIybotus longiconus, have been discovered in the old red sandstone in the vicinity of Petersburg.

In the Orodus, the cones are more compressed, trenchant,

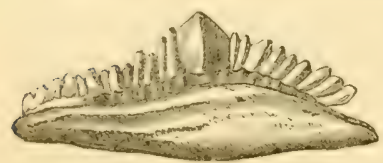

Fig. 28.

Orodus cinctus (tooth). (Carboniferous.) and distinct from the body of the tooth than in Hyboctus; but they present a principal and secondary cones. Fig. 28 is a tooth of the Orodus cinctus $(\mathrm{Ag}$. $)$, from the carboniferous beds near Bristol. The O. porosus and $O$. compressus are from deposits of similar age near Armagh.

If fig. 29 be compared with fig. 27 a, it would seem as if the several teeth of each oblique row in Cestracion had been 
welded into a single dental mass in Cochliodus, the proportions and direction of the rows being closely analogous. Whether in Cochliodus, there were any small anterior prehensile teeth, is hypothetical; the large crushing dental plates must have been admirably adapted to crack and bruise the shells of mollusks and crustaceans. The Cochliodus contortus (Ag.) (fig. 29) has been found in the carboniferous formations near Bristol and Armagh, and the genus is peculiar to that geological period.

Teeth referable to the genus $H y$ -

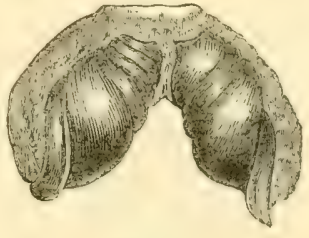

Fig 29.

Cochliodus contortus, Ag. (Carboniferous.) bodus occur in all the secondary rocks from the trias to the chalk inclusive.

A form of tooth which more closely resembles the crushing-teeth of Cestracion, is that on which the genus Acrodus is founded, and which also ranges from triassic strata to the upper chalk of Maestricht. The species here selected (fig. 30) is the Acrodus nobilis, from the lias of Lyme Regis. The upper figure shows the grinding surface, which, from its finely and transversely striated character and dark colour, has suggested to the quarrymen the name of "fossil leeches." The older fos-

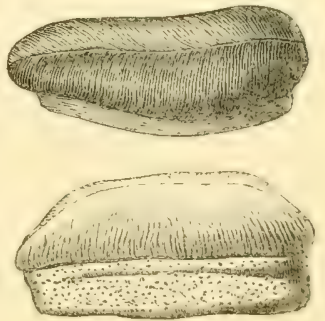

Fig. 30.

Acrodus nobilis (tooth). (Lias.) silists regarded these teeth as petrified Termes ; but the structure, as shown by the microscope, is closely similar to that of the teeth of Cestracion.* Portions of the jaw of the Acroclus have been discorered which show that these tecth were arranged, as in Cestrecion, in oblipue ruws, with at least seven teeth in each row. Acroctus lateralis is a muschelkalk fossil, A. himdo a Tealden fussil, and A. transecisus a cretaceous

* See Owen's Odontography, vol. i., p. 54, pls. 14 and 15. 
fossil. No tooth referable to the genus has been found in any tertiary stratum.

The genus Ptychodus is founded on tecth usually of large size, and of a more or less square form (fig. 31). The crown

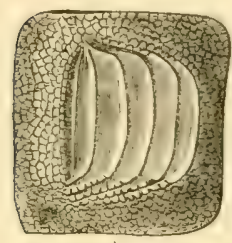
is deeper than the root, which is obtuse and truncate. The enamelled summit of the crown is granulate at the margin, and raised in the middle into an obtuse eminence, disposed in large transverse, parallel, sometimes wavy and rather sharp ridges. With teeth of this form are sometimes found

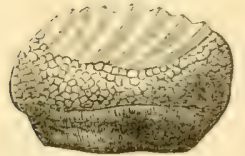

Fig. 31. others of smaller size, with more convex rounded crowns, doubtless forming the extremes of the multiserial pavement which, as in modern sharks and rays, covered Ptychodus latissimus. the broad jaws of the Ptychodonts. Large (Chalk). dorsal spines have been found so associated with the above-described teeth as to indicate the aftinity of the Ptychodus to the Cestraciont family of sharks. All the specimens and species referable to this genus have been found in the cretaceous strata.

\section{FaMiLy II.-SQUaLid}

(Sharlis.)

The well-marked, saw-shaped tooth (fig. 32), so closely resembles the lower jaw-teeth of the sharks, called "grisets" hy the French (Notidanus, Cnv.), as to be referred to that genus by Agassiz. Such teeth nevertheless occur in strata of oolitic age (Notidanus Mïnsteri, Ag., fig. 32). Other species-c. I\%, $N$. pectinatus-are found in the chalk of Kent; and $N$. serratissimus, in the eocene clay at Sheppy.

The tooth (fig. 33) on which $A$ gassiz has founded the gemus Corax, indicates by its close resemblance to those of Carcharias, its relationship with the true sharks (Squalide). Most of the 
species of Corax, including $C$. falcatus, are cretaceous; a few are tertiary : all are extinct.

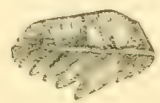

Fig. 32.

Notidanus IFünsteri.

(Upper Oolite.)

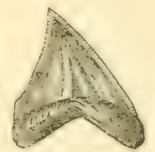

Fig. 33.

Corax falcatus.

(Chalk.)

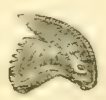

Fig. 34 .

Galeocerdo aduncus.

(Miocene.)

Another form of sharl's touth, deeply notched at one margin, and with the rest of the border finely denticulate, resembles more that of the "topes" or gray sharks (Galeus, Cur.), and is referred by Agassiz to the gemus Galcocerto. The species are found in both the cretaceous and tertiary formations; Galcocerdo aduncus (fig. 34) is from the miocene of Europe and America. In the same tertiary series are found the teeth of the Hemipristis serra, Ag. (fig. 35).

Odontaspis (Ag.), presents a form of tooth most like that in the blue sharks (Lamna) of the present seas. Species of Octontaspis occur in the cretaceous and tertiary beds. The O. Hopei (fig. 36)

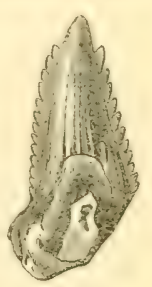

Fig. 35. Hemipristis serra. (Miocene.) is from the London clay of Sheppy. It indicates a rery destructive and formidable species of shark.

Teeth shaped like those of the white sharks (Cercharias), but solid and usually of large size, are referred to the genus Carcharodon. One of these teeth, from miocene beds, Malta, in the Hunterian Museum, London, measures 5 inches 10 lines at its longest side, and 4 inches 8 lines across the base. By the side of it is placed a tooth of an existing Carcharias, 2 inches 3 lines at its "longest sicle," from a shark which measured 20 feet in

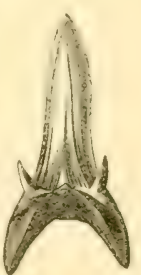

Fig. 36. Odontaspis Hopei. (Eocene.) length. If the tonth of the fossil Carcharodon bore the same 
proportion to the body of the fish, this must have been

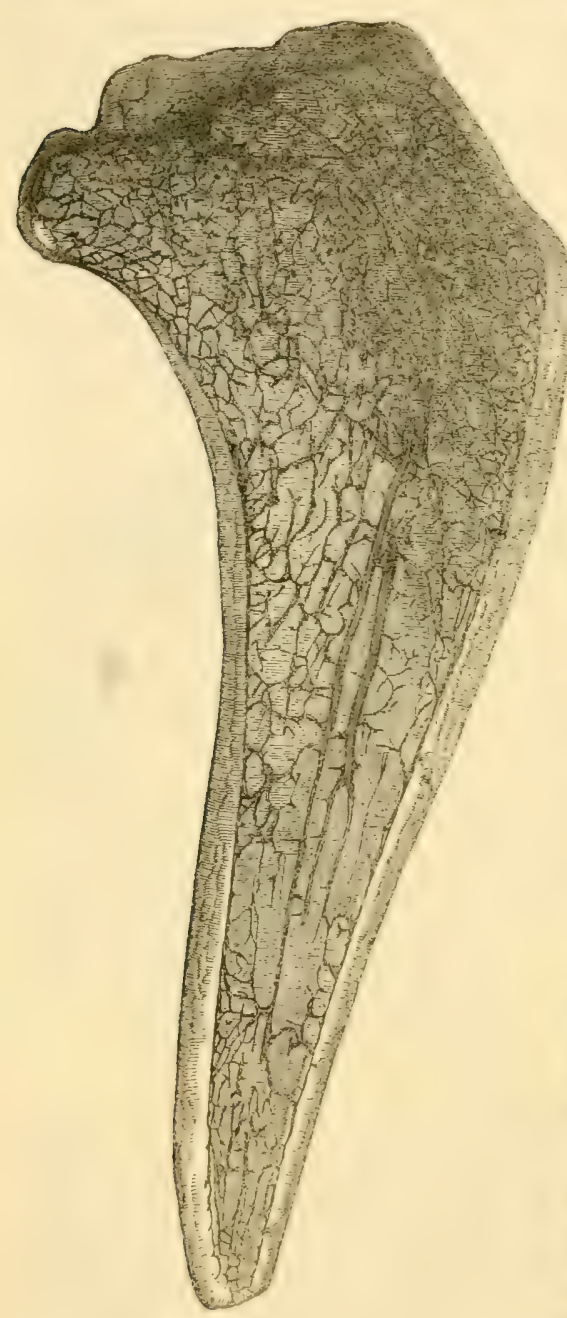
about sixty feet in length.* Teeth of Carcharodon have been obtained from the Red Crag of Suffolk, measuring upwards of six inches in length. The microscopic structure of the teeth in sharks is illustrated by the longitudinal section of a fossil from Sheppy, showing the outer hard layer of "vitrodentine," and the "vaso-dentine" forming the body of the tooth. With these fossil teeth of sharks are found, though

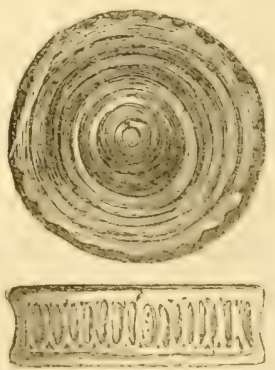

liig. 37.

Fig. $36 a$.

Magn. section of a tooth of a fossil Shark (Lamna).

Side view and back view of the body of a vertebra of a Shark, Lamna or Odontaspis. (London clay, Sheppy.)

sparingly, in both the eretaceous and tertiary beds, petrified

* See the Author's Catalogue of Fossil Reptilia and P'isces, in Mus. R. Coll. of Surgeons. Lond. 4to, 1854, p. 124. 
bodies of vertebra, showing by their extreme shortness in comparison with their breadth, by their bi-concarity, and the fissures on the external surface (as shown on the lower figure of cut 37), that they belonged to a shark closely allied to the Porbeagle (Lamna, Cuv.)

\section{Family III.-RAIID}

(Rays.)

Fossil evidences of this peculiar family of cartilaginous fishes have been discovered in oolitic (Spathobatis Belcmnobatis), cretaceous, and tertiary formations, and consist of defensive spines, dermal tubercles, and teeth, but chicfly the latter. The most peculiar and distinctive modifications of the dental system, presented by the eagle-rays (Myliobatid $\alpha$ ) are unequivocally shown by fossils of the tertiary formations, and have not been found in earlier strata.

The teeth of the rays are in general more numerous than those of the sharks; they have less mobility, are more closely impacted, and in some cases are laterally united together by fine sutures, so as to form a kind of mosaic pavement on both the upper and lower jaws. The Myliobates, or eagle-rays, which present the last-mentioned condition, unique in the rertebrate sub-kingdom, have large and massive teeth (fig. 38) ; but in the rest of the present family of cartilaginous fishes, the teeth (fig. 38) are remarkable for their small size as compared with those of the sharks. The teeth in some species of rays are adapted for crushing, but in others they have the middle or one of the angles of the crown produced into a sharp point. In all genera of the ray tribe, whatever the diversity of size and shape of the teeth, they are placed in several lows, and succeed each other uninterruptedly from behind.

The modification of the plagiostomous type of teeth, for the purpose of crushing alimentary sulstances, is most complete in the genus Ifyliobetes. A view of this armature of the mouth, 
as seen from behind in the Myliobutes aquitu, is given in fig. 3s. Both jaws are covered with a pavement of hroad teeth,

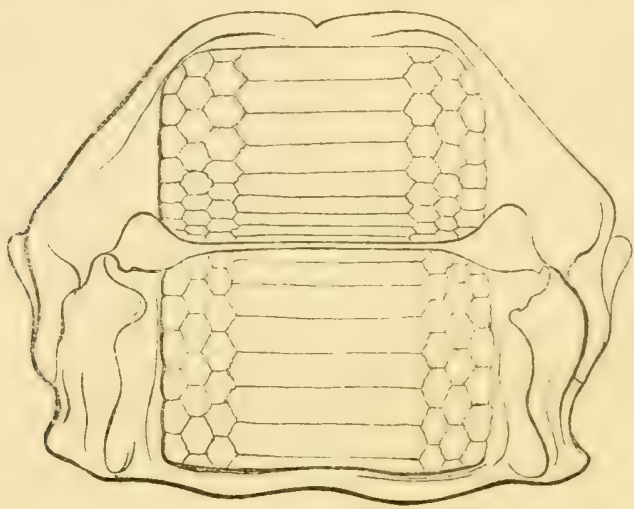

Fig. 38.

Jaws and teeth of an Eagle-Ray (Myliobates aquila).

having a flat grinding surface. To the gemus Myliobates, as now restricted, certain fossils from the London clay of Sheley (Myliobates toliapicus, Ag., fig. 39) belong.

In Zygobates (fig. 40), the middle series of teeth is less

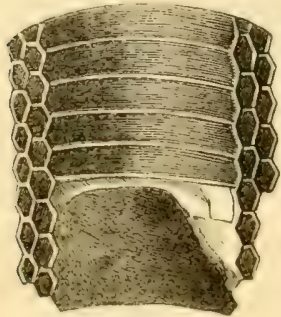

Fir. 39.

Myliobates toliapicus (Eocene, Sheppy).

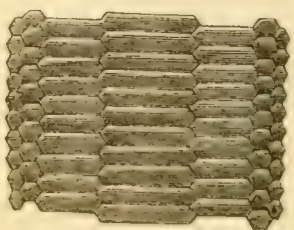

liig. 40.

Ziygobates Woodwardi

(Miocene).

broad; and a narrower series is interposed betweren the middle and the small lateral teeth. Existing rays showing this modifieation are found in Brazilian seas ; fossil teeth of this genus, e. y., Zyggobetes Irourlwarli, Ag. (fig. fo), oceur in the 
tertiary crag (probably miocene) of Norfolk, and in the miocene mollasse of Switzerland.

When the teeth form broad transverse undivided plates, as in fig. 41, they characterize the geuus Etobates. Fossils of this genus occur in the English eocenes and the Swis smollasse.

In the "crag" of Norfolk and Suffolk, and in marine pliocene herls, fossils have heen found which closely resemble

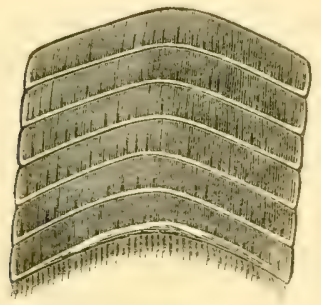

Fig. 41. Atobates subarcuatus (Eocene, Bracklesham).

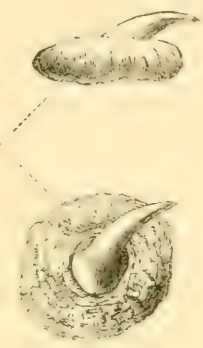

Fig. $41 a$.

Raia clavata

(Dermal spines).

the ossenus and spinigerous plates that beset the skin of the kind of ray called "thomback" (fig: 41 a), and which indicate the existence of a plincene species allied to the Roria clavato.

Thus we obtain evidence of fishes of the plagiostomous order in the marine deposits of every formation from the upper Silurian beds to the present period. But none of the palæozoic fossils are referable to any existing genus. A few only of the mezozoic Plagiostomes, and those chiefly from the chalk, are so determinable: but most of them belong or are allied to a family (C'estraciontirda), now nearly extinct. The evidence of the gemeric forms of Plagiostomes characteristic of the present time lecome common only in the tertiary periods. No fossil species is the same with any existing one. 


\section{ORDER II.-HOLOCEPHALI.}

(Chimaroid Fishes.)

Chat--Jaws bony, traversed and encased by dental plates; endo-skeleton cartilaginous; exo-skeleton as placoid granules; most of the fins with a strong spine for the first ray : rentrals abdominal; gills laminated, attached by their margins ; a single external gill aperture.

To judge from the paucity of existing representatives of this order of cartilaginous fishes, it would seem, like the Cestracionts, to be verging towards extinction. One genus (Chimara, Limn.) is founder on a single known species of the northern seas called "ling of the herrings" (Chimara monstiosa); another genus (Cullorignechus of Gronovius) is represented by two known species in the Australian and Chinese seas. The only parts of chimaroid fishes likely to be fossilized are the jaws and spines. The bony and dental sulsstances are so combined in the more or less beak-shaped jaws, that they characterize the order, and are never found separate. It is chiefly on such fossil mandibles, and portions of them, that the evidence of the Holoccpleali in former geological periods rests. These singular fishes ranged, under different generic and specific modifications, from the bottom of the oolitie series to the present period.

Genus Chinders.-The premaxillary teeth, one in each hone, are ollong, about twice as ligh as they are broad, and terminate helow in a transverse trenchant edge: they present, exteriorly, rertical columns of alternately harder and softer substance, oceasioning a notehed margin when worn by use; interiorly, they have ollicque laninat which do not extend to the margin. The maxillary dental plates, one in each hone, are triangular, and present a broad surface to the lower jaw.

Genus Isciromes, Egerton. - Eitch npler maxillary has four dental columus: the lowere jaw is less proulueed and 
deeper than in Edaphodus. Of this gemus, I. Johnsoni is from the lias of Dorsetshire; I. Egertoni from the Kimmeridge of Shotover ; and I. Tounshendi, a magnificent species, from the Portland stone. Two species (I. Aycessizii and I. Vectirostris) are from the cretaceous beds; at which period the genus appears to have perished.

Gemus Gavodus, Egerton (including Ganodus and Psittacodus of Agassiz). - This genus is exclusively represented by species from the oolitic slate of Stonesfield-e. g., G. Bucklandi, G. Colei, G. Owenii.

Genus Edaphodus, Egerton (including Eeluphodon and Passalodon of Buckland).-Each upper maxillary has three dental columus ; the lower jaw is more produced, but less deep, than in Ischiodus: the premaxillary dental mass consists of five vertical and slightly bent series of oblique and curved transverse plates; the median and longest series being strengthened by a supplementary dental columm behind : it represents the genus Passulodon of Buckland. The large E. Scdgwickii is from the greensand near Cambridge; the still larger $E$. gigus from the chalk of Kent and Sussex. The ichthyodorulite called Psittacodus Mantelli by Agassiz may be the dorsal spine of this species. Three species, including the E. Bucklandi, are found in the eocene of Bagshot and Bracklesham ; and one species (E. helveticus) is from the mollasse of Switzerland.

Genus Elasirodus, Egerton.-Each upper maxillary has three dental columns, but the dentine is confluent, "being rolled round like a scroll on the substance of the bone, one edge forming the margin of the tooth, the other buried deep in its centre. ${ }^{*}$ The premaxillary has a thin incurved scalpriform tooth, rounded at the cutting edge, of a lamellate structure, with a columnar arrangement of the plates, which are juxtaposed. This genus is exclusively represented by species -c.g., E. Hunteri-from the London clay of Sheppy.

* Egerton, Proc. Geol. Soc., May 12, 184. 


\section{ORDER III.-GANOIDEI.}

Chur:- Endo-sliteleton in some osseous, in some cartilaginuus, in some partly usseous and partly cartilaginous; exoskeleton formed hy enamelled bones: fins usually with the first ray a strong spine.

\section{Sub-Order 1.-PLACOGANOIDEI.}

(Ostracostei, Ow. Cat. Mus. Coll. of Surgeons, 4to, 185t, p. 166.)

Chur.-Endo-skeleton cartilaginous, or retaining the nutochord; head and more or less of the trunk protected by large ganoid, often reticulated, plates ; heterocercal.

The last term signifies a form and structure of tail illustrated hy fig. +2 , and to be seen in the sharks, dog-fishes, and sturgeons of the present dily : it results from a prolongation

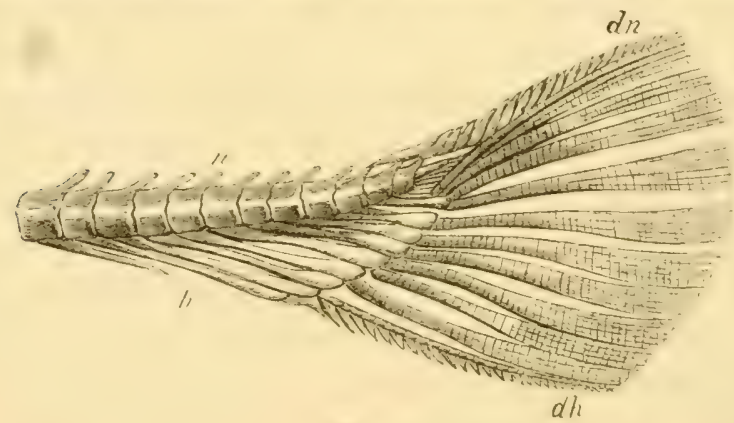

Fig. 42.

Heterocercal tail (Lepidosteus osseus).

whe vertehnal colmm into the upper lobe dne producing an unsymmetrical form of the candal fin, which is contrasted with the symmetrical form of the same fin presented by most fishes of the present day, and illustrated be the Leptedepes spoulliformis (fig. 56, 1. 1+t), in which the vertehnal column termimates at the mildle of the base of the cantial fin. There ane a few exeeptional intermediate ferms and structures of this fin.

Fitm. Placodcrmata.-The fossil remains of the singular 
fishes of the extinct order Placoganoidei were first discovered about 1813, in formations of the "old red" or Devonian age in Russia, and are preserved in museums at st. Petersburg and Dorpat. The relation of these specimens to the class of fishes was first announced by Professor Asmuss, ${ }^{*}$ and shortly after, the generic names Asterolepis and Bothriolepis were invented by Professor Eichwald, $\uparrow$ to express certain modifications of the exterual surface of portions of the ganoid plates, subsequently recognised as constituting the buckler of the fore-part of the extinct fishes. In September 1840 Mr. Hugh Niller submitted to the geological section of the British Association at Glasgow the first discovered specimens, affording a recoynizable idea of the form of one of these "old red" fishes, and for this form Professor Agassiz assigned the generic name Pterichthys (pteron, a wing, ichthys, a fish). Although, therefore, the term Astcrolepis had been attached to a fragment of the cuirass of this fish a few months previously, yet, as no recognizable generic characters were associated with such name, and as Asterolepis has been applied also to other genera - c.y., Homusteus and Heterostius of Asmuss-the example of British palatontologists will be here followed, in retaining the name Pterichthys for the present gemus. "Of all the organisms of the system," wrote the lamented Hugh Miller in his work on the Uld Red Sundstone, "one of the most extraordinary, and the one in which Lamarck would have most delighted, is the Pterichthys, or winged fish, an ichthyolite which the writer had the pleasure of introducing to the acquaintance of geologrists nearly three years ago $(18+0)$, hut which he first laid open to the light about seven years earlier" (1833).

Gones Ptenchturs (fig. 4:3).-The head and the anterior

* Bulletin Scient. par l'Acad. Imp. des Sciences de St. Petersburg, 1840, t. vi., p. 220.

† Ibid, t. vii., p. 78, communicated March 13, 1810. Dr. Fleming had recognized certain fossil scales as those of fishes in the "Old Red "of Fifeshire, in 1827. 
half of the trunk are defemled by ganoid plates-i.e., plates composed of a hard bone coated with enamel; those of the trunk forming a buckler composed of a back plate (fig. 43) and breast-plate (fig. 4t), articulated together at the sides. The rest of the trunk was defenderl by small ganoid scales, flexible, like scale-armour, and bore a small dorsal fin (fig. $43, d)$, and a terminal heterocercal fin, very rarely displayed in fossil specimens. The pectoral spines, $c$, are formed of ganoid material, like the buckler. The armour of the head, or helmet, appears to have been articulated by a movable joint to the trunk-buckler. One of the few existing ganoid fishes (Lepidosteus) is remarkable for the degree in which the head moves upon the trunk. The component dermal plates of the helmet correspond in some measure with the position of the cranial bones in osseons fishes, but not sufficiently to sanction the application to them of corresponding names. They are indicated by figures in the cut $43:_{2}$ is the front terninal or rostral plate; it is followed in the median line by four other plates in the following order:-4, promedian; 6, mdian ; 8, postmedian; ro, nuchal; 3 is the marginal, and 7 the postmarginal; 5 is the prelateral, and 9 the postlatcral. The dorsal shield of the trunk-cuirass is composed of two midplates and two on each side. 12 is the "dorsomedian," 14 the post-dorsomedian; II is the dorsolateral, I3 the post-dorsolateral. The ventral shield (fig. $4 t$ ) consists of one mid-plate and two side-plates: $x_{5}$ is probably a part of the cephalic shield or of the mandible: 19 is the vontroluteral, $2 x$ the postentrolateral ; the small supplementary plate marked 17 is usually confluent with 19 ; 16 is the rentromedian plate; its margins are bevelled oft' and overlapped by the lateral plates.

The pectoral spines (fig. $43, c$ ) are long and slender, and consist of two principal segments, both defended by finely tubereulated ganoid plates, like those of the head and trunk. From their form, they would seem to have server to aid the 
fish in shuffling along the sandy bottom or bed, if left dry at low-water. The fins attached to the Hexible part of the body

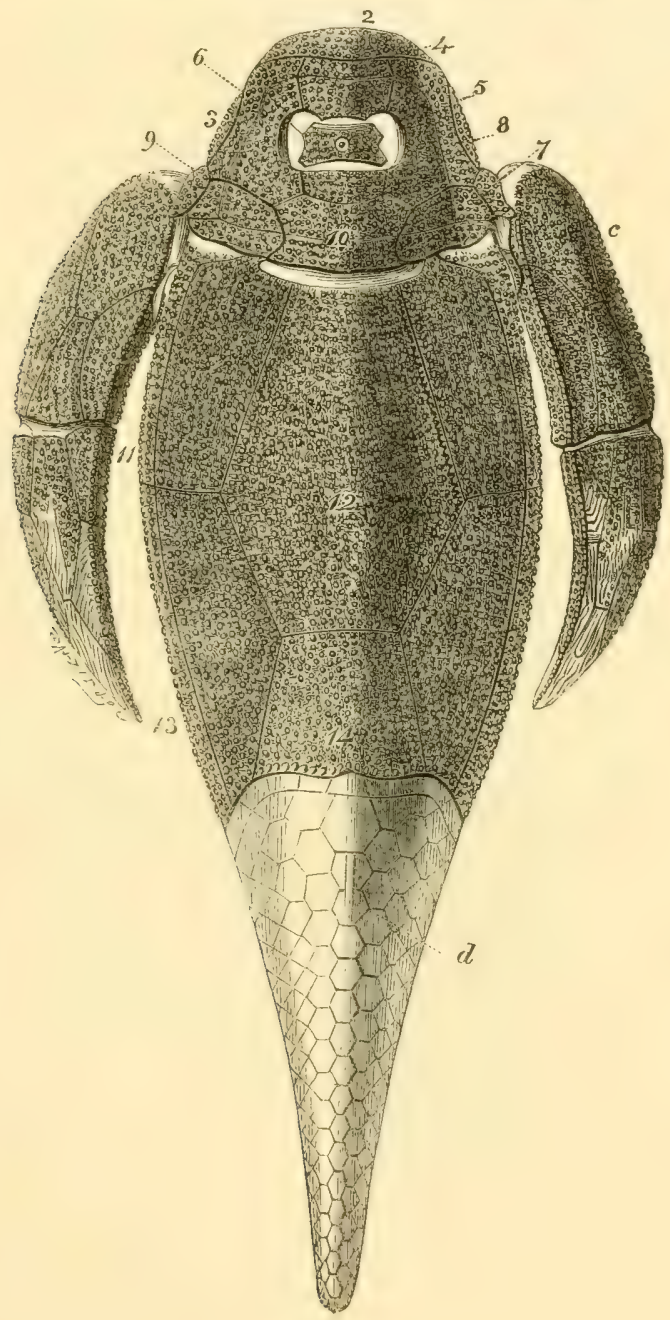

Fig. 43.

Pterichthys Milleri, dorsal surface (Devonian), after Pander.

indicate a certain power of swimming, though not with any great rapidity; they include a small dorsal and a pair of 
ventrals-these latter were first observed by Sir I'. Egerton. The jaws are small, and possess confluent denticles.

The type-species is the Ptrichthys Milleri; others have been based upon proportions of the cuirass, of the pectorals, and the tail ; all are from the "old red sandstone," and the

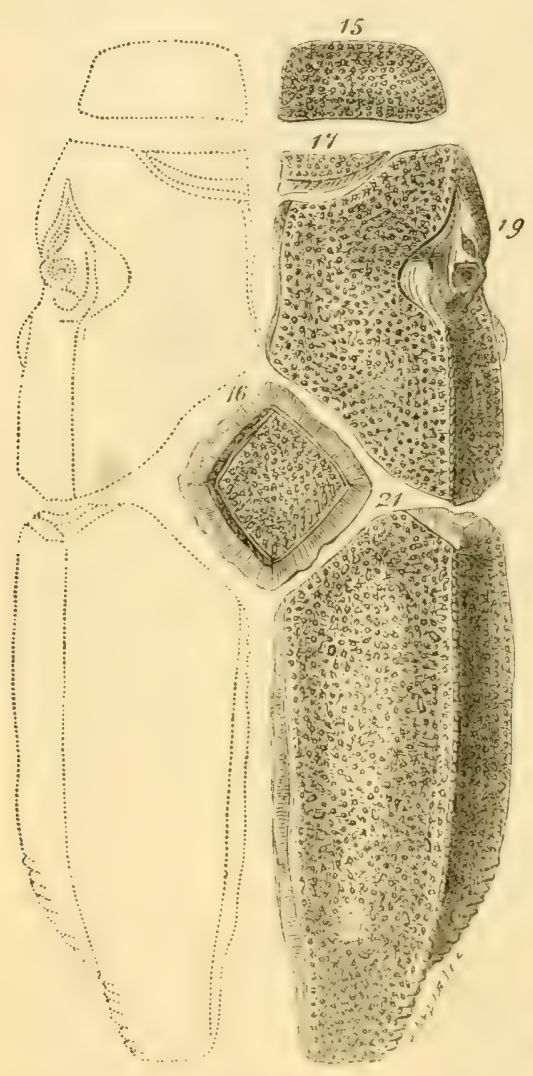

Fig. 4.

P'tericlethys; Plastron or Ventral Shicld. (Devonian), after Pander. great majority have been found in the Devonian strata of Ross-shire, Caithness, and other Scotch localities.

Genus Cephalaspis (kiephale, head: aspis, buckler).-In this genus the posterior angles of the shield-shaped helmet are produced backward in a pointed form, giving to the head the form of a "saddler's knife;" in other' respects the genus closely resembles Pterichthys.

Mr. D. Page has recently acquired specimens of Cephalaspis from Lanarkshire tile-stones, forming the base of the Devonian system, which show a dorsal fin, pectoral fins, and a large heterocercal fin, besides a well-marked capsule of the eye-ball.

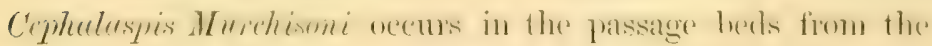
Silurian to the Devonian systems.

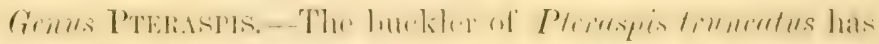

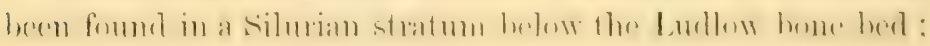


it is the earliest known indication of a vertebrate animal. Pteraspis Lloydii occurs in the lower "old red" of Britain.

Genus Coccosteus (kolikos, berry; osteon, bone).-If a heterocercal fin were adled in outline to the restoration of the fish of this genus, given in fig. 45, a correct idea would be given of the "old red" fossil, which, in the progress of its reconstruction, has suggested so many strange notions of its nature and affinities.

The helmet and cuirass are firmly united, and there is no trace of the jointed appendages, like pectoral fins, which characterize Pterichthys. The unprotected part of the trunk shows an ossification of the neural and hremal spines, and of their appendages, the rays of a "dorsal" and "anal" fin ; and, by the analogy of Ceplualespis, the tail was most probably terminated by an unequal-lobed fin. The lower jaw is composed of two rami, loosely commected at the symphysis; so that, when displaced, as they commonly are in crushed fossil specimens, they gave the notion of the fish being provided with laterally-working jaws, like those of the lobster. But, in reality, the jaw worked vertically upon a fixed upper jaw ; both jaws being provided with from ten to twelve teeth on each side, anchylosed to the bone.

An under-view of the cephalothoracic buckler of Coccosteus, according to Dr. Pander's restoration, is given in fig. 46 , showing the sutures of most of the cephalic plates, and the external surface of the plates of the plastron. 9, rostral plate; 7 , premediun; 5, mediun; 8, preluteral; 6, lateral; 16 and 24, the suborbitul bone; ${ }_{5}$, prementromedian; behind the lozenge-shaped rentromedian, and on each side, are (2z) the precentroluteral and (2o) the prot-rentrolateral. The same figures mark the above plates in the side view (fig. 45 ), with the addition of (12) the dorsomedian and (I4) the post-dorsomedian.

The hlank space hetween the newal (n) and hitual (h) spines of the fossil endo-skeleton indieatres the prosition of the 


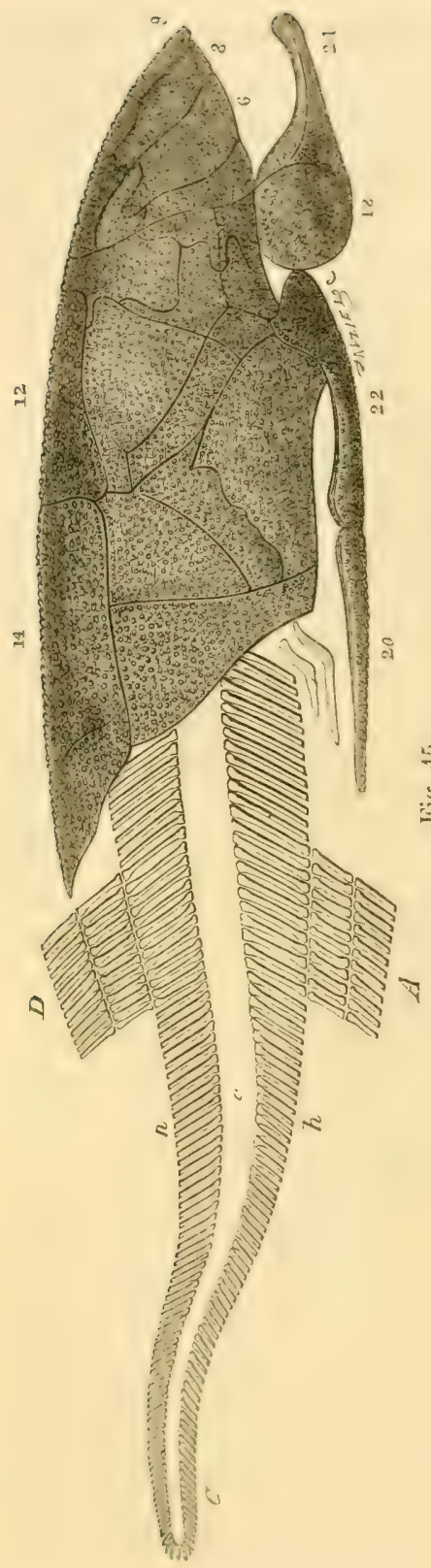

soft "notochord" (c), which has, been dissolved away. The cylindrical gelatinous body, so called (in Latin chorda dorsalis) pre-exists to the formation of the bony bodies of the vertebræ in all vertebrate animals; and the development of those bodies seems never to have gone

s. beyond this embryonal phase है in any palæozoic fish; such fishes are accordingly termed " "notochordal," as retaining the notochord.

There are but two genera of existing fishes which manifest, when full grown, such a structure, associated with ossified peripheral elements of the vertebræ-viz., the Protopterus of certain rivers of Africa, ${ }^{*}$ and the Lepidosiren of certain rivers of South America. Those fishes alone would, if fossilized, present the appearance of the vertebral column shown in fig. 45 , and which characterizes all the oolitic fossil ganoid fishes (see figs.

* See Linnacan Transactions, vol. xviii.; and Proceedings of the Linnæan Society, April 2, 1839. 
54 and 55). This persistence in palieozoic and most mezozoic

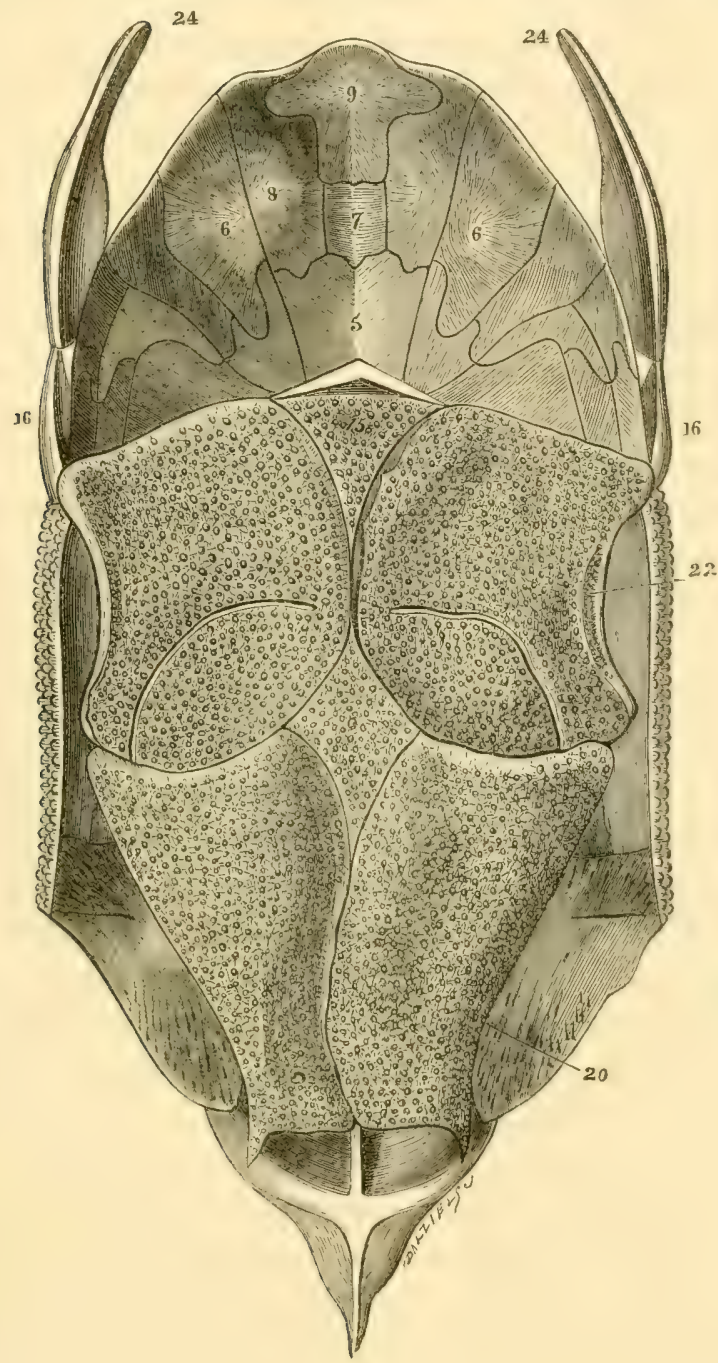

Fig. 46.

Cephalothoracic buckler, ventral aspect, C'uccosteus decipiens (Deronian). fishes of an embryonic rertebral chanacter, transitory in nearly 
all existing fishes, significantly testifies to a principle of "progression."

The external "ganoid" surface of the buckler-plates of Coccosteus is ornamented with small hemispherical tubercles; whence the generic name, signifying "berry-bone." The similarity of this ormamentation to that of the plates of the buckler in some tortoises, led to the belief, when the coccosteal plates were first found, of their being evidence of the chelonian genus Trionye in Devonian berls. Passing notions also got into print of the crustaceous affinities of Coccosters ; whence the trivial name of the type-species decipicns, or the "deceiving" Coccosteus.

Strange as seem the forms and structure of the placoganoid fishes of the "old red" period, there are not wanting existing species which throw much truer light on their nature than any existing Chelonice or Crustacer. The singular little family of "trunk-fishes" (Ostrecionida) shows species in which the body is inclosed in a more or less quadrangular cuirass, composed of suturally-articulated ganoid plates, which are usually tuberculated on the external surface, and with the angles prolonged into spines in some species, like those of the helmet of Cephalaspis. The caudal part of the trunk protrudes fron the hack opening of the cuirass, as in Coccosteus and Pterichthys, and ossification of the endo-skeleton is incomplete. The species of this family are for the most part natives of seas of tropical or warm temperate latitucles.

In another family of existing fishes, called "Siluroids," there are species in which the broad cranial hones, connate with dermal ossifications, form a helmet to the head, whilst one or two dermal spine-bearing bones combine to form the part called "huckler" by Cuvier." In the genus Dorrs, the lateral line is armed with bony ganoid plates ; and in Cullichthiys, these biserial plates are develojed so as to incase the

Histoire des Poissons, tom. xii. 
whole body. But generally, as in Pimclodus, the hinder muscular part of the trunk is undefended, as in Coccostcus. The ganoid plates of the head and back shields are fretted with rows or ridges of confluent tubercles, radiating from the centre to the circumference of the plate, whilst the inmer surface is smooth, as in Coccosteus (fig. 16 ) ; and, moreover, the dorsal plate in existing siluroids sends down a median ridge from its inmer surface, like that from the "dorso-median" plate in Coccosteus. The point of resemblance to be mainly noticed, however, is the contrast furnished by the powerful armature of the head and back with the umprotected nakedness of the posterior portions of the creature-a point specially noticeable in Coccosteus, and apparent also, though in a lesser degree, in some of the other genera of the old red, such as the Pterichthyes and Asterolepides. "From the snout of the Coccostcus down to the posterior termination of the dorsal plate the creature was cased in strong armour, the plates of which remain as freshly preserved in the ancient rocks of the country as those of the Pimclodi of the Ganges on the shelves of the Elgin museum ; but from the pointed termination of the plate immediately over the dorsal fin to the tail, comprising more than one-half the entire length of the animal, all seems to have been exposed, without the protection of even a scale; and there survives in the better specimens only the internal skeleton of the fish and the ray-bones of the fins. It was armed, like a French dragoon, with a strong helmet and a short cuirass; and so we find its remains in the state in which those of some of the soldiers of Napoleon's old guard, that had been committed unstripped to the earth, may be dug up in the future on the fatal field of Borodino, or along the banks of the Dwina or the Wap. The cuirass lies still attached to the helmet, but we only find the naked skeleton attached to the cuirass. The Pterichthys to its strong helmet and cuirass added a posterior armature of comparatively 
feeble scales, as if, while its nuer parts were shielded with plate-armour, a lighter covering of ring or scale armour sufficed for the less vital parts beneath. In the Asterolepis the arrangement was somewhat similar, save that the plated cuirass was wanting. It was a strongly-helmed warrior in slight scale-armour; for the disproportion between the strength of the plated head-piece and that of the scaly coat was still greater than in the Ptcrichthys. The occipital star-corered plates are, in some of the larger specimens, fully threequarters of an inch in thickness, whereas the thickness of the delicately-fretted scales rarely exceeds a line.

"Why this disproportion between the strength of the armature in different parts of the same fish should hare obtained, as in Pterichthys and Asterolepis, or why, while one portion of the animal was strongly armel, another portion should have been left, as in Coccostors, wholly exposed, cannot of course be determined by the mere geologist. His rocks present him with but the fact of the disproportion, without. accounting for it. But the natural history of existing fish, in which, as in the Pimelocti, there may be detected a similar peculiarity of armature, may perhaps throw some light on the mystery. In Hamilton's Fishes of the Ganges, the habitats of the various Indian species of Pimelodi, whether brackish estuaries, ponds, or rivers, are described, but not their characteristic instincts. Of the Silurus, however, a geuns of the same great family, I read elsewhere that some of the species, such as the Siturus Glanis, being mrieldy in their motions, do not pursue their prey, which comsists of small tishes, but. lie concealed among the mud, and soize on the chance stragglers that come in their way. Anct of the Pimclodus gulio, a little strongly-helmed fish with a naked horly, I was informed by Mr. Duff, on the authority of the gentleman who had presented the specimens to the Musemm, that it burrowed in the holes of moluly hanks, fom which it shot ont its 
armed head, and arrested, as they passed, the minute animals on which it preyed. The animal world is full of such compensatory defences; there is a half-suit of armour given to shield half the hody, and a wise instinct to protect the rest. Now it seems not improbable that the half-armed Coccosteus, a heary fish, indifferently fumished with fins, may have burrowed, like the recent Silurus Glanis or Pimclodus gulio, in a thick mud, of the existence of which in vast quantity, during the times of the old red sandstone, the dark Caithness flagstones, the futid breceia of Strathpeffer, and the gray stratified clays of C'romarty, Moray, and Banff unequivocally testify; and that it may have thus not only succeeded in capturing many of its light-winged contemporaries, which it would have rainly pursued in open sea, but may have been enabled also to present to its enemies, when assailed in its turn, only its armed portions, and to protect its unarmed parts in its burrow." *

\section{Sub-Order 2.-LEPIDOGANOIDEI.}

FAMILY I.-DIPTERIDA.

This family includes a few leterocercal fishes with a double anal as well as dorsal fin. The head is large and flattened; the teeth subequal; the scales perforated by small foramina; the notochord persistent.

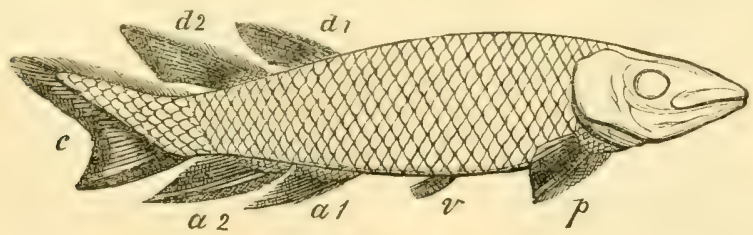

Fig. 47.

Dipterus macrolepidotus (Devonian).

In the genus Dipterus (fig. 47 ), the two dorsals, $d 1, d 2$, are opposite the two anals, $a 1$, $\alpha 2$ : the rentrals, $v$, are in * Hugh Miller, Rambles of a Geologist, p. 288. 
adrance of the first anal and first dorsal. The Dipterus macrolepidotus is characterized by the large size of its scales. Its remains are foumd in the old red sandstone of many localities of Scotland and England.

In the allied genus Diplopterus the vertical fins are oplosite, but the dorsals are wider apart, and the teeth are larger and fewer. Four species have been recognised in the micklle "old red" of Gamrie, Orkney, and Lethenbar, Ross-shire. Two species occur in the carboniferous series.

In the genus Ostcolepis the vertical fins are alternate in position, the first dorsal being near the midtlle of the lack. The teeth are sharp; not any of the species exceel a foot in length : they are all from the middle "old red."

\section{Family II.-Acantiodit.}

The species of this family are characterized by their rery small scales: they are heterocercal and notochordal. There is a strong spine in front of each fin. The hearl is large ; the orbits approximate; the mouth wide, formed chiefly ly the maxillaries, and opening obliquely upwards, so that they

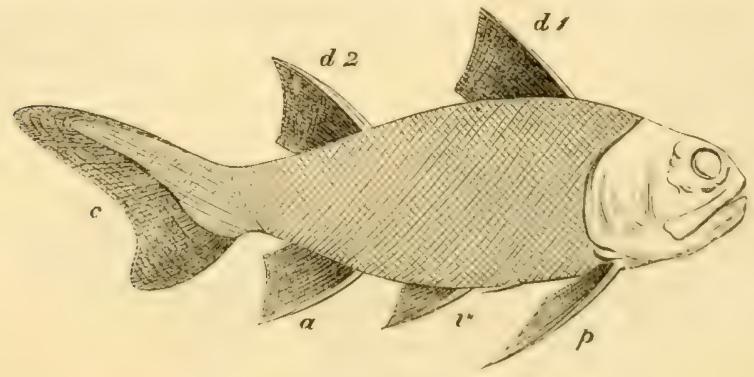

Fig. 48.

Diplacanthus striatus.

have somewhat the aspect of the Uranoscopi. They have many branchiostegal rays. The principal genera are from the old 
red sandstone, and are as follows:-Chciracanthus, with a single dorsal situated in front of the anal; Acanthorles, in which the dorsal is situated behind the anal; and Diplacanthus (fig. 48), in which there are two dorsals.

The Diplacanthus striatus is found in the "old red" of Cromarty. In fig. 48 , as in the other figures, $p$ is the pectoral fin, $d$ the dorsal, $v$ the ventral, $a$ the anal, and $c$ the caudal. In this species the upper lobe of the caudal is much prolonged. The fin-spines in the Acanthot ii were, like those of the recent dog-fish (Spinax), simply imbedted in the flesh, with their base, as it were, unfinished ; not provided, as in the Siluroids and other modem bony fishes, with a joint-structure.

Chcirolepis, with the minute scales of the family, has the dorsal behind the anal, but has no spine in any fin: the mouth is large, the teeth small and uniserial. Some species of the present family, Acanthodes Bronnii, $A c$. sulcatus, existerl in the seas of the carboniferous period.

\section{Family III.-Cgelacantni.}

The species of this family are characterized by the hollowness of the rays or spines; whence the name. The caudal fin has a peculiar structure, the rertebral column being continued into and beyond its middle part, supporting a kind of slender appendage between the two normal lobes. The species of the genus are most abundant in the Deronian and carboniferous formations; but some occur in oolitic and even, if Macropoma. be a true Colacanth, in cretaceous beds; but all became extinct before the tertiary epoch.

Glyptolepis had a heterocercal tail, with rounded scales, smooth externally, and with radiating compartments internally. The $G$. microle-

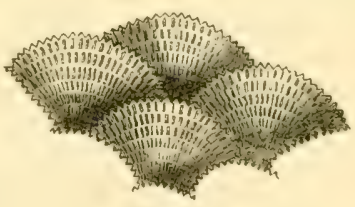

Fig. 49.

Glyptolepis microlepialotus (Devonian). pidotus, of which a magnified view of the inmer side of some 
scales is given in fig. 19 , occurs in the midhlle old red sandstone of Scotland and England.

Phyllolenis is, as yet, known only by its large smouth on concentrically furrowed scales, some of which are six inches in diameter. $P h$. concentricus occurs in the upper old red of Clashbinnie; Asterulpis. in the midule "old red" of Elgin: Bothriolepis in the upper "old red" of Scotland and Russia ; and Glyptopomus, with the cranial bones seulptured externally, in the upper "old red" of Dura Den.

\section{FAMILY IV.-HOLOPTYCHIDE.}

The type-genera of this family were first recognized and characterized by the fossil scales, under the name Holoptychius. (Ag.), and by the fossil teeth, mder the name Rhirodus (Ow.) They inclurle species which have left their remains in the "old red" and the coal measures. They are nearly allied to the Colacanthians, having, like them, but partially ossified bones and spines, the interior of which retained their prinitive gristly state, and appear hollow in the fossils. The head was defended by large externally sculptured and tuberculate ganoid plates. The teeth consist of two kinds-small serial teeth, and large laniary teeth-at long intervals; both kinds show-

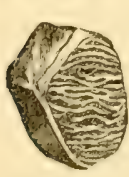
Fis. 50. more robust and obtuse serial teeth, and longer,
Scale of Holoping the "lalyrinthic" structure* at their base, which is anchylosed to the jawbone.

The generic term Rhizodus is now retained for the Holoptycticens of the coal measures which have tychius nobil- sharper, and more slencter laniaries, exemplified by

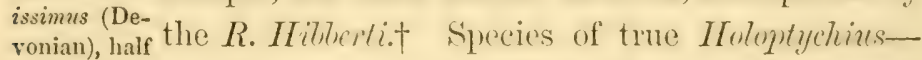
nat. size. $\quad$ c.g., $I I$. giguntrus ( $\Lambda$ g.), $I I$. notilissimus ( $\mathrm{gg}$ ), occur in the old red sandstone. A nohle specinen of the latter species, 2 feet 6 inches in length, discovered in the old red sandstone at C'lashlimie, near Perth, is now in the palaento* Owen's "Odontography," l'late 63 s, fig. 1.

+ Ib. Plates 35 and 36. 
logical series of the British Museum. It is chiefly remarkable for the size and bold sculpturing of the ganoid scales (fig. 50).

Large fossil teeth, with the more complex "dendritic" disposition of the tissues, characterize a genus (Dendrodus), most probably of the Holoptychian family. The complexity is produced by numerous fissures radiating from a central mass of vasodentine, which more or less fills up the pulp-cavity of the seemingly simple conical teeth of this genus. Fig. $50 a$ is ome of these fossil teeth of the natural size- $-\alpha$, a transverse section; and fig. $50 \mathrm{~b}$, a reduced view of a portion of the

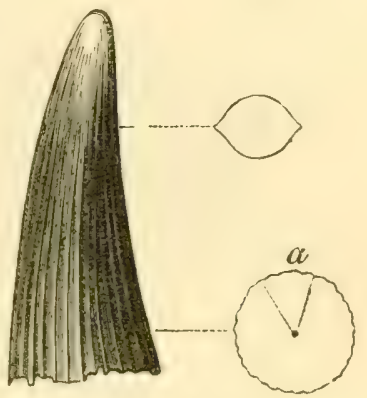

Fig. $50 u$.

Tooth of Dendrodus biporcutes (nat. size). same section enlarged twenty diameters. Thus magnified, a central pulp-cavity of relatively small size, and of an irregular lobulated form, is discemed, a portion of which is shown at $p$; this is immediately surrounded by transverse sections of large cylindrical vascular or pulp canals of different sizes; and beyond these there are smaller and more numerous medullary canals, which are processes of the central pulp-cavity. In the transverse section these processes are seen to be comnected together by a net-work of smaller vascular canals belonging to a coarse osseous texture, into which the pulp has been converted, and this structure occupies the middle half of the section. All the vascular canals were filled up by the opaque matrix. From the circumference of the central net-work straight pulp-fissures radiate at pretty regular intervals to the periphery of the tooth; most of these fissures divide once, rarely twice, in their course-the division taking place sometimes at their origin, in others at different distances from their terminations, and the branches diverge slightly as they proceet. Earh of the above pulp-camals on fissures is continued 
from a short process of the central structure, which is connected by a concave line with the adjoining process, so that the whole periphery of the transverse section of the central

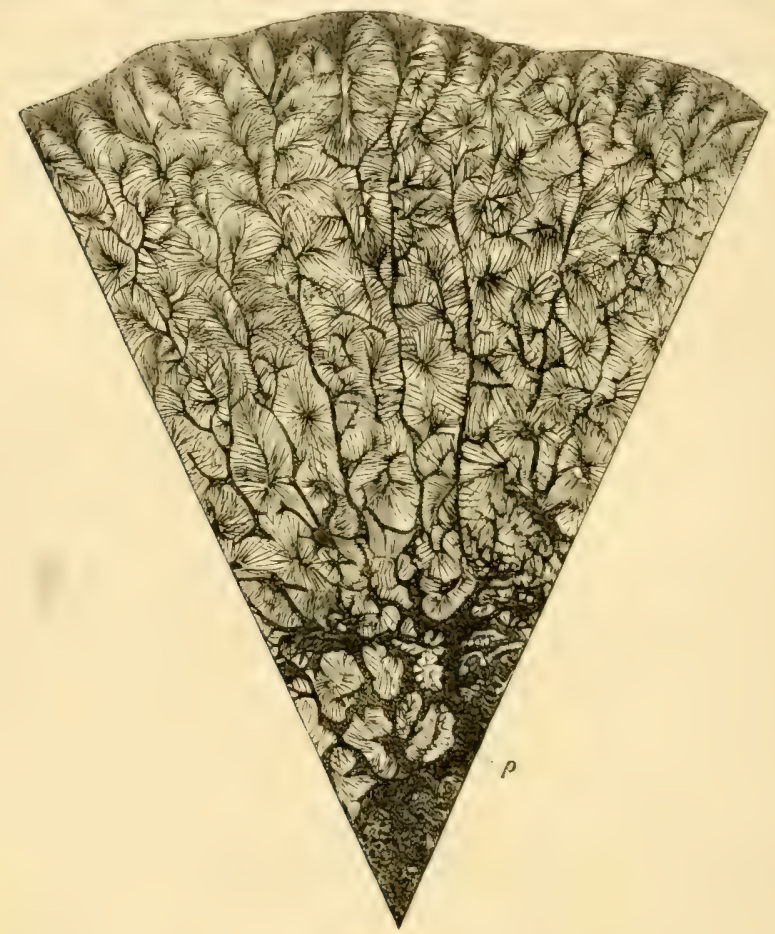

Fig. $50 \mathrm{~b}$.

Magn. section of part of Dendrodus biporcatus.

coarse reticulo-vascular hody of the tooth presents a crenate ontline. From each ray and its primary dichotomons divisions short branches are sent off at brief intervals, generally at right angles with the trumk, or slightly inclined towards the periphery of the tooth. These suldelivile into a few short ramifications like the banches of a shrub, and terminate in irregular and somewhat angulat dilations simmlating leatres, but which resolve themselves into radiating fisciculi of minute dentinal tubes. Thereare from fifteen to twenty-five or thirty- 
six of these short and small lateral branches on each side of the medullary rays. The teeth of Dendrodus occur in the corri-stone beds of the "Old Red" at Scat-crag, near Elgin.

Such are some of the forms and structures of fishes that swam in the seas from which were deposited the sediment that has hardened into the "old red sandstones" of Great Britain, Russia, and other parts of the world. And in this process of consolidation the carcases of the fishes entombed in the primaval mud have had their share. For, just as a plastercast boiled in oil derives greater density and durability from that addition, so the oily and other azotized and ammoniacal principles of the decomposing fish operated upon the immediately surrounding sand so as to make it harder and more compact than the sediment not reached by the animal principles. Accordingly it has happened that in the course of the uhearal and disturbance of old red strata, parts of it, broken up and exposed to the action of torrents, have been reduced to detritus, and washed away, with the exception of certain nodules, generally of a flattened elliptic form, which are harder than the surrounding sandstone. Such nodules form the bed of many a mountain stream in "old red sandstone" districts of S'cotland. If one of these nodules be cleft by a smart and well-applied stroke of the hammer, the cause of its superior density will be seen in a more or less perfect specimen of the fossilized remains of some amimal, most commonly a fish.

But the placoganoid and lepidoganoid, heterocercal and notochordal, fishes of the Devonian epoch existed in such vast shoals in certain favourable inlets, that the whole mass of the sedimentary deposits has been affected by the decomposing remains of successive generations of those fishes. The Devonian flagstones of Caithness are an instance. They owe their peculiar and vilual,e qualities of density, tenacity, and durability wholly to the read fishes that rotterl in their primitive 
constituent mud. From no other part of the world, perhaps, can a large flagstone be got, which a builder could set on its extge with assurance of its holding long together in that position. A great proportion of the county of Caitlmess formed, before its upheaval, the bottom of what may truly be termed a "piscina mirabilis." Tet there are minds, who, cognizant of the wonderful structures of the extinct Devonian fishes-of the evidence of design and adaptation in their structures-of the altered nature of the sediment surrounding them, and its dependence on the admixture of the decomposing and dissolved suft parts of the old fish-would deliberately reject the conclusions which healthy human reason must, as its Creator has constituted it, draw from such proofs of His operations. There are now individuals, one at least, * who prefer to try to make it be believed that God had recently, and at once, called into being all these phenomena; that the fossil bones, scales, and teeth, had never served their purpose-had never been recent-were never truly developed, but were created fussil ; that the creatures they simulate never actually existed; that the superior hardness of the inclosing matrix was equally due to primary creation, not to any secondary cause; that the geological evidences of superposition, successive stratification, and upheaval were, equally with the palieontological evidences, an elaborate design to deceive and not instruct!

Family V.-PAL EONISCIDA.

The Placoganoids, so richly represented in the Devonian epoch, disappear in the carhoniferous one; the Lepidoganoids increase in number. In the present family they combine with rhomboid scales, a heterocereal tail, and jaws armed with numerous, minute, elose-scet, rather hlunt teeth. The typegenus is Palconiseres (fig. 51), suecies of which range throughout the carluniferents and Permian herts: it is chameterized hy

* See Omphalos, by P. II. Gosse, 8vo, 1858. 
moderate-sized fins, the dorsal, $D$, being single, and opposite the interval between the anal, $A$, and ventral, $V$, fins: each fin has an anterior spine; the fore-part of the head is obtuse.

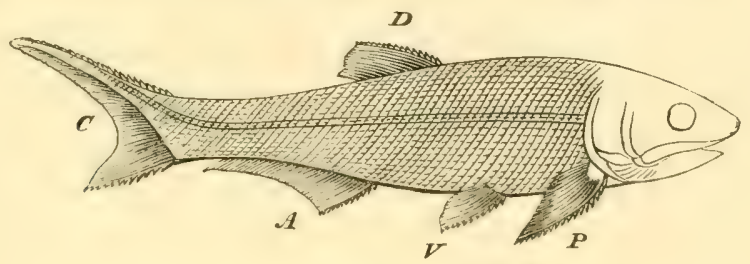

Fig. 1 .

Palceoniscus (Permian).

In the Palconisci from the coal formations at Burdie House, near Edinburgh, the outer surface of the scales is striate and punctate, c.g., in P. ornatissimus, P. striatus; but in the Pulconisci of other British localities, and of the continental and American coal formations, the scales are smooth, e.g., in P. fultus, from North America, P. Duvcrnoyi and P. minutus, from the coal beds of Münster Appel. In the Pulconisci from the Permian copper schales and zechstein, the scales are striate or punctate : the Palconiscus Freicslebeni is the most common in these beds, and was the first recognized species of the genus. Of this there are now forty known species, chiefly from carboniferous and Permian eras: one from the Keuper beds at Rowington, Warwickshire, appears to be the last representative of the genus: it is the Palconiscus superstes of Egerton. A mblyptems, with a geological range like that of $P$ alceoniscus, differs in its shorter and deeper tail, and larger body-fins, which are devoid of anterior spines. In fig. 52, $a$ indi-

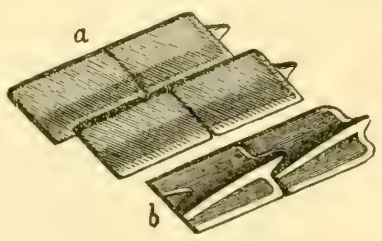

Fig. 52.

Scales of Amblypterus striatus (Carboniferous). cates the outer surface of parts of two series of the rhomboidal ganoid scales; and $b$ the imer surface of two seales, showing the ridge produced at one eml into a projecting peas, which fits 
into a notch of the next scale, in the way that tiles are pegged together in the roof of a house. The species aftording the above structure is the Amblypterus striatus from the coalformations at Newhaven.

Several species of Amblypterus have left their remains in the muschelkalk, at which triassic period the genus seems to have passed away.

\section{Family Vi.-Saurichthyid .}

Magnificent species of heterocercal rhomb-scaled Ganoids, with large dispersed laniary teeth, sometimes of a size rivalling those of great Saurians, for which they have been mistaken, have left their remains in the coal strata at Carluke, near Glasgow, and other localities, and constitute the genus $M$ cyctlichthys of Agassiz. The head is defended by strong ganoid plates, of a beautiful polish; the trunk-scales are usually granulate exteriorly. In this genus, as in the type of the fanily, the fulcra of the fin-rays are in two rows: all the known species of Saurichthys are triassic.

Pygopterus and Acrolepis, with fin-fulera in a single row ; Eurynotus, Elonichthys, Plectrolepis, Graptolepis, Orognathus, Pododus, Acanthodes, and Diplopterus, are carboniferous genera of Ganoids, with rhomboid scales. Calacenthus, Isoulus, Phyllolepis, Hoplopygus, Uronemus, Colonodus, Centionlus, Asterolipi. Psammosteus, and Osteoplur, are genera of Gianoids with rounded scales, represented by species in carboniferous strata.

Of the above-named genera, Acrolpis, Pygoptorus, Pulaoniscess, and Culacenthes, continue to be represented in I'ermian beds; in which also are foumd species of the ganoid generat Dorypterus, IIolucenthodus, and Glotududus, if the teeth on which the latter is based be not those of Platysomes, a pyenodont genus which is both Permian and carboniferous.

The formations of the mezozoic or semmlary periorls give 
evidence of the full development of the ganoid order. In the lowest or "triassic" division this order is still represented by heterocercal and notochordal species belonging to some of the gener'at of the Permian period, as, c.g., Calacanthus, Amblypterus, and Pulconiscus. The genus Placodus, a supposed lycuodont fish of the muschelkalk, has been shown to be a conchivorous Saurian.*

In the oolitic division the heterocercal Ganoids are almost completely superseded by homocercal genera, which now, for the first time, appear on the stage of life; but the ossification of the endo-skeleton is still incomplete. In the cretaceous series the Teleostian, or well-ossified, bony fishes, are numerous; and here also first are seen fishes with the flexible "cycloid" or "ctenoid" scales, and of genera which continue to be represented by living species.

Of 33 genera of fishes in the lias, 4 only were represented in older strata, while the rest extend into the upper oolitic heds. Of these, 19 genera are (ranoids with rhomboid scales, and two (Lepotolepis and Gyrosteus) have rounded scales.

\section{HAMILY VII.-CatURID王.}

Ifomocereal rhombo-molds, with a short dorsal fin, and some of the teeth much larger than the rest and laniariform. Genus Citchis-In this genus the jaws are amed with

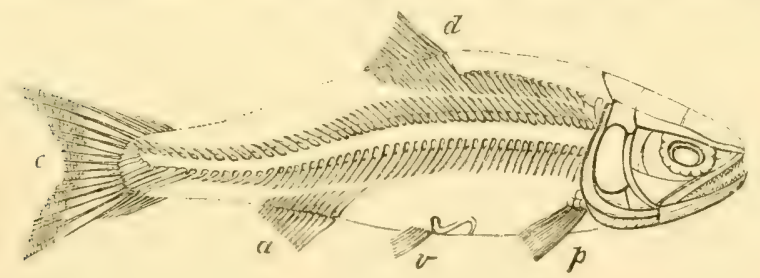

liig. 53.

Caturus furcatus (Oolite, Solenhofen).

close-set, large, conical teeth ; the scales are delicate: the tins

* Owen, in Plhil. 'Trans. 1858, p. 169. 
are of molerate size; all the species are sub-homocercal * and notochordal (fig. 53). The dorsal, $d$, is opposite the ventral, $v$. One species of Caturus (C'. Buclilandi) is from the lias; but the majority, like $C$. fu'cutus, are from the lithographic slates of Solenhofen. The most recent known species ( $C$. similis) is from the chalk of Kent.

Puchycormus, Saurostomus, Sauropsis, Thryssonotus, and Eugnathus, are liassic genera of the present family. It is deemed by some Palieontologists to be represented at the present day by the North American genus Lepidosteus; but in this fish the notochord is converted into bony rertebral bodies, united by ball-and-socket joints, and the tail is heterocercal.

\section{FAMILY VIII.-PyCNOdONTES.}

The name of this group of ganoid fishes refers to the blunt rounded form of the greater proportion of the tecth, especially those attached to the palate and hind alveolar part of the

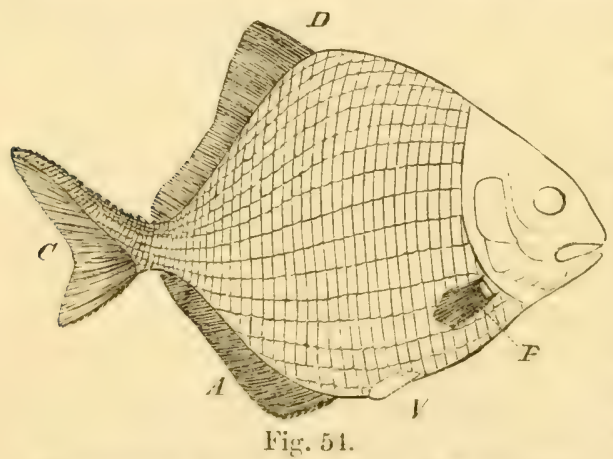

Plutysomus gibbosus (zechstein of Mansfield). lower jaw: the few anterior teeth are smalland sub-prehensile; but the whole dentition bespeaks fishes adapted to feed on small testaceous and crustaceous animals. In the modern "Sea Breams" (Sparoids), with an amalogous dentition, the two premaxillaries oppose the two premandibulas, but in the extinct I'ycnodonts the romer, as in Anerichees, opposes its pavenent of teeth to that of the two

* By this term is meant a symmetrical shape of the tail fin, with an unsymmetrical development of the suphorting spines, the tominal vertebre inclining to the upper lobe. 
closely approximated premandibular or dentary elements of the under jaw.

The Pyenodonts were for the most part deep-bodied fishe, symmetrically compressed from side to side. They were notochordal; a few of the earlier forms were heterocercal, but the majority of the family were homocercal.

The pycnodont type was first manifested in the carboniferous strata by the heterocercal genus Platysomus, and by the species $P$. premulus, which has been found in that formation at Leeds: but this earliest pycnodont gemus is chiefly represented by Permian species, of which Platysomus gibbosus (fig. $54)$ is a fine example.

In the lias, most beautiful fossil fishes of this group are found, which were referred by Bromn to the genus Tetragonolepis, and by Agassiz to the lepidoid sub-order. Sir P. Egerton has, however, shown that the dentition is truly "pycnodont," having a very close resemblance to that of Microdon, but with the masticatory apparatus smaller in proportion to the size of the fish. The scales, moreover, insteal of being articulated by interlocking legs and sockets, as in fig. 52 , are joined in a peculiar way, which Sir P. Egerton describes as follows:"Each scale bears upon its imner anterior margin a thick solid bony rib, extending upwards beyond the margin of the scale, and sliced off obliquely above and below, on opposite sides, for forming splices with the corresponding processes of the adjoining scales. These splices are so closely adjusted, that without a magnifying power, or an accidental dislocation, they are not perceptible. When in situ, and seen internally, these continuous lines decussate with the true rertebral apophyses, and cause the regular lozenge-shaped pattern so characteristic of the pycnodont family." "These decussating "pleurolepidal" lines are, however, confined to the space between the skull and the dorsal fin, as in fig. 55 .

* Proccedings of the Geological Society, May 1853, p. 276. 
The Pyenodonts su characterized are further distinguished from the closely-resembling lepidoid gemus Dapectius, by having the small anterior teeth conical and single-pointed, instead of being bifurcate; and although this character is sulject to occasional variations, nevertheless, on taking a comprehensire view of all the dapedioid species, it seems to have been sufticiently constant to warrant the continuance of the separation of the group into the unicuspid and bicuspid species. And Sir I. Egerton has accordingly proposed to apply the generic terms Echmodus (from aiysù, a point, and ooois, a tooth), , for the unicuspid and pycnodont species, formerly termed Tetragonolcpis, and to continue the name Dapedius for the bicuspid and unequirocally lepidoid homocercal deep-bodied Ganoids, many beautiful species of which are found in the lias.

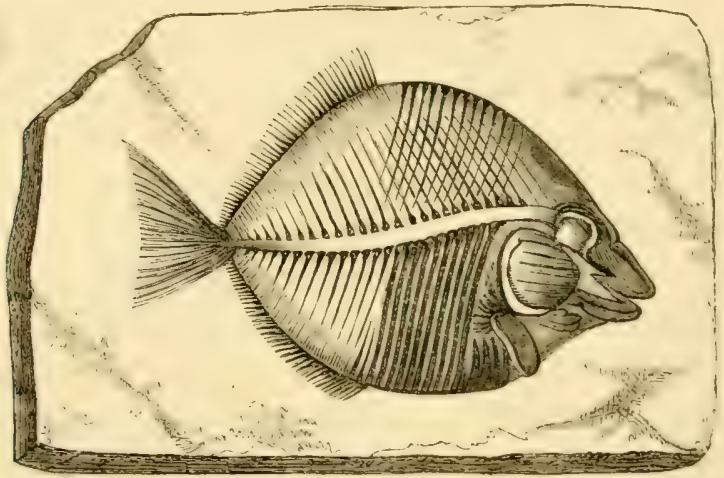

Fig. 55.

Pycnodus rhombus (Upper Oolite).

Genus Prcrodus (fig. 55).-The type-genus of this suborder is characterized by the large size of the round flat crowned teeth, which cover the broad jaws as by a parement of from three to five rows; $\dagger$ at the fore-part of the jaws are two or more trenchant incisive teeth both alove and

\footnotetext{
* Proceedings of the Geological Society, May 1854, p. 367.
}

+ For the disposition of these teeth on the palate, see Owen's Odontography, vol. i., pl. 34, figrs. 1 and 2 ; and for their microscopic structure, ibid, p. 71, pl. 33. 
below. The oblique immer processes of the scales appear as distinct dermal ossicles decussating the neural spines in the space between the occiput and the dorsal fin (fig. 5. 5).

The species of Pycnodus abound in the oolitic formations above the lias: the one figured ( $P$. rhombus) is from a calcareous deposit, so charged with animal remains as to be fortid, at Torre d'Orlando, near Naples. Species of Pycnodus (P. cretcceous, e.g.) occur in the chalk of Kent; and one species ( $P$. toliapicus) has left its remains in the eocene clay of Sheppy. Some teeth from German miocene have been referred to this genus; but at this period, if not at the earlier tertiary one, Pycnodus became extinct.

\section{FAMILY IX.—DAPEDIDA.}

Notochordal rhombo-ganoids, with front teeth conical or bifurcate, back teeth obtuse, vertebral column and side scales continued into the upper lobe of an almost symmetrical tail-fin.

The type-genus, Dapedius, is a compressed deep-bodied fish, with a single dorsal, and a single series of fin-fulcra; the front teeth are commonly notched. All the species are from liassic strata. Amblyurus, with a similar form, and also liassic, has a very narrow anal, and a wide mouth with small pointed teeth. Scmionotus and Pholidophoms are long-bodied fishes, the species of which range from the lias upwards to the Purbecks (Pholidophoms ornatus), and to the chalk (Semionotus Bergeri).

\section{FAMILY X.-LePIDOTIDE.}

Homocercal rhombo-ganoids, with obtuse teeth and well ossified vertebræ.

The type-genus of this family, Lepidotus, is remarkable for the density and polish of its full-sized imbricated rhomboid 
scales; it has a short dorsal fin opposite the anal, and has two rows of fulcra to the anterior rays of all the fins. The species range from the lias to the chalk; one species, indeed (Lepidotus Maximitiani), lingers, after the commencement of the tertiary period, in the "calcaire grossier" of Paris.

In Nothosomus and Ophiopsis the fin-fulcra are in a single row, and the dorsal fin is very long. Notagogus and Propterus have the dorsal fin almost cleft into two.

\section{FAMULX XI.-LEPTOLEPID}

The Ganoids of this family are homocercal, and have rounded scales. In the type-genus (Leptolepis, fig. 56), the

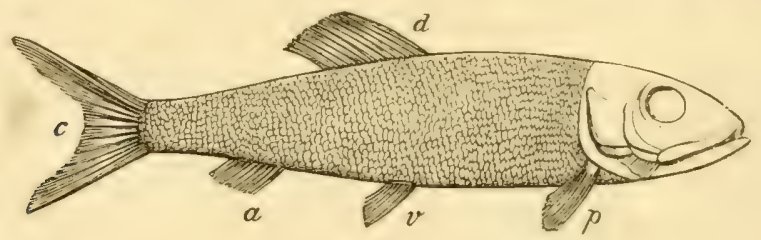

Fig. 56.

Leptolepis sprattiformis (Oolite, Solenhofen).

scales are extremely thin, yet a fine layer of ganoin may be discovered on them. The teeth are minute and $c n$ brosse, with two of larger size in front of the mouth. It has not been determined whether the notochord is ossified; but traces of distinct vertebral bodies appear to the witer to be discernible in some specimens. Species of Leptolepis range from the lias to the calcareous slates of Eichstadt. They are very common in the lithographic slates of Solenhofen and Pappenheim.

\section{FAMILX XII.-MIACROPOMID A.}

Genes Micropoma.-Fine specimens of homocercal ganoid fishes, with rounded scales, sculptured externally, as in fig. 57 , 
have been discorered in the chalk formations of Kent and Sussex. They have been referred by Agassiz to the genus called Macropoma, significative of the large size of the gill-cover, and to the colacanthal family. Casts of the "interior" of the alimentary canal, showing impressions of a broad spiral valve, are preserved in certain specimens in the British Nuseum. One species (1T. Egertoni) is

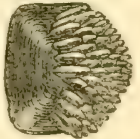

Fig. 57. Hacropome Muntelli (clialk). from the Speeton clay; the other (II. Mantelli) from the: chalk.

\section{FAMILY XIII.-SturioniDæ.}

The family Sturionide, represented by the sturgeons of the present seas, makes its first appearance in the lias, unde+. the generic form of Chondrosteus, which has recently receired a full description and illustration in a memoir communicated by Sir P. Egerton to the Pnyal Society of London.* In this it is shown "that Chondrostcus, though essentially sturionian, yet evidences a transitional form between the sturgeons and more typical Ganoids ; that its food was similar to that of the existing members of the family, but that it was procured in a tranquil sea, rather than in the tumultuous waters frequented by sturgeons at the present time."

In the tertiary division of geological time the ganoid order rapidly diminishes, and its place is taken by fishes with better ossified internal skeletons, and with thimner, more flexible, and usually soluble scales. The gills are supported on bony arehes, and are protected by branchiostegal rays, and by an operculum or gill-cover. The aortic bulb is provided with but two valves; and the optic nerves decussate. For this group, including the majority of existing fishes, and of those which made their appearance during the tertiary period, Miiller proposed the name "Teleostei," which almost corresponds with the "osseous fishes" of Cuvier.

* Proceedings of the Royal Society, April 20, 1858. 
ORDER IV.-ACANTHOP'TERI.

('har.-Endo-skeleton ossified; fins with one or more of the first rays unjointed or inflexible spines ; rentrals in most beneath or in advance of the pectorals; swim-bladder withont air-cluct.

Sub-Order 1.-CTENOIDEI.

Exo-skeleton as ctenoid scales (fig. 58).

Of this sub-order may be giren two genera, both of which are now extinct. One (Semiophorus) belongs to the chetodont

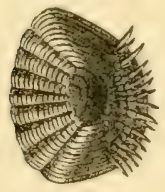

Fig. 58.

Scale of Perca

(Recent).

family; the other (Smerdis) to the Percoids.

The genus Semiophorus, Ag. (fig. 59), is represented exclusively by extinct species peculiar to the tertiary deposits at Monte Bolca. It is characterized by the ex-

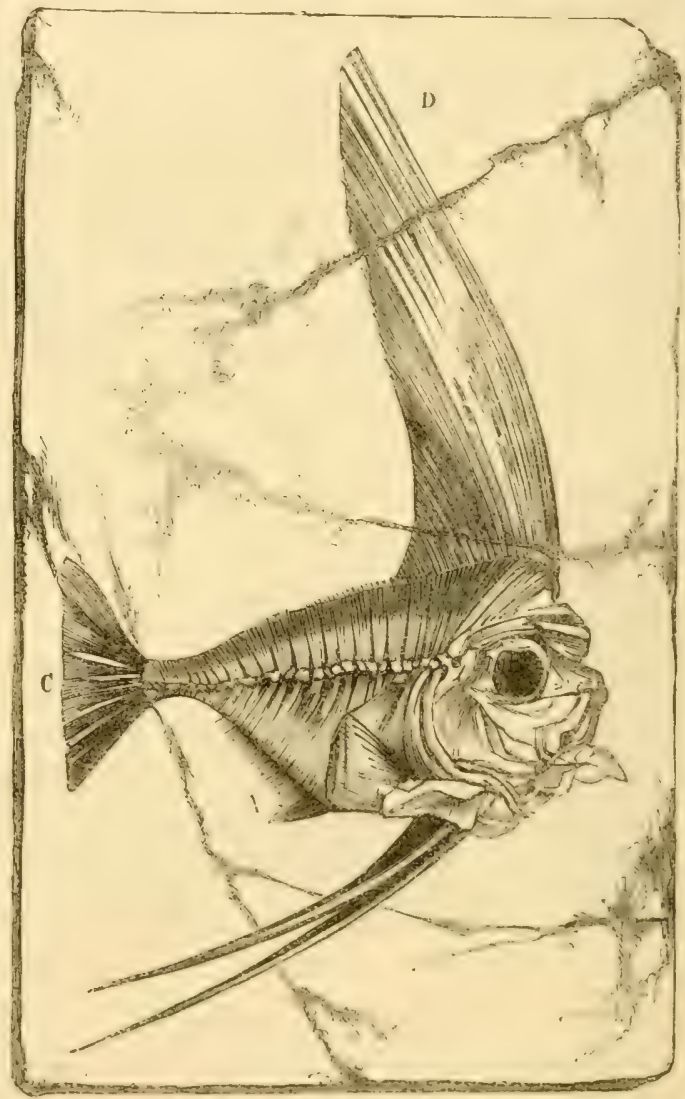

Fig. is.

Semiophorus velicans (Monte Bolca). treme height or prolongation of the anterior part of the dorsal 
fin, 1), and fine the correlative elongation of the slender pointed ventral fins. The anal fin, $A$, is much shorter than the clorsal. Owing to the soluble nature of the scales, and to the wellossified skeleton, the fossils of this, as of most other tertiary fishes, are excmplified by the rertebral column and skull more than by the skin.

Gemus Suerdis.-The species composing this genus are of small size, and are wholly extinct; they likewise are chiefly

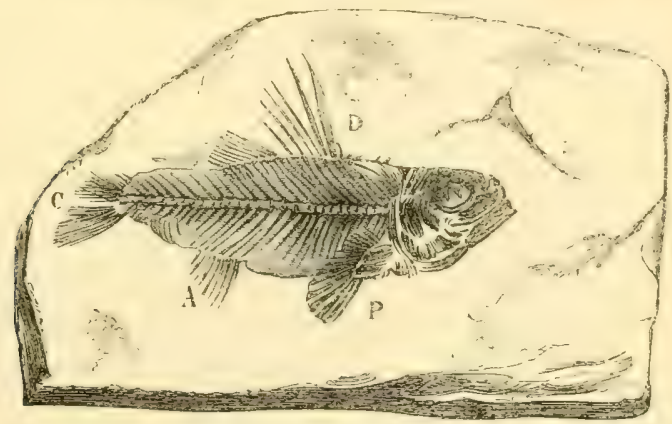

Fig. 60 .

Smerdis minutus (Gypsum of Provence).

met with in the tertiary ichthyolite beds of Monte Bolca ; but some (c.\%., the Smcrlis minutus, fig. 60) are from eocene deposits in France. In all the specius the first suborbital or lacrymal bone is strongly dentate, as is also the preoperculum; hut this has no spine at the angle. The operculum terminates behind by a rounded prominence. There are two dorsals. The scales are minute, lut are occasionally preserverl.

\section{Sub-Order 2.-CYCLOIDEI.}

This sub-order includes the teleostian fishes with undivided and unjointed spines at the fore part of the dorsal, and with smooth flexible circular or elliptical scales (fig. 61). It is not represented by any species of older date than the cretaceous epoch; and both here and in the eocene tertiaries by cxtinct 


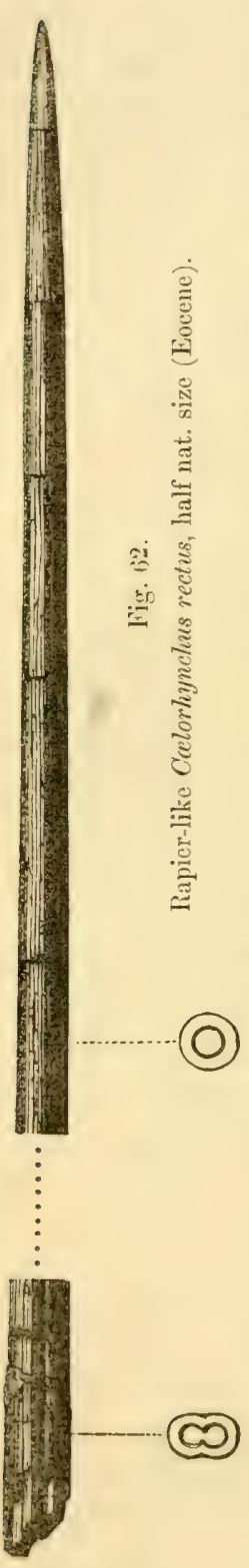

species, mostly of extinct genera. It is most richly represented at the present day by the Sphyrenoid, Scomberoid, and Xiphioid families.

There are two kinds of existing sword-fish, Xiphias and Histiophorus; in the former the sword-like prolongation of Scales of a Scomthe confluent premaxillaries is beroid fish. flattened, in the latter it is rounded.

Fossil remains of a rounded rapier-like "sword," but much longer and more slender than in the existing Histiophorus, have been found in the eocene clay at Sheppy and Bracklesham. They are referred to an extinct genus of the xiphioid family by Agassiz, called Colorhynchus, or "hollowbeak." The most perfect specimen hitherto found is figured in fig. 62 , of half the natural size. It forms part of the instructive collection of Captain Le Hon at Brussels. The upper transverse section shows the single cavity at the middle of the rostrum; and the lower section shows the double or divided cavity near its base.

\section{ORDER V.-ANACANTHINI.}

Char:-Endo-skeleton ossified; exo-skeleton in some as cycloid, in others as ctenoid scales; fins supported by flexible or jointed rays; ventrals beneath the pectorals, or none; swim-bladder without air-duct. 
FAMILY.-PLEURONECTIDA.

(Flat-Fishes.)

In this family the symmetrical form is lost, and both even are on one side of the head. Species of still existing genera of this much-modified family have been found in tertiary deposits. The little turbot (Rhombusminimus, c.g., fig. (6:3) oceurs in the tertiary deposits of Monte Bolca. An equally extinct species of sole (Solec untiqua) has been found in tertiary marls near Ulm.

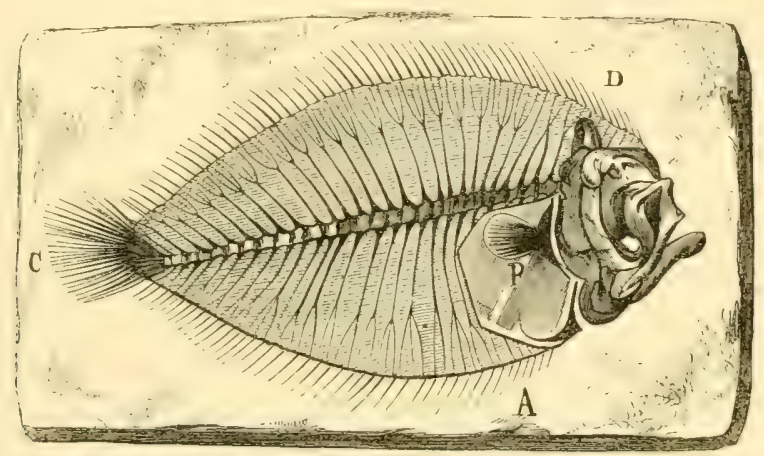

Fig 63.

Rhombus minimus (Monte Bulca).

Fussil fishes of the cod, mullet, carp, salmon, and herring genera, are found in the tertiary formations, but are distinct from all known species. The Ganoids in these formations are reduced to the genera Lepilosteus and Acipenser; but may have been represented by the palates with crushing teeth, from the Sheppy clay, to which the names Pisodus* and Plyyllodus $†$ have been given.

With respect to the fishes of the tertiary period, "they are so nearly related," says Agassiz, "to existing forms, that it is often difficult, consiclering the enormous number (above 
8000 ) of living species, and the imperfect state of preservation of the fossils, to detemine exactly their specific relations. In general I may say that I have not yet found a single species which was perfectly identical with any marine existing fish, except the little Capelin (Mallotus villosus), which is found in the nodules of clay of unkmown geological age in Greenland." These nodules are mostly rery recent, and exemplify the operation of the dissolving soft parts of the fish in consolidating the surrounding matrix.

We cannot, from present knowledge, assign to any past period of the earth's history a characteristic derived from a fuller and more raried development of the entire class of fishes than has since been manifested, nor predicate of the present state of the class that it has degenerated in regard either to the number, bulk, power's, or range of modifications of the piscine type. A retrospect of the genetic history of fishes imparts an idea rather of mutation than of derelopment, to which the class has been subject in the course of geological time. Certain groups, now on the wane, have existed in plenary development, as, $e . y$., the ganoid order in the mezozoic period, and the cestraciont form of Plagiostomes in both palæozoic and mezozoic times.

As to the variety of the forms of fishes, seeing that the earth yields no indisputable evidence of Ctenoids or Cycloids anterior to the cretaceous epoch, yet still retains living representatives of both Cranoids and I'licnids, the present would appear to be the culminating period in the derelopment of fishes, in respect of the number of ordinal forms or modifications of the class. It represents, howerer, rather a period of mutation of the piscine chancter, depending upon the progressive assumption of a more special piscine type, and progressive departure from a more general rerteduater type. The Scombernids, as fishes, are at the heal of the piscine modifiention of the vertolumate type. But as the retention of general 
vertehrate characters implies closer affinity with the proximate cold-blooded class, so a higher character of organization may be predicated of the palieozoic Placoids and Cranoids than of the Ctenoids and Cycloids forming the great bulk of the class at the present day. The comparative anatomist dissecting a shark, a Polypterus, or a Lepiclosteus, would point to the structures of the brain, heart, generative organs, and in the last two genera to the air hladiler, as being of a higher wr a more reptilian character than the enresponding parts would present in most other fishes. But the palicontolngist would point to the persistent notochord, and to the heterocercal tail in palieozoic and many mezozoic fisles, as evidence of an "arrest of development," or of a retention of embryonic characters in those primreval fishes.

No class of animals is more valuable in its application to the great point now mooted by the Uniformitarians and Progressionists of the present day than that of fishes; for they are exempt from the attack of the Uniformitarian on the score of the defective nature of negative evidence, to which attack conclusions from the known genetic history of air-lureathing animals are open. Miany creatures living on land may never be carried ont to sea ; but marine deposits may be expected to yield aderpuate grounds for general conclusions as to the character of the vertelurate animals that swarmed in the seas precipitating such deposits.

One other conclusion may lie drawn from a general retrospect of the mutations in the forms of the fishes at different epochs of the earth's history,-viz., that those species, such as the nutritions end, the savoury herring, the ricls-flaroured salmon, and the succulent turbot, have greatly predominated at the period immediately preceding and acompanying the advent of man; and that they have superseded species which, to judge hy the hony Garpikes (Leprilosters), were much less fitted to afford mankind a sapirl and wholesome foorl. 


\section{ICHNOLOGY,}

In entering upon the genetic history of the class of reptiles, we have to inquire, as in that of fishes, in what period of the earth's history the class was introduced, and under what firms ; at what period it attained its plenary development, in regard to the size, grade of structure, number and diversities of its representatives; and the relations which the existing member's of the class bear to its past condition. Fifteen year's ago, the oldest known reptilian remains were those of the soealled "Thuringian Monitor," from the Permian copper-slates of Germany. Five years ago, the batrachian Aputeon, or Archegoseurus was discovered in a Bararian coal-field; and about the sime period, footprints in carboniferons sandstones of North America, hat been recognized as evidence of the commencement of reptilian existence at that period of the earth's listory. Air-breathing ambulatory animals may leave other evirlence of their former presence upon carth than their fossilized remains.

There are sereral circumstances under which impressions made on a part of the earth's surface, soft enough to armit them, nay he preserved after the impressing body has perished. When a shell sinks into sand or mud, which in course of time becomes hardened into stone, and when the shell is remored by any solvent that may have filtered through the matrix, its place may become occupied by crystalline or other mineral matter, and the evidence of the shell be thus preserved loy a cust, for which the cavity made by the shell has served as a mould. If the shell has sunk with its animal within it, the plistic matrix may enter the dwelling-chamber as far as the whacted soft parts will permit; and as these slowly melt away, their plaes may hecome recupied ly erystallizerl Aepusits of

- Ixvos, a footstep, ani $\lambda \delta$ gos. 
any silicious, calcareous, or other crystallizable matter that may have been lield in solution by water percolating the matrix, and such crystalline deposit may receive and retain some colour from the soft parts of which it thus becomes a cast.

Eridences of soft-bodied animals, such as Actinice and Meduse, and of the excremental droppings of higher animals, have been thus preserved. Fossil remains, as they are called, of soft plants, such as sea-weeds, reeds, calamites, and the like, are usually casts in matrix made naturally after the plant itself has wholly perished.

Even where the impressing force or body has been renoved directly or shortly after it has made the pressure, evidence of it may be preserved. A superficial film of clay, tenacions enough to resist the escape of a bubble of gas, may retain, when petrified, the circular trace left by the collapse of the burst vesicle. The lightning flash records its course by the vitrified tube it may have constructed out of the santy particles melted in its swift passage through the earth. The hailstone, the ripple wave, the rain-drop, even the wind that bore it along and drove it slanting on the sand, have been registered in casts of the cavities which they originally made on the suft sea-beach; and the evidence of these and other meteoric actions, as sun-cracks and frost-marks, so written on imperishable stone, have come down to us from times incalculibly remote. Every form of animal life that, writhing, crawling, walling, running, hopping, or leaping, could leave a track, depression, or foot print, behind it, might thereby leave similar lasting evidence of its existence, and also to some extent of its nature.

The interpretation of such evidences of ancient life has much exereised the sagacity of naturalists since Dr. Duncan, in 1828, first inferred the existence of tortoises at the period of the deposition of certain sandstones in Dumfriesshire, from the impressions left nu those sandstones, and the casts after- 
wards formed in those impressions. The faculty of interpreting has been still more racked hy sinilar evidences of more extraordinary footprints, mobably of linge hatrachian reptiles, first noticed in 1834 at Ifildberghausen in Saxony, in sandstones of the same geological age as those in Scotland.

The vast number and varicty of stch impressions, due either to physical or meteoric forces, to dead organic bodies, parts or products, or to the transitory actions of living heings, have at length raised up a distinct branch of paleontological research, to which the term "Ichmology" has been given.

In this class of evidences the impressions called "protichnites" : (fig. 6t), left upon the "Potsdam sandstones" $†$ of the older Silurian age in Canada, are the most ancient; but the footprints of birds surpass all others in regard to their mumber, distinctness, and variety of sorts.

But how, it may be asked, are such footprints preserved? A common mode may be witnessed daily on those shores where the tide runs high, and the sea-bottom is well adapted to receive and retain the impressions made upon it at lowwater.

Dr. Gould of Boston, U. S., first called the attention of naturalists to this interesting operation on the shores of the Bay of Fundy, where the tide is said to rise in some places seventy feet in height. The particles deposited by that immense ticlal wave are derived from the destruction of prexiously existing rocks, and consist of silicious (flinty) and micacens (talcky) particles, cemented together by calcareus (limy) or argillaceous (clayey) paste, containing salts of corla, especially the muriate (common salt), and coloured with various shades of the oxide or rust of iron, of which the red oxide predoninates. The perfection of the surface for receiving and retaining an impression depends

* See Oren, "Description of the Impressions and Footprints of the Protichnites from the I'otsdam Simlstone of Canada," Quarterly Journal of the (icological Society, 1852, p. 214.

† Iogan, ibid, p. 2. 
much upon the micaceous element. Vast are the numbers of wading and sea birds that course to and fro orer the extensive tract of plastic red surface left dry by the far retreat of the tide in the Bay of Fundy. During the period that elapses between one spring tide and the next, the highest part of the tidal deposit is exposed long enough to receive and retain many inpressions ; even during the hours of hot sunshine, to which, in the summer months, this so-trodden tract is left exposed, the layer last deposited becomes baked hard and dry, and before the returning tidal wave, turbid with the same comminuted materials of a second stratum, has power to break up the preceding one, the impressions left on that stratum have received the deposit. A cast is thus taken of the mould previously made, and the sediment superimposed by each succceding tide, tends more and more surely to fix it in its place. Then, let ages pass away, and the petrifying influences consolidate the sand layers into a fissile rock: it will split in the way it was formed, and the cleatage will expose the old moulds on one surface and the casts on the other.

Another condition for fixing the impressions on a sandy shore is the following:-When an extensive level tract is left dry by the retreating tide, as at the estuary of the small rivers entering the Bay of Morecombe, on the Lancashire coast, those river's occasionally overflow the sands at low-water, and deposit in the footprints made previous to such overflow the fine mud which sudden heary rains have brought down from the surrounding hills. Again, those sudden "freshets," as they are locally callerl, sometimes as quickly subside, and the thin layer of argillaceous mud is left dry on the sand before the returning tide. Such laver of mud readily receives and retains the footprints of the many birds that course over the flat expanse; and as the tide returns, it deposits in such fontprints a layer of the fine sand which the rising waters hold in suspension. 
The best-defined footprints in the new red sandstone quarries at Stourton, on the Cheshire coast, are found where strata of sandstone are separated by a thin layer of argillaceous stone, which, when exposed, soon breaks up and crumbles away. This layer has, however, received the impressions when it was plastic, and the superincumbent deposit of sandstone retains those impressions in relief upon its under surfuce. The observations which have just been recorded, of the circumstances that produce an interposition of a thin larer of claystone between thicker beds of sandstone, and which circumstances the writer has witnessed in the Bay of Morecombe, explain the formation and the preservation of the best "ichnites" of the labyrinthodont and other reptiles in the new red sandstone of Stourton.

There is a third condition under which impressions, and casts of impressions, on a sandy beach may be preserved. On a dry windy day clouds of fine sand are drifted along the surface exposed at low-water, are spread lightly orer all its little inequalities, and fill up every impression that may have been made on it since it was left bare by the retreating waves. On the retum of the tide, the fine sand filling the impressions is moistened, and more wet fine sand is added to it; and a cast is thus fixed in the moulds, to be nore and more firmly fixed by each deposition from successive tidal waves.

Thus may be witnessed the actual conditions and the circumstances daily occuring that tend to preserve footprints and other impressions made on the sea-shore, and which have operated in past time to similarly preserve the impressions then made on tracts alternately exposed and covered hy the tidal wave. The merit of having first discerned the nature and cause of the mumerous small hemispheric pits and tubercular carsts in reliof on the surface of certain saulstone slats, is rlue to Tohn cummgham, Fisy. F.r.S., architect, of Tiver- 
pool:: Since that light was thrown on their nature, they have been recognized under various modifications, as impressions of soft rain, of the big-dropped thunder-shower, of rain driven obliquely by the gale, and making impressions with the side of the eup highest opposite the point whence the wind blew, of frozen rain or hail, etc. Dr. Deane, in 18t.), after witnessing the first exposure and raising of the red sand slabs, near Greenfield, Mass., U. S., writes, "They were characters fresh as mon the morning when they were impressed ; "on that morning gentle showers watered the earth,", etc. Whenever a stratum is proved to be a "seclimentary" one-i.c., to be due to the precipitation of its constituent particles from water, in which they had heen previously suspended-we have evidence of some expanse of water,-pronf, in fact, of the existence of that element, with all its properties of condensation by cold, and expansion and raporization by heat and exposure. Evaporation makes the raw material of rain. No wonder, then, that impressions of rain-drops should be seen on the oldest sedimentary rocks. Conditions are coortinated in meteoric as in organic phenomena; one being given, the rest may be deduced.

The oldest rocks in which rain-drop impressions have been observed are those of the Cambrian age at Longmynd, Wales, describerl and figured by Mr. Salter. $\dagger$ Many of the micaceous flags of the same formation are corered with ripple, or current marks. They show borings of worms, and a trace of a trilobite (Palcopyye) nearly allied to the Diticlocephalus - the oldest known trilobite of America (Lower Silurian or Cambrian at St. Croix, Minnesota).

It is in "Potsdam sandstones" of the same geological antiquity that the impressions have been discovered which the

* Communicated by Dr. Buckland to the meeting of the British Association at Newcastle, 1838; and subsequently by Mr Cunuingham to the Geol. Soc. (Proc. of the Geol. Soc, vol. iii., 1839, p. 99.)

+ Quar. Jour. of the Geol. Soc., vol. xii., 1856, p. 250, pl. iv., fig. 4. 
writer has interpreted to be those of a large entomostracous Crustacean ; ; in evidence of which the following sample, applicable to a single species, may be given, in illustration of the ichnologist's mode of work.

\section{Protichnites.}

\section{Protichnites septem-notatus (fig. 64).}

The subject so named comsists of a series of well-defined impressions, continued in regular succession along an extent of 4 feet; and traceable with an inferior degree of definition, along a further extent of upwards of 2 feet.

In the extent of 4 feet there are thinty successire groups of footprints on each side of a median furrow, which is alternately deep and shallow along pretty regular spaces of about $2 \frac{1}{2}$ inches in extent. The number of prints is not the same in each group; where they are best marked, as in fig. $64,1 \mathrm{~L}$, we see 3 prints in one group, $a, a^{\prime}, a^{\prime \prime}, 2$ prints in the next, $b$, $b^{\prime}$, and 2 in the third, $c, c^{\prime}$, which is followed by a repetition of the group of 3 prints, $a$, $a^{\prime}$, $a^{\prime \prime}$, making the numbers in the three successive groups $3,2,2$; the three groups of impressions being recognizably repeated in succession along the whole series of tracks on both sides of the median groove.

The principal footprints are disposed in pairs, placed with different degrees of obliquity, in each of the three groups towards the median track; the innermost print in the second, B, and third, C, pairs, which are best marked, being usually rather more than half the size of the onter print, $b^{\prime}$ and $c^{\prime}$.

The two footprints of the same pair are a little further apart from each other, in the three succeding pairs, as at $a^{\prime}$, $a^{\prime \prime}, b, b^{\prime}, c, c^{\prime}$, especially in the second and third groupss of each set; the two forming the pair $a^{\prime}$, $a^{\prime \prime}$, again approximating in the next series, and the pairs $b$, li and $e, e$, diverging in the same direction and degree; and this alternate apluoximation

* Quarterly Journal of the Geological Society, vol. viii., p. 214, 1852. 
and divergence is repeated throughout the entire series of the present tracks.

But what strikes the ichmologist, heretofore conversant chiefly with the footprints of bipeds or quadrupeds, is the occurrence in the present series of the third impression $a$,

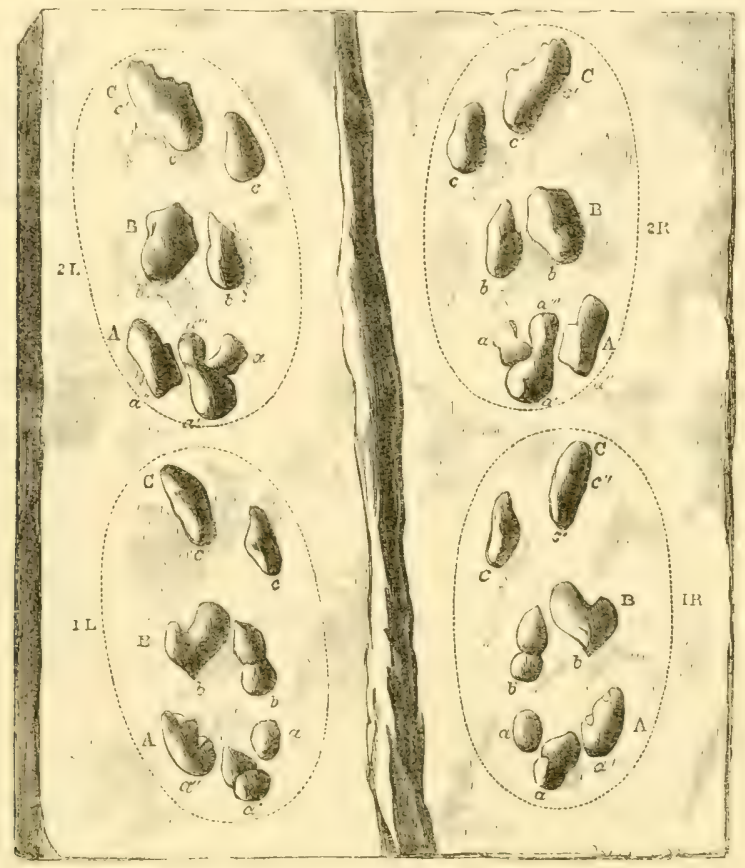

Fig. 64 .

Protichnites 7-notatus (Cambrian).

which complicates the most approximated pair $A$, being placed in front and a little to the imner side of the hindmost impression, $a^{\prime \prime}$, of that pair. The superadded impression $a$, is about the same size as the innemost in each pair, the average diameter of that impression being 5 lines.

Taking this view of the impressions, it appears that whilst the innermost in each pair, $a^{\prime}, b, c$, are of equal size, the outermost, $a^{\prime \prime}, b^{\prime}, c^{\prime}, 1 \mathrm{~L}$, progressirely increase in size, from the most 
approximated to the most divergent of the thee pairs; that of the first, $a^{\prime \prime}$, being narrow in proportion to its length, that of the second $l^{\prime}$, as broad as long, and the outermost, $c^{\prime}, c^{\prime \prime}$, of the third pair being oblong, hut larger than that in the first pair. In some places where the most approximated prir of impressions, $a$, $a$, are deeply markel, they are complicated $b$. a fourth shallow and very small $p$ it, $a^{\prime \prime \prime}, 2 \mathrm{~L}$, mirlway between the third, a, and the ontermost, a", of the pair of impressions.

There are no clear or unequirocal marks of toes or nails on any of the impressions which form the lateral pairs or triplets. Their margins are not sharply defined, but are rounderl off, aml sink gradually to the deepest part, which is a little behind the middle of the depression. There is a slight variation in the form and depth of the answerable impressions, but not such as to prevent their correspondence being readily apprecialile through the whole of the extent here described ; that is to sily, the imnermost of each of the three pairs here describer as first, A, second, B, and third, C, may be identified with the corresponding imnermost impression on the opposite side, and with the same impression of the same pair in the three preceding and the three succeeding pairs.

The impressions selected for fig. 6 t clearly demonstrate that the animal, progressing in an undulating course, made at each action of its locomotive members, answering to the single step of the biped and the double step of the quarlyued, not fewer than, in Protichnites 7-notatus, fourtern impressions, seven on the right and seren on the left; and in Piotichnites S-notulus, sixteen impressions, eight on the right and oight on the left; these seven and eight impressions respectively lowng arranger in three groups-rize, in Protichnites t-nutertes, three, two, and two; in Protichnites S-notatus, three, two, and three -the groups being re-impressed, in suecesive series, so similarly and so regularly as to achuit of mo dould that they were marle by repeated applications of the sime impressing 
instruments, capable of being moved so fur in adrance as to clear the previous impressions and make a series of new ones at the same distance from them as the sets of impressions in the series are from each other. What then was the nature of these instruments? To this four replies may be given, or hypotheses suggested:-They were made either, first, as in the case of quadrupedal impressions, each by his own limb, which would give seven and eight pairs of limbs to the two species respectirely; or, secondly, certain pairs of the limbs were bifureate, as in some insects and crustaceans, another pair or pairs being trifurcate at their extremities ; and each group of impressions was made by a single so subdivided limb, in which case we have evidence of a remarkably broad and short, and, as regards ambulatory legs, hexapod ereature ; or, thirdly, three pairs of limbs were bifurcate, and the supplementary pits were made by small superadded limbs, as in some crustaceans ; or, fourthly, a single broad fin-like member, divided at its impressing border into seven or into eight obtuse points, so arranged as to leave the definite pattem described, must have made the series of three groups by successive applications to the sand.

The latter hypothesis appears to be the least probable,first, as being most remote from any known analogy; and, secondly, because there are occasional varieties in the groups of footprints which wonld hardly accord with impressions left by one definitely subdivided instrument or member. Thus in the group of impressions marked 1 L in fig. 6t, the outer impression, $e^{\prime}$, is single, but in the preceding set it is divided; whilst the impressions, $a, c^{\prime}$, are confluent in that set, and are separate in $1 \mathrm{~L}$. The same variety occurs in the outer pair, $c^{\prime}, c^{\prime \prime}$, in Protichnites 8-notatus.

Yet, with respect to the hypothesis that each impression was made by its own independent limb, there is much difficulty in conceiving how seven or eight pairs of jointed limbs could be aggregated in so short a space of the sides of one 
animal. So that the most probable conception is, that the creatures which have left these tracks and impressions on the most ancient of known sea-shores belonged to a crustaceous genus,-either with three pairs of limbs employed in locomotion, and severally divided to accord with the number of prints in each of the three groups, - or bifurcated merely, the supplementary and usually smaller impressions being mate by a small and simple fourth, or fourth and fifth pair of extremities.

The great entomostracous king-cral) (Limulus) which has the small anterior pair of limbs near the middle line, and the next four lateral pairs of limbs bifurcate at the free extremity, the last pair of lateral limbs with four lamelliform appendages, and a long and slender hard tail, comes nearest to the abore idea of the kind of animal which has left the impressions on the Potsdam sandstone.

The shape of the pits, so clearly shom in the ice-rubbed slabs, impressed by Protichnites S-notutus, accords best with the hard, subobtuse, and subangular terminations of a crustaceous ambulatory limb, such as may be seen in the blunted legs of a large Palinumes or Birgus; and it is erident that the animal of the Potsdam sandstone moved directly forwards after the manner of the Hacrourd and Xiphosure, and not sideways, like the brachyurous Crustaceans.

The appearances in the slab impressed by the Protichnites multi-notatus favour the view of the median track having been formed by a caudal appendage, rather than by a prominent part of the under surface of the trunk.

The imagination is baffled in the attempt to realize the extent of time past since the period when the creatures were in being that mored upon the sandy shores of that most ancient Silurian sea: and we know that, with the exeption of eartain microscopic forms of life, all the actual species of animals came into leing at a periorl goologically very recent in comparisun with the Silurian epoch. 
The deviations from the living exemplars of animal types usually become greater as we descend into the depths of time past; of this the Archegosaur and Ichthyosaur are instances in the reptilian class, and the Pterichthys and Coccosteus in that of fishes. If the vertebrate type has undergone such inconceivable modifications during the Secondary and Devonian periods, what may not have been the modifications of the articulate type during a period probably more remote from the secondary period than this is from the present time? In all probability no living form of animal bears such a resemblance to that which the Potsdam footprints indicate as to afford an exact illustration of the shape and number of the instruments, and of the mode of locomotion, of the Silurian Protichnites.

Since the foregoing interpretation of the Silurian Ichnites of North America was published, similar impressions have been observed in rocks of the like high antiquity in Scotland, as at Binks, Eskdale, which have received the name of Protichnites Scoticus.*

\section{AMPHibichNites.}

Gcmus Cherrotheriux.-Fig. 68 gives a reduced view of a portion of new red sandstone, with three pairs of footprints in relief : the first and third of the left, the second of the right, side. Consecutive impressions of such prints have been traced for many steps in succession in quarries of that formation in Warwickshire and Cheshire, more especially at a quarry of a whitish quartzose sandstone at Storton Hill, a few miles from Liverpool. The footmarks are partly concave and partly in relief; the former are seen upon the upper surface of the sandstone slabs, but those in relief are only upon the lower surfaces, being in fact natural casts, formed on the subjacent footprints as in moulds. The impressions of the

* Harkness and Salter "On the Lowest Rocks of Eskdale," Quarterly" Journal of the Geological Society, vol. xii., pp. 238, 243, fig. 2. 
hind foot are generally 8 inches in length and 5 inches in width ; near each large footstep, and at a regular clistanceabout an inch and a half-before it, a smaller print of the fore foot, $t$ inches long and 3 inches wide, occurs. The footsteps follow each other in pairs, each pair in the same line, at intervals of abont 1t inches from pair to pair. The large as well as the small steps slow the thumb-like outermost toe alternately on the right and left side, ench step making a print of five toes.

Footprints of corresponding form, but of smaller size, have been discorered in the quarry at Storton Hill, imprinted on fire thin heds of clay, lying one upon another in the same quarry, and separated by beds of sandstone. From the lower surface of the sandstone layers the solid casts of each impression project in high relief, and afford models of the feet, toes, and claws of the animals which trod on the clay.

Similar footprints were first observed in Saxony, at the village of Hesshurgh, near Hillburghausen, in several quarries of a grey quartzose sandstone, alternating with beds of red sandstone, and of the same geological age as the sandstomes of Fngland that had been trodden by the same strange animal. The German geologist who first descrihed them (183t) proposed the name of Chcirotherimm (cheir, the hand, therion, beast) for the great unknown animal that had left the footprints, in consequence of the resemblance, both of the fore and hind feet, to the impression of a human hand ; and Dr. Tiaup conjectured that the animal might be a large species of the opossum kind; lut in Didelphys the thmmb is on the immer side of the hind-foot. The fossil skulls, jaws, teeth, and a few other hones, in the sandstones exhiliting the footprints in question, and corresponding in size with those impressions, belong to lalyrinthorlont or huge extinct batrachian reptiles.

The impressions of the Cheirotherium resemble those of the footprints of a salamander, in having the shert outer toe of the hind foot projecting at a right angle to the line of the 
mid toe, but are not identical with those of any known Batrachian or other reptile. They show a papillose integument as in some mammals, but also like that on the sole of certain Geckos, and which nay be another mark of sauroid departure from the modern batrachian type. The proximity of the right and left prints to the median line inclicates a narrower form of bouly, or its greater eleration upon longer and more vertical limbs, than in tailless Batrachia. In the attempt to solve the difficult problem of the nature of the animal which has impressed the new red sandstone with the cheirotherian footprints, we cannot overlook the fact, that we have in the Labyrinthodons also batrachoid reptiles, differing as remarkably from all known Batrachia, and from all other reptiles, in the structure of their teeth; both the footsteps and the fossils are, moreover, peculiar to the new red sandstone; the different size of the footprints referred to different species of Chcirotheria correspond with the different size of ascertained species of Labyrinthodon; and the present facts best support the hypothesis, that the footprints called "cheirotherian," are those of labyrinthodont reptiles.

Genus Otozoca.-The footprints in the red sandstones, probably of liassic age, in Connecticut, described by Prof. Hitchcock under the above name, equalled in size the largest of those of the Chcirothcrium (Ch. Hercules), but the hind foot had but four toes, whilst the fore foot had five toes. It would seem that the hind foot, which was larger than the fore foot, obliterated the print of that foot, by being placed upon it in walking. In the few instances of the fore foot print the toes are turned outward, and the fourth and fifth seem to have been connate at their base. An impression of a web has been clearly discerned in the hind foot. Only one toe on this foot shows a claw, the rest are teminated by "pellets," as in the Batrachia, to which family Dr. Hitchcock refers these footprints, thongh with a surmise of the possibility of their marsupial nature.*

* Ichnology of Massachusetto, 4to, 1858, p. 123. 
Genus Batrachop's (Batrachopus primarus, King.) - In 18tt, Dr. King of Greensburg, Peunsylvania, discorered fossil footmarkis, which he amouncel as being those of a reptile, in the sandstone of the coal measures, near that torn. No reptilian footyrints hat previously been found lower in the series than the New Red sandstone. Dr. King states the impressions to be "near 800 feet beneath the topmost stratum of the coal formation."

Sir C. Lyell, in Silliman's Journal, July 18t6, describes his visit to Greensburg, where he examined these footmarks, and confirmed Dr. King's description of them. He cousidered them to be allied to the labyrinthodont footprints which have been referred to the gemus Cheirotherium. He says- "They consist, as before stated, of the tracks of a large reptilian quadruped, in a sandstone in the middle of the carboniferous series, a fact full of novelty and interest; for here in Pennsylvania, for the first time, we meet with evilence of the existence of air-breathing quadrupeds capable of roaming in those forests where the Sigillaria, Lepidodendron, Caulopteris, Calamites, ferns, and other plants flourished."

These footmarks were first olsserred standing out in relief from the lower surface of slalss of sandstone resting on thin layers of fine unctuous clay, which also exhibited the cracks due to shrinking and drying. Now these cracks, where they traversed the footprints, had produced distortion in them, for the mud must have been soft when the animal walked over it and left the impressions; whereas, when it afterwards dried up and slrmuk, it would be too hard to receive such indentations, and could only affect them in the way of subsequent dislocation.

No less than twenty-three footsteps, the greater part so arranged as to imply that they were made successively by the same animal, were observed in the same quarry.

Everywhere there was a douhle row of tracks, and in each row they occur in pairs, each prair consisting of a hind and 
fore foot, and each being at nearly equal distances from the next pair. The hind foot-print is about one-third larger than the fore foot-print: it has five toes, but the front one only four : some of them exhibit a stunted rudiment of the innermost toe or "pollex," which is the undereloped one. The outermost toe in the hind footprint is shorter and rather thicker than the rest, and stands out like a thumb on the wrong side of the hand.

With this general resemblance to the footprints of Labyrinthodon, from the new red sindstones of Europe, there are well-marked distinctions. In the first place, the right and left series of impressions are willer apart, indicative of a broader-bodied animal. The front print in Batrachopus has only four well-ilereloped toes instead of five, as in Labyrinthodon; it is also proportionably larger, - the fore foot in Labyrinthodon being less than half the size of the hind foot. The distance between the fore and hind print of each pair, and of one such pair from the next on the sime side, is nearly the same in Batrachopus and Labyrinthodon.

Genus Siunopts, Rogers.-Very similar footprints were discorered and described by Mr. Isaac Lea in a formation of red shales, at the base of the coal measures at Pottsville, 78 miles N.E. of Philadelphia. These are of older clate than the preceding, inasmuch as a thickness of 1700 feet of strata intervenes between the footprints at Greensfield and the Pottsville impressions.

Professur 11. I. Rogers, in 18.51, announcerl his discovery in the same red shales, between the Deronian and carboniferous series, of three species of four-footed animals, which he deems to have been rather saurian than batrachian, seeing that each foot was five-toed; one species, the largest of the three, presented a diameter for each footprint of about two inches, and showed the fore and hind feet to he nearly equal in dimensions. It exhibits a length of stride of about nine inches, and a breadth between the right and left footsteps of nearly four inches. The 
impressions of the hind feet are but little in the rear of the fore feet. With these footmarks were associated shrinkage cracks, such as are caused by the sun's heat upon mud, and rain-drop pittings, with the signs of the trickling of water on a wet beach,-all confirming the conclusions derived from the footprints, that the quadrupeds belonged to air-breathers, and not to a class of animals living in and breathing water.

\section{Class II.-REPTILIA.}

\section{Order I.-GANOCEPHALA.*}

The name of this order has reference to the sculptured and externally polished or " ganoid" bony plates with which the entire head was defended. These plates include the "post-orbital" and "super-temporil" ones, which roof over the temporal fossæ. There are no occipital condyles. The teeth have converging inflected folds of cement at their basal half. The notochord is persistent; the vertebral arches and peripheral elements are ossified; the pleurapophyses are short and straight. There are pectoral and pelvic limbs, which are natatory and very small ; large median and lateral "throat-plates;" scales small, narrow, sub-ganoid; traces of branchial arches. The above combination of characters gives the value of an ordinal group in the cold-blooded Vertebrata.

Genus Apateon, Von M. ; Archegosaurus, $†$ Goldf. The extinct animals which manifest the above ordinal characters were first indicated by certain fossils, discovered in the sphicrosideritic clay-slate forming the uprer member of the Bavarian coal measures; and also in splitting spheroidal concretions from the coal-field of Saarshuck, near Treves. They were originally referred to the class of fishes (Pygopterus Lucius, Agassiz) : but a specimen from the Brandschiefer of MIinster-

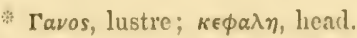

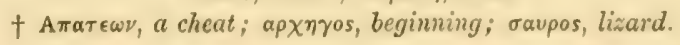


Appel presented characters which were recognized by Dr. Gergens to be those of a salamandroid reptile.* Dr. Gergens placed his "salamander" in the hands of $H$. von Meyer for description, whocommunicated the result of his examination in a later number of the under-cited journal. $t$ In this notice the author states that the salamandroid affinities of the fossil in question, for which he proposes the name of $A$ pateon pedestris, "are by no means demonstrated." $†$ "Its head might be that of a fish as well as that of a lizard, or of a Batrachian." "There is no trace of bones or limbs." M. von Meyer concludes by stating that, in order to test

* Mainz, Oktober 1813. "In dem Brandschiefer von Miinsterappel in Rhein-Baiern habe ich in vorigen Jahre einen Salamander aufgefunden. Gehört dieser Schiefer der Kohlen-formation? in diesem falle wäre der Fund auch in anderen Hinsicht interessant." (Leonhard und Bronn, Neues Jahrbuch fur IFineralogie, etc., 1844, p. 49.)

† Ibid, 1844, p. 336.

‡ "Ob das-A pateon pedestrisein Salamander-artiges Geschiopf war, est keinesweg ausgemacht." (Ibid.)

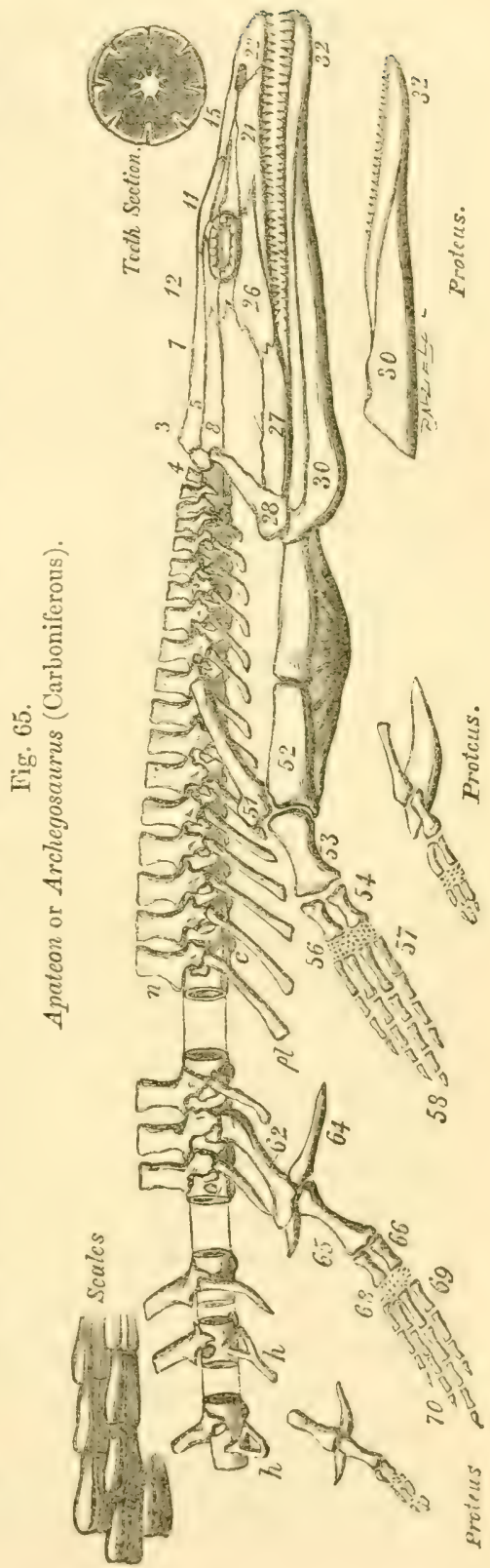


the hypothesis of the Apatcon being a fossil fish, he has sent to Agassiz a drawing with a description of it.

Three years later, better preserved and more instructive specimens of the problematical fossil were obtained by Professor von Dechen from the Bavarian coal-fields, and were submitted to the examination of Professor Goldfuss of Bonn: he published a quarto Mlemoir on them, with good figures, referring them to a saurian genus which he calls Archegosaurus, or primeral lizard, deeming it to be a transitional type between the fish-like Batrachia and the lizards and crocodiles. ${ }^{*}$

The estimable author, on the occasion of pul,lishing the above Memoir, transmitted to me excellent casts of the originals therein described and figmed. They are in the museum of the Royal College of Surgeons, and are described in my Catalogue of the Fossil Reptiles, tto, 185t, p. 117.† One of the specimens appeared to present evidence of persistent branchial arches. The osseous structure of the skull, especially of the orbits, throngh the completed zygomatic arches, indicated an affinity to the Lahyrinthodonts; but the vertebre and numerous very short ribs, with the indications of stunted swimming limbs, impressed me with the conviction of the near alliance of the Archeyoscurns with the Protcus and other peremnibranchiate reptiles.

This conclusion of the affinity of Archegoscurus to existing types of the reptilian class has been confirmed by subsequently-discovered specimens, some of which have been acquired by the British Musem, others have been deseribed

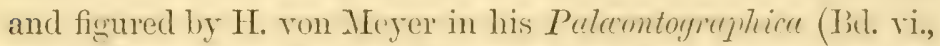
2to Lief. 18.5\%); more especially by his discorery of the embryonal condition of the rertelnal column-i.c., of the persistence of the notochord, and the restriction of nssification

* "Arehegosanrus, Fossile-Saurier ans dem Stein kohlengebirge die den Tebergang der Ichthyoden zu den Iacerten und Frokodilen biliten," p. 3. (Beitrage sur vorueltlichen Fuuna des Stcintiohlengebirges, 4to, 18.4).

+ See also, Quarterly. Tommal of the Geolngical Suciety, vol. iv., 18.18. 
to the arches and peripheral vertebral elements." In this structure the old carboniferous reptile resembled the existing Lepidosiren, and affords further ground for regarding that remarkable existing animal as one which obliterates the line of demarcation between the fishes and the reptiles.

Coincident with this non-ossified state of the basis of the vertebral bodies of the trunk (fig. $65, c$ ), is the absence of the ossified occipital condyles which characterize the skull in better developed Batractia. The fore part of the notochord has extended into the basi-sphenoid region, and its capsule has connected it by ligament to the broad flat ossifications of expansions of the sanue capsule, forming the basi-occipital or basi-sphenoid plate. In fig. 65 are represented the chief modifications of the vertebre, as shown in the neck, thorax, abdomen, sacrum, and tail. The vertebre of the trunk in the fully-developed full-sized animal present the following stage of ossification :-

The neurapophyses (fig. $65, n$ ) coalesce at top to form the arch, from the summit of which was developed a compressed, sub-quadrate, moderately high spine, with the truncate or slightly convex summit expanded in the fore-and-aft direction so as to touch the contiguous spines in the hack; the spines are distinct in the tail. The sides of the base of the nemal arch are thickened and extended outwards into diapophyses, having a convex articular surface for the attachment of the rib, $p l$; the fore-part is slightly produced at each angle into a zygapophysis looking upwards and a little forwards; the hinder part was much produced backwards, supporting twothirds of the netral spine, and each angle dereloped into a zygapophysis, with a surface of opposite aspects to the anterior one. In the capsule of the notochord three bony plates were developed, one on the ventral surface, and one on cach side, p. 61 .

* Reptilien aus der Steinkohlen Formation in Deutchland, Sechster Bant, 
at or near the back part of the diapophysis. These bony plates may be termed cortical parts of the centrum, in the same sense in which that term is applied to the element which is called "body of the atlas" in man and Mammalia, and "sub-rertebral wedge-bone" at the fore-part of the neck in Enaliosauria.

As such neural or inferior cortical elements co-exist with seemingly complete centrums in the Ichthyosaurus, thus affording ground for deeming them essentially distinct from a true centrum, the term "hypopophysis" has been proposed for such independent inferior ossifications in and from the notochordal capsule; and by that term may be signified the sub-notochordal plates in Archcyosaums, which co-exist with proper hæmapophyses $(h)$ in the tail. In the trunk they are flat, subquadrate, oblong bodies, with the angles rounded off; in the tail they bend upwards by the extension of the ossification from the under to the sicle parts of the notochordal capsule; sometimes touching the lateral cortical plates. These serve to strengthen the notochord and support the intervertebral nerve in its outward passage. The ribs $(p l)$ are short, almost straight, expanded and fiattened at the ends, round and slender at the middle. They are developed throughout the trunk and along part of the tail, co-existing there with the hrmal arches, as in the Menopome. ${ }^{*}$ The hrmal arches $(h)$, which are at first open at their base, become closed by extension of ossification inwards from each prouluced angle, converting the notch into a foramen. This forms a wille oval, the apex being prouluced into a long spine; but towards the end of the tail the spine becomes shortened, and the hiemal arch reduced to a mere flattened ring.

The size of the canal for the protection of the canklal bloodressels indientes the powerful muscular actions of that part, fig. 11 . 
as the produced spines from both neural and hæmal arches bespeak the provision made for muscular attachments, and the rertical development of the caudal swimming organ.

The skull of the Archegoscums appears to have retained much of its primary cartilage internally, and ossification to have been chiefiy active at the surface; where, as in the combined dermo-neural ossifications of the skull in the sturgeons and salamandroid fishes-c.g., Polypterus, Amiu, Lepidosteusthese ossifications have started from centres more numerous than those of the true vertebral system in the skull of saurian reptiles. This gives the character of the present extinct order of Batrachio.

The skull is much flattened or depressed, triangular, with rounded angles, and the front one more or less produced according to the species; and in some species according to the age of the individual. The base is concare; the sides nearly straight, or slightly concave. The basi-occipital appears to have retained its primordial soft, unossified state. Of the ex-occipitals, in a distinctly ossified state, no clear view has yet been had. The super-occipital (fig. 65,4 ), is represented, as in the salamandroid fishes, by a pair of flat bones, more probably developed in the epicranial membrane and integument than in the cartilaginous protocranium. The pair of bones external to these, and forming the prominent angles of the occipital region, represent the "par-occipitals." The lower peripheral surface of the basi-sphenoidal cartilage is ossified with a concave border towards the notochord behind, to the capsule of which it seems to hare been attached. The alisphenoids were doubtless cartilaginous, and the protocranium there unaltered, as it was apparently in the ex-occipital region. The peripheral ossifications above representing the "parietal" (7), form a pair of oblong flat bones, with the "foramen parietale" in the mid-suture. External to these, and wedged between the parietals, the super- and par-occipitals, are 
the pair of bones anstrering to the "mastoids" ( 8$)$. They" give attachment extermally and below to the tympanic (28), and to a subsidiary bony plate, holding the position of that development of the mastoid and squamosal, which roofs orer the temporal fossa in the Chclonia : it may be termed "suprasquamosal" (the bone between 8 and 27 in fig. 65). The frontal bones (ir), divided by a mid-suture, like the parietals, increase in length, and are continued far in adrance of the orbits. The bone (rz) which occupies the position of the postfrontal in Chclonic is ossified from two centres, one articulating with the mastoid (8), the other, which is external to it, with the supra-squamosal. This other bone may be termed the "postorbital," as proposed by Ton Meyer. The post-frontal extends forward above the orbit to meet the pre-frontal, separating the frontal (ri) from the orbit, as in the sturgeon (Acipenser), Polypterus, and Lepridosteus, and also in some Chelones. The pre-frontal extends far forward, terminating in a point lotween the nasal (15) and lacrymal. The nasals (15), divided by the median suture, extend to the external nostrils, their prolongation varying with the species and age of the individual.

Thus far the ossification of the superficies of the skull of Archegoscurus closely conforms to that of the salamandroid ganoid fishes above cited; and the homologous bones are determinable without doubt. The lacrymal bone olviously answers to the front large suborbital scale-bone in fishes; its large size and forward extension in Archegnscurus is a mark of that affinity.

The upper jaw consists of pre-maxillary (zz), maxillary (2r), and palatine bones. The pre-maxillaries are divided by a median suture, as in Lejidosteus and Cirocoditus, and are short hones, the brearth exceeding the length in A. latirostris, and also in the young of $A$. Decheni; hut in the old animal opposite proportions prevail. In A. Dechoni each pre-maxillary contains eight teeth; in A. latirnstris not less than eleven. 
The maxillary (2r) which extends from the pre-maxillary to beneath and beyond the orbit, presents a great length, raried according to species and age; it is of small rertical extent, and terminates in a point, which reaches the tympanic. Anteriorly it unites with the pre-maxillary, and enters into the formation of the back boundary of the nostril; mesially it unites above with the lacrymal and suborbital, and below forms the outer boundary of the choanal aperture, joining the romer anteriorly, and the paiatine posteriorly. The palatine is a long narrow bone, rather expanded at both extremities; it forms anteriorly the hinder border of the choanal aperture, and mesially throughout a great part of its extent the outer boundary of the great palatal vacuity. It supports a row of teeth, of which one or two at the fore part are of large size.

Between the orbit and the maxillary exteuds an oblong flat bone (26), forming the lower or outer border of the orbit, uniting with the pre-frontal and lacrymal anteriorly, with the maxillary below, and with the tympanic (9) and another bone behind. In this position, and in its connections, it agrees with the malar of the crocodile, and also with the suborlbital bone or bones of fishes. The latter are unequirocally mucodermal bones, and may not be the homologues of the endoskeletal malar bone of saurians, birds, and mammals. To which of the bones, therefore,- - suborlital or malar,- the one in question of the Archegoscurus answers, may be doubtful. The writer inclines to view it as a dermal ossification, and to conclude that, as in the higher Baticachia, the true malar and the zygomatic arch are not developed. Admitting the doubt on this point, the bone (26) may be termed the "suborlital."

With regard to the next bone (27), the same question, whether it answers to the squamosal in the crocodile, or whether it is a dermal ossification, applies. If a homology with a determinate endo-skeletal bone in the crocodile and higher vertehrates were to he predicated, it would be the 
"squamosal." Above 27 , between it and 8, is the "suprasquamosal." Essentially it indicates the tendency to excessive dermal ossification of the skull, like that which extencls into the superficial temporal fascia from the squamosal and mastoid in the Chclonia; this separate ossification in Archegosaurus roofs over the temporal fossa. It is the homologne of the supernumerary surface-bone called "supersquamosal" in the Labyrinthodonts; and both this and the "postorbital" correspond in position with the posterior suborbital scalc-bones in Amia and Lepidosters.

The hinder angles of the skull are formed by the tympanic; in young individuals the tympanic does not extend backward beyond the par-occipital, but as age adrances it projects further backward. It appears to abut internally against the pterygoid.

The two rami of the mandible were loosely united at a short symphysis, not excecding the brearth or depth of the jaw at that point; the depth gradually augments to near the articular end, but never exceeds a sixth, and is usually only an eighth of the length of the jaw, no definite coronoid process being developed; the upper and lower borders are nearly straight as far as the deepest part. The lower border behind this part rises rather abruptly to an angle, which is just below the articular pit. The angular element (30) presents a convexity answering to the point of ossification whence some faint ridges radiate upon its outer surface. The dentary (3z), if it does not form the artieular surface, begins very near it, and each ramus appears to be composed of these two bones. The dentary developes the coronoid rising. Neither articular nor splenial element has heen elearly demonstrated. If an articular element has existed, it has been very small.

From fishes the lower jaw of Archegosames cliffers in the great length or forward extension of the angular piece $\left(3_{0}\right)$; but it resembles the piscine type in the simplicity of its composition. The angular piece is, however, Inger in the Fanoids 
-c.y., Amiu, Polypterus, Lepidostus,-than in other fishes; in Lepidosiren its proportions are almost those of the Archegoscure!s; and it offers similar proportions in the mandible of the Axolotl and Proteus (fig. 65).

The teeth in Archegoscurus have the simple conical pointed shape. They are implanted in the premaxillary, maxillary, mandibular, and romerine bone, and in a single row in each. In the short premaxillaries there are from 8 (A. Decheni) to 12 (A. lutirostris); they are rather larger than the maxillary teeth. These follow in an unbroken series to beneath and beyond the orbit, and are alout $30 \mathrm{in}$ number ; but their interspaces are such as would lodge double that number in the same extent of alveolar border. The romerine teeth are in a single row, parallel with and near to the maxillary row ; one or two behind the choane are much larger than the rest, which resemble the maxillary teeth in size. The mandibular teeth extend backward to the coronoid rising, and decrease in size, the front ones being the largest. Each tooth is implanted by a simple hase in a shallow cup-shaped socket, with a slightly raised border, to which the circumference of the tooth lrecomes anchylosed. The tooth is loosened by absorption and shed to make way for a successor. These are developed on the imner, hind, and fore part of the base of the old twoth. The teeth are usually sherl alternately. They consist of osteodentine, dentine, and cement. The first substance occulies the centre; the last covers the superficies of the tooth, lut is introduced into its substance by many concentric folds extending along the basal half. These folds are indicated hy fine Iongitudinal, straight strix along that half of the crown. The section of the tooth at that part (see fig. 65, tooth-section) gives the same structure which is shown hy a like section of a tooth of the Lepidosters oxynus.*

The same principle of rental structure is exemplified in * $\mathrm{IV}^{\top}$ man, American Journal of the Natural Sciences, Oct. 1843. 
the teeth of most of the ganoid fishes of the carboniferous and Deronian srstems, and is carried ont to a great and beatiful degree of complication in the "old red" Denchrodonts.

The repetition of this structure in the teeth of one of the earliest genera of Reptilic, associated with the defect of ossification of the endo-skeleton and the excess of ossification in the exo-skeleton of the head and nape, instructirely illustrates the true affinities and low position in the reptilian chass of the so-called Archegosauri.

Resting upon and protected by the throat-plate in the middle line, there is a longish slender bone, which must belong to the median series of the hyoid system, either basi- or urohyal ; it is most probably homologons with the uro-lyyal of Amplizeme and other Peremibranchiates. That two pairs of slender bones projected outward and backward from the median series, is shown by more than one specimen of Ardegosurus in the British Musem. The anterior pair is the lungest; these are situated as if they har heen attacherl, one to each side of the broad "throat-plite," which may have represented a basi-hyal. The anterior pair are homologous with the corresponding longer prir of appendages to the liroad basi-hyal of Amphizma, and are cerato-hyvals. The shorter posterior pair answer to the branchi-hyals in A mpleixma and other Peremiluranchs. There is no such pair in the hyoidean arch of any known Saurian.

External to the ends of the above lateral elements of the hyoid apparatus, feeble traces of arched series of bony nuclei were detected hy Coldfuss, and interpueted hy him as remains of partially ossified bianchial arehes. In all these specimens pussessing them they present the ont line of two ar there areles in dots, or slightly curved series of dorts or points. In the small relative size of these indications of hranchial areles, the Archegosaurus agrees with the Amphinma.

No doubt, in the fully-grown idehgorenter, the lungs 
would be equal to the performance of the required amount of respiration; lut the retention of such traces of the embryonal water-breathing system in the adult leads to the inference that the animal must have affected a watery medium of existence for as great a proportion of its time as is observed to be the case in the existing peremuibranchiate reptiles ; in which, notwithstanding the degree of development of the lungs, the respiratory function seems to be mainly performed by the gills.

The additional marks of aftinity to fishes which the $A$ rchcgoscurus presents in its persistent notochord, cartilaginous basi-occipital, dermal ossifications on the head, and minute body-scales (fig. 65, scales), remove it further from the samrian reptiles, and exhibit it more strongly in the light of an osculant form between the Batrachians and the Ganoids.

The under surface of the body between the head and trunk is defended by broad bony plates, three in number. One is median and symmetrical, of an elongate lozenge shape, with the angles rounded off; slightly convex externally, a little produced along the middle of the anterior inalf into something like a low quasi-kecl. The outer surfice is sculptured by radiating furrows, except at so much of the marginal part as is overlappecl by the lateral pieces, and by the scapular arch. The lateral throat-plates are attached to the anterior half of the sides of the median one, are shaped like heetles' elytra, and converge forwards. Their centre of ossification is towards their outer and back part, from which the external ridges and grooves radiate towards the inner border.

Ton Meyer* comprares these dermal shields to the entoand (p)i-sterual elements of the plastron of Chelonia; their truer homology seems to the writer to be with the median and lateral large throat-plates or scales of Megalichthys and Suctis

* "Die kehlbrust platten komnte man der unparigen Platte und u bm ersteu Platten-paar im Bauchpanzer der Schilitkrijter vergleichen." (Op. cit., p. 100.) 
gigus. The ente-stermal clenent is the only endu-slietetal piece uncombined with a dermal ossification in most Chelonia. The epi-sterual, like the hyo- and hypo-sternals, appear to be abdominal ribs, with superadded demual ossifications in Cheloniu.

The scapule (fig. 65, 5r) are instructively exhibited in the very young specimen of the Airchergosurus figured in t. xiv, fig. t, of Von Meyer's treatise. The coracoids being doul,tless wholly cartilaginous at that stage, are not discernible in the specimen referred to. The upper slender end of the scilpula is opposite the sicle of the vertebral columm, about the fifth neurapophysis from the head, and it curves gently downard and forward, expanding at its humeral end. This expransiom is more sudden in the fully-dereloped animal, giving the bone. the shape of a rudiler, and the direction of the seapula is changed. At least in the specimens (the great majority) in which the skeleton is seen from abore, the slender dorsal end of the scapula is seen overlying, or near the linder border of the lateral throat-plate, and it extends ontward and backwird to its expranded lnmmeral end. The coracoids (5z) are represented by a pair of flat reniform plates, with the convex border turned forwarl, the concare one hackward ; they seem to have overlapped the smooth margins of the posterior half of the meclian throat-plate. It is most probable that, as in A mpleiume, a portion of the broad coracoid remained in the cartilaginous state, and that the full reniform plate answers to the ositient part of that coracoid which it resemlles in shape and relative pusition. The position of the slender scapular, styliform and rib-like, as in the Peremuibmenchiates, is instruetirely shomn in t. xviii., figs. 1 and 2 , of M. Non Meyer's treatice. 'Ther

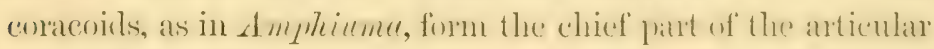
eavity for the humerus.

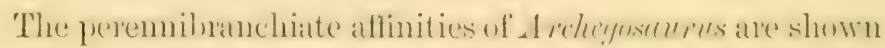

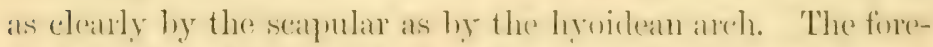

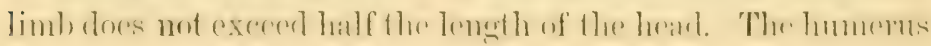


(53) is a short thick bone, slightly constricted at the midllle, expanded and rounded at both ends, the proximal one being the largest. For some time the bone is hollow and open at each end; when ossification funally closes the terminal apertures, it shows that the ends were comnected to the coracoid and to the fore-arm by interposed ligamentous matter,-not, as in true Samians, by a symovial joint. Of the two bones of the forearm the ulna is a little longer and larger than the radius (54). Both bones present the simplest primitive form, gently constricted in the midlle, with the proximal ends a little concare, the distal ones a little convex. The space between the antibrachium and the metacarpus plainly hespeaks the mass of cartilage representing, as in $A$ mplimur, the carpal segment (56) in Archegoscums. No trace of a carpal bone is found save in the largest and oldest examples, in which five or six small roundish ossicles are aggregated near the ulnar side of the carpus. Four digits are present; and considering the pollex to be, as usual, wanting, the second digit answering to the medius of pentadactyle feet, is the largest, and includes at least four phalanges $\left(5^{8}\right)$; these, with the metacarpals (57), are long, slender, terminally expanded, and truncate. They obvionsiy supported a longish, narrow, pointed paddle. The outermost or little finger was the shortest, and has the shortest metacarpal and first phalanx.

It is true that in Mystriosonms the fore limbs are relatively almost as short as in Archegoscurus ; and the oolitic crocodile recalls the arrest of derelopment of the same limbs in the marsupial Potorons; but in Arehegosmurus, not only is the small size of the fore limbs, but also their type of structure, especially that of their scapular arch, closely in accordance with that in the Pcremizranchiceta, as shown in the tridactyle fore-limb of the Proteus anyuinus, of which a fignre is added to that of the Archegosaunus in fig. 65.

The ilium (6z), like the seapula, is expanded at its articular 
or femoral ent. It is less long and slender; one border is straight, the other concave, by the expansion towarl that border of the femoral encl. Two shorter bones on each side complete the pelvis below. One is of a simple form, straight, thicker in proportion to its length than in the ilium: it may be ischium.

The other bone is shown, with its fellow, in t. xiii., fig. 6 , and xviii., figs. 8 and 9, of Von Meyer's treatise. That author compares the pair of bones to the Aptychus in shape; they may be the pubic bones. On this hypothesis, they are restored to their true position at 64 (pulbis) in fig. 65. The femur (65) is slightly expanded, and truncate at both ends ; it is not longer than the ilium. The tibia (66) and fibula are separate bones, like those of the fore-arm; the margins, which are tumed toward each other, are most concave. They are rather more than half the length of the femur.

The foot-bones are separated by a fibro-cartilaginous tarsal mass (68) from those of the leg. The form of the phalanges, expanded and truncate at both ends, bespeaks their simple ligamentous joints, and that they supported, like the fore-limb, a fin or limb adapted simply for swimming. The argument for the saurian affinities of Archegoscumes, based by V. Meyer on the short fore-limbs of Mystriosaurus, already invalidated by the difference of structure, is controverted by the fact, that the hind limbs of Archeyosaurus, like those of the Perennibranchs, are not only as simple in structure, but also as short, as the fore-limbs.

Genus Dendrerpeton.-In 1852 Sir Charles Lyell and MIr. Dawson, in the course of their investigations of the coal strata of Nova Scotia, remarkable for the erect fossil trees in certain parts, discovered in the hollow of the trunk of one of these trees (Sigillaria, 2 feet in diameter), which was wholly converted into coal, some small bones, which Professor II'yman of Boston sumised to have belonged to a batrachian reptile. 
By the professor's advice they were lrought to England and submitted to the writer, who has described and figured them: as batrachian, moler the name Dendreipeton Aculiunum, and with close affinities, from the plicated structure of the teeth, the sculpturing of some broad cranial plates, and the structure and proportions of certain limb-lones, to the genus Areheyosaumes. The subsequent discovery of carinate scales with bones of the Dendremptom adds to the probability of its appertaining to the Ganocephalous order.

Gemes Raxicers.- In about the centre of the great carboniferous basin of Ohio, United States, at the mouth of the "yellow creek," is a seam of coal 8 feet in thickness, the lower four inches of which is "camnel coal." In this has been found the skull, part of the vertebral column, scapular arch, and fore limbs of a reptile referred by Professor Wymant to the batrachian suly-class, under the name of Ranicepss. Two closelyallied fossils, also referred to Batrachia, have been found in the same formation and locality.

\section{Order II.-Labyrinthodontia.}

Head defended, as in the Ganocephala, by a continuous casque of externally sculptured and unusually hard and polished osseous plates, including the supplementary "post-orbital" and "super-temporal" bones, but learing a "foramen parietale." Two occipital condyles. Vomer divided and dentigerous. Two nostrils. Vertebral bodies, as well as arches, ossified, biconcave. Pleurapophyses of the trunk, long and bent. Teeth rendered complex by undulation and side branches of the converging folds of cement, whence the name of the order:

The reptiles presenting the above characters have heen divided into genera, according to minor modifications exempli-

* Quarterly Journal of the Geological Society, vol. ix., 1853.

† American Journal of Science and Arts, March 1857. 
fied by the form and proportions of the skull, and by the relative position and size of the orbital, nasal, and temporal cavities.

Genus Baphetes, Ow.

Sp. Baplectes planiceps.-In January 185t the writer communicated to the Geological Society of London a description of part of a fossil cranium of an animal, from the Picton coal, Nora Scotia, measuring 7 inches across the orbit. From the characters then specified, the fossil was determined to be the fore part of a skull of a sauroid Batrachian of the extinct family of the Labyrinthodonts. It agreed with them in the number, size, and disposition of the teeth ; in the proportions and mode of comnection of the premaxillaries, maxillaries, nasals, prefrontals and frontals; and in the resultant peculiarly broad and depressed character of the skull, the bones of which also present the same well-marked external sculpturing as in the Labyrinthodonts: and amongst the genera that have been established in that family, the form of the end of the muzzle, or upper jaw, in the Pictou coal specimen, best accorded with that in the Capitosaurus and Metopias of Von Meyer and Burmeister. But the orbits had been evidently larger and of a different form than in the reptiles so called; and, for the convenience of distinction and reference, it was proposed to name the fossil Baphetes planiceps ( $\beta a$ arw, I dip or dive), in reference to the depth of its position and the shape of its head.

Being thus introduced at the carboniferous perind to the labyrinthodont order, which attained its full derelopment in the triassic period, the more decisive evidences and typical illustrations of that extinct group of reptiles will next be described.

Genus Labyrintiodon, Ow.

At the period of the deposition of the new red sandstome, in the present comnties of Warwick and Cheshire, the shores of the ancient sea, which were then formed hy that sandy 
deposit, were trodken by reptiles having the esisential bony. characters of the modern Butractia, lut combining these with other bony characters of crocodiles, lizards, and ganoid fishes; and exhibiting all under a bulk which, as made manifest by the fossils and footprints, rivalled that of the largest crocodiles of the present day. The form of the largest Labyrinthodonts, if we may judge by the great breadth and flatness of the skull, and the proportions of certain bones, seems to have been something between that of the toad or land-salamander.

The smooth-skinned Batrachians have no fixed type of external form like the existing higher orders of reptiles, but some, as the broad and flat-bodied toads and frogs, most resemble the Chelonians, especially the soft-skinnerl mud-tortoises (Trionyx); other Batrachians, as the C'ecilia, resemble Ophidians; a third group, as the newts and salamanders, represent the Lacertians ; and among the peremnibranchiate reptiles there are species (Sirca) which combine with external gills the mutilated condition of the apodal fishes.

Thus it will be perceived that, even if the entire skeleton of a Labyrinthodont had been obtained, there is no fixed or characteristic general outward form in the Batrachian order whereby its affinity to that group could have been determined. The common characters by which the Batrachians, so diversified in other respects, are naturally associated into one group or sub-class of reptiles, besides being taken from the condition of the circulating and generative systems, and other

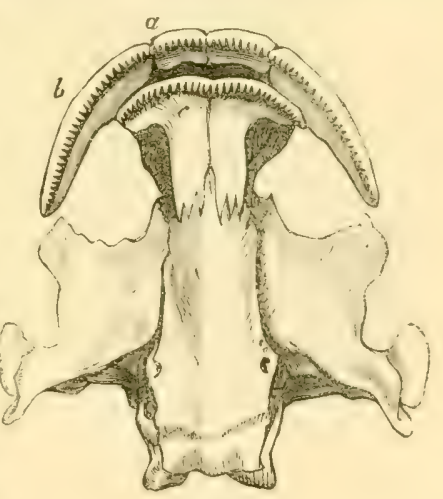

Fig. $65 a$.

Cranium and upper jaw and teeth of the Menopome (Menopoma alleghanniense). perishable parts, are manifested in morlifications of the skeleten, 
and principally m the skull. This is joined to the atlas by the medium of two tubereles, dereloped exclusively from the ex-occipitals ; the bony palate is formed chiefly by two hroad and flat bones (fig. 65 et, c), called "vonerine," and generally supporting teetl. It is only in the Batrachians among existing

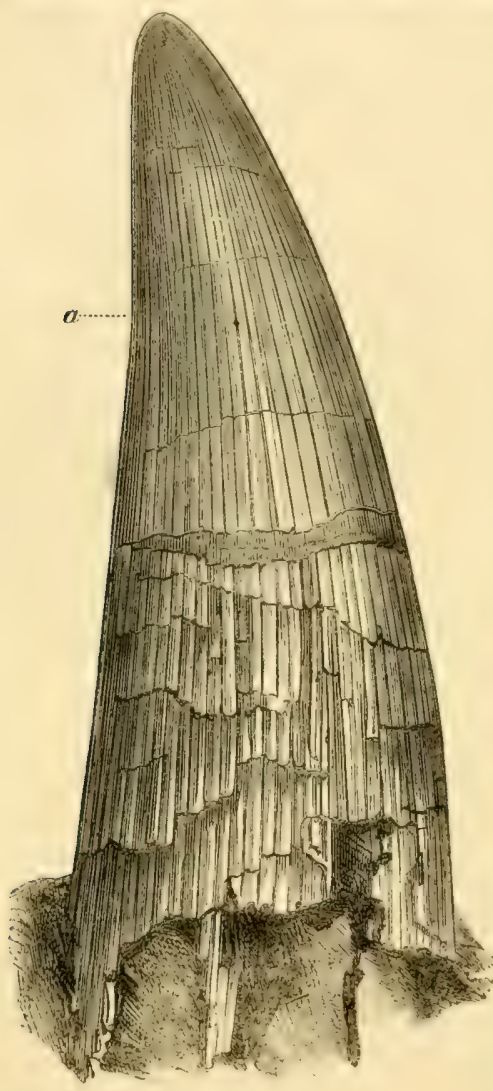

Fig. 66. reptiles that examples are found of two or more rows of teeth on the same bone, especially on the lower jaw (Cacilia, Siren). With regard to vertebral characters, no such absolute batrachian modifications can be adduced as those above cited from the anatomy of the cranium. Some Batrachians have the vertebræ united by ball-and-socket joints, as in most recent reptiles; others by biconcave joints, as in a few recent and most extinct Saurians. Some species have ribs, others want those appendages ; the possession of ribs, therefore, even if longer than those of the Cacilia, by a fossil reptile combining all the essential batrachian Canine tonth of the Lebyyrinthodon . Tugaeri (nat. size.)

characters of the skull, would not be sufficient ground for pronouncing such reptile to be a Saurian. Much less could its samian nature be pronounced from the circumstance of its possessing larere conical striaterl teeth : the ordi- 
nary characters of size, form, number, and eren of presence or alsence of teeth, vary much in existing Batrachians; and the location of teeth on the romerme bones is the only dental character in which they differ from all other orders of reptiles.

The witer's acquaintauce with the remarkable fossils under consideration was begun by the examination, in 1840, of portions of teeth from the new red sandstone of Coton End quarry, Warwickshire. The external characters of these teeth corresponded with those (fig. 66) which had previonsly been discorered by Professon Jaeger in the German Kenper formation in Wirtemberg, and on which the genus Mastodonscumes had been founded.

The results of a microscopic examination of the teeth of the Mastodonsaums from the German Kenper, and of those from the new red sandstone of Warwickshire, proved that the teeth from both localities possessed in common a very remarkable and complicated structure (fig. 67), to the principle of which, - viz., the convergence of numerous inflected folds of the extemal layer of cenent towards the pulp-cavity, - a very slight approach was made in the fang of the tooth of the Ichthynsaurus, whilst a closer aplroximation to the labyrinthic structure in question was made ly the tecth of several species of ganoid fishes, and by those of Archegosaums.

Thus, inasmuch as the extinct animals in question manifested in the intimate structure of their teeth an affinity to fishes, it might be expected that, if they actually belonged to the class of reptiles, the rest of their structure would manifest the characters of the lowest order,-viz., the Batrachia, the existing members of which pass, though not by the dental character alluded to, yet hy so many other remarkable degradations of structure, towards fishes.

In the same formation in Wirtemberg from which the lahyrinthic teeth of the so-called Mastodonsanmes had heen derived, a fragment of the posterior portion of the skull has heen obtained, 
showing the develupment of a sepratate comblyle on eateh exoccipital bone; whence I'rofessor Jaeger, recognizing the identity of this structure with the batrachian character above mentioned, founded upon the fossil a new genus of Batrutiun which he called "Salrmantroüles gigunteres." Subsequent discoveries, however, satisfied the Professor that the bi-condylous fragment of skull, representing the genus Salamantioides, belonged to the same reptile as the teeth on which he harl founded the genus Mastoctonsanms. The following fossils, from the new red sandstone of Wrarwickshire, gave additional proof of the batrachoid nature of the genus to which those

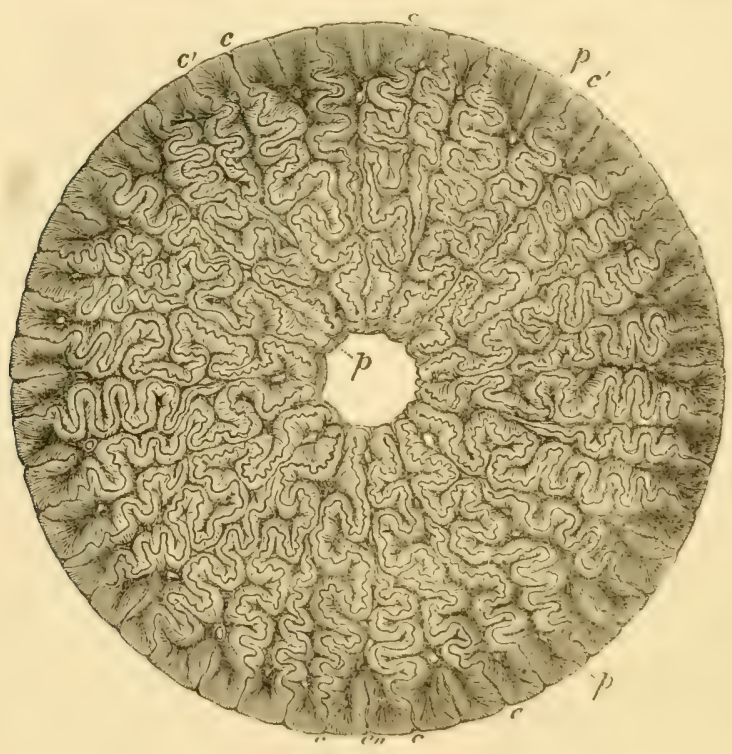

Iin. 67.

Transverse section of a tooth of the Labyrinthodon (magn.)

fossils belong, with the estallishment of tive distinet species, one of which is most probably identical with the Mastodensanmes salamantioules of I'rofessor Jaeger. In reference to the generic denomination Mastodensarens, it mavoidahly recalls the idea of the mammalian cemus. Mustoxtent, or clse a mam- 
milloid form of tooth, whereas all the teeth of the reptile so called are originally, and most of them are permanently, of a cuspidate and not of a manmilloid form; secoudly, because the second element of the worl, sanms, indicates the genus to lelong to the saurian or lacertian order of reptiles. For these reasons, the writer has proposed to designate the genus in question Labyrinthodon, in allusion to the peculiar and characteristic structure of the teeth (fig. 67).

The specinens from British lucalities are referable to five species-viz., 1. Latyyrinthodon salemandroüdes; 2. L. Leatognathes ; 3. L. pacheygnathes ; t. L. ventricosus; and 5. L. scutulutus; and we shall here briefly notice the characters exhibited by the bones assigmalile to the second, third, and fifth species.

Labyinthodon leptognathus.-The remains of this species consist of fragments of the uper and lower jaws, two vertebre, and a stermum. They were found in the new red sandstone quarries at Coton End near Warwick.

A dorsal vertebra from Coton End presents further evidence of the batrachian mature of the Lellyginthocton. It has concare articular cavities at the extremities of the borly,-a condition now known anong existing reptiles only in the Geckos, and in the lower or peremnibranchiate division of Batrachians. It is a common structure in extinct sampins, but the depth of the vertelnal articular carities in the Labyrintloctur exceeds that in the amphicolian Crocodiles and in most Plesiosaur's. The body of the vertebra is elongate and sulb-compressed, with a smooth but not regularly curved lateral surface, terminating below in a slightly-produced, longitudinal, median ridge ; and it exhilits the same exceptional condition in the rejtilian class as do the vertebra of existing Batrachians, in having the superior arch or nemapophysis anchylosed with the centrum. Fon each side of the hate of the nemul areh a thick and stromg

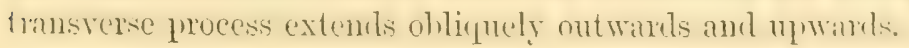


A symmetrical hone, resembling the episternmm of the $I c h$ thyoscurius was associaterl with the preceding remains. It consists of a stem or middle, which gradually thickens to the up per end, where cross piecs are given off at right angles to the stem, and support on each a pretty deep and wide groove indicating strongly the presence of clavicles, and thus pointing out another distinction from crocodiles, in which clavicles are wanting. Most Batrachians possess these bones.

The modifications of the jaws, and more especially those of the bony palate of the Labyrinthodon leptornathus, prove the fossil to have been essentially Batrachian, but with affinities to the higher Sauria, leading, in the form of skull and the sculpturing of the cranial bones, to the crocodilian group, in the collocation of the larger fangs at the anterior extremities of the jaws to the Plesioscuriss, and in one part of the dental structure, in the form of the epistermum, and the bi-concare vertebre, to the Ichthyosoums. Another marked peculiarity in this fossil is the anchylosis of the base of the teeth to clistinct and shallow sockets, by which it is made to resemble the Spliyriena and certain other fishes. From the absence of any trace of excaration at the inner sicle of the base of the functional teeth, or of al reoli of reserve for the successional teeth, it may be concluded that the teeth were reproduced, as in the lower Batrachians and in many fishes, in the soft mucous membrane which covered the alveolar margin, and that they subsequently became fixed to the bone by anchylosis, as in the pike and Lophius.

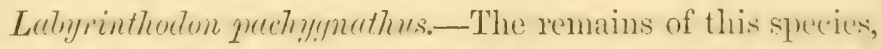
which have been obtained, consist of portions of the lower and mpere jaws, an anterior frontal hone, a flactured lumerus, an ilium with a great part of the aleetahulum, the head of a fimur, and two monal phalanges. A portion, nine and a half incles long, of a right ramus of a lower jaw, in addition to the characfers eommon to it and the fragment of the lower jaw of the 
L. leptognathus, in the structure of the angulatr and dentary pieces, shows that the outer wall of the alveolar process is not higher than the imer, as in frogs and toads, the salamanders and nenopome, in all of which the base of the teeth is anchyIoserl to the immer side of an external alveolar plate. The smaller serial teeth are about forty in number, and gradually diminish in size as they approach both ends, but chiefly so towarls the anterior part of the jaw. The sockets are close together, and the alternate ones are empty. The great laniary tecth were apparently three in each sympliysis, and the length of the largest was one inch and a half, The base of each tooth is anchylosed to the bottom of its socket, as in scomberoid and sauroid fishes; but the Labyrinthodon possesses a still more ichthyic character in the continuation of a row of small teeth anterior and external to the two or three larger tusks. The premaxillary bone presents the same peculiar modification as in the higher organized Batrachia, the palatal process of the premaxillary extending beyond the onter plate both externally and, though in a less degree, internally, where it forms part of the boundary of the anterior palatal formuen, whence the onter plate rises in the form of a compressed process from a longitudinal tract in the uper prort of the palatal process; it is here broken off near its margin, and the fractured surface gives the breadth of the base of the outer plate, stamping the fossil with a Batrachian character conspicuous above all the samian modifications by which the essential nature of the fossil appears at first sight to be masked.

In the pre-frontal bone there are indications of crocodilian structure. Its sulerior surface is slightly convex and pitted with irregular impressions ; and from its prosterior and outer part it sends downwards a broad and slightly concave process, which appears to be the anterior houndary of the orlhit. This process presents near its mper margin a deep pit, from which a groove is continued forwards: and in the eorresponding 
orbital plate of the crocodile there is a similar but smaller foramen.

From these remains of the cranium of the L. pachyynethes: it is evident that the facial or maxillary part of the skull was formed in the main after the crocodilian tyle, but with wellmarked batrachian modifications in the premaxillary and inferior maxillary bones. The most inportant fact which they show is, that this sauroid Batrachian had sulsterminal nostrils, leading to a wide and shallow masil cavity, separated by a broad and almost continuous palatal flooring from the cavity of the mouth; indicating, with their horizontal josition, that their posterior apertures were placed behind the? anterior or external nostrils, whereas in the air-lineathing Batrachia the masal meatus is short and rertical, and the internal apertures pierce the anterior part of the palate, suitable to their mode of breathing ly deglutition. It may he inferrecl, therefore, that the apparatus for breathing hy inspiration must have been present in the Labyrinthodon as in the crocodile: and that the skeleton of the Lathyinthodon will he found to the provided with well-developed costal ribs, and not, as in most of the existing Batrachians, with merely rudimentary styles. Since the essential condition of this defective state of the rils of Patrachians is well known to he their fish-like moke of generation and necessary distension of the abdomen, it is foblable that the generative economy of the Labyrintholunts. in which the more complete ribs womld prevent the exersive ('nlaterement of the ovaria and ovilucts, may have been sinilitr' to that of samian reptiles.

Of the few lones of the extremities which have come nuelere

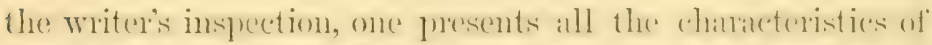

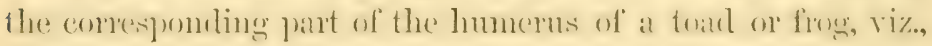
the comvex, somewhat transwersely extended anticulan end, the internal longitudinal de]nesione, and the well-developed del-

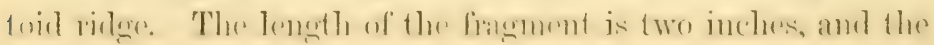


breadth is thirteen lines. The ridges are moderately thick and compact, with a central medullary cavity. In its structure, as well as in its general form, the present bone agrees with the batrachian, and differs from the crocodilian type.

In the right ilinm, about six inches in length, and in the acetabulum, there is a combination of crocolilian and batrachian chanacters. The acetabular cavity is boumded on its upper part by a produced and sharp ridge, as in the frog, and not emairyinate at its anterior part, as in the crocolile.

As the fragment of the ilium was discovered in the same hlock as the two fragnents of the eranium aud the portion of the lower jaws, it is probalile that they may have helonged to the same animal : and if so, as the portions of the head correspond in size with those of the head of a crocolile six or seren feet in length, but the acetahular carity with that of a crocodile twenty-five feet in length, then the hinder extrenities of the Labyrinthodun must have heen of disproportiomate magnitude compared with those of existing Saurians, but of approximate magnitude with some of the living anourous Batrachians. That such a reptile, of a size equal to that of the species whose remains have just heen described, existed at the period of the formation of the new red simlstone, is alomintantly manifester by the remains of those singular impressions to which the term Cheirotherium has been applied. ()ther impressions, as those of the Chcirotherinm Herentes, correspond in size with the remains of the Labyrinthodon sulemendivelles, which have heen discovered at Gruy's Cliff. The hearl of a femur from the same quarry in which the ilimn was found is shown to correspond in size with the articulate cavity of the acetalnulum. The two toe-lones, or terminal phatanges, resemble those of Patrachians in presenting no trace of a nail, and from their size they may he referred to the hind feet of the L. puechymathers.

An entire skull of the laresest species discoveresl in the

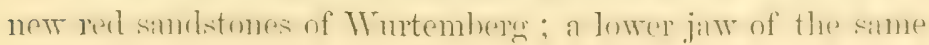


species found in the same formation in Wtarwickshire; some vertelore, and a few fiagments of bunes of the limbs, have served, with the indications of size and shaje of the trunle of the animal vieleded hy the series of consecutive footprints, as the hasis of the restoration of the Luthyinthuton selemendroüles, at the Crystal Palare. It is to he unclexstood, however, that, with the exeeption of the hent, the form of the animal is necessarily more or less conjectural.

Labyrinthodon scutulatus.-The remains to which this specific designation has heen applied compose a clusely and irregularly aggregated group of lumes imbedderl in sandistone, and manifestly belonging to the same slieleton; they consist of four vertelure, portions of rils, a humerus, a femur, two tibire, one end of a large flat home, and sereral suatl ussonts extermally seulptured dermal sentes, which show that the crocodilian nature of a fossil reptile is not deteminalile by scutes only. The mass was discorered in the new red sondstone at Leamington, and was transmitted to the writer in the stummer of 1840 .

The vertebre present bi-concave articular surfaces similar to those of the other species. In two of them the surfaces slope in a parallel direction oblipnely from the axis of the vertebre, as in the clorsal rertelnue of the frog, inclicating a habitual inflexion of the spine, anilogous to that in the humpred back of the frog. The nemapophyses are anchylosed to the rertelnal buly. The spinous process rises fim the whole? length of the midlde line of the nemalpoplyysial areh, and its chicef peculianity is the expansion of its elomeated summit into

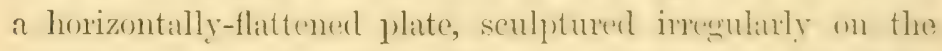
mplece surfice. A similar flattening of the summit of thes elomeater spine is exhilited in the latres atlats of the toad.

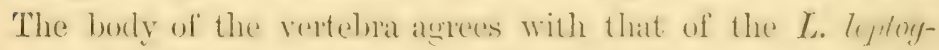

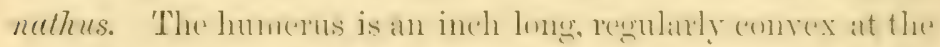
proximal extrenity, and expamiled at losth exterontios, hut 
contracted in the midlle. A portion of a somewhat shorter and flatter home is bent at a subacute angle with the distal extremity, and resembles most nearly the anchylosed radius and ulna of the Batrachia.

The femur wants both the extremities; its shaft is subtrihedral and slighily hent, and its walls are thin and compact, including a large metullary carity. The tibice exhibit that remarkable compression of their distal jortion which characterizes the comesponding hone in the Batrachia; they likewise have the longitudinal impression along the middle of the flattened surface. Were more of the skeleton of the abovedefined species of Lubyrinthodon known, they might present differences of subgeneric value. Such difierences in the forms and proportions of the skull, and in the form and relative position of the orbits, of specinens that have been discorered subsequenty in the triassic sinitstones of Gernany, have been so interpreted.

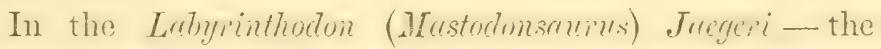
largest of the species-the skull is triangular, the two comlyles projecting from the mildde of the base : the sides are straight, and converge to the obtuse apex. The onbits are oral, narrowest anteriorly, and are situated nearly milway between the fore and hack part of the skull. The nostrils are very small, and are as wide apart as the orbits.

Latyyrinthorton (Trematosaurus) Bramii, Ton Meyer:The name Tiematosenres. was given by Braun to a labyrinthodont reptile, in reference to the marietal foramen, at that time deemed to be peculiar to it, but now linown to be common to all the family. The genus was founcler on an unusually perfect skull discovered in the richly fossiliferous huntersandstein of Bemlumg. It is about one foot long, and, relalively to its hasal breadth, it is longer and narrower than in L. Jetergit, the sides convergings at a more acute angle. The orhits are elliptieal, situated in the midule of the skull, amb 
wider apart than in $L$. Jargri; the nostrils are relatively nearer togethere, their intersace heing only loalf that in the $L$. Jacgeri:

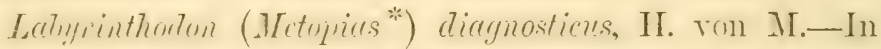
this species the sturll is hroaler in propertion to its length than in the formong; the siles are convex as they converge to the obtuse muzzle. The orbits are small, of a mide elliptical form, situated in the anterior thind of the skull; they are twiee as wile apart as are the nostrils. The parietal foramen is near the occipital rilge. The remains of this species are from the mper heds of the keuper sandstone in Wirtemberg.

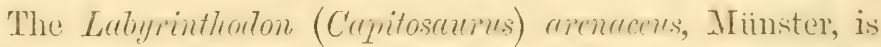
distinguished by a much bromler amd almost truncate muzzle. The orhits are elliptic, and situated almost wholly in the hinder thirel of the cranium ; their interspace is the salne as that hetween the nostrils, which are relatively as lange as in $L$. Braunii.

The name Zy,yosenrus aplear's to have been apllicel with better gromuls, by Eichwald, to a labyrintholumt reptile from the Permian cupriferoms beds at Orenlurge. It has the parabolic skull of $L$. Jaegeri and $L$. diagnosticus ; the orlits large, and divided hy an interval less than their own diameter. The temporal fossie are relatively larger, and hounded hy stronger zygomatic arehes, and seem not to have hren roofed orer hy bone. The dentition is strictly labyrinthodont.

Golonlessmens Voltail is a gemus and speries founderl hy

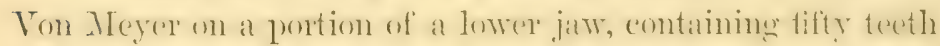

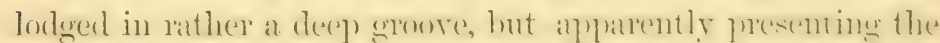

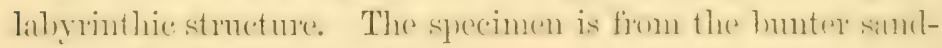
stone of Soultz-les-Bains.

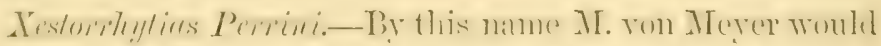

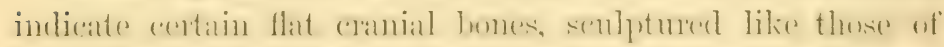

* This generic term has been applied to another fossil ly Kichwalt. 
Latyrinthodon, but with a peculiarly polished gamoid-like surface, from the muschelkalk of Lunéville.

In all the foregoing forms of Labyrinthodonts, renresented hy complete crania, with the exception perhaps of Zyyosaurus, the supplenental osserus plates roofing over the temporal fossit are lresent, as in Arehegosanpus, viz., the "post-orbital" and the "super-squanosal" bunes. In all of then the occipital conclyles are distinct, forming a pair ; and in atl the vomer is divided and bears teeth. The structure and disposition of the entire dental system is strictly labyrinthodont.

The relation of these remarkable reptiles to the samian order has been adrocated to be one of close and true attinity, chicfly on the character of the extent of ossification of the skull, and of the ontward senlyturing of the cranial bones. But the true nature of some of thewe homes alpears to have been overlooked, and the glance of research fir amalogous structures has been too exclusirely upward. If directed clownward from the Labyrinthodonts to the Ad rchyosenri and certain ganoid fishes, it suggests other conclusions.

The conformity of patteru in the dermail, semidermal, or nemolermal bones of the outwardly well-ositied stiull of Polynterus, Lepridusteus, Sturio, and other salamandroil-gimoid fishes, with well-eleveloped lung-like air-blitders, and of the same skull-bones in the Adeheyosentres and the Labrinthodonts; the persistence of the notochord (chorder clorselis) in Areteryosenter, as in Strito; the persistence of the notochord and branchial arches in A ichegoranins, as in Lequidusiren; the absence of oceipital condyle or condyles in Archergoserure, ats in Lepidositen; the presence of lahyrinthic teeth in Archeyosuurus, as in Leprilosteus and Labyrinthodon; the large median and lateral throat-plates in Arehegosenures, as in Mcyulichthys, amd in the modern Arapaime and Lejridusices; -all these chanacters proint fo one great natural groupe perouliar for the

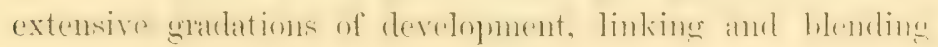


together fishes and reptiles within the linits of such group. The salamandroir (or so-cilled "siluroid") Crannids-Lepidosteus and Polyptorns - are the most ichthyoid, the true Labyrinthodonts are the most simuroid, of the group. The Lepidusinn and Archouscumes are intermediate gradations, one hatring nore of the piscine, the other more of the reptilian characters. The Archeyosenus conducts the march of development from the fish proper to the labyrinthodont type; the Leprilosircu conducts it to the peremilsranchiate batrachian type. Both illustrate the artificiality of the supposed class distinction between fishes and reptiles, and the maturality of the "Hrematocrya," or cold-hlooded Vertehrata, as the one unbroken progressive series. There is nothing in the known structure of the so-named dicheyosan, us or Mastodonsanrus that truly indicates a belonging to the sumian or crocodilian order of reptiles. The exterior ossifications of the skull and the canine-shaped labyrinthic tecth are Toth exampless of the salamandroid modification of the ganoid type of fishes.

The small proportion of the fore limb of the Mystriosoumes in nowise illustrates this alleged sauriun afinity ; for though it be as short as in Areheyosenrux, it is as perfectly constructed as in the crocodile, whereas the short fore limb of Archegosurmes is constructed after the simple type of that of the Proteus and Siren. But the futility of this argument of the samroid affinities is made manifest by the proportions of the hind limb of Adetergosenters. As in Proteus and Amghiuma, it is as stunted as the fore limb: whereas in Mystriosaurus, as in other Telensaurians, the hind limhs are relatively larger and stronger than in the existing crocodiles.

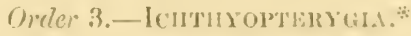

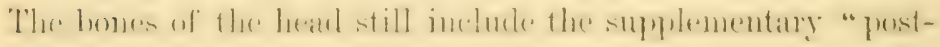
orhitals" and "supra-temporals," but there are small

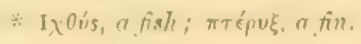


temporal and other racuities between the cranial bones: a "foramen parietale," a single convex occipital condyle, and one vomer which is edentulous. Two antorbital nostrils. T'ertebral centra, ossifiecl, biconcave. Pleurapophyses of the trunk long and hent, the anterior ones with bifurcate heads. Teeth with converging folds of cement at their base; implanted in a common alveolar groove, and confined to the maxillary, premaxillary, and premandibulin bones. Premaxillaries much exceeding the maxillaries in size. Orbit very large; a circle of sclerotic plates. Limbs natatory; with more than five multi-articulate digits; no sacrum. With the retention of characters which indicate, as in the preceding orders, an affinity to the higher Ginoil fishes, the present exclusively marine Reptilia more directly exemplify the ichthyic type in the proportions of the premaxillary and maxillary bones, in the shortness and great number of the biconcave vertebræ, in the length of the pleurapophyses of the vertebru near the head, in the large proportional size of the eyeball and its well-ossified sclerotic coat, and especially in the structure of the pectoral and ventral fins.

It has been usual to unite the present with the following order in the sane group, called Enaliosanitu or sea-lizards. They were adapted for marine life, but breathen the air like the Cetacea : they wcre, howerer, "cold-blooded," or of a low temperature, like crocodiles and other reptiles. The proof that the Enalinsaurs respired atmospheric air immediately, and did not breathe water by means of gills like fishes, is afforded by the absence of the bony framework of the gill apparatus, and by the presence, position, and structure of the air-passages leading from the nostrils to the mouth, and also hy the homy merhanism of the capacions chest or thoracic- 
abdoninal cavity ; all of which chatracters have been demonstrated by their fussil sheletons. With these characters the sea-lizards combined the prenence of two pairs of limbs shaped like fins, and adapted for swimming.

The group of reptiles so termert includes all those which have any lart of the thoracic-abdominal cavity eneompassed by moveable rils. The first character distinguishes them from the Butrachice and Chelonia with fin-shaped limbs.

The Enatiosauria, however, do mot form a strictly natural group ; for this is based upon a single character reating to merely the medium of life and locomotion. Sinne of the labyrinthodont reptiles may have had their linnls in structure and shape as paddles; but more important modifications of structure would keej) them apart, like the lower Butruchiu. and the Chelonia, from the more lizard-like reptiles culled Enaliosauria.

In this group there are two divisions, -one characterized by having five digits in the fin, the other by having more than that typical number. The pentadactyle division may be sub-divided into those in which the ilio-pubie arch is attached to a sacrum and those on which it is freely suspended or not so attached. The polydactyle division presents a general type of structure more conformable with that of which the Arehegosaurs and Labyrinthodonts manifest two fliases of development, and in which the ascent from the gamo-salaminchoid fishes reaches its culninating point in Ichthyosaums.

Genus Icirmyosaurus.-The name (from the Greek ichthys, a fish, and seeness, a lizard) was devised to indieate the closer affinity of the Ichthyosam, as emmpared with the Plesiusalur, 10 the (riss of fishes. The Rehthyosame (lige (is) is remarkable for the shortness of the neck and the erpality of the wielth of the hatek of the lesed with the flent of the chest,

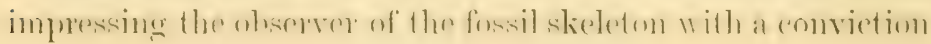


that the ancient amimal must have resembled the whale tribe and the fishes, in the absence of any intervening constriction or neck.

This close approximation in the Ichthyosaurs to the form of the most strictly aquatic vertebrate animals of the existing creation, is accompanied by an important modification of the surfaces forming the joints of the back-bone, each of which surfaces are hollow, leading to the inference that they were originally connected together by an elastic bag or "capsule" filled with fluid-a structure which prevails in the class of fishes, in the Labyrinthodonts and a few extinct aquatic reptiles, in the existing perennibranchiate Batrachia, but not in any of the whale or porpoise tribe.

With the above modifications of the head, trunk, and limbs, in relation to swimming, there co-exist . corresponding modifications of the tail. The bones of this part are much more numerous than in the Plesiosaurs, and the entire tail is consequently longer; but it does not show any of those

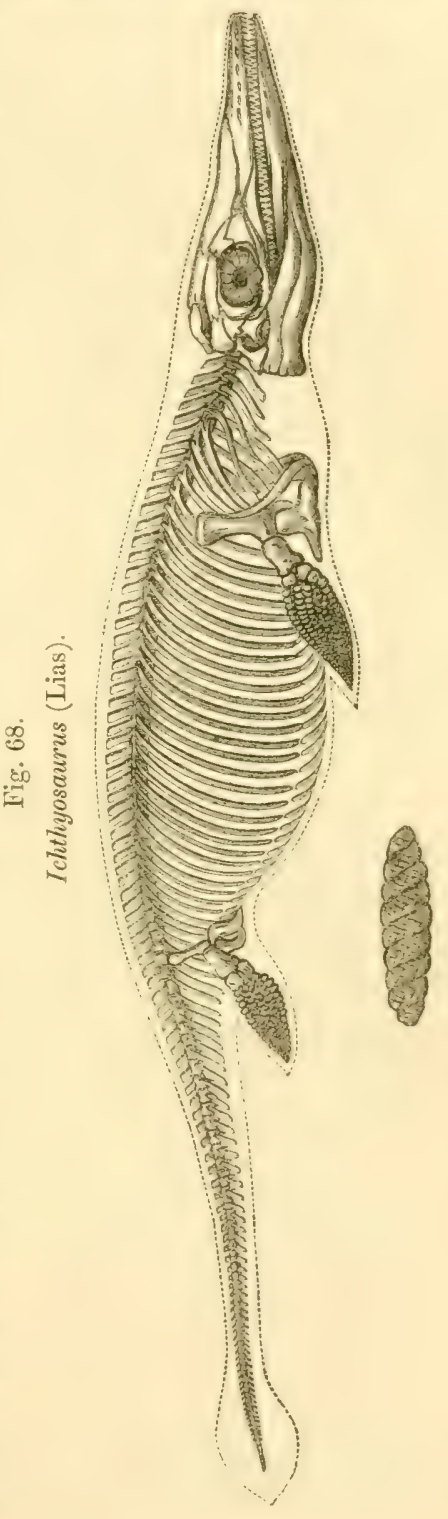


modifications that characterize the hony support of the tail fin in fishes. The numerous caudial rertelore of the Ichthyoseurus, gradually decrease in size to the end of the tail, where they assume a compressed form, or are flattened from side to side, and thus the tail, instead of being short and broad as in fishes, is lengthened out as in crocodiles.

The very frequent occurrence of a fracture of the tail, about one-fourth of the way from its extremity, in well preserved and entire fossil skeletons, is owing to that proportion of the end of the tail having supported a cutaneous and perishable caudal fin.* The only evidence which the fossil skeleton of a whale would yield of the powerful horizuntal tail-fin characteristic of the living animal, is the depressed or horizontally-flattened form of the bones supjorting such fin. It is infered, therefore, from the corresponding bones of the Ichthyosumrs being flattened in the rertical direction, or from sicle to side, that it jossessed a tegumentary tail fin expanded in the rertical direction. The shape of a fin composed of such perishable material is of course conjectural, as is the outline in fig. 6s. Thus, in the construction of the principal swimming organ of the Ichthyosturus we may trace, as in other parts of its structure, a combination of mammalian (beast-likic), saurian (lizardlike), and piscine (fish-like) peculiarities. In the great length and gradual diminution of the tail we pereeive its samrian character: in the termmentary nature of the fin, nusustained by bony fin-rays, its aflinity to the same part in the manmalian whales and porpoises is shown: whilst its rertical position makes it chesely rescunble the tail fin of the fish.

The horizontality of the tail fin of the whate tribe is essenbally connected with their necessities ats warm-lolouded animals beathing atmospllerie air: withut this means of displacing a mass of water in the rertical direction, the lecard of the whale

* Trans, Feol. Soc, 2 d sovies, vol. v., p. 511. 
could not be bromght with the required rapiclity to the surface to respire; but the Ichthyosaurs, not being warm-blooded or quick breathers, would not need to bring their head to the surface so frequently or so rapidly as the whale; and moreover, a compensation for the want of horizontality of their tail fin was provided by the addition of a pair of hind paddles, which are not present in the whale tribe. The rertical fin was a more efficient organ in the rapid cleaving of the liquid element, when the Ichthyosaurs were in pursuit of their prey, or escaping from an enemy.

The general form of the cranimu of the Ichthyoscurns resembles that of the ordinary cetaceous dolphin (Dctphinus tursio); but the I. tenuirostris rivals the Delphinus gangeticus in the length and slenderness of the jaws. The essential difference in the sea-reptile lies in the restricted size of the cerelsal cavity, and the rast depth and breacth of the zygomatic arches, to which the seeming expanse of the cranium is due; still more in the persistent indiriduality of the elements of those cranial bones which have been blended into single though compound hones in the sca-manmal. The Ichthyoscurus further differs in the great size of the premaxillary, and small size of the maxillary lones, in the lateral aspects of the nostrils, in the immense size of the orbits, and in the linge and numerous sclerotic plates, which latter structures give to the slinll of the Ichthyosaurus its most striking features.

The true affinities of the Iehthyosam are, however, to he elucidated by a deeper and more detailed comparison of the structure of the skull; and few collections now afford richer materials for pursuing and illustrating such comparisons than the patieontological series in the British MInsemu* The two smplemental homes of the skull, which have no homologues

* The anatomical reader is referred to the writer's "Report on British Fossil Reptiles," Trans Brit. Assoc. 1839, and to the Anrals and Magazine of Natural History, $1858, \mathrm{n} .388$. 
in existing Crocodilians, are the post-orbital and supersquamosal ; both, howerer', are dereloped in Archeyoscums and the Labyrinthodonts. The post-orbital is the homologue of the inferior division of the post-frontal in those Lacertians - ¿.g., Iyuana, Tejus, Ophisanrus, Anguis, in which that bone: is said to be divided. But in Ichthyosourus the post-ortbital resembles most a dismemberment of the malar. Its thin obtuse scale-like lower end overlajs and joins by a squanous suture the hind end of the malar : the post-orloital expands as it ascends to the middle of the back of the orthit, then gradually contracts to a point as it curves upward and forward, articulating with the super-squamosal and post-frontal. The supersquamosal may be in like mamner regarded as a dismenberment of the squamosal; were it confluent therewith, the resemblance which the bone would present to the zygomatic and squamosal parts of the mammalian temporal would be rery close; only the squamosal part would be removed from the imer wall to the outer wall of the temporal fossa. The super-squamosal, in fact, occupies the position of the temporal fascia in Mammuliu, and should be regarded as a supplemental sclero-dermal plate, closing the racuity between the upper and lower elements of the zygomatic areh, peeuliar to certain airbreathing Oizpure. In the Ichthyoscumes it is a broad, thin, flat, irregular-shaped plate, smooth and slightly convex externally, and wedged into the interspaces between the post-firontal, post-orbital, squamosal, tympanic, and mastoid.

The principal vacuities or apertures in the bony walls of the skull of the Idhthyoscaress ate the following:- In the posterior region the "foranen nuagnmm," the oceipito-prarictal vacuities, and the auditory passigese : on the nplere surfiace the parietal foramen and the temponal fossio ; on the laterat surfaces the orthits and nostrils, the plane of the aperture in both heing vertieal ; on the inferior surface the palato-nasal,

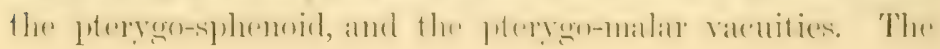


occipito-parietal vacuities are larger than in Crococtitio, smaller. than in Lacertilia; they are bounded internally by the basi-, ex-, and super-oceipitals, externally by the parietal and mastoir. The auditory apertures are bumded hy the tympanic and spuamosal. The tympanic takes a greater share in the formation of the "meatus auditrius" in many lizards; in crocodiles it is restricter to that which it takes in Ichthyosonmes.

The orlit is most remarkable in the Ichthyoscumes, amongst reptiles, hoth for its large proportional size and its posterior position; in the former character it resembles that in the lizards, in the latter that in the crocodiles. It is formed by the pre- and post-froutals above, by the lacrymal in front, by the post-orloital behind, and hy the peculiar long and slender malar bar below. In crocodiles and in most lizards the frontal enters into the formation of the orbits, and in lizards the maxillary also. The nostril is a longish triangular aperture, with the narow base hehind; it is bounded by the lacrymal, nasal, maxillary, and premaxillary hones. It is proportionally larger than in the Plesiosmmes, and is distant from the orbit about half its own lomg diameter. Like the orlit, the plane of its outlet is vertical.

The pterrgo-palatine racuities are very long and narrow, broadest behind, where they are boumled, as in lizards, by the anterior concarities of the hasi-sphenoid, and gradually narrowing to a proint close to the pratine nostrils. These are smaller than in most lizards, and are cireminseribed by the pralatines, ectropterygoid, maxillary, and premaxillary. The pterygomalar fissures are the lower outlets of the temporal fossie; their sudken posterior breadth, due to the emarevination of the pterygoirl, relates to the passage of the muscles for attachment to the lower jaw. The parietal foramen is bounded by both prrietals and frontals ; its presenee is a mark of lahyrintlondont aml lacertian affinities; its formation is like that in Iymun

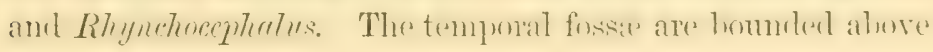


by the parietal intermally, hy the mastoid and post-frontal extemally; they are of an oral form, with the great end forward. In their relative size and backward position they are more crocodilian than lacertian.

In the Reththyosenmes communis there are seventeen selorotic plates forming the fore part of the eyeloall. In a well-preserved example, the pupillary or corneal vacuity, as bounded by those plates, is of a full oval form, $1 \frac{1}{2}$ inch in long diameter, the length of the plates (or breadth of the frame) heing from 8 to 10 lines. In the same skull the long diameter of the orbit is 4 inches. The deep position of the sclerotic circle in this cavity showed how they had sunk, by pressure of the extemal mud, as the eyeball became collapsed by escape of the humours in decomposition.

Whenever the antecentent forms of an extinct gemus of any class are known, the character's of such genus should be compared with those of its predecessors in such class, rather than with its successors or with existing forms, in orter to gitin an insight into its true affinities.

We derive a truer conception of the affinities of the Ictuthyosumpus hy comparisun with the Labyrinthorlonts and other triassic reptiles, as we do of the Plesiosenrus by comparison with the muschelkalk Sintopterygue, than of either by comparison with modern Lacertians and Crocodiliams. It is commonly sitid that the Tehthyo- or the Plisio-scurrus rescemliles more the lizards in such and such characters, and in a less degree the crocodiles, as in such a character. The truer expression would be that the lizands, which ane the prednminating forme of Saurians at the present dicy, latre? retained more of the osteolongent type of the triassice and onlitic reptiles, and that the coecoliles deviate further firm then or exhibit a more morilied or specialized strueture. The posterion position of the nostrils, the small size and position of the

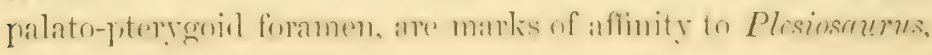


in common with which genus the cranial structure of the Ichthyosenerus exhibits a majurity of lineertium character's.

In comparing the jaws of the Ichthyoscurus tenuirustris with those of the gangetic ('harrial, an equal degree of strength and of alveolar borker for teeth result from two very difierent proportions in which the maxillary and premaxillary hones are combined together to form the mper jaw. The prolungation of the snout has evilently no relation to this difference; and we are acordingly lex to look for some other explanation of the disproportionate development of the premaxillaries in the Ichthyosurus. It appears to me to give additional proof of the collective tendency of the altinities of the Ichthyosaums to the lacertian tyle of structure. The backwart or antorlital position of the nostrils, like that in whales, is related to their marine existence. But in the Lacertians in which the nostrils extend to the fore part of the head, their anterior homularies are formed by the premaxillaries: it appear's, therefore, to be in conformity with the lacertian affinities of the Ichthyosaur that the premaxillaries shunld still enter into the sinne relation with the nostrils, although this involves an extent of anterior development proportionate to the length of the jaws the forward production of which sharp-toothed instrunents fitted them, as in the modern dolphins, for the prehension of agile fishes.

That the Ichthyosaurs occasionally sought the shores, crawled on the strand, and basked in the sunshine may be inferred from the bony structure comnected with their fore fins, which does not exist in any porpoise, dolphin, grampus, and whale; and for want of which, chictly, those wam-bluoched, air-breathing, marne auinals are so helpless when left high and dry on the sands. The structure in question in the Ichthyosaur is a strong osseous arch, inverted and spamming across heneath the chest from one shoulder-joint to the other: and what is most remarkalile in the structume of this "scupular" 
arch is, that it closely rescmbles, in the number, shaje, and disposition of its bones, the same part in the singnlar aquatic: mammalian quadruped of Australia, called Ornithorynches, and Plotypus, or duck-mole. The Ichthyosaur, when so visiting the shore either for sleep or procreation, would lie or crawl prostrate, or with its belly resting or dragging on the ground.

The most extraodinary feature of the heal was the enormous magnitude of the eye: and from the quantity of light admitted by the expanded pupil, it must have possessed great powers of vision, especially in the dusk. It is not nueommon to find in front of the orbit in fossil skinlls, a circular series of petrified thin bony plates, ranged round a central aperture, where the pupil of the "ye was placel. The eyes of many fishes are defended by a bony covering consisting of two pieces ; but a compound circle of overlapping plates is now fomel only in the eyes of turtles, tortoises, lizards, and hirds. This curious apparatus of bony plates would air in protecting the eye-hall from the wares of the sea when the Ichthyosentis.s rose to the surface, and from the pressure of the dense element when it dived to great depths; and they show, writes Dr. Buckland (Bridgeuenter Treatise), "that the enomous eye of which they formed the front, was an optical instrument of varied and prodigions power, enathling the Ichthyostenters to desery its prey at great or little distanees, in the olsenrity of night, and in the depths of the sea."

of no extinct species are the materials for a complete anil exact restoration more ahumelant and satisfietery than of the

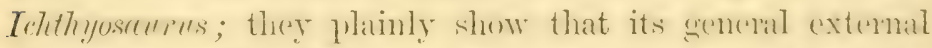

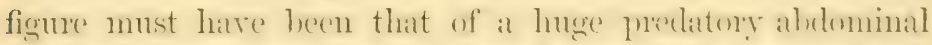
fish, with a longer tail and a smatler tail fin: scalleless, moreorer, and covered ly a smouth or fincly wrinklexl skin, analogous to that of the whale tribe.

The month was wide, ambl the jaws lenes and armed with 
numerous pointed teeth, indicative of a predatory and carnivorous nature in all the species; but these differed from one another in regard to the relative strength of the jaws, and the relative size and length of the teeth.

Masses of masticated bones and scales of extinct fishes, that lived in the same seas and at the same period as the Ichthyoscums, have been found under the ribs of fossil specimens, in the situation where the stomach of the animal was placed ; smaller, harder, and more digested masses, containing also fish-bones and scales, have been found, bearing the impression of the structure of the internal surface of the intestine of the great predatory sea-lizard. One of these "coprolites" is figured beneath the skeleton in fig. 68 .

In tracing the evidences of creative power from the earlier to the later formations of the earth's crust, remains of the Ichthyosaurus are first found in the lower lias, and occur more or less abundantly through all the superincumbent secondary strata up to, and inclusive of, the chalk formations. They are most numerous in the lias and oolite, and the largest and most characteristic species have been found in these formations.

More than thirty species of Ichthyoscumus are known to the writer, many of which have been described or defined.

\section{Order 4.-Sauropterygia.*}

No post-orbital and supra-temporal bones: large temporal and other vacuities between certain cranial bones; a foramen parietale ; two antorbital nostrils ; teeth simple, in distinct sockets of premaxillary, maxillary, and premandibular bones, rarely on the palatine or pterygoid bones; maxillaries larger than premaxillaries. Limbs natatory; not more than five digits. A sacrum of one or two vertebrie for the attachment of the pelvic arch in some, numerous cervical vertebre in most. Pleura-

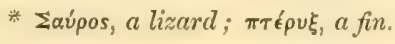




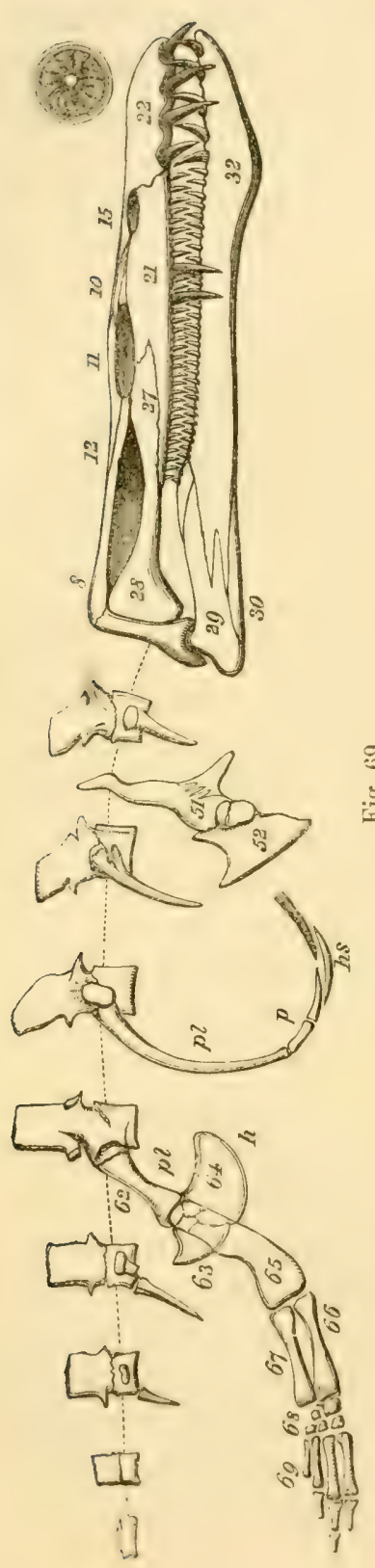

pophyses with simple heads; those of the trunk long and bent.

Genus Nothosaurus, Münster.

Sp. Nothosaurus mirabilis, Münster.-In fig. 69 is given an analysis of the chief characters as yet ascertained of the species which may be regarded as the type of its family; by comparing this diagram with that of the Archegosaums (fig. $\therefore 65)$, the advance in the organization of the aquatic reptiles : :

The skull is no longer defended by a continuous covering of sculptured plate-bones; the vacuities behind the orbits for the temporal muscles are large and widely open. These vacuities are fenced externally by two long and slender horizontal bony bars; the upper one is formed by the mastoid (fig. 69, $8)$, and the post-frontal ( $x 2$ ) ; the lower one by the malar (27), and squamosal (28); the latter answering to the true zygomatic arch in Mammals. The squamosal abuts by its hinder: ex- 
panded end against the almost vertical tympanic pedicle, which gives attachment to the lower jaw. This shows the reptilian compound structure: 29 marks the surangular clement, 30 the angular one, 32 the dentary. In the side-view of the skull in fig. 69,22 is the premaxillary, 21 the maxillary, I5 the nasal-the carity below being the nostril, ro is the prefrontal-between which aud $2 x$ is the lacrymal, 1 the frontal above the orbit. The premaxillary teeth and corresponding premandibular ones are musually long, strong, and sharp; there are two similar teeth in each maxillary; the remaining serial teeth are smaller, but equally acute. There are no teeth on the palate.

The almost entire and undisturbed rertebral columm, from the muschelkalk of Bayrenth, figured by Tron Meyer in pl. 23 of his work on muschelkalk Samians, and attributed by him to Nothosaums mirabilis, gives the earliest indication of that modification of the trunk-bones which reaches its maximum in the Plesioscums (fig. 71), in which it was first detected ly the sagacity of Conybeare.*

Twenty of the anterior vertebre of this series, in Nothoscurus, which begins with the atlas, have the whole or part of the rib-pit situated on the centrum as in the first vertebra in fig. 69 ; the $p^{\text {it }}$ is wholly there on foruteen vertebre ; it legins to ascend upon the nemral areh in the fifteenth, as in the second vertebra, given in fig. 69 , and is wholly placed there on the twenty-first vertebra.

According, therefore, to the characters by which the writer has proposedt to distinguish the cervical from the dorsal rertebrie, Nothosamins has twenty of the former. In the specimen referred to, nineteen consecutive rertelure show the rib-pit supported wholly on an outstanding diapoplyysis from the neural arch, as in the third rertebra in fig. 69 ; these? are

* Trans. Geol. Soc., vol. vi., 1822, and vol. i., 2d series, p. 381, 1824.

† Report of British Fossil Reptiles, 1839, pp. 50, 58. 
tu be reckoned therefore as dorsal vertebrie. In the cervical vertebra the rib-pit is large, vertically reniform, not divided by a groove; its circumference slightly projects in Nothosaurus.

There is no clear evidence of any of the cervical ribs being terminally expanded and hatchet-shaped, as in Plesiosaurus; those of the back are vertically longer than in Plcsiosaums, and more convex.

In the sacral vertebre, fourth in fig. 69 , the rib-pits again begin to sink upon the centrum.

There are two distinct sacral vertebre in Nothosanisus. They are known by their long, straight, terminally-bent, and convergent pleurapophyses, the first of which overlaps a little the second. To the convergent ends of these riblets, the ilimm (fig. 69, 6z, pl) was doubtless ligamentously aflixed. In the first caudal vertebra the par-and di-apophyses stand out much farther than in the sacrum; lout rapidly shorten in the second and third caudals. The compound process in each supports a short stiliform straight riblet, as in the fifth figured vertebra (fig. 69) ; the anterior and succeeding caudals support hiomal arches and spines, after the disappearance of the pleurapophyses. The hremal arch disappears in about the eighth vertebra from the end, and finally the neural arch. The terminal centrums are subelongate and subcompressed. Both Nothoseneres and Pistoscumes had abdominal ribs, of which the median piece (fig. (69, 7.s) was subsymmetrical, the two rays diverging at a very open angle, and terminating in a point or a fork; the side-picess $\left(y^{\prime}\right)$ seem not to have heen so mumerous as in Plesiosaums.

The scapula (fig. 69 ), 5r) is a short and strong bone, its blade appearing as a short and narrow sub-compressed process extending from the subquadrate, thick and expanded end which affords the articular surfaces for the coracoid, clavicle, and humerus. 
The clavicle, which is an exogenous process in Plesiosuurus, is here united by a strong oblique suture to the scapula. It expands into, or sends off from its outer part, a broad, flat, obtuse process, near the suture; then contracts and bends inwards to the episternum, to which it is articulated also by suture.

The coracoid (fig. 69, 52 ) sends forward a broad and short flattened process, separated by a narrow notch from the scapular part of its head; it then contracts and soon expands into a broad, flat, sub-triangular plate, the broad and straight border of which articulates with that of the opposite coracoid. A wide unossified interval separates the coracoid from the episternum. The ossification of the coracoid in the direction of this interval gives the peculiar longitudinal or fore-and-aft extent to those bones in the Plesiosaur, in which they unite with the episternum.

The pelvic arch presents a closer correspondence with that in the Plesioscurnes (fig. 71). The ischium (fig. 69, 63), contracting beyond its articular head, there expands into a flat subtriangular plate. The pubis (fig. 69,64 ) is a subeireular flat bone, with a notch near the articular end.

The bones of the limbs, although evidently those of fins or paddle-shaped extremities, are better leveloped than in Plesiosaurus, and more resemble the corresponding bones in the turtle (Chclones). The tuberosities or processes for muscular attachment near the head of the humerus (omitted in the diagram) are better marked, especially that on the concave side of the shatt ; the distal end is thicker and less expanded. The whole bone is more curved than in any Plesiosentri. The femur (fig. 69,65 ) is relatively longer and less expanded at its distal end. The bones of the fore arm, like those of the leg (ib. 66 and 67), are longer than in Plesioscurrus. The articular surfaces present the foramina with raised borders, which characterize those in Plesiosan'i, and whish indicate the filmocartilaginous nature of the joints. 
There is a ligamentous or unossified space at the back part of both carpus and tarsus (fig. 69,68). At present there is evidence of but four digits in both the fore and hind paddles of Nothoscurnes; the metapodial and phalangeal bones are of the clongate flattened simple form, characteristic of supports of a tegumentary fin.

One species of Tothosenus (T. Schimperi, Ton. .1I.) is fiom the lower division of the trias, called "grès bizarée" of Soulzles-Bains; the other representatives of the genus ( 1 . gigunters, $N$. venustus, N. Münsteri, $N$. Anctriani, $N$. angustifrons, and $N$. mirctitis), are from the muschelkalk of Bayreuth and Luneville.

Genus Pistosaurus, Von Meyer.

Sp. Pistoscurrus longereus. - In this genus the facial part of the skull contracts abruptly in frout of the orloits; so that, viewed from above, it resembles a long-necked bottle; the orbits are situated in the posterior half of the skull, and the nostrils are lateral. From the muschellalk of Bayrenth.

Genus Conchiosaurus, Von Meyer.

Sp. Conchioscumes clavatus.-The facial part of the skull is less prolonged than in Pistoscurus, and the nostrils are terminal. The teeth are twelve in number on each side, are subequal, with a pyriform crown, and are placed at widish intervals. From the muschelkalle at Laineck, near Bayrenth.

Genus Simosaurus, * Von Meyer.

sp. Simosaurus Gaillardoti.-The fossils, chiefly cranial, on which this genus is founderl, ocenr in the dolonitic muschelkatk near Ludwigsherg, and in the muschelkalk of Luneville. The skull presents the large temporal fossie, the divided nostrils, and the general depresied form and compo-

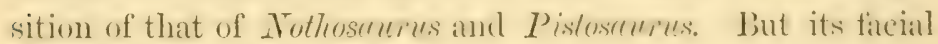
part is mueh shorter; the muzzle is nevither prolomged nor terminally cexpanted, but forms the ohtuse eme of the short

* Einos, snub-noserl, flat-nose. 
depressed face, of which the premaxillary part is the narrowest. The nostrils, consequently, although distant from the orbits by half the diameter of the latter, are yet nearer the fore end of the skull than in the above-cited Sauropterygian genera. The nostrils are relatively nearer to each other, the intervening bony tract being due to the premaxillaries, which, relatively to the breadth of the skull, are much narrower in Simosaums than in Notho- or Pisto-saurus.

The profile of the skull rises from the internasal to the interorbital regions much more than in the Nothosaur, and the depth of the skull behind the orbit is greater in proportion to its length. The post-froutals are most clearly produced backwards, along the upper border of the zygoma to the mastoids. The malars are co-extended, and commected with the post-frontals, but terminate freely and obtusely a little beyond the co-prolonged hind prart of the maxillary, without being met by or joining a squamosal.

Most complete and extensive is the ossification of the roof of the mouth in this genus. The pterygoids are expanded into one broad umbroken imperforate flat expanse of bone, from about one-thirl of the distance from the snout to the occipital condyle; they are united by a median suture, and milerlap the whole of the sphenoid. The teeth, compared with Sothosaums, are few and large, and are subequal, save one or two at the fore and hind extrenity of the series. The crown expands a little above the fing, is conical, sub-bifurcate, and impressed by a few coarse longitudinal ridges: some are obtuse, others acute; but all are shorter and thicker than in Notho- or Pisto-saurus.

The vertebrie have fiat or very slightly concave articular surfaces on the body; the neural arch articulates therewith hy suture. In these characters, and in their general proportions, they resemble those of Totho- and Plesin-smurus. It is significant of some rlifferenen in respeet of the artangement of 
the vertebre in the sime column, that although specimens from the tail, and from different parts of the back, hare been obtained, no cervical vertebra with any probability belonging to this genus has yet been found. The caudal centrum presents two well-defined, rather prominent, hypapophyses for the hæmal arch.

The coracoid in the contraction of the body reminded Curier of that of the Ichthyosaurus, but its expanded median part was differently shaped. The pubis, like that of the Plesioscurus, resembles to a certain degree the pubis in Chclonia. The few bones of the limbs which have been found still more resemble, as do those of Pistosanmes, the corresponding bones of marine Chclonia. Accordingly, there have been entered in palieontological catalogues an Ichthyosaumes Luncitllensis (De la Beche), a Plesiosauns Luncrillensis (Mïnster), and a Chelonia Lunerillensis (Gray and Keferstein) ; lut all these are parts of one and the same gemus of Enaliosaurian, the "Siaurien des environs de Lunéville" of Cuvier, the "Simosaurus" of H. von Neyer.

Genus Placodus.-The cranial structure in this genus of muschellialk reptile is closely similar to that in Simoscurus, but its proportions are different; it is as broad as long; the greatest breadth being behind, whence the sides converge to an obtuse muzzle; the entire figure viewed from above being that of a right-angled triangle, with the corners rounded off. The temporal fosse are the widest, and zygomatic arches the strongest, in the whole class Reptitia; the lower jaw presents a like excessive development of the coronoid processes. These developments, for great size and power of action of the liting and grinding muscles, relate to a most extraordinary form and size of the teeth, which resemble paring-stones, and were evidently adipited to crack and bruise shells and crusts of marine Invertebrata.

The teeth of the upper jaw consist of an extermal or maxillary series, and an internal or palatal series. The 
maxillary series are supported in a marginal row of alveoli by the premaxillary and maxillary bones; the palatal series are implanted in the palatine and pterygoid bones. The maxillopremaxillary teeth are five in number on each side, two implanted in the premaxillary, and three in the maxillary. The premaxillary teeth are subequal, smaller than the maxillary teeth; their crowns are subhemispheric in P. laticeps, but in $P$. Andriani they present a bent, pointed, prehensile character. In $P$. laticops the first maxillary tooth has a full oral crown, $4 \frac{1}{2}$ lines by 4 in diameter; the second measures $5^{\frac{1}{2}}$ lines by $4 \frac{1}{2}$ lines in diameter; the third is subcircular, 8 lines in diameter, on the right side. The palatal series begins on the inner side of this tooth, and consists of two teeth on each side. The first tooth has a full elliptical crown, 10 lines by 8 ; the second tooth, developed in the broad pterygoid bone, presents a full oval shape, 1 inch 9 lines by 1 inch 3 lines in diameter. In Placodus gigas and $P$. Andriani the palatal teeth, three in number on each side, are all of large size, slightly increasing from before backwards; they are situated close together, forming on each sicle a series a little curved with the convexity outwards, and the interspace between the two series is very narrow. The first tooth is triangular, the second and third are quadrangular; each with the angles rounded, and the transverse diameter exceeding the fore and aft or longitudinal one. The maxillary teeth are much smaller than the palatal ones, have a rounded or subquadrate crown, are four in number, and of subequal dimensions. The premaxillary teeth, three in number on each side, are more remote and distinct from the maxillary teeth than in Placodus rostratus and $P$. laticeps ; their crowns are more elongated and conical than in $P$. laticeps ; the prehensile power of the prolonged premaxillary part of the jaw being obviously greater in Placodus gigas than in $P$. laticeps or $P$. rostratus. The size of the last tooth in P. laticeps surpasses that of any of the teeth in the previ- 
ously liscovered species. In proportion to the entire sliull, it is the largest grinding tooth in the animal kingdom, the elephant itself not excepted.

All these teeth are implanted by short simple bases in distinct hollow sockets, subject to the same law of displacement and succession as in other reptiles. By some it may be deemed requisite to separate generically the Placodi with two tecth from those with three teeth in each palatal series; but the Placodus rostratus offers a transitional condition in the small relative size of the first two palatal teeth, and in the roumded form of all the teeth, from the $P$. Andivini to the

\section{$P$. laticeps.}

TVe camnot contemplate the extreme and peculiar modification of form of the teeth in the genus Placodus without a recognition of their adaptation to the pounding and crushing of hard substances, and a suspicion that the association of the fossils with shell-clad Mollushis in such multitudes as to have suggested special denominations to the strata containing Placodus (e.y., muschelkalk, terebratulitenkalk, ete.), is inclicative of the class whence the Placodi derived their chicf subsistence.

No doubt the most numerous eximples of similarly-shaped teeth for a like purpose are afforded by the class of fishes, as, c.y., by the extinct Pycnodonts, and by the wolf-tish (Anarrhichas luppes) and the Cestracion of the existing seas. But the reptilian class is not without its instances at the present day of teeth shaped like paving-stones, of which certain Australian lizards exhibit this peeuliarity in so marled a degree that the generic name C'yclodus hats heen invented to express that peenliarity. Amongst extinct reptiles, also, a species of lizand from the tertiny depestis of the Limagne in France presents romed obtuse texth, of which the last, in

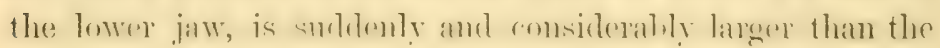
rest. 
Nuthosan'us, Simosanrus, and Pistosaurus present the same evidences of lacertian affinities in the division of the nostrils by the median extension of the premaxillary backwards to the nasals, the same thecolont dentition, and the same circumscription of the orbits and temporal fossa as in Placodus : there is also a general family likeness in the upward aspect of these apertures, accompanying an extreme depression of the skinll. The muzzle, though varying greatly in length in these genera, presents the same obtuseness; and the alveolar border of the jaws the same smooth outward convexity which we observe in the Placodus. The peculiar confluence of the elements of the upper and lower zygomatic arches,-i.e., of post-froutal and malar,-forming the broad wall of bone behind the orbit, is continued still farther backwards in the Simoscurmes. In Pistosaurus the elongated post-frontal, malar, and squamosal are united together in one deep zygomatic arch, which has the mastoid and tympanic for its hinder abutment.

It is remarkable that hitherto no vertebrie or other bones of the trunk or limbs have been found so associated with the teeth of Placodus, as to have suggested their belonging to the same species. Usually, after the indication of a reptile by detached teeth, the next step in its reconstruction is based wyon detached vertebre. The twelve or more evidences of Placolus, afforded by bone as well as tooth, are all portions of the skull. It is possible that some of the singularly modified vertebrie from the muschelkalk, next to be described, may belong to the Placodus; and the same sumise suggests itselt in reference to some of the limb-bones from the muschelkalk that camnot be assigned to other known saurian geuera.

The olovious adaptation of the dentition of Placodus to the crushing of rery hard kinds of food, its close analogy to the dentition of certain fishes known to sulssist hy breaking the shells of whelks and nther shell-clarl Molluskis, and the cha- 
racteristic abundance of fossil shells in the strata to which the remains of Placodus are peculiar, concur in producing the belief that the species of this genus were reptiles frequenting the sea-shore, and probably good swimmers. But as at present we have got no further than the head and teeth in the reconstruction of this mezozoic form of molluscivorous reptile, the present notice will conclude with a remark suggested by the disposition and form of the teeth. In all the species, under the rather wide range of specific varieties of the dentition, there are two rows of the crushing teeth in the upper jaw, and only one row in the lower jaw, on each side of the mouth; and the lower row plays upon both upper rows, with its strongest (middle) line of force directed against their interspace. Thus the crushing force below presses upon a part between the two planes or points of resistance above, on the same principle on which we break a stick across the knee; only here the fulcrum is at the intermediate point, the moring powers at the two parts grasped by the hands. It is obrious that a portion of shell pressed between two opposite flat surfaces might resist the strongest bite, but subjected to alternate points of pressure its fracture would be facilitated.*

\section{Genus Tanystropheus.}

Sp. Tanystrophenes conspicuns, H. von Meyer.-Certain long, slender, hollow bones (fig. 70, 1 ), from the German muschelkalk, were referred by Count Minster to the class Reptilia, under the name of Macrosclosaums, under the impression that they were bones of the limbs. H. ron Meyer subsequently, in more perfect specimens, observing that each slightly expanded extremity of the long bone was terminated hy a symmetrical oval concave articular surface, surmomnted hy a pair of symmetrical lateral incurved plates, resembling confluent

* Previous to the writer's Memoir on P'lecodus in the Philosophical 'l'rans-

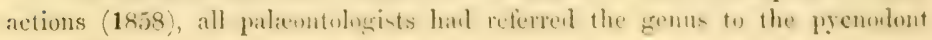
niter of fishes. 
neurapophyses, with articular surfaces, and with their sometimes confluent bases arching over a neural canal (as in figure $\mathrm{B}$, in eut 70), recognized their vertebral character ; and, adopt-

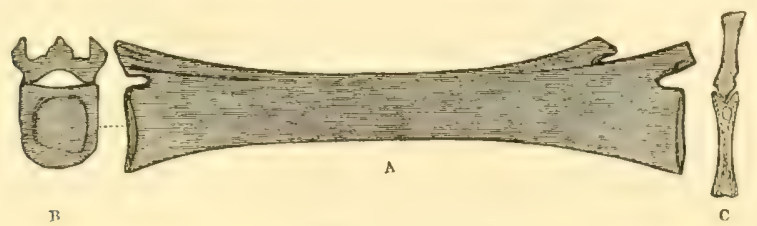

Fig. 70 .

A, B, Tanystrophous ('Trias); c, Ichthyosaurus.

ing the determination of their reptilian nature, but repudiating the idea of their being limb-bones, he discarded Miunster's name, and substituted for it that of Tanystrophaus, ${ }^{*}$ indicative of their peculiar proportions as vertebre. Although the articular ends are for the most part symmetrical, the long intervening body is not so. It is subcompressed, usually broader and flatter below than above; sometimes more flattened on one side than on the other, giving an irregular, vertically oval, or triangular cross section. A low median ridge is not uncommon on the lower surface towards the ends of the vertebra; and similar less regular ridges project from the sides of the otherwise smooth outer surface. The centrum is excavated by a canal, resembling a medullary one, but more probably filled, in the recent state, as in the long caudal style of the frog, with unossified cartilage. The walls of this cavity are compact, and in thickness about one-sixth of the diameter of the bone. The terminal neural arches support each a low median ridge or rudimental spine, which soon subsides. The trace of neural canal in like manner disappears, or is continued by two distinct slender canals, which traverse for a certain extent the substance of the thicker upper wall of the cavity of the vertebral body. A single large vascular canal opens on the wider surface midway between the two ends of the hody.

\footnotetext{
* From $\tau \hat{\alpha} \nu \dot{\omega} \omega$, to elongate, $\sigma \tau \rho \in \phi \omega$, verto.
} 
There is no trace of trinsterse processes, rib-surfices, or hiemapophyses; this, and the absence of the continuous neural canal, indicate these singular vertebric to belong to the tail. From the long caudo-vertebral style of anournus Batrachia the vertebrie of Tanystropheces differ in having distinct articular surfaces at loth ends. The difference of shape and size in the few that have been found also indicates that there were more than two such vertebre in the tail of the extraordinary animal to which they have belonged. Caudal rertebre of the normal proportions and structure, from muschelkalk of the same localities with Tanystropheeus have been referred to Nothosaums. It is possible, howerer, that one or other of the remarkable genera-Simoscurus, Placodus, c.y.-may have possessed the peculiar structure in the tail, or some part of it, which the tanystrophean vertebre indicate. The first four vertebre of the neck or trunk of the Fistulariu trabacaric are those which most resemble in their proportions the rertebra above described; but none of the fistularian vertelsx have the articular concavity and the zyoapophyses at both ends: the first presents them at the fore end, and the last at the hind end, and the modifications of both these finished articular ends pretty closely correspond with those of Tunystroptheus; but the second and third vertebre of Fistularia are united with the first and fourth by sutural surfaces with deeply-interlocking pointed processes.

\section{Genus Sphenosaurds.}

Sp. Sphenosurems Sternbergii, Ton. MI.-The fossil rertelura on which this genus is founded are imbelled in a sandstone, most like the lunter, frem Bohemia or the south of (iemany. Of the twenty-three vertelnate so preserved in nearly their natural position, and with their moler surface exposed, five helong to the tail, the rest to the trumk. Of these, two are sacral, two lumbar, the rest are dorsal or thoracie, with long and stenter rils comnected with them. The nemral areh 
appears to have been suturally united to the centrum with large zygapophyses. The articular end of the centrum is rertical to its axis : both are slightly concave. Between each centrum is a transversely oral, depressed ossicle, homologous with the cervical wedge-bones or hypapophyses in Enaliosaurs. This is the chief peculiarity in Sphenosaurus, and recalls a character in the rertebral column of Archegosutrus.

Genus Plestosiuncs.-The discovery of this genus forms one of the most important additions that geology has made to comparative anatomy. Baron Cuvier deemed the structure of the Plesiosaur "to have been the most singular, and its character's the most anomalous that had been discorered amid the ruins of a former world." "To the head of a lizard it united the tecth of a crocodile, a neck of enormous length, resembling the body of a serpent, a trunk and tail having the proportions of an ordinary quadruped, the ribs of a chameleon, and the paddles of a whale" (fig. 71). "Such," writes Dr. Buckland, "are the strange combinations of form and structure in the Plcsioscurus, a genus, the remains of which, after interment for thousands of years amidst the wreck of millions of extinct inhabitants of the ancient earth, are at length recalled to light by the researches of the geologist, and sulmitted to our examination, in nearly as perfect a state as the lyones of species that are now existing upon the earth."

The first remains of this animal were discovered in the lias of Lyme Regis ahout the year 1822, and formed the subject of the paper by the Rev. MIr. Conylueare (afterwards dean of Llandaff), and Mr. (afterwards Sir Henry) De la Beche, in which the genus was established, and named Plesioscumes ("approximate to the Saurians"), from the Greek words pllesios and sarros, signifying "near" or "allied to," and "lizard," because the authors saw that it was more nearly allied to the lizard than was the Ichthyoscurus from the same formation.

The entire and undisturbed skeletoms of several indivirluals, 
of different species, have since been discovered, fully confirming the sagacious restorations by the original discoverers of the Plesiosaurus.

Vertcural Column.-The vertebral bodies have their terminal articular surfaces either flat or slightly concare, or with the middle of such eavity a little convex. In general the bodies present two pits and holes at their under part. The cervical vertebrae consist of centrum, neural arch, and pleurapophyses. The latter are wanting in the first rertebra; but both this and the second have the hypapophyses. The cervical ribs are short, and expand at their free end, so as to have suggested the term "hatchet-bones" to their first discorcrers. They articulate by a simple head to a shallow pit, which is rarely supported on a process, from the side of the centrum ; but is commonly bisected by a longitudinal groove, a rudimental indication of the upper and lower processes which sustain the cervical ribs in Crocoditia.

The body of the atlas articulates with a large hypapophysis below, with the neurapophysis above, with the body of the axis behind, and with part of the occipital condyle in front; all the articulations save the last become, in Plesiosaurus pachyomus, and probably with age in other species, obliterated by anchylosis. The hypapophysis forms the lower two-thirds, the neurapophysis contributes the upper and lateral parts, and the centrum forms the middle or bottom of the cup for the occipital condyle. The second hypapophysis is lodged in the inferior interspace between the bodies of the atlas and axis; it becomes anchylosed to these and to the first hypapophysis. The first pleurapophysis, or rudimental rib, is developed from the centrum of the axis.

As the cervical vertelme approach the dorsal, the lower part of the costal pit becomes smaller, the upper part larger, until it forms the whole surface, grarlually rising from the centrum to the neurapophysis (fig. 71). 
The dorsal region is arbitrarily commenced by this rertebra, in which the costal surfice begins to be supperted on a diapophysis, which progressively increases in length in the secomd and third dorsal, continues as a transterse process to near the? end of the trunk; and on the vertebra above or between the iliac hones, it subsides to the level of the nemanophysis. In the caudal vertebra the costal surface gradually descends from the neurapophysis upon the side of the centrum; it is never divided by the longitudinal groove which, in most Pleniosanri, indents that surface in the cervical vertebræ. The neural arches remain long unanchylosed with the centrum in all Plesioscuri, and appear to be always clistinct in some species. The plenrapophyses gain in length, and lose in terminal hearth, in the hinder cervicals; and become long and slender ribs in the dorsal region, curving outwards and downwards so as to ancompass the upper two-thirds of the thoracic abdominal eavity. They clecrease in length and curvature as they approach the tail, where they are reduced to short straight pieces, as in the neck, hut are not terminilly expmuded they cease to be dereloped near the end of the tail. The hemapophyses in the abdominal region are suldividerl, and with the hamal spine or median piece, form a kind of "plastron" of transversely-extended, slightly bent, medim aml lateral, overlapping, homy hars, ocenpring the subabluninal space hetween the corteribls and pubicals. In the tail the hemapophyses are Short and straight, and remain re-united loth with the centrum above and with each other below. The hæmal spine is not developed in this region. This modification has been expressed by the statement that there were no cherron-bones in the Plesiosanx. The tail is much shorter in the Plesio-than in the Ichthyo-saurus.

The skull is depressed; its length is rather more than thrice its brealth; but the propurtions somewhat vary in different suredics. The cranial part, or that hethind the orluts, 
is qualrate: thence it contratets laterally to near the maxilloprenaxillary suture, where it continues cither parallel or with a slight swelling hefore rounding into the obtuse anterior termination.

The oribits are at or near the micllle of the slinll : estimating the length of this hy that of the lower jaw, they are in advance of the midrle part in Plexiossneres Harticinsii. The orbits are rather subtriangular than round, being somewhat squared off behind, straight above, and contracted anteriorly. No trace of sclerotic plates has yet heen discerned in any specimen. The temporal frissir are large suhquadrate apertures. The nostrils, which are a little in advance of the orbits, are scarcely larger than the parietal formen. Beneath them, upon the palate, are two similar-sized apertures, probahly the palatal nostrils.

The lower jaw jresents an angular, surangular, splenial, and dentary element, in each ranns: the dentary dements being confluent at the exprandexl symplysis. There is no vacuity between the angular and surangular or any other element of the jaw. The coronoid process is developed, as in Placolus, from the sumugular, hut rises only a little higher than in crocndiles. The alveoli are clistinct cavities, and there is a groove along their inner border in both jaws.

When the suceessional teeth first project in that groore. they give the appearance of a double row of teeth. All the teeth are sharp-pointed, long, and slender, circular in cross section, with fune longitulinal ridges on the enamel: the anterior teeth are the longest.

The scapula is a strong triadiate bone, the longest ray being formed by the acromial or elavicular furoses, which arches formand and inmarel to alut agatinst the stermum or epicolacoid.

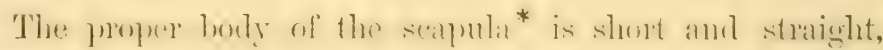
* 'This is ornitted in most of the published restorations of the Plesiosaurus. 


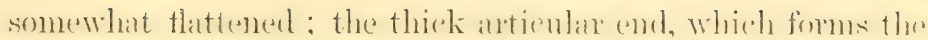
shortest ray, is subequally divided by the articular surface for the coracoid, and that for the head of the humerus.

The coracoids are chiefly remarkable for their excessive expansion in the direction of the axis of the trunk, extending from the abdominal ribs forward, so as . to receive the entosternum, which is wedged into their anterior interspace. The median borders meet and unite for an extent determined by their degree of curvature or convexity, which is always slight. The coracoids unite anteriorly with the clavicles, as well as with the episternum ; laterally they articulate with the scapula, combining to form the glenoid cavity for the humerus.

The episternum has the same general form as the median pieces of the abdominal ribs, being, like those pieces, a modified hremal spine, only more advanced in position; the lateral wings or prolongations are broader and Hatter; the median process is short; a longitudinal ridge projects from the middle of the internal surface. The humerus is a moderately thick and long bone,

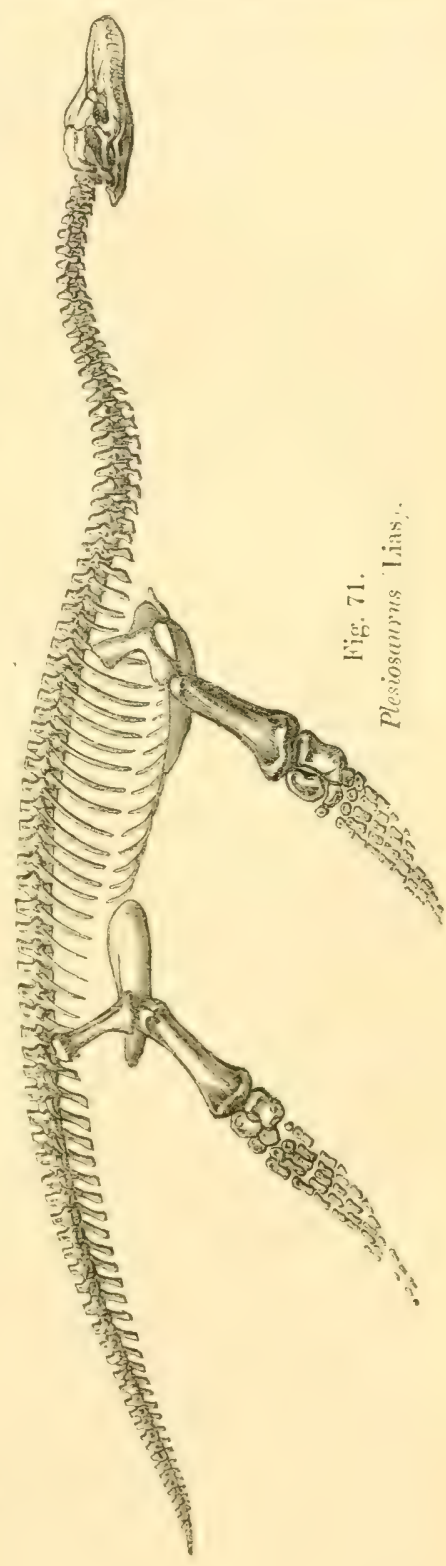


with a comrex hearl, smb-eylintrical at its proximal emel, becoming flattened and sromlually expanded to its distal end, where it is diviled into two indistinct surfices for the radius and ulna. The shaft in most sprecies is slightly curved backwark, or the hind bonter is concave, whilst the front one is straight. The radius and ulna are alyout half the length of the humerus; the former is straight, the latter enrext or reniform, with the concavity towards the raclius; woth are flattened; the radius is a little contracted towards its carpal end, and in some species is longer than the ulnil. The ean'pus consists of a double row of flat rounded dises,- the langest at the radial side of the wrist; the unnar or hinder side appearing to have contained more unossified matter. The metacirpals, five in number, are elongate, slender, slightly expanded at the two ends, flattened, and sometimes a little bent. The phalanges of the five rligits have a similar form, hut are smaller, and progressively decrease in size; the expansion of the two ends, which are truncate, makes the sides or margins concare. The first or radial digit has generally three phalanges, the second from five to seven, the third eight or nime, the fourth eight, the fifth five or six phalanges. All are flattenext the terminal ones are nailless; and the whole were obviously includer, like the pardle of the porpoise and turtle, in a common sheath of integument. The pelvic arch consists of a short but strong and straight narrow moveable ilimm, and of a broad and flat pubis and ischium; the former subquarlyate or subcircular, the latter triangular; the fore-and-aft expanse of both hones nearly equals that of the corncoids. All concur in the formation of the hip-joint. The ischimm and pulis asmin unite together near their mesial horders, having a wide elliptic vacuity, or "formmen ovale," hetween this junction and thein outer acetalular one. The pelvic pachlle is usually of equal

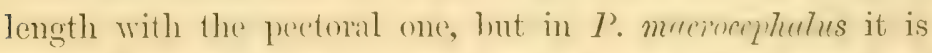
longer. The bones chesely anrespond, in number, arrange- 
ment, and form, with those of the fore limb. The temur has the hind marein less concave, and so apleats more straight. The filuula, in its reniform shapes, agrees with its homotype the nlna. The tarisal lunes are also smallest on the tibial side. (1) existing repitilen, the lizands, and amongst these the old worlel Monitors (Irannes, Fitz.), ly reason of the crimial vacuities in fromt of the orbits, most resemhle the Plesiosaur in the structure of the skull. The division of the mostrils, the vacuities in the occipital region between the exoccipitals and tympanies, the parietal foramen, the zygomatic extension of the prost-frontal, the palato-naxillary, and pterygo-sphenoid vacuities in the bony palate, are all lacertian characters, as contradistinguished from crocodilian ones.

But the antorbital racuities between the nasal, pre-frontal, and maxillary bones are the sole extermal nostrils in the Plesionaurs; the zygmatic arch abuts against the fore lint of the trmpanic, and fixes it. A much greater extent of the rouf of the mouth is ossified than in lizards, and the palatomaxillary and pterygo-sphenoid fissures are reduced to small size. The teeth, finally, are implinnted in elistinct sockets. That the Plesiosaur had the "hearl of a lizard" is an emphatic mode of expressing the anount of resemblance in their cranial conformation. The crocolilian afhinities, however, are not confinerl to the teeth, lint extend to the structure of the skull itself.

In the sinnple nocle of articulation of the rils, the lacertian affinity is again strongly manifested; lout to this rertebral whater such affinity is limited; all the other's exemplify the ordinal distinction of the P'lesiosanes from known existing reptiles. The shape of the joints of the centruns; the numlese of vertelnat between the hearl and tail, especially of those of the neck: the slight indication of the sireral vertuhrae: the

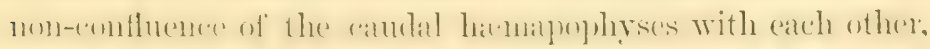

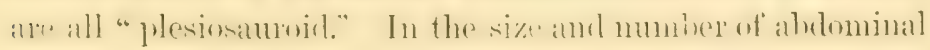


ribs and sternum maty gerhilys be discerned a first step in that series of derelopment of the hamapophyses of the trumli which reaches its maxinum in the plistron of the Chelonia.

The comnation of the clavicle with the scatula is common to the Chelunia with the Plesionare; the expansion of the coracoinls-extreme in Plesiusenti-is greater in Cheloniu than in Crocudilia, hut is still greater in some Lacertiu. The form and proportions of the pubis and ischium, as complared with the ilium, in the pelvic arch of the Plesiosurerind fhe nearest approach in the pelvis of marine Chelonice: and no other existing reptile now offers so near, although it he so remote, a resemblance to the structure of the padelles of the Plesiosaur. Amongst the many figmative illustrations of the nature of the I'lesiosanr in which popular writers have indulged, that which compares it to a smake threaded thromgh the trunk of a turtle is the most striking; but the number of vertelnae in the Plesiosam is no true indication of aftinity with the ophidian order of reptiles.

The reptilian skull from formations underlying the lias, to which that of Plesiosume has the nearest resemblance, is the skull of the Pistosume; in this genus the nostrils have a similar position and diminutive sizer, but are somewhat more in advance of the ortits, and the premaxillaries enter into the formation of their boumlary : the premaxillary muzle and the temporal fossie are also somewhat longer and namower. The post-frontals and mastoids more clearly combine with malars and squamosals in forming the zycomatic areh, which

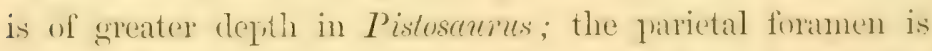
larger: there is no trace of a median parietal crest. (On the palate, besides the vacuities between the piteryonds and presphenoids, and the small formmina hetween the palatines, premaxillaries, and maxillanter, there is in Pistesenters a single median foranen in andranee of the latter linamina, hetween

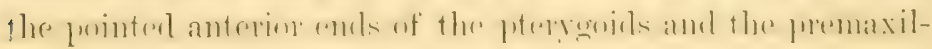


laries. In Tothosenens the piteryotids extend back, underlapping the basi-sphenoid, as far as the basi-occipital, the median suture uniting them being well marked to their termination; and there is no appearance of vacuities like the pteryon-sphenoid ones in Plesin- and Pisto-smuns. The tympanics are relatively longer, and extend farther back in Pistothan in Plesio-scums. There is no trace of lacrymals in Pistusturus; and its maxillaries are relatively larger than in Plesiosums. In Pistosturas there are 18 teeth on each the upuer jaw, including the spremaxillary teeth; in Plesiosaum there are from 30 to 40 teeth on each side. In Pistoscurus the teeth are relatively larger, and present a more oral transverse section: the anterior teeth are proportionally larger than the posterior ones than they are in Plesioscuns. The disproportion is still greater in Tothosurus, in some species of which the teeth behind the premaxillary and symphrsial terminal expansions of the jaws suddenly become-c.g., in Tothosanns mirebilis (fig. 68)-rery small, and form a straight, numerous, and close-set single series along the maxillary and corresponding part of the mandibular bone.

Both Tothoscures and Pistoscurns had many neck-rertebree, and the transition from these to the dorsal series was effected, as in Plesiosemen, by the ascent of the rib-surface from the centrum to the nemapophysis; but the surface, when divided hetween the two elements, projected further outwards than in most Plesiosauri.

In both Notho- and Pisto-saurus the pelvic vertebra develops a combined process (par- and di-apophysis), but of relatively larger, rertically longer size, standing well out, and from near the fore part of the side of the rertebra. This process, with the coaleseed riblet, indicates a stronger ilimu, and a firmer base of attachment of the hind limb to the trunk, than in Plesinscurus. Both this structure, and the greater length of the lemes of the fore arm and lece show that the 


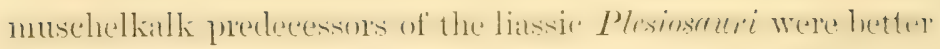
organized for occasional progression on dry land.

More than twenty speciess of Plesiosmens have been deseribed hy, or are known to, the writer ; their remains oecur in the onlitic, Wealden, and cretacenss formations, ranging firom the liats mprarts to the chalk, inchusive. A comprarison of remains of ramious Plesiosau, $i$ has led to a conviction, that specific distinctions are aceompanied with well-marked differences in the structure and proportions of answerable vertebras, but are not shown in small differences of number in the cervical, dorsal, or caudal vertebræ.

When any region of the rertelsial columm presents an unusual excess of development in a genus, such region is more liable to variation, within certain linits, than in genera where its proportions are more normal. The differences of the number of cervical and clorsal rerteblex, ramging between 29 and 31 in the Plesiosanins Ifurtinsil, e.y.-as noted in the description of that species in the writer's lieport on British Fossil Reptiles, 1839-indicate the range of variety observed in the only species of which, at that time, the vertebral columm of different individuals could be compared.

Gemus Pliosadres, Ow- - II. rom Meyer regards the number of eervical vertebrie and the length of neck as characters of prime importance in the classification of Reptitie, and foumds thereon his order called Mtecrotracteden, in which he includes Simosaume, Pistosun'us, and Nothosenres.s, with Plesiosenures. No doubt the number of vertebre in the same skeleton bears a certain relation to ordinal groups: the Ophidtu find a common character therein; yet it is not their essential character, for the snali-like form, deperedent on multiplied vertchlar, chatraterizes expally certain Batrandhims (Cacitiu)

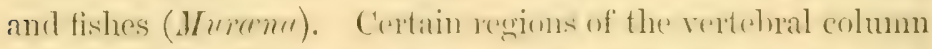
are the seats of great varetere in the same natural gromp of

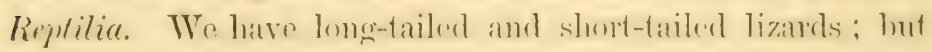


do not therefore: separate: those with numerous candal vertebrat, as "Macroura," from those with few or more. The extinct

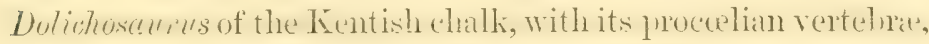
cammot be ordinarily separated, liy reason of its more numerons

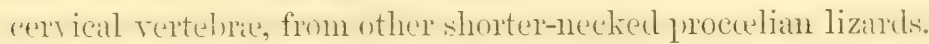
As little can we separate the short-necked and big-hearled anphiculian Pliosaur from the Macrotrachelians with which it has its most intimate and true affinities.

There is much reason, indeerl, to suspect that some of the muschelkalli saurians, which are as closely allied to Suthosoures as Plinanues is to Plexisunes, may have presenterl analogous modifications in the number and proportions of the cervical rertelnie. It is harlly possible to contemplate the broad and short-snonted skull of the Simosenrus, with its proportionally large teeth, without inferring that such a head must have been supported hy a shorter and more powerful neck than that which bore the long and slender head of the Nothosaums or Pistosaums. The like inference is more strongly inpressed upon the mind liy the skull of the Placodus, still shorter and bromler than that of Simosemris, and with vastly larger teeth, of a shape indicative of their adaptation to crushing molluscous or crustaceous shells.

Neither the proportions and amature of the skull of Placolns, nor the mode of oltaining the food indicated by its cranial and dental chancters, permit the supposition that the head was supported hy other than a comparatively short and strong neck. Tet the composition of the skull, its proportions, cavities, and other light-giving anatomical characters, all bespeak the close essential relationship of Placolus to Simosourus and other so-called "macrotrachelian" reptiles of the muschelkalk beds. I still, therefore, regard the fin-like modification of the limbs as a hetter ordinal character thin the number of vertebre in any particular region of the spine. But by those who would retain the term Enatiosanta for the 
large extinct matatery gromp of sambian reptiles, the essential

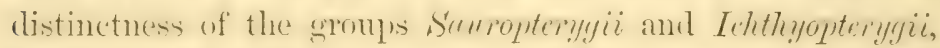

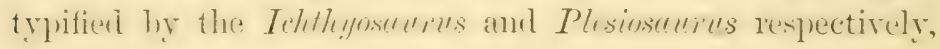
shovld be borne in mind.

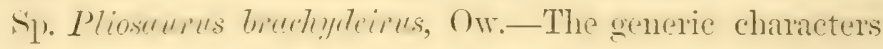
of Plivenmens are given ly the teeth and the cervical vertelore. As compram with those of Plesinaures, the teeth are thicker in proportion to their length, are sulptrihedral in transverse section, with one side flattened, and bounded by lateral promi-

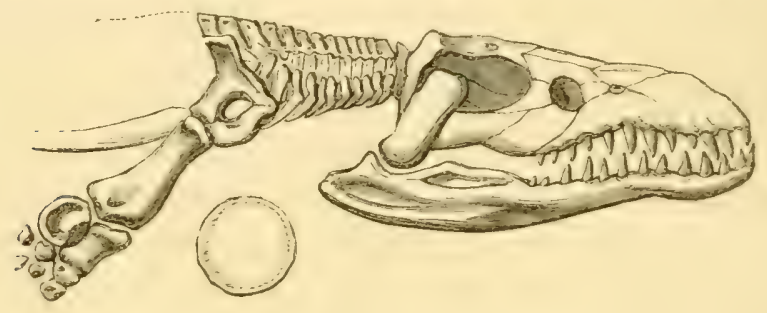

Iig. 72.

Pliosaurus (Kimmeridgian).

nent ridges from the more convex sides, which are rounded off into each other, and alone show the longitudinal ridges of the enanel; these are there very well defined. The vertebrax of the neck, presenting a flat articular surface of the shape shown in outline below the neck in fig. 72 , are so compressed from before hackward as to resemble the rertelnute of the Ichthiyoseums (fig. 70, c), and as many as twelve may be connpressed within the short neek intervening between the skull and scapular arch, as shown in fig. 72 . For the rest, sive in the more massive froportions of the jairs and paddle-lones, the bony framework of Plinemens closely aceords with that of

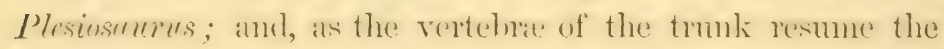
flesionarian pongertions, they give little indieation of the

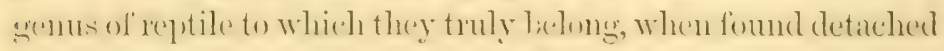

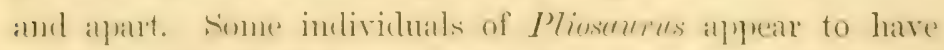
attained a lemeth of hetween :30 and fo foet. The lemains of 
this modified form of Emaliosan are peculiar to the Oxfordian and Kimmeridgian divisions of the uner oolitic system. They have been discovered in these herls in Russia (Pliosenmes Worinstii and Spondylosen: us of Fischer), as well as in those connties of England where the Kimmeridge and Oxford clay's have been deposited.

Genus Iolyptrchodon.-A genus represented by species equalling in size those of Plioscurus. The teeth have a strong conical crown with a sub-circular transverse section, and the longitudinal ridges of the enanel are set cluse all round the crown, whence the name of the genus, signifying "manyridged tooth;" they may be distinguished from the teeth of Mosascurus or Pliosanurus by the absence of the smooth almost Hattened facet of the crown, which, in those genera, is divided by two strong ridges from the rest of the crown. The teeth are implanted in distinct sockets, as in Plesioseums. The vertebre found in the same strata, corresponding in size with the teeth, present the plesiosamoid type. Bones of a large parklle or natatory limb, from the chalk of Kent, may also belong to Polyptychodon. A portion of the cranium of Polypstychodon interinptes, from the chalk, shows the "foramen parietale," and a plesiosauroid type of temporal fussie.

Remains of Polyptychodon have hitherto been met with only in the cretaceons formations: in the green-sand of Kent and Cambridge, also at Kursk, in Russia, and in the chalk of Kent and Sussex.

\section{Order 5.-ANOMODONTIA.}

Teeth wanting, or limited to a single maxillary fair, having the form or proportions of tuskis : a "foramen parietale;" two nostrils; tympanic pedicle fixed; vertebræ biconcave; trunk-ribs long and curved, the anterior ones with a bifurcate head; sacrum of more than two vertebre. Limbs ambulatory. 
Fay.-Dicynodonta.

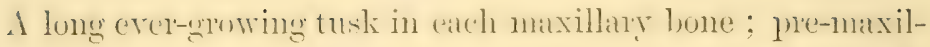
laries commate, forming with the lower jaw a beakshaped mouth, probably sheathed with horn.

Genes Dicrsooox; ()w:- In 184\% Mr. Andrew G. Bain, who had been engaged in the construction of nilitary ruals in the coluny of the Cape of Good Hope, discorered, in the tract of comntry extending northwards from the county of Alliany, about 450 miles east of Cape Tuwn, sereral notules or humps of a kind of andstone, which, when hroken, displityed in most instances evidences of fossil bones, and usually of a skull with two large projecting teeth. Accordingly these evidences of ancient animal life in south Afriea were first notified to English geologists hy Mr. Bain uneler the name of "Pitentals ;" and the specinens transmitterl he hinn were sulnuitted to the witer for examination. The results of the comprarisoms thereupon instituted went to show that there had formerily cxisted in south Africa, and from genlegical evielence, probably; in a great lake or inland sea, sinee converted into dry land, a race of reptilian animals presenting in the construction of their skull (fig. 73) characters of the crocodile, the tortuise, and the lizand, enuled with the presence of a prair of huge sharp-pointerl tuskis, growing downwards, one firm calch side of the uplex jaw, like the tusks of the mammalian morse (Tricheres). No other kind of teeth were developed in these singular amimals: the lower jaw appears to have been amert, als in the tortoise, by a trenchant sheath of horn.

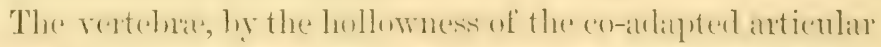

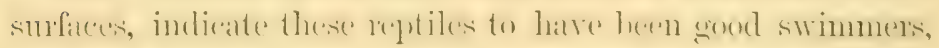
and foublaty to have hathitually existed in water ; but the

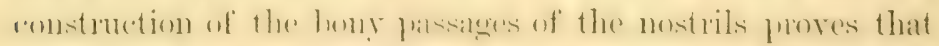

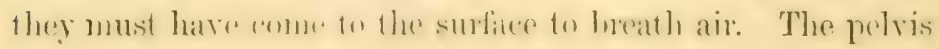


consists of a sacrum composed of 5 confluent reitelume, with very broad iliac lomes, and thick and strong ischial and pubive bones.

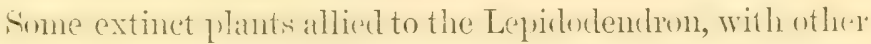
fossils, rencler it probable that the sandstones containing the dicynodont reptiles were of the same geological age as those that have revealed the remains of the Rhynchosaurs amb Labyrinthodonts in Europe.

The generic name Dicynodon is firm the Greeds words sinnifying "two tusks or canine teeth." Four species of this genus, having a rounderl profile and less strongly ridged maxillaries, have been demonstrated from the fossils transmitted by Mr. Bain.

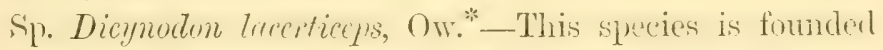
on a skull six inches in length, of which a reduced figure is given in cut 73 , where $c$ shows the canine tusks.

Sp. Dicmnodon testudiceps, Ow.-In this species the skull, and the facial part more particularly, is shorter than in $\mathrm{D}$. lacerticeps.

Sp. Dieynorton stiviceps, ()w.-The shortening of the jaws and blunting of the muzzle are carried to an extreme in this species, in which the nostrils are situated almost beneath the orbits.

Sp. Dicynodon tigriceps, Ow.†-In

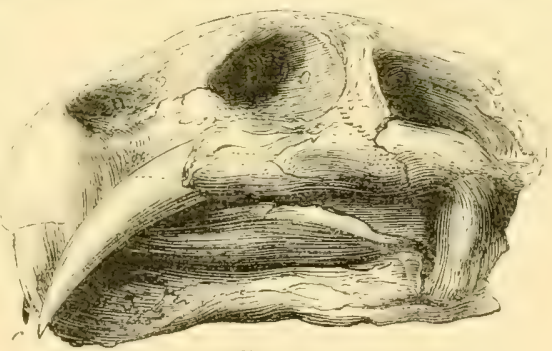

Fig. 73 .

Skull and tusks of Dicynodon lacerticers. this species the length of the skull is 20 inches, its breatth across the widest part of the zygomatic arehes being 18 inches. It differs from the $D$. lacertices not only in size, lut in the tooth.)

Trans. Geological Society, $2 d$ series, vol. vii. (dis, two; kunodos, canine+ Trans. Geol. Soc., 2 d series, vol. vii, p. 233. 


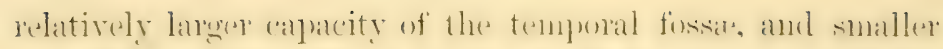
size of the orbits. These cavities in l). Tarediecps oceupy the midlle third of the skull, lut in $D$. tigriegs are wholly in the anterior half of the skull. The profile of the skull in D. laritticeps legens to slope or curve down from a line prarallel with the back part of the orbits, lut in D. tigricegs it does not hegin to bend down until in adrance of the orbits.

Gemus Ptrchogratios, Ow.-Thee other species, showing a remarkable angular contour of the skull, with strongly ridgerl maxillary and upwardly produced mandibular hones, have been subgenerically separated under the name Ptychognathws. Their remains characterize the same formations as those of Dimgnodon. No evidenee of the Dicrundent family las rot been met with out of South Africa.

\section{Fam.-Cryptodontia.}

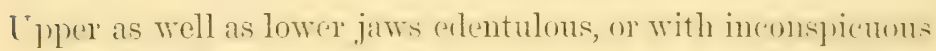
teeth.

Gemes Oudenodox, Bain.

Sp. Uutenoton Bainii.-The fossils on which the above genus and species are founded are from a bluish argillo-ferruginous limestone in Sonth Africa, and form part of a collection transmitted to the British Musemu ly A. G. Bain, Est.

One portion of the fossil skull includes all that part in artrance of the temporal fosse; the fore part of the temporal rislges, at the upper and back jart of this fragment, curve as the diverge from each other to the hack part of the orthit. The uple interortital part of the eranimu is nearly llat, with the orbital mangins slightly mised, and terminating anteriorly in a low antorbital prominenere; the least hreadth of the interorbital space is one inch. A slight depression divides the antorlital from the supmatisal tulerosities. The masal hones form an almost flat rhombeid surfice, from the eontracted fore

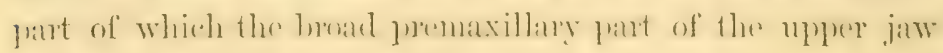


inclines downward and forwarl at an open angle. This part is traversed by a low olituse median ridge, and terminates below in a trenchant edentulous border.

The nostrils are small, ovil, and separated from each other by the broad junction of the asceming branch of the premaxillary with them.

The maxillary bone presents the elief peculiarity, being traversed obliquely by a strong angular ridge, commencing a little anterior to the orbit, amb terminating at the alveolar horder, not far from the maxillo-premaxillary suture. The alvolar borler gently curres to this termination, and shows no trace of a tooth or alveolus.

The compound structure of the lower jaw is shown at the fractured back part, where an upper (smangular?) element, thick and rounded above, is received into an outer and lower. dement, thin above, and thick and bent below, forming a groove for the reception of the nuper element. On the outer side of the jaw, about the middle of the part preserved, there is a Iongitudinal depression or narow vacuity, ahove which there is a low ridge. The symplyysis is thick, long, and hent. up in the form of a beak, terminating by an edentulous sultrenchant border; its fore and onter part is traverserl by a low median ridge. The length of this portion of the skull is 6 inches: its breadth across the maxillary rilges is 2 inches 10 lines; the extent of the symphysis of the Jower jaw is 2 inches 6 lines. Oudenodon is more closely allied to the African bidental reptiles of the following order than to the English Rhynchosanurs: so closely, in the construction of the: skull, as to suggest the sumnise that the absence of the two upper teeth may be a sexual character.

Genus Rhyxchosaurus, Ow.

Si. Rhynchosermes emticrus, Ow. "-The fossils in which

Transactions of the Cambridge Philosophical Society, vol, vii., part iii., $18+2$, p. 355 , plates 5 and 6 . 


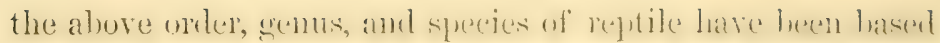

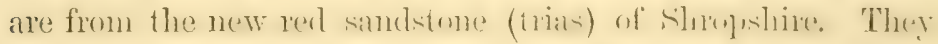

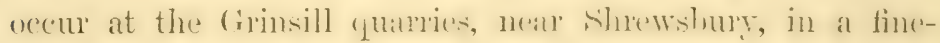

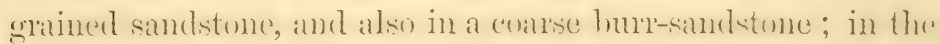

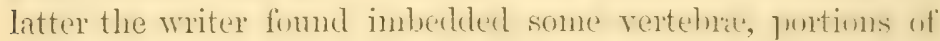
the lower jaw, a nearly contire skull, framments of the pelvis and of two funora: in the fine-grainet sandistone, vertelnat, ribs, and some bones of the scapular and felvic archess are imbeded. The bones present a rery bitte and compund texture; the exposed surface is misully smootle, or rery fincly. striated, and of a light blue colour. The sandstones containing these bones ocasionally exhibit impresions of foutsteps which resemble those figured in the Mlenoir hy Murehison and Stricklaud (Geol. Trams., 2d series, rol. v., pll. xxriii. fig. 1); hut they differ in the more distinct matis of the daws, the lesis distinct impression of a wet, the more diminutive size of the

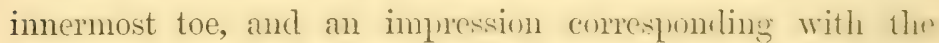
hinder part of the fort, which reminds one of a hind tore pointing backwards, and which, like the hind toe of some hinds. mly tonched the ground with its point. The footprints an's likewise more equal in size, and likewise in their intervals, than those figured in the above-cited Memoir : they measure from the extremity of the outermost or fifth toe to that of the innermost or first rulimental toe, about one inch and a half. They are the only fontprints that have as yet heen detected in the new red sandstone quitries at Grinsill.

As the fossil bones have always been foumd nearly in the same bed as that impressed by the footsteps above describerl, they probably helong to the same animal. In tine vertelnat both articular surfiess of the centrum are concave, and ane deeper than in the biencave rerteblat of the extinct Crocodilians; the fexture of the eentrum is eompat thronglont. The neural arde is anchylesed with the centrum, without. trace of sulure, as in most lizards; it inmediately expmuds 
and sends ontwards from each angle of its base a broad triangular process with a flat articular surface; the two anterion surfiees look directly upwarls, the posterior ones downwarels; the lattei are continued backwards beyond the posterior extremity of the centrum; the tubercle for the simple articulation of the rib is situated immediately beneath the anterior ololique process. So far the rertebre of the Rhynchosan:as, always exepting their biconcare structure, resemble the vertebre of most recent lizards. In the modification next to he noticerl, they show one of the vertebral characters of the Dinosentia. A broal obtuse ridge rises from the upler conves surface of the posterior articular process and arches formands along the neural areh above the anterior articular proces; and gradually subirles anterine to its base: the uper part of this arehed angular ridge formin, with that of the opposite side, a platform, from the midrlle line of which the spinous process is developed. Nothing of this kind is present in existing lizards ; the sides of the nemal arch immediately converge from the articular processes to the base of the spine, without the intervention of an angular ridge formed by the sides of a raised plitfinm. The base of the spinous process is broadest helind, and commences there by two roots or ridges, one from the "lper and back part of eich posterior articular process. The anterion margin of the spinnus frocess is thin and trenchant: the height of the spine dess not exceed the antero-posterion dianeter of its base; it is obliquely romeled off. The spinal camal sinks into the milllle part of the centrum amb rises to the base of the spine, so that its rertical diameter is twice as great at the midlle as at the two extremities: this modification resembles in a certain degree that of the vertebrae of the Palcosaures from the Bristol conglomerate.

The skull presents the form of a fomr-sided pyramil, com-

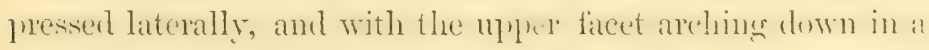
sraceful curve to the apex, which is formed he the termination 
of the muzzle. The very narrow cranium, wide temporal fosse on each side, bounded posteriorly by the parietal and the mastoid bones, and laterally by strong compressed zygomata : the long tympanic pedicle, descending freely and rertically from the point of union of the posterior transverse and zygomatic arches, and terminating in a convex pulley for the articular concavity of the lower jaw ; the large and complete orbits, and the short, compressed, and bent down maxillie, all combine to prove the fossil to belong to the lacertian division of the saurian order. The mode of articulation of the skull with the spine cammot be determined in the present specimen, but the lateral compression and the depth of the skull, the great vertical breadth of the superior maxillary bone, the small relative size of the temporal spaces, the rertical breadth of the lower jaw, prove that it does not belong to a reptile of the batrachian order. The shortness of the muzzle, and its compressed form, equally remove it from the Crocodilians. No Chelonian has the tympanic pedicle so long, so narrow, or so frecly suspended to the posterior and lateral angles of the cranium.

The general aspect of the skull differs, however, from that of existing Lacertians, and resembles that of a bird or turtle, which resemblance is increased by the apparent absence of teeth. The dense structure of the produced encls of the premaxillaries indicates an analogy of function to the tusks of Dicynodon; the premaxillaries are double, as in crocodiles and ('helonians; but most of the essential characters of the skull are those of the lizarl. The rami of the lower jaw are remarkable, as in Bulleygnathus, for their great depth, but not the least trace of a tooth is discemible in the alverolar horden of the dentary element.

The cranium, in my first described Rihynchosaur, was preserved with the mouth in the naturally elosed state, and the upper and lower jaws in elose contact. In this state we must 
suppose that they were originally buried in the sandy matrix which afterwards hardened around them; and since lizards, owing to the unlimited reproduction of their tecth, do not become edentulous by age, we must conclude that the state in which the Rhynchosaun's was buried, with its lower jaw in undisturbed articulation with the head, accorded with its natural condition, while living, so far as the less perishable hard parts of its masticatory organs were concerned. Nevertheless, since a view of the inner side of the alveolar border of the jaws has not been obtained, we cannot be quite assured of the actual edentulous character of this very singular Saurian. The indications of a dental system are much more obscure in the Rhynchoscums than in any existing Lacertian; the dentations of the upper jaw are absolutely feebler than in the chameleon, and no trace of them can be detected in the lower jaw, where they are strongest in the chameleon. The absence of the coronoid process in the Rhynchosaums, which is conspicuously developed in all existing lizards, corresponds with the unarmed condition of the jaw, and the resemblance of the Rhynchosaums in this respect to the Chelys ferox, would seem to indicate that the correspondence extended to the toothless condition of the jaws. The resemblance of the mouth to the compressed beak of certain sea-birds, the bending down of the curved and elongated premaxillaries, so as to be opposed to the deep symphysial extremity of the lower jaw, are further indications that the ancient Rhynchosaur may have had its jaws encased by a bony sheath, as in lirds and turtles, the dentinal ends of the premaxillaries projecting from, or forming, the deflected end of the upper mandible.

There are few genera of extinct reptiles of which it is more desirable to obtain the means of determining the precise modifications of the locomotive extremities than the Rhymehosanurs. The fortunate preservation of the skull has brought to light morlifications of the lacertine structure learling towards 
Chelonia and birds which hefore were unknown ; the vertelnate likewise exhibit very interesting deviations from the lacertian type. The entire reconstruction of the skeleton of the Rhynuchosuumes may be ultimately accomplished, if clue interest be taken in the collection and jreservation of the fussils of the Grinsill quarries.

The crimium of a Rhynchosamian reptile with small palatal teeth and obscure maxillary dentations, has heen discovered in the problematical sandstones, containing the Leptopleuron, near Elgin; and adds to the probability of their triassie age.

\section{Order Vi.-Pterosauria.}

Char:-Pectoral members, by the elongation of the antibrachium and fifth digit, arlapted for flight. Tertelsrar proccelian; those of the neck very large, not exceeding eight in number; those of the pelvis fer and small. Most of the bones pnemmatic. Head large; jaws loner, and armed with teeth.

The species of this order of reptiles are extinct, and peculiar to the mezozoic period. Although some members of the preceding order resembled birds in the shaje or the edentulous state of the mouth, those of the present order make a closer "lpmoach to the feathered class in the texture and pnemuatic character of most of the bomes, and in the development of the pectoral limbs into orgins of flight (fig. $7+$ ). This is due to an elongation of the antibrachial bones, and more especially to the still greater length of the metaciupial and phalingial bones of the fifth or outemost digit (fig. 7t, 5), the last phalanx of which terminates in a point. The other fingers were of more ortinary length and size, and terminated by claws. The number of ploalanges is progressive from the first (fig. $7.4, x)$ to the fouth (4), which is a reptilian charatert. The whole osserous system is morlified in ancordance with the 
possession of wings ; the bones are light, hollow, most of them permeated by air-cells, with thin compact outer walls. The scapula and coracoid are long and narrow, but strong. The vertebre of the neck are few, but large and strong, for the support of a large head with long jaws, armed with sharp-

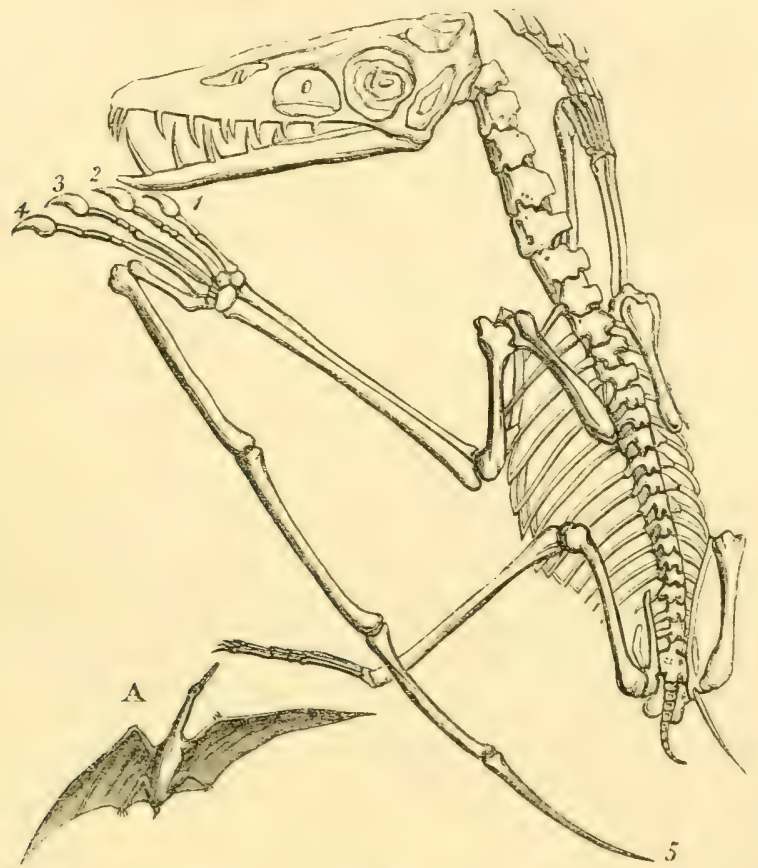

Fig. 74.

Fossil skeleton of Pterodactylus crassirostris: A, Sketch of living Pterodactyle.

pointed teeth. The skull was lightened by large vacuities, of which one (o, fig. $7 t$ ) is interposed between the nostril $n$ and the orbit 7 . The vertebre of the back are small, and grow less to the tail. Those of the sacrum are small, from three to five in number: but the weak pelvis and hind limbs bespeak a creature unable to stand and walk like a bird. The body must have been dragged along the gromel like that of a bat. The Pterosmoria may have heen gond swimmers as wotl as 
Hyers. The rertebral bodies unite by ball-and-socket joints, the cup being anterior, and in them we have the earliest manifestation of the "procolian" type of vertebra. The atlas consists of a discoid centrum, and of two slencler neurapophyses; the centrum of the axis is ten times longer than that of the atlas, with which it ultimately coalesces; it sends ofl from its under and back part a pair of processes, above which is the transversely extended convexity articulating with the third cervical vertebra. In each rertebra there is a large pneumatic foramen at the middle of the side. The neural arch is confluent with the centrum. The anterior ribs have a bifurcate head. The dentition is thecodont.

Genus Dinorphodon, Ow.

Sp. Dimorithodon macrony, Bkd.-The Pterodictyles are distributed into sub-genera, according to well-marked modifications of the jaws and teeth. In the oldest known species, from the lias, the teeth are of two kinds; a few at the fore part of the jaws are long, large, sharp-pointed, with a full elliptical base ; behind them is a close-set row of short, conpressed, very small lancet-shaped teeth. In a specimen of Dimorphodon macronyx, from the lower lias of Lyme Regis, the skull was 8 inches long, and the expanse of wing about t feet. There is no evidence of this species having had a long tail.

Genus Ramphorhychus, Von Meyer--In this genus the fore part of each jaw is without teeth, and may have been encased by a horny beak, but behind the edentulous production there are four or five large and long teeth, followed by several smaller ones. The tail is long, stiff, and slender.

The Ramphorhynchus longicuutus, $R$. Gemmingi, and $R$. Munsteri belong to this gemus. All are from the lithographie (middle oolitic) slates of Bavaria.

Gemus Pteronartwas, (uv, - The jaws are provided with 
teeth to their extremities; all the teeth are long, slender, sharp-jointed, set well apart. The tail is very short.

$P$. longirostris, Ok.-About 10 inches in length; from lithographic slate at Pappenheim. P. crassirostris, Goldf-About 1 foot long; same locality (fig. 74). P. Kochii, Wagn. -8 inches long; from the lithographic slates of Kehlhein. $P$. medius, Mnst. - 10 inches long; from the lithographic slates at Meulenhard. P. grandis, Cuv.-1 it inches long; from lithographic slates of Solenhofen. Two small aud probably immature Pterodactyles, showing the short jaws characteristic of such immaturity, have been entered as species under the names of P. Urevirostris and P. Meyeri. The latter shows the circle of sclerotic eye-plates.

The fragmentary remains of Pterodactyle from British oolite-C.g., Stonesfield slate, usually entered as Ptcrodactylus Bucklandi-indicate a species about the size of a raven.

The evidences of Pterodactyles from the Wealden strata indicate species about 16 inches in length of body. Those (P. Fittoni and P. Sedgrvickii, Ow.) from the greensand formation, near Cambridge, with neck-vertebre 2 inches long, and humeri measuring 3 inches across the proximal joint, had a probable expanse of wing of from 18 to 20 feet. The $P$. Cuvicri, Ow., and P. compressirostris, Ow., from the chalk of Kent, attained dimensions very little inferior to those of the greensand Pterodactyles.

More evidence is yet needed for the establishment of the pterosamian genus, on the alleged character of but two phalauges in the wing-finger, and for which the term "Ornithopterus" has been proposed by Von Meyer.

With regard to the range of this remarkable order of flying reptiles in geological time, the present evidence is as follows: The oldest well-known Pterodactyle is the Dimorphodun macionyy, of the lower lias; but bones of Pterorlactyle have heen discovered in the coeval lias of Wirtemherg. The next in point 
of ane is the Dimorphorton Bunthensis, from the "Posidonomyenschiefer" of Banz in Bararia, answering to the alum shale of the Whithy lias; then follows the P. Buclalendi from the Sitonesfield oulite. Abore this come the first-defined and numerous species of Pterublactyle from the lithograplice slates of the middle oolitic system in Germany, and from Cinin, on the Rihome. The I'terodactyles of the Wealden are as yet known to us by only a few bones and bone fragments. The largest known species are those from the upper greensand of Cambridgeshire. Finally, the Pterodactyles of the middle chalk of Kent, almost as remarkable for their great size, constitute the last forms of flying reptile known in the history of the crust of this eartl.

\section{Order VII.-Theconontia.}

Char--Tertebral bodies liconcave: ribs of the trunk long. and bent, the anterior ones with a bifurcate head: sacrum of three vertebre: limbs ambulatory, femur with a third trochanter. Teeth with the erown more or less compressed, pointed, with trenchant and finely serrate margins : implanted in distinct sockets.

\section{Gemus Thecodontosaures.}

Sp. Thecodontosaurus antipues.-In 1836 certain reptilian remains from the "dolomitic conglomerate" at liedland, near Bristol, ware described by Messrs. Riley and stutchbury.* The matrix has heen referred to the Permimn period: it is now thought hy some good ohserver's to be not older than the triassic.

The tecth in these reptilian fossils are lonlgerl in distinct sockets; they are arranged in a close-set series, slightly decreasing in size towards the posterior part of the jaw ; each ramus of the lower jaw contained twenty-ane tectly. These

* Geolngical Transactions, 2d series, vol. v., p. 34t. 
are conical, rather slender, compressed and acutely pointed, with an anterior and posterior finely-serrated edge, the serratures being directed towards the apex of the tooth; the outer surfiace is more conver than the inner one; the apex is slightly recurverl ; the base of the crown contracts a little to form the fang, which is subcylindrical.

Genus P'aleositrits, Riley and stutchibury. In the sante formation as contained the jaw and teeth of the Thecudontosanrus two other teeth were separately discovered, differing from the preceding and from each other ; the crown of one of these teeth measuring nine lines in length and five lines in breadth. It is compressed, pointed with opposite trenchant and serrated margins, lunt its brearth as comprared with its length is so much greater than in the Thecolontosaums, that upon it has been fimmled the genus Palcosaurus, anr it is distinguished by the specific name of platyed on, from the second tooth, which is referred to the same genus under the name of Palcosanns cylindrodon. The portion of the tooth of the Palcosaums cylindrodon which has been preserved, shows that the crown is sulcompressed and traversed by two opposite finely-serrated riclges, as in the Thecodontosaurus; its length is five lines, its breadth at the base two lines.

The vertehre associated with the two kinds of teeth above described are sub-biconcave, with the middle of the body more constrictex, and terminal articular cavities rather deeper than in Telcosene'ns; but they are chiefly remarkable for the depth of the spinal canal at the middle of each vertebra, where it sinks into the substance of the centrum; thus the canal is wider, rertically, at the midule than at the two ends of the rertebra: an analogous structure, but less marlied, olstains in the dorsal vertebrie of the Rhynchosanins from the new red sandstune of Shropshire.

I'esides deviating from existing lizards in the thecodom rentitim and hiconcave vertebrie, the Samrians of the rolomitic 
conglomerate also differ in having some of their ribs articulated by a head and tubercle to two surfaces of the rertebra, as at the anterior part of the chest in crocodiles and Dinosaurs. The shaft of the rib was traversed, as in the Protorosaur and Rhynchosaur, by a deep longitudinal groove. Some fragmentary bones indicate obscurely that the pectoral arch deviated from the crocodilian, and approached the lacertian or enaliosaurian type, in the presence of a clavicle, and in the breadth and complicated form of the coracoid. The sacrum includes at least three vertebrie. The humerus appears to have been little more than half the length of the femur, and to have been, like that of the Rhynchosurus, unsually expanded at the two extrenities. The fenur is chiefly remarkable for a third process or trochanter, just above the middle of the shift, which shows a medullary carity. The distal condyles are flattened, the outer one being the larger; there is a deep depression between them posteriorly, and a rery light one anteriorly.

The tibia, fibula, and metatarsal bones manifest, like the femur, the fitness of the Saurians for progression on land. The ungual phalanges are sub-compressed, curved downwards, pointed, and impressed on each side with the usual curved canal.

The following conclusions may be drawn from the knowledge at present possessed of the osteology of the Thecodontosaurus and Palcosaurus: in their thecodont type of dentition, biconcave vertebra, clouble-jointed ribs, and proportionate size of the bones of the extrenities, they agree with the ampliccelian crocodiles; but they combine a dinosaurian femur, a lacertian form of tooth, and a lacertian structure of the peetoral and prohably pelvic arch with these crocodilian characters; and they have distinctive modifications, such as the moniliform spinal canal, in which, however, the almost contemporary Rhyonchosaur participates. It would he interesting 
to ascertain whether the caudal vertebre are characterized, as in the Thuringian Protorosaur, by double diverging spinous processes.

\section{Genus Belodon, Von Meyer.}

Sp. Belodon Plicningeri.-The reptile from the upper white keuper sandstone of Wirtemberg, described by Plieninger, agrees in its essential characters so closely with the thecodont Saurians of the Bristol conglomerate as to add to the probability of both belonging to the same lower mezozoic period.

Three rertebre are modified to afford adequate attachment to the iliac bones in Belodon, and this additional evidence of affinity to Dinoscuric may have characterized also the English Thecorlonts.

Genus Cladyodon, Ow.

Sp. Cladyodon Lloydii.-In the Memoir on the Triassic Red Sandstones of Trarwick, by Murchison and Ntrickland, published in 1840, in the $2 d$ series of the Geological Transactions, rol. v., a tooth, which is an extremely rare fossil in those English formations, was figured in pl. xxriii., fig. 6.

Having lad the opportunity of studying the original specimen and fragments of some others of seemingly the same species from the new red sandstones of Warwick and Leamington, the writer recognized the affinity of the reptile possessing those tecth to the thecodont reptiles of the Bristol conglomerate, and indicated what appeared to be a generic modification of dental form by the term Cladyodon. $†$ He subsequently received other specimens of the teeth characterizing this genus, which may be described as being two-edged, sub-compressed; the sides more or less convex; the edges more or less sharp, and

* Würtemb. naturf. Jahreshefte, viii., Jahrg. 1857, p. 389. Jaeger's Phytosaurus appear's to have been founded on casts of the sockets of the teeth of Belodon.

† Reports of the British Association, "Brit. Fossil Reptiles," 1841, p. 155. (See fuller descriptions, with fignres, in Odontography, pl. $62, \mathrm{~A}$, fig. $4, a, b$.) 
frequently fincly serrate; the crown shightly bent sideways, the immer side towarls the mouth-eavity. The teeth are sometimes laneet-shapeel, through convergence of the extgess towards point; sometimes throngh one edge heing eonvex and the other concave, the crown is slightly curved or sickleshaped ; sometimes through use, the point is blunted. The ('namel is very thin, smooth, showing under the lens a slight longitudinal striation, forming wrinkles. The dentine is disposed in concentric layers; it is not lahyrinthic; the base of the tooth shows a conical pulp-carity. These teeth indicate a Saurian about ten feet in length.

The writer camnot discem any generic, or eren good specific distinctions, between the teeth from the Warwickshire keuper, on which in 1840 he founded the genus Cladyodun, and those from the Wirtemberg keuper, on which M. Ton Merex in 18tt founded the genus Belodon. Both are nearly allied to Palcosaunus.

The two following genera are referred provisionally and with doubt to the present order:-

Gonus Bathygnathus, Leidy.

Sp. Bathy!nathus borealis, Leidy.-Allied to the Cladyouton and Beloctur by the shape of the teeth is the Samian from the new red sandstone of Prince Edward's Island, North America, the generic and specific characters of which have been deduced by Dr. Leirly * from a portion of lower jaw, containing seren teeth, but with interspaces from which others have been lost. The depth of the dentary bone is five inches; a peculiarity which sugresested the greneric name (buthus, deep; gnuthos, jaw). The juecise mode of implantation of the teeth is not described.

The fossil was discovered at a clepth of 21 feet from the

* Journal of the Acadeny of Sciences, Philadelphia, rol. ii., p. 327, pl. xxxiii. 
surface, in a red sandstone supposed to be of the same age as that of Comnecticut, so remarkable for the various and singular foot-marks, referable, some to reptiles, and others to large birds.

Genus Protorosidrus, Von. Meyer.

Sp. Protoroscumes Spcneri, Von M.-The first fussil Saurian on record is that which marks the circumstance by its generic name, and honours its deseriber by the specific one. The slab of "copper-slate" from the Permian beds of Eisenach in Thuringia, displatying, either in fossils or impressions, the skull, verteloral columm, and lomes of the fore foot of the reptile in question, was figured and described hy Spencr, a physician at Berlin, in 1710.* The original specinen is now in the museum of the Roryal College of Surgeons, London, where it forms part of the Hunterian series of fossils. It wis obtained from a copper-mine near Eisenach, at a depth of 100 feet from the surface.

A second specimen, showing the two fore limbs, a hind limb, and part of the trunk, was described by Link in $1718 . \dagger$ C'uvier gives copies of portions of two other specinens in his Ossemens Fossiles.t

The healthy, honest mind of Spener is shown by the conclusions which he formed from the state of prescrvation of his specimen ("omnia, enim, minutissima, etiam apophyses, spina," cte.), ant from its association with equally wellpreserved remains of fishes, and even of the delicate leaves of plants, against the notions of those fossils merely simulating, and never having been, the living organisms which they represented-notions which were then arrocater under the sounding phrase of "plastic force," as they have lately been under that of "prochronism." Spener's only doulit was, whether the reptile had been a crocolile or a lizard; but he

\footnotetext{
. Miscellanea Berolinensia, 4to, i., p. 99, figs. 24 and 25.

† Acta Erulitorum, 1718, p. 188, pl. ji.

\$ El. 8 ro, 1836, pl. cexxxrii., figs. 1 and 2.
} 
inclined to the former view, on account of the proportions of the head to the trunk. He then enters upon speculations as to how a crocodile could have come into Germany; and shows the usual effect of a mind biassed by a hypothetical diluvial catastrophe not demonstrated by observation and inductive research, and to the extent of such bias benumbed in the exercise of the faculty for the acquisition of natural truth.

The seven cervical vertebræ are proportionally larger than in any known recent or fossil terrestrial or aquatic Saurian; they resemble in this respect the cervical vertebre of Pterodactyles; the tail is long, and its vertebre differ from those of all other known reptiles, recent or fossil, in having the spinous processes bifurcate, diverging in the direction of the axis of the body.*

The muscular power of the neck is indicated by traces of bone-tendons. The dorsal rertebre exceed eighteen in number, and have higher spines than in the modern NIonitors; the dorsal ribs are long, and longitudinally impressed. The hind limb is much longer than the fore limb, and the leg is longer, in proportion to the thigh and foot, than in the Monitors. The teeth are sharp-pointed, slender; there appear to be at least twenty in both upper and lower jaws in Spener's specimen.

It may be concluded, from the length and strength of the tail and the peculiar provision for muscular attachments in that part, and from the proportions of the hind limbs, that the Protoroscums was of aquatic habits, and that the strength of its neck and head, and the sharpness of its teeth, e'muled it to seize and overeome the struggles of the active fishes of the waters which deposited the old Thuringian copper-slates.

At Siynie and Cummingstone, in the neighlourhood of Elgin, N. 13., in a stratum of a fine-grained whitish sandstone,

* A character first printed out in the writer's "Report on British Fossil Reptiles," 'Trans. of Brit. $\Lambda$ ssoc., 1841, p. 155. 
('emented by carbonate of lime, situated between "Old Red" and "Purbeck" formations, and resting conformably upon the former, evidences of Sturian (Crocodilian and Lacertian) reptiles, characteristic of triassic time, have been discovered. The remains of the large reptile, with pitted bony dermal scales, had been, on their first discovery, referred to a genus of fishes by Agassiz, under the name of Staganolepis, or "pittedscale," probably from the belief that the formation belonged to the "Old Red System." I determined the crocorlilian nature of the scales, and the affinity of the reptile to the Thecodonts, in the breadth of the coracoid or pubis as shown by the cast of the bone, at the meeting of the British Association at Leeds, in September 1858. I have since been favoured by MIr. Duff with a tooth, assoicated with seales of Staganolepis, which is "thecodont" in character, and like that of Cladyodon.

In the same sandstone, in the quarry at Cummingstone, near Elgin, a continuous series of thirty-four impressions have been observed. The impressions are in pairs, forming two parallel rows, the lind one being one inch in dianeter.

I had some years before determined the true samian nature of the impression of the skeleton of the trunk and part of the head of a small reptile discovered by Mr. Patrick Duff" of Elgin, at Spynie, and noticed by him in the "Elgin Commut" of October 10th, 1851, as evidence of an air-breathing vertebrat in "Old Red Sandstone." The specinen was sulmitted hy Mr. Duff to my examination, the result of which was given, Dec. 15, 1851, in the "Literary Gizette" of that week, as follows :-

"It is the impression, in two pieces, of a grey variety of the old red sandstone, of a long and slender four-footed vertchrate animal, four inches and a half in length, clearly belonging, by the form, proportions, and positions of the scapular and pelvic arches, and their appended limbs, to the reptilian class. The osseous substance has disappeared ; the cavities in the sandstone which contained it remain, stained 
ly a deposit of an ochreous tint. The impressions ane so well definerl, as clearly to show that there were twenty-six vertebre between the skull and sacrum, two sacral vertehre, and thirteen caudal vertebre, before the tail disappears hy dipping into an unexposed part of the matrix. Impressions of twenty-one pairs of rils are preserverl, all very slender, short where they commence near the head, hut rapidly gaining length as they are placed further hack. The cervical and anterior rilss are expanded, but not lifureate, at their rertehral rand; all the ribs articulate close to the bolies of the vertelure. In the crocodilian reptiles the anterior rilss are bifurcate, and the posterior ones, with a sinule heal, articulate with long diapophyses. The distinctive characters of the batrachian skeleton are the double oceipital condyle; rils wanting, or very short and suberual; a single sacral vertebra, and rihshaped ilium. The first character camnot he determinerl, the oceipital articulation mot being preserved in the fossil. Instend of the second character, the fossil shows rihs of varied length, and most of them much Ionger than in the salananders, newts, or any known Patrachian. With regard to the third character', the impression in the matrix clearly shows two sacral rertebrie and a short subquadrate pelvis.

"Both the humerus and the femur show the lacertian signoid shape, and near equality of length, which distinguish them alike from the erocodilian and hatrachian orders: they are likewise, as in lizards, relatively longen than in the newts and salamanders. Nean the innereferet impression of the heal

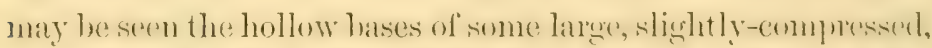
romical teethe which also tell for the saurian and against the hat rathian nature of this ancient reptile. I pupenese to call it

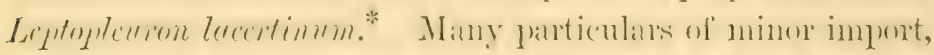
Jearing upon the mone immerliate affinities of this most rare

". $\Lambda \epsilon \pi \tau \delta$ s, slender; $\pi \lambda \in v \rho \delta$, rib; for this compound we have the anthority of Poilitopleuron, already applied to an extinct genus of Samrians. 
and interesting fussil, have been noted, and will be given, will the figures, in my History of British Fossil Reptiles, for which mork Mr. Duff has kimbly consenterl to place the specimen at my alisposal. Tn the memwhile I beg to ofter the alure precis of the main characters of the fossil.-RICHARD OwEN."

Other palientologists regreded the fossil as a hatrachian reptile; but $n$ evilence, osteological or rental, has been pointed out in support of this view.*

With regard to the ceological age of the calcareous sandstone containing Strugenolepis and Leptepterion, the author has remarked, in the article "Palientulngy," when the belief of some eminent geologists in the Deromian age of the stratum is quoted-."As yet, howerer, no characteristic Deronian or 'Old Red' fossils of any class have been discovered associated with the foregoing evidences of reptiles, which, aweorling to the determination of strata ly characteristic fossils, would belong to the secondary or mezuzoir prind." $\dagger$ It is, most probably, of triassic age.

\section{Order VIII.-Divosaunia.}

Chrr.-Cervical and anterior diorsal rertebre with par- an! di-apophyses, articulating with bifurcate ribs; dorsal vertebræe with a neural platform, sacral vertebræ ex-

* The following notice of this determination of the fossil will be found in the Athenceum of Dec. 13, in the title of a paper to be read at the ensuing meeting of the Geological Society :- "Notice of the occurrence of Fossil FootTracks, and the Remains of a Batrachian Reptile, in the Old Red Sandstone of Morayshire, by Capt. Brickenden and Dr. Mantell." The belief in the antiquity of the stratum showing the impression of the skeleton-remains of the skeleton there are none-appears to have weighed with these gentlemen in placing the animal at the bottom of the air-breathing series of vertebrals, as well as in proposing for it the name of Telerpeton, or "last of reptiles;" ( $\tau \in \lambda$ os, the end or issue of a thing, or $\tau \in \lambda \epsilon \iota o s$, having reached its end, and $\epsilon \rho \pi \epsilon \tau o \nu$, a reptile), at lesst as traced backwards in time. The term Leptopleuron has, however, the priority of publication: being also the result of a truer exposition of the nature and affinities of the fossil, and free from the signification of its appearance in time, it will be, probably, preferred.

† Encyclopredia Britannica, rol. xxii., p. 130. 


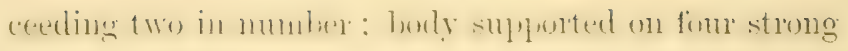
unguiculate limbs.

The well-ossified vertehrat, large and hollow limb-bones, and tritrochanterian femorit of the thecolont reprites of the Bristol conglomerate, together with the structure of the sacral vertebre in the allied Bctoctun, indicate the begimning, at the triassic preriorl, of an order of Reptilia which acquired its full development and typical characteristics in the oolitic period.

Genus Scelidosulrus, Ow.-By this name is indicated a Samrian with large and hollow limb-bones, with a femur, laving the third imner trochanter, and with metacarpal and phalangial bones, arlapted for movement on land. The fussils occur in the lias at Charmouth, Dorsetshire.

Genus Mradositris, Bkild--The true dinosamian chitracters of this reptile have heen established by the discovery of the sacrun, which consists of five rertebra, interlocked ly the alternating position of nerual arch and centrum. The articular surfaces of the free vertebre are nearly flat; the neural arch develops a platform which in the anterior dorsals supports very long and strong spines.

The compressed piercing and trenchant form of tooth which characterises the existing varanian lizarls was manifested hy the Megaloscumes. The specimen which is most illustrattive of the dental peenliarities of this gigantic reptile is at juntion of the lowere jaw with a few teeth. The first ehat raceter which attratets attention in this fossil is the inedpullity in the heright of the onter and imere alveolar walls : a similar ineruality charaterizes the jaws of almost all the existing

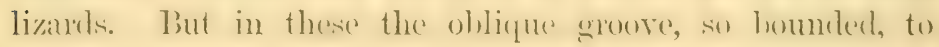
which the hases of the derelegned teeth are anchylosed, is much more shallow, and is relatively wider ; and the teeth in all the strages of growth are completely exposed when the gum has been removed. 
In the dregalosme as the greater relative derelomment wi the imner alreolar will, as compared with the dentigerons pant of the jaw in existing saurians, narrows the lental growe, and cover's a greater proportion of the hases of the tecth, besides conceating more or less completely the germs of their -necessors. Moreover, instead af the mere shallow impressions mon the immer side of the onter alveolar plate to which the teeth are attached in molern lizarels, there are distinct sockets formed by bony partitions comnecting the outer with the ime? alveolar wall in the jaw of the Megalosaurus. These partitions rise fiom the outer side of the immer alveralar wall in the form of triangular vertical plates of bone, and from the miduld, of the outer side of each plate a bony partition crosses to the outer parapet, completing the alverli of the fully-formed ar more advanced tecth; the series of triangular plates forming a lind of zig-zag huttress along the imner side of those alventi. The outer parapet rises an inch highex than the immer one.

Fig. 75 exhibits a purtion of another jaw of the Meyclosaurus, also from Stonesfield oulite, from which the inner watl has heen removed to show the werm of a suceessional touth $c$, ahout to suceed an old tooth ", which has been hroken, and near to which is a newhy-forment tuoth, $b$, coming into place. These treth will exemplify the sh:ipe of the crown of the tonth, which is suheompersed, slightly recurved, sharp edged, and sharp-pointed, the edges being mimutely serrated : the extge upon the convex or front horder $b$ hecomes blunted as it descends about two-thirds of the way towards the base of the tooth; that upon the concave hinder border a is continued to the base. The lower half of the crown is thicker unarels the fore margin than towards the hind one: so that a transverse section, like that above, $a$, in fig. 75, gives a narrow oval ferm pointed behind. At the upper half of the crown the siles slope more equally from the midelle thickest prent to lonth malloini- and the section is a namow pointer rllipse. The 
crown is covered hy a smonth and polisherl mamel, which
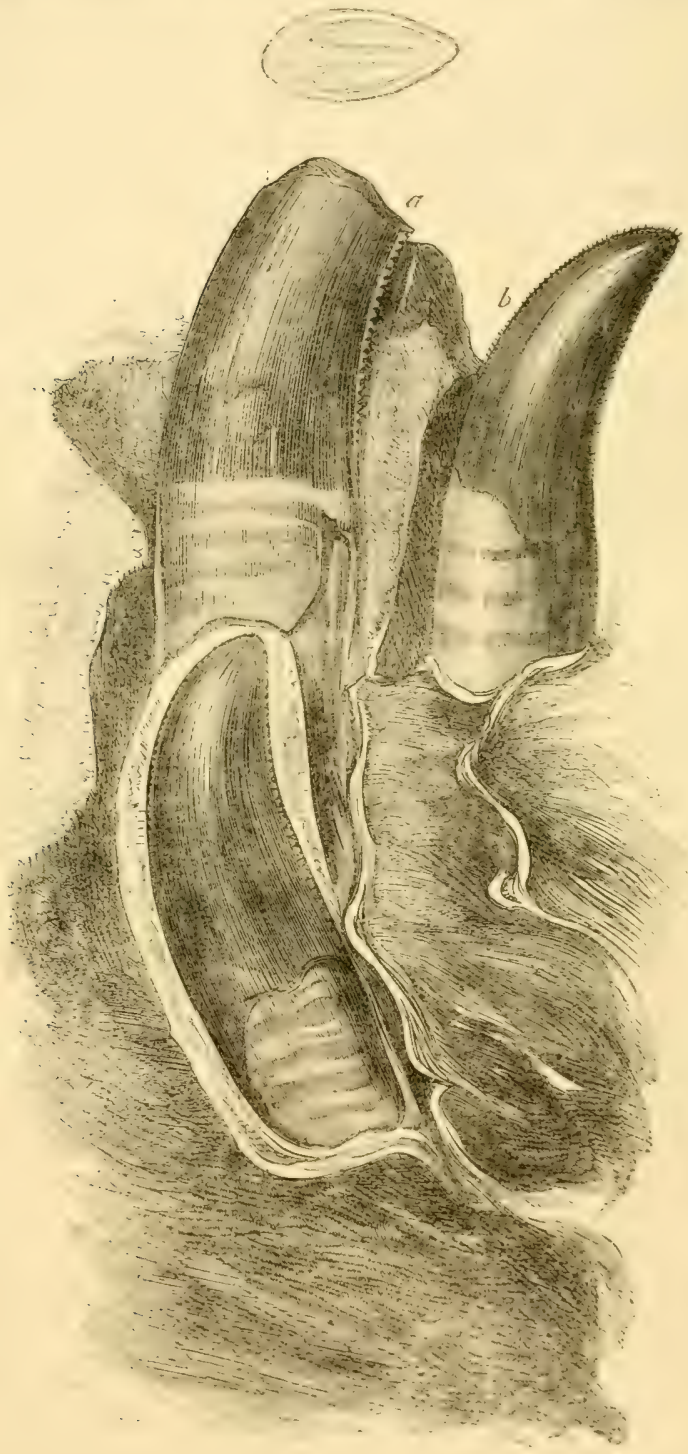

Fig. 75.

Section of jaw with tecth of the Megalosanurus Buclilandi, nat. size. 
wholly forms the manginal serrations. The base of the tooth is coated with a smooth, lighter-coloured cement, forming a thin liy:er, and becoming a little thiclier towards the implanted end of the tooth. The renains of the pulp are converted into usteo-dentine in the basal part of the completely formed tooth. Moderately magnified, the surfice of the enamel pressents a finely winkled appearance. The marginal serrations show, under a somewhat higher power, that the points are directed towards the apex of the tooth-a structure well adapted for dividing the tough tissues of the samrian integunent.

The main body of the tooth consists of dentine, of that hard unvasenlar kind of which the sime part of the teeth of existing crocodiles and most mammals is composed. No part of the dentine is pervaded by medullary canals, as in the Iguanodon.

A series of tecth from indivichal Megalositurs, of difierent ages, are preserved in the British Mrsemu and in the greological musem at Oxford; although diflering in size, they preserve the characteristie form above described. In one specinen the point of the crown and the trenchant margins have been rubbed down to a smooth obtuse surface; it seems to have come firm the hinder part of the dental series, where the teeth may have been smaller and less sharp, or more liable to be blunted by a greater share in the imperfect act of mastication, than the teeth in advance.

Successional teeth in different stages of growth are shown in the original portion of jaw of the Megalosaur in the Oxford musem. Some, more advanced, show their crowns projecting from alveoli already fomed by the plates extending across from the triangular processes before described: racant sockets, from which fully formed teeth have escaped, oceur, gencrally in the intervals between these more advanced teeth. The summits of less developerl treth are seen protuding at the inner sile of the lasal intersiaces of the trimgular plate, 


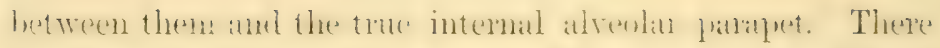

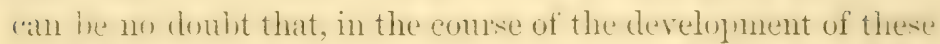
teeth, corresponding changes talie place in the jaw itself, hy which new triangular plates and alveolar partitions are formed, as the old anes hecome alsortred, analogons to those concomitant changes in the growth and form of the tecth, alveoli, and firw-, which take place in so striking a degree in the elephant. The peculiarity of the Megalosant, as compared with the rocodilen and lizards which have a like endless suceession of frecth, is the deeper position of the successional tooth (fig. 75, c), in relation to the one (e) it is destined to replace, and the great proportion of the tooth which is formed before it is protrueled. The anterior tooth a in this speceinen shows at the imner side of its base the commencing absorytion stimmlated by the encruaching capsule of the suceessional tooth c helow, the ('mwn of which is completed externally, thomgh nut consuliditied. On one of the fractured margins of this piece of jaw, a part of the basal shell of an absortied and shed tooth rematins, with part of the root of the suecessional tuoth. which has risen into place, but which shows its hase full of matrix, the pulp' not having been calleitied at that perind of the troth's growth.

In the proportion of the successional teeth which is firmed in the formative cavity in the sulustance of the jaw, the Megatlosaur offer's a closer resemblance to the mammilian class than do any of the recent or extinct crocodilian or lacertian i'prtiles. But the evidence of minterrupted and firepuent

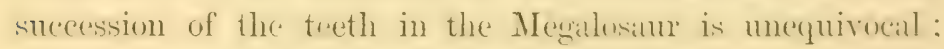
ant this pant of the dental eeomomy of the great camivorous

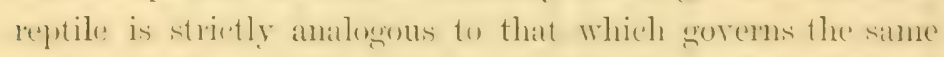
systeme in the existing members of the elar.s. The different lorms of the tereth at diflerent stages of protrusion elid not fial

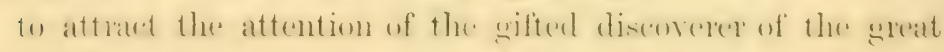

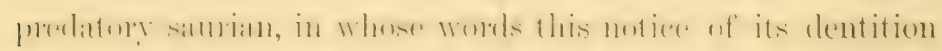
may be fitly concluded :- 
"In the structure of these tecth we find a combinuion of"

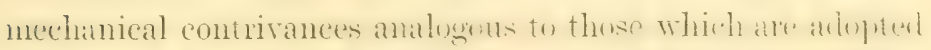

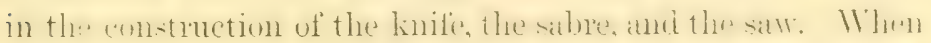

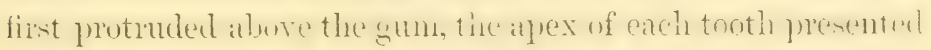
a doulle cutting elge of serrated eminrel. In this stage its

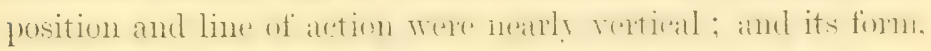

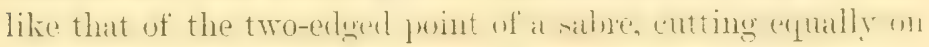

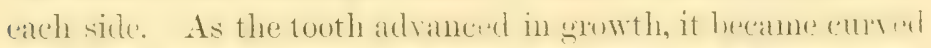

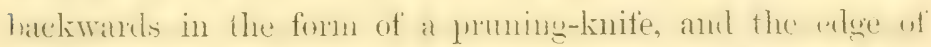
serrated emanel was contimued downwares to the hase of the imer and cutting side of the touth. whilst wn the onter sile it similin edge descended, hut a thomt distance fimm the juint : and the conver portion of the touth lecame hlunt and thick,

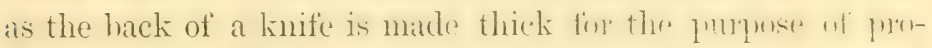
ducing strength. The strength of the tooth wath further incluased by the expansion of its sick. Had the serrature continued along the whole of the hlunt and enwex portion of the touth. it would in this position have posisessed no nseful cutting juwer: it ceased precisely at the print herondel whirh it rould no longer he effective. In a tomth thus linmed tin cutting

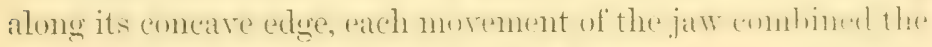
fuwer of the knife and saw : whilst the ajes, in moking the

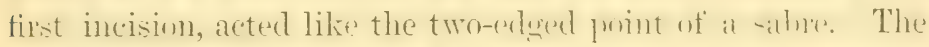

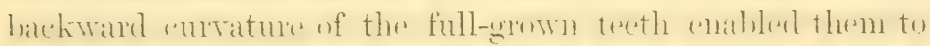

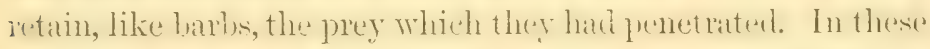
arlaptations we see contrivanees which homan ingunuity hat also adopted in the preparation of various instruments of art."

The olelest known herls from which any remains of IVeguloselies have been obtained are the luwer oolites at Selshy Hill,

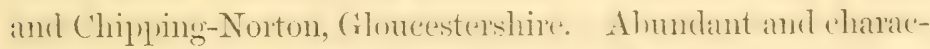
teristic remains oecur in the stomesfolel slate, ()xfordshire.

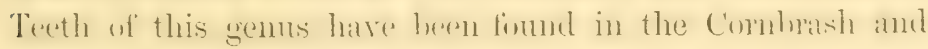

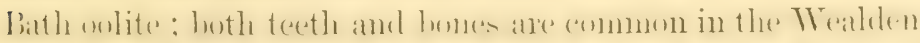

" Buckland, "Bridgewater 'Treatise," p. 236. 
strata and l'urbeck limestone. Some of these fussils indicate a reptile of at least 30 feet in length.

Gicmes IrLeasultres, Mtll.--Remains of the Dinosaurian so called have hitherto been fouml only in Wealden strata, as at Tilgate, Iolney, and Battle. 'The most instructive evidence is that which was exposed by the quarreymen of the Wealden stone at Tilgate, and wis obtained and described by Mantell in $18: 32$. It consisterl of a block of stone measuring $4 \frac{1}{2}$ feet hy 21 feet (fig. 76 ), and included the following jarts of the

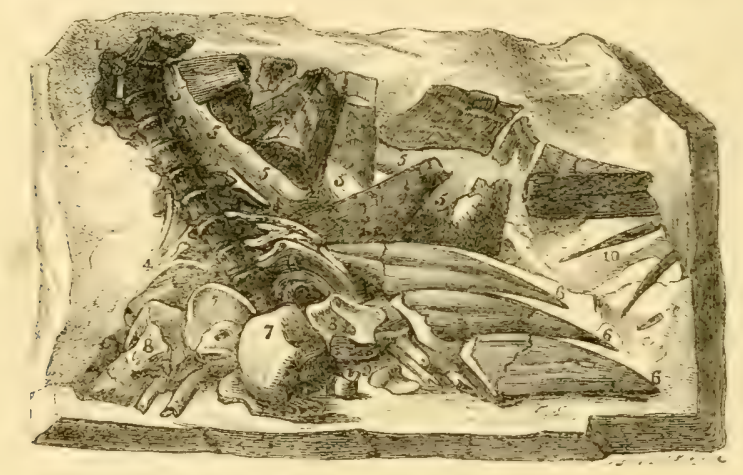

Fiig. 76 .

Hylceosaurus (W'ealden).

skeleton in almost natural juxtaposition :- - a, anterior vertebrae, the first supporting jart of the base of the skull ; several ribs, 4, 4; some enormons dermal bony spines, 5, 6, 6, which supported a strong defensive erent along the halek: two conat-

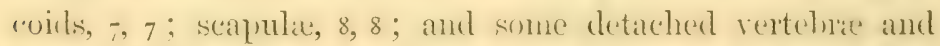
fragnents of bones. In 18.1 the writer showed that the sacrum was dinosaurian, and included five rertebre.

The treth are relatively small, chese-set, therendent in int-

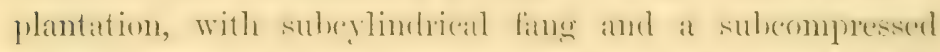
slightly expanded and inemonl arown, with the horderis staight and eonverenges to the hime alpex. They indicate

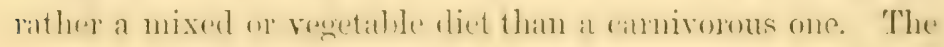


skin was defended by subcircular bony scales. The length of the Hylæosaur may have been 25 feet.

Genus Igtrasodon, Ittl. - Remains of the large herbivorous: reptiles of this genus have been found in Wealden and neocomian (greensand) strata. Femora, four feet in length, showing the third inner trochanter, have been discovered. The sacrum included five, and in old animals six, vertebre; the claw-bones are broad, flat, and obtuse. There were only three welldeveloped toes on the hind foot; and singular large tridactyle impressions, discovered by Beceles in the Vealden at Hastings, have been conjectured to have been made by the Iguanodon.

With vertebrus, subconcave at both articular extremities, having, in the dorsal region, lofty and expanded neural arches, and doubly articulated ribs, and characterized in the sacral region by their unusual number and complication of structure ; with a Lacertian pectoral arch, and unusually large bones of the hind limbs, excavated by large medullary cavities, and adapted for terrestrial progression; - - the Iyuanodon was distinguished by teeth, resembling in shape those of the Iguana, but in structure differing from the teeth of that and every other known reptile, and unequivocally indicating the former existence in the Dinosamian order of a gigantic representative of the small group of living lizards which subsist on vegetable substances.

The important difference which the fussil teeth presented in the form of their grinding surface was pointed out by Cuvier, of whose description Dr. Mantell adopted a conclensed view in lis Illustrations of the Geology of Sussex, Hto, 1827, p. 72. The combination of this dental distinction with the vertebral and costal characters, which prove the Iynanocton not to have balmoged to the same groul of Saurians as that which includes the Iguana and other modern lizards, rendered it highly desirable to ascertain by the inmproved modes of investi-

\%semens Fustiles, 1824 , vol. v., pt. ii., p. 351. 
gating rental structure, the actual anomet of correspondences between the Ifyenculon and Iguana in this respect. 'This has been done in the anthor's general description of the teeth of reptiles, ${ }^{*}$ from which the fillowing notice is abridged:-The wexth of the Imanodon (fig. 77), though resembling most

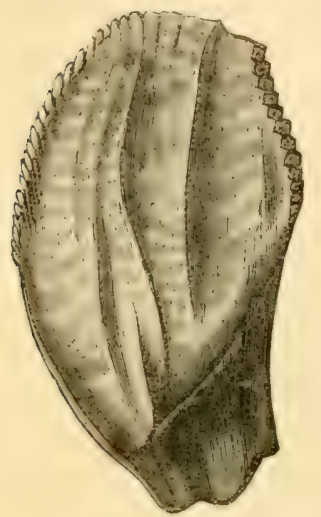

Fig. 77

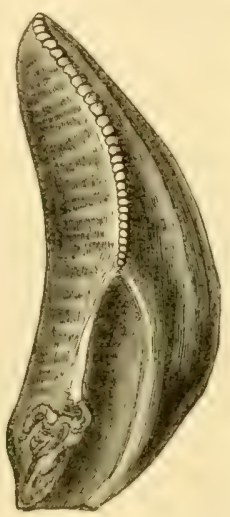

closely those of the Iguana, do not present an exact magnified image of them, but differ in the greater relative thickness of the crown, its more complicated external surface, and, still more essentially, in a modification of the internal structure, by which the Igua-

Front and side views of a tooth of the lower jaw of the Iguanodon, nat. size.

norton equally deriates ficm every other known reptile.

As in the Iguana, the base of the tooth is elongated and contrated; the erown expanded and smoothly convex on the imner side; when first formed it is acuminated, compressed, its sloping sides serrated, and one surfice, external in the npper jaw, internal in the lower jaw, is traversed by a median longitulinal ridge, and coated by a layer of enanel ; but beyond this point the deseription of the touth of the Iynanocton indicates character's peculiar to that genus. In most of the teeth that have hitherto been found, theee longitudinal ridges traverse the ridged surfice of the (rown, one on each side of the median prinitive rilge; these ane sepratated from each othere and from the serrated matroins ol the erown ly. fonr wile and smooth lomertudinal groores. The relative * Odontograplyy, pt. ii., p. 2.49; 'Transactions of the British Association, 1838. 
width of these grooves varies in diflerent teeth; sometimes : bouth small longitulinal ridge is develoned on the ridged sib of the cromb. The marginal serrations whith, all tirst sight aplyear to be simple notches, as in the Tommon, mesent under a low magnifying power (fig. 78), the form of transverse ridges, themselves notched, so as to resemble the mammilated margins of the unworn plates of the elephant's grinder; slight grooves lead from the interspaces of these notches upon the sides of the marginal ridges. These ridges or dentations domotextend beyond the expanded part of the crown; the longitudinal ridges are continued farther down, especially the median

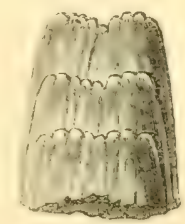

Fig. 78.

Marginal ridges on the tooth of the Iguanodon, magn. wes, which do not subside till the fang of the tooth hegins to assimne its subcylindrical form. The tooth at first increases both in breadth and thickness: then it diminishes in hreadth, hut its thickness goes on increasing; in the larger and fully formed teeth, the fang decreases in erery diameter, and sometimes tipuers alnost to a point. The smooth unbroken surface of such fings indieates that they did not adhere to the inner' side of the maxillae, as in the Tguana, but were placed in serparate alrenli, as in the Crocodile and Megalositur: such smplurt would appear, imberd, to be indispensable to teeth so worn by mastication as those of the Igranodon.

The apex of the tooth son begins to be worn away, and it womld alpear, by many specimens, that the teetlo were retained until nearly the whole of the crown had yichled to the daily abrasion. In these tecth, however, the deep excavation of the remaining fang plainly besperalis the progress of the suceessional tooth prepared to supply the place of the worn-ont grinder. At the eanlier stages of abrasion a sharpe erlge is maintaned at the risgeel part of the tooth by means of the emanel which covers that surface of the crown; the prominent rilges rymen that surfiter give a sinume contour to the mirlelle of the cutting 
edge, whilst its sides are jagged by the lateral serrations. 'The adaptation of this admirable dental instrument to the cropping and comminution of such tough vegetable food as the Clathrarice and similar plants, which are found buried with the Iguanodon, is pointed out by Inr. Buckland, with his usual felicity of illustration, in his Bridgewater Treatise, vol. i., 1) 246.

When the crown is worn awa beyond the enamel, it prerents a broad and nearly horizuntal grinding surface (fig. 79),

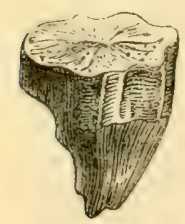

Fig. 79. and now another dental substance is brought into use, to give an inequality to that surface; this is the ossified remmant of the pulp, which, being firmer than the surounding dentine, forms a slight transverse ridge in the middle of the grinding surface; the tooth in this stage has A worn tooth of exchanged the functions of an incisor for that the Iguanoton. of a molar, and is prepared to give the final eompression, or comminution, to the coarsely divided regetable matters.

The marginal edge of the incisive condition of the tooth and the median ridge of the molar stage are more effectually established by the introduction of a modification into the texture of the dentine, by which it is rendered softer than in the existing Iguane and other reptiles, and more easily worn away. This is effected by an arrest of the calcifying process along certain cylindrical tracts of the pulp, which is thus continued, in the form of melullary canals, anilogous to those in the soft dentine of the Megatherium's grinder, from the central cavity, at pretty regular intervals, paralled with the dentinal tubes, nearly to the surfire of the tenth. The medullary camals radiate from the internal (upere jaw) or external (lower jaw) sicles of the pulp-eavity, and are confined to the dentine forming the corresponding walls of the tooth. Their dianeter is $\frac{1}{1 \cdot 2501}$ th of an inch. They are separated by pretty resular interrals, equal to from six to eight of their own diameters. They 
sometimes clivide once in their course. Wach medullary canal is surromed by a clear space. Its carity was occupied in the section described by a substance of a deeper vellow colour than the rest of the dentine.

The lentinal tubes present a diameter of $\frac{1}{1 \cdot 250}$ th of an inch, with interspaces equal to ahout four of their diameters. At the first part of their course, near the pulp-cavity, they are bent in strong undulations, but afterwards proeced in slight and regular primary curves, or in nearly straight lines to the periphery of the tooth. The secondary undulations of each tooth are regular, and rery minute. The branches, both primary and secondary, of the dentinal tubes are sent oft from the concave side of the main inflections; the minute secondary branches are remarkable at certain parts of the tooth for their flexuous ramifications, anastomoses, and dilatations into minute calcigerous cells, which take place along nearly parallel lines for a limited extent of the course of the main tubes. The appearance of interruption in the course of the dentinal tubes, occasioned by this modification of their secondary branches, is represented by the irregularly dotted tracts in the figure. This modifieation must contribute, with the medullary canals, though in a minor degree, in producing that inequality of texture and of density in the dentine, which renders the hroad and thick tooth of the Iynunodon more efficient as a triturating instrument.

The enamel which invests the harder dentine, forming the rirlged side of the tooth, presents the same peculiar dirty brown (olour, whein riewed by transmitted light, as in most other' tenth. Very minute and scarcely perceptible undulating fibres, muning vertically to the surface of the tonth, form the only discernible structure in it.

The remains of the pulp in the contracted cavity of the complotely formed tooth are converted into a dense but true ossenus substance, characterized by minute elliptical moliated (a)k, whose long axis is parallel with the plane of the eoneen- 


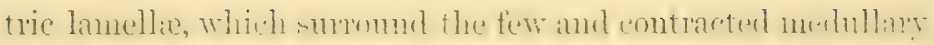
canals in this substance.

The microsenpical examination of the structure of the Iysenodon's tereth thus contributes additional evidence of the perfection of their adaptation to the offices to which their more obvious characters had indicated them to have heen destined.

To preserve a trenchant edge, a partial coating of enanel is applied: and, that the thick borly of the tonth might he worn away in a more regularly ollique plane, the dentine is rendered softer as it recedes from the enamelled edge, by the simple contrivance of arresting the calcifying process along certain tracts of the opposite wall of the tooth. When attrition has at length exhausted the enimel, and the tooth is limitexl to its function as a grincler, a third substance has been prepareed in the ossified remmant of the pulp to add to the efficiency of the dental instrument in its final capacity. Ans if the following reflections were natural and just, atter a review of the external characters of the dental organs of the Iyuanocton, their truth and beanty become still more manifest as our knowleclge? of their subject becomes more particular and cxact:-

"In this curious piece of animal mechmism we tind a varied arljustment of all parts and proportions of the tooth, to the excrese of peculiar functions, attended by compensations adapted to shifting conditions of the instrmuent during dinterent stages of its consumption. And we must estimate the works of nature by a different standard from that which we alply to to the pruluetions of human art, if we can view such examples of mechunical contrivance, mited with so much economy of expenditure, and with such anticipated allaptations to varyjug conditions in their application, without fouling at pofound conviction that all this adjustment has roultul form design and high intelligence."

All trace of dinosatuin reptiles disilpeats in the lower cretaceous beds. 
Order IX.-Crocodilia.

cher.-Teeth in a single row, implanted in distinct sockets: external nostril single and terminal or sub-terminal. Anterior trunk rertebre with par- and di-apophyser, and hifurcate ribs; sacral vertebre two, each supporting it, own neurai arch. Skin protected by bony, usually pitted plates.

\section{Sub-Order 1.-AMPHicela.*}

Crocodiles closely resembling in general for'm the long and slender-jawed kind of the Ganges callecl "gavial "or "gharrial," existed from the time of the deposition of the lower lias.

Their teeth were similarly long, slender, and sharp, adapted for the prehension of fishes, and their skeleton was modified for more efficient progress in water by the rertebral surfaces being slightly concave, ly the hind limbs being relatively larger and stronger, and hy the orbits forming no prominent olstruction to progress through water. From the nature of the deprosits containing the remains of the so-modified "rocodiles, they were marine. The fossil crocodile from the Whithy liats, described and figmed in the Philosophical Transactions, 1758, p. 688, is the type of these amphicalian species. They have been grouped under the following generic heads:- Telersaurus, Stencosumes, Mystriosanis, Macrospondylus, Mussospondylus, to which must be added Peciloplcuron, Pelergosererus, Eolodon, Suchosaurus, Goniophotis.

species of the above genera range from the lias to the challi inclusive.

Suchosemins of the Wrealden is characterized by the compressed crown and trenchant margins of the teeth ; Goniophotix, of the P'mbeck beds, by some of the demal scales having the same peg-anct-pit interlocking as in the scales of the gimoid fish in fig. 52 .

* Ampli, both; koilos, hollow; the vertebra being hollowed at both ends. 


\section{Sub-Order 2.-OpisthocceliA.*}

The small group of ('rocodilia so called is an artificial one, based upon more or less of the anterior trunk rertebre being united by ball-and-socket joints, but having the ball in front. instead of, as in modern crocodiles, hehind. Cuvier first pointed out this peculiarityt in a Crocodilian from the Oxfordian beds at Hontleur, and the Kimmeridgian at Havre. The writer has described similar opisthocnelian rertebre from the great oolite at Chipping Norton, from the upper lias of Whitby, and, but of much larger size, from the Wealden formations of Sussex and the Isle of Wight. These specimens probably helong, as suggested hy the writer in $18+1, t$ to the fore part of the same vertebral column as the middle dorsal vertebre, flat at the fore part, and slightly hollow behind, on which he founded the genus Cfiosmums. The smaller oppisthoccelian rertebra described hy Curier have heen referred hy Von Meyer to a genus called Streptospondylus.

In one species from the Wealden, dorsal rertebræ measuring 8 inches across are only + inches in length, and caudal vertelore nearly 7 inches across are less than 4 inches in length. These characterize the species called Celiosaurus brevis.\$

Caudal vertebre measuring 7 inches across and $5 \frac{1}{2}$ inches in length, from the lower oolite at Chipping Norton, and the great oolite at Enstone, represent the species called Cetiosamms medius.

Caudal rertebre from the Portland stone at Garsington, Oxfordshire, measuring 7 inches 9 lines across and 7 inches in front

* Opisthos, behind; koilos, hollow; vertebra concave behind, convex or flat

† Annales du Muséum, tom. xii., p. 83, pl. x. xi.

7 "Report on British Fossil Reptiles," Trans. Brit. Assoc. for 1811, p. 96.

2. They have since been referred to the dinosaurian order under the name af' P'elorosaurus, but without any evidence of the true sacral characters of that order; the carities of long bones are common to Crocorlilians and Dinosalurs. 
in length, are referred to the C'etiosaums longus. The latter must have been the most gigantic whale-like of coendilians.

\section{Sub-Order 3.-Proccelia.*}

The best aud most readily recognizable characters by which the existing Crocolilians are grouped in apynopriate genera are derived from modifications of the dental system.

In the caimans (genus Alligator) the teeth vary in mumber from $\frac{18-18}{18-13}$ to $\frac{22-22}{22-22}$; the fourth tooth of the lower jar or canine, is recived. into a cucity of the palatal surface of the upper jaw, where it is concealed when the mouth is shut; in old individuals the upper jaw is perforated by these large inferior canines, and the fosse are converted into foramina.

In the true crocodiles (genus Crocodilus) the first tooth in the lower jaw perforates the palatal process of the intermaxillary bone when the mouth is closed; the fourth tooth in the lower jaw is reccived into a notch excavated in the side of the alveolar border of the upper jaw, and is visible externally when the mouth is closed.

In the two preceding genera the alreolar borders of the jaws have an uneven or wary contour, and the teeth are of unequal size.

In the gavials (genus Gavialis) the teeth are nearly equal in size and similar in form

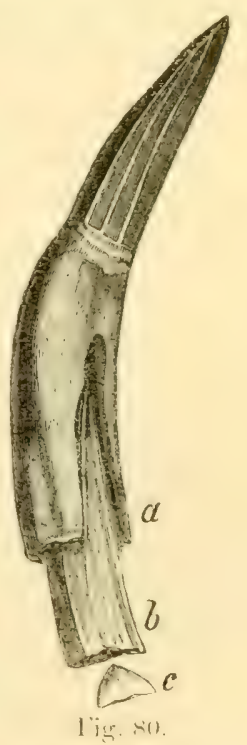
in both jaws, and the first as well as the T'eeth of the Gavial. fourth tooth in the lower jaw passes into a groove in the margin of the upper jaw, when the mouth is closed.

The number of teeth is always greater in the sarials than in the crocodiles or alligators. The first five pairs of teeth

* Pros, finnt; lioilos, hollow; vertebra with the eup at the fore part and the ball behind. 
above are sulpurted by the fremaxillary lunes: the first, second, and fourth of the lower jaw are the longest.

The eight or nine posterior teeth are nearly conical, the rest are sub-compressed antero-posteriorly, and present a trenchant elge on the right and left sille, hetween which a few faint longitudinal ridges traverse the lassal part of the enamelled crown (fig. 80 ).

The position of the opyosite sharp ridges, and the direction of the flat sides of the crown, are reversed in the extinct crocolile (Croe.cultrictens), which in other respects most nearly resembles the gavial in the form of the teeth.

In most of the extinet species of Crocodilians the tecth are characterized by more numerous and strongly developed longitudinal ridges mion the enamelled crown, than in the recent species; and they are commonly longer, more slender, and sharp-pointed. But in one of the crocodiles with sub-hiconcare vertebra (Goniopholis crassidens), from the Wealden formation and Purbeck limestone, the tecth have crowns which are as round and as thick in proportion to their length as in the recent crocodiles or alligators.

The more ancient erocodiles, from the Oolite and Lias, called Steneoscuri and Telcoscuri, had jaws like those of the modern gavials, but sometimes longer and more attenuated, and armed with more numerous, equal, and slender teeth, alapted for the eapture of fishes, which appear to have been the only other vertebrate animals existing at those periods in numbers sufficient to vield subsistenee to camivomens marine Saurians.

In all the Telrosentri the texth are more slemeler, hess exmpressed, and shaper pointed than in the gavial they ane slightly recurved, and the emanelled crown is traversed hy more munerous and leetter defined ribes-two of which, on

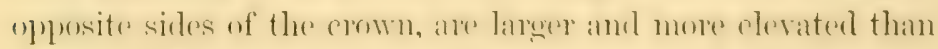
the rest. The fang is smonth, erlindrical, and always exeit- 
vated at the base. The teeth of the Sterreosaniv, or extinct (roconliles with long and slender jaws, and with vertehina subconcave at hoth extremitics, but with subterminal nostrils, cliffer from these of the Telosani in being somewhat thickes in proportion to their length, and larger in proportion to the jaws.

The teeth of both the existing and extinet crocorlilian reptiles consist of a body of compact dentine, forming a crown covered by a coat of enamel, amd a root invested by a moderately thick lixyer of cement. The root slightly enlarges or maintains the same breadth to its base (fig. 80, a), which is aleeply exeavated ly a conical pulp-carity extending into the erown, and is commonly either perforated or notehed at its concave or inner side.

The touth-germ e (figs. 80 and 81 ) is developed from the membrane covering the angle between the floor and the inner wall of the socket. It becomes, in this situation, completely enveloped by its capsule, and partially calcified, before the young tooth penetrates the interior of the pulp-eavity of its predecessor.

The matrix of the young growing tooth affects, by its pressure, the inner wall of the socket, as shown in figs. 80 and 81 , and forms for itself a shallow recess; at the same time it

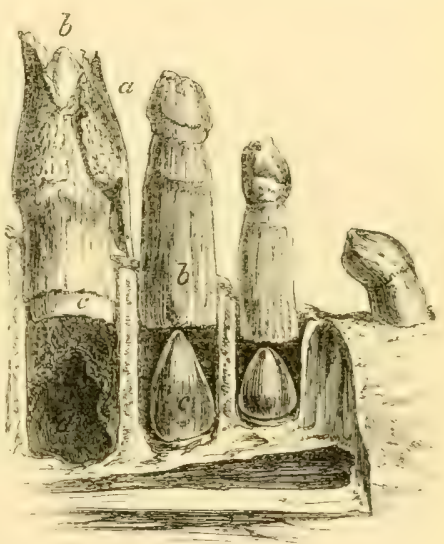

Fin. 81.

Section of jaw with teeth of the Alligator. attacks the side of the hase of the contained tooth: then, gaining a more extensive attachment by its basis and increased size, it penetrates the large pulp-cavity of the previnus? formed tonth eithere hy at circular or semicireular fuerforation. 
The size of the perforation in the tonth, and of the depression in the jaw, proves them to have been in great part caused hy the soft matrix, which must have produced its effect hy exciting absorbent action, and not by mere mechanical force. The resistance of the wall of the pulp-carity having heen thus overcome, the growing tooth and its matrix recede from the temporary alveolar depression, and sink into the substance of the pulp contained in the carity of the fully-formed tooth.

As the new tooth grows, the pulp of the old one is remored; the old tooth itself is next attacked, and the crown, heing undermined by the absorption of the inner surface of its base, may be broken off by a slight extrinal force, when the point of the new tooth is exposed.

The new tooth disembarrasses itself of the eylindrical base of its predecessor (fig. 81, a) with which it is sheathed, ly maintaining the excitement of the absorbent process so long as the cenent of the old fang retains any vital connection with the periosteum of the socket; but the frail remains of the old cylinder, thus reduced, are sometimes lifterl out of the sucket upon the erown of the new tooth (as in fig. s1, a), when they are speedily removed by the action of the jaws. This is, however, the only part of the process which is immediately produced ly violence; an attentive observation of the more important previous stages of growth, teaches that the pressure of the growing tooth operates upon the ome to he displaced only through the medium of the rital alsorlent action which it has excited.

No somer has the young tooth (fig. 80, l) penetrated the interior of the old one (fig. $80, a)$ than anothere gerem e. hexims to be developed from the angle leetween the lase of the young tonth and the immer alveolar proesss : or in the same relative position as that in which its prederesson began to rise, and the processess of sueression and displateenent are carried on 
minterruptedly throughout the long life of these cold-blooded carnivorous reptiles.

From the period of exclusion from the egg, the teeth of the crocodile suceed each other in the vertical direction; none are alded from behind forwards like the true molars in Mammalia. It follows, therefore, that the number of the teeth of the croculile is as great when it first sees the light as when it has acquires its full size; and, owing to the rapidity of their succession, the carity at the base of the fully-formed tooth is never consolidated.

The forisil jaws of the extinct crocodilians demonstrate that the same law regulater the succession of the teeth at the ancient epochs when those highly-organised reptiles prevailed in greatest numbers, and under the most varied generic and specific morlifications, as at the prosent period, when they are velucerl to a single family composed of so fer and slightly varied species as to have constituted in the system of Linneus a small fraction of the genus Laccrta.

The large, thick, extermally ridged or pitted scales, though commm to the crocodiitian order, are not peculiar to them. The labyrinthoknt Anisunes, the thecolont Stayenolepis, the lacertian Saurillus, have left similar petrified scales.

Crocodilians with cup-and-ball vertebre, like those of living species, first make their appearance in the greensand of North Anerica (C'rocotilms basifiesus and ('. Uresitmeatus). In Europe their remains are first found in the tertiary strata. Such remains from the plastic clay of Meudon have been refered to C'. isorthynches, C. celorhynchus, C. Becquereli. In the calcaire grossier of Argenton and ('astelnaudry have heen found the C'. Rullimetions C'. Dodunii. In the coeval eocene Lomilon clay at shely Island the entire skull and charac-

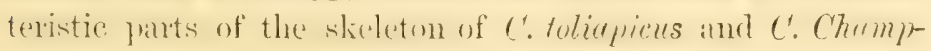

* "Lublyinthodun scutulutus," Trans. Geol. Soc, 2d series, rol. vi. p. 538 , pil. 46. 
soïdes ocener. In the somewhat later eocene berk at Bracklesham oceur the remains of the garial-like C. Dironi. In the Hordle heds have heen foumd the $C$. Hestingsice, with short and broikl jiws; and also a true alligator ( $C$. Hentoniensis). It is remarkahle that forms of procelian Crocodilia, now geographically restricted - the gavial to $A$ sia, and the alligator to America-shonld have been associated with tue crocodiles, and represented hy species which lived, during nearly the simme geological period, in rivers flowing over what now forms the south coast of England.

Many species of procelian Crocodilia have heen fourded on fossils from miocene and pliocene tertiaries. One of these, of the gavial sub-genus (C. crossidens), from the Seralik tertiary, was of gigantic dimensions.

\section{Order X.-Lacertilia.}

(Lizards, Monitors, Iguance.)

Chai:- Tertelnie procelian, with a single transverse proeess on each side, and with single-headed ribs; sacral verteliwe not excecting two : two external nostrils ; a formen parietale in most.

Small vertebre of the lacertian type have been found in the: Wealden of Sussex. They are more aloundant, and are associated with other characteristic parts of the species, in the eretaceous strata. On such evidence have heen hised the Raphioseneres sutuldens, the Coniasumes crassidens, and the Dotirhosentres lomgicullix.* The Iast-named species is rematriable for the length and stemelemess of its trumk and neceli. indieative of a temener to the ophidian forme. But the most rematkable and extreme molification of the latertian tye in

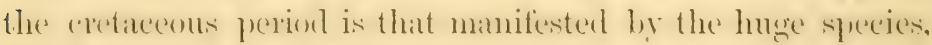

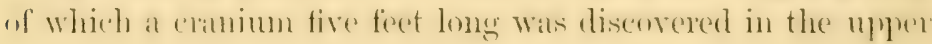

* Owen, "Ihistory of British Fossil Reptiles," 4to, pr. 173-183, pls. 2, 8, 9. 
chitle of st. Peter's Mount, near Maestricht, in 1780. 'The. vertehre are gently concare in front, and convex behind: there are thirty-four between the head and the base of the tail; a sacrum seems to have been wanting. The caudal verteline hate lomg nemal and hiemal spines, both of which arches coalesce with the centrum, and formeel the basis of at powerful swimming tail. The teeth are anchylosed to eminences along the alveolar border of the jaw, aceording to the acrolunt type. There is a row of smatl teeth on each pterygoid bone. For this genus of huge marine lizard the name Mosctsanims has heren proposed. Bessiles the M. Hofmanni of Matestricht, there is a M. Mue imillieni, from the eretaceous becls of North America, and a smaller species, II. greccitis, from the chalk of Sussex. ${ }^{*}$ The Leiodun anceps of the Norfolk chalk was a nearly allied marine Lacertian. $†$

Small pleurodont lizards, known at present only by jaws and teeth, with associated pitted scutes, but which may have hat procelian vertebre, have been discovered in Purbeck heds, and have been referred to the genera Sanrillus, Macetfoclus, ete.t Many small terrestrial Lacortions have left their remains in European tertiary formations.

\section{Order XI. - OPHIDIA.}

(Slow-xorms, Serpents.)

('has:- Vertebrite very numerous, proculian, with a single transverse process on each side; no sacrum; no visible limbs.

The order Ophidia, as it is characterized in the system of ('uvier, requires to be divided into two sections, according to the nature of the food, and the conserpuent undification of the jaws and teeth. Certain species, which subsist on worms,

$$
\begin{aligned}
& \text { * Op. cit. p. 185, pls. } 1,2,9 . \quad+\text { Op. cit. p. 195, pl. 10. } \\
& \text { † Quart. Journ, Geol. Soc., No, 40, 1854, p. } 120 .
\end{aligned}
$$


insects, and other snall invertelsate animals, hase the tympanic pedicle of the lowex jaw immediately and immoreably articuliterl to the walls of the eranium. The lateral branches of the lower jaw are fixed together at the symplyssis, and are opposed by the usual rertical morement to a similarly complete maxillary ath above; these belong to the genera $A$ mphisbene and Anguis of Limatus, the latter represented hy our common slow-worm. The rest of the Ophiclians, including the ordinary serpents and eonstrictors, which form the tropical members, and by far the greatest proportion, of the orter, prey. "1,on living animals of frequently much greater diameter than their own; and the maxillary apparatus is conformally and peculiarly modified to permit of the requisite distension of the soft parts surromding the month, and the transmission of their prey to the digestive cavity.

The carliest evidence of an ophidian reptile has been ubtained from the eocene elay at shepry ; it comsists of vertebra indicating a seryent of 12 feet in length, the Palcenthis toliopicys. Still larger, more numerous, and better preserved vertebre have been oldained from the eocene beds at Bracklesham, on which the Palcophis typhans and $P$. proicutus have heren founder." These remains indicate a boa-constrictor-like snake, of about 20 feet in length. Ophidian vertebre of much smaller siz', from the newer cocene at Hordwell, support the species called Palerya rhomlifer and P. deyressus. $†$ Fossil vertehre from a tertiary formation near salonica have been referred to a serpent, probathly poisomens, under the name of Lecophis.t it species of true vipere hats heen discovered in the mincene depersits at Simsans, south of France. Three forsil (Mphilians

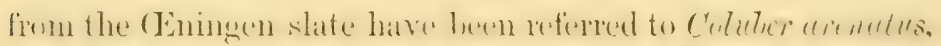
C. Kargii, and C!. Onenii.

$*$ History of British Fossil Reptiles, p1). 139-149, pls. 22 and 3. † Op. cit., p. 149, jl. 2, figs. 29-32.

1 "Quarterly Jumrnal of the Geological Socicty," vol. xiii, p. 196, pl. iv. 


\section{Order XII.-Chelonia.}

(Tortoises and T'urtles.)

Cher:-Trunk-ribs broal, flat, suturally united, forming with vertelbre and stermm an expanded thoracie abdominal case, into which, as into a portable chamber, the head, tail, and limbs can, usually, be withdrawn. No teeth : external nostril single.

lieference has already been made to the impressions in simdstones of triassic age in Dumfriesshire, referred by Lr. Duncan to turtoises. These inpressions have been finely illustrated in the great work hy Sir William Jardine on the footprints at Corncockle Murr. The earliest proof of chelonian life which the witer has olitained has been afforded by the skull of the Chelone planiceps, from the Portland stone; and hy the carrapace and plistron of the extinct and singularlymodified enydian genera Tretusternon and Plcurosternon * (fig. S2). In the first genus the plastron retains the central vacuity; in the second genus an additional pair of bones is interposed between the hyosternals (hs) and hyposternals (ps). In the specinen figmed (fig. 82), the plastron, and the under surface of the marginal pieces ( $z$ to $r z$ ) of the carrapace, of Plenrosternon cmanginatum are shown. This fine chelonite is now in the British Museum.

True marine turtles (Chelone Camperi, C. obovata, C'. muldriceps) have left their remains in cretaceums heds.t The emydian Protcmys is from the greensand near Maidstone.t The eocene tertiary deposits of Britain yield rich evidences of marine, estuary, and fresh-water tortoises. More species of true turtle have left their remaius in the London clay at the mouth of the Thames than are now known to exist in the

* Monograph of the Fossil Chelonian Reptiles of the Wealden and Purbeck Limestones, 4to, 1853, Palieontographical Society.

† Owen, "Hist. Brit. Fossil Reptiles," pl. 155-168, pls, 41-46.

\$ Op. cit, p. 169, pl. 47 . 
whole world; and all the encene Chelones are extinct. One of them ( $C$. gigues, Ow) attained unusual dinnensions; the skull, now in the British Musemm, measures nuwards of a fout across its hack part. ${ }^{*}$ The estuary genus Triony.r (soft

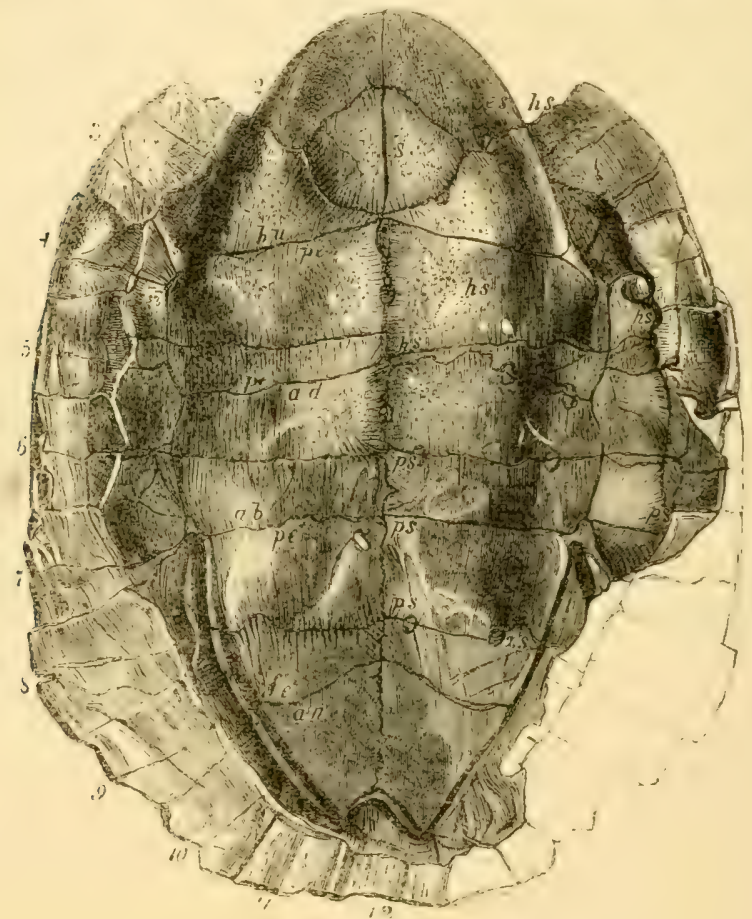

Fïg. 82.

Pleurosternon emarginatum (Purbeck).

furtle) is represented ly many heatiful species in the nyputi

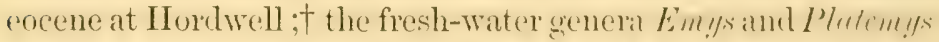
hy as many species, both at sheply amt Inotwell. lu the

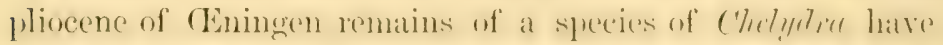

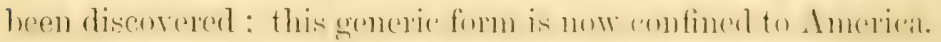

* The upper end of the femur from Sheppy, in t. xxix. of Monograph of Fossil Reptilia of the London Clay, Palecontographical Society, 1850, belongs to this species. See also "Hist. of Brit. Foss. Reptiles," pp. 10-40, pls, 1-22.

† Op. cit., pp. 50-60, pis. 26-33. 
Lienains of land-tortoises (Testudo, Brong.) indicate several extinct species in the miocene and pliocene formations of continental Europe. Strata of like age in the Sewalik Hill: have revealed the carapace of a tortoise 20 feet in length; it is called ly its discoverers, Cautley and Falconer, Colossochelys afles. The same locality has also afforted the interesting evidence of a species of Emys (E. tectnm, Gray) having contimmer to exist from the (probahly miocene) perior of the Sivatherium to the present day.

\section{Order XIII.-BATRACHIA.}

(Toads, Frogs, Newts.)

Char- Tertebrat liconcave (Siren), procalian (Rena), or opisthoculian $(P$ ija $)$ p pleurnophyses short, straight. Two occipital condyles; two vomerine bones, in most dentigerous: no scales or scutes. Larve with gills, in most deciduous.

It is only in tertiary and post-tertiary strata that extinct species, refurable to still existing genera or families of this orler, have been fombl. The reptiles with anphibian or hatrachian characters, of the carboniferous and triassic perinds. rombinesl those characters with others which gave them distinctions of ordinal value: they illustrated, indeed, rather a retention of the more general cold-blooded vertebrate tye, with conconitant piscine and samrim features, than any near athinity with the more specially modified naked or soft-skimed reptiles to which the nane Butrachie is given in zoulogieal catalogues of existing species.

Of the tailless or "anourous" Batrachia, toads of extinct specter (I'eleophrynes Gessneri and P. dissimilis) have been discerered in the Eningen leeds: and frogs, more alomelantly, in both mioene and pliosene depesits of Franee and (xermany.

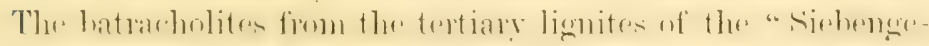


birge," near Bomm, slum different stages of transformation of the Rene dilucinne, Cill. 'Tertiary shates from Bonbar have mate known to the auther the small fossil Rume pusille.

(1) the sillmander fimily, the most noted fusil is that which was refermed, when first discovered at Eningen in 17:66, 10 the human spereies, ats Homo dilurii testis. C'uvier demonstrated its near aftinities to the water-salamander (Henopomu) of the Inited States: nore recently a living species of salanander has been discovered in Japun which equals in size the fossil in question-Andrias Scheuchzeri.

A retrosperet of the forexging outline of the palieontulogy of the class of reptiles shows that, unlike that of fishes, it is now on the wane: and that the period when Reptiliu fourished under the greatest diversity of forms, with the highest grade of structure, and of the most colossal size, is the mezozuic. The progress of air-lireathing vertehrates, gracluating hy chose? transitional steps from the water-breathing class, has becn checked, as if it had heen unequal to the exigencies and lifecapacities of the present state of the planct. Peptiles have been superseded by air-hreathers of higher types, which cammot he directly derived from the class of fishes. A more generalized rertebrate structure is illustrated, in the extinct reptiles, by the aftinities to ganoid fishes shown by the Gandepluale. Labyrinthodontie, and Iefhthyopteryyiat by the aftinities of the Pterosentice to birels, and by the alproxination of the Dinoscempire to Xammals. It is manifesterl by the comblumation of modern crocorlilian, chelonian, and lacertian chatraters: in the

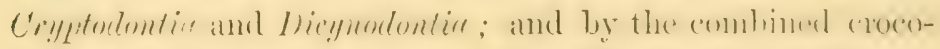

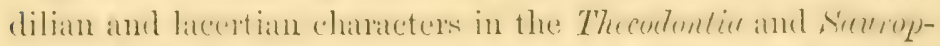

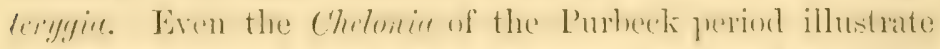
the same principle, he the mone typical number of molified

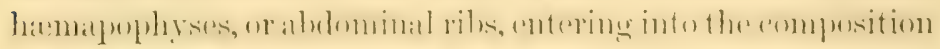
of their plastron. 
The diagram (fig. 83) gives a concise view of the geological relations, or distribution in time, of the principal groups of the class Reptitio. In the column opposite the right hand, the dark mark shows that the ganocephalous group represented by the Archegosaurus began, culminated, and ended in the carboniferous period. The Labyrinthodonts, culminating in the trias, disappear at the base of the oolitic system. Of the true Batrachia, those retaining the tail appear to have been at their maximum during the upper tertiary period, and to have begun to decline after

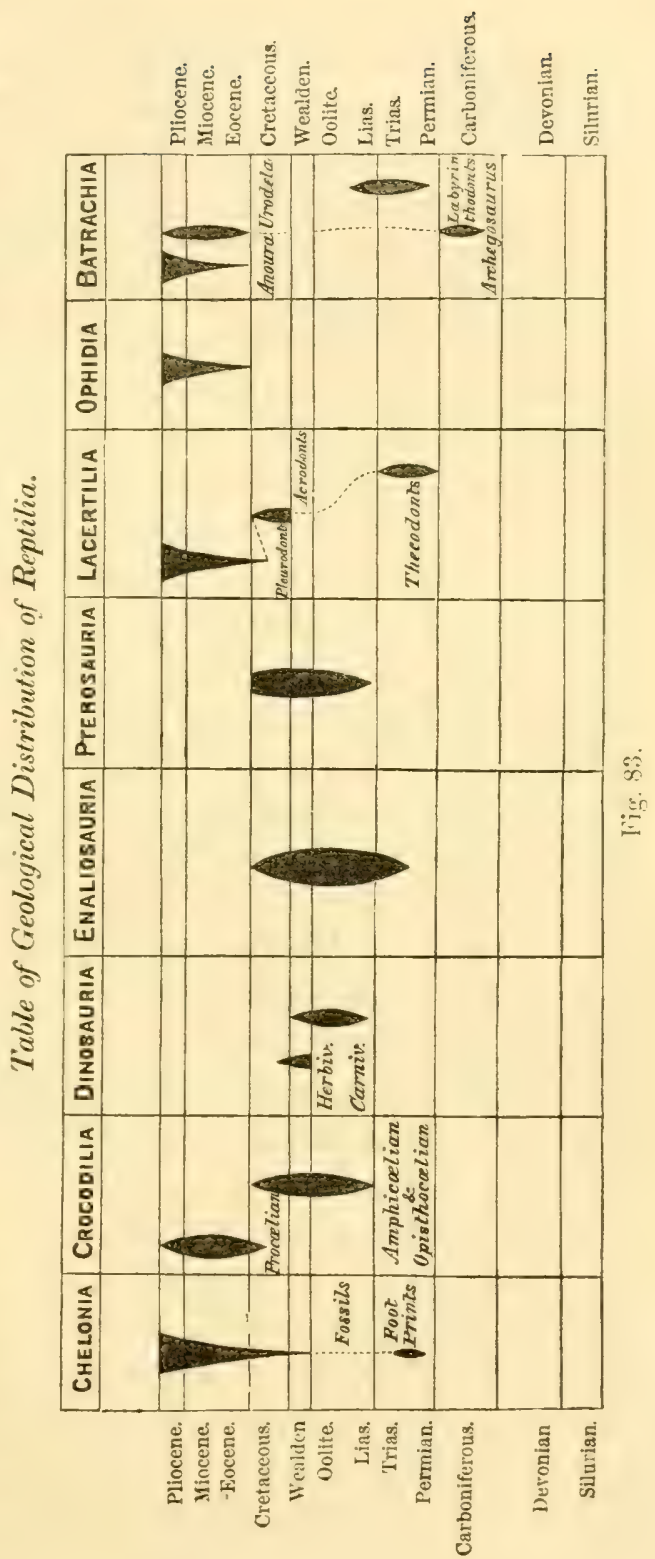


that time; whilst the tailless genera and species are nost numerous and varions at the present day. The Opthedie. resemble the Anoura, commencing in the older tertiary, and showing their maximum of derelopment at the present day. The true procelian, and especially the pleurodont, lizards, commencing a little earlier in the chalk, have also gone on increasing in number and variety of forms to the present day. The acrodont group, was represented by MLosescurrus, with a maximum of size, during the cretaceous period. The Thecodonts have but the partial relationship to modern Lacertilice which the Labyrinthodonts bear to the molern Butruchiu. The great ordinal grouls of Ichthyo- and Sentro-pterygue, of Pterosauria, and Dinosentia, together with the amphi- and opistho-colian Crocolilie, passed away ere the tertiary time had dawned. The procelian crocodiles which culminated in the lower and middle tertiary times, are now on the wane. Perhaps, also, the same might be sail of the Chclonie, in regard to the size of individuals and the number of speeies of certain genera (e.g. Chelone, Trionyx, Chelydra).

\section{Class III.-A VES.}

Long before any evidence of birds from actual or recognizable fossil remains is obtained in tracing the progress of life from the oldest fossiliferous deposits upwards, we meet with indications of their existence impressed in sandstones of the triassic or liassic period.

These earliest evidences of the class are by footprints in some former tidal shore, preserved in one or wher of the ways explained in the section "Ichnology." The forsil bones of lireds have not been found save in stratir of much later dite than the impressed sandstones; and they are much more rare than the remains of mammals, reptiles, and fishes, in any formations except the most recent in certain liniter localities, - c.g., New Zealand. 
sir (: Lyell has well remarked, that "the power's of flight possessed by most birds would insure them against perishing by numerous casualties to which quadrupeds are exposed during llooks." The same writer further argues, that "if they (hance to be drowned, or to die when swimming on water, it will scarcely ever happen that they will be submerged so as to become preserved in sedimentary deposits." * It is true that the earcase of a floating bird may not sink where it has died, hut be carried far along the stream : ultimately, however, if not deroured, its bones will sulside when the soft liarts $^{\text {nats }}$ have rotted, and both the compactness of the osseous tissue, and the facts made known by the ornitholites of the greensand near Cambridge, of the London clay at Sheppy, and of the Montmartre eocene quarry-stone, show that they can be preserved in the fossil state. The length of time during which the carcase of a bird may float, doubtless exposes it the more to be devoured, and so tends to make more scarce the fossil remains of birds in sedimentary strata. Certain it is that the major part of the remains of extinct birds that have as yet been found are those of hirds that were deprived of the power of flight, and were organized to live on land.'

The existence of birds at the triassie period in geology, or at the time of the formation of sandstones which are certainly. intermediate between the lias and the coal, is indicated by abundant evidences of footprints impressed upon those sandstones which extend through a great part of the ralley of the Connecticut River, in Comnecticut and Massachusetts, Nortlı America.

The footprints of birds are peculiar, and more readily distinguishable than those of most other animals. Birds tread on the toes only; these are articulated to a single metatarsal bone at right angles equally to it, and they diverge more from each other, and are less comnected with each other, than in * Principles of Geology, ed. 1847, p. 721. 
other animals, except as regards the weh-footed order of birds.

Not more than three toes are directed forwarl; $*$ the fourth when it exists, is directed hackward, is shorter, usually rises higher from the metatarsal, and takes less share in sustaining the superincumbent weight. No two tnes of the same foot in any bird have the same number of joints. There is a constant numerical progression in the number of phalanges (toe-joints), from the innermost to the outermost toe. When the back toe exists, it is the immermost of the four toes, and it has two phalanges, the next has three, the third or middle of the front toes has four, and the outermost has five phalanges. When the back toe is wanting, as in some waders, and most wingless birds, the toes have three, foul, and five phalanges respectively. When the number of toes is reduced to two, as in the ostrich, their phalanges are respectively four and five in number : thus showing those toes to answer to the two outermost tore in tridactyle and tetradactyle birds.

The same mumerical progression characterizes the two phalanges in most lizards from the innermost to the fourth : but a fifth toe exists in them which has one phalumx less than the fourth toe. It is the fifth toe which is wanting in erery hird. In some Gallinace, one or two (Paro bienlearetus) spurs are superadded to the metatarsus; lut this peeuliar weapon is not the stunted homolngue of a tor. I)r. J)eane of Cireenficld, United States, noticel, in 1835, impressions respmlling the feet of hirds in some slahs of sandstone from connectient River, and first, in a letter to Dr. Hitehenck, dated Mareh 7. 1835, recorded his belief that they were the finotstepes of a hirrl. He prepared casts of the impressions, some of which he transmitted, with his opinion of their nature, to Professon Silliman, Erlitor of the "American . Iommal of Seienee" in April 78.35. I)r. Hitrhenek, I'resirdent of Amherst ( oullewe, United States, first * Save in the Swift. 
made public the fact, based on scientific comparison, and submitted to the geological world his interpretations of those impressions as having been produced by the feet of living birds, and he gave them the name of Ormithichnites.

It was a startling amnomeement, and a conclusion that must have had strong evidence to support it, since one of the kimds of the tracks had been made hy a prair of feet, each leaving a print 20 inches in length. Cnder the term Omithichnites gigantens, however, 1r. Hiteheock did not shrink from proclaiming the fact of the existence, during the period of the deposition of the red samdistomes of the valley of the ('ommecticut, of a bird which must have been at least four times larger than the ostrich.* The impressious succeederl each other at regular intervals; they were of two kinds, but differing only as a right and left foot, and alternating with each other, the left foot a little to the left, and the right font a little to the right, of the mid-line hetween a series of tracks. Each footprint (fig. 84, $b$ and $r$ ) exhilits three toes, diverging as they extend forwarks. The distance between the tips of the inside and outside toes of the same foot was 12 inches. Each toe was terminated ly a short strong claw projecting from the mid the a little on the inner side of its axis, from the other two toes a little wn the outer sicle of theirs. The end of the metatarsal bone to which those toes were articulated rested on a two-lohed cushion which sloped upwards behind. The inner toe (r) showed distinctly two phalangeal divisions, the mirldle toe three, the onter toe $(b)$ four. And sinee, in living birds, the penultimate and ungual phalanges usually leave only a single impression, the inference was just, that the toes of this large foot had been characterized hy the same progressively-increasing number of phalanges, from the imner to the outer one, as in hirds. And, as in hirds also, the toe with the greatest number of joints was not the longest; it

* American Joumal of Science for 1836, vol. xxix., pl. i. 
measured, c.y., $12 \frac{1}{2}$ inches, the middle toe from the same baseline measured 16 inches, the outer toe 12 inches. Some of the inmpressions of this huge tridactylous footstep were so well preserved as to demonstrate the papillose and striated character of the integument covering the cushions on the under sicle of the foot. Such a structure is rery similar to that in the ostrich. The average extent of stride, as shown by the distance between the impressions, was between three and four feet; the same limb was therefore carried out each step from six to seven feet forward in the ordinary rate of progression.

These footprints, although the largest that have been ol)served on the Connecticut sandstones, are the most numerons. The gigantic Brontosoum, as Principal Hitchcock proposes to term the species, "must have been," he writes, "the griant rulers of the valley. Their gregarious character appear's from the fact, that at some localities we find parallel rows of tracks a few feet distance from one another."

The strata of red sandstone, with the above-ilescribed impressions, occupy an area more than 1.50 miles in length, and from 5 to 10 miles in breadth. "Having examined this series of rocks in many places, I feel satisfied that they were formed in shallow water, and for the most part near the shore; and that some of the beds were from time to time raised above the level of the water and laid dry, while a newer series, composed of similar sediment, was forming." "The tracks have been found in more than twenty places, scattered through an extent. of nearly 80 miles from N. to S., and they are repreated through a succession of beds attaining at some points a thickness of more than 1000 feet, which may have heen thousands of year's in forming." **

One of the evidences of hirds from the cimminilge greensand, transmitted to the writer hy their cliseoverer, Mr. Barret, is the lower half of the trifiel netatarsal, showing the outer toe-

* Lyell, Manual of Elementary Geology, 8vo, 1855, ]. 343. 
joint mueh higher than the other two, and projecting backwards above the middle joint; it indicates a bird about the size of at woodcock.

In the conglomerate and plastic clay at the base of the rocene tertiary system at Mendon, near Paris, the leg and thigh bones (tibia and femur) of a bird (Gastomis Parisicnsis) have been discovered: they indicate a genus now extinct. They belonged to a species as liurge as an ostrich, but more robust, and with affinities to wading and aquatic birds.*

In the eocene clay of thepry, fossil remains of hirds have heen found, indieating a small vulture (Lithornis vulturinus); also a bird, probably of the hing-fisher family (Hulcyornis tolirpricus), and a species of the sea-gull family. In the same formation at Highgate, remains of a species of the heron fanily have been found.

The fossil bones of hirds from the gypsum quarries at Montmartre were referred or approximated by Cuvier to eleven ristinct species. Good ornitholites have been obtained from the Hordwell fresh-water deposits.

The most ancient example of a passerine bird is the Pintornis Glarisionsis, founded on an almost entire skeleton discovered in the schistose rock of Crlaris, referable to the alder. division of the encene tertiary series. This skeleton is about the siz' of a lark, and in some respects similar to that bircl.

Comparisons of the ornitholites of the eocene tertiaries show that the following ordinal modifications of the class of birds were at that period represented: the raptorial, or birds of prey, by species of the size of our ospreys, buzzards, and smaller' falcons, and most probalbly also by an owl; the insessorical, or tree-perehing birds, by species seemingly allied to the nuthatch and the lark; the scunsorids or anisodactyles, by species as

* Hebert, "Comptes Reudus de l'Acad. des Sciences," 1855. Owen "On the Aftinities of Gastornis Parisiensis," Quarterly Journal of Geological Socjety, vol. xii., 1856, p. 204. 
large as the cuckoo and king-fisher ; the resuriuls, by a species of small quail; the cursorials, by a species as large as, but with thicker legrs than, an ostrich; the grallatorial, by a curlew of the size of the ibis, and by species allied to Scolopax, Tringa, and Pelidna, of the size of our woodcocks, lapwings, and sanderlings; and the nataturial, by species allied to the cormorant, but one of them of larger size, though less than a pelican ; also by a species akin to the divers (Merganser').

The remains of birds becone more abundant and raried as we approach the present time ; especially in the miocene strata, so richly developed in France, although wanting in Britain. One of the most singularly-modified forms of beak is shown by the flamingo. The fossil skull of a species of this genus (Phcenicoptems) has been found in the miocene fresh-water deposits of the platean of Gergovia, near Clermonte-Ferrand ; the entire metatarsal bone of a species of eagle (Aquila) or osprey (Pandion) in the same deposits at Chaptusal, Allier ; and the humerus of a bird allied to and as large as the albatross, in the molasse coquillière marine at Armagne. Remains of a vulture, most probably a Cathartes, have been found in the miocene lacustrine deposits of Cantal. Indications of all the other orders of birds, save the great Cursores or Struthionida, have also been discovered in miocene strata-those of wading birds being the most numerous.

Fossil egrs of birds oceur in miocene deposits in Aurergne ; and impressions of feathers have been discovered in the pliocene calcareous marls at IIntebolca. In pliocene brick-earth deposits in Essex has been found a fossil metatarsal of a swan, as large as, and not distinguishable from, the existing wild swan; in the pleistocene clay at Lawford a fossil humerus like that of a wild goose. But most of the ornitholites of this recent tertiary periol have heen discovered in ossiferous eaverns. They belong to birds closely resembling the falcon, wood-pigeon, lark, thrush, teal, and a small wader. The writer 
has receired information of skeletons of birds found deeply imbedded in stratified clay at Aberdeen and Peterhead.

The most extraordinary additions to the present class have heen obtained from the superficial deposits, turbaries, and caves in New Zealand.* This island is remarkable for the absence of aboriginal species of land - mammals, and for the presence of a small bird with very rudimental wings, and the keel-less sternumandloose plumage of the Struthious order, but of a peculiar genus called $A p$ teryx: the legs are very robust, and have three front toes and a very small back toe. Birds resembling the Apteryx in the

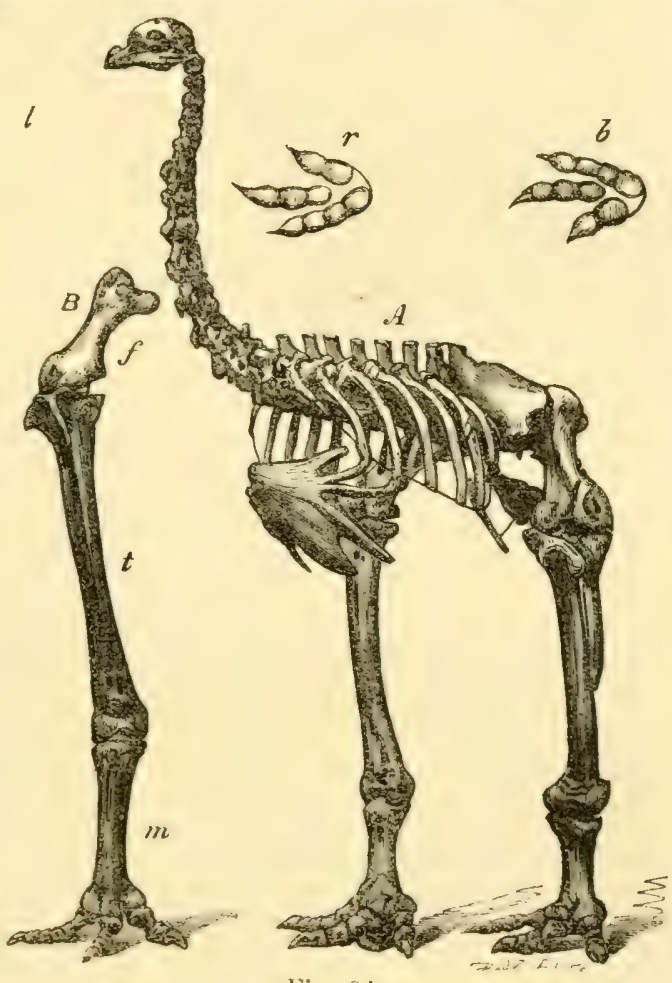

Fig. 84.

A. Dinornis elephantopus.

$B$. Log-bones of Dinornis giganteus.

$b, r$. Impressions called Ornithichnites.

shape of the sterum and hony structure of the gelvis and hind limbs, some retaining also the small back toe, others apparently without it, formerly existed in New Zealanul

* These remains are described in eight memoirs by the writer, published in the thirl and fourth volumes of the Transactions of the Zonlegical Secicty of London. The description of the first fragment of the bone, indicative of the Diromis, is in rol. iii., p. 39, pl. 3. 
under different specific forms ranging in height from 3 feet to 10 feet. They have heen referred by the writer to the genera Dinomis and Paluptery.r. The gigantic species are interesting, as exhibiting birds equal to the formation of tridactyle impresions as large as those of the Comnecticut sandstones, called Ornithichnites (Brontozoum) gigas (fig. St, r, b). In this 'ut is given a figure of the leg-bones of Dinornis giganters $(B)$, in which the tibia $(t)$ measures upwards of a yard in length. In the entire skeleton $(A)$ of another species, the metatarsus is as thick, but only half as long, as in the $D$. giganters; the framework of the leg is the most massive of any in the class of birds ; the toe-bones almost rival those of the elephant; whence the name Dinomis elcphantopus, given to this species. Several other species of these extinct tridactyle wingless birds have been determined-e.g., Dinomis ingens, D. struthioüles, D. thë̈les, D. diomioides, D. casuarinus, D. robustus, D. crassus, D. gerunoüdes, D. curtus. With these remains have been found bones of a bird the size of a swan, but of an extinct gemus (Aptornis); also those of a large coot (Noturmis Mantelli) which, founcled originally on fossil remains, was afterwards discorered living in the Middle Island of New Zealand. Two species of Aptery, not distinguishable from the existing kinds, were contemporaries with the gigantic Dinomis, and the writer has received evidence that the $D$. elephantopus afforded food to the natives at probably no very remote period. Some of the smaller kinds of Dinomis may yet be found living on the Middle Islind.

In Madagascar portions of mestatarsal bones, indicating a three-toed bird (Epiomis) as large as, but generically distincet from, the Dinomis gigunters, have been diseovered in alluvial banks of streams ; and with them entire exgs, meatsuring from 13 to $1+$ inches in long diameter. The enntents of one of these roges is emputed to eynal those of six ostrich regres, of of one hundred and forty-eight hen's eggs.

In the neighbouring istand of Manritius the dodn (Didns 
ineptus) has been exterminated by man within the period of two centuries; and in the islands of Bourbon and Rodriguez the "solitaire" (Pcrophaps) has also become extinct. Both these birds had wings too short for flight.

\section{CLASS IV.-MAMMALIA.}

\section{(Warm-blooded, Air-breathing, Viviparous Vertebrates.)}

Every calcified part of an animal, whether coral, shell, crust, tooth, or bone, can preserve its form and structure when buried in the earth during the changes there gradually operated in it, until every original particle may have been removed and replaced by some other mineral substance previously dissolved in the water percolating the bed containing the fossil. A bone, or other part so altered, is said to be "petrified." Not only are all its outward characters preserved, but even the minutest structure may be, and in most cases is, denonstrable in the fine sections under the microscope.

Fossil bones and teeth have been discorered in every intermediate stage of alteration, from their recent state to that of complete petrifaction. Recent bones consist of a soft-commonly called animal or organic-basis, hardened by earthy salts, chiefly phospluate of lime** Fishes have the smallest proportion, birds the largest proportion, of the earthy matter in their bones. The soft part is chicfly a gelatinous substance.

\section{Proportions of Hard and Soft Matter in the Bones of the} Vertebrate Animals.

FISHES.

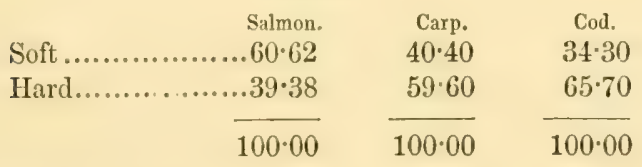

* 'That this combination of phosphorus and calcium has ever taken place in nature, save under the influences of a living organism, remains to be proved. 


\begin{tabular}{|c|c|c|c|}
\hline \multicolumn{2}{|c|}{$\begin{array}{l}\text { Soft ................35 } 50 \\
\text { Hard..............6 } 64 \cdot 50\end{array}$} & $\begin{array}{l}\text { Snake. } \\
31 \cdot 04 \\
69 \cdot 96\end{array}$ & $\begin{array}{l}\text { Lizard. } \\
46 \cdot 67 \\
53 \cdot 33\end{array}$ \\
\hline \multicolumn{2}{|c|}{$100 \cdot 00$} & $100 \cdot 00$ & $100 \cdot 00$ \\
\hline $\begin{array}{l}\text { Porpoise. } \\
\text { Soft ...........35.90 } \\
\text { Hard ...........64 } 64 \cdot 10\end{array}$ & $\begin{array}{l}\text { MMALS. } \\
\text { Ox. } \\
31 \cdot 00 \\
69 \cdot 00\end{array}$ & $\begin{array}{l}\text { Lion. } \\
27 \cdot 70 \\
72 \cdot 30\end{array}$ & $\begin{array}{l}\text { Man. } \\
31 \cdot 03 \\
68 \cdot 97\end{array}$ \\
\hline $100 \cdot 00$ & $100 \cdot 00$ & $100 \cdot 00$ & $100 \cdot 00$ \\
\hline $\begin{array}{l}\text { Soft............ } \\
\text { Hard........... }\end{array}$ & $\begin{array}{l}\text { BIRDS. } \\
\text { ose. } \\
.91 \\
.09\end{array}$ & $\begin{array}{l}\text { Turkey. } \\
30 \cdot 49 \\
69 \cdot 51\end{array}$ & $\begin{array}{l}\text { Hawk. } \\
26 \cdot 72 \\
7: 3 \cdot 28\end{array}$ \\
\hline & & $100 \cdot 00$ & $100 \cdot 00$ \\
\hline
\end{tabular}

The chemical nature of the hardening particles, and of the soft basis of bone, is exemplified in the suljoined talble, including a species of each of the four classes of Tertebrata :-

Chemical Composition of Bones.

\begin{tabular}{|c|c|c|c|c|}
\hline Ingredients. & Hawk. & Man. & Tortoise. & Cod. \\
\hline $\left.\begin{array}{c}\text { Phospliate of lime, with } \\
\text { trace of fluate of lime ... }\end{array}\right\}$ & $64 \cdot 39$ & $59 \cdot 63$ & $52 \cdot 66$ & $57 \cdot 29$ \\
\hline Carbonate of lime ............... & $7 \cdot 03$ & $7 \cdot 33$ & $12 \cdot 53$ & $4 \cdot 90$ \\
\hline Phosphate of magnesia.......... & 0.94 & $1 \cdot 32$ & 0.82 & $2 \cdot 40$ \\
\hline $\left.\begin{array}{c}\text { Sulphate, carbonate, and } \\
\text { chlorate of soda .......... }\end{array}\right\}$ & $0 \cdot 92$ & $0 \cdot 69$ & 0.90 & $1 \cdot 10$ \\
\hline Glutin and chondrin............ & $27 \cdot 73$ & $29 \cdot 70$ & $31 \cdot 75$ & $32 \cdot 31$ \\
\hline 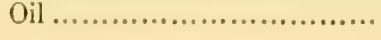 & $0 \cdot 99$ & $1 \cdot 33$ & $1 \cdot 34$ & $2 \cdot 00$ \\
\hline & 100.00 & $100 \cdot 00$ & $100 \cdot 00$ & $100 \cdot 00$ \\
\hline
\end{tabular}

The most common change which bones first underen is the loss of more or less of their original soft and soluble basis. This effect of long interment is reatily tested by applying the? specinen to the tongue, when the allinity of the pores of the? earthy constituent, after having lost the gelatine for fluid, is so great, that the speecimen allheres to the tomerne like a preser of dry ahalli. Bumes and tereth in this state quickly absom a 
solution of gelatine, and thus their original tenacity may he restored.* Petrified fossils need no such treatment; they are usually harder and more durable than the original bone itself.

The interpretation of such fossil remains requires a comparison of them with the corresponding parts of animals now living, or of previously determined extinct species. In the case of the vertebrate animals, such comparison is limited to the usseous and dental systems. The interpretation of a vertebrate fossil, therefore, presupposes a knowledge of the various modifications of the skeleton and teeth of the existing vertebrate animals; and the more extensive and precise such knowledge may be, the more successful will be the efforts, and the more exact the conclusions, of the interpreter.

The determination of the remains of quadrupeds is beset, as Cuvier truly remarks, with more difficulties than that of other organic fossils. Shells are usually found entire, and with all the characters by which they may be compared with their analognes in the musemus, or with figures in the illustrated books, of naturalists. Fishes frequently present their skeleton or their scaly covering more or less entire, from which may be gathered the general form of their body, and frequently both the generic and specific characters which are derived from such internal or extemal hard parts. But the entire skeleton of a fossil quatruped is rarely found, and when it occurs, it gives little or $n$ information as to the hair, the fur, or the colour of the species. Portions of the skeleton with the bones dislocated, or scattered pell-mell-detached bones and teeth, or their fragnents merely-such are the conditions in which the petrified remains of the mammalian class most commonly present themselves in the strata in which they occur.

* The writer's experience of this effect led him to suggest the application of a similat process to the long burith ivory omaments from the mins of Nineveh in the British Muscum; it proved successful. 
Prior to the time of C'uviel but little progress had been made in the interpetation of such fragmentary remains. The striking success which attended the application of the great comparative anatomist's science to this previously neglected field of study, was referred hy Cuvier to principles in the organization of animal hodies, which he termed the "Correlation of For'ns and structures," and the "Subordination of Organs"- principles which his clear-thinking biographer, MI. Flourens, in common with most contemporary philosophers, has regarded as the most effective and successful instrument in the restoration of extinct animals. They will be exemplified in the course of the present section of this work.

A teminal phalanx modified to fit a hoof may give, as Cuvier declared, the modifications of all the bones of the fore limb that relate to the alsence of a rotation of the fore leg, and all the modifications of the jaw and skull that relate to the mastication of food ly broal-crowned complex molars.

But there are certain associated structures for the coincidence of which the physiological law is munown. "I doubt," writes Cuvier, "whether I should have ever divined, if observafion had not taught it me, that the ruminant hoofed beasts should all have the cloven foot, and be the only heasts with horns on the frontal bone." $\dagger$ We know as little why loms should be in one or two pairs on the frontal home of those Lngulates only which have hoofs in one or two pairs; whilst in the horned Lngulates with thee hoofs, there should be either one horn, or two horns placed one behind the other in the mirldle line of the skull; or why the Ungulates with one or three hoofs on the hind foot should have three trochanters on the fimur, whilst those with two or four hoofs on the hind foot should have only two trochanters.

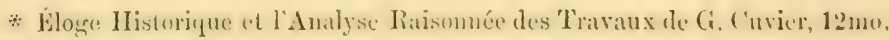
P'aris, 1841, p. 42 .

† Ossemens líussiles, 8vo, el. 1834, tom. i., p. 184. 
"Howerer," continues C'uvier, "since these relations are constant, they must have a sufficing cause; but as we are ignorant of it, we must supply the want of the theory ly means "li olservation.* This, if adequately pursued, will serve to (stablish empirical laws almost as sure in their application as rational ones." "That there are secret reasons for all these relations, observation may convince us independently of general philosophy." "The constancy between such a form of such wrgan, and such another form of another organ, is not nerely specific, but one of class, with a corresponding gradation in the development of the two organs." $\dagger$

"For example, the dentary system of non-ruminant Lngulates is generally more perfect than that of the Bisuleates ; inasmuch as the former have almost always both incisors and canines in the upper as well as the lower jaw ; the structure of their feet is in general more complex, inasmuch as they have more digits, or hoof's less completely enveloping the phalanges, or more bones distinct in the metacarpus and metatarsus, or nore numerous tarsal bones; or a more distinct and better developed fibula ; or a conconitance of all these molifications. It is impossible to assign a reason for these relations; hut, in proof that it is not an aftair of chanee, we find that whenerer a hisulcate animal shows in its dentition any tendeney to alproach the non-puminant L'ngulates, it also manifests a similar tentency in the conformation of its feet. Thus the cannels, which have canines and two or four incisors in the nuper jaw, have an additional bone in the tarsus, resulting from

* "Puisque ces rapports sont constants, il faut bien qu'ils aient une cause suffisante; mais comme nous ne la connoissons pas, nous devons suppléer au défaut de la théurie par le moyen de l'observation." (Tom. cit., p. 184.)

t " En effet, quand on forme un tableau de ces rapports, on y remarque nonseulement une constance spécifique, si l'on peut s'exprimer ainsi, entre telle firme de tel organe, et telle atute forme d'un organe diflérent; mais l'on apergent anssi une constance de classe ct une gradation correspondante dans le dévi loughe ment de ces leux organes, qui montrent, presque aussi bien qu un misonnement effectif, leur influence mutuelle." ('Tom, cit., p. 185.) 
the scaphoid not being confluent with the cuboid: and the small hoofs have correspondingly small phalanges. The muskrleer, which have long upper canines, have the fibulia co-extensive with the tibia, whilst the other ruminants have a mere rudiment of fibula articulated to the lower end of the tibia." "There is then a constant harmony between two organs to all appearance quite strangers to each other, and the gradations of their forms correspond uninteruptedly even in the cases where one can render no reason for such relations." "But in thus availing ourselves of the method of observation as a supplementary instrument when theory abandons us, we arrive at astonishing details. The smallest articular surfice (facette) of a bone, the smallest process, presents a determinate character relating to the class, to the order, to the genus, and to the species to which they belong; so that whoever possesses merely the well-preserved extremity of a bone, may, with application, aided by a little tact (adresse) in discerning analogies, and by sufficient comparison, determine all these things as surely as if he possessed the entire animal."*

There have been, of course, instances, and will be, where for' want of the "efficacious comparison," and the "tact in discerning likeness," such results have not rewarded the endeavours of the palrentologist; and these shortcomings, and the mistakes sometimes made, even by Cuvier himself, have been cast in the teeth of his disciples, as arguments against the principles by which they believed themselves guided in their endeavours to complete the nlorious edifice of which their master laid the foundations.

The writer has, therefore, quoted from the well-known "Prelininary Discourse" to ('urier's steat work on Fossil Remains, with a view to nentralize the efforts of statements reiterated in applarent ignomene of the clear and explicit manner in which curier there defines the limits within which the 
law of correlation of animal structures may be successfully applied, and indicates the instances in which-the physiologieal condition being unknown, and the coincident structures being understood empirically-careful observation and rigorous comparison must supply the place of the physiologically understood law.

Those who deny the existence of design in the construction of any part of an organized body, and who protest against the deduction of a purpose from the valves of the veins or the lens of the eye-ball, repuliate the reasoning which the palieontologist carries out from the hoof to the grinder, or from the carnassial molar to the retractile claw, through the guidanre of the principle of a pre-ordained mutual adaptation of such parts; but such minds are not, nor have been, those who have contributed to the real advancement of physiology or palæontology.

By reference to the "Table of Strata" (fig. 1), it will be seen that the earliest evidence of a rertebrate animal is of the cold-blooded water-breathing class in the upper Silurian period. Next follows that of a cold-blooded but air-breathing vertebrate, under the batrachism grade, in the carboniferous period. The warm-blooded air-breathing classes are first indicated, as birits, by footmarks in a sandstone of probably triassic but not older age; and, as mammals, by fossil teeth from bone-beds of the upper triassic system in Wirtemberg, and of the same age near Frome, Somersetshire. Mammalian remains have also been found in a coal-field in North Carolina, which may be earlier, but cannot he later, than the lias formation.

Gcnus Microlestes.-The mammalian teeth from Geman and English trias indicate a very suall insectivorous quadruperl, to which the above generic name was given by Professor' I'lieninger. The German specimens were discovered in $\mathbf{1 8 4 7}$ in a bone breccia at Diegerloch, alout two miles from stutt- 
gardt, the gevological relatiuns of which are well determinerl ats hetween lias and Fenper sandstone. The teeth of Microlestes from Frome, sulmitted to the writer by the discoverer, Mr. Charles Noore, F.G.S., in 185\%, are four in number, two being molars of the upper jaw, each with four fangs; one a molar with a narrower crown and two fangs from the lower jaw ; and the fourth a small, pointed, front tooth. The crowns of the molars are short rertically in proportion to their lreadth; the distinct enamel contrasts with the cement-covered fangs; the grinding surface shows a wide and shallow depression, surrounded by small, low, obtuse cusps, three of equal size being on one side, a larger cusp near one end, and smaller and less regular cusps on the side opposite the three. One lower molar shows a similar type, but with the three marginal cusps lest equal in size : a second smaller, and from a more anterior part of the series has three low ensps on one side, and but one cus]' on the other side of the crown, the grinding surfice of which presents an elongate triangular form. This tooth had two fangs. The crown of the largest of the upper molars does not exceed one line in its longest diameter. Amongst existing Mammals, some of the small molars of the marsupial and insectivorous Myrmecobius of Australia offer the nearest resemblance to these fossil teeth ; but a still closer one is presented hy the small tubereular molars of the extinct oolitic Mammal called Plagiaulax (fig. 93, $m, \mathrm{~s}$ and $\mathrm{z}$ ).

Gems Dromatheritu.-It would appear that the Mammal from the American triassic or liassic coal-hed (Dromatherium syleestre, Emmons) also found its nearest living analogue in Myrmecobins ; for each ramus of the lower jaw contained 10 small molars in a continuous series, 1 canine, and 3 conical incisors, the latter leeing divided hy short intervals.

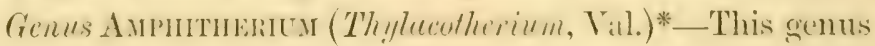

* For the full description and demonstration of the mammatian nat oure of this much-discussed fossil, see ()wen, History of Jriti-h Fussil Mammals, Svo, p. 234. 
is founded upon a few specinens of lower jaw, one ramus of which (fig. 85) gave the entire dentition of its side,--viz., three small conical incisols $(i)$, one rather larger canine $(c)$, six premolars, unicuspid, with a small point at one or hoth sides of the base $(p, \mathbf{I}-6)$, and six quinque-cuspid molars $(m, \mathbf{r}-6)$ not departing very far from the type above describel. The molars, and most of the

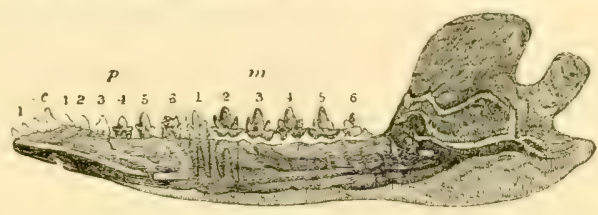

Figr. 85.

Lower jaw and tecth of the Amphitherium Prevostii (twice nat. size.)

premolars, are implanted ly two roots. The condyle of the jaw is convex, and is a little higher than the level of the teeth ; the coronoid process is broad and high ; the angle project: backward, with a feeble production inward. It is, again, to the marsupial Myrmecotius, amongst living forms, that the present geuus is most nearly allied. The remains of Amphitherium are from the lower oolitic slates of Stonesfield (fig. 87, stratum 8).

Gemus Anphilestes* - This genus is founded on a ramus of the lower jaw, from the Stonesfield oolitic slate, slowing true molars of a compressed form, with a large middle cusp and a smaller, hut well marked, one at the fore and back part of its hase ; the "cingulum," or hasal ridge, peculiar to mammalian teeth, traverses the inner ridge of the crown, where it develops three small cusps, one at the hase of the large outer or principal cusp, and the other two forming the anterior and posterior encls of the crown. This form of tooth is unknown in existing Mammalia, hut is as well adapted for crushing the cases of coleopterous insects (elytra of which are found fossil in the same oolitic matrix) as are any of the multi-cuspid molars of small opossums, shrews, and bats. The Amphilestes Broderipii was somewhat larger than Amplhitherium Picrostii.

* Owen, Hist. Brit. Foss. Mam., p. 58, fig. 19 (Amphitherium Broderipii). 
Genus Phiscolothenilu.-Although the evidence of the very slight degree of inflection of the angular process of the? lower jaw of $A$ mplitherium may favour its aftinity to the placental Insectivores, yet the range of variety to which that mandibular character is subject in the different genera of existing Marsupialia warns us against laying undue stress upon its feeble development in the extinct genus of the oolitic epoch; and incites us to look with redoubled interest at whaterer other indications of a marsupial character may be present in the fossil remains of other genera and species of Mammalia that have been detected in the Stonesfield slate.

In the specimen of Phascolutherium (fig. 86) presented to the British Museum by William .T. Broderip, Esq., F.R.S., its

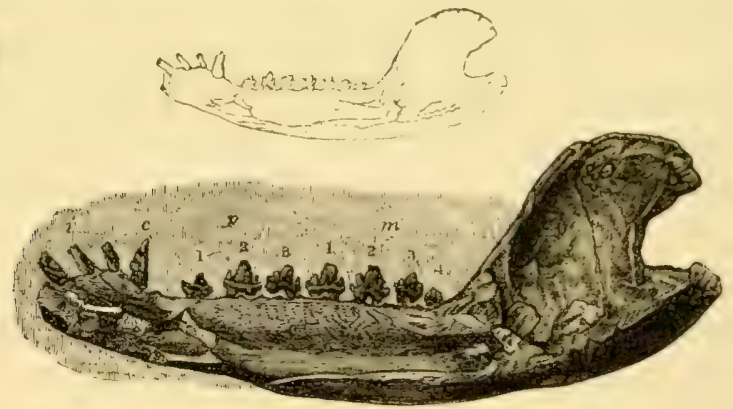

Fig 86.

Lower jaw and tecth of the Phascolotherium (nat. size in outline), Lower Oolite.

original describer, which is as perfect in regard to the dentition as the jaw of the implitherium ahove described, the marsupial characters are more strongly manifested in the general form of the jaw, and in the extent and position of the inflected angle, while the agreement with the gernus Didelpleys in the number of the premolar and molar teeth is complete. The forms of the crowns of these teethe differe from these in Didtholyys, and eorrespond so elosely with those in the Amplitestes Bromeripii,

* Zoological Journal, vol. iii., p. 408, pl. xl., 1828. 
as to show the cluser affinity of the Phascolothere with the latter oolitic Insectivora ; and, accordingly, whatever additional evidence of marsupiality is afforded by the Phascolothcrium, may be regarded as strengthening the claims of both Amphilestes and Amphitherium to be admitted into the marsupial group. The general form and proportions of the coronoid process of the jaw of Phascolotherium resemble those in the zoophagous Marsupials; and especially with that of the Thylacyms in regard to the depth and form of the entering notch between this process and the condyle.

The base of the inwardly-bent angle of the lower jaw progressively increases in Didllphys, Dasyurus, and Thylacinus; and judging from the fractured surface of the corresponding part of the fossil, it most nearly resembles the jaw of Thylacinus. The condyle of the jaw is nearer the plane of the inferior margin of the ramus in the Thylacine than in the Dasyures or opossums: and consequently, when the inflecterl angle is broken off, the curve of the line continued from the condyle along the lower margin of the jaw is least in the Thylacine. In this particular, again, the Phascolothere resembles that Australian Carnivore. In the position of the dental foramen, the Phascolothere, like the Amphithere, differs from the zoophagous Marsupials and placental Carnivora and Insectivora, and resembles the Hypsiprymnus, a marsupial Herbivore, that orifice being near the vertical line dropped from the last molar tooth. In the direction of the line of the symphysis, the Phascolothere resembles the Opossums more than the Dasyures or Thylacines. It is probable that the teeth at the fore part of the jaw showed the same correspondence. In the number of the molar series, the Phascolothere differs from Amphitherium, Amphitestes, and Myrmccotius, and resembles the Thylacine and Opossum, but without having the prenolars $(p, \mathbf{x}, 2,3)$ distinguished, as in them, from the true molars $(m, r, 2,3,4)$, by smaller and more simple crowns. As, however, 
these two kinds of teeth can only be determined by their order of development and succession, the Phascolothere may well have had three premolars and four true molars.

The difference between these teeth in the lower jaw of Didclpluys is shown by the addition, in the true molars, of a pointed tubercle on the inner side of the middle cone. In Phascolotherium a mere basal ridge or cingulum extends along the inner side of the middle cone. Such a ridge is present in the last molar of Sarcophilus, but not in the other molars; but in these there are two small hind cusps on the same transverse line, whilst that cusp appears to be single in Phascolothcrium. The cingulum, moreover, in the second to the penultimate of the molar series of this fossil, extends so far as to form a small talon at the fore and back part of the crown; thus making five points, which are very distinct in the third to the penultimate tooth inclusive; and by this character the dentition of Phoscolotherium differs materially from any existing Marsupial, and repents the type of molar which, as yet, would seem to be peculiar to the Insectivora of the oolitic epoch. There is a feeble indication of this structure in the antepenultimate and penultimate molars of Thylacinus, but the hinder division of the crown shows two small cusps on the same transverse line, besides the rudimental hindmost one; and there is no cingulum. Upon the whole, it would seem that, though the aflinity may not be close, Phascolotherium most resembles Thylucinus amongst existing Nammals ; but Thylacinus is now confined to Tasmania, and is there fast verging to extinction.

The resemblance shown by the lower jaw and its teeth of the Amphithere and Phaseoluthere to marsupial genera now confined to Australia and Tasmania, leads one to reflect on the interesting correspondence between other organic remains of the Oxfordshire volite and other existing forms now confined to the Australian continent and surromeling sea. Iere, for example, swims the Cestracion, or Port-Jackson shark, which 
has given the key to the nature of the "palates" from our oolites, now recognized as the teeth of congeneric larger forms of cartilaginous fishes. Mr. Broderip, in his Memoir abovequoted, observes, "that it may not be uninteresting to note that a recent species of Trigonia has very lately been discovered on the coast of Australia, that land of marsupial animals. Our specimen lies imbedded with a number of fossil shells of that genus." Not only Trigonia but Terebratulce exist, and the latter abundantly, in the Australian seas, yielding food to the Cestracion, as their extinet analogues doubtless did to the allied Plagiostomes with crushing teeth, called Acrodus, Psammodus, ete. Arau-

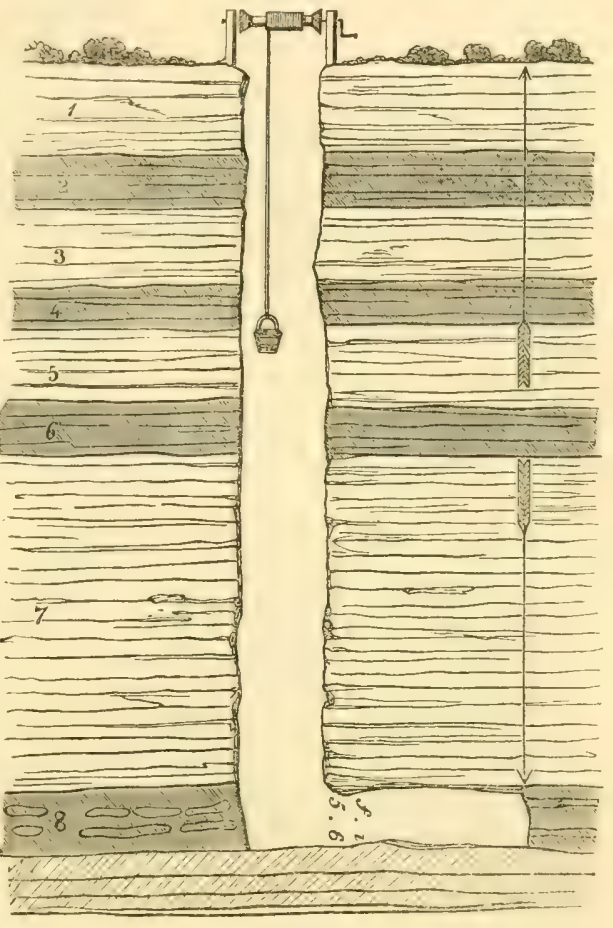

Fig. 87.

(After Fitton.)

1. Rubbly limestone (corubrash).

2. Clay, with Terebratulites.

3. Limestone rock.

4. Blue clay.

5. Oolitic rock.

6. Stiff clay.

7. Oolitic rag, or limestone.

8. Sandy bed containing the Stonesfield slate. corice and cycadeous plants, like those found fossil in oolitic beds, flourish on the Australian continent, where marsupial quadrupeds now abound; and thus appear to complete a picture of an ancient condition of the earth's surface, which 
has been superseded in our hemisphere by other strata and a higher type of mammalian organization. Fig. 87 represents a section of the strata overlying the slates whence the fossil mammalian jaws, with associated Megalosaurs, I'terodactyles, and other oolitic organisms, have been obtained at Stonesfield in Oxfordshire. The vertical thickness of the strata through which the shaft is sunk to the gallery is 62 feet; on the side opposite the right hand is marked the deptl of the horizontal gallery, where the slate is dug which contains the fussils; on the opposite side the strata are numbered in succession.

Genus Stereogratius.-The last evidence of a mammalian animal discovered in the Stonesfield slate is of peculiar interest, because it exhibits a type of grinding teeth quite distinct from any of the previously acquired jaws from that lo-

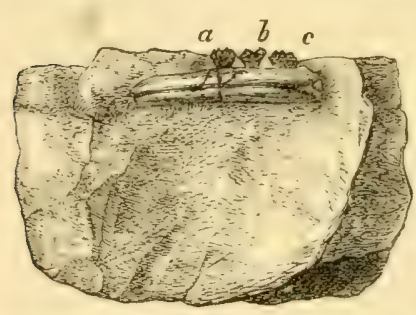

Fing 88.

Stereognathus; portion of jaw, imbelded in oolitic matrix (nat. size). cality, and affords evidence of a small regetable-feeding or omnivorous quadruped. It consists of a portion of a lower jaw, imbedded in the characteristic matrix (fig. 88), about 9 lines in extent, and containing three molar teeth $(a, b, c)$. It is nearly straight; the side exposed is convex vertically; a slight bend downwards, and decrease of rertical diameter towards the ent, indicates it to be part of a left ramus. This is umusually shallow, broad or thick below, the side passing by a strong convex curve into the lower part; a very narrow longitudinal ridge, continued after its subsidence hy a few fine lines, forms a tract which divides the lateral from the moler surface; elsewhere the bone is smooth, without consprenous rascular perforations. The depth or vertical diameter of the ramus is not more than two lines. Of the three teeth remaining in this portion of jaw, the middle one is the least mutilated. The 
crown of this tooth (fig. $89, B$ ) is of a quadrate form, 3 millimetres by $3 \frac{1}{2}$ millimetres, of very little height, and supports six subequal cusps in three pairs, each pair being more closely connected in the antero-posterior direction of the tooth than transversely.

The outer side of the crown (fig. $88, b$ ), supported by a narrow fang which contracts as it sinks into the socket, shows two principal cusps or cones, and a small
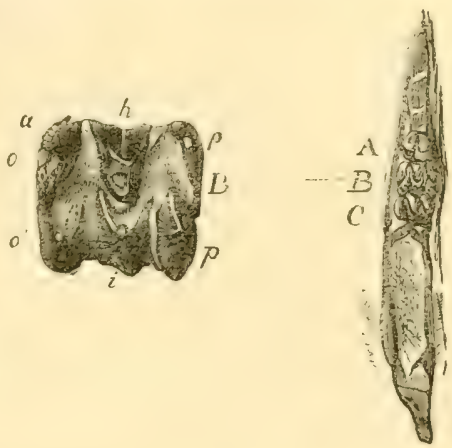

lig. 89 .

accessory basal cusp. The Stereognathus; upper view of purtion hard and shining enamel which covers these parts of of jaw (nat. size), and magnified view of the milddle tooth, $B$ (Stonesfield Oolite).

the crown contrasts with the lighter cement that coats the root. The two outer lobes or cones are subcompressed, and placed obliquely on the crown, so that the hinder one $\left(o^{\prime}\right.$, fig. 89$)$ is a little overlapped externally by the front one $o$, the fore part of the base of the hinder one being prolonged inwards on the inner side of the base of the front cone. The tro midlle cones $(h, i)$ are subcompressed laterally, with the fore part of their base a little broater than the back part. The two inner cones $\left(p, p^{\prime}\right)$ have their inner surface convex, with their stummits slightly inclined forwards. The fore part of the base of the hinder cone is prolonged obliquely towards the centre of the cromn, beyond the contiguous end of the base of the front cone, so as to cause an arrangement like that of the two outer cones $\left(o, o^{\prime}\right)$, the obliquity of the posterior cone of both the onter anct the inner pairs being such that they shightly converge as they extend forwards.

This type of tooth differs from that of all other known lecent or extinet Mammals. The nearest approarh to it is marle he 
the middle true molar of Pliolophus vulpiceps, a small extinct herbivorous Mammal from the London clay (fig. 96, $m, z$ ).

That the fragment in question is the jaw of a Mammal is inferred from the implantation of the tooth by two or more roots. Most Mammals are known to have certain teeth so implanted. Such complex mode of implantation in bone has not been observed in any other class of animals. Why two or more roots of a tooth should be peculiar to viviparous quadrupeds, giving suck, is not precisely known. That a tooth, whether it be designed for grinding hard or cutting soft substances, should do both the more effectually in the ratio of its firmer and more extended implantation, is intelligible. That a more perfect performance of a preliminary act of digestion should be a necessary correlation, or be in harmony, with a more complete conversion of the food into chyle and blood,and that such more efficient type of the whole digestive machinery should be correlated, and necessarily so, with the hot blood, quick-beating heart and quick-breathing lungs, with the higher instincts, and more vigorous and varied acts of a Mammal, as contrasted with a cold-blooded reptile or fish,-_is also conceivable. To the extent to which such and the like reasoning may be true, or in the direction of the secret cause of the constant relations of many-rooted teeth discovered by observation, - to that extent will such relations ascend from the empirical to the rational category of laws.

The interest which the above-described fossil from the Stonesfield oolitic slate exeites is not exclusively due to its antiquity, its uniqueness, or its peculiarity ; much is attached to its relations as at test in palicontology of the actual value of a single tooth in the determination of other parts of the organization of the animal. According to our opinion of these unseen parts, we frame our expression of the nature and affinities, or of the place in the zoological system, of the extinct species. From the resemblane of the lower molars of Strirnguethess to 
those of Plioloplues, which, though not close, is closer than to the teeth of any other known animal, it is probable that the Stercornathus was hoofed, and consequently herbivorous, or deriving the chief part of its subsistence from the regetable. kinglom. Cuvier has written,-_ "La première chose ì faire dans l'étude d'un animal fossile est de réconnaitre la forme de ses dents molaires; ou determine par la s'il est carnivore ou herbivore, et dans ce dernier cas, on peut s'assurer, jusqu’ì un certain point de l'ordre d'herbivores auquel il appartient." * In the case in question the form of the molar teeth of one jaw is recognizable, but the herbivority of the fossil is not thereby determined. We can only infer it to be more probable that the fossil was a Herbivore than an Insectivore or a mixed-feeding Carnivore.

Admitting the herbivority of the fossil, it is not certain that it was hoofed; there is nothing in the form and structure of the tooth to prove that. Both form and structure are compatible with the hoofless muticate type of herbivorous Mammal, as shown by the Manatee; it is the small size of the Stercogncethus which renders it less probable that it was a climinutive kind of Manatee, and more probable that it was a diminutive form of Ungulate. But seeing the manifold diversities of the multi-cuspid form of molar teeth in recent and extinct insectirorous unguiculate quadrupeds, it is not impossible but that the Stercognathus may have belonged to that order ; there is no known physiological law forbidding it.

The form of the cusps, and their regular symmetrical arrangement in the Stercognathus, as compared with the known modifications of multi-cuspid molars in certain small extinct forms of hoofed quadrupeds, constitute the grounds upon which an opinion is formed of its most probably belonging to the same section of Ungulata.

Then, is it not true, it may he asked, that hy rintue of * Ossemens Fossiles, 4to, tom. iii., 1822, p. 1. 
certain established laws of correlated structures, an extinct animal may be re-constructed from a single tooth or from a fragment of bone? Is the Curierian basis, or what has been so regarded, of palreontology unsound? Not necessarily from atught that has been said or written on the subject of the Stereognuthus. We do not know the comparative anatomy of the family of quadrupeds to which the Stereognathus belonged. What we do know of its teeth suggests that that family may have had modifications of the slieleton so far different from those of any, the modifications of which are known, as to have constituted a type of, perhaps, a marsupial family; but a type as well marked, and as distinct, as the type of skeleton which Cuvier inductively studied in the feline Camirora (fig. 128), and in the ruminant Herbivore (fig. 129), and by which preliminary study he was enabled to enunciate that beautiful law' of the "correlation of forms and structures" to which allusion has been already made, and which will be illustrated by examples, and its mode of application pointed out, in another part of the present work.

In certain instances of constant coincidences of structure, as demonstrated by comparative anatomy, the sufficient-i.e. recognizable, intelligille, or physiological-cause of them is not yet known. But, as Cuvier in reference to such instances truly remarks, "Since these relations are constant, there certainly must be a sufficient cause for them." * In certain other cases Cuvier believed that he could assign that "sufficient cause," and he selects, as such, the correlated structures in a feline Carnirore, and in a hoofed Herbivore. The physiological knowledge displayed by lim in his explanation of the cenclition of those correlations is most exact; its application in the restoration of the Anepletherium and Pelestherium nost exemplary.

In the ratio of the knowledge of the reason of the coineiflences of animal structures--in wher words, as those conei-

* Discours sur les Rérolutions do la Surface du Globe, 4to, 1826, p. 50. 
dences become "correlations"-is our faith in the soundness of the conclusions deduced from the application of such rational law of correlations; and with the certainty of such application is associated a greater facility of its application. A knowledge of the physiological conditions governing the relations of the contents of the cavities of bones to the flight and other modes of locomotion in birds both enabled the writer to infer from one fragment of a skeleton that it belonged to a terrestrial bird deprived of the power of flight, and to predict that such a bird, but of less rapid course than the ostrich, would nltimately be found in New Zealand.**

This principle, however-those modes of thought-which Curier affirmed to have guided him in his interpretation of fossil remains, and which he believed to be a true clue in such researches, were repudiated or contested by some of his contemporaries.

Geoffroy St. Hilaire denied the existence of a design in the construction of any part of an organized body; he protested agrainst the deduction of a purpose from the contemplation of such structures as the valves of the reins or the conrerging lens of the eye.

Beyond the cu-existence of such a form of flood-gate with such a course of the fluid, or of such a course of light with such a converying medium, Geolfroy affirmed that thought, at least his mode of thinking, could not sanely, or ought not to go.

The present is not the place for even the briefest summary of the arguments which have been adduced by teleologists and antiteleologists from Democritus and Plato down to Comte and Whewell. The writer would merely remark, that in the degree in which the reasoning faculty is developed on this flanet and is exercised by our species, it appears to be a more healthy and normal condition of such ficulty,-certainly one which has lexen productive of most aceession to truths, as exemplified

* Transactions of the Zoological Society, vol. iii., p. 32, pl. 3 . 
in the mental workings of an Aristotle, a Galen, a Harrey, and a Cuvier,--to adnit the instinctive impression of a design or purpose in such structures as the valves of the rascular system and the dioptric mechanism of the eye. In regard to the few intellects,- they have ever been a small and unfruitful minority,-who do not receive that impression and will not admit the validity or existence of final causes in plysiology, the writer has elsewhere expressed his belief that such intellects are not the higher and more normal examples, but rather manifest some, perhaps congenital, defect of mind, allied or analogous to "colour-blindness" through defect of the optic nerve, or the inaudibleness of notes above a certain pitch through defect of the acoustic nerve.

The truth of a physiologieal knowledge of the conclition of a correlated structure, and of the application of that linowledge to palieontology, is not affected by instances adduced from that much more extensive series of coincident structures of which the physiological condition is not yet known. Nor is the power of the application of the physiologically interpreted correlation the less certain because the merely empirically recognized coincidences have failed to restore, with the same certainty and to the same extent, an extinct form of animal.

Certain coincidences of form and structure in animal bodies are determined by observation. By the exercise of a higher faculty the reason, or a reason, of these coincidences is discovered, and they become correlations; in other words, it is known not only that they do exist, but how they are related to each other. In the case of coincidences of the latter Find, or of "correlations" properly so called, the mind infers with greater certainty and conficlence, in their applieation to a fossil, than in the case of coincidences which are held to he constant mly because so many instances of them have been olserved.

Because the application of the latter kind of coincidences is limited to the actual amount of olservation at the period 
of such application, and because mistakes have been made through a miscalculation of the value of such amount, it has been argued that a rational law of the correlation of animal forms is inapplicable to the determination of a whole from a part; * and it has not only been asserted that the results of such determination are unsound, but that the philosopher who beliered himself guided by such law deceived himself and misconceived his own mental processes! † But the true state of the case is, that the non-applicability of Cuvier's law in certain cases is not due to its non-cxistence, but to the limited extent to which it is understood.

The consciousuess of that limitation led the enunciator of the law to call the attention of palieontologists expressly to the extent to which it could then be applied, as, for instance, to the determination of the class, but not the order; or of the order, but not the family or genus, etc.; and to caution them also as to the extent of the cases in which, the coincidences being only known empirically, he consequently enjoins the necessity of further observation, and of caution in their induction. Curier expresses, however, his belief that such coincidences must have a sufficient cause, and that cause once discorered, they then become correlations and enter into the category of the higher law. Future comparative anatomists will have that great consummation in view, and its result, doubtlessly, will be the vindication of the full value of the law in the interpretation of fossil remains as defined by the illustrious founder of palæontology.

Genus Sphlacotheriux, Ow,-The next stratum overlying the older oolites in which mammalian remains have been detected, is a member of the newest oolitic series at Purbeck, Dorsetshire, called the "marly " or "dirt-bed." In a series of

* De Blainville, Ostéographie, 4to, fasc. 1, 1839, p. 34.

+ Prof. Iuxley, "Juecture on Natural History," etc., Roval Institution of Great Britain, Feb. 15, 1856. 
fossils discovered there by Mr. IV. R. Brodie, and transmitted for determination in $\mathbf{1 5 5}+$ to the writer, amongst the remains of fishes and small saurians, constituting the majority of the specimens, were detected three unequirocal eridences of a mammalian species, which were described under the name of

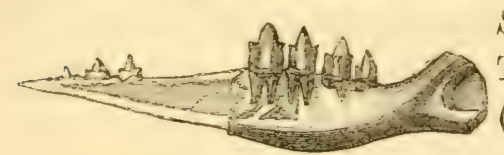

Fig. 90. Spalacotherium* tricuspidens. The specimen here selected (fig. 90) to exemplify the above extinct insectivorous Mammal, is a right ramus of the lower jaw. The posterior Spulacotherium tricuspidens (twice nat. size), Purbeck beds. half contains four teeth, and extends backward beyond the dental series; but instead of showing the compound structure which that part of the jaw exhibits in the lizard tribe, it continues undivided; the convex surface showing a smooth depression for the insertion of the temporal muscle; the lower bounlary answering to that going to the condyle and angle of the jaw, and the upper one to that going to the coronoid process in the ramus of the jaw of the mole and shrew. The crowns of the teeth are long, narrow, and tricuspid, the imner part of the crown being produced into a point both before and belind the longer cusp which forms the chief outer division of the crown. Each of these teeth is implanted by a fing divided externally into two roots, in a distinct socket in the substance of the jaw. The multicuspid crown, the divided root of the tooth, its complex implantation, and the unclivided or simple structure of the ramus of the jaw, all concured, therefore, to prove the mammalian nature of this fossil.

The other specimens showed that the Spralucuthitum had ten molar teeth in each ramus of the lower jaw, preceded hy a small canine and incisons. The anterior molars are comperesced, increase in height and thickness to the sixth, and from the serenth derevese in size to the hindmost, which seems to be

* From $\sigma \pi \alpha \dot{\lambda} \alpha \xi$, a mole; Anplov, a beast. 
the last of the series. The sharp multicuspid character of so much of the dental series as is here preserved, repeats the general condition of the molar teeth of the small insectivorous Mammalia in a striking degree: one sees the same perfect adiptation for picreing and crushing the tough chitinous cases and elytra of insects. The particular modification of the pointed eusps, as to number, proportion, and relative position, resembles in some degree that of the Cape mole (Chrysochlora aurea), but both in these respects and in the number of molars, the dentition accords more closely with that of the extinct Amphitherium. The chief interest in the discovery of the Spalacotherium is derived from its demonstration of the existence of Mrammalia about midway between the older oolitic and the oldest tertiary periods.

Both the Oxford oolitic slate and the Purbeck marly shellbeds give evidence of insect life ; in the latter formation abundantly. The association of these delicate Invertebrata with remains of plants allied to $Z$ amia and $C y c a s$, is indicative of the same close interdependency between the insect class and the vegetable kingdom, of which our power of surveying the phenomena of life on the present surface of the earth enables us to recognize so many beautiful examples. Amongst the numerous enemies of the insect class ordained to maintain its due numerical relations, and organized to pursue and secure its countless and diversified members in the air, in the waters, on the earth and heneath its surface, bats, lizards, shrews, and moles now carry on their petty warfare simultaneously, and in warmer latitudes work together, or in the same localities, in their allotted task. No surprise need therefore be felt at the discovery that Mammals and Lizards co-operated simultaneously and in the same locality at the same task of restraining the undue increase of insect life during the period of the deposition of the Lower Purbeck beds.

Genus Triconodon, Ow. 
Sp. Triconodon mordax.-This name is proposed for a small zoophagous Mammal, whose generic distinction is shown by the shape of the crowns of the molar teeth of the lower jaw, which consist of three nearly equal cones on the same longitudinal row, the middle one being very little larger than the front and hind cone; and these cones are not complicated by

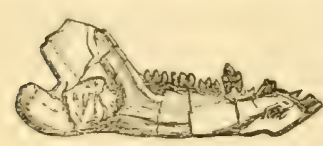

Fig. 91. any cingulum or accessory basal cusp. The convex condyle is below the level of the alveoli, and there is no angular process projecting beneath it. The coJaw of Triconodon mordax ronoid process is broad and high, with (nat. size), Purbeck. its hinder point not extended so far back as the condyle; the depression marking the insertion of the temporal muscle extends nearly to the lower border of the jaw. There are the obscure remains of three broken incisors, and the point of apparently a canine; next come the two stumps, or broken roots of a small premolar; then the crown of a second double rooted premolar, which show a principal cone and a small anterior cusp; the next tooth is wanting; then there is a larger premolar, with the two fungs raised some way out of their socket: the crown of this tooth shows a principal cone, with a small anterior and large posterior talon; it rises, apparently from partial displacement, higher than the succeeding molars; these are three in number, and present the characteristic three-coned structure already described; each cone is smooth, and convex extemally. The three cones seem to answer to the three middle or principal cones of the molars of Amphilestes and Phascolotherium, lout the front and hind cones are raised to near equality with the middle cone in Triconodon.

The lower jaw of this species, in the relation of the condyle to the lower border, resembles that of Phascolotherium more than that of $A$ mplhitherium, but it differs from both; there is not the same gradual curve from the comlyle to the srmphysis 
as in Phascolotherium; and the condyle, besides being on a lower level, is divided by a less deep notch from the coronoid process. This process is larger in proportion to the entire jaw ; approaches more nearly to the quadrate or rhomboid form, the rpper border being less curved; it affords a more extensive surface of attachment to the principal biting muscles than in most predatory extinct or recent quadrupeds. This character, with the depth and strength of the jaw, suggested the specific name. From the shape of the exposed part of the ramus, we may conclude that the part answering to the angle is bent inwards, and that Triconodon was a genus of the marsupial order. The specimen was discorered by Mr. Beceles in the same " clirtbed" at Purbeck as that in which Spalucotherium was found.

Gemus Plighuldr, * Fr.--The most remarkable of Mr. Beccles' discoveries in the above formation are the mammalian jaws indicative of the genus above named, of which two sprecies have been determined by Dr. Falconer.

Sp. Plagianlax Bcclesii, Fr.-Two specimens exemplified the shape and proportions of the entire jaw of this species (fig. 92). The foremost tooth $(i)$ is a very large one, shaped like a canine, lout implanted by a thick root in the

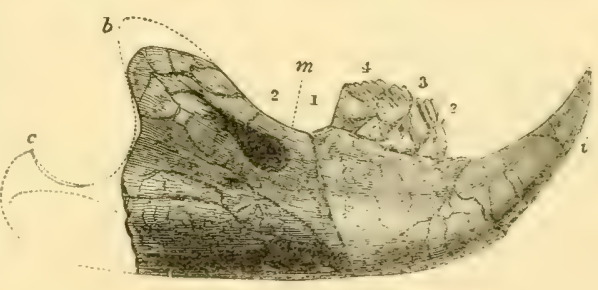

Fig. 92.

Plagiaulax Becclesii (twice nat. size), Purbeck. fore part of the jaw, like the large lower incisor of a shrew or wombat. The three anterior teeth in place have compressed trenchant crowns, and rapidly augment in size from the first (z) to the third (4). They are followed by sockets of two much smaller teeth, shown in other specimens to have sub-

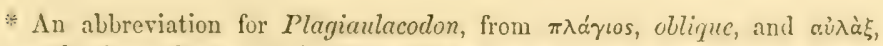
groove; having reference to the diagonal grooving of the premolar tecth. 
tuberculate crowns resembling those of Microlestes. The large front tooth of Plagiaulax is formed to pierce, retain, and kill ; the succeeding teeth, like the carnassials of Carnivora, are, like the blades of shears, adapted to cut and divide soft substances, snch as flesh. As in Carnivora, also, these sectorial teeth are succeeded by a few small tubercular ones. The jaw conforms to this character of the dentition. It is short in proportion to its depth, and consequently robust, sending up a broad and high coronoid process $(b)$, for the adequate grasp of a large temporal muscle; and the condyle (c) is placed below the level of the grinding teeth-a character unknown in any herbivorous or mixed-feeding Mammal; whilst the lever of the coronoid process is made the stronger by the condyle being carried farther back from it than in any known carnirorous or herbivorous animal. The angle of the jaw makes no projection below the condyle, but is slightly bent inward, according to the marsupial type.

Sy. Plagiaulax minor, Fr.-In this species the first premolar

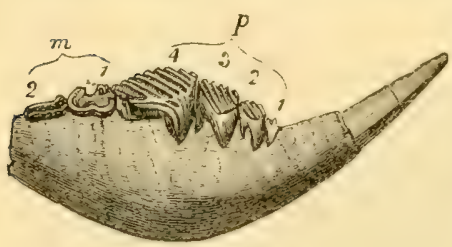

Fig. 93. (fig. $93, p, \mathbf{1}$ ) is preserved; the rest $(p, 2,3$, and 4$)$ show nearly the same shape and proportions as in $P$. Becclesii. The first $\operatorname{molar}(m, \mathrm{r})$ has a broad depression on the grinding Plagiaulax minor (four times nat. size), surface, surrounded by tuberPurbeck (after Lyell).

cles, of which three are on the outer border; the marginal tubercles of the second smaller tooth are smaller and more numerous.

In the general shape and proportions of the large premolar $(p, 4)$ and succeeding molars, Plagiaular most rescmbles Thylacolco (fig. 141, p, m, I and 2), - a much larger extinct predaceous Marsupial from tertiary beds in Australia. But the sectorial teeth in Plagianlax are more deeply grooved; whence its name. The single compressed premolar of the 
kangaron-rat is also grooved ; lut it is differently shaped, and is succeederl by four square-cromed double-ridged grinders arlapted for regetable food; and the pnsition of the condyle, the slenderness of the coronoid, and other characters of the lower jaw, are in conformity to that regimen. In Thylucolen the lower canine or canine-shaped incisor projected from the fore part of the jaw close to the symphysis, and the corresponding tooth in Plagiaulax more closely resembles it in shape and direction than it does the procumbent incisor of Hypsiprymme. From this genus Plagianlax differs by the obliquity of the grooves on its premolars; by having only two true molars in each ramus of the jaw, instead of four; by the salient angle which the surfaces of the molar and premolar teeth form, instead of presenting a miform level line; by the broader, higher, and more vertical coronoid; and by the very low position of the articular condyle.

The physiolngical deductions from the above-described characteristics of the lower jaw and teeth of Plagiaulax are, that it was a carnirorous Marsupial. It probably found its prey in the contemporary small insectirorous Mammals and Lizards, supposing no herbirorous form, like Stereognathus, to have co-existed during the upper oolitic period.

In the Woolwardian Museum at Cambridge is a specimen of anchylosed cervical rertebre of a cetaceous animal as largo as a grampus, but presenting specific distinctions from all known recent and fossil species. It is stated to have been found in the brown clay or "till" near Ely ; but in its petrified condition, colour, and specific gravity, it is so different from the true bones of the "till," and so closely like the fossils of the Kimmeridge clay, as to make it extremely probable that it has been washed out of that formation.

No evidence of the mammalian class has yet been met with in the chalk beds. 
The examples of the Manmolia first met with in tertiary strata are the Coryphotnit and Pulconcyon, respectively representing the ungulate (herhivorous) and mouiculate (camirorous) modifications of the class ; their remains have been found in the plastic clay aurl equivalent lignites in England and France.

Genus Corrphodox, Ow.-Rarely has the writer felt more misgiving in regard to a conclusion based, in palæontology, on a single tooth or bone, than that to which he arrived after a study of the mique fragment of jaw with one tooth dredged up off the Essex coast, and on which he founded the genus Coryphodon**

The marked contraction of the part of the jaw near one end of the tooth seemed, at first view, clearly to show it to be the narrower fore part of the ramus; in that case the tooth would have been a premolar, and of comparatively little value in the determination of a genus or species. But a closer inspection showed the line of abrasion of the summits of the two transverse ridges of the tooth to be on one side, and the general law of the relative apposition and reciprocal action of the upper and lower grinders in tapiroid Pachyderms determined that those oblique linear abrasions must be on the hinder side of the ridges. The smaller characters carried conviction against the showing of the larger and more catching ones. So, in determining the position of the nautilus in its pearly aboule, when the animal without its shell was first brought to England in 1831, the reasons afforded by some small and ineonspicuous parts in like manner outweighed the first impressions from more olvious appearances, as well as the liats from the general analogies of testaceous Univalves. Some conteniporary naturalists asserterl, and for a time it was believed, that the nautilus had been put upsicle down in its shell, just as some

* History of British Fossil Mammals, 8vo, p. 299, figs. 103, 104.

+ In plate i. of the writer's Memoir of the Nautilus, 4to, 1832. 
contemporary anatomists sumised that the writer had mistaken the fore for the back part of the jaw of his Coryzhodon, which, in that case, might only be the known Lophiodon. In both instances the conclusions founded on the less obvious characters have proved to be correct. And the writer would remark that, in the course of his experience, he has often found that the prominent appearances which first catch the eye, and indicate a conformable conclusion, are deceptive ; and that the less obtrusive phenomena which require searching out, more frequently, when their full significance is rensoned up to, guide to the right comprehension of the whole. It is as if truth were whispered rather than outspoken hy Nature.

Truth, it is sometimes said, lies at the bottom of a well. The first additional glimpse that the writer obtained of the veritable nature of one of our most ancient tertiary Mammals was derived from the inspection of a fossil tooth brought up from a depth of 160 feet, out of the "plastic clay," during the operations of sinking a well in the neighbourhood of Camberwell, near London. It was a canine tooth, ${ }^{*}$ belonging, from its size (near 3 inches in length), to a large quadruped, and, from the thickness and shortuess of its conical crom, not to a carnivorous but to a hoofed Mammal, most resenbling in shape, though not identical with, that of the crown of the ranine tooth of some large extinet tapiroid Mammals, which Cuvier had referred to his genus Loplliodon, but which has proved to belong to Coryphodon.

The last lower molar of Lophiodon has three lobes; the molar determined to be the ultimate one, in the fragment of lower jaw above referred to, resembles that of the tapir in the alsence of a third or posterior lobe, but the posterior ridge or part of the cingulum is less developor than in the tapir. It presents two divisions in the form of transverse ridges or aninences, the front ridge being the largest, and with its elger

Hist. Brit. Foss. Mamm., p. 306, fig. 105. 
most entire. From the outer end of each division a ridge is continued obliquely forward, inward, and downward: the anterior one extencls to the antero-internal angle of the base of the erown; the posterior one trminates at the nidulle of the interspace between the two chief divisions of the crown. The trenchant summit of the anterior ridge is slightly concave toward the fore part of the tooth, as in that of Lopliciodun; but its outer and inner ends rise higher, and appear as more distinct cones or points ; whence the generic name of Corypliodon. The posterior division is lower than the anterior one, and is licuspid ; the trenchant margin comneting the onter and inner points does not extend across the crown parallel with the anterior ridge, as in Taprires and Lophiodon, but bends back so as to form an angle, the apex of which rises into a third point.

Some lophiodontoid fossils from the lignites of Soissons and Laon, and from the plastic clay of Meudon in France, including the upuer molar tonth figured hy Curier in the chapter of the Ossemens Fossiles entitled "Aninaux roisins de Tapirs," pl. vii., fig. 6, belong to the genus Coryphodon. Cuvier compares this tooth with one from Bastberg, which he figures in pl. vi., fig. 4 , and which is certainly the last upper molar of a true Lophiodon, and points out truly that the Soissons tooth differs in the external border passing into the posterior one, so that, instend of leing quadrangular, its crown is triangular; but he explains this difterence on the hypothesis that the Bastberg tooth was a penultimate molar. The reduction of the seend or posterior ridge to a semi-cireular one, developed at its middle and hindmost part into a prominent cone, so far agrees with the modifieation of the same lmut of the last molar of the lower jaw of the Coryphodon as to menter it very probilule that the last upyer molar from soiscoms, fignued lyy ('uvier in pl. vii., fig. 6, above quoted, also belomes to the gemus Comprithedon. Cuvier states that the entire skeleton was found, indieative of an 
animal as long and almost as large as a bull; but that the workmen employed in the sandpit (schloniere) preserved only that one tooth. Both the lower molar from Harwich, and the upper one from Soissons, indicate an animal of at least double the size of the American tapir.

Professor Hebert * has recently described a very instructive series of teeth and bones from the oldest eocene deposits in France, which he refers to the genus Coryphodun: the last molar is identical in form with the tooth from the plastic clay of Essex, on which the genus was originally founded.

Genus Plolopirs, Ow--The most complete and instructive example of a Nammal from the next orerlying division of the eocene tertiaries, viz., the "London clay," is that which the writer has described $†$ under the name of Pliolophus vulpiceps. It is a hoofed Herbivore, but presents a dentition not exhibited by any later or existing species of Mammal.

The length of the skull (fig. 9t) is $t$ inches, its extreme

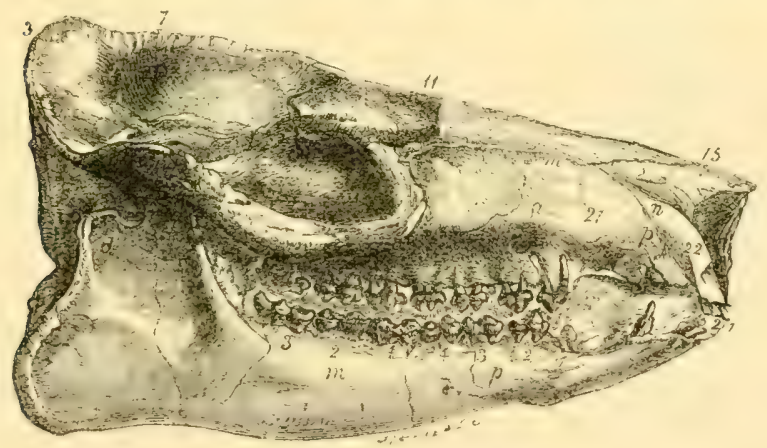

Fig. 94.

Skull of Pliolophus vulpiceps (half nat. size), London clay.

breadth 2 inches 2 lines, the height of the cranium opposite the first premolar tooth 9 lines. Its shape and chatracteristics

\footnotetext{
* Comptes Rendus de l'Acad, des Sciences, I'aris, 26th January 1857 (Coryphodon Owemi, Hebert).

+Quarterly Journal of the Geological Society, rol. xir., p. 54
} 
determine the hoofed nature of this species, and its aftinities to the Perissodactylat, or the order of Ungulata with toes in odd number. The extent and well-defined boundary of the temporal fossa by the occipital ( 3 ), parietal ( 7 ), and post-frontal ridges, and their free communication with the orbits, give almost a carnivorous character to this part of the cranium of Pliolophus; but as in the hog, Hyrax, and Palieothere, the greatest cerebral expansion is at the middle and toward the fore part of the fosse, with a contraction toward the occiput; the brain-case not continuing to enlarge backward to beyond the origin of the zygomata, as in the fox. The zygomatic arches have a less outward span than in the Carnicora. In this part of the cranial structure Pliolophus resembles Palcotherium more than it does any existing Mammal; but the post-frontal processes are longer and more inclined backward. The incompleteness of the orbit oceurs in both Anoplotherium and Peleotherium, as in Rhinocuros, Tapirus, and the hog tribe; but in the extent of the deficient rim, Pliolopthus is intermediate between Palaotherium and Tapirus. The orbit is not so low placed as in Palcothcrium, Tapirus, and Rhinoceros, nor so high as in Hyrax or Sus. The straight upper contour of the skull ( 7 to 15 ) is like that in the horse tribe and Hyaux, and differs from the convex contour of the same part in the Anoplothere and Palwothere. The size of the antorbital foramen $(\alpha)$ indicates no musual development of the muzzle or upper lip. In the conformation of the masal aperture by four bones (two nasals, 15 , and two preuaxillaries, 22), Pliolophlus resembles the horse, Hyrax, hog tribe, and Anoplothere, and differs from the rhinoceros, tapir, and Palcothere, which have the maxillaries, as well as the nasals and fremaxillaries, entering into the formation of the external bony nostril.

The ungulate and herbivorous character of Pliolophes is most distinctly maked hy the modifieations of the lower jaw, especially by the relative dimensioms wif the prats of the ascend- 
ing ramus which give the extent of attachment of the biting (temporil) and grinding (masseteric and pterggoid) muscles respectively. In the shape of the mandible Pliolophus most resembles Tapirus among existing Mammals, and the Palcotherium among the extinct ones in which that shape is known. As in almost every species of eocene quadruped yet discovered, the Pliolophus presents the type-dentition of the placental diphyodont series, viz.-

$$
i \frac{3-3}{3-3}, c \frac{1-1}{1-1}, p \frac{4-4}{4-4}, m \frac{3-3}{3-3}=44 .^{*}
$$

The incisors are preserred in the lorrer jaw with marks of attrition on their crowns demonstrating corresponding teeth of the same number (six), and of similar size, in the upper jaw, from which the alveolar part of the premaxillaries had been broken away.

The canines are small in both jaws: they are separated by a vacant space from the outer incisors, and by a longer inter-

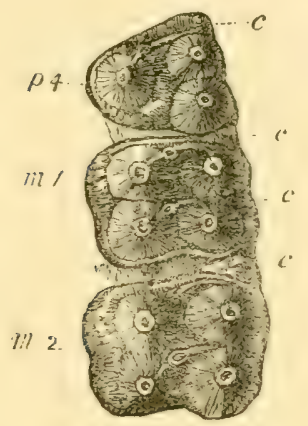

Fig. 95.
True molars, upper jaw (twice nat. size), Pliolophus.

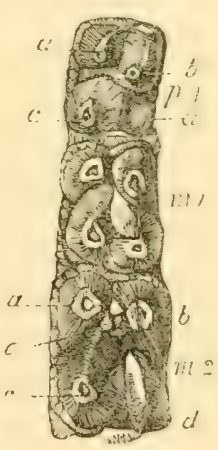

Fig. 96.

True molars, lower jaw (twice nat. size), Pliolophus.

val from the first premolars. These form a continuous series with the remaining teeth in the upper jaw, but are separated

* See Ency. Brit., art. Odontologr, vol. xvi., p. 478, for the "Homologies of the 'Teeth," and explanation of their symbols. 
by a space of about half their brealth from the second premolar in the lower jaw. The succeeding teeth $(p x, z, 3,4)$ increase in size to the penultimate molar in the upper, and to the last molar in the lower jaw ( $p$ 4, in figs. 95 and 96), which tooth has a third lobe.

In the last premolar upper jaw (fig. $95, p 4$ ) the cingulum is uninterrupted along the outer side from its anterior welldeveloped talon $(c)$ to the back part. The two outer cones resemble those of the true molars; but there is only one inner cone, and the crown of $p 4$ differs accordingly from that of $m$ $\mathrm{I}$, in being triangular rather than square. A ridge is continued from the interspace between the anterior talon $(c)$, and the outer anterior lobe obliquely inward and backward to the inner lobe, swelling into at small tubercle at the middle of its course.

The first molar $\left(m_{1}\right)$ presents four luw thick cones, two internal and two external : each external cone is comnected with its opposite internal one by a low ridge, swelling into a tubercle at the middle of its oblique course. The cingulum (cc) seems to be continued uninterruptedly round the crown of this tooth, thickest at the fore and back part, and at the interspace of the inner lobes; and developing the small accessory antero-external tubercle. The second molar ( $m z$ ) is similar to, hut rather larger than, the first ; the tubercle on the oblique ridge connecting the two front lobes is less developed. The cingulum is olliterated on the imner side of the posterior lobe.

The last molar is rather narrower behind than $m=$; the tubercle on the anterior of the oblique connecting ridges is smaller: that on the posterior ridge is almost olsolete.

In the last lower premolar (fig. 96, $p$, 4) the division and derelopment of the anterior lobe gives rise to a prair of cones, one external (a), the of her internal ( $(1)$. commerted anteriorly by a hasal ridge, in finnt of which is the fore part of the 
cingulum. The low posterior lobe (c) shows the rudiment of a second internal cone $(d)$.

The first molar (fig. 96, $m$ ) has a pair of front lobes and a pair of hind lobes, with an oblique ridge continued from postero-internal lobe to the interspace between the front pair.

The second molar $\left(m_{2}\right)$ shows an increase of size; but its chief and most interesting modification is the development of a tubercle $(e)$ between the two anterior lobes, making three cones on the same transverse line, and thus repeating the character of the molar tooth of Stereognathus (fig. 97, e). The oblique ridge from the outer and hinder lobe $(c)$ abuts against the intermediate tubercle $(e)$. The nearest approach to the above dentition is made by the extinct

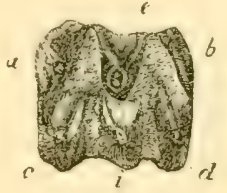

Fig. 97.

True molar, lower jaw (magn.). Stereognathus ooliticus. Hyracotherium; also a fossil from the London elay.

The third trochanter on the femur of Pliolophus, and the association of three metatarsals in one portion of the matrix, as if belonging to the same hind foot, confirm the essentially perissodactyle affinities of that genus as shown by the skull and teeth. Pliolophus and Hyracotherium form a well-marked section in the lophiodont family, which seems to have preceded the palsotherian family in the order of appearance, and to have retained more of the general ungulate type than that family. This is shown by the graduation of the tapiroid modification of the molar teeth into one more nearly resembling that of the Anthracotheria and Charopotami, by the absence of the postero-internal cone on the ultimate premolar, by which all the premolars are, as in artiodactyles, less complex than the true molars, by the form and position of the nasal bones and hy the structure of the external nostril.

Gemus Lopllonon, Cuv.-In the year 1800 Cuvier* first annomiced the discovery of the fossil remains of a quarlupper

* Bulletin des Sciences, Paris, Nirose, an. viii, No. 34. 
allied to and of the size of the tapir, in the lacustrine deposits of the Montagne Noir, near Issel, department of Aude in Languedoc. The outer incisor of the lower jaw was shortened to give ron to the longer corresponding incisor above, as in the tapir; the canines offered the same proportional development; but the three first molars (premolars) of the lower jaw presented a more simple structure, having the crown compressed, and forming two cones, the front one being the largest; -in short, a structure, the type of which is presented only by the first of the three premolars $(p z)$ in the genus Tapirus.*

Years elapsed ere Cuvier obtained clear evidence of the structure of the upper molars of this new fossil Mammal. Such detached teeth as had been obtained from the freshwater formations near Issel were referred, owing to the way in which they departed from the type of the upper molar teeth of the Tapir, to the genus Rhinoccros. This fact is indicative of the annectant affinities of the Lophiodon in the perissodactyle series. $t$ Besides the character of form, the upper molar series of Lophiodon differs, like the lower one, from that in Tapins, in the greater simplicity of the last two premolar's; these teeth have a single cone on the inner side in Lophiodon; they have there two cones in Tapirus, forming the imer terminations of two transrerse ridges, as in the true molars. These teeth in the Lopthiodun differ from those in the Tapirus in the greater fore-and-aft expanse of the outer terminations of the transverse ridges, and the less depth of the cleft between them : a more complete coalescence of thuse parts causes a more entire outer wall of the crown, and completes the transition to the Iilinoceros type, towards which the Palrotherium offers the next step.

Gemus Palmotuentur, Cur.-This extinct genus of quadruped was restored (fig. 98) by Curier through a series of admirahly instructive steps, ultimately verified ly a complete

*Ency. Brit, art. Onontolocis, p. 471, fig. 136, p2.

+Ibid., p. 470. 
series of fossils, obtained chiefly from the upper eocene gypseous formation at Montmartre and other parts of France. The

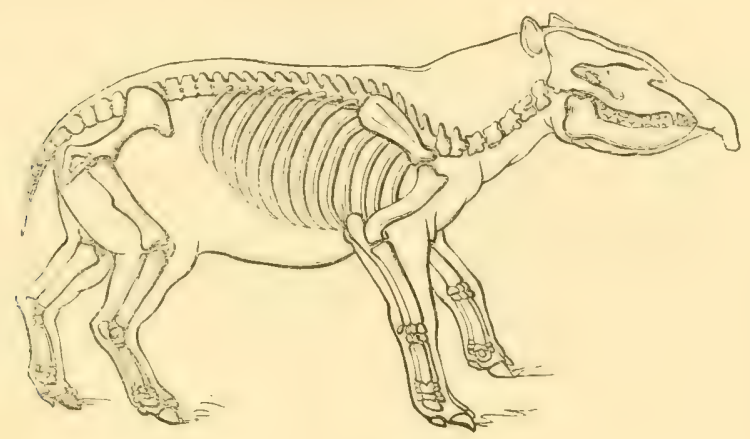

Fig. 98.

Restoration of the Palceotherium (Eocene Gyps).

molar teeth of Palcotherium (fig. 99) approach nearer to those of the rhinoceros; but in the number, kind, and general arrangement the entire dentition resembles that of Pliolophus. The skull aftords indications that the Paleothere possessed a short proboscis. It had three toes on each foot, each terminated by a hoof; the middle one being the largest. The femur had a third trochanter, and the dorso-Iumbar vertebrre were 21 in number. Several species of Palcotherium have been determined, ranging from the size of a sheep ( $P$. curtum) to that of a horse (P.magnum). Fig. 99 gives the grinding surface of an upper molar of this species from the upper eocene of the Bembridge berls, Isle of Wight. The crown is

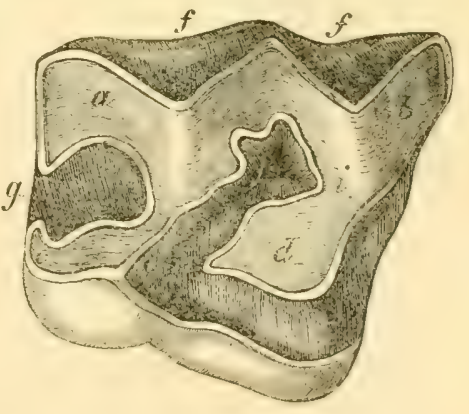

Fig. 99.

Upper molar, Palcotherium magnum (Eocene). divided into an anterior $(b, d)$ and posterior $(d, c)$ part ly an 
oblique fissure (e), continned from near the middle of the inner surface of the crown obliquely across two-thirds of the tooth. Each division is subdivided partially into an outer $(a b)$ and an imner $(c d)$ lobes; the anterior division, by the terminal expansion ( $i$ ) of the fissure $(c)$, the posterior one by the fissure $(g)$. The lobes $(c$ and $d)$ are bordered near their base by a ridge. This is the type of grinding surface, on which are superinduced the modifications of that surface in the upper molars of the rhinoceros and horse. The dental formula of Palcotherium is $i \frac{3-3}{3-3}, c \frac{1-1}{1-1}, p \frac{4-4}{4-4}, m \frac{3-3}{3-3}=44$. The canines exceed in length the other teeth, and there are consequently vacancies in the dental series for the lodgment of the crowns of the canines when the mouth is shut.

Genus Axoplotherium, Cuv.-With the same dental formula as in Palcotherium, the present genus, like Dichodon (fig. 102) has no interval in the series of teeth; neither the canine nor any other tooth rising above the general level. The grind-

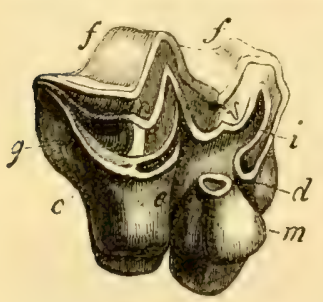

Fig. 100. ing surface of the molar teeth somewhat resembles and prefigures the ruminant type; in the upper jaw the crown (fig. $100)$ is divided into a front $(f e)$ and a back $(f d)$ lobe by a valley (c) extending two thirds across. A second valley ( $g i$ ) crosses its termination at right angles, Upper molar, Anoplotherium commune (Eocene Gyps). forming a curved depression in each division, which it thus subdivides into two lobes, concave towards the outer side of the tooth. There is a large tubercle $(m)$ at the wille entry of the valley (c). The Anoplothere (tig. 101) was of a lighter and more elegant form than the Falarothere: its limbs terminated each in two digits, with the metapodial bones distinct, and the last fhalanx hooferl. Some transitoly oharacters of the embryo ruminant were refamed thronghont life by the Anoplothere. The speries restored in fig. 101 was ahout 
the size of a fallow-deer : it had a long and strong tail, and was probably of aquatic habits. Smaller and more delicate species of Anoplotherioids from upper eocene strata have been referred to distinct generi by later palieontologists. The re-

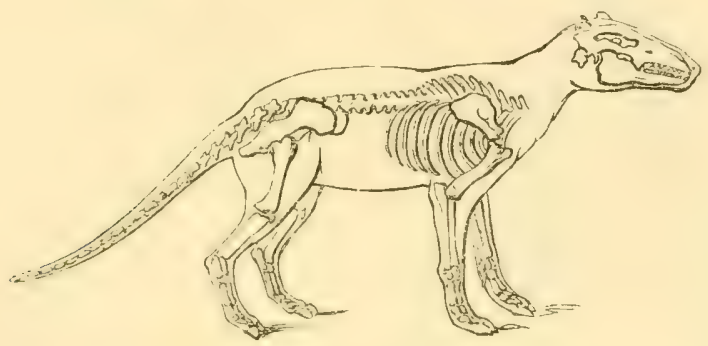

Fig. 101.

Restoration of the Anoplotherium (Eocene Gyps).

searches of Baron Cuvier, which resulted in the restoration of the Palcotherium and Anoplotherium, are the most instructive which the palieontologist can study. They form the third rolume of the 4to edition of the Ossemens Fossiles, 1822-5.

Gcnus Dichodos, Ow.-The upper eocene beds of Hampshire have yielded evidence of an extinct form of even-toed (artiodactyle) hoofed quadruped, most interesting as a transitional form between the Anoplotherioids and the true Ruminants. Like the Anoplotherinm the dental series is continuous, without break-a character which is only manifested by mankind among existing Mammals-the crowns of the teeth, in Dichodon, being all of nearly equal height, as they are in man. On each side of both upper and lower jaws there are in the Dichodon (fig. 102) three incisors $\left(i_{1}, 2,3\right)$, one canine $(c)$, four premolars $(p \mathbf{1}, \mathbf{2}, 3,4)$, and three true molars $(m \mathbf{x}$, 2,3 ) -in all forty-four teeth, constituting the typical diphyodont* dentition which so many mammalian genera, on their first appearance in the eocene strata, exhibit. It is formulized as follows :- $i \frac{3-3}{3-3}, c \frac{1-1}{1-1}, p_{4-4}^{4-4}, m \frac{3-3}{3-3}=44$. From the first incisor

\footnotetext{
* See Ency. Brit., art. Odontoloax, p. 439.
} 
to the third premolar the teeth have a more or less trenchant crown. The back of the third premolar ( $p 3$ ), and all the fourth premolar ( $p \cdot 4)$, show the crushing form of

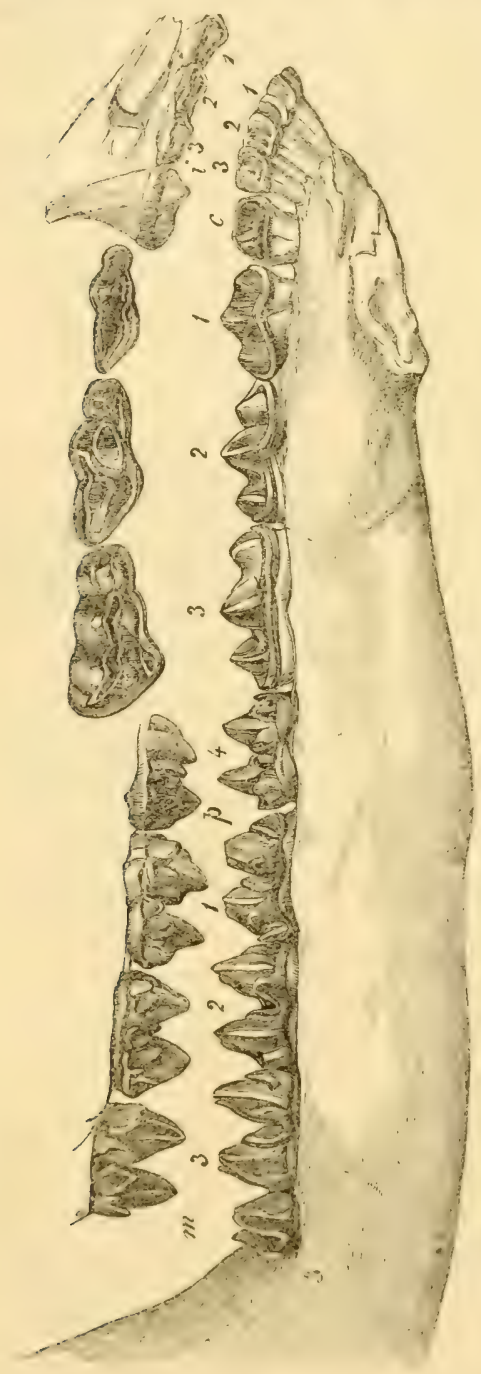
crown ; the pattern of which in the true molars, after the wearing

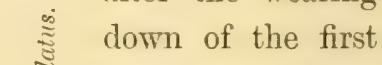
: ริ duces the double ง : enamel which are 筞 now peculiar to the Ruminants : quadrupeds. The first ( $p$ r), second $\left(p_{2}\right)$, and third $\left(\begin{array}{ll}p & 3\end{array}\right)$ premolars, have their crown \% much extended from before backwards, with three progressively more developed and pointed compressed cusps on the same line: to which is added, in the upper jaw, an imner ridge, dereloped in the third premolar (2) 3) into an inner posterior cusp. The fourth premolar $(p+4)$ 
has a thicker and shorter crown with two pairs of cusps. The upper true molars $(m x, 2,3)$ have the two pairs of cusps sharp and pointed, with a series of five low accessory points developed from the outer part of the cingulum. The lower molars $(m \cdot \mathbf{r}, 2,3)$ have as complex crowns as the upper ones, but with the accessory basal points $(a, b, c, \epsilon)$ developed from the inner, instead of the outer sile of the crown, and with the convex sides of the chief cusps turned in the opposite direction to those above. At the upper part of fig. 102 the outer side of the true molars, of the last premolar, of the canine, and of the incisors, is shown, together with the grinding surface of the three anterior premolars in the upper jaw. Below these the inner surface

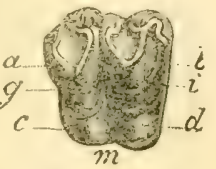

Fig. 103 .

Upper molar of Dichodon. of the entire series of the lower teeth is shown, together with the grinding surface of the three true molars, the last of which $\left(\begin{array}{ll}m_{3} & 3\end{array}\right)$ here supports a third pair of lobes $(c$.$) As$ compared with the anoplotherian molar (fig. 100), the outer lobes $(a, b)$ of that of the Dichodon (fig. 103) are thicker and sharper; the imner ones $(c, d)$-especially the latter-are dereloped to an equality with the outer ones, and more distinctly separated from them. The valley $(m)$ extends across the whole breadth of the tooth, and is crossed at right angles by the fore-and-aft doubly-curred valley ( $g$ and $i$ ). The extinct species showing the above characters, and on which the genus was founded, w was nearly the size of a fallowdeer : it is called Dichodon cuspidatus, in reference to the numher of sharp points on the unworn molars. The dentition indicates that its food may have been of a peculiar character, perhaps not exclusively of a vegetable nature.

In the same upper eocene formation of Hampshire have been found instructive examples of some smaller menters of the extinct anoplotherioid family.

* Quarterly Journal of the Geological Society, tom. iv., 1847, p. 36, pl. 4. 
Genus Dichobune.-The genus Dichobune (from si\%a, bipartitus; Bouvis, collis) was proposed by Cuvier, in the second edition of his Osscmens Fossiles, 4to, tom. iii., 1822, p. 64, for the Anoplotherium minus of the original Memoir in the Annales du Muséum, tom. iii., 1803, and for the A.leporinum of the th edition, 1822, tom. i., pl. 2, fig. 3 ; and tom. iii., pp. 70 and 251. It is closely allied to the anoplotherioid genus Xiphodon; the dental formula is the same, only there is a slight interval between the canine and the first premolar in both jaws; the first three premolars are subcompressed, subtrenchant, but less elongated from behind forwards than in Xiphodon. Besides the two normally-developed and functional digits on each foot, there may be one, sometimes two, small supplemental digits.

The best illustration of the structure of the upper true molars is afforded by the figure of one of these teeth in the Procecdings of the Geological Socicty, May 20, 18t6, pulblished in the Quarterly Joumal, vol. ii., p. 420. "The anoplotherian character of the tooth is shown by the large size of the lobe ( $p, x$, fig. 1), and the subgeneric peculiarity by the continuation of its dentinal base with that of the inner and anterior lobe $(i d)$, at the early stage of attrition presented by the crown of the tooth in question. In the large and typical Anoplotheria, the lobe $(p)$ preserves its insular form and uninterrupted contour of enamel until the crown is much more worn down than in the present tooth (fig. 1). In this respect, as in the modifications of the lower molar teeth, the genus Dichobune shows its closer affinity to the true Ruminants; hut the little fold of enamel dividing the lobe $i d$ from $p$ distinguishes the upper molar tooth in question from that of any Ruminant." (P. 421.)

A new and interesting specius of this genus, called Dichobne orina, has been foumderl upon an almost entire lower jaw with the permanent dental series, wanting only the four middle 
incisors, which now forms part of the palæontological collection in the British Museum. The dental formula, as shown by the mandibular teeth, and by the evidence on their crowns of the presence of the teeth of the upper jaw, is the typical one in diphyodont Mammalia, viz.- $i \frac{3-3}{3-3}, c \frac{1-1}{1-1}, p \frac{4-4}{4-4}, m \frac{3-3}{3-3}=44$. The canine, with a crown like that of the first premolar, and not longer, is separated from it by an interval of half the breadth of the crown, and by a narrower interral from the outer incisor. The first premolar is dirided by an interval of scarce a line's breadth from the second. The rest of the molar series are in contact. The total length of the lower jaw is 5 inches 11 lines $\left(0^{\mathrm{m}} \cdot 148\right)$; that of the molar series is 2 inches 11 lines $\left(0^{\mathrm{m} .} 075\right)$; that of the three true molars is 1 inch $4 \frac{1}{4}$ lines $\left(0^{\mathrm{m} .} 035\right)$. The near equality in height of the crowns of all the teeth, and their general character, show that the animal. belonged to the anoplotherioid family. The dentition of the present species differs from that of Dichodon in the absence of the accessory cusps on the inner side of the base of the true molars; and both from Dichodon cuspidatus and Xiphodon gracitis in the minor antero-posterior extent of the premolars; it corresponds with Dichobune (as represented by the $D$. leporina, Cuvier) in the proportions of the premolars and in the separation of the canine from the adjoining teeth: to this genus, therefore, the fossil is referable, provisionally, in the absence of knowledge of the molars of the upper jaw, which are the most characteristic: and the writer has proposed to call the species, from the size of the animal represented by the fossil, Dichobunc ovina. It is from Hampshire eocene.

Genus Xiphodon.-The genus Xiphodon was indicated, and its name proposed, by Cuvier, for a small and delicate, long and slender-limbed, anoplotherian animal, which, in his first Memoir (Annales du Nuséum, tom. iii., p. 55, 1803), he had called Anoplotherium medium; but he altered the name, in 
the second th edition of the Ossemens Fossiles (tom. iii., pp. 69 and 251, 1822), to that of Anoplotherium gracile.

The distinction indicated by Cuvier is now accepted by palæontologists as a generie one, and a second species ( $\mathrm{X}$ iphodon Geylensi:s) has been added by MI. Gervais (Paléontographlic Française, 4to, 18ł5, p. 90) to the type-species, Xiphodon gracilis, of which he figures an instructive portion of the dental series of both jaws, obtained from the lignites of Débruge near Apt. The dental formula of Xiphodon is the typical one, viz.- $i_{3-3}^{3-3}, e_{1-1}^{1-1}, p_{4-1}^{4-4}, m_{3-3}^{3-3}=44$.

The tecth are arranged in a continuous series in both jarrs. The canines and first three premolars have the crowns more extended antero-posteriorly, lower, thimner, transversely, and more trenchant, than in the type Anoplotheric (whence the name Xiphlodon, or sword-tooth). The feet are didlactyle, with metacarpals and metatarsals distinct. The tail is short. The lower true molars have two pairs of crescentie lohes with the convexity turned outwards. It was nearly allied to Dichodon.

Genus Microtheriusi.-Entire crania of Microtherium, from the lacustrine calcareous marls of the Puy-de-Dôme, are in the British Museum, and these show that the hinder dirision of the upper true molars was complicated by the additional (third) cusp.

With regard to Microtherium, the musually perfect fossil skulls of that small Herbivore, which did not exceed in size the delicate cherrotains of Java and other Indo-Arehipelagic islands-e.g. Tragulus kenchil-are of importance in regard to the question of their alleged affinity to the Ruminantiu, on account of the demonstration they give of the persistent and functional upper incisor teeth. The little encene event-toed IIerhivores, like the larger Anoplotherioids, thus departed from the characters of the true limminants of the present day, in the same degree in which they adhered to the more general type of the artiodactyles. Had M. de Blainville, who helieved 
them to be Ruminants, possessed no other evidence of the Microtherium than of the Dichobune murince and Dichobune oblique, Cur., he would have had the same grounds for referring the Microtheria, as the Dichobunes, to the genus Trangules or Mosehus (les Cherrotains); but the entire dentition of the upper jaw of the species Anoplotherium murinum and $A$. obliqum, referred hy Cuvier to his genus Dichobune, must be known before the existence of Ruminants in the upper eocene gypsum of Paris can be inferred.

No doubt the affinity of these small Anoplotherioids to the Cherrotains was rery close. Let the formative force be transferred from the small upper incisors to the contiguons canines, and the transition would be effected. We know that the ruminant stomach of the species of Tragulus is simplified by the suppression of the psalterium or third bag. The stomach of the small Anoplotherioids, whilst preserving a certain degree of complexity, might have been somewhat more simplified. The certain information which the gradations of dentition displayed by the above-cited extinet species impart, testifies to the artificial character of the order Ruminantia of the modern systems, and to the natural character of that wider group of eren-toed hoofed animals for which has been proposed the term ARTIODACTYLA.*

Genus Hrexodox, Laiz. - With the delicate and beautiful. Herbivora of the upper eocene and lower miocene periods, there coexisted carnivorous quadrupeds, which, to judge by the character of their flesh-cutting teeth (carnassials), were more fell and deadly in their destructive task than modern wolves or tigers. Of these old extinct Camivora a species of the remarkable genus Hyanodon, of about the size of a leopard, has left its remains in the upper eocene of Hordwell, Hampshire. Fig. 10t shows the dentition of the under jaw of another species of the same genus from miocene heds at * Quarterly Journal of the Geological Society, vol. iv., 1847. 
Débruge and Alais, France. The carnassial teeth $(m, \mathrm{r}, 2,3)$, instead of being one in number in each ramus of the jaw, as in modern Felines, were three in number, equally adlapted by their trenchant shape, to work like scissor-blades on the teeth

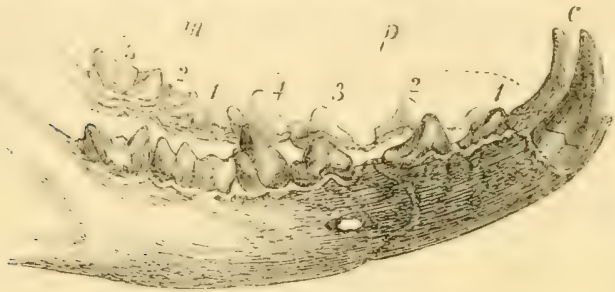

Fig. 104.

Dentition, lower jaw, of Hycenodon. of the upper jaw, in the act of cutting flesh. After the small incisors came a pair of large piercing and prehensile canines (c), followed by four compressed pointed and trenchant premolars $(p, x, 2,3,4)$ in each side of the jaw ; the whole of this carnivorous dentition conforming to the diphyodont type :-

$$
i \frac{3-3}{3-3}, c \frac{1-1}{1-1}, p^{4-4}, m \frac{3-3}{3-3}=4.4 .
$$

Genus Auphicyox. - With the foregoing predecessor of the digitigrade Carnivora was associated a forerumer of the

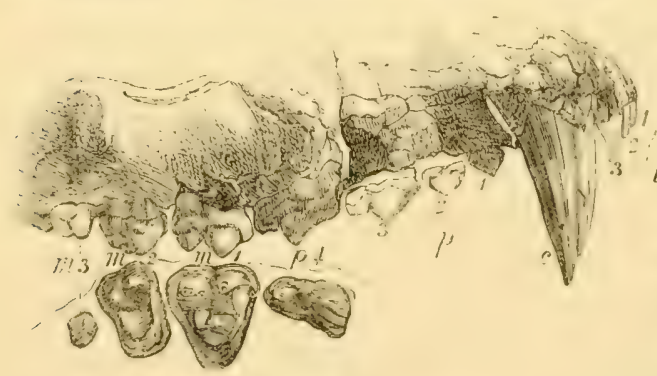

Fig. 105.

Dentition, upper jaw, of Amphicyon. plantigrade $\mathrm{fa}-$ mily, viz., a large extinct species having the molars tuberculated, after the pattern of those of the bears; but retaining, like $H y$ anodon, the perfect type of diphyodont dentition. Fig. 105. shows the teeth of one side of the upper jaw of the Amptricyon giganters. The first and second molaris ( $m$, x and $z$ ) have each two tubereles on the outer side and one on the inner side: the last tuherenlar molar $(m, 3)$ is of rery small size. Fossil remains of $A m p$ thi- 
cyon have been found principally in the miocene deposits at Sinsans, south of France. Those of a smaller species from the miocene at Eppelsheim, have been referred to the wolverine genus, as Gulo diaphorus, Kaup.

The proofs of the abundant mammalian inhabitants of the erocene continent were first obtained by Cuvier from the fossilized remains in the deposits that fill the enommous Parisian excaration of the chalk. But the forms which that great anatomist restored were all new and strange, specifically, and for the most part generically, distinct from all known existing culudrupeds. By these restoratious the naturalist was first made acquainted with the aquatic cloven-hoofed Anoplothere, and with its light and graceful congeners, the Dichobunes and Xiphodon, with the great Palæotheres, which may be likened to hornless rhinoceroses, with the more tapiroid Lophiodon, with the large peccari-like Choropotamus, and with about a score of other genera and species of placental Mammalia.

Almost the sole exception to the generic distinction of these eocene forms from modern ones was yielded by the opossum of Montmartre (Didelphlis Gypsom, fig. 106) ; and what made this discovery the more remarkable was the fact that all the known existing species of that marsupial genus are now confined to America, and the greater part to the southem division of that continent. An opossum apjears to have been associated with the Hyracotherium in the eocente sand of Suffolk; where likewise, a porcine beast with tusks like ordinary canines, and some remains of a monkey (Eopithecers), have been found. With respect to the Didelphis Gypsorum, its generic relations were deduced from characters of the lower jaw and teeth; but these were associated with other parts of the skeleton in the same block of stone. When Cuvier expressed his convictions from the teeth and other parts first exposed and exanined, his scientific associates were incredulous. He invited then, there- 
fore, to witness a crucial test. The outline of the back part

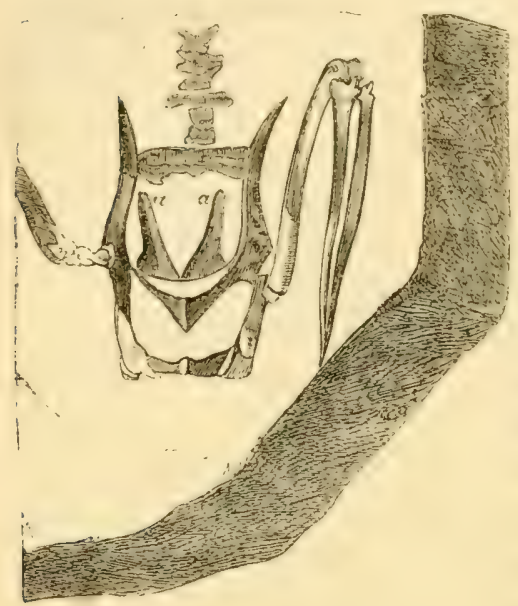

Fig. 106.

Pelvis and marsupial bones of Didelphis Gypsorum (Eocene, Paris). of the pelvis was exposed, the fore part buried in the matrix. By his delicate use of the graving-tool, Cuvier brought to light the forepart of the pelvis with the two marsupial bones (fig. $106, a, a)$ in their natural position. He thus demonstrated that there had been buried in the soft freshwater deposits, hardened in after ages into the buildingstone of Paris, an animal whose gemus at the present day is peculiar to America. It is not uninteresting to remark that the Peceari, the nearest existing ally to the old Choropotamus, is, like the opossum, now peculiar to America; and that two species of tapir, the nearest living allies to the Lophiodon and Palaothere, exist in South America.

The marine deposits of the miocene epoch show the remains

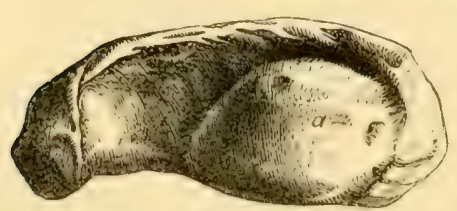

Iiig. 107 . of extinct genera of dolphins (Ziphizes and Dioplodon) and of whales (Balcenodon). Petrified cetaceous teeth and ear-bones, called "cetotolites" (fig. 107) Cetutolite or fossil ear-lyme of Bulreno- have been wakhed ont of predon gibbosus (lied Crag, Suflolk). vious strata into the red cratg of Suffulli. These fossils helong to speciess distinct from any known existing Cetacea, and which, jrohaloly, like some contemporaly yuadrupeds, retained fully-eleveloped characters which are embryonic and transitory in existing cognate 
Mammals. The teeth of these Cetacea were determined in 1840 , the ear-bones in $\mathbf{1 8 4 3}$. The vast numbers of these fossils, and the proportion of phosphate of lime in them, led Professor Henslow* to call the attention of agricultural chemists to the red crag as a deposit of valuable manure. Since that period it has yielded a large supply, worth many thousand pounds annually, of the superphosphates. The red crag is found in patehes from Walton-on-Naze, Essex, to Aldbro', Suffolk, extending from the shore to 5 or 15 miles and more inland. It averages in thickness 10 feet, but is in some places to feet. Broken-up septarian nodules form a rude flooring to the crag, left by the washing oft of the London clay, and called "rough stone." The phosphatic fossils, or "cops" as they are now locally termed, occur' in greatest abundance immediately above the "rongh-stone." Thousands of cubic acres of earlier strata must have been broken up to furnish the cetacean nodules of the "red crag." This is a striking instance of the profitable results of a scemingly most unpromising discovery in pure science,- - the determination of what in $18+0$ was regarded as a rare, unique, and most problematical British fossil. $\dagger$

Our knowledge of the progression of mammalian life during the miocene period is derived chiefly from continental fossils. These teach us that one or two of the generic forms most frequent in the older tertiary strata still lingered on the earth, but that the rest of the eocene Mammalia had been superseded by new forms, some of which present characters intermediate between those of eocene and those of pliocene grenera. The Dinotherium and narrow-toothed II astodon, for example, diminish the interval between the Lophioulon and the elephinet the Anthrecotherinm and Himpohys, that hetween

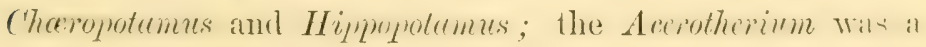


link connecting Pulceutherium with Rhinoccros; the Hippotherium linked on Puloplutherium with Equus.

One of the most extraordinary of the extinct forms of the cetaceous order has been restored from fossil remains discovered in formations of the miocene age in Europe and North America. The teeth of this carnivorous whale, for which the generic name Zeuglodon seems now to be generally accepted, were first described and figured by the medietral palieontologist scilla, in his treatise entitled De Corporibus Marinis (tto, $17 \pm 7$, tab. xii., fig. 1), and have since given rise to various interpretations. The originals were obtained from the miocene stratia at Malta, and are now preserved in the Woodwardian museum at Cambridge.

The remains of a gigantic species of the same genus, discovered by Jr. Harlan in miocene formations of Arkansas, Mississippi, were described and figured by him as those of a reptile, under the name of Busiloscurus.* Teeth of a smaller

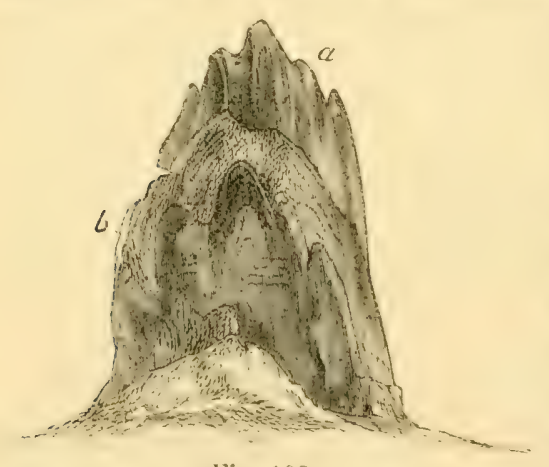

Fig. 108.

I)eciduous amd permanent teeth of the $Z$ exylodon. species, discovered by M. Grateloup, in miocene beds of the Gironde and Herault, were ascribed by him also to a reptile, under the name of Squalodon. + In 1839 Dr. Harlan brought over his specimens of Basilosaurus to London, and submitted them to the writer's inspection, by whom they were deternined to be mammalian and ectaceons. The entire skeleton has since heen obtained from miocene deposits in Alahame, revealing a length of body of about 7 (o feet. The

* Medical and Physical Liesearches, p. 333.

† Act. Soc. Linn. de Bordeaux, 1840, p. 201. 
skitull is very long and narrow; the nostril single, with an upward aspect, above and near the orbits. The jaws are armed with teeth of two hinds, set wide apart; the anterior teeth have subcompressed, conical, slightly-recurved, sharp-pointed crowns, and are implanted by a single root; the posterior teeth are larger, with more compressed and longitudinally extended crowus (fig. 108), conical, but with a more obtuse point, and with both front and hind borders strongly notched or serrated. The crown is contracted from side to side in the middle of its base, so as to give its transverse section an hour-glass form (fig. 109), and the opposite wide longitudinal grooves which produce this form become deeper
as the crown
approaches the
socket, where
they meet and
divide the root into two fangs.

Fig 109.

The name Zeu- Transverse section of a tooth of the Zeuglodon. Nat. size. glodon (yoke-tooth) refers to this structure. The mode of succession of the teeth in this genus conforms to the general mammalian type more than does that of any of the existing carnivorous Cetaceans. In the figure given by Dr. Carus * of a portion of the jaw of $Z$ enegloclon cetoïdes, a deciduous molar (fig. $108, a)$ is about to be displaced and succeeded, vertically, by a second larger molar. This mode of succession is not known in the Platanista or Inia, which among existing true Cetacea present teeth most like those of Zeuglodon; but it is a mode of suceession and displacement affecting certain teeth in the herbivorous Cetacea, or Sirenia; and we thus seem to have in the Zeuglocton another of those numerous instances of a more generalized character of organization in older tertiary Man-

* Nova Acta Cæes. Leop. Carol, vol. xxii., tab. xxxix. B, fig. 2, p. 340. 
malia. In systematic characters, Zeuyludon typifies a distinct family or group, intermediate between Cetacea proper and Sirenia.

Of the latter family or order, however, represented at the present day by the Dugongs, Manatees, and Stellerians or Arctic Manatees (if the species still survives), there were abundant and more widely distributed representatives during the miocene period, having, upon the whole, the nearest affinity with the existing African Manatee (Manatus Sencgalensis), but with associated characters of the Dugong (Halicore). There were, e.g., two incisive tusks in the upper jaw, and four or five small incisors along the deflected part of each ramus of the lower jaw. The upper molars, with three roots, were thickly enamelled, like those of the Manatee, but with a pattern of grinding surface which led Cuvier to sttribute detached specimens to a small species of Ifippopotumus. The lower molars had two roots. All the bones have the dense or solid structure of those of the Sircnia. On the remains of this remarkable amphibious Mammal, discorered by Kaup in 1838, in the miocene beds at Eppelsheim, he founded the genus Halitherium. Other remains have been discovered in Piedmont, Asté, and many parts of France, from the "calcaire grossier" of the Gironde, containing Lophiodont fossils, up to the pliocene near Montpellier; at which period the Halithcrium seems to have become extinct.

Gonus Macrotheriun, Lartet.-The elentate order, which is so abundantly and rariously represented in South America, which has its Orycteropes and Pangolins in Afriea, and its Manises in tropical Asia, has no living representative in Europe. Perhaps the most mexpecter form of Mammal to be revealer by fossil remains firn European tertiary deposits, after a Marsupial, was a memlere of the erlentate ordere. cuvier, hy whom the evidenere of this extinet aninal wats first made known, prefies his deseription of the single mutilateal 
phalangeal bone, on which that evidence was founded, by the remark, that "nothing proves better the importance of the laws of comparative osteology than all the consequences which one may legitimately draw from a single fragment." One willingly admits the proof so afforded of the former existence of animals now unknown; but one may demur to the conclusion that their extinction was due to some sudden catastrophe.

The single mutilated ungual phalanx on which Cuvier based his conclusions in regard to the species in question was discovered, associated with remains of Rhinoceros, Mastodon, Dinotherium, and Topi, in a formation near Eppelshein, Hesse-Darmstadt, which is now determined to belong to the miocene division of the tertiary series. This phalanx shows two distinctive character's of the edentate order:-1st, Its posterior surface for articulation with the antepenultimate phalaux is a double pulley, hollowed out on each side, with a salient crest between, constituting the firm kind of ginglymoid joint peculiar to certain Edcntata; 2 7 , The concare arch formed by that pulley curves furthest backward at its upper part, which would prevent the claw being retracted upward, as in the cat tribe, and constrain the flexion downward"ainsi c'est necessairement un onguéal d'edenté."* To the foregoing characters are joined two others which Cuvier believed to determine "as necessarily" the genus. The species of Myrmecophaya have on the upyer part of the pointed end of the claw-phalanx a groore, indicative of a disposition to bifurcate; in the species of Manis the bifurcation is complete, the cleft extending as far as the middle of the claw-bone: so likewise in this fossil. The Pangolins (Manis) have not thuse bony sheaths which, in the sloths, some ant-eaters and armitdillos, rise from the hase and cover the root of the claw ; there was a like absence of any clatw-sheath in the fossil. Thus the fossil (daw-bone has no homologne in existing nature save those

* Ossemens Fossiles, 4to, t. v., pt. i., p. 193. 
of the Manis ; and, "according to all the laws of co-existence, it is impossible to doubt that the most marked relations of the animal that bore it should have been with that genus of quadrupeds." But what must have been its size? The phalaux was not one of the largest on the foot-for it had not those slight raised borders which one sees in the large claw-bones of the Pangolins. This question, which Cuvier answered by the proportions of the short-tailed Manis, at $2+$ French feet, has had a more reasonable reply given to it by certain other bones of the skeleton subsequently discovered in the miocene tertiaries of France. These discoveries have likewise rectified and moderated the absolute application of the correlative law to the necessary determination of the genus as well as of the order. The relations of the double-jointed and cleft phalanx to the Edentata is beautifully confirmed; but the additional fossils, and especially some evidences of teeth, have shown that it belonged to a peculiar and now extinct genus intermediate between the Manis and the Orycteropus. And these relations are deeply interesting, on account of the geographical position of both those edentate genera, on tracts of land, viz., which are now most contiguous to the continent containing the remains of the extinct osculant genus.

The locality in France is near the village of Sansan, near Auch, department of Gers, Haute-Pyrenées. The formation is a lacustrine deposit of the miocene period.

Portions of two molar teeth have been found, 1 inch 8 lines in greatest transverse diameter; the tooth preserving the same size and slape through the whole length of the portion-viz., $1 \frac{1}{2}$ inch. They resemble in shape those of the Orycterope, but are less regular and have not the same tubular tissue. Their microsenpie texture appears not to hare been analyzed ; it would be important to determine whether it resembled that of the teeth of the sloths or armadillos. The

* Ossemens Fossiles, 4to, t. v., pt. i., p. 194. 
humerus differs from that of the ant-eaters and armadillos by its greater length in proportion to its breadth, and by the peculiar flattening from before backwards of its lower half, and especially at the condyles, above which it is expanded transversely by both external and internal supra-condyloid ridges. It is not perforated above the imner condyle, as the same bone is in both the Manis and Orycteropus. In the degree to which it departs from the type of the ant-eaters it approaches that of the Megatherioids and sloths_-viz., in its relative length, flattening at the distal end, and the imperforate character of that end. The radius also presents a slothlike character in its greater proportionate length, which exceeds that of the humerus; and in the compression of its lower slightly-expanded end. In both the Pangolin and Orycterope, the radius is shorter than the humerus. The ulna differs likewise from both that of the Pangolin and Orycterope, and still more from that in the Armadillos by the much smaller development of the olecranon, whereby, again, it more resembles that of the sloths. The femur is relatively longer and more slender than that of the terrestrial and fossorial Edentata; it has not the third trochanter which characterizes it in the Orycterope, nor so marked a development of the great and small trochanters as in the Pangolin. In the flattened form of the shaft of the femur, and the position of the rotular surface near one side of the distal end, it resembles the femur of the Megatherium and Mylodon. It is shorter than the humerus; whereas, in both the Pangolin and Orycterope the femur is longer: in this respect the femur of the Macrothere resembles that of the sloths. The great width of the popliteal space dividing the condyles is an edentate and more especially a megatherioid character. The internal condyle is much broader than the external one, as it likewise is in the Megatherioids; it is certainly with the femur of the latter family of the Edentata, rather than with that of the 
Proboscidians or Pachyderms, that one should compare the femur of the Macrothere: it is not so long or so slender relatively as in the sloths. The tibia is much shorter than the femur, and in the expansion of its proximal end and its relative length to the femur it resembles that of the Mregatheroids more than that in the Pangolin or Orycterope; it was not anchylosed to the tibia as in the Armadillos, Glyptodons, and Megatherium, but remained a distinct bone, as in the Mylodon and sloths.

Genus Pliopithecus, Gerv.-In the same miocene deposits of the south of France as those which contained the Macrotherium, fossil remains of two kinds of Quadrumana, resembling a small and large species of Hylobates, have been discoverecl. The smaller of these extinct apes, called Pliopithecus antiqurs by Gervais, is based upon the lower jaw and dentition. The teeth occupy an extent of $1 \frac{1}{2}$ inch; the two incisors are narrower, the canine less, and the last molar is larger than in the siamang $(H$. syndactyla). As in this species the first premolar is uni-cuspid, and the hind talon of the second is more produced than in the chimpanzee and gorilla, and to the degree in which the fore-and-aft diameter of the tooth exceeds the transverse one, it departs farther from the human type; in the degree of the development of the talon or third lobe of the last lower molar, the Pliopithceus resembles the tailed monkeys (Semnopithecus and Innus).

Genus Dryopitineces, Lart.-In the larger miocene ape (Dryopithecus Fonteni, Lart.) the canine is relatively larger than in the IIylobutes, and the incisors, to jutge by their alveoli, are relatively narrower than in the chimpanzee and human sulject. The first premolar has the outer cusp pointed, and raised to douthe the height of that of the second premolar, and its imer lobe is more rudimental than in the chimpanzee,*

* Compare Comptes Rendus de l'Aend. des Sciences, tom. xliii. (July 28, 1856, plate, fig. 7), with Trans. Zool. Soc., vol. iv., plate 32, fig. 3, p. 3. 
and departs proportionally from the human type. The posterior lobe or talon of the second premolar is more developed, and the fore-and-aft extent of the tooth greater, than in the chimpanze, thereloy more resembling the second premolar of the siamang, and less resembling that of the human subject. The last (third) molar is mudeveloped in the fossil jaw of the Dryopithecus, and its anount of departure from the human type, and approach to that of Innus, cannot be determined. The canine is more rertical in position than in Troglodytes or Pithccus, but this character is offered by some of the small South American apes, and camnot be eited as a mark of real affinity. From the portion of humerus associated with the jaw of Diyopithceus, the arm would seem to have been proportionally longer and more slender than in the chimpanzee and gorilla, with a cylindrical shaft, more like that in the long-arıned apes (Hylobates), and less like the arm of the human subject.

The characters of the nasal bones, orbits, mastoid processes, relative length of upper limb to trunk, relative length of arm to fore arm, relative length and size of thumb, relative length of lower limb; and, above all, the size of the hallux and shape of the astragalus and calcaneum, must be known before any opinion can be trusted as to the proximity of Dryoprithecus to the human subject.

Genus Mesopitnects, Wagn--In tertiary formations of Greece, at the base of Pentelicon, remains of a Quadrumane have been found, which Professor. Wagner * regards as transitional between Hylobates and Scmnopithecus: the third lobe of the last molar is, however, as well developed as in the latter genus.

In the pliocene deposits of Montpellier remains of a monkey occur, referred by Christol to a Cercopithecus; and in pliocene brick-earth in Essex the writer has determined part of the fossil jaw and teeth of a Macacus.

* Abhanglungen der k. bayer Akademie, bd. ii., 1854, Munchen. 
Genus Dnothericx, Cuv. and Kp.-This name was given by Kaup, after the discorery of the singular shape and armature of the lower jaw, to the huge bilophodont Mammal, first made known by Cuvier under the name of "Tapir gigantesque." The length of the skull, from $f$ to $d$, in fig. 110 , is 3 feet 8 inches.

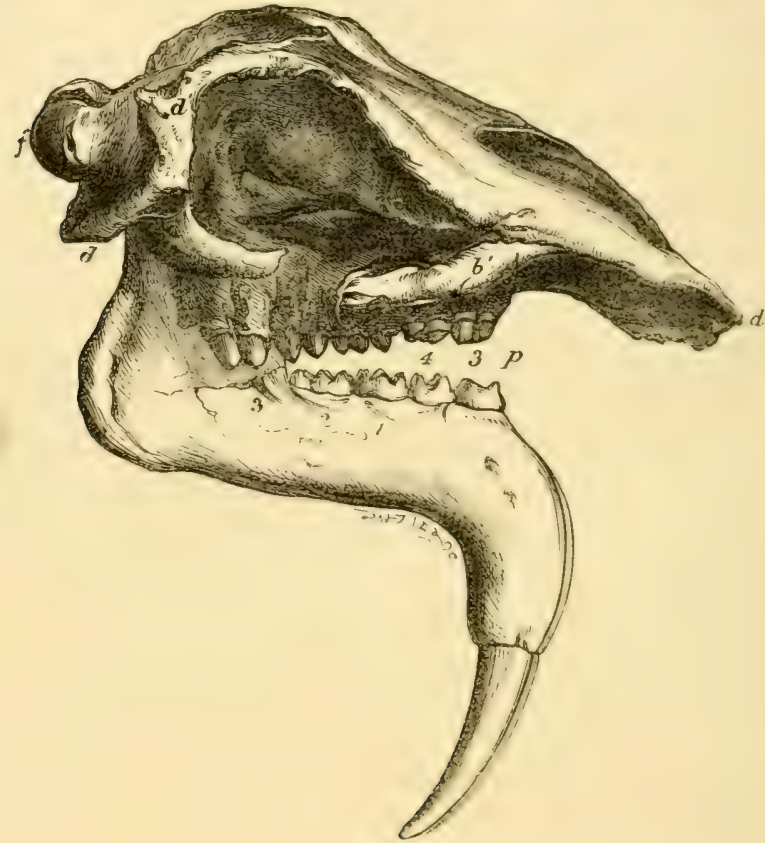

Fig. 110.

Skull of Dinotherium giganteum (Miocene, Eppelsheim).

The teeth in this skull, in addition to the two large deflecter tusks of the lower jaw, are five in number on each side of both jaws. A study of the changes of dentition in fossils of young Dinotheria show that the first two teeth answer to the third and fourth premolars, as signified by the symbols $p, 3$ and 4 ; and that the rest are true molars $(m, 1,2,3)$. Of these, the first tooth $(p, 3)$, is rather trenchant than triturant; the third tooth ( $\mathrm{x}$ ) has three transverse ridges. The other grinders have two transverse ridges. This "bilophodont" 
or two-ridged type is shown by the molars of the Tayir, (fig. 111), Lophiodun, Mcyatherium, Difrotodon, Nototherium, Kangaroo, and Manatee. In the general shape of the skull and aspect of the nostrils Dinotherium most resembles Manctus. Bones of limbs have not

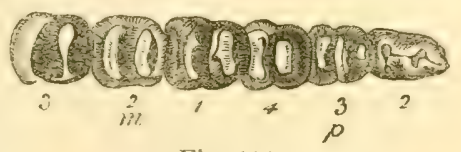

Fig. 111.

yet been found so associated with teeth as to determine the ordinal affinities of Dinotherium. Iet cranial and dental evidences of the genus have been discovered in miocene deposits of Germany, Fance, Switzerland, and I'erim Istund, Crulf of Cambay.

Genus Mastodon, Cur.-The earliest appearance of this genus of proboscidian or elephantoid Mammal is in tertiary strata of miocene age, and by a species in which the fore part of the lower jaw was produced into a pair of deep sockictis containing tusks; but these are only slightly deflected from the line of the grinding teeth (fig. 112, ('). This species of Mastodon, discovered in the miocene of Eppelsheim, was called longirustris by Kilup; but he afterwards recognized it as the same with a species which had been previously called MIastodon aremensis (Croizet and Jobert).* Both belong to that section of Mestodon in which the first and second true molins have each four transverse ridges, and for which Ir. Falconer proposes the name Tetralophodon. In the newer tertiary reposits of North America remains of a Mastodom (WI. Ohioticus) have been discovered, in which the transverse ridges of the grinders are in shape more like those of the Dinothere than in any other Hastodon; the first and second, mrreorer, are bilophodont, the third trilophodont; but this is follower by two three-ridged molars and a last larger molar with four

* Beitrage zur Nacheren Kenntniss der Urweltlichen Saeugethiere, 4to, 1857 , p. 19 . The name angustidens was first applied by Cuvier to teeth of this type or species.

+ First demonstrated by Kaup, Ossemens Fossiles de Darmstadt, 4to, 1835. 
or five ridges.* For the Mastodons with penultimate and antepenultimate grinders with three ridges, Dr. Falconer pro-

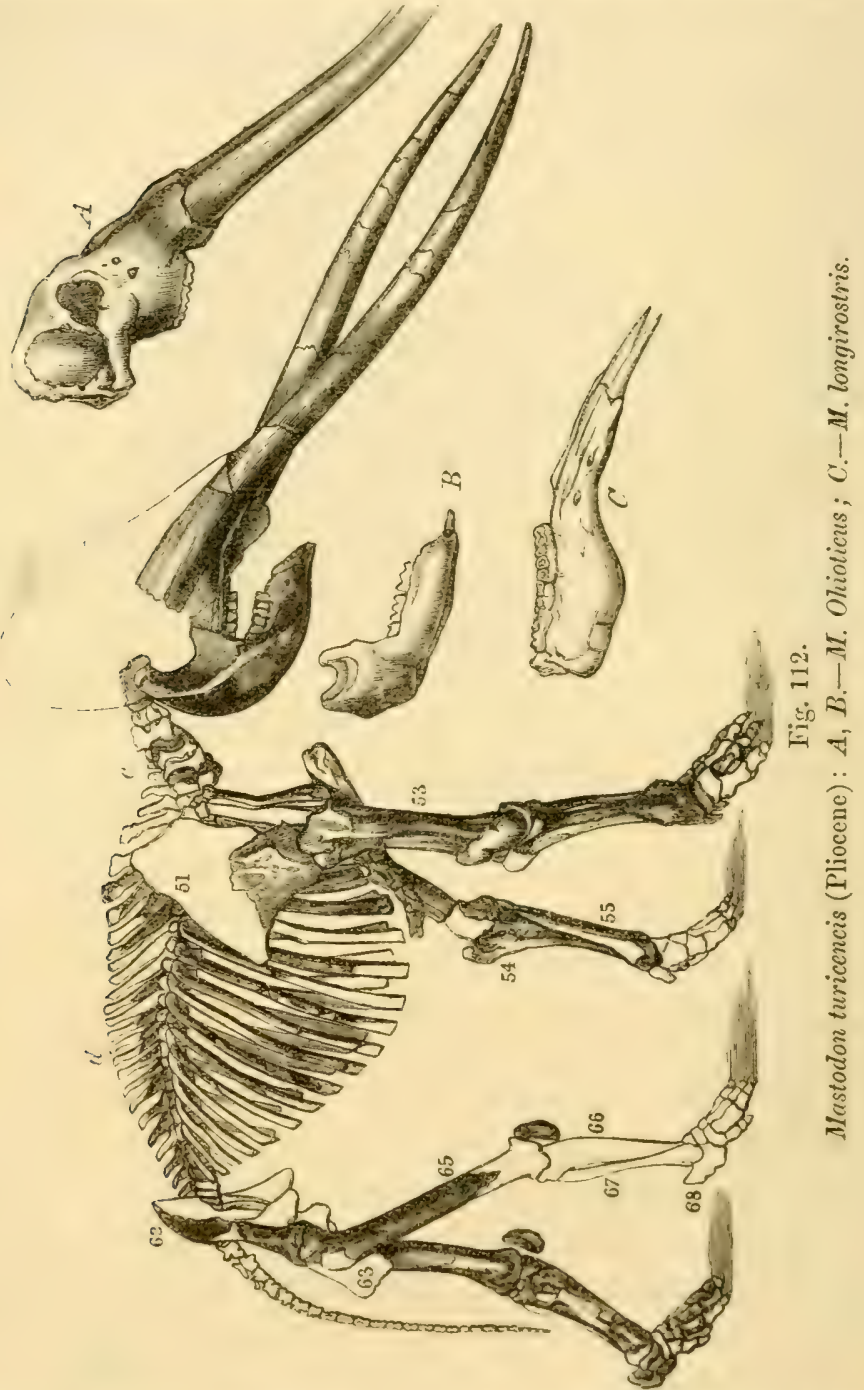

poses the name Tritoptorton. In the Mastocton Ohioticus the lower jaw has two tuskis in the young of both sexes: these * Oren's "Odontography," 4to, 1845, p. 617, pl. 144. 
are soon shed in the female, but one of them is retained by the male (fig. $112, B$ ). The upper tusks are long and retained in both sexes (fig. 112, $A$ ).*

All almost entire skeleton of a Mastodon (1I. turicencis) has been discovered in the pliocene deposits of Asté, Piedmont, and has been elescribur and figured by Professor Sismonka, from whose beautiful Memoir fig. 112 is taken. The total length from the tail to the end of the tuslis is 17 feet. The teeth have the same narrow shape and multi-mammillate structure as in $M$. aricrnens, hut in the numerical character of transverse divisions of the crown this species agrees with

\section{Ohioticus.}

The Mastudons were elephants with the grinding tecth less complex in structure, and adapted for bruising coarser regetable substances. The grinding surface of the molars (fig. 113), instead of being cleft into numerous thin plates, was divided into wedge-shaped transverse ridges, and the summits of these were subdivided into smaller cones, more or less resembling the teats of a cow, whence the generic name.f A more important modification appeared to distinguish the extinct genus, in respect of the structure of the molar teeth; the dentine, or principal substance of the crown of the tooth (fig. 113, d) is covered by a thick coat of dense and brittle

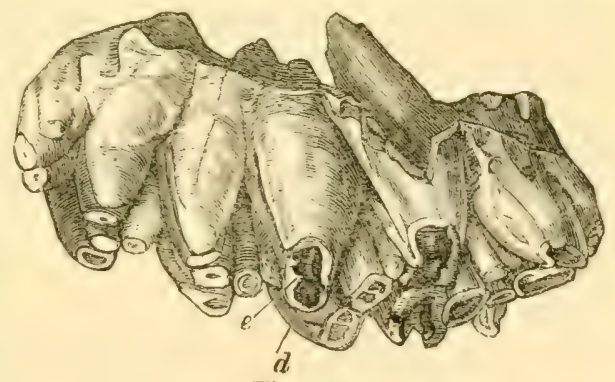

Fig. 113 .

Upper molar of Mastodon. enamel (c); a thin coat of cenent is continued from the 
fangs upon the crown of the tooth, but this substance does not fill up the interspaces of the divisions of the crown, as in the elephant's grinder (fig. 118, c). Such at least is the character of the molar teeth of the two species of Mastodon, which Cuvier has termed Mastodun giganteus and Mastodon angustidens (fig: 113). Fossil remains of proboscidians have subsequently been found principally in the tertiary deposits of tropical Asia, in which the number and depth of the clefts of the crown of the molar teeth, and the thickness of the intervening cement, are so much increased as to establish transitional character's between the lamello-tuberculate teeth of the elephants and the mammilated molars of the typical Mastodons, showing that the characters deducible from the molar teeth are rather the distinguishing marks of species than of genera in the prisent family of mammalian quadrupeds.

The dentition of this family may he expresserl hy the formula-

$$
\text { d. } i \frac{1.1}{2} ; \frac{1.1}{1.1}: c \frac{0.0}{0.0} ; \text { d } m \frac{3.3}{3.3} ; p \frac{1.1}{1.1} ; m \frac{3.3}{3.3}=34 \text {; }
$$

that is to say, in the Proloscidians in which the dentition most nearly approached to the typical one, thirty-four teeth wore developed, as follows:-in the upper jaw, two deciduous

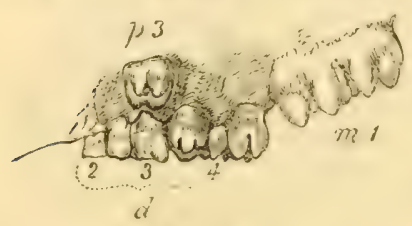

lig. $11+4$

1).e iduons dentition. young Mastodon longirostris. incisors, followed by two permanent incisors developed as tusks; six deciduous molars (three on each side, $d_{2}, 3,4$, fig. 114); two premolars (one on each side, $p$, fig. 11t), and six true molars (three on each side, $m$ r, $2,3$, figs. 114 and 115$)$; - in the lower jaw, two incisons as tuskin

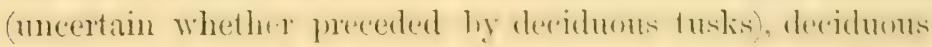
molars, premolars, and molars, as in the upper jaw.

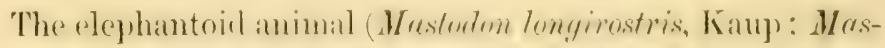

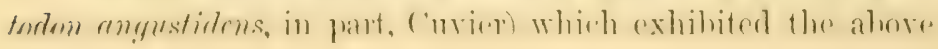


instructire dentition of the probuscidian family, once roamed orer the part of the earth now forming England, France, Italy, and Germany. The first steps in our knowledge of its dentition were made by Cuvier, who called it the narrow-tonthed Mastodon "Mastudon à dents ét roites," or Mastodon angnestidens. This name was suggested by the less brearth of the grinding surface of the teeth as compared with those of a previously described species of Mastodon from North America, called the Mast.

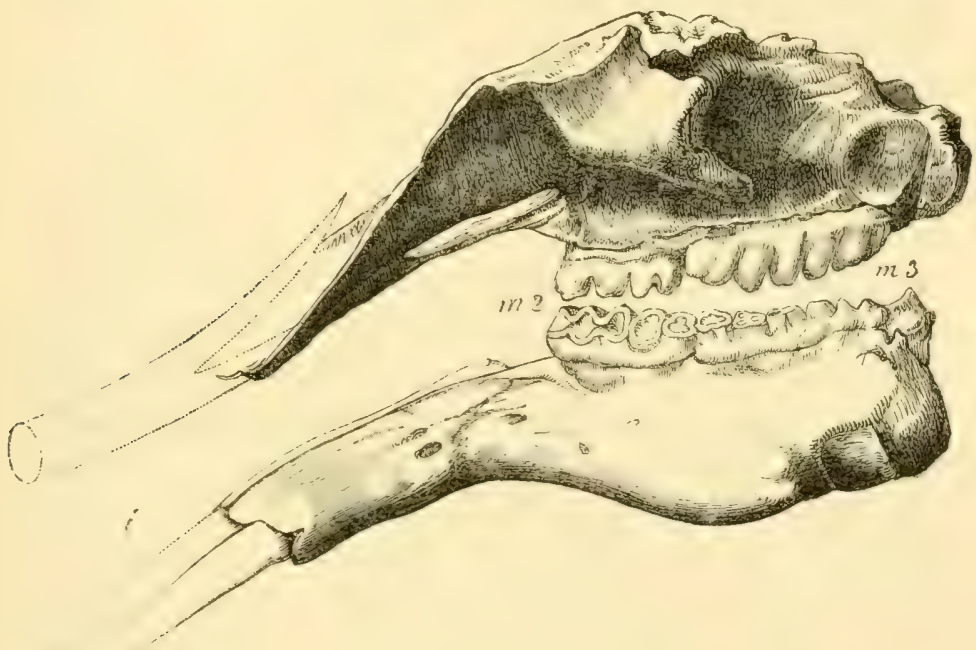

Fig. 115 .

Dentition of old Mastudon longirostris

gigantens or $M$. Ohioticus. Cuvier describes and figures a last. molar, upper jaw, from Trévoux, consisting, as in the specimen from Norfolk Crag (fig. 113), and as in that from Eppelshein (fig. $115, m_{3}$ ), of five transverse ridges, with a front and back talon or subsidiary ridge. The latter is the largest, and sul)divided into teat-shaped tubercles, so as almost to merit the name of a sixth division of the tooth. The principal ridges are divided into two chief or primary tulereles, with secondary tubercles in the interspace; the chief tubereles are more or 
less deeply grooved lengthwise, or cleft at top, so that mastication wore them down to small circles of dentine surrounded by a thick border of enamel, and further attrition reduced these to a trilobed or trefoil form.

The last lower molar of the MIast. angustidcns from La Rochetta di Tanaro, ${ }^{*}$ exhibits the same five prineipal transverse ridges and the hinder one, as in the corresponding tooth in the Eppelsheim Mastodon (fig. 115, m. 3), and heing the first of the series of narrow mastodontoid teeth to which Curier applied the name angustidens, it may he regarded as the type of that species. The characteristic premolar of the Mast. angustidens, with a quadrate crown of two ridges, each cleft into two tubercles (fig. 11t, 13 ), is figured by Cuvier, in Op. cit. pl. i., fig. 3, and again, in sitn, with the last deciduous molar ( $\left.d_{4}\right)$ in a portion of the upper jaw of the Hastodon angustidens from Dax (ib. pl. iii., fig. 2). The nature of this quadrituberculate tooth as a premolar, i.c., as a tooth which displaced and succeeded an earlier or deciduous tooth in the rertical direction, was recognized by Cuvier. "Je crois encore qu'on peut en conclure que la dent antérieure était susceptible de remplacement de haut ou bas, comme dans l'hippopotame : ma raison est, que cette petite dent de Dax n'est pas encore usée et qu'il faut qu'elle soit venue après la grande qui l'est."† Dr. Kaup has described and figured the same premolar in the upper jaw of a younger individual of the Mastodon angustidens (his longirostris), in which it is still concenled in its formative cavity above the three-lobed deciduous tooth which it has replaced in Cuvier's specimen. The tooth next behind, which is the homologne of the last milk-molar ( 14 , fig. 11 f) of the typical series, consists, in both the Dax and Lipelsheim specimens, of three principal ridges and a posterior bitubereulate talon; this accessory portion being more developed in the

* Cuvier, Op. cit. Divers IIastolontes, pl. iv., fin. 1, top view, fig. 2, fide view. † Ossemens Fossiles, 4to, 1821, tom. i., p. 256. 
Eppelsheim specimen. Whether such difference be valid for a specific distinction may be doubted; but that Cuvier assigned the name angustidens to a HKastodon with narrower molars than the $\boldsymbol{M}$. giganteus, which had a quadri-tubereulate premolar, a penultimate molar of four principal divisions and a talon, and a last molar with five principal divisions and a talon, is certain. To that Mastodon, therefore, which has the same shaped and sized ultimate and penultimate true molars and premolar, the same name is here assigned.

The antepenultimate molar (fig. 114, $m \mathrm{r}$ ) consists of four ridges and a talon.

Three molars are developed anterior to this tooth; the first (fig. 114, $d z$ ) is the smallest, with a subquadrate crown of two transverse ridges. The second molar (ib., $d_{3}$ ), of twice the size of the first, has three ridges. The third molar (ib., $d 4$ ), with an increase of one-third the bulk of the former, has three ridges and a bituberculate talon, which in some specimens might almost be reckoned as a fourth ridge. The two-ridged premolar (ib., $p$ 3) above described, takes the place of the second of the above molars, after the first and second are shed. The above definition of the molar series applies to both upper and lower jaws, the cut (fig. 11t), and the symbolic letters and numbers, preclude the necessity of rerbal clescription.

From the analogy of the existing elephants, it may be inferred that the long tusks (fig. 115, i) supported by the premaxillaries, were preceded by a pair of small decidnous incisors. There is not such ground for concluding their existence in the mandible ; but this jaw, in the male Mastodon longirostris (fig. 115), supported two incisive tusks, shorter and straighter than those above.

In the proboscidian quadrupeds the molar teeth, progressively increasing in size, and most of them in complexity, follow each other from before backwards, at longer intervals than in other quadrupeds, and are never simultaneously in 
place. Not more than three are in use at any period on one side of either jaw ; all the molars, save the penultimate (fig. $115, m z$ are shed by the time the crown of the last molar has cut the gum, and the dentition is finally reduced to $m_{3}$ on each side of both jaws, with commonly the loss of the inferior tusks, as in the old Mastodon turicuncis, from the tertiary deposits of the Po, described and figured by sismonda.*

The genus was represented by speeies ranging, in time, from the miocene to the upper pliocene deposits, and in space, cosmopolitan with tropical and temperate latitudes. The transition from the mastodontal to the elephantine type of dentition is very gradual.

Genus LLePHas, L. - The latest form of true clephant which obtained its sustenance in temperate latitudes is that which Blumenbach called mimigenims, the "Mammoth" of the siberian collectors of its tusks (fig. 119). Its remains necul ahiefly, if not exclusively, in pleistocene deposits, and have

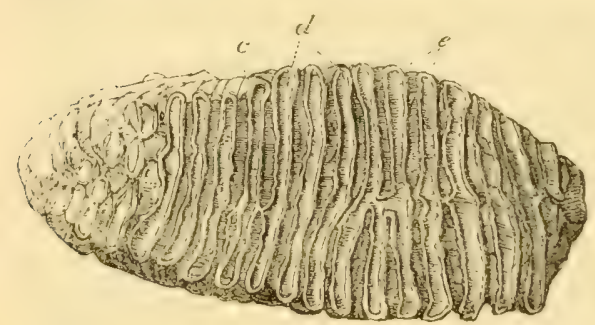

Fig. 116. even been found in turbary near Holyhead. Its grinders (fig. 116) are broader, and have narrower and more numerous and close-set transverse plates and ridges, than in other I purer grinder of the Alammoth (Elculues mimi. elephants. In the exgenius).

isting Indian species, e.g., (fig. 117), the molars are relatively namower, the plates $(d d)$ are less numerous, and their enamelled horder $(c)$ is festooner. In the African elephant (fig. 118) the plites are still fewer, are relatively larger, and so expanded at the mildle as to present a lozenge shape. The Elephus priscus, (relf., of European

* Osteografia di un Mastodonte Angustidente, 4to, Turin, 1851. 
pliocene bedis, has molar's most like those of the present African species. The tuskis of the elephant, like those of the Mastodon,

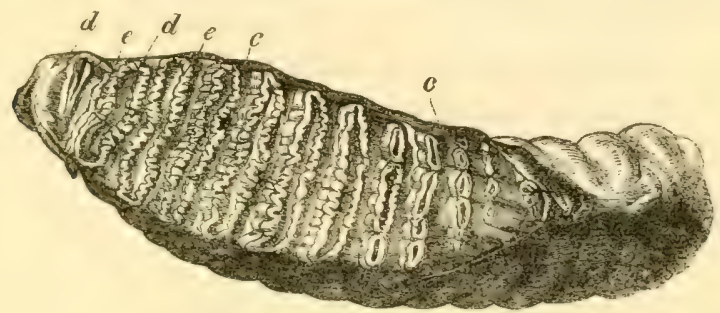

Fig. 117.

Upper molar, Asiatic Elephant.

consist of true irory, which shows, in transwerse fractures $\mathrm{or}^{-}$ sections, strix proceeding in the are of a circle from the

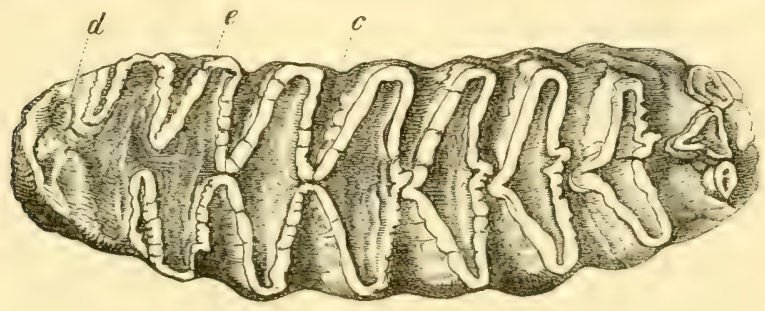

Fig. 118.

Upper molar, African Elephant.

centre to the circumference in opposite directions, and forming, hy their decussations, curvilinear lozenges. This character is a valuable one in the determination of fragments of fossil tusks.

The tusks of the extinct Elephus mimigenius, or mammoth, have a bolder and more extensive curvature than those of the Eleqhas indicus; some have been found which describe a circle, but the curve being oblique, they thus clear the head, and point outward, downward, and backward. The numerous fossil tusks of the Mammoth which have been discovered and recorded, may he ranged under two averages of size-the larger ones at nine feet and a half, the smaller at 
five feet and a half in length. The writer has elsewhere assigned reasons for the probability of the latter helonging to the female Mammoth, which must accordingly hare differed from the existing elephant of India, and have more resembled that of Africa, in the development of her tusks, yet manifesting an intermediate character by their smaller size. Of the tusks which are referable to the male Mammoth, one from the newer tertiary deposits in Essex measured nine feet ten inches along the outer curve, and two feet five inches in circumference at its thickest part; another from Eschscholtz Bay was nine feet two inches in length, and two feet one and a half inches in circumference, and weighed one hundred and sixty pounds. A specimen, dredged up off Dungeness, measured eleven feet in length. In sereral of the instances of Mammoth's tusks from British strata, the irory has been so little altered as to be fit for the purposes of manufacture; and the tusks of the Mammoth, which are still better preserved in the frozen drift of Siberia, have long been collected in great numbers as articles of commerce.

In a specimen of the extinct Indian elephant (Elcphas ganesa, Fr. and C.) preserved in the British Museum, the tusks are ten feet six inches in length, and in consequence of their small amount of curvature, they project eight feet fire inches in front of the head. Their apparent disproportion to the size of the skull is truly extraordinary, and exemplifies the maximization of dental development.

The mammoth is more completely known than most other extinct animals by reason of the discovery of an entire specimen preserved in the frozen soil of a cliff at the mouth of the river Lena in Siberia. The skin was clothed with a rededish wool, and with long black hairs. It is now preserved at St. Petersburg, together with the skeleton (fig. 119). This measures, from the fore part of the skull to the end of the mutilated tail, 16 feet 4 inches ; the height, to the top of the dorsal 
spines, is 9 feet 4 inches; the length of the tusks, along the curve, is 9 feet 6 inches. Parts of the skin of the head, the eye-ball, and of the strong ligament of the nape which helped

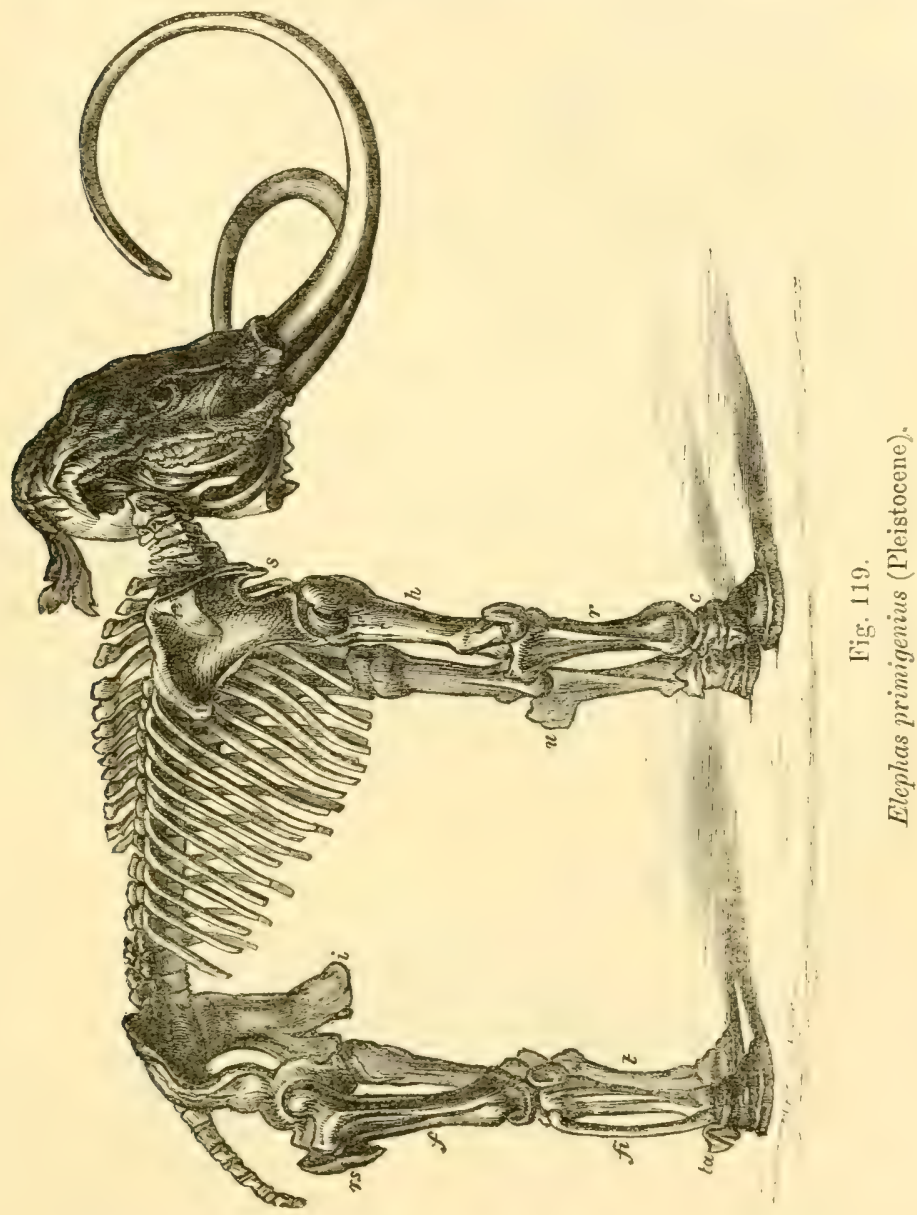

to sustain the heavy head and teeth, together with the hoofs, remain attached to the skeleton. These huge elephants, adapted by their clothing to endure a cold climate, subsisted on the branches and foliage of the northern pines, birches, 
willows, ete.; and during the shot stmmere they probatly migrated northward, like their contemporary the mush-buffalo which still lingers on, to the 70th degree of $\mathrm{N}$. latitude, retreating during the winter to more temperate quarters. The mammoth was preceded in Europe by other species of elephant-c.y., Elcphas miscus, Goldfuss, and Elephas meridionalis, Nesti, which, during the pliocene period, seem not to hare gone northward beyond temperate latitudes.

Genus Hippopotanus, L. - The discovery, in lacustrine and fluviatile deposits of Europe, of the remains of an amplibious genus of Mammal now restricted to African rivers, gives scope for speculating on the nature of the land which, uniting England with the Continent, was excavated by lakes and intelsected by rivers, with a somewhat warmer temperature than at present, to judge by a few S. European shells which occur in the fresh-water formations--e.y., at (irays, Essex, where remains of the large extinct Hippopotamus major have been found. The specimen of the lower jaw (fig. 121) was discovered in similar deposits on the Norfolk coasts. Other localities are specified in the writer's " History of British Fossil Mammals."

The first premolar has a simple subcompressed ennical crown, and a single root; it rises early, and at some distance in advance of the second premolar, and is soon shed; the other premolars form a continuous series with the true molin's in the existing species, but in the Hippopotanus major the second premolar is in advance of the third by an interval equal to its own breadth. This and the fourth premolar retain the simple conical form, but with increased size, and are impressed by one or two longitudinal grooves on the outer surface, which, when the erown is much worn, give a lobate character to the grinding surface. The true molars are primarily divided into two loles or cones by a wide transrerse valley, and each lole is sublivided by a narrow antero-pos- 
terior cleft into two half cones, with their flat sides next each other ; the convex side of each half cone is indented by two angular vertical notches, bounding a strong intermediate prominence. When their summits begin to be abraded, each lobe, or pair of demicones, presents a double trefoil of enamel on the grinding surface, as shown in fig. 120; when attrition has proceeded to the base of the half cones, then the grinding surfaces of each lobe presents a quadrilobate figure. The crown of the last molar tooth

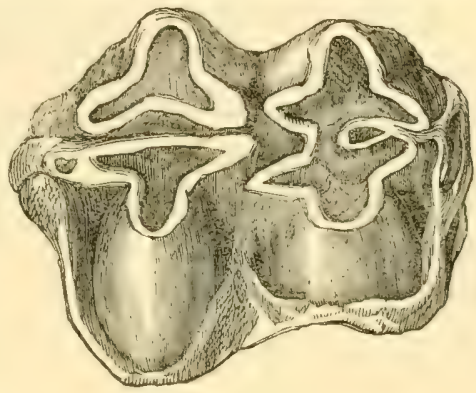

Fig. 120.

Molar tooth, Hippopotamus. of the lower jaw is lengthened out by a fifth cone, developere behind the two normal pairs of half cones, and smaller in all its dimensions.

The hippopotamus is first met with in pliocene strata. The remains of $H$. major have hitherto been found only in Europe; they are common along the Mediterranean shore, and do not oceur north of the temperate zone. In Asia this

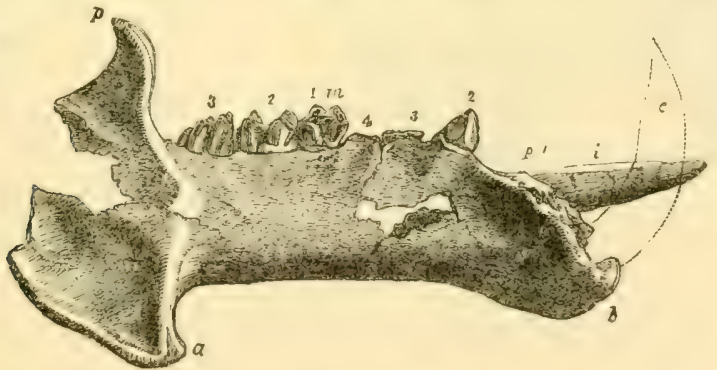

Fig. 121.

Lower jaw of Hippopotamus major (fresh-water Pliocene, Cromer, Nirfolli). form of Pachyderm was represented, prerhaps at an earlier period, by the genus Heraprotodon-exsentially a hippopotamus, with six incisor teeth, instead of four, in each , jaw. 
Genus Rimpoceros, L--The rhinoceros, like the elephant, was represented in pliocene and pleistocene times, in temperate and northern latitudes of Asia and Europe, by extinct species. One (Rhinoceros liptorthinus) associated with the Hippoprotemus major in fresh-water pliocene deposits; another (R. tichorrhinus) with the mammoth in pleistocene beds and drift. The discovery of the carcase of the tichorrine rhinoceros in frozen soil, recorded by Pallas in his "Toyages dans l'Asie Septentriomale,"* showed the same adaptation of this, at present tropical, form of cuadruped to a cold climate, by a twofold covering of wool and hair, as was subsequently de-

\section{$\hat{h}$}

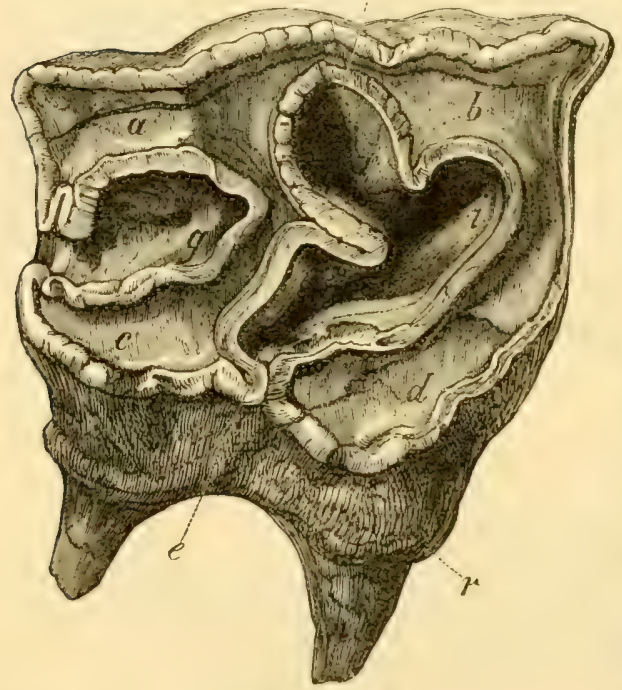

Fig. 122.

monstrated to be the case with the mammoth. Both the above-named fossil rhinoceroses were two-horned; but they were preceded, in the pliocene and miocene periods, by species devoid of horns, yet a rhinoceros in all other essentials (Accrotherium, Kaup).

The modifications which the upper molars of the Upper molar, Rhinoceros. Nat. size. rhinoceros present as compared with thuse of its antetyje, the Palicotherimn, wil be readily understood by comparing fig. 99) with fig. 122, and are as follows:-The concarities $(f f)$ on the outer side of the rrown, in fig. 99, are almost levelled, and from nne of them a 
slight convexity projects, in some species of Rhinoceros, giving a gently undulated surface to that sicle of the tooth. The ralley (c) is more expanded at its termination ( $\imath$ ), in the Phinoceros; and, in some species, it bifurcates and deepens, so that one branch may form an insulated circle of enamel when the crown is worn. The posterior valley $(g)$ is usually deeper and more extended. The ordinary lobes $(a, b, c, d)$ are very similar, and produce, by the confluence of a with $c$, and of $b$ with $d$, the two oblique tracts of dentine which are more decidedly established as transverse ridges in the Lophiodont or Tapiroid group. A basal ridge (r) girts more or less completely the inner and the fore and hind parts of the base of the crown. Not fewer than twenty species of extinct rhinoceroses are entered in Palæontological catalogues.

The extinct Cheropotamus, Anthiracotherium, Hyopotamus, and Hippohyus, had the typical dental formula, and this is preserved in the existing representative of the same section of non-ruminant Artiodactyles, the hog. The first true molar when the permanent dentition is completed, exhibits the effects of its early development in a more marked degree than in most other Mammalia, and in the Wild Boar has its tubercles morn down and a smooth field of dentine exposed by the time the last molar has come into place; it originally bears four primary cones, with smaller sub-divisions formed by the wrinkled enamel, and an interior and posterior ridge. The four cones produced by the crucial impression, of which the transverse part is the decpest, are repeated on the second true molar with more complex shallow divisions, and a larger tuberculate posterior ridge. The greater extent of the last molar is chiefly produced by the development of the back ridge into a cluster of tubercles; the four primary cones being distinsuishable on the anterior main body of the tooth. The crowns of the lower molars are rery similar to those above, hut are 
rather narrower, and the outer and immer basal tubercles are

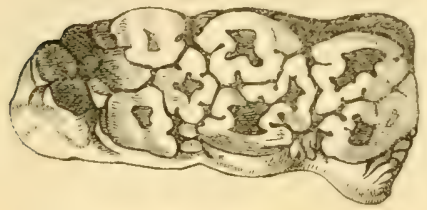

Fig. 123. much smaller, or are wanting; the grinding surface of the last is shown in fig. 123.

Extinct species of hog have been found in miocene beds at Eppelsheim (Sus palcocherus, Last lower molar, Hog. Nat. size. Kp.), and at Simorre (S. simorrensis, Lt.) ; in pliocene beds (S. arvernensis, Crt.), and in pleistocene and later deposits, where the species (S. scrofa fossitis) is indistinguishable from the present wild boar.

\section{Order RUMINANTIA.}

Of other forms of beasts subsisting on the regetable productions of the earth, and more akin to actual European Herbivora, there co-existed, in Europe, with the now exotic genera Elephas, Rhinoceres, Hippopotumus, ete, a vast assemblage of species, nearly all of which have passed away. The quadrupeds called "Ruminants," from the characteristic: second mastication of the partly-digested food by the act called " rumination" or " chewing the cud," constitute at the present period a circumseribed group of Mammalia, which Guvier believed to be "the most natural and best-definced oreler of the class." * He characterized it as having incisive teeth only in the lower jaw (fig. 128, c), which were replaced in the upper jaw by a callous gum. Petween the incisors and molars is a diastema, in which, in certain genera only, naly he formel one or two camines. The molars (fig. 128), $h$, almost alway, six on each side of hoth jaws, have their crown matked hy two double crescents, with the convexity tumed inwarls in the upper set, outwards in the lewer. The four legs are termimated hy two toese and two houfs, Hatfeneed at the rombiguoms 
sides, so as to look like a single hoof cloven; whence the name "cloren-footed," also given to these animals. The perfect circumscription and definition of this order, so desirable by the systematic zoologist, is indeed invaded, in the actual Ruminantia, by certain peculiarities of the camel tribe.

In entering upon the evidences of the first appearance in this planet of the order of animals, which now are the most valuable to man, it may be well to call to mind the characters of the Anoplothcrizm. The upper true molars have two double crescents, convex inwards, one of the inner ones being encroached on by a large tubercle, the reduced homologue of which may be seen in the internal inner space of the crescents in the ox and some other Ruminants. The lower true molars also, at one stage of attrition, form crescentic islands of enamel, with the convexity turned outwards, as in Ruminants, the last molar having the accessory crescent behind. The functional hoofs were two in number on each foot, but must have resembled those of the camel tribe in shape; the scaphoid and cuboid of the tarsus were distinct also, as in the Cemelida; and the metacarpal and metatarsal bones were divided, as in the water musk-deer (Moschus aquaticus), and in the embryos of all Ruminants. The dentition of the extinct Dichodun (figs. 102, 103) made a still nearer approach to that of the Ruminants. The chief distinction of this and other extinct Herbivores with double crescentic molars is the completion of the upper series of teeth by well-developed incisors. But the premaxillaries in the new-horn cancl contain each three incisors, one of which becomes fully developed. The Camelide are hornless, like the Anoplotherioids and Dichodonts; and with one exception-the giraffe-all Ruminants are born without horns.

Thus the Anoplotherium, in several important characters, resembled the embryo Ruminant, but retained throughout life. those marks of adhesion to a more generalized mammalian type. The more modified ne specialized form of honfert animal. 
with cloven feet and ruminating stomach, appears at a later period in the tertiary series.

The modification of the upper molars of the existing Ruminant quadrupeds consists in the lower and less pointed lobes of

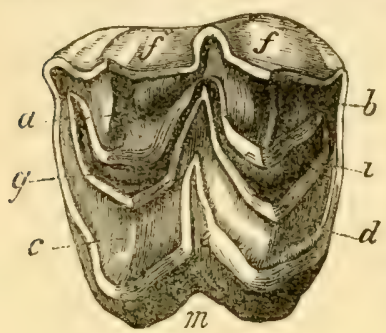

Fig. 124. the crown, the unworn summits of which are at first rather trenchant, like curved blades, than piercing. They are soon abraded by mastication, and present the crescentic lobes of dentine $(a, b, c, d)$ shown in fig. 124 . The transverse double-crescentic valley $(g, i)$ contains a thicker layer Uper molar of Megaceros. of cement, and forms two detached crescents in worn teeth. The premolars resemble in structure one half of the true molars.

\section{Family I.-Bovide.}

Fossil molars of the ruminant type and bovine character have hitherto been found, with unequivocal evidence, to the writer's knowledge, only in beds or breccias of pliocene and pleistocene age. At those periods in Britain there existed a very large species of bison (Bison priscus), and a larger species of ox (Bos antiquus), from pliocene fresh-water beals; whilst a somewhat smaller but still stupendous wild ox (B. primigenius) has left its remains in pleistocene marls of England and Scotland. With this was associated an aboriginal British ox of much smaller stature and with short horns (B. longifions), which continued to exist until the historical period, and was probably the source of the domesticated eattle of the Celtic races before the Roman invasion. A buflito, not distinguishable from the musk kind (Bubalus moschatus), now confined to the northern latitudes of North America, roamed over sinilax latitudes of Europe and Asia in emmany with the hair-elad elephants and rhinoceroses. 


\section{Fanily II.-Cervid A.}

Cuvier* first made known the fact of teeth with the character of ruminant molars, and of portions of antlers, being associated with remains of Lophiodon and Mastodon in the freshwater miocene beds of Montabusard, department of the Loiret. These early ruminant fossils agreed in size with the roebuck; but there were characters showing that they differed almost generically from all known deer. In 183+ Professor Kaup received from the miocene strata near Eppelsheim, Darmstadt, the entire cranium of a small Ruminant, the teeth of which were identical with those described and figured by Cuvier; but the series being complete, showed that the animal had long procumbent canines, as in the Moschus noschiferus; in some secondary characters of the teeth, however, as in the proportions of the premolars, and especially the presence of the first of that series, at least in the lower jaw, it was generically distinct from Moschus or Tragulus. Moreover, the animal had possessed, like the males of the small deer of India called "Muntjac," antlers as well as long canine teeth. Both in the miocene beds of Ingré and Eppelsheim, antlers have been found which were supported on long pedicles, as in the muntjac, and simply bifureate near their end. It is probable that these horns, which have been referred to the nominal species Cervus unocens, may belong to the Dorcatherium of Kaup.

Other species of Cervidce were, however, associated with that remarkable form in the miocene period. Dr. Kaup ascribes some more or less mutilated antlers, which had been shed, to a species he calls $C$. dicranocems. The beam rises from one to two inches without sending off any branch or browantler ; it then sends off a branch so large and so oblique that the beam seems here to bifureate; the anterior prong is, however, the smallest and shortest. The writer has received similar shed and mutilated antlers from the red crag of Sussex, which

Ossemens Fossiles, 4to, tom. iv., p. 104, pl, viii., figs. 5 and 6. 
seems to contain a melange of broken-up beds of eocene', mincene, and pliocene age.*

The cervine Ruminants have been divided into groups according to the forms of the antlers. Of the group with

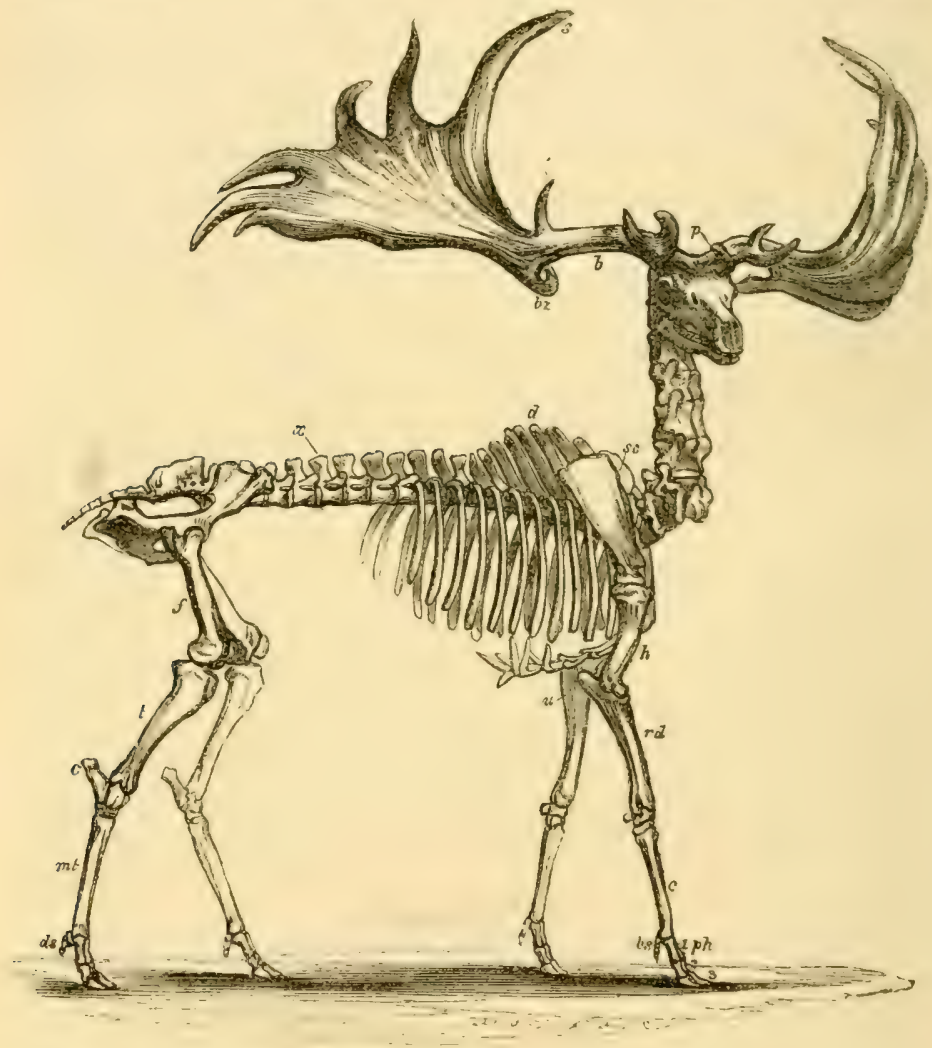

Fig. 125.

Megaceros Hibernicus (Pleistocene marl).

antlers expanded and flattened at top, of which the fallow-derer (Dama) is the type, no fossil examples have been fouml in Britain. Cuvier has described and figured antlers of great size from the plioene depesits of the valkey of the Somme, near

* Quarterly Jour, of the Genl. Soc., rnl, xii, 1856, p. 217, figs. 14-16. 
Abbeville, which, from the relative position and direction of the brow-snag and mid-snag, and from the terminal palm, he regards as a large extinct species of fallow-deer; the name Cerrus Somoncnsis has since been attached to this species. But there once existed a group (Mcyaceros, fig. 125) characterized by a form of antler at present unknown amongst existing species of deer. With a beam (b) expanding and flattening towards the summit, and a brow-snag $(p)$, as in the Dame tribe, this antler shows a hack-snag $(b z)$. Noreover, in antlers, showing an expanse of ten feet in a straight line from tip to tip, and which, from their size and form, seem to have been developed by the deer at its prime, the brow-snag expands and sometimes bifurcates-a variety never seen in the fallow-deer, but which becomes exaggerated in the rein-deer group. The representative of the subgemus Mcgaceros is an extinct species (1I. Hibcrnicus, fig. 125), remarkable for its great size, and especially for the great relative magnitude and noble form of its antlers: it is the species commonly but erroneonsly called the "Irish elk;" for it is a true deer, intermediate between the fallow and rein-deer; and though most abundant in, it is not peculiar to, Ireland. In that country it occurs in the shell-marl underlying the extensive turbaries. In Eugland its remains have been found in lacustrine beds, brick-earth, red crag, and ossiferous caves.*

The rein-decr (Cerus Tarandus) has peculiar antlers (fig. 126), and proportionably the largest of any of existing species. The beam is somewhat flattened throughout, but expands only and suddenly at its extremity, a similar expansion characterizing the brow-snag $\left(b r^{\circ}\right)$ and micl-snag $(b z)$, two, three, or more points being developed from all these expansions in fullydeveloped antlers. The brow-snag is remarkable for its length. There is also frequently a short hack-snag. It is plain. therefore, from the presenes of this smag, from the great relat- 
tive size of the antlers, from the complex brow-snag, and the terminal expansion of the beam, that we have in the rein-deer the nearest of kin to the extinct Megaceros.

The existing species (Tarandus) is restricted to northern latitudes, ranging to extreme ones in Europe, and in America from the Arctic Circle southward to the latitude of Newfoundland, where the large variety called "Carabou" still exists. Rein-deer of similar size, ranged over continental Europe, appear to have been seen by Cæsar in Germany, and have left good

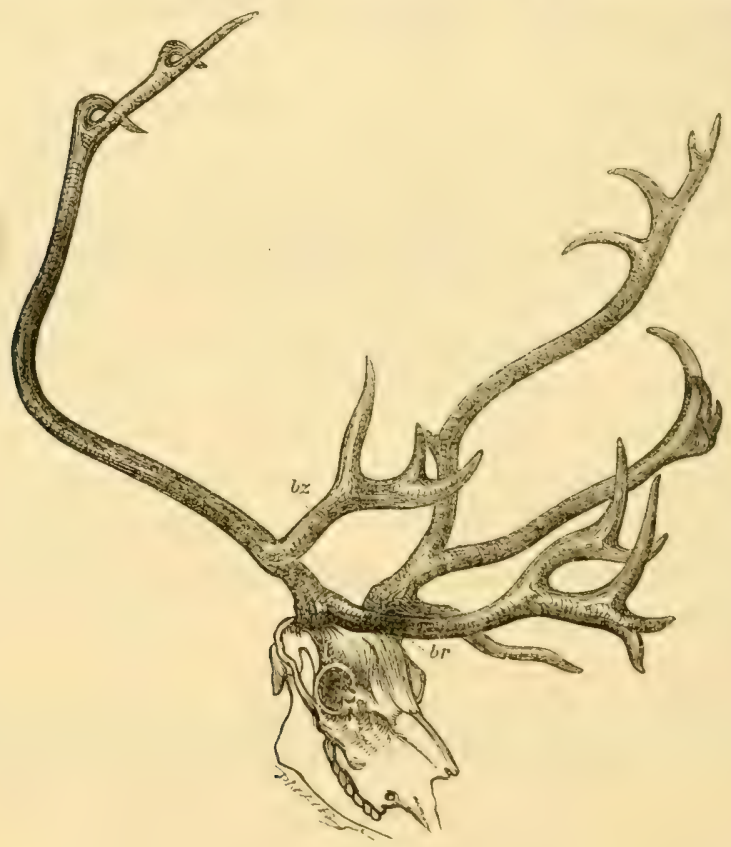

Fig. 126.

Skull and antlers of Cervus Tarandus.

evidence of their existence in many parts of England. The specimen figured (fig. 126) was found in pleistocene "till" at Bilney Moor, East Dereham.

A large deer, with subeompressed ramified antlers, slightly expanding at the base of the terminal divisions, but differing 
from the rein-deer in the absence of the brow-snag, has left its remains in the pleistocene sands of Riège, near Pézenas, France. It is the Cervus martialis of Gervais; and seems to have been an intermediate form between the rein-deer (Tarandus) and the elk (Alces). There is no existing representative of this interesting annectant form of deer.

In formations of corresponding age in France, called "allurions volcaniques" by Gervais,* fossil antlers of two other extinct species of deer have been discorered, in which, as in Alces, the brow-antler is absent, but in which the beam does not expand into a palm.

In North America remains of a large deer (Cervus amcricomus fossitis, Harlan), much resembling the Wrapiti. (Cerrus canadensis) have been found in pleistocene deposits on the banks of the Ohio. In South America Dr. Lund discovered fossil antlers of two species in bone-caves in Brazil: they were associated with remains of an antelope (Antilope maquinensis, Lund) of which genus no living representative is now known in South America.

Of deer with antlers of the type of the existing reddeer (C. elaphus), a species is indicated in pleistocene beds and bone caves which

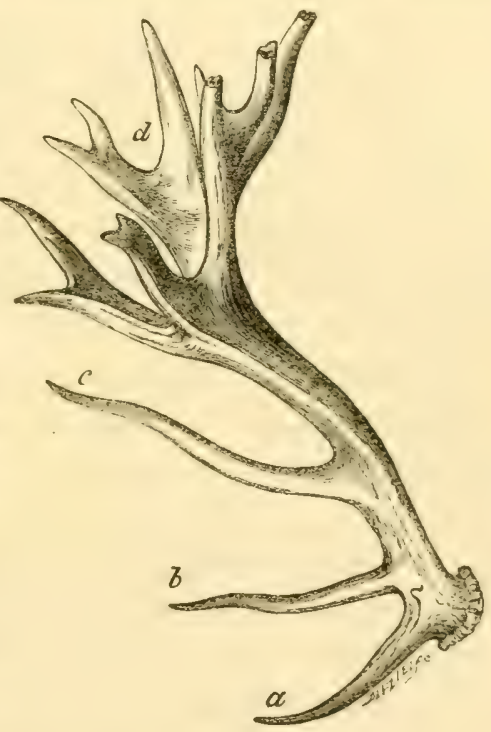

Fig. 127. rivalled the Megaceros in Antler of Red-deer, from allurium, Ireland. bulk (Strongyloceros spclceus); and with this are found, in similar places of deposit, remains of a red-deer with antlers * Zoologie et Paléontologie Française, 4to, p. 82. 
equalling or surpassing the finest that have been observed within the historical period.

Fig. 127 represents one of a pair of antlers from the bed of the Boyne at Drogheda, now in the museum of Sir Philip Egerton, Bart., which measures 30 inches in length, and sends off not ferrer than fifteen branches or "snags." $a$ is the "brow-snag," which rises immediately above the "burr;" $b$ the second, $c$ the third, and $d$ the "crown" or terminal cluster of snags, which gave to the deer dereloping them at the period of his full perfection the title of " crowned hart."

The little roebuck, like the red-deer, appears from its fossil remains to have continued to exist from the prehistorical pleistocene times to the present period.

\section{Order CaRnivora.}

The quadrupeds which subsist by preying upon others co-existed under corresponding rarieties of form, and in adequate numbers, with the numerous and rarious Herbirora of the newer tertiary periods. A brief description has already been made of some of the singular forms, the genera of which are extinct, that lived in eocene and miocene times.

Genus Galectruts, Ow--In 1829 the fossil skeleton of a Carnivore, of the size of a fox, was discovered by Sir Roderick I. Murchison in the pliocene schist of Eningen. On a close comparison of this specimen, the writer finds that the first premolar is smaller, and the third and fourth larger than in the fox, and all the teeth are more close-set and occupy a smaller space than in the genus $C^{\prime}$ anis; the bones of the feet are more robust; and these, with other characters, indicate an extinct genus intermediate between $C^{\prime} a n i s$ and Tirora.* The mique specimen is now in the British Afuseum.

Genes Feurs, L.-As it is by this form of perfect Carnirore that Curier chiefly illustrated his principle of the correlation

* See Quarterly Joumnal of the Geological Society, vol. iii., 18.17, p. 55. 
of animal structures, it will be exemplified more particularly in this place, and by the aid of the subjoined cut (fig. 128). The founder of palrontology thus enunciates the law which he believed to guide effectively his labours of reconstructing extinct species :-

"Every organized being forms a whole, a single circumscribed system, the parts of which mutually correspond and concur to the same definitive action by a reciprocal re-action. None of these parts can change without the others also changing, and consequently each part, taken separately, indicates and gives all the others." *

Cuvier did not predicate that law by an ì priori method, by any of those supposed short cuts to knowledge, the fallacy of which Bacon so well exposes; he arrived at the law inductively, and after many dissections had revealed to him the facts - of the jaw of the Carnivore being strong by virtue of certain proportions; of its having a peculiarly shaped and articulated condyle, with a plate of bone of breadth and height adequate for the implantation of muscles, with power to inflict a deadly bite-a process grasped by muscles of such magnitude as necessitated a certain extent of surface for their origin from the cranium, with concomitant strength and curvature of the $z y$ gomatic arch ; the facts of the modified occiput and dorsal spines in relation to rigorous uplifting and retraction of the head when the prey had been griped; the size and shape of the picreing, lacerating, and trenchant teeth ; the mechanism of the retractile claws, and of the joints of the limb that wielded them;-it was not until after C'uvier had recognized these facts, and studied them and their correlations in a certain number of typical Carnirora, that he felt justificer in asserting that "the form of the tooth gives that of the condyle, of the blade-bone (s), and of the clars, just as the equation of a curve erolves all its properties; and exactly as, in

* Ossemens Fossiles, 4to, tom. i. (1812), p. 58. 
taking each property by itself as the base of a particular equation, one discovers both the orlinary equation and all its properties, so the claw, the blade-bone, the condyle, the femur, and all the other bones individually, give the teeth, or are

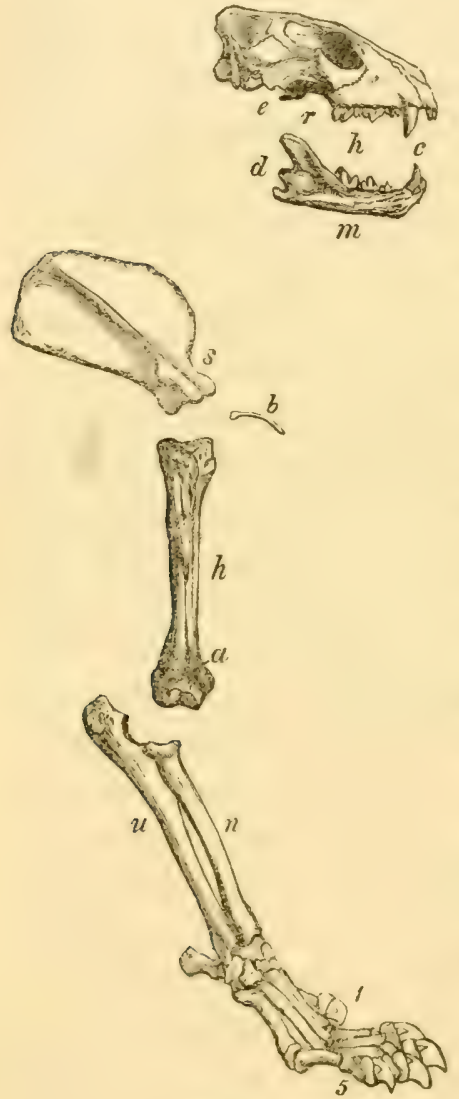

Fig. 128. given thereby reciprocally ; and in commencing by any of these, whoever possesses rationally the laws of the organic economy will be able to reconstruct the entire animal." The principle is so evident, that the non-anatomical reader will have little diffculty in satisfactorily comprehending it by the aid of the subjoined diagram.

In the jaws of the lion (fig. $128, h, m)$, there are large pointed teeth (laniaries or canines, c) which pierce, lacerate, and retain its prey. There are also compressed trenchant teeth $(h)$, which play upon each other like scissor-blades in the movement of the lower upon the upper jaw. The lower jaw $(m)$ is short and strong; it articulates to the skull by a transversely extendPalrontological characters of a Feline ed convexity or condyle $(d)$, Carnivore.

received into a corresponding concavity $(c)$, forming a close-fitting joint, which gives a firm attachment to the jaw, but almost restricts its movements to one plane, as in opening and closing the mouth. The plate 
of bone, called coronoid process $(r)$, which gives the surface of attachment to the chief biting muscle (crotaphyte or temporal) is broad and high; the surface on the side of the sliull (temporal fossa, $t$ ) from which that muscle arises is correspondingly large and deep, and is augmented by the extension of ridges of bone from its upper and hinder periphery.

The bar or bridge of bone (zygomatic arch) which spans across the muscle, bends strongly outwards to angment the space for its passage ; and as it gives origin to another powerful biting muscle (masseter), the arch is also bent upwards to form the stronger point of resistance during the gripe of that muscle. From almost all the periphery of the back surface of the skull there is a strong pitted ridge, affording extensive attachment to powerful muscles which raise the head, together with the animal's body which the lion may have seized with his jaws; this beast of prey being able to drag along the carcase of a buffalo, and with ease to raise and bear off the body of a man. If we next examine the framework of the fore limb, which is associated with the above-defined structure of the skull, we find that the fore paw consists of five digits $(I-5)$; the innermost and shortest ( $x$ ) answering to our thumb, and having two bones; the other four digits having each three bones or "phalanges." All those digits enjoy a certain freedom of motion and power of reciprocal approximation for grasping; but their chief feature is the modification of the terminal phalanx, which is enlarged, compressed, subtriangular, and more or less bent; with a plate of bone, as it were, reflected forwards from the base, from which the pointed termination of the phalanx projects like a peg from a sheath. A powerful, compressed, incurved, sharp-pointed, hard, horny claw is fixed upon that peg, its base being firmly wedged into the interspace between the perg and the sheath. The toe-joint so armed is retractile. This complex, prehensile, and destructive paw is articulated to the two bones of the fore leg (ra- 
dius, $n$, and ulna, $"$ ) ; they are both strong, are both distinct, are firmly articulated to the arm-bone $(h)$ by a joint, which, although well knit, allows great extent and freedom of motion in bending and extension; and, besides this, the two bones are reciprocally joined so as to rotate on each other, or rather the radius upon the ulna, carrying with it, by the greater expansion of its lower end, the whole paw, which can thus be turned "prone" or "supine " whereby its application as an instrument for seizing and tearing is greatly advantaged. The humerus or arm-bone $(h)$ is remarkable for the extension of strong ridges from the outer and inner sides, just above the elbow-joint. These ridges indicate the size and force of the supinator, pronator, flexor, and extensor muscles of the paw. To defend the main artery of the fore leg from compression during the action of these muscles, a bridge of bone ( $u$ ) spans across it as it passes near their origin. The uper end of the arm-bone is equally well marked by powerful ridges for muscular implantation, especially for the deltoid; but these ridges do not project beyoud the round "head" of the bone, so as to impede its movements in the socket.

The blade-bone (scapula s) is of great breacth, with welldeveloped processes (spine, acromion, and coracoid) for muscular attachments; the size and shape of this bone relate closely to the volume of the muscles which operate upon the arm-bone and fore limb. A small clavicular bone (b) is interposed between a muscle of the head and one of the arm, giving arkitional force and determination of action reciprocally to both muscles.

Such are some of the modifications of the teeth and framework of a beast of prey, which concur, and were dexmed hy Cuvier to be correlated, in the organization of such animals.

Let us compare them with those of the corresponding parts in an ox (fig. 129). The teeth answering to the great laniaries in the lion are absent; at most, one recognizes the 
homologues of the lower canines, reduced in size and altered in shape, so as to form the outer teeth $(c)$ of a bent row of incisors terminating the lower jaw. The back teeth $(h)$ instead of being trenchant, have broad and flat crowns, roughened with hard ridges, opposing each other with a grinding action, like millstones. The lower jaw is long and slender; it articulates to the skull by a flat condyle $(d)$, admitting of rotatory movements upon a flattened articular surface on the skull, and limiting the extent of opening and shutting the mouth. The coronoid process $(r)$ is very slender, and the fossa which marks the size of the temporal muscle $(t)$ is correspondingly small. The zygomatic arch (o) is short and feeble, and its span is narrow; it is almost straight, or with a slight bend downwards. The parts of the skull (pterygoid plates) which afford attachment to the rotating muscles of the jaw, and the (angular) part $(f)$ of the jaw into which they are in- Palreontological characters of a Ruminant serted, are of great extent.
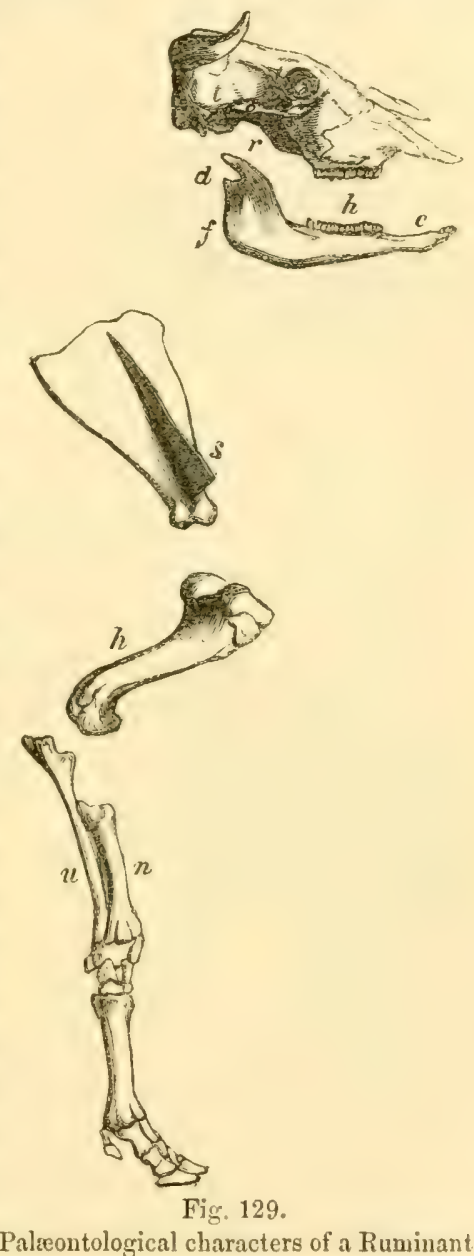

The ox masticates grass with great efficiency ; it inflicts no injury to other animals with its tecth. The lonens are its weapons, and they are chicfly defensive. 
The fore foot of the ox is reduced to two principal toes, with two rudimentary ones dangling behind. Each of these has its extremity enreloped by a thick horny case, or hoof: this molification is accompanied by a junction or coalescence of the radius $(n)$ and ulna $(u)$, preventing reciprocal rotation or worement of those bones on each other; by a joint restricting the movement of the fore arm (antibrachium) upon the arm (brachium or humerus, $h$ ) to one plane; by a long and narrow blade-bone $(s)$, with a stunted coracoid and no clavicle ; in short, by modifications adapting the limb to perform the movements required for locomotion, and almost restricting it to such. This type of fore limb is always associated with broad grinding teeth, and with the modifications of jaw and skull above defined. The due amount of observation assured Cuvier' that these several modifications, like the contrasted ones in the Carnivora, were correlated, and he enumerates the physiological grounds of that correlation.

These grounds may be traced to a certain degree in the secondary modifications of the camivorous order. If the retractibility of the claw be suppressed, the carnassiality of the teeth is reciprocally modified. If the unguiculate foot is reduced from the digitigrade to the plantigrade type, the dentition is still more altered, and made more subservient to a mixed diet.

By the application of the correlative principle to the fossil mammalian remains of pliocene and later deposits, the Herbivora have been distinguished from the Carnivora; and out of the latter have been reennstructed extinct species of the feline, viverrine, ursine, and other families of the order. In England and continental Europe a peculiarly destructive feline quadruped existed, with the upler canines much elongated, trenchant, sharp-pointed, salure-shilped, whence the name Machairodus proposed for this feline suh-genus. It was regresenter hy species as large as a lion (M. rultrietens and 
M. latidens); and by others of the size of a leopard ( 1 . palmidens and $M$. meyantercon). This form is first found in the miocene of Auvergne and of Eppelsheim; next in the pliocene of the Val d'Arno; and finally in cave breccia in Devonshire.

The penultimate tooth in the upper jaw and the last touth in the lower jaw were denominated by Cuvier "dents carnassières." The carnassial or sectorial is a very characteristic tooth in the carnivorous order, but undergoes many modifications, and preserves $z$

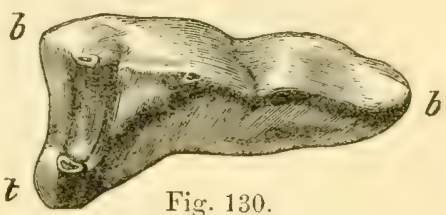
its typical form, as repre- Working surface of the upper sectorial sented in figures 130 and 131, tooth, Hyæna. Nat. size. only in the most strictly flesh-feeding species. In it may be distinguished the part called the "blade" (fig. 130, b, b), and the part called the "tubercule" (fig. 130, $t$ ). The lower sectorial in the genus Felis consists exclusively of the blade (fig. 131), which is pretty equally divided into two lobes. The blade of the upper sectorial always plays upon the outside, and a little in advance of the lower sectorial.

The upper sectorial succeeds and displaces a deciduous tubercular molar in all Carnivora, and is, therefore, essentially a premolar tooth; the lower sectorial comes up behind the deciduous series and has no immerliate predeces- Side view of lower sectorial sor; it is, therefore, a true molar, and tooth, Lion. Nat. size. the first of that class. The sectorial teeth present gradational varieties of form in the carnivorons series, from Machairodus, in which the crown consists exclusively of the "hlade" in hoth jaws, to Ursus (fig. 132, m, r), in which it is totally tuhereular : 
the development of the tubercle bearing an inverse relation to the carnivorous propensities of the species.

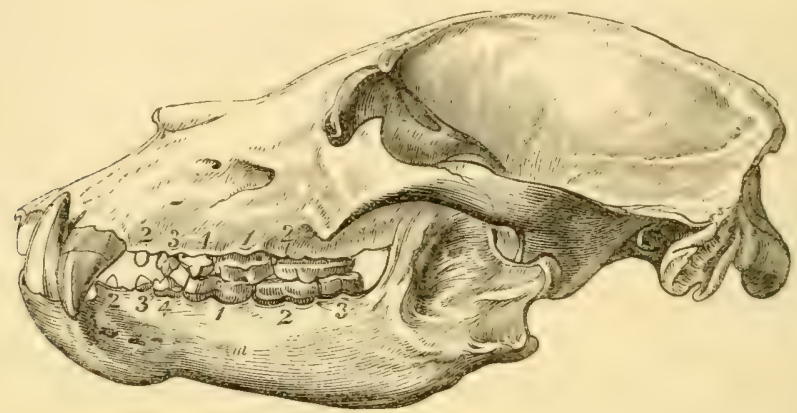

Fig. 132.

Dentition of the Bear (Ursus).

The finest examples of the large pleistocene lion (Felis spelca) have been discovered in bone-caves-e.g., in those of Banwell, Somersetshire, and of Belgium. The production of the apex of the nasal process of the maxillary, as far back as that of the nasal bone, proves this species to have been a lion, not a tiger. It roamed over pliocene and pleistocene Europe, and has left its remains in many stratified deposits of the former period in Britain.

Under similar circumstances have been found, more abundantly in Germany, the remains of the gigantic bear (Ursus spelous), and more abundantly in England those of the great hyæna (Hycena spelece), probably a spotted one, like the fierce "Crocuta" of the Cape. Wolves, fores, balger's, otters, wolverines, and martin-cats, foumarts and weasels, have left their remains in the newer tertiary deposits and bone caves. Bats, moles, and shrews, were then, as now, the forms that preyed upon the insect world in Europe. The majority of these Carnivora, like the hares, rallits, voles, and other Rodents, are not distinguishable from the species which still exist. These smaller unguiculate Mammals, like the smaller pleistorene Ruminants, seem to have survived those 
changes during which the larger species perished. It is probable that the horse and ass are descendants of species of pleistocene antiquity. At the pliocene period there existed a species similar in size to a zebra. There is no certain character by which the present wild boar can be distinguished specifically from the Sus, which was contemporary with the mammoth.

\section{Order Rodentia.}

This order includes an extensive series of small Mammals in which a single pair of large, curved, ever-growing incisors in each jaw is associated with many other peculiarities of structure. These incisors (fig. 133, $i$ ), separated by a wide interval from a short series of molars, characterize the whole order of Rodents ; the single exceptional family, Leporida, including hares, rabbits, and Picas or tailless hares of

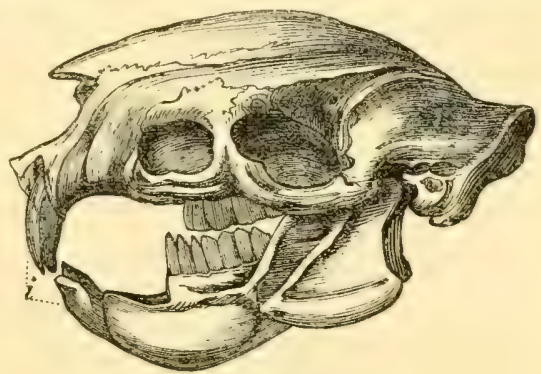

Fig. 133.

Skull and teeth of a Porcupine.

Siberia, retaining a second minute incisor behind each of the larger ones in the upper jaw.

The small size of the great majority of the species of this order leads to the neglect or the oversight of their fossil remains by the labourers in quarries and other deposits of stone, to whom the palreontologist is usually indebted for his first accuaintance with characteristic fossils of such formations. No evidence has yet been obtained of any unequivocal remains of a rodent animal in strata more ancient than the eocene tertiary deposits. Cuvier detected renains of Rodents allied to the dormouse (Myoxus) and sfuirrel (Sciumus) in the eocene building-stone of the Montmartre quarrics near Paris. The lacustrine marls of the middle 
(miocene) tertiary period have yielded evidences of not fewer than eleven genera of Rodentia distinct from any now known to exist. The deposits at Eppelsheim, near Darmstadt, of the same miocene age, have given evidence of Rodents akin to the marmot and the beaver. The more recent tertiary formations and the bone-caves in England have furnished fossil remains not distinguishable from the existing beaver, hare, and rabbit, water-role and field-role, as well as remains of a Pica, or tailless hare, belonging to the gemus Lagomys, now confined as an existing species to Asia ; and of a very large Rodent, akin to the beaver, called Trogonthorium. Similar fossil remains have been abumdantly found in the pliocene and pleistocene formations of continental Europe, including representatives of the genus Hystrix, or fossil porcupines (H. refosso, Ger.), from the pliocene of Issuire (fig. 133). The coeval dejosits of America have yielded fossil remains of extinct species belonging to genera-c. I., Largostomus, Echimys, Ctenomys, Caloyenys, and other Caviesnow restricted to South America. In North America, fossil remains of a Rodent of comparatively gigantic size have recently been discovered. Some parts of the skeleton, and more especially the dentition of the rodent order, are higlly characteristic - the form of the articular surface for the lower jaw, which is a longitudinal groove, the molars, especially of the phytiphagous kinds, crossed by enanch plates more or less transverse-these, with the long, curved, chisel-shaped incisors, two in ench jaw, suffice to determine the ordinal relations of the fossil. The incisors alone would not be always so safe a guide, for the rodent moditication of these teeth is repeated in the marsupial wombat and the lemurine aye-aye.

With regared to the Rodentia, the great beaver (Trogontherium) seems to have hecome extinct in Fingland and the Eumpen-Asiaticentiuent hefore the hiscorieal period : whilst

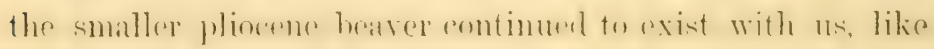


the wolf, until hunted down by man. It still survives in a few of the great continental rivers. Of the little Lagomys of our ossiferous caves no living example remains in either England or Europe. The species, indeed, may be extinct: its genus is now limited to Central and Southern Asia.

\section{GEOGRAPHICAL DISTRIBUTION OF PLEISTOCENE MAMMALS.}

A most interesting generalization has been eluced from the mass of facts relating to the fossil Mammals of the later tertiaries - viz., the close correspondence between the fauna of those and of the present periods in the Europreo-Asiatic expanse of dry land. For here species continue to exist of nearly all those genera which are represented by pliocene aud post-pliocene mammalian fossils of the same natural continent, and of the immediately adjacent island of Great Britain.

The bear has its haunts in both Europe and Asia; the hearer of the Rhone and Danube represents the great Trogontherium; the Lagomys and the tiger exist on both sides of the Himalayan mountain chain; the hyouna ranges through Syria and Hindostan; the Bactrian camel typifies the huge Mcryeutherium of the Siberian drift; the elephant and rhinoceros are still represented in Asia, though now confined to the south of the Himalayas. The true macacyues are peculiar to Asia, and though most abundant in the southern parts of the continent and the Indian Archipelago, also exist in Japran; a closely-allied sub-genus (Innus) is naturalized on the rock of Gibraltar at the present day. A fossil species of Macacus was as:uciated with the elephant and rhinoceros in England during the period of the deposition of the newer pliocene fresh water beds. The more extraordinary extinct forms of Mammalia, called I:Tr.smutherimm and Sicuthrim, have their nearest existimg yachydermal and ruminant analogues in the same continent to 
which those fossils are peculiar. Cuvier places the Elasmothere between the horse and rhinoceros. The existing fourhorned antelopes, like their gigantic extinet analogues, the Sivathere and Bramathere, are peculiar to India. It may be regarded as part of the same general concordance of geographical distribution, that the genus IIippopotamus, extinct in England, in Europe, and in Asia, should continue to be represented in Africa, and in none of the remoter continents of the earth-Africa also having its hyæna, its elephant, its rhinoceros, and its great feline Camivores. The discovery of extinct species of Camelopardalis in both Europe and Asia, of which genus the sole existing representative is now, like the hippopotamus, confined to Africa, adds to the propriety of regarding the three continuous continental divisions of the Old World as forming, in respect to the geographical distribution of pliocene, post-pliocene, and recent mammalian genera, one great natural province. The only large edentate animal (Pangolin gigantesque, Cuvier; Macrotherium, Lartet) hitherto found in the tertiary deposits of Europe, manifests its nearest affinities to the genus Manis, which is exclusively Asiatic and African.

Extending the comparison between the existing and the latest of the extinct series of Mammalia to the continent of South America, it may be first remarked that, with the exception of some carnivorous and cervine species, no representatives of the above-cited mammalim genera of the Old World of the geographer have yet been found in South America. Thuffon* long since enumciated a sinnilar generalization with regard to the existing species and genera of Mammalia ; it is almost equally true in respeet of the forsil. Not a relic of an elephant, a rhinoceros, a hippopotamus, a hisom, a hysena, or a lagomys, has yet heen detected in the caves ar the more recent tertiary deposits of south America.

* Histoire Naturelle, tom. ix., p. 13, 4to, 1758. 
On the contrary, most of the fossil Mammalia from those formations are as distinct from the Europaro-Asiatic forms as they are closely allied to the peculiarly south American existing genera of Mammalia.

The genera Equus, Tapirus, and the still more ubiquitous Mastodun, form the chief, if not sole exceptions. The representation of Equus during the pliocene period by distinct species in Asia (E. primigenius) and in South America ( $E$. curvidens), is analogous to the geographical distribution of the species of Tapinus at the present day.

South America alone is now inhabited by species of slotl, of armadillo, of cary, aguti, ctenomys, and platyrrhine monkey; but no fossil remains of a quadruped referable to any of these genera have yet been discovered in Europe, Asia, or Africa. The types of Bradypus and Dasypus were, however, richly represented hy diversified and gigantic specific

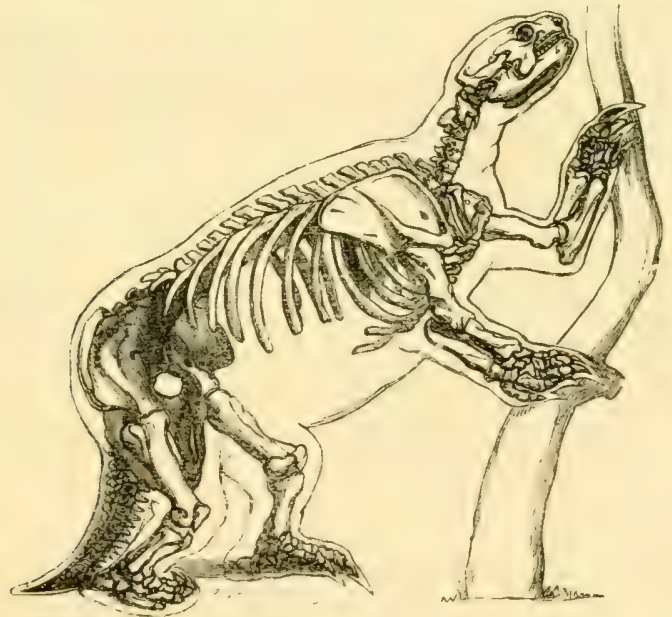

Fig. 134.

Extinct Terrestrial Sloth, Mylodon robustus (Pleistocene, S. America).

forms in South Ameriea during the geological periods immediately preceding the present. The skeleton of one of these forms of the sloth tribe is represented in fig. 13 ; ; it measures 
from the fore part of the skull to the end of the tail, 11 feet. It was discovered huried 12 feet deep in the fluviatile deposits seven leagues north of the city of Buenos Ayres in the year 18t1. It forms the subject of a work entitled, Description of the Skeleton of an Extinct Gigantic Sloth (Mylocton robustus), ${ }^{*}$ in which are set forth in detail the groumels for regarding it as a member of the same natural fanily as the present small arboreal sloth, and as being modified to olitain its leafy food by uprooting and prostrating trees.

A still larger species of terrestrial sloth (Megatherium) coexisted with the Mylodon in South America. Its skeleton, now complete in the British Musemm, measures 18 feet; its rlentition

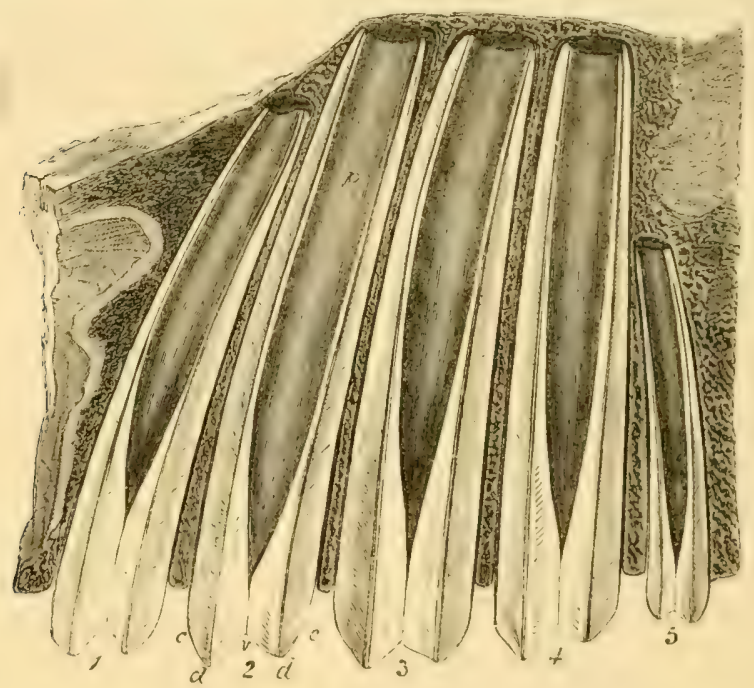

Fig. 135.

Suetion of uppere molal teeth, Megatherium (nne-third nat. size), I'leistocene, Sonth America.

angeess as to number and kind of teeth with that of the slothe

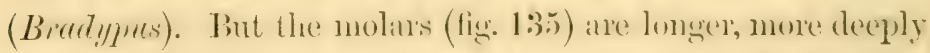
implanted, of more complex structure, and with grinding

4to, 1842, Van Voorst. 
surfaces of the bilophodont type. The elephants, which subsist on similar food to that of the Megatherium, had their grinding machinery maintained by a numerous succession of teeth: the same end was attained in the Megatherium, by a constant growth and renovation of the same teeth. The formative pulps were lodged in the deep basal carities, exposed in the section figured (fig. 135). The molar teeth were five in number on each side of the upper jaw, and four in number on each side of the lower jaw (fig. 136). In this bone the fore part is much prolonged, and grooved above, to support a long, cylindrical, powerfully muscular tongue, by which the Megatherium, like the giraffe, stripped off the small branches of the trees its colossal strength enabled it to prostrate. The dentition of Mylodon differed only from that of Megatherium in the shape of the teeth. The same may be said of the allied genera Megalonyx and Scelidotherium. They were contemporary and geographically associated genera of the same, now quite extinct, family of great terrestrial sloths.

In like manner, the small loricated and banded quadrupeds of South America called armadillos were represented in pleistocene times in that

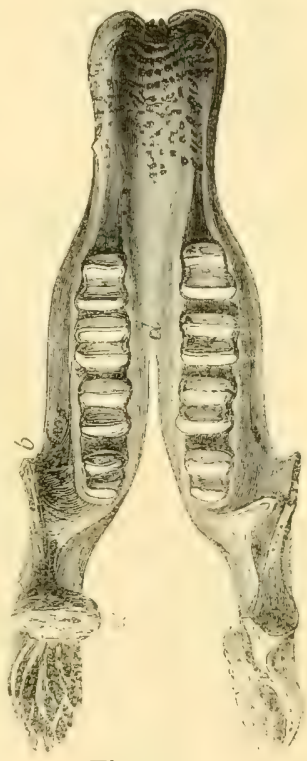

Fig. 136.

Lower jaw and teeth of Megatherium (Pleistocene, South America). continent by as well-defended species, rivalling the Megatherioids in bulk. The specimen of the almost entire skeleton and bony armour (fig. 137) is one of the smaller species of these. great extinct non-banded armadillos ; yet it measures from the snout to the end of the tail, following the curve of the back, 9 feet; the tesselated trunk-armour lecing 5 feet in length and 7 
feet across, following the curve at the middle of the back. These large extinct species differ from the modern armadillos, in having no bands or joints in their coat of mail, for the purpose of contracting or bending the body into the form of a ball. They also differ in the fluted form of the teeth (fig. 138); whence the generic name (Glyptodon) assigned to them. The species are distinguished, like their present puny representatives (Dasypus), by peculiar patterns of the outer surface of the constituent ossicles of the tesselated mail. In the species figured (G. clavipes), a large raised central circular plate is surrounded by smaller portions. The species named G. reticulatus, G. tuher-

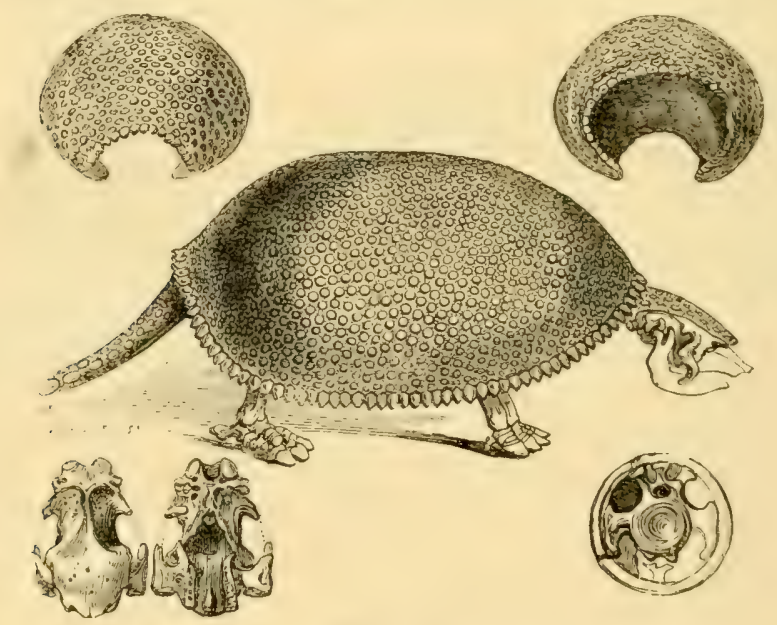

Fig. 137.

Extinct gigantic Armadillo (Glyptodon clavipes).

culatus, $G$. ornatus, etc., have their names from other modifications of the sculptured surface of their amour. Above the principal figure in eut 137 are shown the front and hack margins of the body-armour; below it, opposite the left hand, are upper and under views of the cranium, which was defended by a tesselated bony casque. The tail also had its independent osseous sheath, supported ly the rertelna within, as shown in the figure opposite the right hand. 
Torodon, Macrauchemia, $†$ and Protopithecus, $\downarrow$ are additional evidences of extinet South American Mammals, matcher only by species now peculiar to that continent.

Australia in like mamner yields evidence of an analogons correspondence between its last extinct and its present aboriginal mammalian fauna, which is the more interesting on account of the very peculiar organization of most of the native quadrupeds of that division of the globe. That the Marsupialia form one great natural group, is now generally admitted by zoologists ; the representatives in that group of many of the orders of the more extensive placental sub-class of the Mammalia of the larger continents have also been recognized in the existing genera and species: the dasyures, for example, play the parts of the Camivora, the bandicoots (Perameles) of the Insectivora, the phalangers of the Quadrumana, the wombat of the Rodentia, and the kangaroos, in a remoter degree, that of the Ruminantia. The first collection of mammalian fossil ${ }_{\mathrm{S}}$ from the ossiferous caves of Australia $\S$ brought to light the former existence on that continent of larger species of the same peculiar marsupial genera: some,

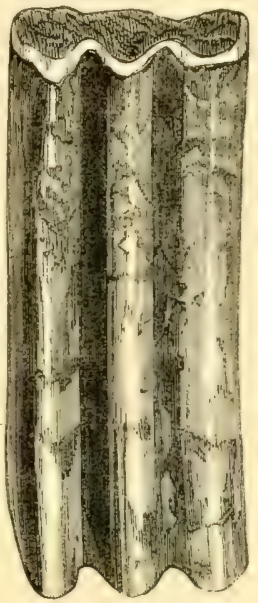

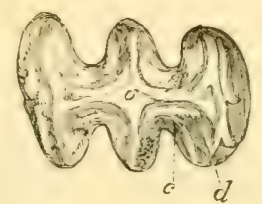

Fig. 138.

Teeth of great extinct Armadillo (Glyptodon clavipes), Pleistocene, South America. as the Thylacine, and the dasyurine sub-genus represented by the $D$. ursinus, are now extinct on the Australian continent, but one species of each still exists on the adjacent island of Tasmania; the rest were extinct wombats, phalangers, poto-

* Owen, "Fossil Mammalia of the Vorage of the Beagle," 4to, 1839.

† Ib. † Lund. Annales des Sciences Nat, 2 d series, tom, xiii., p. 313.

\& Mitchell's (Sir Thos.) Three Expeditions into the Interior of Australia, 8ro, 1838, vol. ii., p. 359 . 
roos, and liangaroos-some of the latter (Macropus Atlas, $M$. Titan) being of great stature. A single tooth, in the same collection of fossils, gave the first indication of the former existence of a type of the marsupial group, which represented the Pachyderms of the larger continents, and which seems now to have disappeared from the face of the Australian earth. Of the great quadruped, so indicated under the name Diprotodon in 1838, successive subsequent acquisitions have established the true marsupial character and the near affinities of the genus to the kangaroo (Macropus), lout with an osculant relationship with the herbirorous wombat. The

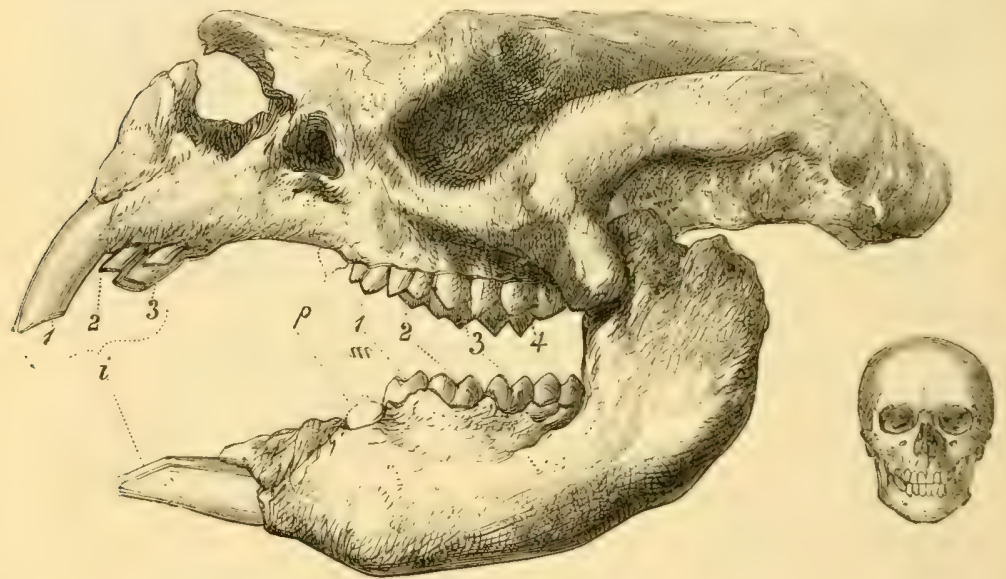

Fig. 139.

Skull, gigantic Pachydermoid Kangaroo (Dimotodon Australis) I'leistocene Australia.

entire skull of the Diprotocton Australis (fig. 139) has lately been aequired by the British Museum, showing in situ the tooth $(i)$ on which the genus was founded. This skull measures 3 feet in length; that of a man is inserterl in the cut to exemplify the huge dimensions of the primeral kangaroo. Like the contemporary gigantic sloth in South America, the Diprotodon of Australia, while retaining the dental formula of its living lomologue, shows great and 
remarkable modifications of its limbs. The hind pair were much shortened and strengthened, compared with those of the kangaroo; the fore pair were lengthened as well as strengtlened ; yet, as in the case of the Megatherium, the ulna and radius were maintained free, and so articulated as to give the fore paw the rotatory actions. These in Diprotodon, would be needed, as in the herhivorous kangaroo, by the economy of the marsupial pouch. The dental formula of Diprotodon was $i \frac{3-3}{1-1}, c \frac{0}{v}, p \frac{1-1}{1-1}, m \frac{4-4}{4-4}=28$, and, as in Macropus major, the first of the grinding series ( $(2)$ was soon shed; lout the other four two-ridged teeth were longer retained, and the front upper incisor $(i, \mathrm{r})$ was very large and scalpriform, as in the wombat. The zygomatic arch sent down a process for angmenting the origin of the masseter muscle, as in the kangaroo. The foregoing skull, with parts of the skeleton, of the Diprotodon Austrelis, were discovered in a lacustrine deposit, probably pleistocene, intersected by creeks, in the plains of Darling Downs, Australia.

The same formation has yielded evidence of a somewhat smaller extinct herbivorous genus (Nototherium), combining, with essential affinities to Macropus, some of the characters of the Koala (Phascolarctus).† The writer has recently communicated descriptions and figures of the entire skull of the Tototherim Mitchelli to the Geological Society of London.t The genus Phascolomys was at the same period

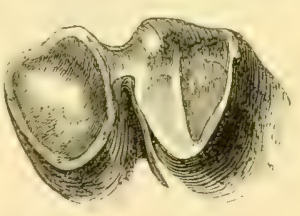

Fig. 140.

Grinding surface of molar of Phascolomys giyas (nat. size), Pleistocene, Australia. represented by a wombat $(P$. gigas $)$ of the magnitude of a tapir, one of the grinding teeth of which is represented, of the natural size, in fig. 140 .

See that of Macropus, explained in Ency. Brit., article Odontology, p. 449. 1844.

+ "Report on the extinct Mammals of Australia," Trans. of Brit. Assoc.,

$\ddagger$ Quarterly Journal of the Geol. Soc., pt. iv., 1858. 
The pleistocene marsupial Carnirora presented the usual relations of size and power to the Hcrbirora, whose undue increase they had to check. Fig. 141 represents an almost entire skull, with part of the lower jaw of an animal (Thylaenlen)

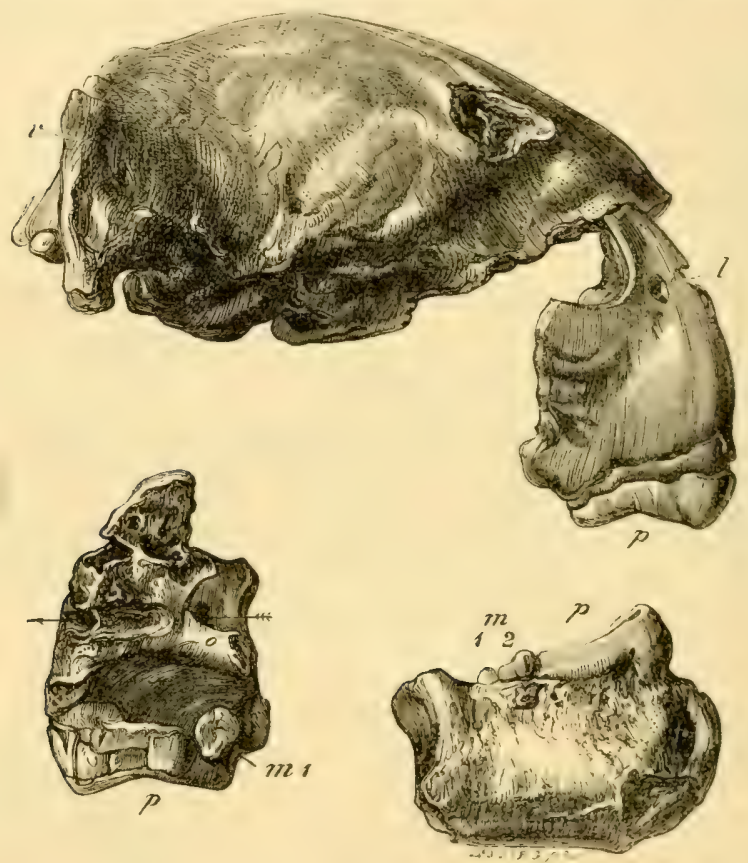

Fig. 141.

Skull of a large extinct Marsupial Carnivore (Thylacoleo carnifex), Pleistocene, Australia.

rivalling the lion in size, the marsupiality of which is demonstrated by the position of the lacrymal foramen $(l)$ in fromt of the orbit; by the palatal vacuity $(o)$, by the loose trmpanic bone, the development of the tympanic bulla in the alisphenoid, hy the very small relative size of the brain, and other characters detailed in the "Philosophical Transactions" * for 18.5.?. The carnassial tooth $(p)$ is 2 inches 3 lines in longitudinal extent, or

* "On tho Fossil Mammals of Australia. Part I. Description of the Thiylacoleo camifex." By Prof. Owen, etc. 
nearly double the size of that in the lion. The upper tubercular tooth $(m, s)$ resembles in its smallness and position that in the placental Felines. But in the lower jaw the carnassial $(p)$ is succeeded by two very small tubercular tecth ( $m, \mathbf{r}$ and $z$ ), as in Plagiaulaw (fig. 93, p. 320); and there is a socket close to the symphysis of the lower jaw of Thylacolco which indicates that the canine may have terminated the dental series there, and have afforded an additional feature of resemblance to the Plagiaulax.

The foregoing are some of the more interesting illustrations of the law, that "with extinct as with existing Mammalia, particular forms were assigned to particular provinces, and that the same forms were restricted to the same provinces at a former geological period as they are at the present day." That period, however, was the more recent tertiary one.

In carrying back the retrospective comparison of existing: and extinct Mammals with those of the eocene and oolitic strata, in relation to their local distribution, we obtain indications of extensive changes in the relative position of sea and land during these epochs, in the degree of incongruity between the generic forms of the Mammalia which then existed in Europe and any that actually exist on the great natural continent of which Europe now forms part. It would seem, indeed, that the further we penetrate into time for the recovery of extinct Mammalia, the further we must go into space to find their existing analogues. To match the eocene Paleotheres and Lophiodons, we must bring Tapirs from Sumatra or South America, and we have to travel to the antipodes for Myrmecobians, the nearest living analogues to the Amphitheres of ou oolitic strata.

On the problem of the extinction of species, little, remonstratively, can be said; and on the more mysterious suliject

* Report on the Extinct Mammals of Australia, 1844. 
of their coming into being, no light has yet been thrown by experiment or observation. As a cause of extinction in times anterior to man, it is most reasonable to assign the chief weight to those gradual changes in the conditions affecting a clue supply of sustenance to animals in a state of nature which must have accompanied the slow alternations of land and sea brought about in the atons of geological time. Yet this reasoning is applicable only to land-animals; for it is scarcely conceivable that such operations can have affected sea-fishes. There are characters in land-animals rendering them more obnoxious to extirpating influences, which may explain why so many of the larger species of particular groups have become extinct, whilst smaller species of equal antiquity have survived. In proportion to its bulk is the difficulty of the contest which, as a living organism, the individual of such species has to maintain against the surrounding agencies that are ever tending to dissolve the vital bond, and subjugate the living matter to the ordinary chemical and physical forces. Any changes, therefore, in such external agencies as a speeies may have been originally adapted to exist in, will militate against that existence in a degree proportionate to the bulk of the species. If a dry season be gradually prolonged, the large Mammal will suffer from the drought sooner than the small one; if such alteration of climate affect the quantity of vegetable food, the bulky Herbivore will first feel the effects of stinted nourishment; if new enemies be introdnced, the large and conspicuous animal will fill a prey, while the smaller kinds conceal themselves and escape. Small quadrupeds are more prolific than large ones. Those of the bulk of the Mastodons, Mexatheria, Glyptodons, and J)iprotodons are uniparous. The actual presenee, therefore, of small species of anmals in comntries where larger species of the same natural families formerly existerl, is not the conserpuenee

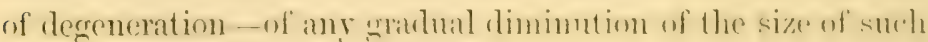


species-but is the result of circumstances which may be illustrated by the falble of the "oak and the reed;" the smaller" and feebler animals have bent and accommodated themselves to changes to which the larger species have succumbed.

That species, or forms so recognized by their distinctive characters and the power of propagating them, have ceased to exist, and have successively passed away, is a fact no longer questioned. That they have been exteminated by exceptional eataclysmal changes of the earth's surface has not been proved. That their limitation in time, in some instances or in some measure, may be lue to constitutional changes accumulating by slow degrees in the long course of generations, is possible. But all hitherto observel causes of extirpation point either to continuous slowly operating geological changes, or to no greater sudden cause than the, so to speak, spectral appearance of mankind on a limited tract of land not before inhabited. It is most probalsle, therefore, that the extinction of species, prior to man's presence or existence, has been due to ordinary causes-ordinary in the sense of agreement with the laws of organization and of the nerer-ending mutation of the geographical and climatal conditions on the earth's surface. The species, and individuals of species, least adapted to bear such influences, and incapalile of modifying their organization in agreenent therewith, have perished. Extinction, therefore, on this hypothesis, implies the want of self-adjusting power in the individuals of the species subject thereto.

But adnitting extinction as a natural law, which has (p)erated from the begimning of life under specific forms of plants and animals, it might be expected that some evidence of it should occur in our own time, or within the historical period. Reference has been made to several instances of the extirpation of species, certainly, jobably, or possibly, rlue to the direct ageney of man. The hook-tillerl parrot (Kistor

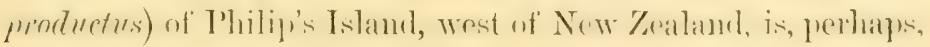


the latest instance of this kind. But this cause avails not in the question of the extinction of species at periods prior to any evidence of human existence; it does not help us in the explanation of the majority of extinctions, as of the races of aquatic Invertebrata and Vertebrata which have successively passed away.

The Great Auk (Alca impennis, L.) seems to be rapidly verging to extinction. It has not been specially hunted down, like the dodo and dinornis, but by degrees has become more scarce. Some of the geological changes affecting circumstances favourable to the well-being of the Alca impennis, have been matters of observation. The last great auks, known with anything like certainty to have been seen living, were two which were taken in $18 \mathrm{tt}$ during a visit made to the high rock, called "Eldey," or "Meelsoekten," lying off Cape Reykianes, the S. IV. point of Iceland. This is one of three principal rocky islets formerly existing in that direction, of which the one specially named from this rare bird "Geirfugla Sker" sank to the level of the surface of the sea during a volcanic disturbance in or about the year 1830. Such disappearance of the fit and favourable breeding-places of the Alea impennis must form an important element in its decline towards extinction. The numbers of the bones of Alca imponis on the shores of Iceland, Greenland, and Demmark, attest the abundance of the bird in former times.

Within the last century, academicians of Petersburg and good naturalists described and gave figures of the hony and the perishable parts, including the alimentary camal, of a large and peculiar fucivorous Sirenian-an amplhibious animal like the Manatee, which Cuvier classified with his herbirorous Cetacea, and called Rytine Stelleri, after its discoverer. This animal inhabited the siberian shores and the mouths of the great rivers there disembongung. It is now believed to be extinet, and this extinction appears not to have heen rue to any spectial 
quest and persecution by man. We may discern in this fact the operation of changes in physical geography, which have at length so affected the conditions of existence of the Siberian manatee as to have caused its extinction. Such changes had operated, at an earlier period, to the extinction of the elephant and rhinoceros of the same region and latitudes: a future greneration of zoologists may have to record the final disappearance of the Arctic buffalo (Ovibos moschatus). Remains of Oribos and Rytine show that they were contemporaries of Elephas primigenius and Rhinoceros tichorrinus.

But recent discoveries indicate that, in the case of the last two extinct quadrupeds, a rude primitive human race may hare finished the work of extermination, begun by antecedent and more general causes.

Flint weapons called "celts," unquestionably fashioned by human hauds, have been discovered in stratified gravel, containing remains of the mammoth, in the valley of the Somme near Abbeville and Aniens, at difterent periods, from the year 18\$7 (Boucher de Perthes, "Antiquités celtiques et antediluviennes," Paris, 1S+7) to the present time.

These evidences of the human species have been extracted from the deposit in question, by Mr. Prestwich (" 77 feet from the surface in undisturbed ground," "Proceedings of the Royal Society," May 26,1859 ) ; by $M[r$. Flower, (" 20 feet from the surface, in a compact mass of grarel," "Times," Norember" 18, 18599) ; by M. Gaudry (“L'Institut," October 5, 18.59); and by M. Geo. Pouchet,-all with their own hands in the course of the year 1859. Besides the Elcphas primigenius, remains of Rhinocros tichorthinus, Cerrus somonensis, Ursus speleus, and of a large extinct Bovine animal, have been found in the same bed of gravel.

Mr. Prestwich, F.(r.S., after a careful study of the geolologeal relations of this hed, refers it to the post-plincene 
age; and to a period "anterior to the surface assuming its prescnt outline, so far as some of its minor features are concerned."

Similar tlint weapons had been discovered by Mr. John Frere, F.R.S. ("Archeologia," vol. xiii., "An account of flint weapons discovered at Hoxne in Suffolk," 1800) in a bed of flint gravel, 16 feet below the surface, of the same geological age as that in the valley of the Somme.

Flint weapons have been discovered mixed indiscriminately with the bones of the extinct cave-bear and rhinoceros. One in particular was met with beneath a fine antler of a rein-deer, and a bone of the cave-bear, imbedded in the superficial stalagmite in the bone-cave at Brixham, Devonshire, during the careful exploration of that care conducted by a committee of the Geological Society of London in $18.5 \mathrm{~s}$ and 1859 .

Dr. Falconer, F.Cr.S., has communicated ("Proceedings of" the Ceological Society," June 22, 1859) the results of his examination of ossiferous caves in Palermo; and in respect to the "Maccagnone cave," he draws the following inferences:-That, "it was fillerl up to the roof within the human period, so that a thick layer of bone splinters, teeth, landshells, coprolites of hyrena, and human objects, was agghtinated to the roof by the infiltration of water holding lime in solution; that subsequently and within the human period, such a great amount of change took place in the physical configuration of the district as to have caused the cave to be washerl ont, and emptied of its contents, excepting the floorbreccia and the patches of material cemented to the roof, and since coated with additional stalagmite." (I. 136.)

Sir Charles Lyell belieres "the antiquity of the Abbeville and Amiens flint instruments to be great indeed, if compared to the times of history or tradition. ..." "It must have reguired a long period fore the wearing down of the dhalk which 
supplied the broken flints for the formation of so much gravel at various heights, sometimes $\mathbf{1 0 0}$ feet above the present level of the somme, for the deposition of fine sediment including entire shells both terrestrial and aquatic, and also for the denudation which the entire mass of stratified drift has undergone, portions having been swept away, so that what remains of it often terminates abruptly in old river cliffs, besides being covered by a newer unstratified drift. To explain these changes, I should infer considerable oscillations in the level of the land in that part of France; slow movements of upheaval and subsidence, deranging but not wholly displacing the course of ancient rivers. Lastly, the disappearance of the elephant, rhinoceros, and other genera of quadrupeds, now foreign to Europe, implies in like mamner a vast lapse of ages, separating the era in which the fossil implements were framed, and that of the invasion of Gaul by the Romans."**

As to the successive appearance of new species in the course of geological time, it is first requisite to avoid the common mistake of confounding the propositions, of species being the result of a continuously operating secondary cause, and of the mode of operation of such creative cause. Biologists may entertain the first without accejting any current hypothesis as to the second.

That the species of the mineralogist and the botanist should be owing to influences so different as is implied by the operation of a second cause, and the direct interference of a first cause, is not probable. The nature of the forces nperating in the production of a lichen may not be so clearly understood as those which arranged the atoms of the erystal on which the lichen spreads. Pouchet has contributed the most valualie critence as to the fact and mode of the production hy external

* Address, on opening the Section of Geology, at the Meeting of the British Association at Aberdecn, September $15,1859$. 
influences of species of Protuzoa.* With regard to the species of higher organisms, distinguishable as plants and animals, their origin is as yet only matter of speculation.

Buffon $\uparrow$ regarded varieties as particular alterations of species, which illustrated the mutability of species themselves. The so-called varieties of a species, species of a genus, genera of an order, etc., were with him but so many evidences of the progressive degrees of change, which had been superinduced by time and successive generations, and chiefly by degradation from a primordial type. Applying this principle to the species of which he had given the history in his great work, he believed himself able to reduce then to a very small number of primitive stocks, of which he enmmerates "fifteen."

Lamarck, \& adverting to observed ranges of variation in certain species, affirmed that such variations would proceed and keep pace with the contimued operation of the causes producing them ; that such changes of form and structure would induce corresponding changes in actions, and that a change of actions, when habitual, became another cunse of altered structure; that the more frequent employment of certain parts or organs leads to a proportional increase of development of such parts ; and that as the increased exercise of one part is usually accompanied by a corresponding disuse of another part, this very disuse, by inducing a proportional degree of atrophy, becomes another element in the progressive mutation of organic forms.

A third theorist $\S$ calls to mind the instances of sudden departure from the specific type, manifested by a malformed or monstrous offspring, and quotes the instances in which such malformations have lived and propragated the deviating structure. He notes also the extreme degrees of change and

* Heterogenie, 8vo, 1859.

† Histoire Naturelle, Dégénération des Animaux, tom. iv., p. 311.

$\ddagger$ Philosophie Zoologique, 8 vo, 1809, tom. i., clis. 3 and 7 .

"Vestiges of the Natural History" of Creation." 
of complexity of structure undergone by the germ and embryo of a highly organized animal in its progress to maturity. He speculates on the influence of premature birth, or on a somewhat prolonged foctation, in establishing the beginning of a specific form different from that of the parent.

Mr. Wallace, ${ }^{*}$ assuming that varieties may arise in a wild species, shows how such deriations from type may tend to adapt a variety to some changes in surrounding conditions, under which it is better calculated to exist, than the typeform from which it deviated.

No doubt the type-form of any species is that which is best adapted to the conditions under which such speeies at the time exists; and as long as those conditions remain unchanged, so long will the type remain; all varieties departing therefrom being in the same ratio less adapted to the environing conditions of existence. But, if those conditions change, then the variety of the species at an antecedent date and state of things will hecome the type-form of the species at a liter date, and in an altered state of things.

Mr. Charles Darwin had, previously to Mr. Wallace, pondered over and worked at this principle, which he illustrates by ingenious suppositions, of which I select the following :- "To give an imaginary example from changes in frogress on an island:-let the organization of a canine animal which preyed chiefly on rabbits, but sometimes on hares, hecome slightly plastic; let these sane changes cause the mumber of rabbits very slowly to decrease, and the number of hares to increase ; the effect of this would be that the fox or dog would be driven to try to catch more hares; his organization, howerer, being slightly plastic, those individuals with the lightest forms, longest limbs, and best eyesight, let the difference be ever so small, would be slightly favoured, and would tend to live longer, and to survive during

\footnotetext{
* Procecdings of the Linnæan Socicty, August 1858, p. 57.
} 
that time of the year when food was searcest; they would also rear more young, which would tend to inherit these slight peculiarities. The less fleet ones would be rigidly destroyed. I can see no more reason to doubt that these causes in a thousand generations would produce a marked effect, and adapt the form of the fox or dog to the catching of hares instead of rabbits, than that greyhounds can be improved by selection and careful breeding.*

Observation of animals in a state of nature, however, is still required to show their degree of plasticity, or the extent to which varieties do arise; whereby grounds may be had for judging of the probability of the elastic ligaments and jointstructures of a feline foot, for example, being superinduced upon the more simple structure of the toe with the nonretractile claw, according to the principle of a succession of varieties in time.

Farther discoveries of fossil remains are also needed to make known the antetypes, in which varieties, analogous to the observed ones in existing species, might have occurred, seriatim, so as to give rise ultimately to such extreme forms as the Giraffe.

This application of palæontology has always been felt by myself to be so important that I have never omitted a proper opportunity for impressing the results of observations showing the "more generalized structures" of extinct, as compared with the "more specialized forms" of recent animals.

But observation of the effects of any of the above hypothetical transmuting influences in changing any known species into another has not yet been recorded. And past experience of the chance aims of human fancy, unchecked and unguided by observed facts, shows how widely they have erer glanced away from the gold centre of truth.

* Proceedings of the Limnean Socjety, $\Lambda$ ugnst 1855, 1. 49. 'The principle is more fully illustrated in the work "On thr. Origin of Species," 8ro, 1859. 
The principles, based on rigorous and extensive observation of facts, which have thus been inductively established, and have tended to impress upon the minds of the closest reasoners in Biology a conviction of a continuously operative secondary creational law, are the following:- the law of irrelative or vegetative repetition : the law of unity of plan or relations to an archetype: the phenomena of parthenogenesis: the progressive departure from general type as exemplified in the series of species from their first introduction to the present time.

Table of Geological Distribution of Mamals.

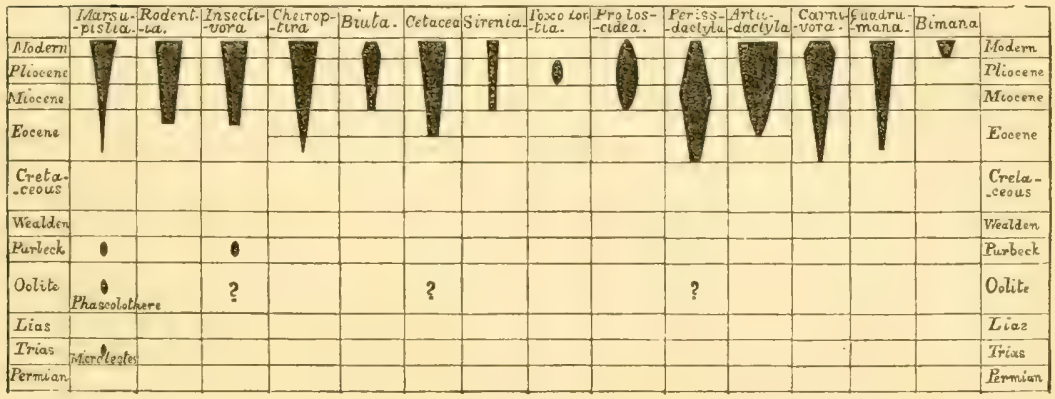

Fig. 142.

The Table (fig. 142) expresses the sum of the observations at the present date, on the succession, appearance, and geological relations of the screral order's of the Mammalian class.

The earliest evidences are of small species, which, whenever they have presented grounds for ordinal determination, have proved to belong to the low organized Marsupialia. The doubt, when it has existed, lies between this and the Insectivorous order, also low in the class according to cerelumal characters. One example only, from Stonesfield oolite, the Stcreognathus, may prove to be a minute Lngulate, as is indicated by the note of interrogation under Pcrissoductyla. The

*wen, "On the Classification and Geographical Distribution of the Mimmalia," 8vo, 1859. 
similar mark, under C'ctacce, refers to the fossil, probably washed out of an Upper Oolitic bed, referred to at p. 321. The Marsupialiu recur, under distinct generic forms, in the eocene strata, and, according to actual knowledge, present their fullest development in pliocene and modern times, more especially in Australia. The orders Bruta, Pcrissodactyla, and Carnirora, have become reduced in numbers; the Proboscictia still more so ; the representatives of the singular group Torodontia have wholly disappeared.

The sum of the evidence which has heen obtained seems to prove that the successive extinction of Microlcstcs, Amphitheria, Spalacotheria, Triconodons, and other mesozoic forms of mammals, has been followed by the introduction of much more numerous, raried, and ligher-organized forms of the class, during the tertiary periods.

It may be, however, objected that negative evidence cannot satisfactorily establish the proposition that the mammalian class is of late introduction, nor prevent the conjecture that it may have been as richly represented in primary and more ancient secondary as in tertiary times, could we but get remains of the terrestrial fama of the continents. To this objection it may be replied: in the palieozoic strata, which, from their extent and depth, indicate, in the earth's existence as a seat of organic life, a period as prolonged as that which has followed their deposition, no trace of mammals has been observed. Were mammals peculiar to dry land, such negative evidence would weigh less in producing conviction of their non-existence during the Silurian and Devonian wons, beeause the explored parts of such strata have been deposited from an ocean, and the chance of finding a terrestrial and airbreathing creature's remains in oceanic defosits is rery remote. But in the present state of the warm-lilooded, air-lireathing, viviparous class, no gencra and species are represented by steh numerous and widely dispersed individuals, as those of 
the order Cetacea, which, under the guise of fishes, dwell, and can only live, in the ocean.

In all Cetacea the sheleton is well ossified, and the vertebre are very numerous: the smallest Cetacean would be deemed large amongst land-manmals; the largest surpass in bulk any creatures of which we have yet gained cognizance: the hugest ichthyosaur, iguanodon, megalosaur, mammoth, or megathere, is a dwarf in comparison with the modern whale of a hundred feet in length.

During the period in which we have proof that Cetacect have existed, the evidence in the shape of bones and teeth, which latter enduring characteristics in most of the species are peculiar for their great number in the same individual, must have been abundantly deposited at the bottom of the sea; and as cachalots, grampuses, dolphins, and porpoises are seen gambolling in shoals in deep oceans, far from land, their remains will form the most characteristic evidences of vertebrate life in the strata now in course of formation at the bottom of such oceans. Accorlingly, it consists with the known characteristics of the cetacean class to find the marine deposits which fell from seas tenanted, as now, with vertebrates of that high grade, containing the fossil eridences of the order in vast abundance.

The red crag of Suffolk and Essex contaius petrified fragments of the skeletons and teeth of rarious Cetacea, in such quantitics as to constitute a great part of that somrce of phosphate of lime for which the red crag is worked for the mantfacture of artificial manure. The scanty and dubious evidence of Cetace in secondary beds seems to indicate a similar period for their begimning as for the soft-scaled cycloid and ctenoid fishes which have superseded the ganoid orders of mesozoic times.

We cannot doubt but that had the genera Ichthyoscuurus, Plioscurns, or Plisiosenims, heen represented by species in the 
same ocean that was tempested by the Balanodons and I)inplodons of the miocene are, the bones and tecth of those marine reptiles would have testified to their existence as ahumdantly as they do at a previous epoch in the earth's history. But no fossil relic of an enaliosaur has been found in tertiary strata, and no living enaliosaur has been detected in the present seas: and they are consequently held hy competent naturalists to be extinct.

In like mamner does such negative evidence testify to the non-existence of marine mammals in the liassic and oolitic times. In the marine deposits of those secondary or mesozoic epochs, the evidence of vertebrates governing the ocean, and preying on inferior marine rertebrates, is as alundant as that of air-breathing rertebrates in the tertiary strata; but in the one the fossils are exclusively of the cold-blooded reptilim class, in the other, of the warm-blooded mammalian class. The Enaliosauria, Cetiosauria, and Crocortitia, played the same part and fulfilled similar offices in the seas from which the lias and oolites were precipitated, as the Delphinide and Balanidar did in the tertiary seas, and still do in the present ocean. The unbiassed conclusion from both negative and positive evidence in this matter is, that the C'ctacer succeeded and superseded the Enaliosariria. To the mind that will not accept such conclusion, the stratified oolitic rocks must cease to be trustworthy records of the condition of life on the earth at that period.

So far, however, as any general conclusion can be derluced from the large sum of evidence above referred to, and contrasted, it is against the doctrine of the Unifornitarian. Organic remains, traced from their earliest linown grates, are succeeded, one series ly another, to the present preriod, and never re-alpear when once lost sight of in the ascending search. As well might we exprect a living Ichthyosaur in the I'acific, as a fossil whale in the Idias: the rule governs as 
strongly in the retrospect as the prospect. And not only as respects the Fertebrata, but the sum of the animal species at each successive geological period has been distinct and peenliar to such period.

Not that the extinction of such forms or species was sudden or simultaneous: the evidences so interpreted have been but local. Over the wider field of life at any given epoch, the change has been gradual; and, as it would seem, obedient to some general, continuously operative, but as yet, ill-comprehended, law. In regard to amimal life, and its assigned work on this planet, there has, howerer, plainly been "an ascent and progress in the main."

Although the mammalia, in regard to the plenary development of the characteristic orders, belong to the Tertiary division of geological time, just as "Echini are most common in the superior strata; Ammonites in those beneath, and Proclucti with numerous Encrini in the lowest" * of the secondary strata, yet the begimnings of the class manifest themselves in the formations of the earlier preceding division of geological time.

We are not entitled to infer from the Lucina of the permian, and the Oxis of the trias, that the Lamellibranchiate Mollusks existed in the same rich variety of development at those periods as during the tertiary and present times; and no prepossession can close the eyes to the fact that the Lamellibranchiate have superseded the Palliobranchiate bivalves.

On negative evidence, Orthisina, Theca, Producta, or Spirifer are believed not to exist in the present seas: on negative evidence the existing genera of siphonated bivalves and univalves are deemed to have been very rare in permian, triassic, or oolitic times. To suspect that they may have then albundantly existed, but have hitherto escaped olservation, hecause certain Lamellibranchs with an open mantle, and some holustomatous

\footnotetext{
A generalization of William Smith's.
} 
and asiphonate Gastropods, have left their remains in secondary strata, is not more reasonable, as it seems to me, than to conclude that the proportion of mamualian life may have been as great in secondary as in tertiary strata, because a ferw small forms of the lowest orders have made their appearance in triassic and oolitic beds.

Turning from a retrospect into past time for the prospect of time to come, I may crave indulgence for a few words, of more sound, perhaps, than significance, relative to the amount of prophetic insight imparted by Palcontology. But the reflective mind cannot erade or resist the tendency to spreculate on the future course and ultimate fate of rital phenomena in this planet. There seems to have been a time when life was not; there may, therefore, be a period when it will ceatse to be.

Our most soaring speculations still show a kinship to our nature: we see the element of finality in so much that we have cognizance of, that it must needs mingle with our thoughts, and bias our conclusions on many things.

The end of the world has been presented to man's mind under divers aspects: as a general conflagration; as the same, preceded by a millemial exaltation of the world to a paradisiacal state,-the abode of a higher race of intelligences.

If the guide-post of Palerontology may seem to point to a course ascending to the condition of the latter speculation, it points but a very short way, and in leaving it we find ourselves in a wilderness of conjecture, where to try to adrance is to find ourselves "in wandering mazes lost."

With much more satisfaction do I return to the legitimate decluctions from the phenomena which have hecn under review.

In the survery which has been taken of the various forms of life that have passed away-of their characters, succession, geoIngienl position, and gengraphical distribution-if I have sue- 
ceeded in demonstrating the adaptation of any structure to the exigencies, habits, and well-being of the species, I have fulfilled one object which I had in view, viz., to set forth the beneficence and intelligence of the Creative Power.

If, in all the striking changes of form and proportion which have passed under review, we could discern only the results of minor modifications of a few essential elements, we must be the more strikingly impressed with the mity of that Cause, and with the wisdom and power, which could produce so much variety, and at the same time such perfect adaptations and endowments, ont of means so simple. For, in what have those contrasted limbs, hoofs, paws, fins, and wings, so variously formed to obey the behests of volition in denizens of different elements, differed from the mechanical instruments which we ourselves plan with foresight and calculation for analogous uses, save in their greater complexity, in their perfection, and in the unity and simplicity of the elements which are modified to constitute these several locomotive organs?

Everywhere in organic nature we see the means not only subservient to an end, but that end accomplished by the simplest means. Hence we are compelled to regard the Great Cause of all, not like certain philosophic ancients, as a uniform and quiescent mind, as an all-pervading anima mundi, but as an active and anticipating intelligence.

By applying the laws of comparative anatomy to the relics of extinct races of animals contained in and characterizing the different strata of the earth's crust, and corresponding with as many epochs in the earth's history, we make an important step in advance of all preceding philosophies, and are able to demonstrate that the same pervading, active, and beneficent intelligence which manifests His power in our times, has also manifested His power in times long anterior to the records of our existence.

But we likewise, ly these investigations, gain a still more 
important truth, viz., that the phenomena of the world do nut succeed each other with the mechanical sameness attributed to them in the cycles of the epicurean philosophy; for we are able to demonstrate that the different epochs of the earth were attended with corresponding changes of organic structure; and that, in all these instances of change, the organs, still illustrating the unchanging fundamental types, were, as far as we could comprehend their use, exactly those best suited to the functions of the being. Hence we not only show intelligence evoking means adapted to the end; but, at successive times and periods, producing a change of mechanism adapted to a change in external conditions. Thus the highest generalizations in the science of organic bodies, like the Newtonian laws of universal matter, lead to the unequivocal conviction of a great First Cause, which is certainly not mechanical. 


\section{N D E X.}

ACALEPH. 17.

Acanthias, 100.

Acanthocladia, 28.

Acanthodes, 131.

Acanthodii, 130.

Acanthopteri, 146.

Acanthospongia, 6 .

Acanthoteuthis, 91 .

Acervularia, 23.

Acervulina, 11.

Acheta, 47.

Acrodus, 109.

Acrolepis, 138.

Acternella, 80.

Acteonina, 74, 80.

Acrocidaris, 36 .

Acrosalenia, 36.

Actinoceras, 85.

Actinocrinus, 31.

Actinocyclus, 13, 14.

Actinoida, 21.

Actinophrys, 9 .

Eolodon, 271.

Etobates, 115.

Agathistega, 11.

A gnostus, 42.

Alaria, 73.

Alca, 400 .

Alecto, 28.

Alligator, 273.

Alveolina, 12.

Amblypterus, 137.

Amblyurus, 143.

Ambonychia, 57.

Ammonites, 86.

Amoba, 9.

Anphibichnites. 163.

Amphicolia, 271.

Amphicyon, 340.

Amphidotus, 36.

Amphilestes, 303.

Amphitherium, 303.

Amphiura, 33.

Amplexus, 23.

Anacanthini, 148.

Ananchytes, 34 .

Anastoma, 79.

Anatinida, 57 .
Ancyloceras, 86 .

Andrias, 284.

Annulata, 39.

Anomia, 58.

Anomodontia, 235.

Anoplotherium, 332.

Anthocrinus, 31.

Anthozoa, 21.

Anthracotherium, 367.

Anthrocosia, $66^{\circ}$.

Antipathes, 21.

Apateon, 168.

Aphis, 47.

Apioceras, 83.

A piocrinus, 30.

Aporrbais, 73 .

Apteryx, 294.

Apus, 45.

Aptychus, 86 .

A rachnida, 48.

Arbacia, 36.

Arca, 61.

Arcella, 9.

Archaocidaris, 35 .

Archæoniscus, 45.

Archegosaurus, 168, 177.

Archiacia, 36.

Archimedipora, 20.

Arthraster, 34.

Asapbus, 44.

Ascidia, 27.

Ascoceras, 83.

Asilus, 47.

Aspidiscus, 25.

Aspidura, 33.

Astartida, 57.

Asteriadæe, 33 .

Asteropterichius, 104.

Astræa, 36.

Astrogonium, 34.

Athrris, 50.

Atlanta, 72.

Atrypa, 50 .

Aturia, 82.

Aulacanthus, 105.

Ares, 286.

Aviculidx, 60.

Aviculopecten, 5\%.
Axinus, 57.

Bacillaria, 14, 16.

Bactrites, 85 .

Baculites, 86 .

Bakewellia, 60 .

Balzenodon, 342.

Balanophyllia, 26.

Balanus, 40.

Balistes, 100.

Baphetes, 184.

Bathygnathus, 252.

Batrachia, 283.

Batrachopus, 166.

Belemnites, 92.

Belemnitella, 93.

Belemnoris, 90 .

Belemnosepia, 91.

Bellerophon, 72.

Bellinurus, 42.

Belodon, 251.

Beloptera, 90.

Beloteuthis, 90.

" Berg-mehl," 15.

Berosus, 47.

Beyrichia, 42.

Bifrontia, 77 .

Bison, 370 .

Blastoidea, 30.

Blattidæ, 47.

Borsonia, 75.

Bos, 370.

Bothrioconis, 6 .

Bothriolepis, 132.

Bourgetocrinus, 29, 34 .

Brachiolites, 8.

Brachiopoda, 49.

Brissus, 36 .

Brontozoum, 290.

Bryozoa, 27.

Bubalus, 370.

Buccinum, 71, 97.

Buprestis, 47.

Byssacanthus, 103.

Calceora, 53.

Callorhynchus, 116.

Calymene, 42. 
Calyptræidæ, 77.

Camarophoria, 51.

('amaroceras, 83.

Cameloparialis, 388 .

Campanularia, 17.

Campylodiscus, 15.

Cancellaria, 76 .

Cantharid $x, 47$.

Capitosaurus, 196.

Caprina, 63.

Caprinella, 64.

Caprotina, 64.

Carabidx, 47.

Carcharodon, 111.

Cardiad $x, 65$.

Cardiomorpha, 64.

Cardiola, 60.

Cardium, 65.

Carinaria, 73.

Carnivora, 376.

Carolia, 58.

Caryocrinus, 31.

Cassidaria, 76.

Cassidulidæ, 36.

Cassis, 76.

Catantostoma, 78.

Catopygus, 35 .

Caturus, 139.

Caturidæe, 139.

Cellepora, 28.

"Celts," 401.

Centriscus, 103.

Centrodus, 138.

Cephalaspis, 122.

Ceratiocaris, 43 .

Ceratites, 82 .

Cercomya, 68.

Cercopis, 47.

Ceromya, 68.

Cervus, 371.

Cerylon, 47.

Cestracion, 106.

Cetiosaurus, 272.

Chama, 62 .

Cheiracanthus, 131.

Cheirolepis, 131.

Cheirotherium, 163.

Chelonia, 281.

Chelydra, 282.

Chemnitzia, 77 .

Chenendopora, 7 .

Chimæra, 116.

Chiton, 77.

Choanites, 7.

Chøropotamus, 367.

Chotites, 23.

Chondrosteus, 145.

Chonetes, 53.

Chrysaora, 28.

Chrysodomus, 97.

Chrysomelidx, 47.

Cicada, 47.

Cidaris, 35.

Cimicidx, 47.
Cirripedia, 40.

Cirrus, 78.

Cladacanthus, 104.

Cladodus, 108.

Cladyodon, 251.

Clavagella, 69.

Clavella, 75 .

Cleodora, 71.

Cliona, 8.

Climatius, 103.

Clymenia, 83.

Clypeaster, 36 .

Cnemidium, 7.

Coccinella, 47.

Coccosteus, 123.

Coccotenthis, 90 .

Cochliodus, 109.

Colacanthi, 131.

Cœlogenys, 386.

Coclorhynchus, 148.

Coenites, 20.

Colèia, 45 .

Cololites, 39.

Colonodus, 138.

Colossochelys, 283.

Coluber, 280.

Columbellarina, 73 .

Colymbetes, 47 .

Comatula, 29, 34 .

Conchiosaurus, 214.

Conchorhynchus, 86 .

Conocardium, 57,65 .

Conoclypeus, 36 .

Conodonts, 97.

Conorbis, 75 .

Conularia, $7 \mathrm{l}$.

Copris, 47.

Corallium, 21.

Corax, 111.

Corbicula, 66.

Corbis, 65 .

Corbula, 68 .

Cordylodus, 96.

Cornulites, 46.

Coryphodon, 322.

Corystes, 47.

Coscinodiscus, 13, 16.

Cosmacanthus, 103.

Crania, 55.

Crassatella, 66.

Crenella, 62.

Cribrispongia, 7 .

Crinoidea, 29.

Crioceras, 89.

Cristellaria, 12.

Crocodilia, 271.

Crocodilus, 273.

Crossostoma, 74.

Crotalocrinus, 30.

Crustacea, 41.

Cryptangia, 26.

Cryptoceras, 82 .

Cryptodon, 65.

Ctenacantluus, 100.
Ctenodonta, 57.

Ctenognathus, 96.

Ctenomys, 386.

Ctenoidei, 146.

Cucculæa, 59.

Cupularia, 28.

Cupulispongia, 7 .

Curculionidre, 47.

Cuvieria, 72.

Cyathophyllum, 23.

Cyathina, 26.

Cyathocrinus, 31.

Crelas, 42.

Cycloidei, 147.

Cyclolites, 25.

Cyclopthalmus, 48.

Cyclostoma, 79.

Cyelnstrema, 77 .

Cymba, 76.

Cyphon, 47.

Cypraidx, 76 .

Cyprida, 46.

Cyprinidx, 57.

Cypris, 42.

Cyitis, 50.

Cyrtoceras, 83.

Cyrtolites, 7\%.

Cyrena, 65.

Cystoidea, 30-32.

Cytherea, 67.

Cytherida, 42.

Dapenies, 142.

Davidsonia, 53.

Defrancia, 28.

Dendrerpeton, 182.

Dendrodus, 133.

Dendrophyllia, 26.

Dendropupa, 79.

Dentalina, 11, 12.

Dentalium, 77.

Deshayesia, 75 .

Diastopora, 28.

Diatomaceæ, 13, 16.

Dibranchiata, 90.

Diceras, 62, 64 .

Dichobune, 336.

Dichodon, 333.

Dicynodonts, 236.

Didacna, 65.

Didelphis, $3 \pm 1$.

Didus, 295.

Didymograpsus, 20.

Diftugia, 9.

Dikelocephalus, $15 \%$.

Dimeracanthus, 103.

Dimorphodon, 216.

Dinornis, 293.

Dinosauria, 257.

Dinotherium, 352.

Diplacanthus, 130.

Diploctenium, 25.

Diplodonta, 65.

Diplograpsus, 20. 
Diplopterus, 150.

Dipriacantlus, 101.

Diprotodon, 394.

Dipterus, 129.

Disaster, 35.

Discinidæ, 56 .

Discoidea, 36.

Discosorus, 84.

Dithyrocaris, 42.

Ditrupa, 40.

Dolichosaurus, 278.

Dolium, 74.

Donacia, 47.

Donax, 68.

Dorypterus, 138.

Dreissenia, 61.

Dromatherium, 302.

Dromilites, 46.

Dryopithecus, 350.

EсHirs, 386.

Echinarachnius, 36 .

Echinodermata, 29.

Echinoidea, 34.

Echinolampas, 36.

Echinopsis, 35.

Edaphodus, 117.

Edmondia, 57.

Elasmodus, 117.

Elasmotherium, 387.

Elater, 47.

Elephas, 360.

Elonichthys, 138.

Emys, 282.

Enallostega, 11.

Encrinus, 30.

Entalophora, 28.

Entomostega, 11.

Entomostraca, 41.

Entomoconchus, 42.

Entosolenia, 11.

Eopithecus, $3 \pm 1$.

Epiaster, 36.

Epionis, 294.

Erismacanthus, 104.

Eryon, 46.

Eschara, 28.

Estheria, 42.

Etyus, 46.

Eucalyptocrinus, 31 .

Eudea, 7.

Eugeniacrinus, 31, 34.

Eugnathus, 140.

Eulima, 77.

Euomplialus, 72.

Eupatagus, 36.

Eurynotus, 138.

Eurypterus, 43.

Exogyra, 58.

Fasciculatia, 29.

Favosites, 23.

Favositidæ, 23.

Felis, 376 .
Fenestrella, 20, 28.

Ferussina, 75, 79 .

Firolidx, 72 .

Fistularida, 102.

Flabellina, 6, 12.

Flabellum, 26.

Flustra, 29.

Foraminifera, 9 .

Fungid $æ, 25$.

Fusulina, 6, 12.

Fusus, 76 .

Gailionelz $\$ 14$.

Galecynus, 376.

Galeocerdo, 111.

Galerites, $3 \pm$.

Galeus, 111.

Ganocephala, 168.

Ganodus, 117.

Ganoidei, 118.

Gastornis, 291.

Gastrochæna, 68.

Gavialis, 273.

Geocrinus, 31.

Geoteuthis, 91 .

Gervillia, 59.

Gilbertsocrinus, 31.

Gitocrangon, 45.

Glandina, 79 .

"Glenotremites," 32.

Globiconcha, 80 .

Globigerina, 10.

Globulus, 77.

Globulodus, 138.

Glyphea, 45.

Glypticus, 36.

Gly ptocrinus, 31 .

Glyptolepis, 131.

Glyptodon, 392.

Glyptopomus, 132.

Gnathodus, 96.

Goniatites, 84.

Goniodiscus, 31.

Goniomya, 67,

Goniopholis, 271.

Gorgonida, 21.

Grammysia, 57.

Graphularia, 20.

Graptolites, 19.

Grateloupia, 67.

Gryphxa, 58.

Guettardia, 6, 8 .

Gulo, 341.

Gyracanthus, 104.

Gyrinus, 47.

Gyroceras, 84.

Gyropristis, 104.

Gyrosteus, 139.

Halysites, 23.

Hamites, 86.

Haplacanthus, 103.

Harpalus, 47.

Helicerus, 94.
Helicoceras, 89.

Helicoidea, 11.

Helicostega, 11.

Heliolites, 23.

Helix, 75, 79.

Helophorus, 47.

Hemerobioides, 47.

Hemiaster, 36 .

Hemicidaris, 35.

Hemipneustes, วิ5.

Hemipristis, 111.

Heterocercal fish, 119.

Heteropoda, 72.

Heterosteus, 119.

Himantopterus, 43.

Hinnites, 59.

Hippalimus, 7.

Нірросrena, 73.

Hippohyus, 367.

Hippopotamus, 364.

Hippopodium, 67.

Hippurites, 64.

Hippuritidæ, 58.

Histiophorus, 148 .

Holaster, 36.

Holectypus, 36 .

Holocystis, 25.

Holopella, 77.

Holoptychius, 132.

Holostomata, 76 .

Holothurioidea, 37.

Homacanthus, 103.

Homosteus, 119.

Hoplopygus, 138.

Hornera, 29.

Hurnan remains, 401.

Huronia, 84.

Hyæna, 384.

Hyænodon, 339.

Hyalæa, 71 .

Hyalonema, 21.

I1 ybodus, 105, 108.

Hydrophilida, 47.

Hydrozoa, 19.

Hylæosaurus, 264.

Hymenocaris, 43.

Hyopotamus, 367.

Hystrix, 386.

JAxIRA, 59.

lanthina, 77 .

Ichnology, 152.

Ichthyopteryyia, 198.

"Ichthyodorulites," 104.

Ichthyosaurus, 200.

Idmonea, 28.

Iguanodon, 265.

Illænus, 42.

Indusial limestone, 48.

Infusoria, 14.

Inoccramus, 8, 59 .

Insecta, 47 .

Invertebrata 17.

Jouannetia, 69. 
Ischiodus, 117.

Isis (Isisina), 21.

Isoarca, 59 .

Isodus, 138.

KELLIA, $6 \tilde{\text { J }}$

LABYRINTHONONTIA, 183. Iacertilia, 278.

Laccophilus, 47.

Lagena, 11.

Lagomys, 386.

Lagostomus, 386.

Lamellibranchiata, 57.

Lamna, 112.

Leda, 61.

Leiacanthus, $10 \pm$.

Leiodon, 279.

Lepadidx, 41.

Leperditia, 42.

Lepidaster, 33.

Lepidoganoidei, 129.

Lepidosteus, 119.

Lepidotus, 144.

Lepracanthus, 104.

Leptxna, 54 .

Leptacanthus, 104.

Leptocheles, 43.

Leptolepis, 141.

Leptopleuron, 255.

Lenita, 36.

Libellula, 47.

Limanomia, 58.

Limnæa, 79.

Limuius, 47.

Limopsis, 67 .

Limulus, 43.

Lingula, 56 .

Litharæa, 26

Lithocardium, $65,67$.

Lithodendron, 23.

Lithornis, 291.

Lithostrotion, 23.

Litorinidæe, 77.

Lituites (Breynius), 84.

Lituola, 6, 12.

I,oligosepia, 91.

Lophiodon, 329.

Loricula, 46.

Loxonema, 71.

Lucinidxe, 65.

Lucinopsis, 67.

Luidia, 33.

Lunulites, 28.

Lutraria, 68 .

Lyrodesma, 57, 62.

MAcrulodus, 279.

Machairodus (Pander) fish, 98 .

Machairodus (Kaup) mammal, 382.

Maclurea, 71.

Macrauchenia, 393.
Macrochilus, 71.

Macrodon, 61 .

Macropetalichthys, 100.

Macropoma, 144.

Macropus, 394 .

Macropthalma, 46 .

Macrospondylus, 271.

Macrotherium, $3 \pm 6$.

Mactra, 67.

Malacostraca, 45.

Mallotus, 150.

Mammalia, 295.

Geological distribution of, 407 .

Mammillopora, 6 .

Manon, 6.

Marginula, 15.

Marsupites, 30 .

Martesia, 69 .

Massospondylus, 271 .

Mastigophora, 91.

Mastodon, 353.

Mastodonsaurus, 195 .

Megaceros, 372 .

Megachirus, 46.

Megalodon, 63.

Megalosaurus, 258.

Megaspira, 79.

Megatherium, 390 .

Melania, 77.

Melanopsis, 77.

Melocrinus, 31.

Melolontha, 47.

Menopoma, 185.

Merycotherium, 387.

Mesopithecus, 351.

Mesostylus, 47.

Metopias, 196.

Meyeria, 45.

Michelinia, 24.

Nicrabacia, 25.

Micraster, 36 .

Microconchus, 10.

Microlestes, 301.

Microtherium, 338.

Millericrinus, 31.

Milleporidx, 23.

Mitra, 75.

Modiola, 62.

Modiolopsis, 61.

Mollusea, 48.

Monodacna, 65.

Monopleura, $6 t$.

Monostera, 11.

Monotis, 60 .

Montlivaltia, 25.

Mosasaurus, 279.

Murchisonia, 71 .

Muricida, 73 .

Mya, 68.

Myacidx, 58.

Mv'acites, 68 .

Myalina, 57.

Myliobates, 105.
Mylodon, 359.

Mlyopara, 62.

Myophoria, 62 .

Myoxus, 38.5.

Myriapoda, 48 .

Mystriosaurus, 271.

Mytilidx, 61,

Narcodes, 103.

Natica, 75.

Naulas, 103.

Nautilus, 75.

Nautiloceras, 81.

Navicula, 14.

Neæra, 68.

Nebalia, 43.

Neithea, 59.

Nemacanthus, 104.

Nepadx, 47.

Neptunia, 76 .

"Nereites," 39.

Nerinaa, 74.

Nerita, 78.

Neritoma, 74 .

Nestor, 399.

Nodosaria, 12.

Notagogus, 1.4.

Nothosaurus, 210, 231.

Nothosomus, $1 \pm \pm$.

Notidanus, 110.

Notopocorystes, 46.

Notornis, 291.

Nototherium, 395.

Nucleobranchiata, 72.

Nucleolites, 36.

Nucula, 61 .

Nucunella, 62.

Nummulites, 6-13.

Ororus (Ungula), 53.

Oculina, 26.

Odontacanthus, 103.

Odontaspis, 111.

Odontosaurus, 196.

Oldhamia, 20, 28.

Oliva, 75 .

Onchus, 100, 103.

Onychoteuthis, 91 .

Operculina, 12.

Ophidis, 279.

Ophioderma, 33.

Ophiopsis, 14t.

Ophiura, 3\%.

Ophiurella, 33.

Ophiuride, 33.

Opis, 67.

Opisthocolia, 272.

Oracantlus, 104.

Orbitoides, 6, 12.

Orbitolites, 12.

Oreaster, 34.

Ornithichnites, „288.

Orodus, 108.

Orognatlus, 138. 
Orthacanthus, 104.

Orthis, 53.

Orthoceras, 85 .

Orthonotus, 61 .

Orthophlebia, 47.

Osteolepis, 130.

Osteoplax, 138.

Ostracoda, 42.

Ostracostei, 118.

Ustreida, 58.

Otozoum, 165.

Oudenodon, 238.

Ovibos, 401.

Ovulites, 6, 12 .

Pachycoranus, 140.

Pachygyra, 25.

Pachyrisma, 66.

Palisister, 33.

Palæchinus, 35.

Palreocrangon, 45.

Palæocyclus, 25.

Palæoniscus, 137.

Palxophrynos, 283.

Palxophys, 280.

Palieopyge, 157.

Palæosaurus, $2 \pm 9$.

Palæospongia, 6 .

Palreoteuthis, 81 .

Palæotherium, 330.

Palapteryx, 294.

Paleryx, 280.

Paludina, 77.

Pamphagus, 9.

Pandora, 68.

Panopra, 68.

Parasmilia, 25.

Parexus, 103

Passalodon, 117.

Patella, 79.

Pecten, 58.

Pectunculus, 62.

Pelagosaurus, 271.

Pelorosaurus, 272.

Pentacrinus, 29, 30.

Pentamerus, 50.

Pentremites, 30 .

Perna, 60.

Petricola, 67.

Pezophaps, 295.

Phacops, 42.

Phascolomys, 395.

Phascolotherium, 304.

Phcenicopterus, 292.

Pholadomya, 63.

Pholas, 69.

Pholidophorus, 143.

Phragmoceras, 83.

Phryganea, 47.

Phyllodus, 149.

Phyllolepis, 132.

Phyllopora, 28.

Physa, 79.

Physonemus, 104.
Pileolus, 74.

Pisces, 99.

Pisodus, 149.

Pistosaurus, 214, 230.

Placodermata, 118.

Placodus, 216.

Placoganoidei, 118.

Placoidei, 118.

Placuna, 58.

Placunopsis, 58.

Plagiaulax, 319.

Plagiostoma, 59.

Plagiostomi, 99.

Planorbis, 79.

Platemys, 282.

Platyacanthus, 104.

Platycrinus, 31.

Platysomus, 138.

Plesiosaurus, 223.

Plectrodus, 101.

Plectrolepis, 138.

Pleuracanthus, 103.

Pleuraster, 33.

Pleurophorus, 57, 66 .

Pleurosternon, 281 .

Pleurntomaria, 78.

Plicatilia, 15.

Plicatula, 59.

Pliolophus, 3:5.

Pliopithecus, 350 .

Pliosaurus, 232.

Pododus, 138.

Podopilumnus, 46.

Pacilopleuron, 271.

Pollicipes, 41.

Polycystinex, 10, 13.

Polygastria, 14.

Polypi, 19.

Polypothecia, 7.

Polytremaria, 78.

Polyptychodon, 235.

Polythalamia, 11.

Porambonites, 51.

Porcellia, 71.

Poromya, 68.

Posidonomya, 12, 57.

Potamides, 77.

Poteriocrinus, 30.

Prionus, 47.

Procolia, 273.

Producta, 53.

Propterus, 144.

Prosoponiscus, 45.

Protaster, 33.

Protemys, 281.

Protichnites, 159.

Protopithecus, 393.

Protornis, 291.

Protorosaurus, 253.

Protovirgularia, 20, 39.

Protozoa, 5.

Psammosteus, 138.

Pseudocrinus, 30 .

Psittacodus, 117.
Pteraspis, 101.

Pterichthys, 119.

Pterinea, 60.

Pterocera, 73.

Pterocoma, 31.

Pterodactylus, 246.

Pterodonta, 80.

Pteroperna, 60.

Pteropoda, 71.

Pterosauria, 244.

Pterotheca, 72.

Pterygotus, 43.

Ptilodictya, 20.

Ptilopora, 20, 28.

Ptyacanthus, 103.

Ptychoceras, 89.

Ptychodus, 110.

Ptychognathus, 238.

Pulmonifera, 70.

Pulvinites, 60.

Purpurina, 73.

Pycnodontes, 140.

Pycnodus, 142.

Pygaster, 34.

Pygocephalus, 45.

Pygopterus, 168.

Pyramidella, 76 .

Pyrina, 36.

Pyritonema, 21.

Pythina, 65.

Radiata, 19.

Radiolites, 63.

Raia, 115.

Raiidx, 113.

Ramphorhynchus, 246.

Rana, 284.

Ranella, 73.

Raniceps, 183.

Raphiosaurus, 278.

Raplistoma, 77.

Rastrites, 20.

Reptilia, 168.

- Geological distribution of, 285 .

Requienia, 63.

Retzia, 52.

Rhabdoidea, 11.

Rhinoceros, 366 .

Rhinodon, 98.

Rhizodus, 132.

Rhodocrinus, 31 .

Rhizopoda, 8.

Rhombus, 149.

Rhyncholites, 86 .

Rhynchonella, 51.

Rhynchosaurus, 239.

Rhynchoteuthis, 81 .

Rimella, 73 .

Ringicula, 80 .

Rissoa, 62.

Rodentia, 385.

Rosalina, 12.

Rostellaria, 73. 
Rotalina, 12.

Ruminantia, 368 .

liytina, 346, 400 .

Saccosoma, 31 .

Salenia, 35.

Saurichthyide, 138.

Saurillus, 279.

Sauropsis, 140

Sauroptery gia, 209.

Sauropus, 167.

Saurostomus, 140.

Saxicava, 69.

Sealaria, 77.

Scalites, 77

Scalpellum, 41.

Scaphites, 89.

Scelidosaurus, 258.

Scelidotherium, 391.

Schizaster, 36 .

Schizodus, 62.

Sciurus, 385.

Scoliostoma, 71.

Scutella, 34 .

Scutellina, 36.

Scyphia, 6.

Semionotus, 143.

Semiophorus, 146.

Sepia, 90.

Septifera, 61.

Seraphs, 73.

Serpula, 40.

Siluridæ, 100.

Simosaurus, 214.

Siphonia, 6.

Siphonotreta, 53 .

Sivatherium, 387.

Sinerdis, 147.

Solecurtus, 68.

Solemra, 62 .

Solenella, 62.

Solenidre, 68.

Soroidea, 11.

Sowerbya, 67 .

Spalacotherium, 315.

Sparella, 97.

Sparsispongia, 6 .

Spatangidae, 35.

Spharonites, 30.

Sphagodus, 100.

Sphenacantlius, 104.

Sphenotrochus, 26.

Sphinx, 48.

Spinax, 105.

Spiniferites, 8.

Spinigera, 74.

Spirifera, 50.

Spiroglyphus, 40 .

Spirorbis, 40.

Spirula, 90.

Spirulirostra, 90.

Spondylus, 59.

Sponges, 5.
Squalidx, 110 .

Staganolepis, 257 .

Steganodictyum, 6 .

Stellaster, 33.

Stellispongria, 7 .

Steneosaurus, 271, 274.

Stephanophvllia, 26.

Stereognathus, 308.

Stichostega, 11.

Strepsidura, 75 .

Streptospondylus, 272.

Stringocephalus, 50.

Stromatopora, 6 .

Strombus, 73.

Strophalosia, 55.

Strophomena, 53.

Sturionidx, 145.

Styliua, 25.

Suchosaurus, 271.

Sus, 368.

Synapta, 37.

Syndosmya, 68.

Synocladia, 28.

Syringopora, 23.

TANCREDIA, 67.

Tanystropheus, 220.

Teleosaurus, 271, 274.

Tellina, 67.

Tellinidre, 58.

Telephoridx, 47.

Temnopleurus, 36.

Tentaculites, 46 .

Terebellaria, 28.

Terebellum, 73 .

Teredina, 69.

Terebralia, 77.

Terebratella, 49 .

Tetragonolepis, 142.

Teuthidæe, 90 .

T'extularia, 15

'Thamniscus, 28.

Thecidium, 50 .

Thecodontia, 248.

Thecodontosaurus, 248.

Thecosmilia, 25.

Thetis, 68 .

Thryssonotus, 140.

'Thylacoleo, 396 .

Tinea, 48.

Tornatella, 80 .

'Toxaster, 36.

Toxoceras, 89.

'T'oxodon, 393.

Tragos, 6.

'Trematosaurus, 195.

'Tretosternon, 281.

'Trichites, 61.

'Iriconodon, 318.

Iridacna, 65.

'I'rigonellites, 86.

'Trigon, 105.
Trigona, 67.

Trigoniadx, 58, 62.

Trigonoceras, 83.

Trigonosemus, 50.

I'rilobites, 44.

Trimucleus, 42.

Trionyx, 282.

"T'ripoli," 14.

Triton, 76 .

Trivia, 76.

Trochidx, 77.

Trochocyathus, 26.

'Trochotoma, 74.

'Trogontherium, 386.

Tropidaster, 33.

'Tropifer, 45.

'Trvstichius, 104.

'T'ubina, 71.

'Iubulipora, 29.

Tunicata, 17.

Turbino!ia, 25.

Turbo, 62.

Turrilites, 89.

Turritella, 77.

Tylostoma, 80 .

Uxcites, 50.

Unicardium, 65.

Unionida, 62.

Uronemus, 138.

Ursus, 381.

VAGIXELI.A, 75.

Varigera, 80.

Veneridx, 58.

Venerupis, 67.

Ventriculites, 6, 8 .

Vermetus, 40.

Vermicularia, 40.

Vermilia, 40.

Verruca, 41.

Verticellopora, 7 .

Verticordia, 62.

Volutidre, 76 .

Volutilities, 75.

Volvaria, 75 .

W ALDHEIMIA, 49.

Webbina, 12.

Woodocrinus, 31.

Xantuidum, 8.

Xestormytias, 196.

Xinhias, 148.

Xiphodon, 337.

Yoldia, 62.

Za pirtextis, 23.

Zeuglodon, 314.

Zygrobates, 114.

Zygosaurus, 196. 
A

CATALOGUE 0 F W 0 RKS

PUBLISHED BY

ADAII AND CHARLES BLACR,

E D I N B U R G H. 


\section{INB E}

Exctclopadia Brtmantica, . . . . . . . 3-1 Sir Watter Scott's Woriss, . . . . . . . 22-2!

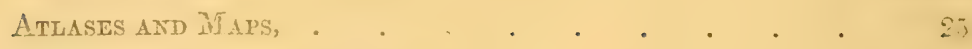

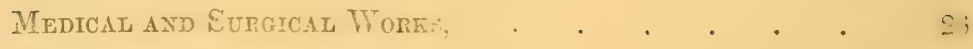
Educationat Works, . . . . . . . . 27-20

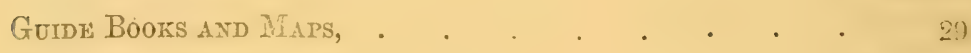

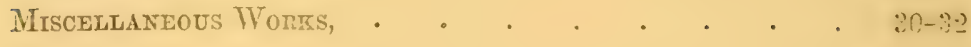




\title{
ENCYCLOPADIA BRITANNICA,
}

\section{FICETH}

\author{
IJow Publishing in ITonthly Parts, price 8s,
}

AND

\author{
Quarterly Volumes, price 24s.
}

\section{LIST OF SOME OF THE CONTRIBUTORS.}

Right HoN. Lord Mtacaulay.

Right Rev. RichaRd TWAAELY, D.D., English Literature in University Archbishop of Dublin.

Right Rev. R. Dichson Hampden, Sir John F. W. Herschel, Bart., D.D., Bishop of Hereford.

K.H., M.A., D.C.L., \&c.

William Wreweli, D.D., Trinity D. F. Arago, late Member of the Royal College, Cambridge.

Sir David Brewster, K.H., LL.D., Sir Jomn Robison, LL.D., late Professor Principal of the University of Edin- of Natural Philosophy in the Univerburgh.

Rrchard Owen, Esq., F.R.S., Superin- Sir WAlter Scot, Bart. tendent of the Natural History De- C. C. J. Bunsen, D.D.. D.C.L.. partments in the British Museum.

JoHn LEE, D.D., late Principal of the University of Edinburgh.

Sir William Hamilton, Bart.

Sir Archibald Alison, Bart.

Sir JoHN RICHARDSON.

Sir JOHN M·NEILL.

Henry Rogers, Esq., Author of the "Eclipse of Faith," \&ic.

IsAAC TAYlor, Esq., Author of the JoHn Playfair, F.R.S., late Professor "Natural History of Enthusiasm," \&c. of Natural Philosophy in the Uni-

Rer. Charles Kingsley, Author of versity of Edinburgh.

"Hypatia," "Westward Ho," \&c. The Right Hon. Sir JAMES MAckin-

J. D. Fonbes, Professor of Natural TosH, LL.D., \&c. Philosophy in the University of Dugald Stewart, F.R.SS. L. and E. Edinburgh, \&c., \&c.

Robert Stephenson, Esq., Mi.P., late President of the Institution of Civil Jean Baptiste Brot, Member of the Engineers, \&c. Ricirard Monckton Milnes, Esq., Right Rev. George Gleig, D.D. M.P.

Hepivorte Dixon, Esq.

Trieodore Martin, Esq.

MIajor-General Portlock. R.M.A., President of the Geological Society of London.

Patrick Fraser Tytuer, Esq́.

Sir James E. Smith, F.R.S.. late President of the Linnean Society.

EAN Baptiste Biot, Member of the

Lieut.-Col. Charles Hamilton Sirti, F.R.S.

E. G. Seuier, formerly Chargé D'Affaires of the United States to the Republics of Central America. Sir John Gramam Dalyell, Bart.

A. H. Layard, LL.D. 
Robert Jayeson, F.R.S., late Regius J. B. Jures, Esq., M.A., Vice-Presi-

Professor of Natural History in the

University of Edinburgh.

Alan Stevenson, Esq., F.R.S.E., C.E. Edward Edwards, Esq.

Jomn Crawfurd, Esq., F.R.S.

J. Y. Simpson, M.D., Professor of Midwifery in the University of Edin.

THOMas DE QUINCEY, Esq.

R. G. Latinam, Esq., M.A., M.D., \&c.

W. E. Aytoun, Professor of Rhetoric and Belles Lettres in the University of Edinburgh.

J. R. M'Cullocir, Esq., Member of the Institute of France, \&c.

Augustus Petermane, Esq., F.R.G.S., \&e.

William Spalding, M.A., Professor of Logic and Metaphysics in the University of St Andrews.

Rev. P. Kelland, M.A., Professor of Mathematics in the University of Edinburgh.

Antonio Panizzi, Esq.

Thomas Anderson, M.D., Professor of Chemistry in the University of Glasg.

Dr Doran, Author of "Habits and Men," \&c.

William Fairbairn, Esq., C.E., Manchester.

H. L. Mansele, Reader in Moral and Metaphysical Philosophy, Magdalen College, Oxford.

James Catrd, Esq., M.P.

DANiel Wilson, LL.D., F.R.S.A., \&c.

Lawrence Oliphant, Esq., Author of the "Russian Shores of the Black Sea."

George Farquhar Graham, Esq.

Richard Westmacott, Esq., Professor of Sculpture, R.A., F.R.S.

E. B. Denrson, Esq., M.A., Q.C., \&c.

Rev. Jomn CaIrns, M.A.

J. H. Balfour, M.D., Professor of Botany in the University of Edinburgh.

J. S. Blackie, Professor of Greck in the University of Edinburgh.

James Montgomery, Esq., Author of "Greenland and other Poems," \&c.

Sir Benjamin Pine.

Dr Sandwiti, K.B.

Georae Wilson, M.D., Professor Techmology in the University Edinburgh.

Walter Bagstiot, Esq.

Robert Carruthers, Esq.

John Hill Burton, Esq. dent of tho Geological Society of Dublin.

William Hosking, Professor of Arts and Construction, King's College, London.

Rev. Robert Main, M.A., F.R.A.S., \&c. JonN 'I'vlloch, D.D., Primarius Professor of Divinity, St Andrews.

Charles Maclaren, Esq., F.R.S.E., \&c.

J. L. Ricardo, Esq., M.P.

EdwARD Thornton, Esq., Author of "Gazetteer of India," \&c.

F. Grace Calvert, Professor of Chemistry, Royal Institution, Manchester.

Robert Christison, M.D., Professor of Materia Medica in the University of Edinburgh.

R. S. Poole, Esq., M.R.S.L., \&e.

Joirn Barrow, Esq., Admiralty.

JoSEPH D. HoOKER, M.D., R.N.

Charles Tomlinson, Esq., Editor of a "Cyclopedia of Useful Arts," \&c.

WV. L. Alexander, D.D.

Thomas Bazley, Esq., M.P.

W. H. LANGLey, Esq., Editor of "Bell's Life in London."

Charles Macintosh, Esq., Author of the "Book of the Garden."

T. C. Archer, Esq., Author of "Popular Ėconomic Botany."

Sir J. P. Lacaita, LL.D.

ARthur Ashpitel, Eisq.

A. V. Kirwan, Esq.

Williaß Blain, Esq., Anthor of "Inquiry into Slavery amongst the Romans," \&c.

Robert Chambers, Esq.

Rev. Richard Waterston, M.A.

Edwin Lankester, M.D.

Henry Letheby, M.D.

Rev. Citarles Merivale, B.D.

Hon. Edward Everett.

Richard Garnett, Esq.

J. H. Bennetr, M.D., l'rofessor of the Institutes of Medicine in the Univer sity of Edinburgh.

WILLIAM HowitT, Esq.

William Stirling, Esq., M.P.

Rev. WILLIAM ELLIS.

of liev. W. H. Guorn, D.D.

of liov. F. W. Fankan, Fullow of Trinity College, Cambridgo.

Goldwin Surtu, M.A., Professor of Modern History in the University of Oxford. 


\title{
ENCYCLOPFEDIA BRITANNICA.
}

\author{
EIGHTH EDITION.
}

\section{PRINCIPAL SUBJECTS.}

\section{VOLUME I.}

DISSERTATION FIRST.-On the Progress of Mletaphysical and Ethical Philosophy, since the Revival of Letters in Europe. By DUGALD STEWART, late Professor of IIoral Philosophy in the University of Edinburgh.

DISSERTATION SECOND.-On the Progress of Ethical Phitosophy, chiffy during the serenteenth and Eighteenth Centuries. By Sir Jasies Macisirrosh, LL.D. With a Preface by Willias Wheweld, D.D.

DISSERTATION THIRD.-On the Rise, Progress, and Corruptions of Christianity. By Richard Whately, D.D., Archbishop of Dublin.

DISSERTA'TION FOURTH.-On the Progress of Mathematical and Physical Science since the Revival of Letlers in Europe. By Sir JoHN PLarFaIr, late Professor of Natural Philosophy in the University of Edinburgh.

DISSERTATION FIFTH.-On the Progress of Mathematical and Physical Science, chiefly during the Eighteenth Century. By Sir Jonx Ltsure, late Professor of Natural Philosophy in the University of Edinburgh.

DISSERTATION SIXTH. - On the Progress of Mathematical and Physical Science during the Nineteenth Century. By Jases D. ForBes, Professor of Natural Philosophy in the University of Edinburgh.

\section{VOLUME II.}

ABERRATION \& ACOUSTICS. By George Brchanan, F.R.S.l. ACHROIIATIC GLASSES and AERONAUTICS. By Sir Jom LESLIE.

ADMIRAL and ADMIIRALTY. By Sir Jomn BArrow, Bart. Revised by John BArrow, Admiralty.

ADDISON (JOSEPH), By Williaj Spalding, A.M., Professol of Logic in the University of St. Andrews.

TESCHYLTS. By J. S. Blackie, Professor of Greek in the University of Edinburgh.

E'TNA and ALPS. By Robent Jayeson, late Professor of Natural History in the University of Edinburgh.

AfGHaNistaN. By David Buchaxan and Edward Tugriton, East India House.

AFriCA. By Augustus Petermann, F.R.G.S.

AGRICULTLRE. By J. Wilson, Eldington Mains, Berwickshire.

AGRICULTURAL CHEMISTRT. By Tuomas Anderson, M.L., Professor of Chemistry in the University of Glasgow.

AGRARIAN LAWS. By George Ferguson, Professor of IIuminity, King's Collese, Aberdcen. 


\section{VOLUAE II.-Continued.}

ALGEBRA. By Wirtan Wallace, LL.D., late Proficsor of Mathematics in the University of Edinburgh.

AMERICA.' By Chamles Maclaren, F.R.S.E.

ANATOMY. By David Craigie, M.D., F.R.S.E.

Abbreviation-Abyssinia-Acactemy-Algiers-Alphubet-Alum.

VOLUME III.

ANATOMY. By David Craigie, M.D., F.R.S.E.

ANCHOR. By Jonatran Aylen, Greenwich.

ANDES, ANGLE, \&c. By Sir John Leslie.

ANGLING, ANIMAL KINGDOM, and ANIIALCULE. B JAMES WiLson, Author of various works on Natural History.

ANNUITIES. By Joshua Milie.

ANT. By P. M. Roget, M.D., F.R.S.

ANTRIM and ARMAGH. By Henry Senion.

APPARITIONS. By James BRowne, LL.D.

AQUEDUC'T. By George Buchanan, C.E.

ARabia. By D. Buchanan and W. Plate, LL.D.

ARCH. By Jom Robison, late Professor of Natural Philosophy in the University of Edlinburgh, and WiLLIA3I WALLACE, LL.D.

ARCH EOLOGY. By Daniel Wilson, LL.D.

ARChiteCture. By Wildian Hosisisa, Piofessor of Arts and Construction, King's College.

ARISTOTLE \& ARISTOTLE'S PHILOSOPHY. By R. DICEลON Haxpden, D.D., Bishop of Hereford.

ARIIY. By J. Browne, LL.D., and J. II. Stoceleler.

ARTillery. By Captain Spearinn and Colmel Portlock.

ARTS. By W. Hazhit and WV. B. Jomnstone, R.S.A.

ASIA. By H. Murrar, F.R.S.E., and W. Plate, LL.D.

ASSAYING. By Ronert Musmet, of the Royal Mint.

astronony. By Tuns. Galloway, Sir Jomn Playfarr, and Tuos. Imenderson. With Supplement by Rev. Fombrt Maix, lioyal Observatory, Greenwich.

$$
\text { Archery-Arithmetic. }
$$

\section{VOLUME IV.}

ASTRONOMIY. By Tros. Ciamoway, Sil Jorn Playfare, and Tros. IIexdurson. With Supplements by Rev. R. MI.un, lioyal Observatory, Greenwich.

ATHENS and ATTICA. By TAmes Brownr, TI.D. Revised by Dr. L. Schintz, F.R.S.E., lector of the High School of Ldinburgh. 
VOLUME IV.-Continued.

ATMOIETER, BAROMETER, and BAROEETRICAL MEASUREMENTS. By Sir Jonn Lestie. With Supplements.

ArMOSPIERE. Iy Tuonas Thomson, late Professer of Chemistry in the University of Glasgow.

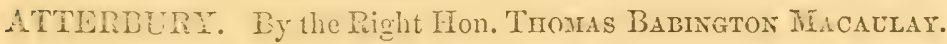
ATTRACTION. By JAMES IVORY, F.R.S.

AURORA BOREALIG. BY RomEnT JArESON, F.R.S., late Professor of Natural History in the University of Edinburgh.

ACSTRALAGIA \& ATSIRALIA. Br Gir JoHN BARRow. Tith continuation by SArroel MIossuna, Author of the "Gold Fields of Australia," etc.

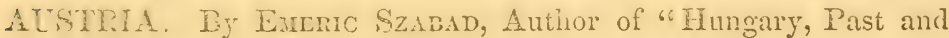
Present."

AVERAGE. By JoHn WArrack, Average Stater.

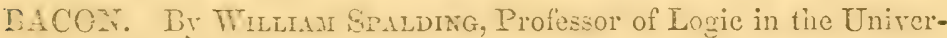
sity of St. Andrews.

LAIING, BLEACIING, ctc. By JAIES STAR, M.D., F.R.S.E. BAILIE, BAREOUR, BALLAD, BARCIAT, etc. By DATID InviNG, LL, D.

BALATCE OT POWEP and TIBLOGRAYIIT. By MACVEX NAPIER, late Professor of Conveyancing in the University of Edinburgh.

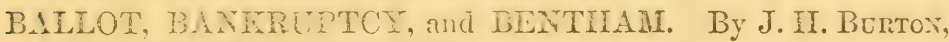
Author of the "History of Scotland," etc.

BASIET-MIAKING. By Sir J. G. DALzel..

BATHING, BECCARI, elc. By Tromas Toung, H.D.

BinGat. By EDWard Thompon, East India IIouse.

BEAUTY. By LoRd JEFFREY.

BEE. By JAMrs Wrison, F.R.S.E.

BEETHOVEN. By George Farquhar Gramajr.

BELGIUNI.

BELL, (SIR CHARLES.) By Sir JomN MiNeILt.

BIBLE and BIBLE SOCYETIES. By Rev. Jares Tayion, D.D.

BIACT SEA. By Lawrence Oliphant, Anthor of "The Russian Shores of the Black Sea."

ILASThig. By Robert and Thomas Stevenson, Civil Engineers. BOIIEMIIAN BRETIIREN. By James MFNtgomery, Author of "Greenland and other Poems."

BOLIVIA.

Bubylon-Deptism-Bernouilli . Blind-Dl ch-1Fatinery-Diourips. 


\section{VOLUME V.}

Bookbinding. By Charies Martel.

BOMBAY, BURAIA, etc. By Ev. Thornton, East India House. BOOK-KEEPING. By JoserH Lowe.

BORNEO and BORNOU. Revised by Acgustus Petermann, F.R.G.S., etc.

BOTany. By John Hutton Balfoer, M.D., Professor of Botany in the University of Edinburgh.

BRAHMINS. By JaMes Browne, LL.D,

BRASS. By Charles Sylvester, C.E.

BRAZIL.

BREAKWATER. By Sir JoHs Barrow, Bart. Revised by Johr Barrow, Admiralty.

BREWLNG. By James Stark, M.D., F.R.S.E.

BRICKAIAing. By Sauuel Holmes, Liverpool.

BRIDGE. By 'Thomas Young, M.D., F.R.S.

BRITAIN. By James Browne, LL.D., with Continuation.

BRUCKER. By Sir William Haxmlon, Bart.

BUILDing. By Wilitan Hosing, Author of "Architecture."

BUNYaN. By the Right Hon. 'Thomas Babington Macaclay.

BURMAH. By D. Buchanan and E. Thornton.

\section{VOLUME VI.}

BUt'ter (BISHOP.) By Hexry Rogers, Author of the "Eclipge of Faith," etc.

BURNiNG-GLASSES. By George Buchanan, F.R.S.E.

CALENDAR. By Thomas Galloway, F.R.S.

CALIFORNIA.

CALVin and CHANNING. By Rev. W. L. Alexander, D.D.

CAMIPBELL, 'TIIOMIAS. IBy W. E. Artoun, Professor of Rhetoric and Belles Lettres in the University of Edinburgh.

CANADA. By J. B. Brows, Author of "Views of Canada."

CANARY ISLANDS. By J. Y. Jonnson, Madeira.

CANNON. By Colonel Portlock, Woolwich.

CAPILLARY ACTION. By James Ivori, F.R.S.

CARTHAGE. By Jamrs Browne, LL.D., and Dr. Scmutz.

CARPENTRY and CHROMATICS. By Tuomas Young, M.D.

CAVAN and CLARE. By Henry Sexior.

CFNTRE. By Joms Romison, late Professor of Natural Philosoplyy in the University of Edinburgh. 


\section{VOLUME VI. $\rightarrow$ Continued.}

CEYlon. By J. Capper, Ceylonese Commissioner to the Great Exhibition of 1851 .

Cildliiers, (THOMAS.) By Rev. William Hania, LL.D.

CHEMIISTRY. By William Gregorr, Protessor of Chemistry in the University of Edinburgh.

CHESS. By James Donaldson.

CHILI. By C. B. BLack.

CHINA. By Sir John Barrow.

CHIVAlRY. By Sir WAlter Scott, Bart.

CHLOROFORII. By J. Y. Simpson, MI.D., Professor of Midwifery in the University of Edinburgh.

CHRONOLOGY.

Civil LAT. By David Irving, LL.D.

Clinlate. By Sir John Leslie.

\section{VOLUME VII.}

CLOCK and WATCH WORK. By Eduund Beckett Denison, M.A., Q.C.

COHEsion. By Thomas Young, MI.D., F.R.S.

COINAGE. By Robert Musnet of the Royal Mint.

COLD and DEW. By Sir Jonn Leslie, late Professor of Natural Philosophy in the University of Edinburgh.

COLLISION, COIBINATION, CORN-LAWS, CORN-TRADE, and COTTAGE SYSTEM. By J. R. M'Culloch.

COLliery. By William Alexander, Mining Engineer.

COLONY. By JaMes Mill.

COLOUR-BLINDNESS. By George IVIlson, M.D., F.R.S.E.

COMet. By Thomas Gallowat, F.R.S.

COMMUNISA and CORPORATION. By J. H. BurTON.

CONiC SECTions. By William Wallace, LL.D., late Professor of Mathematics in the University of Edinburgh.

CONSTRUC'TiOn. By Willinin Hosking, Author of "Architecture."

CONSTANTINOPLE. By EDwatd Sane, late Professor of Mechanical Philosophy in the Imperial School, Constantinople.

COPPER SiIELTING. By Jamis Napier, Glasgow.

CORK. By Henre Senior.

COTTON MANUFACTURE. Revised by Tromas Bazlez, Chairman of the Chamber of Commerce, Manchester.

COWPER. By A. Surti, Author of "A Life Drame," etc.

CRIMEA. By James LAURe. 
VOLUME VII.Contmued.

CRUSADES, CUTTEL, DANION, and DEFOE. Dy JAus Browye, LL.D.

CRLSTACEA. By Jom Fleme, D.D., Professor of Niatural Science, New College, Edinburgh.

CUNAITAIAM, DALRYMPLE, and DE.IPSTER. By DArid InYiNg, LL.D.

DAIRY. By John Tilson, Author of "Agriculture."

DEAF and DUMIB. By P. MI. Roget, M.D., F.R.S.

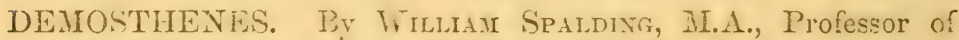
Logic and Metaphysics in the University of St. Andrews.

DENian. By Emeric Sizabad, Author of the Article "Austria." Dialling. By Henty Meikle, C.E.

Comnarce-Constantinopolitan ITistory-Comyright-CrystallizationDeluge.

VOLUME VIII.

DIPLOAIACY and ENTAIL. By JOIN IIILL EURTO:.

DISTILtation. By Jajies Stark, M.D., F.R.S.E.

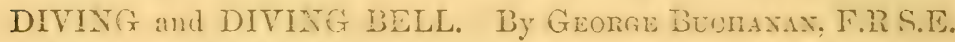

DOCK and DOCK-YARD. By Sir Jomn BAmow, Bart. Revised by his Son, Jonn Barrow, Admiralty.

DOLLOND, DOLOMHEU, and DUHAMEL. By Tiromas Iotyg, M.D., F.R.S.

DONEGAL, DOWN, and DUBLTN. By Hextry Sexior.

DRATNAGE of TOWNS. By W. Hosreng, Autior of "Architecture," etc.

DRAINAGE of LANDS. By J. Wilson, Author" of "Agriculture," etc.

DRAMIA. By Sir Walter Scott, Bart.

IDAWING and EYGRAVING. By W. II. LrzAIs.

DRY ROT. By Sir John Barizor, Bart.

DUMONT, LORD I) UNCAN, ete. By JAMES Browne, LL.D.

DUNBAR, (WILLIANI,) and ENGLISH LANGUAGE. Ly DAVID Irving, LL.D.

Dieing (Calico Printixa.) By iv. Crace Carvent, Profusor of Chemistry, Royal Institution, Manchester.

D TNAMICS. Iny Jom Rnemser, late Professor of Natural Philosophy in the University of Edinburgh.

ECONOMISTS. By James MiLt.

LDINIURGII and EDINBURGISTHRT:

EGTPT. 13y R. Stcare Poote, of the Department of Antiçnities. British Museum. 
VOLUME VIII.-Continued.

ELECTRICITY. By Sir David Brewater, K.II. II.A., D.C.Y., etc.

EMBANIMUENT. By J. C. LoUdon.

EIIGHATION. By J. l. II.Cullocir, Author of "Commercial Dictionary," etc.

ENGLAND. By Jhms Browse, LL.D, with Continuation.

VOLUMIE IX.

ENTOMOLOGY, FISILERES, and LDWARD FOIBDES. By JiNIES WILSON, F.R.S.E.

EPHRAEM SYRUS. By Rev. Henry Burgess, LL.D.

EPISCOPACY. By Rev. Gromge Gleig, D.D.

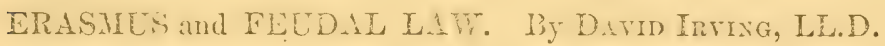

EQUATIONS. By Jaxies Ivorx, F.R.S.

ETHNOLOGY. By R. G. Lathan, M.A., M.D.

ETRLSCANS, EUGENE, FEYELON, cte. By JAMES BRowx. L.L.D.

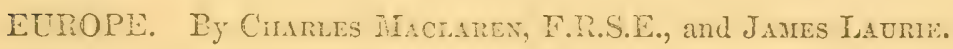
EVIL. By Rev. W. L. Alexander, D.D.

EXAMINATIONS. By J. F. MACLENAAN,

EXCIITUGE, EXCIEQLER BILLS, and EXCISE. By J. R. Mi'CuLLocir.

ERTREAE UNCTIOA, FATIERS, FEDERAL GOYERNMIENT', etc. By Rev. J. T'AXLor, D.D.

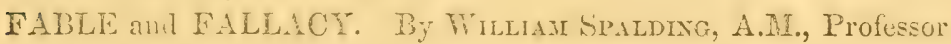
of Logic in the University of St. Andrews.

FALCONER, FARQUMAR, and FAIRFAX. By RUUEт Carrutitins.

FASIIION. By Dr. Doman, Author of "Habits and Aien," ete. FERIIANAGH. By HeNry Semror.

FEzZan. Revised by Augustus Petemitann.

FICHTE. By Jorr ColquHoun, F.R.S.E.

FIFESHIRE and FORTH. By Thomas Barclay.

FIGURE of the EARTH. By Tromis Gallowar, F.R.S.

FILTER. By George Buchanan, F.R.S.E.

FLINTSHIRE. By JoIn GIrdwood.

FLORIDA. By J. Surtm Homans, New York

FLUXIONS. By WrLliaji Wallace, LL.D.

FONTANA, FOSTER, and FOURCROT: by Thomas Folig, M.D.

FOOD. By Thovas Liwdra Tessp, M. 1). 
VOLUME IX.-Continued.

FORFAR. By Jaures Cowie.

FORTIFICATION. By Colonel Portlock.

FOSTER. By J. E. Rrland, M.A.

FOX, C. J. Бу JoHn Allex.

\section{Exhibition-Fanaticism.}

VOLUME $\mathbf{X}$.

FRANCE. Iy A. V. Knzwax, of the Middle Temple, Barristerat-Law.

Franklin, (BENJAMiN.) By Alexander Nicholson.

FRANKLIN, Sir JOHN By Sir Jomin Richardoson.

FUEL and GAS LIGHT. By Chamles Tomlinson, Editor of "Cyclopædia of Useful Arts," etc.

FULLER, ANDREW. By J. E. RYıand, M.A.

FUNDING SYSTEM. By D. Ricardo, supplemented by J. L. Rtcardo, Mi.P.

FURNACE. By George Buchanan, F.R.S.E.

GALILEO. By James Browne, LL.D.

GAlWAY. By Henry Sentor.

GANGES. By Edward 'Thornton, India House.

GASSENDI and GIBBON. By Henre Rogers, Author of the "Eclipse of Faith," etc.

GEOGRaPhY. By Rev. John Wallace, D.D.

GEOMETRY. By William Wallace, LL.D.

GEOMETRY, ANALY'TICAL. By Rer. P. Iielland, M.A., Professor of Mathematics in the University of Edinburgh.

GERMANY. By W. Јасов. Revised by James Laume.

GLACIER and FRESNEL. By J. D. Forbes, Professor of Natural Philosophy in the University of Ėdinburgh.

GLASGOW. By John Strang, LL.D.

GLASS. By James Ballantyne.

GNOSTICISM. By John Tulloch, D.D., Primarius Professor of Divinity, St. Andrews.

GOETHE. By 'Thomas de Quincex.

GOLDSMITI. By the Right IIon. T. B. Macallay.

CAPE' of GOOD HOPE. By B. C. Pine, late LieutenantGovernor of Natal.

GO'TAMA BUDDHA. J3y Rev. R. SPrice Hatidy, IIon. M.R.A.S., Author of "Eastern Monachism," etc.

GO'THS. By Leonamd Scmmiz, LL.D.

GOVERNMENT. By P. E. Dove, Author of the "Theory of Human Progression," etc.

GRAMIMAR. By Bishop Greis. Revised by W. Spalding, Professor of Logic in the University of St. Andrews. 
VOLUME XI.

GRAi, HerricK, and HOGG. By Robert Carruthers. GREECE. By Cuarles Maclarex, F.R.S.E. Revised. GREEK CHURCH. By W. M. IIetherington, D.D., LL.D. GREGORY of NAZIANZUM. By JohN Tul.Loch, D.D. GREGORY (Dr. JAMES.) By W. P. Alison, M.D.

GUINEA and HOUSSA. By Agustus Petermani, F.R.G.S., etc. GUN-COTTON, GUNPOWDER, GUTTA PERCHA, and HAT-MAKING. By CHARLES TOMLINSON.

GUN-MAKING. By P. E. Dove.

GUNNERY. By Colonel Portlock.

HALL (ROBERT.) By HeNry Rogers.

HARBOURS. By Thomas Stevenson, C.E.

HARE (C. J.) By W. L. Alexander, D.D.

HARVEY. By Thomas Larcock, M.D., Professor of the Practice of Physic in the University of Edinburgh.

HEAT. By 'T. S. Traill, M.D., Professor of Medical Jurisprudence in the University of Edinburgh.

HELMINTHOLOGY. By JAMES Wilson, F.R.S.E.

HEMIP. By T. C. Archer, Author of "Popular Economic Botany," etc.

HERALDRY. By T. W. Krng, York Herali, Herald's Collegre.

HEYNE. By Sir William Hamilton, Bart.

HIEROGLYPHICS. By R. S. Poole, M.R.S.L., etc.

HIMALAYA MOUNTAINS. By Joseph D. Hooker, M.D., F.R.S.

HINDUSTAN. Revised by Edward Thornton, India House.

HISTORY. By David Masson, M.A., Professor of English Literature, University College.

HOLLAND. Revised by the Rev. Jantes Ingrair, M.A.

HOMIER. By Jonn S. Blackie, Professor of Greek in the University of Edinburgh.

HOMGEOPATHY. BY T. T. GAIRDNER, M.D.

HOOD (THOMAS.) By Ricuard Monckton Milnes, Esq., M.P.

HORACE. By Theodore MartiN.

HORSE, HORSEMANSHIP, and HOUND. Revised by W. H. LANGLEY, Editor of "Bell's Life in London."

HORTiCULTURE. By Charles Macintosir, Author of the "Book of the Garden."

HOTVARD (JOHN.) By HEPIFORTH DixoN.

HOUSEHOLd (ROYAL.) By SAMuel RediRay 
TOLUMIE XII.

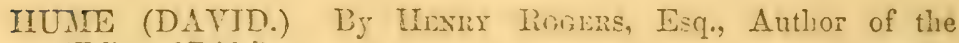
"Eclipse of Faith," etc.

HUNGAlis. By Emenc Stands, liate Secrelary under the Hungarian National Gorernment of 1819.

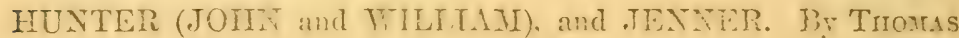
LAYcock, Mr.D., Profuszor of the Practice of Medicine in the Univerzity of Fdiuburgh.

H[NTING. By Nmmod. Reviced ly W. II. Haxenz, Esq, Editor of "Bell's Life in Lonilon."

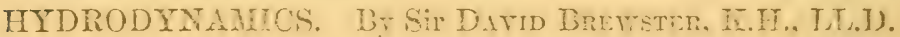

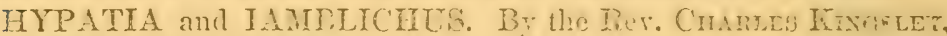
Author of "Westward Ho," etc.

ICELAND. By Rorert Altax, Esq. Revised by Eore?ti Cindubers, Esq.

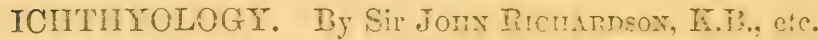

ICITTIYOLOCI (FOSGIL.) BY T. S. TRSILI, M.1)., Professor of Medical Jurisprudence in the University of Elinburgh.

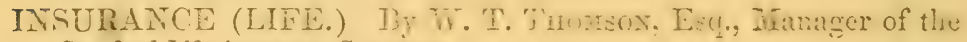
Stardard Life Assurance Company.

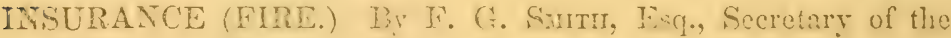
Scottish Union Fire and Life Insurance Company.

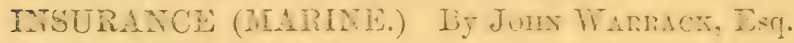

INTEREST. By J.R. II'Cullocr, Esq.

IONIAN ISLANDS. By TitLIMI IiLAm, Ear.e late liemier of

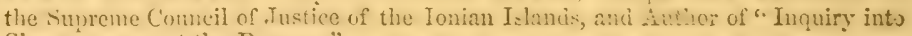
Slavery amongst the Romans."

IRELAND (HISTORY.) I'y Rev. L. Grovis. ("'tatistics) by Hexry Sexior, Esq.

IRON. By Willati Fammimix, Esq., F.R.S., F.G.S., etc.

IRON BRIDGES, By Ronrat Stemmexsox, Esq. A.P., President of the Institution of Civil Engincers.

IRRIGATION. By JAMES CAIRD, Esq., Author of "English Agriculture in 1850-51."

ITAYY. By * * *

JAIIAICA. By Stephex Cave, Esq.

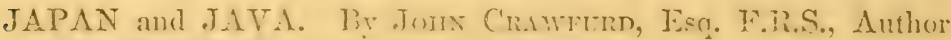
of "A Descriptive Dictionary of the Indian Islands."

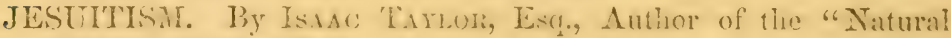
History of Enthusiasm," ctc.

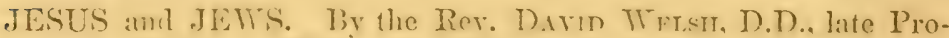
fessor of Eeclesinstical History in the University of Elinburgh. Revised.

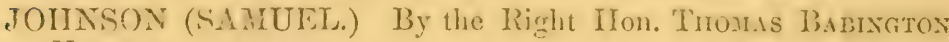
Macautax.

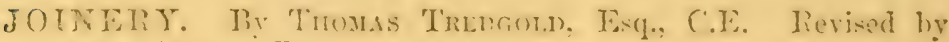
Artuun Asmutwi, Lsq. 
VOLUIIE XIII.

KAFRARIA. By Sir Benjamin Pine.

KANT. By the Rev. John Cairns, M.A.

KARS. Revised by Dr. Sandwith, K.B.

INIGHTS, INIGHWIOOD, LIVERY, and LORIAINE. I? Dr. Doris.

LAJRADOR and IAPLAND. Rerised by Augustus Petman, F.R.G.S., etc.

LAGRATGE and LALANDE. By TLOMAS Foung, M.D.

LAMGUAGE. Tevised by R. G. Lathas, M.A., M.D., ete.

LAW. By J.F. MILLennan, MI.A., Adrocate.

LAW OE AATONS an:1 LIBERTY OF THE PRESS. By JAMES MitLL.

IEAD, LEATHER, and LIRE PRESERVERS. By Charles TosmLinson.

LEPRCSY. My J. Y. Snipson, M.D., Professor of Midwifery in the University of Edinburgh.

IIBRARIES. By Enwand Enwands, Free Library, Mtanchester.

LIGIIT. By T. G. 'Trant, M.D., Professor of Medical Jurisprudence in the University of Edinburgh.

LiGHThouses. By Alan Stevenson, C.E.

LOCK. By E. B. Denison, M.A., Q.C.

IOGiC. Hy Niflian Spating, M.A., Professor of Logic and Metaphysics in the University of St. Andrews.

LOMIBARDS and LORIBARDX. By the Author of the Article "Italy."

LONDON. By H. G. REID.

I.UTHER. By C. C.J. Buxser, D.D., D.C.L., D. Ph., ete.

IADAGASCAR. By Rer. W. Eucis, Author of "Polynesian Researches," etc.

MADEIRAS. Ty J. Y. Junsor, Author of a "IImobouk for Madeira. 


\section{VOLUME XIV.}

MAGretisir. By Sir David Brewster, K.H., \&c.

MLAMIALIA. By Janies WiLson, Author of the article "Entomology."

MANCHESTER. By Tromas Bazley, Chairman of the Chamber of Commerce, Manchester.

MANUFACTURES. By J. R. M'Culloch.

MIECHANICS. By W. J. M. Rankine, Professor of Civil Engineering and Mechanics in the University of Glasgow.

MEDICAL JURISPRUDENCE. By T. S. Traill, M.D., Professor of Medical Jurisprudence in the University of Edinburgl.

MEDICINE. By Tromas Laxcock, MI.D., Professor of the Practice of Physic in the University of Edinburgh.

IIElboUrne. By William Westgartin, Author of the "Gold Fields of Australia," etc.

MIEMNON and MEMPHIS. By R. S. Poole, Author of the article "Egypt."

MENSURATION. By William Swan, Lecturer on Mathematics and Natural Philosophy.

MENTAL DISEASES. By David Srae, M.D., Plyysician to the Royal Edinburgh Asylum.

METAPIIYSICS. By Rev. H. L. Mansed, Reader in Moral and Metaphysical Philosophy, Magdalen College, Oxford, and one of the Editors of Sir William Hamilton's Works.

Meteorology. By Sir .Tonn F. W. Herschel, Bart., K.H., M.A., D.C.L., etc.

\section{MEXICO.}

MICROAIETER. By Sir DAvil Btewster, K.H.. etc.

MCROSCOPE. By Sir David Brewster, Ki. II., etc. 


\section{VOLUME XV.}

MILAN, MODENA, and NAPLES. By the Author of the article "Italy."

MLtTon. By Datid Masson, Mr.A., Professor of English Literature, University College, London.

MINERAL WATERS. By R. MI. GLover, M.D., Author" of "The Mineral Waters of Great Britain and the Continent."

MINERALOGICAL SCIENCE.

MINERALOGY. By Jayes Nicol, Professor of Natural History, Marischal College, Aberdeen.

GEOLOGY. By J. B. Jukes, Vice-Presiclent of the Geological Society of Dublin.

MINES and MINING. By J. R. Leifchild, Author of "Our Coal Fields and our Coal Pits."

MIRACLES. By Rev. James TAYLoR, D.D.

MISSIONS. By William Brown, Mr.D.

MISSISSIPPI, MISSOURI, and MOBILE. By J. B. D. DE Bow, Author of the "Industrial Resources, etc., of the South and West."

mobILIER, CREDIT. By Walter Bagehot.

mohammedanisir. By Rev. J. G. Cazenove.

MIOLLUSCA. By Richard Owen, F.R.S.

MONARCHY. By Dr. Doran.

MONEY. By J. R. M'Culloch.

MONTREAL. By Hon. Jonn Young.

MOORE (THOMAS). By R. Carrothens.

MORAL PHILOSOPIY. By W. L. Alexander, D.D.

MOSQUiTO SHORE. By E. S. Squier, Author of "Notes on Central America."

MOZART and MUSIC. By G. F. GRAhair.

MUNICIPAL CORPORATIONS. By J. I. BUITON.

NATAL. By Sir Benjanin Pine.

NATIONAL EDUCATION. By J. D. MIORELl, one of II. MI. Inspectors for Schools. 
VOLUME XVI.

NAVIGATION. By Rev. Joseri Wooller, LL.D., F.R.A.S., late Principal of the School of Arathematics and Naval Construction at Portsmouth.

NAvigation. Inlayd. By David Stevenson, F.R.S.E., M.I.C.E., etc.

NAVY and NORWAY. By JoHn BaRRow, Author of "Excursions in the North of Europe," etc.

NEANDER. By John Tulloch, D.D., Principal and Primarius Professor of Divinity, St. Mary's College, St. Andrews.

NELSON. By JaMes Browne, LL.D.

NEPAUL. By EDward Thonston, Author of "Gazetteer of India."

NEUTRALITY. By J. R. M'Culloch.

NEWSPAPERS. By Edward Edwards, Author of the Article "Libraries."

NEWTON (Sir ISAAC), and OPTICS. By Sir David Bretrster.

NEW YORK. By Freenan Hunt, late Editor of "Hunt's Merchants' Magazine," New York, U.S.

NEW ZEALAND. By Rev. W. B. Borce.

NICARAGUA. By E. G. Seuier, Author of the Article "Mosquito Shore."

NiEbUhr. By Rev. Charles Merivale, B.D., Author of a "History of the Romans under the Empire," etc.

NIIE. By George Melly, Liverpool.

NINEVEH. By A. H. Layard.

NORTH-TESTERN PROVINCES OF INDIA. By E. B. EAsTwick, Professor of Hindustani and Teluga, East India College, Haileybury.

NUMISMATICS. By R. S. Poole, Author of the Articles "Egypt" and "Hieroglyphics."

ODONTOLOGY and OKEN. By Richand Owen, F.R.S., Superintendent of the Departments of Natural History, British Museum.

CEHlenscillager. By Tueodore. Martin.

DHIO. By J. D. B. De Bow, Professor of Political Economy in the University of Louisiana, and Superintendent of United States Census.

OILS and OPIUM. By Professor T. C. Archer, Honorary Director of the Museums of Natural History and Applied Science, Liverpool Royal Institution.

ORDINATION. By W. L. Alexander, D.D.

ORFIlA. By Robert Cinistison, MI.D., Professor of Materia Medica in the University of Edinourgh.

Organ. By George Farquina Grainam, Author of the Article "Nusic."

ORNithology. By Jasies Wrison, Author of the Article "Mammalia." 


\section{VOLUME XVII.}

OUDE and PERSIA. By E. B. F.istwick, Professor of Hindustani and Teluga, East India College, Haileybury.

OWEN (JOHN). By Axdrew Thouson, D.D.

PAINTING. By Besjamin Robert IIfydon, with Supplement by W. B. Johnston, IR.S.A.

PALFONTOLOGX. By Richarn Owex, F.R.S., Superintendent of the Departments of Natural History, British' Mluseum.

PALESTINE and PERU. By David Kay, F.R.G.S.

PALEY and PASCAL. By Henry Rogers, Author of "The Eclipse of Faith," etc.

PALINPSESTS and PAPYRUG. By C.T. Russeli, D.D.

PANTHEISM. By JoHN Downes.

PAPAL STATES. By the Author of the Article "Italy."

PAPER. Revised by Charles Cowan, M.P.

PARASITE. By Dr. Doran.

PARIS. By James Camichaer, Mi.A., one of the Masters in the Edinburgh Academy.

PARLIAMENT. By JoHn Hill Burton.

PARRY (Sir WILLIAII EDWARD). By his Son, Edward PARRY.

PARTNERShip (Limited and Unlinited Liability): Бy J. R. i'Culloch.

PA'TENTS. By Janes YATE Jonnson, Editor of the "Patentee's Manual," etc.

ST. PAUL and ST. PETER. By W. L. Alexander, D.D.

PEEI, (Sir ROBERT). By Goldwin Sirth, MI.A., Regius Professor of Modern History, Oxford.

PENDULUM and PERSPECTIVE. By Edward SaNG, F.R.S.E.

PENN (Willian). By Robert Carruthers.

PESTALOZZI. By John Tilleard.

St. Petersburg. By Professor Siaw, B.A., St. Petersburg.

PHIlologr. By the Rev. J. W. Donaldson, D.D., Author of the "New Cratylus," Classical Examiner in the University of London.

Photograpity, etc. By Sir David Brewster, K.H., etc.

Phrenology. By Thomas Laycock, M.D., Professor of the Practice of Physic in the University of Edinburgh.

PHYSICAL GEOGRAPIIY. By Sir Jomn F. W. Herschele, Bart., K.H., etc.

PHysiology. 13y Jomin IIugnes Bennetr, M.D.. Professor of the Institutes of Medicine, and Senior Professor of Clinical Medicine in the University of Edinburgh.

PIT' (WILLIAM). By Lord Macautay.

PLANTING. By J. C. Loudon, Author of "Encyclopedia of Gurdening," etc.

PLATO. By the Right Rev. the Bishop of IEREFord. 


\section{VOI.UME XVIII.}

PLAYFAIR (JOHN). By Lord JefFrey.

PNEUniatics. By Sir Jomn Robison, late Professor of Natural Philosophy in the University of Edinburgh.

POETRY. By George Moir, Adrocate. Revised by W. Edsonstoune Artoun, Professor of Rhetoric and Belles Lettres in the University of Edinburgh.

POISON. By Robert Christison, M.D., Professor of Materia Medica in the University of Edinburgh.

POLAND. By James Brown, LL.D. Revised.

POLAR REGIONS. By Sir John Richardson, K.B.

POlICE and POST-OFFICE. By Edward Edwards, Author of the article "Libraries."

POLITICAL ECONOMY AND PRECIOUS METALS. BY J. R. MI'CULLOCH.

POLYNESIA. By the Rev. W. Ellis, Author of the Article "Nadagascar."

POOR-LAWS. By George Coode, Barrister-at-Law.

POPE. By Thomas de Quinchy.

Population. By the Rev. T. R. Maltinus, late Professor of Political Economy, East India College, IIertford.

POTTERY and PORCELAIN. By Chamles Tomminson.

PRECESSION and PROBABILITY. By 'Themas Gallowar, late Secretary to the Royal Astronomical Society.

PRESBYTERIANISM. By the Rev. Wurman H. Goold, D.D.

PRESCOTT. By William Stirling, M.P.

PRINTING. By T. C. HANSARd, Barrister-at-Law.

PRISON DISCIPLINE. By JoHn Hilt. Berton.

PRUSSIA. By Dr. G. Von Bunsen.

PUNJAB. By E. B. EAstwick, Author of the article "Persia."

QUAKERS. By William Howitt, Author of "Visits to Remarkable Places," etc.

QUESNAY. By J. R. MI'CULLOCH.

QUiNTILIANUS. By Frederic W. Farrar, Fellow of 'Trinity College, Cambridge.

RABELAIS. By 'Treodore Mantin.

RAILWAYS. By D. K. Claki, Author of "Mechanical Engineering of Railways," etc. etc.

REGISTRATION. By' James 'T. II amack, Superintendent General Register Office. 


\section{VOLUME XIX.}

REPTILIA. By James Wilson, Author of the Article "Fisheries." Reticulation. By the Hon. and Rev. Charles Bathurst, LL.D.

liEUCHIIN and RICHTER. By W. H. Crumaers, late Assistant Librarian of the Advocates' Library.

RHETORIC, and SIR WALTER SCOTT, Bart. By Wr. Spalding, A.M., Professor of Logic and Metaphysics in the University of St Andrews.

IRICARDO. By J. R. M'Culloch.

lichelieU. By Gustate Masson, Harrow Sehoul.

RIVER. By Sir Jonn Robrson, late Professor of Natural Philosophy in the University of Edinburgh.

ROAD-MIAING, and ROBISON (J.) By Tuoras Young, M.D., late Corresponding Member of the Royal Institute of France.

ROBERTSON (W.) and ROGERS (Sayuel). By Ronert Carrutuers. ROBINSON (Robert) and SCHLEIERMACHER, By J. E. Ryland. ROMANCE. By George MIorr, late Professor of Rhetoric in the University of Edinburgh. With Continuation by W. Edmoxstouxe Axtoux, Professor of Rhetoric and Belles Lettres in the University of Edinburgh.

ROMAN History and ROME. By the Rev. Charles Merivale, B.D., Author of a "History of the Romans under the Empire."

ROOF. By Antiun Ashpiter, F.S.A., Architect.

liope and ROPEMAKING. By Janes Nemlands, Borough Engineer, Liverpool.

Rotation. By Tinomas Galloway, F.R.S., late Secretary to the Royal Astronomical Society.

ROABUtighshite. By Jayes Duxan, Denholm.

RUSSTA (Statistics). By Hexir J. Bishop, Adjunct Professor of the Ecclesiastical Academy, Alexander Neffiski's Monastery, St Petersburg.

SABBATH and SCRIPTURE. By W. Lindsay Alexander, D.D.

SAlT. By Chanles Tombinson, Author of a "Cyclopredia of Useful Arts," \&e.

SANiTARY SCIENCE. By E. L.inkester, M.D., \& H. Letheby, M.B. SARDINIA. By Sir James P. Lacaita, LL.D.

SAVINGS BANKS. By Edward Edwards, Author of the Articlo "Libraries."

SAW. By Edward Sang, C.E.

SCANDINAVIAN LITERATURE. By Willia Howitr, Author of "Visits to Remarkable Places," \&c.

SCEPTICISM. By Jonn Downes, M.A.

SCHILlER. By Thomas de Quincex.

SCOTIAnd. By Patrick Fraser Tytler. With Continuation.

SCOTT (Jorr) and SCOTT (Williay). By J. F. Miclennay, MI.A. SCUlpture. By Ricmind Westuacott, Professor of Sculyturo, R.A., F.R.S. 


\section{SIR WALTER SCOTT'S WORRS.}

\section{THE WAVERLEY NOVELS.}

Six Editions as follows:

I.

Library Edition. Illustrated by upwards of Two

Hundred Engravings on Steel, after Drawings by Turner, Landseer, Wilkie. Stanfield, Roberts, etc., including Portmaits of the historical Personats describut in the Novels. Complete in 25 volumes demy octavo, elegantly bound in extra cloth, price $£ 13: 2.6$.

II.

A New Illustrated Edition. To be completed in 48 Handr Volumes, at 4s. Gd. each, containing 96 Steel Engraviugs, and ujwards of 1500 Wood Engravings.

III.

Author's Furourite Edition. 48 portable foolscap

8 ro vols. (96 Engravings), price $£ 7: 4 \mathrm{~s}$.

IV.

Cabinet Edition. 25 vols. foolscap 8vo (26 Illustrations), £3: $13: 6$.

V.

People's Edition. 5 large volumes royal Sro, £2:2s.

VI.

Separate Novels, People's Eclition, in beautifully illuminated covers, price $1 \mathrm{~s}$. $6 \mathrm{~d}$. each, as follows:-

1. WAVERLEx.

2. Guy Manneriva.

3. Antiquari.

4. Rob Roy.

5. Old Mortality.

6. The Buack Dwarf, and LEGEND OF MONTROSE.

7. Heart of Mid-Lothian.

8. BRIDE OF LAMMERMOOR.

9. IVANHOE.

10. Monastert.

11. Аввот.

12. Kenimtiontu.

13. Pirate.
14. Fortunes of Niget.

15. Peveril of the Peak.

16. Quentin Dorward.

17. St. RoNaN's WeLI.

18. ReDGaUNTLET.

19. BETROTHED AND UIGMLAND WIDOW.

20. The Tatismax.

21. Woonstock.

22. Fair Maid of Pertir.

23. ANNe OF Geifrstem.

24. Count Robert of Paris.

25. Surg̨en's DAUgnter AND Castle Dangerous.

Separate Novels may also be had from any of the other Editions. 


\section{SIR IVALTER SCOTT'S \\ MISCELLANEOUS PROSE WORKS.}

\section{CONSISTING OF}

Tales of a Grandfuther, (History of Scotland).

Tales of a Grandfuther, (History of France).

Life of John Dryden.

Memoirs of Jonathan Swift.
Memoirs of Eminent Norelist.s, etc.

Paul's Letters to his Kinsfoll:

Essays on Chivalry, Romance, and the Drama, etc.

Provincial Antiquities of Scotlend. Life of Napoleon Bonaparte.

\section{Miscellaneous Criticisms, etc.}

\section{COMPLETE EDITIONS.}

I. In Twenty-eight volumes Foolscap 8vo, with Fifty-six Engravings from Turner. Price $£ 4: 4 \mathrm{~s}$.; Separate volumes, $3 \mathrm{~s}$.

II. In Three volumes Royal 8ro. (Peorle's EDrtion.) Bound in cloth, price $£ 1: 6 \mathrm{~s}$. Separate Volumes, I. and II., 10s. each; III. (TALES of a Grandfatier), price 6 .

Illustrated Edition of the TALES OF A GRANDFATIER-

(HISTORY OF SCOTLAND). With Six Engravings after Turner, and upwards of Fifty on Wood. In Three volumes Foolscap 8ro, cloth, 12s.; extra, cloth, gilt edges, $15 \mathrm{~s}$.

(HISTORY OF FRANCE.) Tith Two Engrarines from Turner, and upwards of Fifty on Wood. One volume Foolscap $8 \mathrm{vo}$, cloth, $4 \mathrm{~s}$.; extra, cloth, gilt edges, $\bar{s}$,

School Edition of the IISTORY OF SCOTLAND, with MIap. In Two volumes, Crown 8vo, bound, 10 s.

LIFE OF NAPOLEON BONAPARTE. Five volumes Foolscap 8ro, Maps, Portrait, and Nine Engravings after Turner. Cloth, price $£ 1$.

Another Edition in larger type. Nine volumes Foolscap Sro, Maps, Portraits, and Engravings. Cloth, price $£ 1: 7 \mathrm{~s}$.

\section{SELECTIONS FRONI \\ SIR WALTER SCOTT'S WORKS.}

Belgiem and Waterloo.

France and Paris.

Tales of Chivalry.

Rojantic Narratives.

Cimaracters of Eminent Persons.

The Highland Chans.

Scottish Scenes and Characters.

Narrative and Descriptive Pieces.

Price Eighteenpence, or Tro Shillings, Cloth.

BEAUTIES OF SIR IVALTER SCOTT, being SElections From IIIS Writrings AND Life. One volume, Crown Octavo, with Two Engravin!ss. Cloth, gilt, $5 \mathrm{~s}_{\text {. }}$; extra cloth, gilt sides and edges, $6 \mathrm{~s}$.

The same volume bound as a School Book. Price 3s. $6 \mathrm{~d}$.

READINGS FOR TIIE YOUNG, FroII THE Works of Sir WAIter SCOTr. In 'Three volumes, witli Thirty-six Illustrations on Wood, price $2 \mathrm{~s} .6 \mathrm{~d}$. each; or bound in One volume, cloth, gilt edges, $7 \mathrm{~s}$. 


\section{SCOTT'S POETICAL WORKS.}

CONSISTING OF

Fijst, The Metrical Romances, - The LAY of tue Last Misstrel; Marshos: The Lady of the: Lake; Rokesy; The Lonn of tie Isles; The Vision of DuN loderick; The Bridal of Trierasin; and Harold the Daunteess.

Second, Dramas, Songs, and Ballads.

Third, The Minstrelsy of the Scottish Border.

The following are the only Coprrigit linirioxs, with the Actnor's LAst Notes and IMPROYEMENTS .-

I. In One portable Foolscap volume, including all the Mrtrical Romances (except the Bridal of Triermain and Harold), the Principal Songs and Ballads, and several Illustrations. Bound in cloth, gilt edgis, price 5s.; or morocco antique, 10 s.

II. In One Crown octavo volume (same contents as previous Edition), with numerous Engravings on Steel and Wood, after Turner, Gilbert, and Foster. Bound in cloth, gilt edges, 7s. 6d. ; morocco antique, 14s.

III. In 'îwelve volumes. Foolscap) 8vo (24 Engravings), £1 : 16 s. This is the only Edition which contains the Minstrelsy of the Scoltish Border.

IV. In Six volumes. Foolscap sro (12 Engravings), $\pm 1: 4 \mathrm{~s}$.

V. In One volume. Royal 8vo (People's Evirior), 10s.

VI. 'The Ambotsword Enition, printed on Tinted Paper, with upwards of Sixty Illustrations on Steel and Wood, after Turner, Gilbert, and Foster. Elegantly bound in extra cloth, gilt edges, price $£ 1: 11: 6$; morocco elegant or antique, $£ 2: 2 \mathrm{~s}$.

VII. Tonnists' Litions of The LAy of the LAst Mixstrei, MARJion, LADY of THE LAKE, LORD OF THE IsLes, RoKeBY, and BIIIMAL

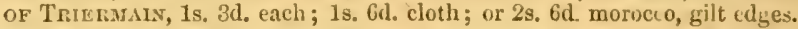

VIII. New Illustrated Filitions of The Lady of the Lake, Marmon, LAY OF THE LAST MiNSTREL, and LonD OF THE IsLes, containing each from Seventy to One Hundred Illustrations on Wood, by Birket Foster and Jolnn Gilbert. Printed in the best style, on Tinted Paper, and elegantly bound in cloth, gilt edges, price $18 \mathrm{~s}$. each ; morocco, elegant or antique, $£ 1$ : $5 \mathrm{~s}$. ; enamelled tartan boaris, $£ 1: 16 \mathrm{~s}$.

\section{LIFE OF SIR WALTER SCOTT, \\ By J. G. LOCKHART, Esq.}

\section{Three Editions as follows :-}

I.

In Ten volumes Foolscap Sro, uniform with the Author's Farourite Edition of the Novels. T'wenty Engravings on Steel, price $£ 1: 10$ s.

II.

In One Vol. royal Sro, uniform with the Norels, PEopie's EDrtox. With Portrait. price 10s.

'The same, Larce l'aper, uniform with the Novels, AnBotsendid EDITrox. With Eleven Engravings from Turner, Portraits, \&c., price $18 s$.

III.

In One rol. Crown Sro, with Twelve Engravings from Turner and Cthers. P'rice 7s. 6l. ; extra, cloth, gilt elges, 8s. 6l. 


\section{ATLASES AND MAPS.}

I.

GENERAL ATLAS OF THE WORLD.-Containing upwards of Serenty Mans, engraved on Steel, in the first Style of the Art, by HUGHES, BAR. THOLONEw, and others; with Introductory Chapters on the Geography and Statistics of the different Countries in the World, and an Index of all the Names occurring in the several Maps, amounting to 60,000, with their Latitude and Longitude, and the number of the Map in which they will be found. New Edition, with numerous improvements and additions. Strongly and elegantly half-bound in moroceo, with gilt leaves, Price L.3.

II.

ATIAS OF NORTH AMERICA, with IIAPs of the various Prorinces, States, and Countries of that Continent, and Plans of the City of New York, the Environs of Montreal, and Panama Railway. Constructed from the inost recent authorities. By JoHN BARTHOLOMEW, F.R.G.S.

Princreal Contexts.-No. I. North America. II. British, Russian, ani Danivh Amo. rica-Polar Regions. III. Upper Canada. IV. Lower Canada, New Brunswick. V. to XVIII. Separate States and Territories of the United States. XIX. Mexion, Central America, and West Indies. XX. Steamer Routes and Oceanic Currents. With deseriptive Letterpress, and an Index of 21,000 Names. Imperial fulio, 16 s.

III.

HAND-ATLAS OF MODERN GEOGRAPHY. A Series of ThirtyEight Maps. By William Hughes, F.R.G.S.; and John Bartholomew, F.R.G.S. With a Complete Index of Names. Quarto, half-bound, 21s.

\section{IV.}

SCHOOL ATLAS OF IIODERN GEOGRAPHY. NEW Enition. A Series of Thirty-Seven Maps, for Instruction in Physical, Ancient, and Scripture Geography. With Index. 4to or 8 ro, cloth, 10s. 6 d.

$\mathrm{V}$.

SCHOOL ATLAS FOR BEGINNERS. New Edtron. A Series of 'Twenty-Seren Maps of the Principal Countries in the World. Oblong 12 mo or $18 \mathrm{mo}, 2 \mathrm{~s}, 6 \mathrm{~d}$.

VI.

ATLAS OF AUSTRALIA; with all the Goun Regrons. A Series of Maps from the latest and best authorities. Contents:-I. General Map of Australasia, New Zealand, Polynesia, and Surrourding Islands. II. AustraliaDivided into Districts. III. New South Wales, Victoria, and South Australia, showing the different Gold Deposits. IV. New South Wales-Divided into Counties, with all the Gold Deposits accurately laid down, and a plan of Sydney. V. Victoria-Divided into Counties, with all the Gold Districts accurately laid down, and a Plan of the Mount Alexander Gold Region. VI. New Zealand, Van Diemen's Land, and the settled portion of Western Australia, comprehending Swan River and Australind. Quarto, cloth, 6s.

VII.

MIAP OF EUROPE. Size, 3 by 4 feet 4 inches. Scale, 80 miles to the inch. Engraved from the most recent authorities, and coloured with the greatest precision and accuracy. Price 14s. Mounted on Linen, in a handsome Portable Case, and 21s. on Roller Varnished.

\section{VIII.}

IIAP OF AUSTRALIA, TASMANIA, AND NEW ZEALAND. Size, $48 \frac{1}{2}$ by 39 inches. This Map, taken from the British and French Government Surveys, and other sources of recent and authentic information, has undergone great alterations, and been increased by large and important additions, kindly furnished to the Publishers by William Westgarth, Esq., Author of "The Gold-Fields of Australia. It contains also, on an enlarged seale, the Colony of Victoria; Mount Alexander Gold Region and Plan of Sydney; Port Philip with Melbourne; Map of Norfolk Island, and a Slietch Map, showing the Principal Commercial Routes. New Edition, price 18s. in Sheets; $21 \mathrm{~s}$. bound in Cluth, Sro or 4 to; and $27 \mathrm{~s}$, on Rollers Varnished. 


\section{MIRDICAL AIID SURGICAL WORKS.}

By JOHN HUGHES BENNETT, M.D., Professor of the Institutes of Medicine, and Senior Professor of Clinical Medicine, in the Lniversity of Edinburgh, a Third Edition of

CLINICAL LECTURES on the PRINCIPLES and PRACTICE of MIEDICINE. 8ro. P1. 1000, with 500 Illustrations on Wood. Price 30s.

By the same Author, a Third Edition of

AN INTRODUCIION to CIINICAL VEDICINE. Six Lectures on the Method of examining Patients, and the means necessary for arriving at an exact Diagnosis, 12mo. Price 5s.

In $12 \mathrm{mo}$, profusely illustrated, price $6 \mathrm{~s}$,

OUTLINES OF PHYSIOLOGY.

In Demy 8ro, price 7s. 6d.,

THE PATHOLOGY and TREATMENT of PLLMONARY CONSUMPTION.

By JAIIES Y. SIMIPSON, MI.D., Professnr of Midwifery in the Unirersity of Edinburgh,

OBSTETRIC MEMOIRS and CONTRIBUTIONS; including those on Anrsthesia. Elited by Drs Priesteey and Storner. Illustrated. 2 vols. 8 ro. Price L.1, 16 s.

By JAMES MILLER, F.R.S.E., Professor of Surgery in the Unirersity of Edinburgh,

THE PRINCIPLES of SURGERY. Third Edition. Illustrated. Demy 8ro. Price 16s.

By the same Author,

THE PRACTICE of SURGERY. Third Elition. Illustrated. Demy 8vo. Price 16s.

By JOHN HUTTON BALFOUR, M.D., Professor of Medicine and Botany in the University of Edinburgh,

CLASS-BOOK of BOTANY. Being an Introduction to the Study of the Vegetable Kingdom. 8ro. Price L.1. 11s. Gd. Profusely Illustrated.

By JAMES D. FOIBES, D.C.L., F.R.S., Professor of Natural Philosophy in the University of Edinburgh,

A REVIEW of the PROGRESS of MITHENATICAL and PHYSICAL SCIENCE in more Recent Times, and particularly between the Years 1775 and 1850 ; being one of the Dissertations prefixed to tho Eighth Edition of the Encyclopedia Britannica. 4to. Price 8s. 6d.

By ROBERT CHRISTISON, M.D., Professer of Materia Mrelliea in the University of Edinburgh,

A TREATISE on POISONS in relation to Medical Jurisurudence, Ihysiology, and the Practice of Physic. Fourth Edition, Demy 8vo. Prico 10s.

By THOMAS LAYCOCK. M.D., Professor of the Practice of Plysic in the University of Edinburgh,

LECTURES on the PRINCIPLES and METIODS of MIEDICAL OBSERVATION and RESEARCH. Crown 8vo. Prico 6s.

By T. S. TRAILL, M.D., Trofessor of Mredienl Jurisprulence in the University of Edinburgh,

MEDICAL JURISPRUDENCE. Thind Edition. 12mo. Price õs. 


\section{EDUCATIONAL WORRS.}

I.

BLACK'S SCHOOL ATLAS of Modern, Ancient, Scripture, and Physical Geography: a Series of Forty Mraps by W. Hughes, H.R.G.S.S., and J. Bartholemew, F.R.G.S., with a complete Index of Names, exhibiting the latitude and longitude of each place, and a reference to the Map. Royal 4 to or $8 \mathrm{ro}, 10 \mathrm{~s} .6 \mathrm{~d}$.

II.

BLACK'S ATLAS for BEGINNERS. A Series of Twenty-seven Coloured Maps of the Principal Countries in the World. In oblong $12 \mathrm{mo}$ or $18 \mathrm{mo}, 2 \mathrm{~s} .6 \mathrm{~d}$.

III.

THE LATIN READER of JACOBS and CLASSEN. Edited, with Notes and a Vocabulary, by James Donaldson, M.A., one of the Classical Masters of the High School of Eidinburgh. 12mo, 3s. 6d.

** The above may be had in Two Parts, at 1s. 9d, and 2s. each.

First Course : Exercises on the Inflections.

Second Course : Fables, Mythology, Anecdotes, Roman History, etc. IV.

ELEMENTARY GRAMMAR of the GREEK LANGUAGE. By Dr L. Schmitz, Rector of the High School of Edinburgh. 12mo, 3s. 6d. $\mathrm{v}$.

EXERCISES IN ATTIC GREEK for the use of Schools and Colleges. By A. R. Carson, LL.D., F.R.S.E., late Rector of the High School of Edinburgh. 12mo, $4 \mathrm{~s}$.

VI.

By the same Author,

PHEDRI AUC्रUSTI LIBERTI FABULARUM IESOPIARUM, quas Oculis Puerarum Subjicii fas est Libras quinque, cum Indice Verborum Phrasiumque Dilliciliarmu Anglice Redditorum. Nerv edition, revised by Rev. Wм. Veiтch. 18mo, 2s.

VII.

RUDIAENTS OF THE LATIN IANGUAGE. By TrLtax M. Guns, LL.D., late One of the Masters of the High School, Edinburgh. $12 \mathrm{mo}, 2 \mathrm{~s}$.

vIII.

GREER VERBS, IRREGULAR AND DEFECTIVE; their forms, meaning, and quantity, embracing all the Tenses used by the Greek writers, with References to the Passages in which they are found. By Rev. Wrr. VeitcI. Post 8ro, 6s.

FIRST STEPS IN THE PHYSICAI AND CLASSICAL GEOGRAPHY OF 'THE ANCIENT WORLD. By J. Pillans, Professor of Humanity in the University of Edinburgh. Third Edition, 12mo, 1s. 6d. $\mathrm{x}$.

A SUMMARY OF THE PRINCIPAL EVIDENCES FOR TIIE TRUTH AND DIVINE ORIGIN OF THE CHIISTIAN REVELATION. By the late Berlery Pofteous, D.D., Bishop of London; with Definitions, Amalyses, of the several Proprositions, and Examination Questions, by Janes Boyd, LL.1), late Oae of the Masters of the IIigh School of Elinburgh. $18 \mathrm{mo}, 1 \mathrm{~s}$. 
XI.

THE ADVANCED PROSE AND POETICAL READER: being a Collection of Select Specimens in English, with Explanatory Notes and Questions on each Lesson; to which are appended Lists of Prefixes and Affixes, with an Etymological Vocabulary. By Alexanden Winton Buchas, F.E.I.S., Teacher, Glasgow. 12mo, 3s.6d.

THE POETICAL READER separately, 1s. $3 \mathrm{~d}$.

XII.

CLASS-BOOK OF ENGLISH POETRY ; comprising Extracts from the most distinguished Poets of the Country, from Craucen to Texrisox, with Biographical Sketches, and a rapid riew of the characteristic attributes of each, preceded by an Introrluctory Essay on the Origin and Progress of English Poetical Literature. By Daniel Scryargeour, late one of H.AI. is Assistant Inspectors of Schools for Scotland. Fifth Edition, 12mo, price 4s. 6d. Also to be had in Two Parts, at 2s. 6d. each. Part I. containing the Poets from Chaucer to Otway. Part II., Prior to Tennyson.

XIII.

CLASS-BOOK OF ENGLISH PROSE. Comprehending Specimens of the most distinguished Prose Writers, from Chaucer to the present time, with Biographical Notices, Explanatory Notes, and Introductory Sketches of the History of English Liternture. By Robert Demaus, MI.A., 12mo, price 4s. 6d. Also to be had in Two Parts at 2s. 6d. each.

XIV.

OUTlines OF PHYSIOLOGY. By J. Hughes Bennett, M.D., F.R.S.E., Professor of the Institutes of MIedicine in the University of Edinburgh. $12 \mathrm{mo}, 6 \mathrm{~s}$.

XV.

COLLECTION FOR SCHOOLS, from the Works of Sir WALTER SCOTT. Seventh Edition, roan, price 3s. 6d.

XVI.

OSWALD'S ETYMOLOGICAL DICTIONARY OF THE ENGLISH LANGUAGE. By the Rev. Jorn Oswald. Serenth Edition, 18mo, bound, price $5 \mathrm{~s}$.

HISTORY OF SCOTLAND. Br Sir WALter Scott, Bart. From the Earliest Period to the Close of the Rebellion, 1745-6. Twentieth Edition, 2 vols, bound, price 10 s.

xviri.

HISTORY OF SCOTLAND. By P. F. Trtler, Esq. Enlarged and continued to the Present Time. By tho Rev. JaMes TAYLor, D.D.; and adapted to the purposes of Tuition by AlEx. Rero, LL.D. Sixth Edition, $12 \mathrm{mo}$, price $3 \mathrm{~s} .6 \mathrm{~d}$.

XIX.

IIISTORY OF FRANCE. By Sir Walten Scotr, Bart. New Edition. Illustrated. Fcap. $8 \mathrm{ro}$, price $4 \mathrm{~s}$.

$\mathrm{xx}$.

HISTORY OF PALESTINE. By Jorn KitTo, D.D. From the Patriarchal Age to the Present Time; containing Introductory Chapters on the Geography and Natural History of the Country, and on the Customs and Institutions of the Hebrews. Adapted to the purposes of Tuition, by ALExAxder ReID, LL.D. 12mo, price 3s. 6d. ; or with Map of Palestine, 4s.

Xxi.

MODERN HISTORY. By A. F. Trtefr, late Professor of Universal Ifistory in the Unirersity of Edinburgh. Fifth Edition, 12mo, 3s.

By the samo Author,

ANCIENT HISTORY. Fourth Elition. 12mo, 3s. 


\section{GUIDE BOOKS AND TRAVELLING MAPS.}

BLACK'S PICTURESQUE TOURIST OF SCOTLAND. Jllustrated by One Hunired and Thirty-six Maps, Charts, and Views, and containing all the most recent informu. tion. A New and Greatly Improved Edition (the 13th). Price 8s.6d.

BLACK'S PICTURESQUE TOURIST OF ENGLAND. 4th Edition, 10s, 6 . BLACK'S PICTURESQUE TOURIST OF IRELAND, 2d Edition, 5s.

BLACK'S GUIDE TO DUBLIN AND TIIE WICKLOW MOUNTAINS. 1s. 6d. BLACK'S GUIDE TO KILLARNEY AND THE SOUTH. 1s. 6d.

JLACK'S GUIDE TO THE SHANNON AND WEST. 1s.6d.

13LACK'S GUIDE TO BELFAST, GIANT'S CAUSEWAY, AND THE NORTH. 1s. 61. BLACK'S CUUDE TO THE ENGLISH LAKES. Illustrated by Birket Foster. 7s. 6d. 13LACK'S GUIDE TO THE ENGLISH LAKES, 6th Edition, 5s.

13LACK'S GUIDE TO THE EXGLISH LAKES. Cheap Edition, 1s, 6d.

BLACK'S GUIDE TO WALES. Illustrated by Birket Foster. 5th Edition, 53.

I3LACK'S GUIDE TO NORTH WALES. 3s, 6d.

IBLACK'S GUIDE TO DERBYSHIRE (Chatsworth, Buxton). 2s.

13LACK'S GUIDE TO HAMPSHIRE AND DORSETSHIRE. 2s.

BLACK'S GUIDE TO DEVONSHIRE AND CORNWALL. 2s.

BLACK'S GUIDE TO WARWICKSHIRE. 2s.

ULACK'S GUIDE TO YORKSHIRE. $2 \mathrm{~s}$.

WLACK'S GUIDE TO GLOUCESTER, \&c. 2s, 6d.

BLACK'S GUIDE TO KENT AND SUSSEX. 3s.6d.

BLACK'S GUIDE TO SUTHERLANDSHIRE. 1s.

J3LACK'S GUIDE TO THE TROSACHS (Loch Katrine and Loch Lomond). 1s.6d.

BLACK'S GUIDE TO THE HIGHLANDS OF PERTISHIRE. 1s.

BLACK'S GUIDE TO THE HIGHLANDS OF ARGYLESHIRE. 1s. 6 d.

BLACK'S GUIDE TO STAFFA, IONA, AND GLENCOE. Is.

BLACK'S GUIDE TO THE ISLE OF SKYE, 1s.

BLACK'S GUIDE TO ABERDEEN AND BRAEMAR. 1s.

BLACK'S GUIDE TO MOFFAT, ST MARY'S LOCH, \&c. Is.

BLACK'S GUIDE TO GLASGOW AND ENVIRONS. 1s. and 2s, $6 \mathrm{~d}$.

BLACK'S GUIDE TO EDINBURGH AND ENVIRONS. 2s.6d.

ANDERSON'S GUIDE TO THE HIGILANDSAND ISLANDS OF SCOTL $A N D .10 \mathrm{~s}, 6 \mathrm{~d}$. MAP OF ENGLAND AND WALES. 32 Inches by $22 \frac{1}{2}$, 4s. $6 \mathrm{~d}$.

Do. Do. Size 19 Inches by $15,2 \mathrm{~s}$. 6d. Or uncoloured and unmounted, $1 \mathrm{~s}$.

MAP OF THE ENGLISH LAKE DISTRICT. 19 Inches by 14. 2s. 6 d.

Do. Do. Uncoloured and unmounted. 8d.

MAP OF WALES (North and South), 14 Inches by 11 1 . 18. 6d. each.

MAP OF SCOTL $\Lambda$ ND. 32 Inches by $22 \frac{1}{2}, 4 \mathrm{~s} .6 \mathrm{~d}$.

Do. Smaller size. 19 Inches by 15. 2s. 6d. Or uncoloured and unmounted, is.

MAP OF IRELAND. Size, 20 Inches by $14 \frac{1}{2}$. 2s. 6 d.

ORDNANCE SURYEY MAPS OF SCOTLAND. Si, far as published, including Counties of Edinburgh, Haddington, Fife, Kirkcudbright, Wigton, \&c. 2s. 6d. and 5s. per Shut. Index Maps may be had.

COUNTIES OF SCOTLAND, in separate Maps, coloured, and neatly bound in cloth cases. 1s, each.

TOURIST'S AND SPORTSMAN'S COMPANION TO THE COUNTIES OF SCOTIAND. A Series of Thirty-six Maps, showing all the Roads, Railways, Villages, Country Seats, Rivers and Lakes, Places of Historical and Legendary Note; Memoranda of Buttles, Heights of Mountains, \&c, \&ce. In a portable volume, strongly bound. 10s. 6d. 


\section{MISCFILANEOUS WORKS.}

ADDRESSES TO NIEUIC II STLDENTS, Delivered at the Instance of the Edinburai Medical Missionary Suclety, 1855-56. 12mo, 3s. 6 d.

ANDERSON-LIGHT IN DARTNESS; or, Comfort to the Sick and Aflicted. By the Rev. W. ANDERsox. Crown 8ro, cloth, antique, 5s.

BALFOUR-CLASS-BOOK OF BOTANY. Being an Introduction to the Study of the Vegetable Kingdom. By J. H. BALFour, M.A., M.D., F.R.SS.I. and E., F.L.S., Regius Keeper of the Royal Butanic Garden, and Prufessor of Medicine and Botany in the Uuiversity of Edinburgh. In one large volume, 8 ro, with 1800 illustrations. Price 31s. 6d.

By the same Author,

BOTANY AND RELTGION; or Illustrations of the Trorks of God in the Structure, Functions, Arrangement, and Distribution of Plants. Profusely illustrated. Crown 8vo, 6s. 6d.

BLAIR'S GRAVE. New Erlition, Illustrated by Brrnet Foster, with Proface by the Rev. F. W. Farran, Fellow of Trinity College, Cambridge. Small 4 to, 7s, 6 d.

BOWDLER-THE RELIGION OF TIIE HEART, as Exemplified in the Life and Writings of JoHix BowdiER, late of Lincoln's Inn, Barrister-atLaw. Edited by his brother; Chiarles Bowdere. Cloth, antique, $5 \mathrm{~s}$.

CAIRD-THE POOR LAW MANUAL FOR SCOTLAND. BY Alex.ander M'Neel Caird, Esq. Sixth Edition. Crown 8ro, 7s.6d.

COCKBURN-MEMTORIALS OF HIS TIIE. By Henry Cockburs; late nne of the Senators of the College of Justice. With Portrait after Raeburn. Demy 8vo, 7s. 6d.

By the same Author.

LIFE OF LORD JEFFREY, late one of the Senators of the College of Justice. Second Edition. 2 vols. 8vo, 20̄s.

CANDLISH-LIFE IN A RISEN SATIOUR, being Discourses on the Resurrection. By Robert S. Cavdish, D.D. Fourth Thuusand. Crewn $8 \mathrm{vo}, 7 \mathrm{~s} .6 \mathrm{~d}$.

CREUZE-A TREATISE ON TIIE THEORY AND PRACTICE OF NAVAL ARCHitecture. Bv Augustine F. B. Creuze. 4to, 12.

DENISON-CLOCKS AND LOCKS. From the Eighth Edition of the "Encyclopædia Britannica." Second Fdition, with a full account of the Great Clock at Westminster. By Edmund BecketT Denison, M.A., Q.C. Illustrated. $12 \mathrm{mo}, 3 \mathrm{~s} .6 \mathrm{~d}$.

FALCONER'S SIIPTRECK. New Edition. Edited and with Preface, by Roizert Carretiners. Illustrated by BhiKet Foster, Fennell, \&c. Suall 4to, 12s. 6d.

FARRAR-ERIC; or, Little by Little. A Tale of Roslyn School. By Frederic W. Farrar, Fellow of Trinity Cullego, Cambridge. Fuurth Edition. Crown 8ro, 6s. 6d.

By the samo Author.

JULTAN HOME. A Tale of College Lifo. 
FORBES-A REVIEW OF THE PROGRESS OF MATHEMATICAL AND PHYSICAI SCIENCE in more recent times, and particularly between the years 1775 and 1850; being one of the Dissertations prefixed to the Eighth Elition of the "Ercyclopedia Britannica." By James D. Furbes, D.C.L., F.R.S., Professor of Natural Philosophy in the University of Edinburgh. 4to, Ss.6d.

By the same Author,

NORTAY AND ITS GLACIERS. Followed by Journals of Excursions in the High Alps of Dauphiné, Berre, and Savoy. By JAmEs D. Forbes, D.C.L., F.R.S., Sec. R.S.. Edin., Corresponding Member of the Institute of France, and Professor of Natural Philosophy in the University of Edinburgh. With Two Maps, Ten Lithographic Views printed in colours by Day and Son, and Twentytwo Wood Engravings. Royal 8vo, 21s.

By the same Author,

THE TOUR OF MONT BLANC AND OF MONTE ROSA. Be-

ing a Personal Narrative, abridged from the Author's "Travels in the Alps of Savoy," \&c. Illustrated, 12mo, 5s.

"An admiraule edition, and the Jlap of the Mer de Glace most correct and ralanble."-ALbErT SMitil.

OCCASIONAL PAPERS ON THE THEORY OF GLACIERS. Now first collected, and chronologieally arranged, with a Prefatory Note on the Recent Progress and Present Aspect of the Theory. With Ten Plates and Twentynine Woud Engravings. 8vo, price 10s. 6 d.

GENESIS OF THE EARTH AND OF MAN. Edited by R. S. Poole, British Museum. Crown 8ro, 5s.

GRAHAM-MIUSICAL COMPOSITION : Its Thenry and Practice. With numerous Engravings and copious Musical Illustrations interspersed with the text. By G. F. GrahaM, Author of the article Misic in the "Encyclopredia Britannica." 4 to, $9 \mathrm{~s}$.

GUTHRIE-THE GOSPEL IN EZEKIEL. Illustrated in a Series of Discourses. By 'Thomas Guthrie, D.D. Trenty-fifth Thousand, Crown 8 ro, price 7s. $6 \mathrm{~d}$.

By the same Author,

CHRIST AND THE INHERITANCE OF THE SAINTS. Illustrated in a Series of Discourses from the Epistle to the Colossians. 12th Thousand, Crown 8 vo, $7 \mathrm{~s} .6 \mathrm{~d}$.

By the same Author, a New Edition of

BERRIDGE'S CIIRISTIAN WORLD UNMASKED; PRAY COME AND PEEP. 12mo, price 2s. 6 d.

By the same Author,

CHRIST, AND CHRIST CRUCIFIED. A Sermon on occasion of the Death of William M. Guns, LL.D. Fourth Thousand, Crown 8vo, price 1s.

By the same Author,

WAR-In some of its Social, Political, and Religious Aspects. 12mo, served, price $1 \mathrm{~s}$.

By the same Author,

THE STREET PREACHER: Being the Autobiography of Rosert Flockhart, late Corporal 81st Regiment. Cloth limp, price 2s.

JEFFREY-VOICES FROM CALVARY ; or, the Seven Last Sayings of our Dying Lord. By Robert T. Jeffrey, M.D., Minister of Caledonian Road Church, Glasgow. Crown 8vo, price 3s. 6d.

JOHNSON-MADEIRA, ITS CLIMATE AND SCENERY : a Hand-Book for Invalid and other Visitors. By RoBERT WHite. Second Edition. Edited by James Yate Johnson, of the Middlo Temple. With Map. Crown 8vo, 7., 6d. 
JUKES-THE STUDENT'S IIANUAL OF GEOLOGX. By J. B. JukEs, M.A., F.R.S., Lrieal Director of the Geulogical Survey of Ireland, and Lecturer in Geology to the Museum of Irish Industry. Crown 8ro, 8s. 6d.

KITTO-CYCLOP EDIA OF BIBLICAL LITERATURE. 2 vols. medium $8 \mathrm{vo}, 60$ s.

By the same Author,

POPULAR CICLOP EDIA OF BIBLICAL LITERATURE. 8ro, cloth, 10s. 6d.

By the same Author,

HISTORY OF PALESTINE. Illustrated. Crown 8vo, cloth, plain, 6s.; cloth, gilt edges, 6s. $6 \mathrm{~d}$.

IAMARTINE-MARY STUART. By Alphonse de Lamartine. Crown 8ro, $5 \mathrm{~s}$.

MIACAULAY'S DICTIONARY of DOALESTIC MEDICINE. 14th Edition, demy 8ro, 10s.6d.

M.CULLOCH-A TREATISE ON METALLIC AND PAPER MONEY AND BANKS, written for the "Encyclopadia Britanuica." By J. R. MiCulloch, Esq. 4to, 5 s.

"By modern students it will be found most concise and valuable, since it brings the entire subject to its latest stage, and is characterised by all the rigour and clearness of expression peculiar to the author of the Ccmmercial Dictionary."-The Times.

By the same Author,

TREATISES AND ESSAYS ON MONEY, EXCIIANGE, INTEREST, the LETTING of LAND, ABSENTEEISII, the IIISTURY of CONMERCE, MANUFACTURES, \&c., with Accounts of the Lives and Writings of Quesnay, Adam Smith, and Ricardo. Second Edition, price 10s.6d.

NICOL-ELEMENTS OF MINERALOGI; containing a General Introduction to the Seience, with Descriptions of the Species. By JAMrs NicoL, F.G.S., Professor of Natural History in Marischal Cullege and University of Aberdeen. $12 m 0,5 \mathrm{~s}$.

NIMROD-THE HORSE AND THE HOUND; their various Uses and Treatment, including Practical Instructions in Horsemanship and Hunting, \&c., \&c. By Nimrod (the late Charles James a prerley, Esq.) Third Edi。 tion, with Numerous Illustrations on Wood and Steel, after drawiugs by Herring, Alken, and Harrison Weir. Crown 8vo, 10s. 6d.

PARK'S TRAVELS IN AFRICA. New Edition. Illustrated by C. A. Doyle. Square $12 \mathrm{mo}$, gilt edges, $3 \mathrm{~s}, 6 \mathrm{~d}$.

POETRY AND POETS OF BRITAIN; being a Reprint of the Class-Book of Poetry. Crown 8ro, cloth, 7s. 6d. ; gilt edges, 8s.

SHAKESPEARE-A NEW EXEGESIS OF. Crown Svo, 7s. 6d.

SMITH'S WEALTH OF NATIONS. By M'Cullocir. 8ro, 16s. SPALDING'S ELEMIENTS OF LOGIC. 12mo, 4s. 6ul.

STEVENSON-CANAI, and RIVER ENGINEERING. By DAYID STEVENSON. 8vo, 4s. Gd.

STEWART-TIE PRACTICAL ANGLER. By T. C. Stewart. Third Edition, 12n0, 33.6d.

WARDLAW'S (Dr) TIIEOLOGY. 3 rols. 8ro, $36 \mathrm{~s}$.

WARDLAW (Dr), LIFE OF. By TW. L. Alexander, D.D. 8vo, 12s. 




\section{Date Due}

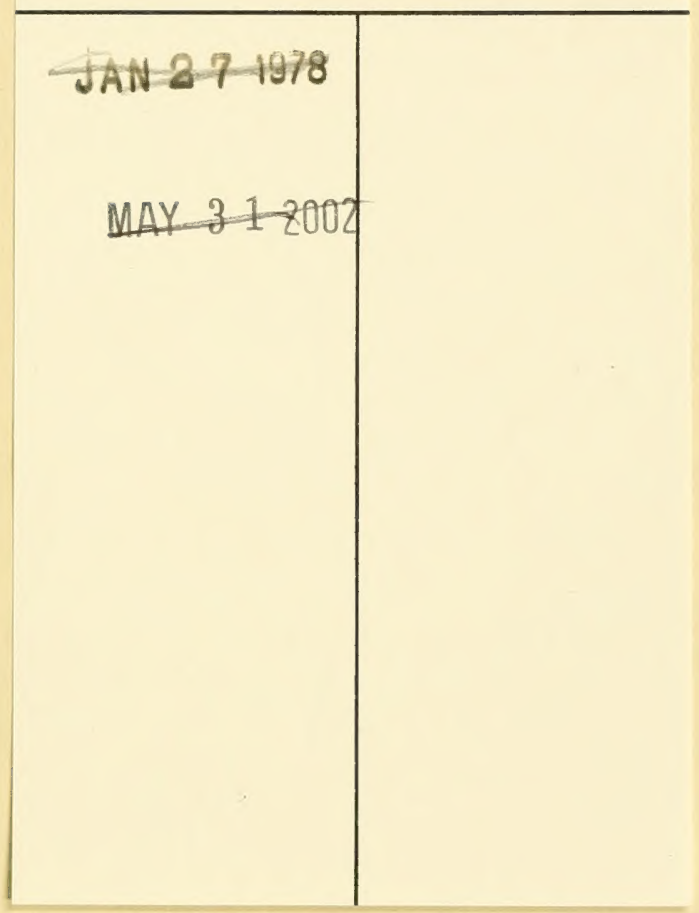


